Nevada

Environmental

Restoration

Project

Closure Report for Corrective

Action Units 530, 531, 532, 533,

534, 535: NTS Mud Pits

Nevada Test Site, Nevada

Controlled Copy No.:

Revision No.: 0

July 2006

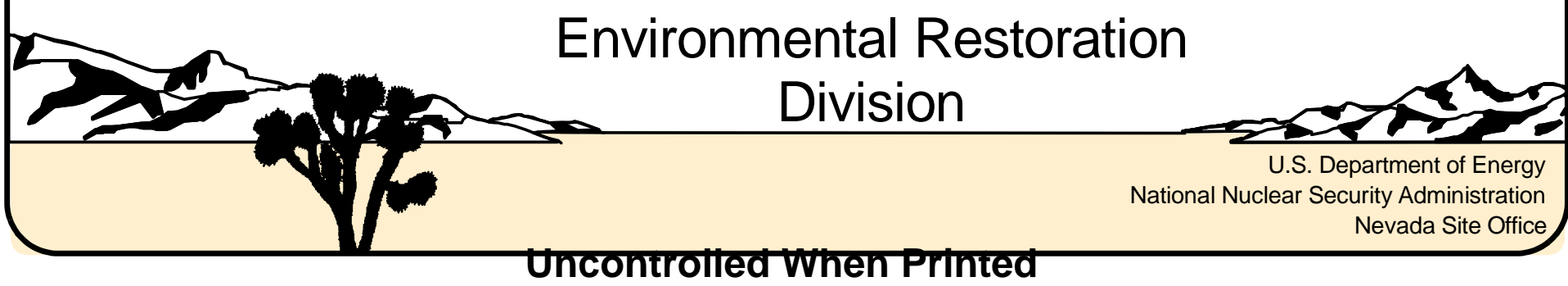


Available for public sale, in paper, from:

U.S. Department of Commerce

National Technical Information Service

5285 Port Royal Road

Springfield, VA 22161

Phone: 800.553.6847

Fax: 703.605.6900

Email: orders@ntis.gov

Online ordering: http://www.ntis.gov/ordering.htm

Available electronically at http://www.osti.gov/bridge

Available for a processing fee to U.S. Department of Energy and its contractors, in paper, from:

U.S. Department of Energy

Office of Scientific and Technical Information

P.O. Box 62

Oak Ridge, TN 37831-0062

Phone: 865.576.8401

Fax: 865.576.5728

Email: reports@adonis.osti.gov

Reference herein to any specific commercial product, process, or service by trade name, trademark, manufacturer, or otherwise, does not necessarily constitute or imply its endorsement, recommendation, or favoring by the United States Government or any agency thereof or its contractors or subcontractors. 


\title{
CLOSURE REPORT FOR CORRECTIVE ACTION UNITS 530, 531, 532, 533, 534, 535: NTS MUD PITS, NEVADA TEST SITE, NEVADA
}

\author{
U.S. Department of Energy \\ National Nuclear Security Administration \\ Nevada Site Office \\ Las Vegas, Nevada
}

Controlled Copy No.:

Revision No.: 0

July 2006 


\section{CLOSURE REPORT FOR \\ CORRECTIVE ACTION UNITS 530, 531, 532, 533, 534, 535: NTS MUD PITS, NEVADA TEST SITE, NEVADA}

Approved by: APPROVED SIGNATURE

Date: $7 / 3 / 2006$

Kevin J. Cabble

Federal Sub-Project Director

Environmental Restoration Project

Approved by: APPROVED SIGNATURE

Date: $7 / 3 / 2006$

Janet Appenzeller-Wing

Federal Project Director

Environmental Restoration Project 


\section{Table of Contents}

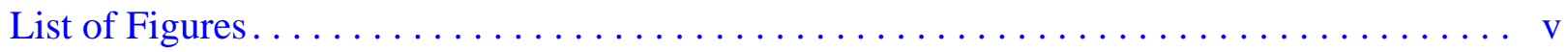

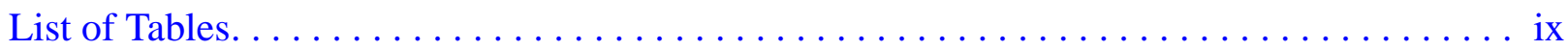

List of Acronyms and Abbreviations $\ldots \ldots \ldots \ldots \ldots \ldots \ldots \ldots \ldots \ldots \ldots \ldots \ldots \ldots \ldots \ldots \ldots \ldots \ldots$

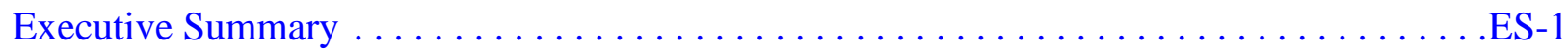

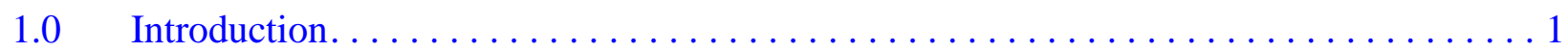

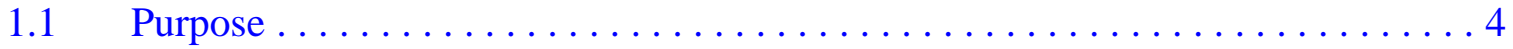

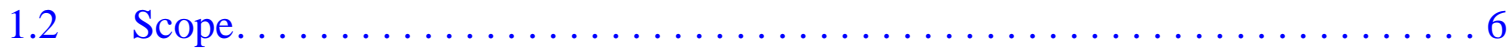

$1.3 \quad$ Closure Report Contents............................... 20

$2.0 \quad$ Closure Activities . . . . . . . . . . . . . . . . . . . . . . . . . . 22

$2.1 \quad$ Description of Corrective Action Activities ..................... 22

2.1.1 Environmental Sample Collection ...................... 22

2.1.1.1 Standard Activities . ...................... 23

2.1.1.1.1 Uncovered CASs . ............... 23

2.1.1.1.2 Covered CASs ................... 24

2.1.1.2 Corrective Action Site-Specific Activities ............ . 24

2.1.1.2.1 Determination of New Sample

Coordinates ................... 24

2.1.1.2.2 Samples Submitted for Radiological

Analyses ......................25 25

2.1.1.2.3 Collection of Biased Samples .......... 26

2.1.1.2.4 Samples Submitted for SVOC and

VOC Analysis ..................27

2.1.2 Visual Habitat Surveys.......................... 28

2.1.3 Waste Characterization......................... 28

2.1.4 Conceptual Site Model Validation ..................... 28

2.1.5 Housekeeping............................... 29

2.2 Deviations from SAFER Plan as Approved .................... 29

2.2.1 CAU 532, CAS 09-09-05 and CAS 09-09-15 . . . . . . . . . 29

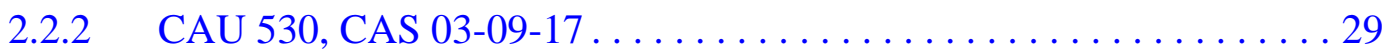

2.3 Corrective Action Schedule as Completed ...................... 30

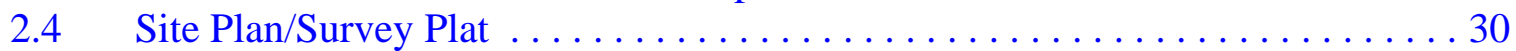

$3.0 \quad$ Waste Disposition..................................... 33

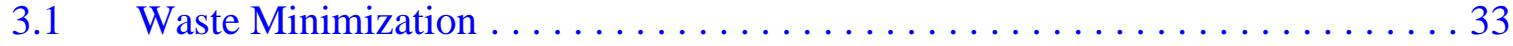

3.1.1 Characterization ................................. 33

3.1.2 Waste Streams ............................. 34

3.1 .3 Waste Sampling ............................. 34

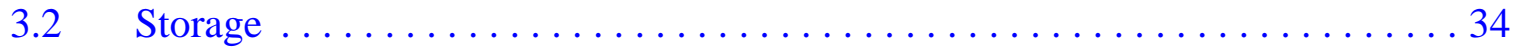




\section{Table of Contents (Continued)}

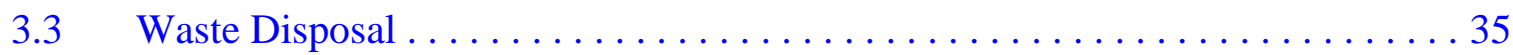

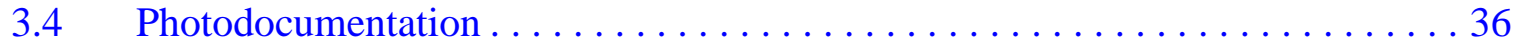

$3.5 \quad$ Housekeeping Activities............................... 36

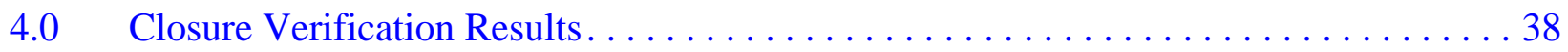

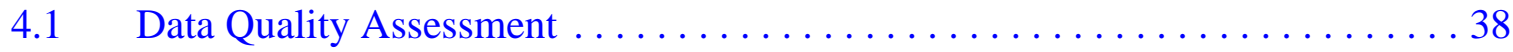

$4.2 \quad$ Use Restriction . . . . . . . . . . . . . . . . . . . . . . . . . . . . . . . . . 39

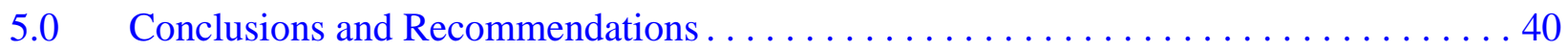

$5.1 \quad$ Justification for No Further Action....................... 40

5.2 Future Applications of Mud Pit Risk-Based Closure Strategy . . . . . . . . . . . . 40

$6.0 \quad$ References . . . . . . . . . . . . . . . . . . . . . . . . . . . . . . 42

Appendix A - Data Quality Objectives as Developed in the SAFER Plan for CAUs 530-535: Nevada Test Site Mud Pits, Nevada Test Site, Nevada

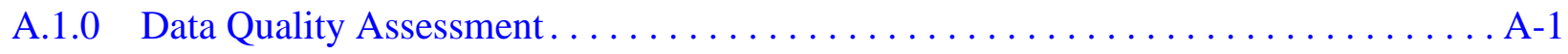

A.1.1 Step 1 - Review the DQOs and the Sampling Design $\ldots \ldots \ldots \ldots \ldots \ldots \ldots$ A-1

A.1.1.1 Review Closure Investigation Objectives . . . . . . . . . . . . A-1

A.1.1.2 Translate Objectives into Statistical Hypotheses . . . . . . . . . . . . . A-2

A.1.1.3 Develop Limits on Decision Errors . . . . . . . . . . . . . . A-5

A.1.1.4 Review Sampling Design ........................ A-7

A.1.2 Step 2 - Conduct a Preliminary Data Review . . . . . . . . . . . . . . . A-7

A.1.2.1 Review Quality Assurance Reports . . . . . . . . . . . . . . . . A-7

A.1.2.1.1 Data Quality Indicators . . . . . . . . . . . A-8

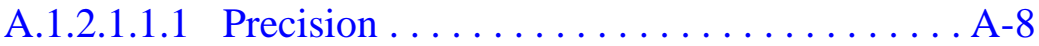

A.1.2.1.1.2 Accuracy................. A-9

A.1.2.1.1.3 Sensitivity $\ldots \ldots \ldots \ldots \ldots \ldots \ldots \ldots$ A-9

A.1.2.1.1.4 Comparability .............. A-10

A.1.2.1.1.5 Representativeness ............. A-11

A.1.2.1.1.6 Completeness ................ A-11

A.1.2.1.2 Statement of Acceptability and Usability . . . . . . . . A-12

A.1.2.2 Calculate Basic Statistical Quantities. . . . . . . . . . . . . . A A-12

A.1.2.3 Graph the Data .......................... A $\ldots \ldots$

A.1.3 Step 3 - Select the Statistical Test. . . . . . . . . . . . . . . . . . . . . A-14

A.1.3.1 Select Statistical Hypothesis Test. . . . . . . . . . . . . . . . A A-14

A.1.3.2 Identify Assumptions Underlying the Statistical Test . . . . . . . . . . A-15

A.1.4 Step 4 - Verify the Assumptions of the Statistical Test . . . . . . . . . . . . A-15

A.1.4.1 Determine an Approach for Verifying Assumptions . . . . . . . . . . A-15

A.1.4.2 Perform Tests of Assumptions ................. A-16 


\section{Table of Contents (Continued)}

A.1.4.3 Determine Corrective Actions ..................... A-17

A.1.5 Step 5 - Draw Conclusions from the Data $\ldots \ldots \ldots \ldots \ldots \ldots \ldots \ldots \ldots$ A-18

A.1.5.1 Perform the Statistical Hypothesis Test ................ A-18

A.1.5.2 Draw Closure Investigation Conclusions................ A-18

A.1.5.3 Evaluate Performance of the Sampling Design ............ A-20

A.2.0 References........................................... A-21

Appendix B - Closure Certification for CAUs 530-535: Nevada Test Site Mud Pits, Nevada Test Site, Nevada

B.1.0 Closure Certification..................................... B-1

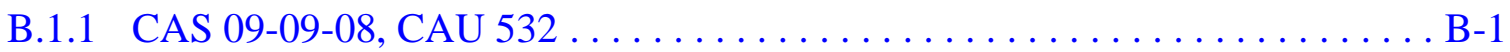

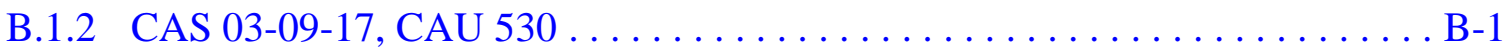

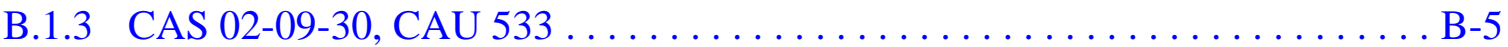

Appendix C - As-Built Documentation for CAUs 530-535: Nevada Test Site Mud Pits, Nevada Test Site, Nevada

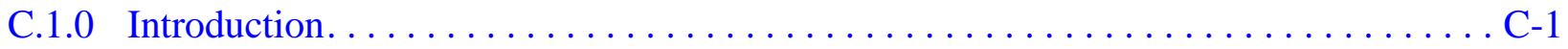

Appendix D - Confirmation Sampling Test Results for CAUs 530-535: Nevada Test Site Mud Pits, Nevada Test Site, Nevada

D.1.0 Introduction. . . . . . . . . . . . . . . . . . . . .

D.1.1 Soil Samples .................................... D-1

D.1.2 Aqueous Samples $\ldots \ldots \ldots \ldots \ldots \ldots \ldots \ldots \ldots \ldots \ldots \ldots \ldots \ldots \ldots \ldots \ldots \ldots \ldots \ldots$

D.2.0 References......................................... D

Appendix E - Waste Disposition Documentation for CAUs 530-535: Nevada Test Site Mud Pits, Nevada Test Site, Nevada

E.1.0 Waste Disposition. ................................... E-1

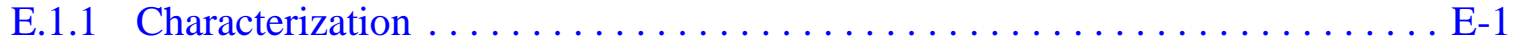

E.1.2 Waste Streams. ................................ E-1

E.1.3 Investigation-Derived Waste Generated. . . . . . . . . . . . . . . E-2

E.1.4 Waste Characterization Samples ........................ E-3

E.1.4.1 CAS 09-09-08, U-9yz-26 Mud Pit (2) ................... E-3

E.1.4.2 CAS 03-09-17, U-3hc Mud Pit (2).................. E-4

E.1.4.3 Decontamination Rinsate, Multiple CASs .............. E-4 


\section{Table of Contents (Continued)}

E.2.0 References................................... E

Appendix F - Modifications to the Post-Closure Plan for CAUs 530-535: Nevada Test Site Mud Pits, Nevada Test Site, Nevada

F.1.0 Modifications to the Post-Closure Plan $\ldots \ldots \ldots \ldots \ldots \ldots \ldots \ldots \ldots \ldots \ldots \ldots$ F-1

Appendix G - Evaluation of Risk for CAUs 530-535: Nevada Test Site Mud Pits, Nevada Test Site, Nevada

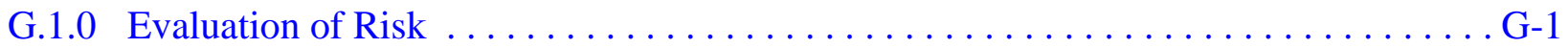

G.1.1 Human Receptors . . . . . . . . . . . . . . . . . . . . .

G.1.1.1 Exposure Assessment. ....................... . .

G.1.1.1.1 Exposure Point Concentrations . . . . . . . . . . G-3

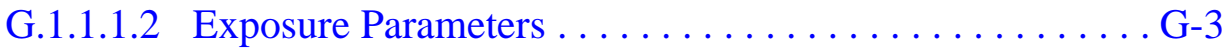

G.1.1.1.3. Chronic Daily Intake Results . . . . . . . . . . . . G-4

G.1.1.2 Toxicity Assessment. . . . . . . . . . . . . . . . . . . . G-4

G.1.1.3 Risk Assessment. . . . . . . . . . . . . . . . . . . . G-6

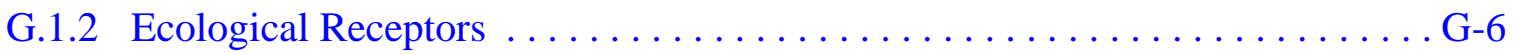

G.1.3 Conclusions.................................

G.2.0 RESRAD Calculations for CAS 09-09-24 . . . . . . . . . . . . . . . . . . . . G-11

G.3.0 References.................................. G-15

Attachment G - RESRAD Tables

Appendix H - Nevada Division of Environmental Protection Comments 


\section{List of Figures}

Number

Title

Page

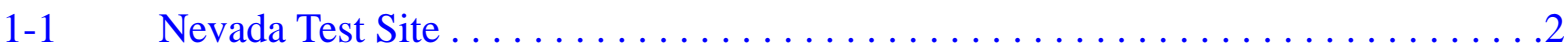

1-2 Location of NTS Mud Pits CASs in CAUs $530-535 \ldots \ldots \ldots \ldots \ldots \ldots$

2-1 Example Mud Pit Sample Distribution for a One- and Two-Pit System . . . . . . . 32

A.1-1 Cumulative Probability Distribution for TPH-DRO Concentrations at CAUs 530-535

A.1-2 Sign Test to Determine the Number of Samples Required for Decision A . . . A-17

B.1-1 Housekeeping Debris Removal CAS 09-09-08 ...................

B.1-2 Coal Tar Epoxy Debris Removal, CAS 03-09-17. ................... B-4

C.1-1 CAS 01-09-02 Sample Locations .........................

C.1-2 CAS 01-09-04 Sample Locations . . . . . . . . . . . . . . . . . . C-4

C.1-3 CAS 02-09-03 Sample Locations .........................

C.1-4 CAS 02-09-09 Sample Locations . . . . . . . . . . . . . . . . . . C-6

C.1-5 CAS 02-09-12 Sample Locations .........................

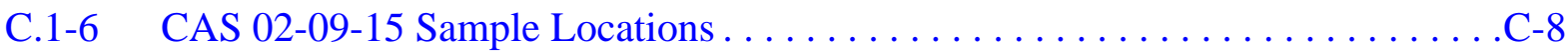

C.1-7 CAS 02-09-18 Sample Locations . ........................

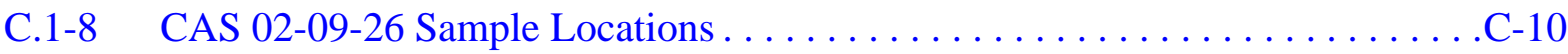

C.1-9 CAS 02-09-30 Sample Locations . . . . . . . . . . . . . . . . . . . C-11

C.1-10 CAS 02-09-33 Sample Locations . . . . . . . . . . . . . . . . . . . . . C-12 


\section{List of Figures (Continued)}

Number

C.1-11 CAS 02-09-52 Sample Locations

C.1-12 CAS 03-09-15 Sample Locations

C.1-13 CAS 03-09-17 Sample Locations

C.1-14 CAS 03-09-21 Sample Locations C-16

C.1-15 CAS 03-09-30 Sample Locations C-17

C.1-16 CAS 04-09-06 Sample Locations

C.1-17 CAS 04-09-08 Sample Locations

C.1-18 CAS 04-09-14 Sample Locations

C.1-19 CAS 04-09-18 Sample Locations

C.1-20 CAS 05-09-02 Sample Locations

C.1-21 CAS 06-09-02 Sample Locations

C.1-22 CAS 07-09-10 Sample Locations C-24

C.1-23 CAS 07-09-13 Sample Locations C-25

C.1-24 CAS 07-09-22 Sample Locations C-26

C.1-25 CAS 07-09-25 Sample Locations

C.1-26 CAS 07-09-27 Sample Locations

C.1-27 CAS 07-09-28 Sample Locations 


\section{List of Figures (Continued)}

Number

C.1-28 CAS 08-09-06 Sample Locations

C.1-29 CAS 09-09-15 Sample Locations

C.1-30 CAS 09-09-10 Sample Locations

C.1-31 CAS 09-09-16 Sample Locations

C.1-32 CAS 09-09-20 Sample Locations C-34

C.1-33 CAS 09-09-23 Sample Locations C-35

C.1-34 CAS 09-09-24 Sample Locations C-36

C.1-35 CAS 09-09-27 Sample Locations

C.1-36 CAS 09-09-35 Sample Locations

C.1-37 CAS 09-09-40 Sample Locations

C.1-38 CAS 09-09-42 Sample Locations C-40

C.1-39 CAS 10-09-12 Sample Locations C-41

C.1-40 CAS 10-09-18 Sample Locations C-42

C.1-41 CAS 10-09-26 Sample Locations C-43

C.1-42 CAS 14-09-02 Sample Locations C-44

C.1-43 CAS 19-09-12 Sample Locations C-45

C.1-44 CAS 19-09-17 Sample Locations C-46 


\section{List of Figures (Continued)}

Number

Title

Page

C.1-45 CAS 19-09-19 Sample Locations

C.1-46 CAS 19-09-27 Sample Locations C-48

C.1-47 CAS 20-09-15 Sample Locations C-49

C.1-48 CAS 20-09-27 Sample Locations C-50

C.1-49 CAS 20-09-31 Sample Locations C-51

C.1-50 CAS 20-09-35 Sample Locations C-52

C.1-51 CAS 20-09-40 Sample Locations C-53

C.1-52 CAS 20-09-46 Sample Locations C-54

G.2-1 CAS 09-09-24 Dose Contribution, All Radionulides Summed, All Pathways Summed.

G.2-2 CAS 09-09-24 Dose Contribution, All Radionulides Summed, All Component Pathways 


\section{List of Tables}

Number

Title

Page

1-1 Summary of Characterization Activities Conducted at CAUs 530-535 . . . . . 7

2-1 CAUs 530-535 SAFER Investigation Schedule as Completed . . . . . . . . . 31

3-1 Non-Hazardous Debris Removed During SAFER Activities . . . . . . . . . 36

A.1-1 Calculation of the Maximum Allowable Mean TPH-DRO Concentration ..... A-3

A.1-2 Hypotheses Statements for Decision A . . . . . . . . . . . . A-4

A.1-3 Hypotheses Statements for Decision B . . . . . . . . . . . . A-5

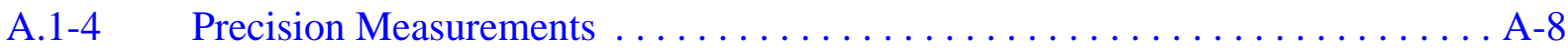

A.1-5 Accuracy Measurements $\ldots \ldots \ldots \ldots \ldots \ldots \ldots \ldots \ldots \ldots \ldots \ldots \ldots$

A.1-6 Analytes Failing Sensitivity Criteria $\ldots \ldots \ldots \ldots \ldots \ldots \ldots \ldots \ldots \ldots$ A-10

A.1-7 Hypothesis Test Results Supporting Decision A. . . . . . . . . . . . . . A-19

B.1-1 Soil Waste Results for TCLP Lead Detected above Minimum Detectable Concentration Limits at CAS 09-09-08, U-9yz-26 Mud Pit (2) . . . . . . . . . B-3

B.1-2 Soil Sample Results for SVOCs Detected Above Minimum Detectable Concentration Limits at CAS 03-09-17, U-3hc Mud Pit (2) . . . . . . . . . . . B-5

C.1-1 As-Built Drawings for CAU 530-535 Corrective Action Sites . . . . . . . . . C-1

D.1-1 Samples Collected at CAS 01-09-02, U-1e Mud Pit (2) . . . . . . . . . D-2

D.1-2 Soil Samples Results for TPH-DRO at CAS 01-09-02, U-1e Mud Pit (2) ..... D-3 


\section{List of Tables (Continued)}

Number

Title

Page

D.1-3 Soil Sample Results for Gamma-Emitting Radionuclides Detected Above Minimum Detectable Concentration Limits at CAS 01-09-02,

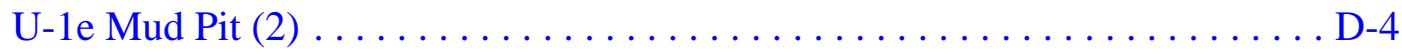

D.1-4 Soil Sample Results for Isotopic Uranium Detected Above

Minimum Detectable Concentration Limits at CAS 01-09-02,

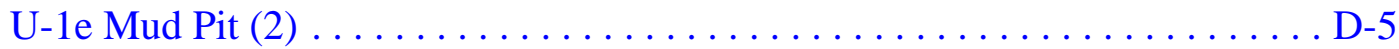

D.1-5 Samples Collected at CAS 01-09-04, UE-1L Mud Pit (1) . . . . . . . . . . D-6

D.1-6 Soil Sample Results for TPH-DRO at CAS 01-09-04, UE-1L Mud Pit (1) . . . D-7

D.1-7 Soil Sample Results for Gamma-Emitting Radionuclides Detected

Above Minimum Detectable Concentration Limits at CAS 01-09-04,

UE-1L Mud Pit (1). . . . . . . . . . . . . . . . . . . . . . D-8

D.1-8 Soil Sample Results for Isotopic Uranium Detected Above Minimum

Detectable Concentration Limits at CAS 01-09-04, UE-1L Mud Pit (1) . . . . . D-8

D.1-9 Samples Collected at CAS 02-09-03, U-2dc \#4 PS \#1A Covered

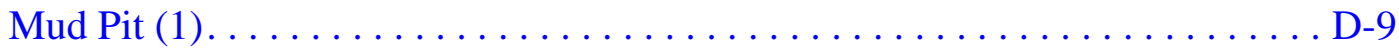

D.1-10 Soil Sample Results for TPH-DRO at CAS 02-09-03, U-2dc \#4 PS \#1A

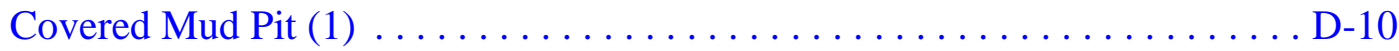

D.1-11 Samples Collected at CAS 02-09-09, U-2az \#2 Mud Pit (2). . . . . . . . . . D-11

D.1-12 Soil Sample Results for TPH-DRO at CAS 02-09-09, U-2az \#2

Mud Pit (2) . . . . . . . . . . . . . . . . . . . . . . . . . D-12

D.1-13 Samples Collected at CAS 02-09-12, U-2gd Mud Pit (1) . . . . . . . . . . D-13

D.1-14 Soil Sample Results for TPH-DRO at CAS 02-09-12, U-2gd Mud Pit (1). . . D-14 


\section{List of Tables (Continued)}

Number

D.1-15 Samples Collected at CAS 02-09-15, U-2do Mud Pit (1)

D.1-16

D.1-17

D.1-18

D.1-19

D.1-20

D.1-21

D.1-22

D.1-23

D.1-24

D.1-25

D.1-26

Soil Sample Results for TPH-DRO at CAS 02-09-33, U-2er PS \#1A

Covered Mud Pit (1)

D.1-27

Samples Collected at CAS 02-09-52, U-2dc \#1 PS \#1A Mud Pit (1) . .

D-26

D.1-28
Title

Page

$$
\text { Soil Sample Results for TPH-DRO at CAS 02-09-15, U-2do Mud Pit (1)... D-16 }
$$

Samples Collected at CAS 02-09-18, U-2ez Mud Pit (1)

D-17

Soil Sample Results for TPH-DRO at CAS 02-09-18, U-2ez Mud Pit (1) . . . D-18

Samples Collected at CAS 02-09-26, U-2cv Mud Pit (1)

D-19

Soil Sample Results for TPH-DRO at CAS 02-09-26, U-2cv Mud Pit (1) . . . D-20

Soil Sample Results for Gamma-Emitting Radionuclides Detected

Above Minimum Detectable Concentration Limits at CAS 02-09-26,

U-2cv Mud Pit (1)

Soil Sample Results for Isotopic Uranium Detected Above Minimum

Detectable Concentration Limits at CAS 02-09-26, U-2cv Mud Pit (1).... . . D-21

Samples Collected at CAS 02-09-30, U-2dp PS \#1A Mud Pit (1) ........ D-22

Soil Sample Results for TPH-DRO at CAS 02-09-30, U-2dp PS \#1A

Mud Pit (1)

Samples Collected at CAS 02-09-33, U-2er PS \#1A Covered Mud Pit (1) ... D-24

Soil Sample Results for TPH-DRO at CAS 02-09-52, U-2dc \#1 PS \#1A

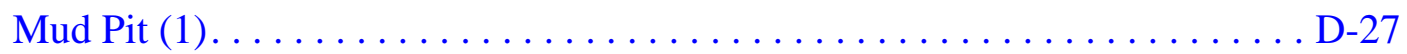




\section{List of Tables (Continued)}

Number

D.1-29

D.1-30

D.1-31

D.1-32

D.1-33

D.1-34

D.1-35

D.1-36

D.1-37

D.1-38

D.1-39

D.1-40

D.1-41

Soil Sample Results for TPH-DRO at CAS 04-09-06, U-4uPS \#1A

Covered Mud Pit (1) D-40

D.1-42

Title

Page

Soil Sample Results for Gamma-Emitting Radionuclides Detected Above

Minimum Detectable Concentration Limits at CAS 02-09-52,

U-2dc \#1 PS \#1A Mud Pit (1) ............................. D-28

Soil Sample Results for Isotopes Detected Above Minimum

Detectable Concentration Limits at CAS 02-09-52, U-2dc \#1 PS \#1A

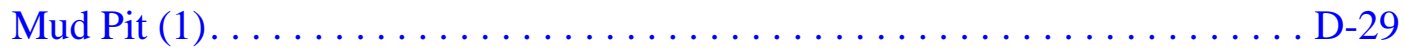

Samples Collected at CAS 03-09-15, U-3kL Mud Pit (2)............ D-30

Soil Sample Results for TPH-DRO at CAS 03-09-15, U-3kL Mud Pit (2). . . D-31

Samples Collected at CAS 03-09-17, U-3hc Mud Pit (2) ........... D-32

Soil Sample Results for TPH-DRO at CAS 03-09-17, U-3hc Mud Pit (2) . . . D-33

Soil Sample Results for Total SVOCs Detected Above Minimum

Reporting Limits at CAS 03-09-17, U-3hc Mud Pit (2) ............ D-34

Samples Collected at CAS 03-09-21, U-3gv Mud Pit (2) ............ D-35

Soil Sample Results for TPH-DRO at CAS 03-09-21, U-3gv Mud Pit (2) . . . D-36

Samples Collected at CAS 03-09-30, UE-3Lj/Inst. Mud Pit (1) . . . . . . . D-37

Soil Sample Results for TPH-DRO at CAS 03-09-30, UE-3Lj/Inst.

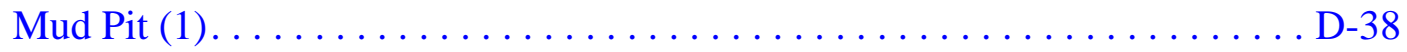

Samples Collected at CAS 04-09-06, U-4uPS \#1A Covered Mud Pit (1) . . . D-39

Samples Collected at CAS 04-09-08, U-4ad Mud Pit (1) . . . . . . . . . D-41 


\section{List of Tables (Continued)}

Number

D.1-43

D.1-44

D.1-45

D.1-46

D.1-47

D.1-48

D.1-49

D.1-50

D.1-51

D.1-52

D.1-53

D.1-54

D.1-55

D.1-56

Samples Collected at CAS 07-09-22, U-7bw Mud Pit (3) D-55

D.1-57

D.1-58
Title

Page
Samples Collected at CAS 04-09-14, U-4av PS \#1A Covered

Mud Pit (1)...

Soil Sample Results for TPH-DRO at CAS 04-09-14, U-4av PS \#1A

Covered Mud Pit (1)

Samples Collected at CAS 04-09-18, UE-4ai Mud Pit (1) . . . . . . . . . D-45

Soil Sample Results for TPH-DRO at CAS 04-09-18, UE-4ai Mud Pit (1) . . D D-46

Samples Collected at CAS 05-09-02, RNM \#1 Mud Pit (1) .......... D-47

Soil Sample Results for TPH-DRO at CAS 05-09-02, RNM \#1 Mud Pit (1) . D-48

Samples Collected at CAS 06-09-02, U-6f Mud Pit (2) . . . . . . . . . D-49

Soil Sample Results for TPH-DRO at CAS 06-09-02, U-6f Mud Pit (2) . . . . D-50

Samples Collected at CAS 07-09-10, U-7aw Mud Pit (2). . . . . . . . . D-51

Soil Sample Results for TPH-DRO at CAS 07-09-10, U-7aw Mud Pit (2) . . D-52

Samples Collected at CAS 07-09-13, U-7bz Mud Pit (2) . . . . . . . . D-53

Soil Sample Results for TPH-DRO at CAS 07-09-13, U-7bz Mud Pit (2) . . . D-54

Soil Sample Results for TPH-DRO at CAS 07-09-22, U-7bw Mud Pit (3) . . D-56

Samples Collected at CAS 07-09-25, U-7i PS \#2D Covered Mud Pit (1) . . . D-57 


\section{List of Tables (Continued)}

Number

D.1-59

Soil Sample Results for TPH-DRO at CAS 07-09-25, U-7i PS \#2D

Covered Mud Pit (1)

Title

Page

D.1-60 Samples Collected at CAS 07-09-27, UE-7k Mud Pit (1). . . . . . . . . . D-59

D.1-61 Soil Sample Results for TPH-DRO at CAS 07-09-27, UE-7k

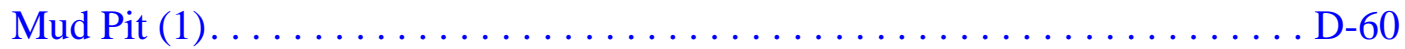

D.1-62 Samples Collected at CAS 07-09-28, Unknown \#12

Mud Pit/Disposal Area.............................. D-61

D.1-63 Soil Sample Results for TPH-DRO at CAS 07-09-28, Unknown \#12

Mud Pit/Disposal Area.............................

D.1-64 Samples Collected at CAS 08-09-06, UE-8e \#2 Mud Pit (1) . . . . . . . . . D-63

D.1-65 Soil Sample Results for TPH-DRO at CAS 08-09-06, UE-8e \#2 Mud Pit (1) . D-64

D.1-66 Samples Collected at CAS 09-09-10, U-9 ITS S-25 Mud Pit (2) . . . . . . . . D-65

D.1-67 Soil Sample Results for TPH-DRO at CAS 09-09-10, U-9 ITS S-25

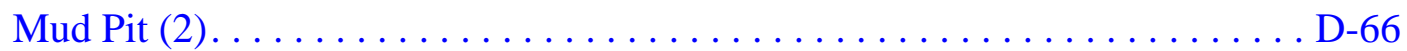

D.1-68 Samples Collected at CAS 09-09-15, U-9 ITS X-22 Mud Pit (2) . . . . . . . . D-67

D.1-69 Soil Sample Results for TPH-DRO at CAS 09-09-15, U-9 ITS X-22

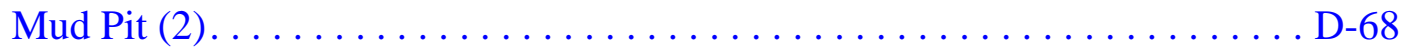

D.1-70 Samples Collected at CAS 09-09-16, U-9 ITS Z-21 Mud Pit (2) . . . . . . . D-69

D.1-71 Soil Sample Results for TPH-DRO at CAS 09-09-16, U-9 ITS Z-21

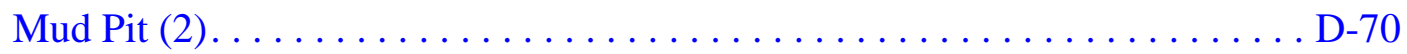

D.1-72 Samples Collected at CAS 09-09-20, U-9 ITS Z-24 Mud Pit (2) . . . . . . . D-71 


\section{List of Tables (Continued)}

D.1-73 Soil Sample Results for TPH-DRO at CAS 09-09-20, U-9 ITS Z-24

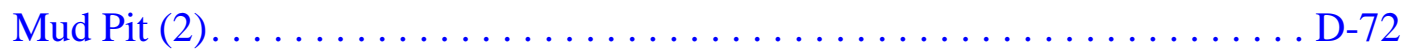

D.1-74 Samples Collected at CAS 09-09-23, U-9 ITS Y-30 Mud Pit (2) . . . . . . . D-73

D.1-75 Soil Sample Results for TPH-DRO at CAS 09-09-23, U-9 ITS Y-30

Mud Pit (2) . . . . . . . . . . . . . . . . . . . . . . . . . . . . D-74

D.1-76 Samples Collected at CAS 09-09-24, U-9 ITS V-24 PS \#1A

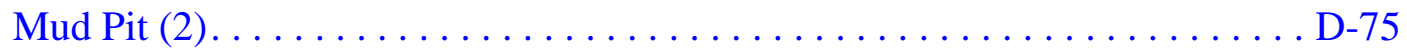

D.1-77 Soil Sample Results for TPH-DRO at CAS 09-09-24,

U-9 ITS V-24 PS \#1A Mud Pit (2) ....................... D-76

D.1-78 Soil Sample Results for Gamma-Emitting Radionuclides Detected Above

Minimum Detectable Concentration Limits at CAS 09-09-24,

U-9 ITS V-24 PS \#1A Mud Pit (2) ..................... D-77

D.1-79 Soil Sample Results for Isotopes Detected Above Minimum Detectable

Concentration Limits at CAS 09-09-24, U-9 ITS V-24 PS \#1A

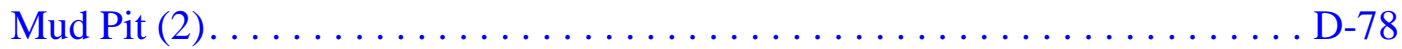

D.1-80 Samples Collected at CAS 09-09-27, U-9yz-26 PS \#1A Mud Pit (1). . . . . . D D-79

D.1-81 Soil Sample Results for TPH-DRO at CAS 09-09-27, U-9yz-26 PS \#1A

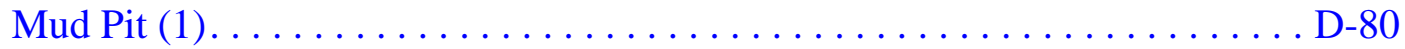

D.1-82 Samples Collected at CAS 09-09-35, U-9bi \#1 PS \#1A Mud Pit (1) . . . . . . . D-81

D.1-83 Soil Sample Results for TPH-DRO at CAS 09-09-35, U-9bi \#1 PS \#1A

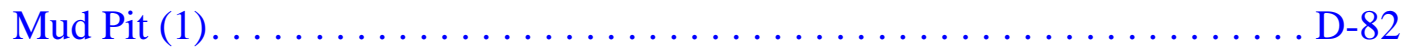

D.1-84 Samples Collected at CAS 09-09-40, U-9cu Grout Test Mud Pit (1) . . . . . . . D-83 


\section{List of Tables (Continued)}

Number

D.1-85

D.1-86

D.1-87

D.1-88

D.1-89

D.1-90

D.1-91

D.1-92

D.1-93

D.1-94 Samples Collected at CAS 14-09-02, UE-14a Mud Pit (1)

D.1-95 Soil Sample Results for TPH-DRO at CAS 14-09-02, UE-14a

Mud Pit (1).

Mud Pit (1).

Title

Page

Soil Sample Results for TPH-DRO at CAS 09-09-40, U-9cu

Grout Test Mud Pit (1).

Samples Collected at CAS 09-09-42, U-9bm PS \#1A Mud Pit (1)......... D-85

Samples Collected at CAS 10-09-12, U-10d Mud Pit (2) .

D-87

Soil Sample Results for TPH-DRO at CAS 10-09-12, U-10d Mud Pit (2) . . . D-88

Samples Collected at CAS 10-09-18, U-10ap \#3 PS \#1A Mud Pit (1) . . . . . D-89

Soil Sample Results for TPH-DRO at CAS 10-09-18, U-10ap \#3 PS \#1A

Mud Pit (1)...

D-90

Samples Collected at CAS 10-09-26, U-10aj Mud Pit (1)

D-91

Soil Sample Results for TPH-DRO at CAS 10-09-26, U-10aj

Mud Pit (1). .

D.1-96 Samples Collected at CAS 19-09-12, U-19q Mud Pit (1) . . D-95

D.1-97 Soil Sample Results for TPH-DRO at CAS 19-09-12, U-19q

Mud Pit (1)...

D.1-98 Samples Collected at CAS 19-09-17, U-19bj Mud Pit (1) D-97 


\section{List of Tables (Continued)}

Number

D.1-99

D.1-100

D.1-101

D.1-102

D.1-103

Soil Sample Results for TPH-DRO at CAS 19-09-27, U-19zS PS \#1D

Covered Mud Pit (1) ................................

D.1-104 Samples Collected at CAS 20-09-15, U-20au Mud Pit (1) .

D.1-105

Soil Sample Results for TPH-DRO at CAS 20-09-15, U-20au Mud Pit (1) . D-104

D.1-106

Samples Collected at CAS 20-09-27, U-20aj PS \#1A Mud Pit (1). .

D-105

D.1-107

Soil Sample Results for TPH-DRO at CAS 20-09-27, U-20aj PS \#1A

Mud Pit (1)...

D.1-108 Samples Collected at CAS 20-09-31, U-20aq PS \#1A Covered

Mud Pit (1)...

D.1-109 Soil Sample Results for TPH-DRO at CAS 20-09-31, U-20aq PS \#1A

Covered Mud Pit (1) ...............................

D.1-110 Samples Collected at CAS 20-09-35, U-20ax PPS \#1A Mud Pit (1) . . . . . . D-109

D.1-111 Soil Sample Results for TPH-DRO at CAS 20-09-35, U-20ax PPS \#1A

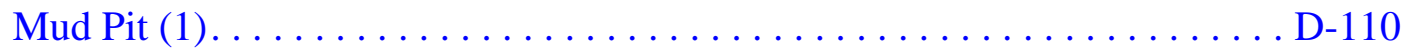

\section{Uncontrolled When Printed}




\section{List of Tables (Continued)}

Number

Title

Page

D.1-112 Samples Collected at CAS 20-09-40, UE-20n \#1 Mud Pit (1)

D.1-113 Soil Sample Results for TPH-DRO at CAS 20-09-40, UE-20n \#1

Mud Pit (1)...

D.1-114 Samples Collected at CAS 20-09-46, Unknown \#14

Mud Pit/Disposal Area.

D.1-115 Soil Samples Results for TPH-DRO at CAS 20-09-46, Unknown \#14

Mud Pit/Disposal Area.............................. D-114

G.1-1 Exposure Parameters for the Risk Assessment $\ldots \ldots \ldots \ldots \ldots \ldots \ldots$ G-4

G.1-2 Reference Doses for TPH-DRO $\ldots \ldots \ldots \ldots \ldots \ldots \ldots \ldots \ldots \ldots \ldots \ldots \ldots \ldots$

G.1-3 Risk Assessment Results for the Industrial Area Reuse Scenario . . . . . . . . . G-8

G.2-1 Maximum Annual Dose Contributions for CAS 09-09-24 Using Remote

Work Area Scenario (occurs at year zero) (mrem/yr) . . . . . . . . . . G-12

G.2-2 CAS 09-09-24 Sum of Fractions and Proportional Scaling (Single Radionuclide Guidelines) . . . . . . . . . . . . . . . . . . . G-14 


\section{List of Acronyms and Abbreviations}

\begin{tabular}{|c|c|}
\hline bgs & Below ground surface \\
\hline CAS & Chemical Abstracts Service \\
\hline CAS & Corrective Action Site \\
\hline CAU & Corrective Action Unit \\
\hline CDI & Chronic daily intake \\
\hline $\mathrm{CF}$ & Correction factor \\
\hline $\mathrm{cm}$ & Centimeter \\
\hline COPC & Contaminant of potential concern \\
\hline CR & Closure Report \\
\hline Cs & Cesium \\
\hline CSM & Conceptual site model \\
\hline CTE & Coal tar epoxy \\
\hline DOE & U.S. Department of Energy \\
\hline DOT & U.S. Department of Transportation \\
\hline DQA & Data quality assessment \\
\hline DQO & Data quality objective \\
\hline DQI & Data quality indicators \\
\hline DRO & Diesel-range organics \\
\hline $\mathrm{Eu}$ & Europium \\
\hline $\mathrm{EZ}$ & Exclusion zone \\
\hline FFACO & Federal Facility Agreement and Consent Order \\
\hline FSL & Field-screening level \\
\hline FSR & Field-screening result \\
\hline $\mathrm{ft}$ & Foot \\
\hline gal & Gallon \\
\hline GPS & Global Positioning System \\
\hline
\end{tabular}




\section{List of Acronyms and Abbreviations (Continued)}

Нa

HAA

HE

HI

Ho

HQ

HWAA

IDW

LANL

$\mathrm{lb}$

LLNL

LLW

$\mathrm{M \& O}$

MACC

MADEP

MAMC

MDC

$\mathrm{mg} / \mathrm{kg}$

mi

$\mathrm{mrem} / \mathrm{yr}$

MS/MSD

N/A

NAD27

NDEP

NNSA/NSO

NTS
Alternate hypothesis

Hydrocarbon Accumulation Area

High explosives

Hazard Index

Null hypothesis

Hazard Quotient

Hazardous waste accumulation area

Investigation-derived waste

Los Alamos National Laboratory

Pound

Lawrence Livermore National Laboratory

Low-level waste

Management and Operating

Maxiumum allowable characteristic concentration

Massachusetts Department of Environmental Protection

Maximum allowable mean concentration

Minimum detectable concentration

Milligrams per kilogram

Mile

Millirem per year

Matrix spike/matrix spike duplicate

Not applicable

North American Datum of 1927

Nevada Division of Environmental Protection

U.S. Department of Energy, National Nuclear Security Administration Nevada Site Office

Nevada Test Site 


\section{List of Acronyms and Abbreviations (Continued)}

\begin{tabular}{|c|c|}
\hline PAL & Preliminary action level \\
\hline $\mathrm{Pb}$ & Lead \\
\hline $\mathrm{pCi} / \mathrm{g}$ & Picocuries per gram \\
\hline PID & Photoionization detector \\
\hline PPE & Personal protective equipment \\
\hline ppm & Part per million \\
\hline PRG & Preliminary remediation goal \\
\hline $\mathrm{Pu}$ & Plutonium \\
\hline QA & Quality assurance \\
\hline QAPP & Quality Assurance Project Plan \\
\hline QC & Quality control \\
\hline RBCSR & Risk-Based Closure Strategy Report \\
\hline $\mathrm{RCA}$ & Radiological Contamination Area \\
\hline RCRA & Resource Conservation and Recovery Act \\
\hline RESRAD & Residual Radioactive computer code \\
\hline RMA & Radioactive Materials Area \\
\hline ROTC & Record of Technical Change \\
\hline RPD & Relative percent difference \\
\hline SAA & Satellite Accumulation Area \\
\hline SAFER & Streamlined Approach for Environmental Restoration \\
\hline SBMS & Standards-Based Management System \\
\hline SNJV & Stoller-Navarro Joint Venture \\
\hline $\mathrm{Sr}$ & Strontium \\
\hline SVOC & Semivolatile organic compound \\
\hline TCLP & Toxicity Charateristic Leaching Procedure \\
\hline TPH & Total petroleum hydrocarbons \\
\hline
\end{tabular}




\section{List of Acronyms and Abbreviations (Continued)}

$\mathrm{U}$

Uranium

UCL

Upper confidence limit

UTM

Universal Transverse Mercator

VOC

Volatile organic compound

VSP

Visual Sample Plan

$\mathrm{yd}^{3}$

Cubic yard

$\mu \mathrm{g} / \mathrm{kg}$

Micrograms per kilograms 


\section{Executive Summary}

This Closure Report (CR) presents information supporting the recommendation of no further action for the following six Corrective Action Units (CAUs):

- CAU 530 - LANL Preshot Mud Pits

- CAU 531 - LANL Postshot Mud Pits

- CAU 532 - LLNL Preshot Mud Pits

- CAU 533 - LLNL Postshot Mud Pits

- CAU 534 - Exploratory/Instrumentation Mud Pits

- CAU 535 - Mud Pits/Disposal Areas

This CR complies with the requirements of the Federal Facility Agreement and Consent Order (FFACO) (1996) that was agreed to by the State of Nevada, the U.S. Department of Energy, and the U.S. Department of Defense. CAUs 530-535 are located in Areas 1-10, 14, 17, 19, and 20 of the Nevada Test Site and are comprised of 268 Corrective Action Sites (CASs) listed in Table 1-1.

The purpose of this CR is to validate the risk-based closure strategy presented in the Mud Pit Risk-Based Closure Strategy Report (RBCSR) (NNSA/NSO, 2004) and the CAUs 530-535 SAFER Plan (NNSA/NSO, 2005b). This strategy uses 52 CASs as a statistical representation of CAUs 530-535 to confirm the proposed closure alternative, no further action, is sufficient to protect human health and the environment. This was accomplished with the following activities:

- A field investigation following a probabilistic sampling design to collect data that were used in a non-carcinogenic risk assessment for human receptors

- Visual habitat surveys to confirm the lack of habitat for threatened and endangered species

- Disposal of debris and waste generated during field activities

- Document Notice of Completion and closure of CAUs 530-535 issued by Nevada Division of Environmental Protection.

The field investigation and site visits were conducted between August 31, 2005 and February 21, 2006. As stated in the RBCSR and Streamlined Approach for Environmental Restoration (SAFER) Plan, total petroleum hydrocarbons-diesel-range organics (TPH-DRO) was the only contaminant of potential concern identified for CAUs 530-535. This analyte was detected in 22 percent of the soil samples, but the risk assessment confirmed that the reported levels did not pose 
an unacceptable risk to human receptors (i.e., the associated Hazard Index for each CAS is $\leq 1.0$ ). A data quality assessment was performed on the collected TPH-DRO data to confirm they were of sufficient quality and quantity to satisfy the data quality objective decisions. The collected dataset met all the criteria specified in the SAFER Plan. Visual habitat surveys were conducted at 201 CASs and confirmed that the mud pit CASs are not suitable habitat for threatened or endangered species. Based on these activities, there is also no unacceptable risk to ecological receptors. These results support the recommended closure alternative of no further action for the 268 CASs within CAUs 530-535. Therefore, the U.S. Department of Energy, National Nuclear Security Administration Nevada Site Office provides the following recommendations:

- No corrective actions and no Corrective Action Plan are required at CAUs 530, 531, 532, 533, 534, and 535.

- $\quad$ No use restrictions are required at CAUs 530-535.

- $\quad$ No further action is required at CAUs 530, 531, 532, 533, 534, and 535.

- A Notice of Completion is requested from the Nevada Division of Environmental Protection for the closure of CAUs 530, 531, 532, 533, 534, and 535.

- $\quad$ CAUs 530-535 should be moved from Appendix III to Appendix IV of the FFACO.

This CR also documents housekeeping activities conducted at CAS 09-09-08 in CAU 532 to remove debris not related to drilling or mud pit operations. These activities consisted of removing two lead acid batteries from the CAS for recycling, proper disposal of the soil directly under the former battery locations, and collection of verification samples following removal of the soil.

This closure investigation has shown that TPH-DRO is not a contaminant of concern at Nevada Test Site mud pit CASs. According to the conclusions and recommendations in the RBCSR and SAFER Plan, CASs identified in the future should be transferred directly from Appendix II to Appendix IV of the FFACO provided the following criteria is met:

- The CAS is either a single mud pit or a system of mud pits.

- The CAS is not located in a radiological or radioactive material posted area.

- The CAS does not serve as habitat for threatened and endangered species.

- There are no biasing factors evident based on a visual inspection. 


\subsection{Introduction}

This report details the closure investigation, closure activities, and analytical results for Corrective Action Units (CAUs) 530, 531, 532, 533, 534, and 535, Nevada Test Site (NTS) Mud Pits, NTS, Nevada. The NTS is located approximately 65 miles (mi) northwest of Las Vegas, Nevada (Figure 1-1). The six mud pit CAUs were established based on sponsoring agency and historical drilling practices and include the following:

- CAU 530 - LANL Preshot Mud Pits

- CAU 531 - LANL Postshot Mud Pits

- $\quad$ CAU 532 - LLNL Preshot Mud Pits

- $\quad$ CAU 533 - LLNL Postshot Mud Pits

- $\quad$ CAU 534 - Exploratory/Instrumentation Mud Pits

- $\quad$ CAU 535 - Mud Pits/Disposal Areas

CAUs 530-535 are comprised of 268 Corrective Action Sites (CASs) located in Areas 1-10, 14, 17, 19, and 20 of the NTS (Figure 1-2) and listed in Table 1-1.

Closure investigation activities were conducted in accordance with the CAUs 530-535 Streamlined Approach for Environmental Restoration (SAFER) Plan (NNSA/NSO, 2005b), herein referred to as the SAFER Plan, that was developed under the Federal Facility Agreement and Consent Order (FFACO) (1996). The SAFER Plan is based upon the Mud Pit Risk-Based Closure Strategy Report (RBCSR) (NNSA/NSO, 2004) that was approved by the Nevada Division of Environmental Protection (NDEP) in August 2004. The RBCSR recommended that: (1) total petroleum hydrocarbons (TPH)-diesel-range organics (DRO) be considered the only contaminant of potential concern (COPC); (2) the risk to human receptors be evaluated through a risk assessment; and (3) with an acceptable decision error, only a portion of the CASs in CAUs 530-535 need be characterized in order to represent all the CASs within CAUs 530-535. Acceptance sampling was used to determine that 52 CASs needed to be characterized following a probabilistic sampling approach to statistically represent all 268 CASs in CAUs 530-535. Another statistical test, called the Sign Test, was used to estimate that 10 samples from each CAS were adequate for characterization. Using this risk-based strategy, if all 52 sampled mud pit CASs do not pose an unacceptable risk, then there is a 90 percent probability that the remaining 216 CASs in CAUs 530-535 also do not pose an unacceptable risk. Therefore, all 268 CASs in CAUs 530-535 can be closed with no further action. 


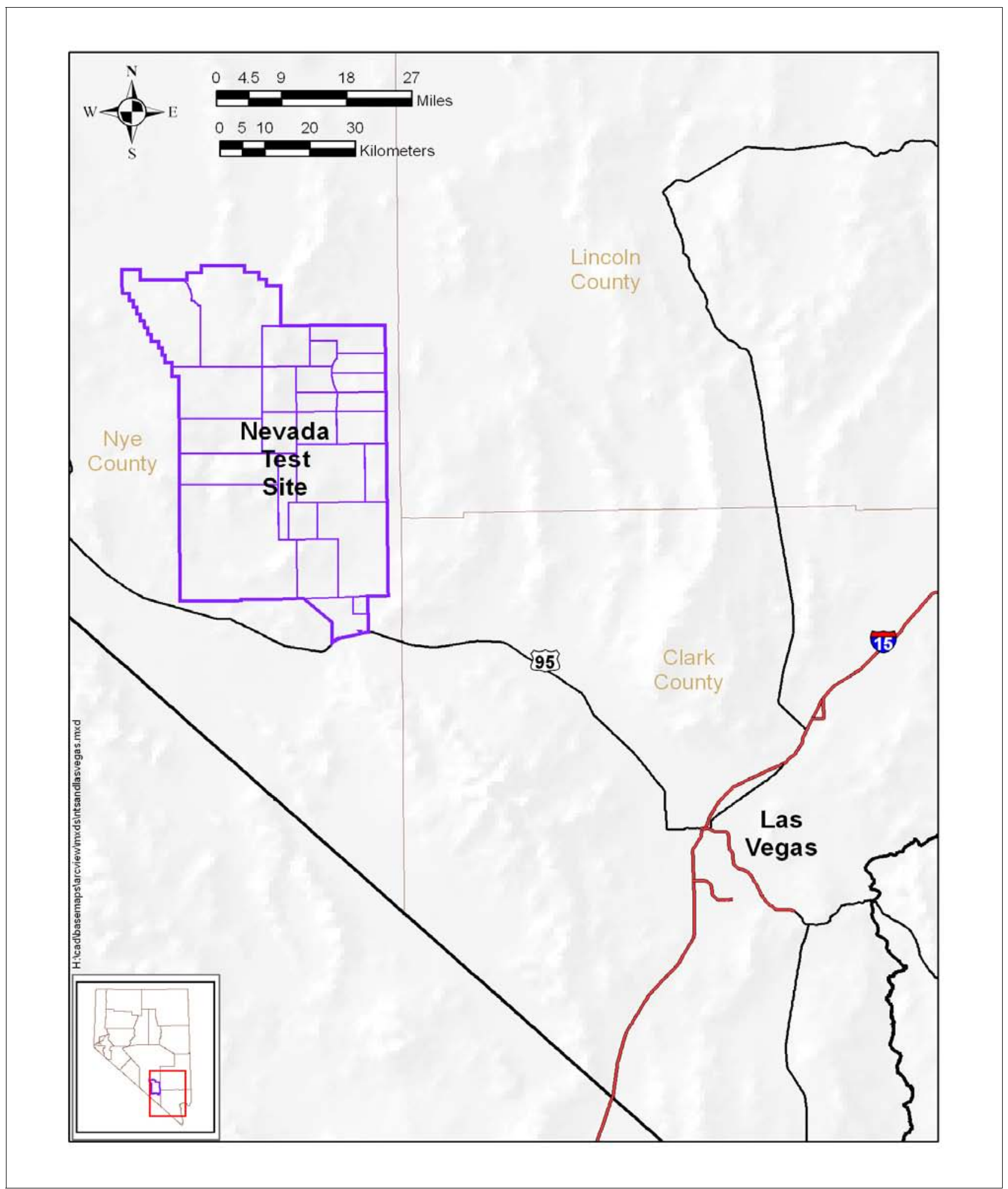

Figure 1-1

Nevada Test Site 


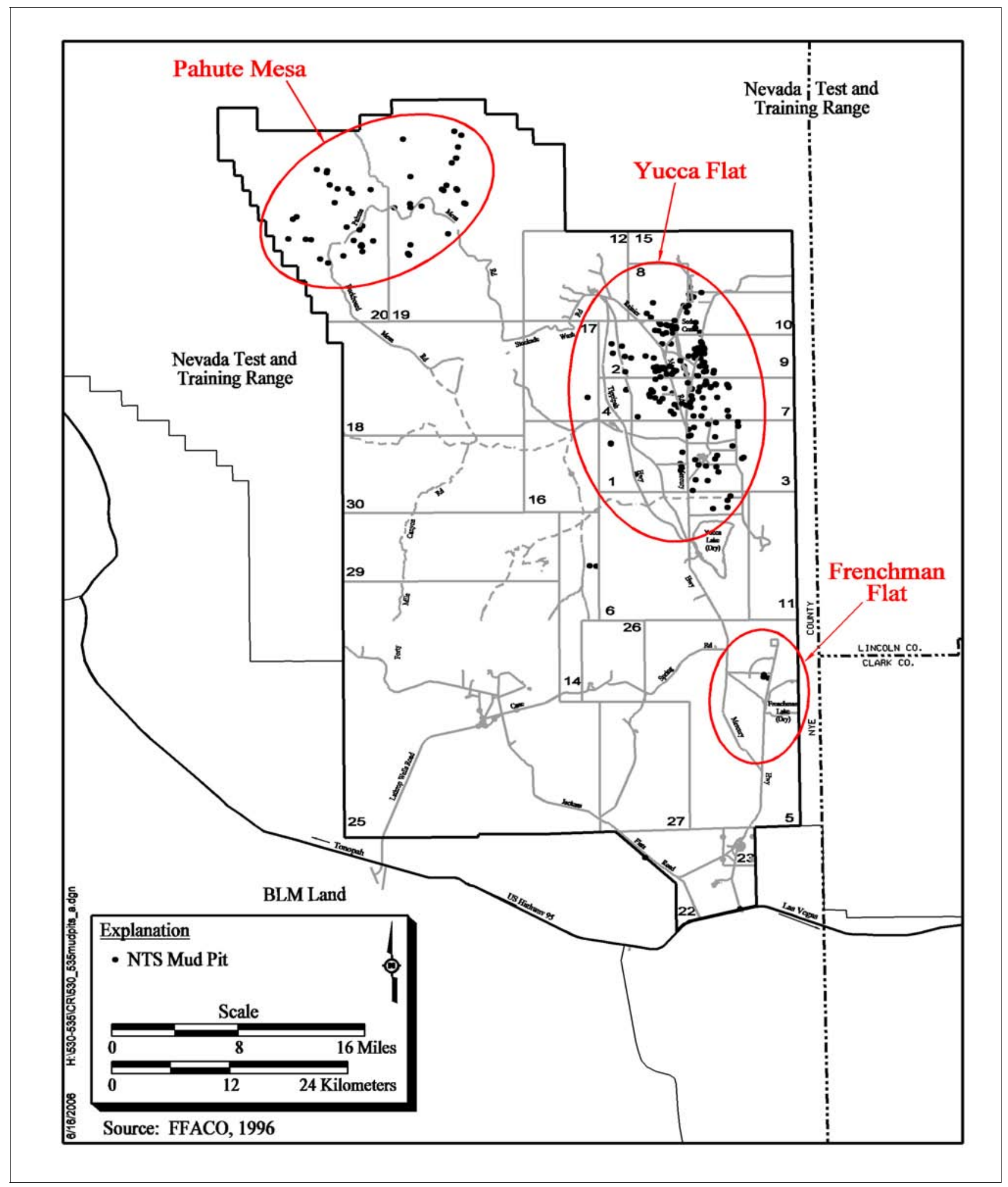

Figure 1-2

Location of NTS Mud Pits CASs in CAUs 530-535 


\subsection{Purpose}

The purpose of this closure report (CR) is to provide: (1) documentation of the field activities completed during the closure investigation of CAUs 530-535; (2) data to validate the risk-based closure strategy presented in the RBCSR (NNSA/NSO, 2004) and the CAUs 530-535 SAFER Plan (NNSA/NSO, 2005b); and (3) risk assessment results that confirm the drilling mud does not pose an unacceptable risk to human health or the environment and that confirm the proposed closure alternative for CAUs 530-535, no further action, is the acceptable closure alternative.

The mud pit CASs in CAUs 530-535 are in-ground structures used during drilling activities that supported the underground nuclear weapons testing program conducted at the NTS. Drilling activities were conducted to either place the device, obtain lithologic data on the geologic material in which the test was being conducted, emplace monitoring devices both before and after the test, or collect postshot data on the effects of the test. Drilling fluids were typically used during these drilling activities to cool and lubricate the drill bit; stabilize the wall of the drill hole to keep it from collapsing; and suspend the drill cuttings and bring them to the surface (REECo, 1994; Witt, 2000). The drilling fluid used was primarily a bentonite, polymer, or detergent mixture, but was sometimes supplemented with diesel fuel to lubricate the drill bit or to increase the viscosity of the drilling mud and provide better lift for removing the drill cuttings (DOE/NV, 2001). Typically, mud containing suspended drill cuttings would be deposited in a return mud pit where the cuttings would settle out. Then the mud would be transferred to the suction mud pit where it would be recirculated to the drill hole.

The 54 mud pit CASs of CAU 530 were constructed as part of Los Alamos National Laboratory (LANL) preshot drilling activities and generally consist of one large, earthen return mud pit or two earthen mud pits (a return pit and a suction pit) with a connecting trench or piping. The mud pits were typically not covered with native soils after use.

The 13 mud pit CASs of CAU 531 were constructed as part of the LANL postshot drilling activities and generally consist of one small, earthen return mud pit. Although a two-pit system was commonly used, the suction pit was contained in a metal tub, rather than excavated into native soil, and removed after use leaving only the return mud pit. After use, these return mud pits were commonly allowed to dry out, surveyed for radiation, and covered with native soils (DOE/NV, 2001). 
The 78 mud pit CASs of CAU 532 were constructed as part of the Lawrence Livermore National Laboratory (LLNL) preshot drilling activities and generally consist of one large, earthen return mud pit that was not covered with native soils after use. A metal tub was commonly used as the suction pit for these systems, but it was removed after drilling was completed leaving only the return mud pit.

The 69 mud pit CASs of CAU 533 were constructed as part of the LLNL postshot drilling activities and generally consist of one small, earthen return mud pit. After use, these return mud pits were commonly allowed to dry out, surveyed for radiation, and covered with native soils (DOE/NV, 2001).

The 39 mud pit CASs of CAU 534 were constructed during the drilling of exploratory and instrumentation holes and generally consist of one small, earthen return mud pit. Generally, these return mud pits were not covered with native soils after use (DOE/NV, 2001).

The 15 mud pit CASs of CAU 535 do not appear to be associated with a borehole but instead were constructed as part of mud pit/disposal activities and generally consist of disposal reservoirs for leftover drilling mud. They were typically not covered with native soils after use.

Preliminary assessments were conducted at select CASs within CAUs 530-535 prior to development of the SAFER Plan. Table 1-1 indicates which CASs were included in each assessment. A summary of these assessment and their associated reports are as follows:

- Preliminary Assessment Sampling. This investigation involved collecting mud pit surface (0 to 6 inches) soils at biased locations and analyzing them for a suite of analytes including metals, radionuclides, hydrocarbons, semivolatile organic compounds (SVOCs), and volatile organic compounds (VOCs). The results are presented in the RBCSR (NNSA/NSO, 2004).

- Radiological Survey. This investigation consisted of walkover and drive over surveys to determine if radiological contamination was present within surficial soils of the mud pits at concentrations statistically greater than surficial soil from undisturbed background locations. The results are presented in a technical memorandum (Nicosia, 2003).

- Assessment of Mud Pit CASs Potentially Contaminated with Radionuclides. As part of this investigation, those CASs in CAUs 530-535 which are located within posted radiological areas were sampled at two depths ( 0 to 3 and 3 to 6 inches). The samples were analyzed for radionuclides and the data were used to support an Federal Facility Agreement and Consent Order (FFACO) modification to transfer CAS 09-09-41 and CAS 09-09-45 to CAU 177 (NNSA/NSO, 2005a). 
The SAFER Plan closure activities, detailed in this report, were conducted at the CASs indicated in Table 1-1 and consist of:

- Environmental Sample Collection. Soil samples representing the surface horizon of the mud pits ( 0 to 6 inches in depth at uncovered CASs and 0 to 6 inches below the soil cover/mud interface at covered CASs) were collected. As specified in the RBCSR, a minimum of 10 randomly located samples were collected from each of the 52 mud pit CASs that were selected for sampling. The samples were analyzed for TPH-DRO and, if necessary, radionuclides.

- Visual Habitat Surveys. Visual surveys were conducted at 149 mud pit CASs that were not previously characterized during any of the preliminary assessments of CAUs 530-535 nor during the SAFER sampling activities. As specified in the SAFER plan, the pits were surveyed only to verify the lack of threatened and/or endangered species habitat. The habitat surveys were conducted during the site walkdowns at each CAS that was sampled during SAFER closure activities and any anomalies were noted in the Field Activity Daily Log.

In the course of the preliminary assessments and the SAFER Plan activities, all 268 CASs in CAUs 530-535 have been visited.

\subsection{Scope}

The scope of closure activities for CAUs 530-535 included:

- Collecting samples that statistically represent the mud pit CASs in CAUs 530-535.

- Performing risk assessments on a statistically representative number of mud pit CASs from each CAU to confirm they pose no unacceptable risk (i.e., the associated Hazard Index for each CAS is $\leq 1.0$ ).

- Confirming the proposed closure alternative, no further action, is valid for CAUs 530-535.

- Removing and disposing of non-hazardous, easily manageable (i.e., 50 pounds [lb] or less) debris.

- Verifying the lack of habitat for threatened or endangered species by conducting visual habitat surveys at CASs sampled as part of this closure investigation as well as at CASs not previously visited during historical characterization efforts. 
Table 1-1

Summary of Characterization Activities Conducted at CAUs 530-535 (Page 1 of 13)

\begin{tabular}{|c|c|c|c|c|c|c|c|}
\hline \multirow[b]{2}{*}{ CAU } & \multirow[b]{2}{*}{ CAS } & \multirow[b]{2}{*}{$\begin{array}{l}\text { FFACO } \\
\text { Name }^{a}\end{array}$} & \multicolumn{3}{|c|}{ Preliminary Assessment Activities } & \multicolumn{2}{|c|}{ SAFER Closure Activities } \\
\hline & & & $\begin{array}{l}\text { Preliminary } \\
\text { Assessment } \\
\text { Sampling }\end{array}$ & $\begin{array}{l}\text { Radiological } \\
\text { Survey }\end{array}$ & $\begin{array}{l}\text { Assessment of } \\
\text { Mud Pit CASs } \\
\text { Potentially } \\
\text { Contaminated with } \\
\text { Radionuclides }\end{array}$ & $\begin{array}{l}\text { Closure } \\
\text { Sampling }\end{array}$ & $\begin{array}{l}\text { Visual Habitat } \\
\text { SurveysOnly }\end{array}$ \\
\hline \multirow{22}{*}{530} & 01-09-01 & U-1f Mud Pit (2) & $\overline{\bar{X}}$ & & & & \\
\hline & $01-09-02$ & U-1e Mud Pit (2) & & & & $\mathrm{X}$ & \\
\hline & $01-09-03$ & U-1d Mud Pit (2) & & & & & $\mathrm{X}$ \\
\hline & $02-09-02$ & U-2ct Mud Pit (1) & $\mathrm{X}$ & $\mathrm{X}$ & & & \\
\hline & $03-09-08$ & U-3Lf Mud Pit (2) & $\bar{x}$ & $\mathrm{X}$ & & & \\
\hline & 03-09-09 & U-3mh Mud Pit (2) & & & & & $\mathrm{X}$ \\
\hline & $03-09-10$ & U-3mr Mud Pit (2) & & & & & $\mathrm{x}$ \\
\hline & $03-09-11$ & U-3Lb Mud Pit (2) & & & & & $\mathrm{x}$ \\
\hline & $03-09-12$ & U-3Lp Mud Pit (2) & & & & & $\mathrm{X}$ \\
\hline & $03-09-13$ & U-3ko Mud Pit (2) & & & & & $\mathrm{X}$ \\
\hline & $03-09-14$ & U-3Lx Mud Pit (2) & $\bar{x}$ & $\mathrm{X}$ & & & \\
\hline & $03-09-15$ & U-3kL Mud Pit (2) & & & & $\mathrm{X}$ & \\
\hline & $03-09-16$ & U-3mt Mud Pit (2) & & & & & $\mathrm{X}$ \\
\hline & 03-09-17 & U-3hc Mud Pit (2) & & & & $x$ & \\
\hline & 03-09-18 & U-3ke Mud Pit (2) & & & & & $x$ \\
\hline & 03-09-19 & U-3mk Mud Pit (2) & & & & & $x$ \\
\hline & $03-09-20$ & U-3mu Mud Pit (2) & $\mathrm{x}$ & $\mathrm{X}$ & & & \\
\hline & $03-09-21$ & U-3gv Mud Pit (2) & & & & $x$ & \\
\hline & $03-09-22$ & U-3ka Mud Pit (2) & & & & & $x$ \\
\hline & $03-09-23$ & U-3gy Mud Pit (1) & $\bar{x}$ & $x$ & & & \\
\hline & $03-09-24$ & U-3mq Mud Pit (2) & & & & & $\mathrm{X}$ \\
\hline & 04-09-01 & U-4i Mud Pit (2) & & & & & $\mathrm{X}$ \\
\hline
\end{tabular}

\section{Uncontrolled When Printed}


Table 1-1

Summary of Characterization Activities Conducted at CAUs 530-535 (Page 2 of 13)

\begin{tabular}{|c|c|c|c|c|c|c|c|}
\hline \multirow[b]{2}{*}{ CAU } & \multirow[b]{2}{*}{ CAS } & \multirow[b]{2}{*}{$\begin{array}{l}\text { FFACO } \\
\text { Name }^{a}\end{array}$} & \multicolumn{3}{|c|}{ Preliminary Assessment Activities } & \multicolumn{2}{|c|}{ SAFER Closure Activities } \\
\hline & & & $\begin{array}{l}\text { Preliminary } \\
\text { Assessment } \\
\text { Sampling }\end{array}$ & $\begin{array}{l}\text { Radiological } \\
\text { Survey }\end{array}$ & $\begin{array}{l}\text { Assessment of } \\
\text { Mud Pit CASs } \\
\text { Potentially } \\
\text { Contaminated with } \\
\text { Radionuclides }\end{array}$ & $\begin{array}{l}\text { Closure } \\
\text { Sampling }\end{array}$ & $\begin{array}{l}\text { Visual Habitat } \\
\text { SurveysOnly }\end{array}$ \\
\hline \multirow{22}{*}{$\begin{array}{c}530 \\
\text { (cont.) }\end{array}$} & $\overline{004-09-02}$ & U-4o Mud Pit (2) & $\overline{\bar{X}}$ & $\overline{\bar{X}}$ & & & \\
\hline & 04-09-03 & U-4r Mud Pit (2) & & & & & $x$ \\
\hline & 04-09-04 & U-4s Mud Pit (1) & & & & & $\mathrm{X}$ \\
\hline & $06-09-02$ & U-6f Mud Pit (2) & & & & $x$ & \\
\hline & $07-09-06$ & U-7bg Mud Pit (2) & & & & & $\mathrm{X}$ \\
\hline & $07-09-07$ & U-7an Mud Pit (2) & & & & & $\mathrm{X}$ \\
\hline & $07-09-08$ & U-7br Mud Pit (2) & & & & & $\mathrm{X}$ \\
\hline & 07-09-09 & U-7ay Mud Pit (2) & & & & & $\mathrm{X}$ \\
\hline & $07-09-10$ & U-7aw Mud Pit (2) & & & & $\mathrm{x}$ & \\
\hline & $07-09-11$ & U-7by Mud Pit (2) & & & & & $\mathrm{X}$ \\
\hline & $07-09-12$ & U-7be Mud Pit (2) & & & $\mathrm{X}$ & & $\mathrm{X}$ \\
\hline & $07-09-13$ & U-7bz Mud Pit (2) & & & & $\mathrm{X}$ & \\
\hline & $07-09-14$ & U-7bc Mud Pit (2) & & & & & $x$ \\
\hline & $07-09-15$ & U-7cc Mud Pit (2) & & & & & $x$ \\
\hline & $07-09-16$ & U-7bf Mud Pit (2) & $\bar{x}$ & $\mathrm{x}$ & & & \\
\hline & $07-09-17$ & U-7ag Mud Pit (2) & & & & & $\mathrm{X}$ \\
\hline & $07-09-18$ & U-7ap Mud Pit (1) & & & & & $\mathrm{X}$ \\
\hline & $07-09-19$ & U-7bx Mud Pit (2) & & & & & $\mathrm{X}$ \\
\hline & $07-09-20$ & U-7bh Mud Pit (2) & & & & & $\mathrm{X}$ \\
\hline & $07-09-21$ & U-7bt Mud Pit (2) & $\mathrm{x}$ & $\mathrm{x}$ & & & \\
\hline & $07-09-22$ & U-7bw Mud Pit (3) & & & & $\mathrm{X}$ & $\mathrm{X}$ \\
\hline & $19-09-08$ & U-19af Mud Pit (2) & & & & & $\mathrm{x}$ \\
\hline
\end{tabular}

\section{Uncontrolled When Printed}


Table 1-1

Summary of Characterization Activities Conducted at CAUs 530-535 (Page 3 of 13)

\begin{tabular}{|c|c|c|c|c|c|c|c|}
\hline \multirow[b]{2}{*}{ CAU } & \multirow[b]{2}{*}{ CAS } & \multirow[b]{2}{*}{$\begin{array}{l}\text { FFACO } \\
\text { Name }^{a}\end{array}$} & \multicolumn{3}{|c|}{ Preliminary Assessment Activities } & \multicolumn{2}{|c|}{ SAFER Closure Activities } \\
\hline & & & $\begin{array}{l}\text { Preliminary } \\
\text { Assessment } \\
\text { Sampling }\end{array}$ & $\begin{array}{l}\text { Radiological } \\
\text { Survey }\end{array}$ & $\begin{array}{l}\text { Assessment of } \\
\text { Mud Pit CASs } \\
\text { Potentially } \\
\text { Contaminated with } \\
\text { Radionuclides }\end{array}$ & $\begin{array}{l}\text { Closure } \\
\text { Sampling }\end{array}$ & $\begin{array}{l}\text { Visual Habitat } \\
\text { SurveysOnly }\end{array}$ \\
\hline \multirow{10}{*}{$\begin{array}{c}530 \\
\text { (cont.) }\end{array}$} & 19-09-09 & U-19ab PS \#1A Covered Mud Pit (1) & & & & & $\overline{\bar{X}}$ \\
\hline & $19-09-10$ & U-19ak Mud Pit (2) & & & & & $\mathrm{x}$ \\
\hline & $19-09-11$ & U-19L Mud Pit (2) & & & & & $\mathrm{X}$ \\
\hline & $19-09-12$ & U-19q Mud Pit (1) & $\mathrm{X}$ & $\mathrm{X}$ & & $\mathrm{X}$ & \\
\hline & $19-09-13$ & U-19x Mud Pit (1) & & & & & $\mathrm{X}$ \\
\hline & $19-09-14$ & U-19bi Mud Pit (1) & & & & & $\mathrm{X}$ \\
\hline & $19-09-15$ & U-19bf Mud Pit (2) & & & & & $\mathrm{X}$ \\
\hline & $19-09-16$ & U-19am Mud Pit (2) & $\bar{X}$ & $\mathrm{X}$ & & & \\
\hline & $19-09-17$ & U-19bj Mud Pit (1) & & & & $\mathrm{X}$ & \\
\hline & $19-09-18$ & U-19ba Mud Pit (2) & & & & & $\mathrm{X}$ \\
\hline \multirow{12}{*}{531} & $03-09-25$ & U-3Lc PS \#1A Covered Mud Pit (1) & $\mathrm{X}$ & $\mathrm{X}$ & $\bar{X}$ & & \\
\hline & $03-09-26$ & U-3kq PS \#1A Covered Mud Pit (1) & & & & & $\mathrm{x}$ \\
\hline & $03-09-27$ & U-3mh PS \#1A Covered Mud Pit (1) & & & & & $\mathrm{x}$ \\
\hline & $03-09-28$ & U-3kt PS \#1D Covered Mud Pit (1) & & & & & $\mathrm{x}$ \\
\hline & 04-09-05 & U-4ak PS \#2A Covered Mud Pit (1) & $\bar{X}$ & $\bar{x}$ & & & \\
\hline & 04-09-06 & U-4u PS \#1A Covered Mud Pit (1) & & & & $\mathrm{X}$ & \\
\hline & $04-09-20$ & U-4t PS \#2A Mud Pit (1) & & & & & $\mathrm{X}$ \\
\hline & $07-09-23$ & U-7j PS \#2D Covered Mud Pit (1) & $\mathrm{X}$ & $\bar{X}$ & & & \\
\hline & $07-09-24$ & U-7j PS \#1D Covered Mud Pit (1) & & & & & $\mathrm{X}$ \\
\hline & $07-09-25$ & U-7i PS \#2D Covered Mud Pit (1) & & & & $\bar{x}$ & \\
\hline & $19-09-19$ & U-19x PS \#1D Mud Pit (1) & & & & $\mathrm{X}$ & \\
\hline & $19-09-20$ & U-19ay PS \#1A Covered Mud Pit (1) & $\bar{x}$ & $\bar{x}$ & & & \\
\hline
\end{tabular}

\section{Uncontrolled When Printed}


Table 1-1

Summary of Characterization Activities Conducted at CAUs 530-535 (Page 4 of 13)

\begin{tabular}{|c|c|c|c|c|c|c|c|}
\hline \multirow[b]{2}{*}{ CAU } & \multirow[b]{2}{*}{ CAS } & \multirow[b]{2}{*}{$\begin{array}{l}\text { FFACO } \\
\text { Name }^{a}\end{array}$} & \multicolumn{3}{|c|}{ Preliminary Assessment Activities } & \multicolumn{2}{|c|}{ SAFER Closure Activities } \\
\hline & & & $\begin{array}{c}\text { Preliminary } \\
\text { Assessment } \\
\text { Sampling }\end{array}$ & $\begin{array}{l}\text { Radiological } \\
\text { Survey }\end{array}$ & $\begin{array}{l}\text { Assessment of } \\
\text { Mud Pit CASs } \\
\text { Potentially } \\
\text { Contaminated with } \\
\text { Radionuclides }\end{array}$ & $\begin{array}{l}\text { Closure } \\
\text { Sampling }\end{array}$ & $\begin{array}{l}\text { Visual Habitat } \\
\text { SurveysOnly }\end{array}$ \\
\hline $\begin{array}{c}531 \\
\text { (cont.) }\end{array}$ & $20-09-11$ & U-20a PPS \#1D Mud Pit (2) & $\mathrm{X}$ & $X$ & & & \\
\hline \multirow{20}{*}{532} & $02-09-03$ & U-2dc \#4 PS \#1A Covered Mud Pit (1) & & & & $\mathrm{X}$ & \\
\hline & $02-09-04$ & U-2ec Mud Pit (1) & & & & & $\mathrm{X}$ \\
\hline & 02-09-05 & U-2dc \#1 Mud Pit (1) & $\mathrm{X}$ & $\mathrm{X}$ & & & \\
\hline & $02-09-06$ & U-2dc \#2 Mud Pit (1) & & & & & $\mathrm{X}$ \\
\hline & $02-09-07$ & U-2dp Mud Pit (2) & & & & & $\mathrm{X}$ \\
\hline & $02-09-08$ & U-2dm Mud Pit (1) & & & & & $\mathrm{X}$ \\
\hline & 02-09-09 & U-2az \#2 Mud Pit (2) & & & & $\mathrm{X}$ & \\
\hline & $02-09-10$ & U-2cj Mud Pit (1) & $\mathrm{X}$ & $\mathrm{X}$ & & & \\
\hline & $02-09-11$ & U-2gi Mud Pit (1) & $\mathrm{X}$ & $\mathrm{X}$ & & & \\
\hline & $02-09-12$ & U-2gd Mud Pit (1) & & & & $\mathrm{x}$ & \\
\hline & $02-09-13$ & U-2fh Mud Pit (1) & & & & & $\mathrm{X}$ \\
\hline & $02-09-14$ & U-2az \#3 Mud Pit (2) & & & & & $\mathrm{X}$ \\
\hline & $02-09-15$ & U-2do Mud Pit (1) & & & & $\mathrm{X}$ & \\
\hline & $02-09-16$ & U-2ds Mud Pit (1) & $\mathrm{X}$ & $\mathrm{X}$ & & & \\
\hline & $02-09-17$ & U-2gc Mud Pit (1) & & & & & $\mathrm{X}$ \\
\hline & $02-09-18$ & U-2ez Mud Pit (1) & & & & $\mathrm{x}$ & \\
\hline & 02-09-19 & U-2bp \#2 Zero Station Mud Pit (1) & & & & & $\mathrm{X}$ \\
\hline & $02-09-20$ & U-2bp \#1 Zero Station Mud Pit (2) & & & & & $\mathrm{X}$ \\
\hline & $02-09-21$ & U-2gk Mud Pit (1) & $\mathrm{X}$ & $\mathrm{X}$ & & & \\
\hline & $02-09-22$ & U-2ea Mud Pit (2) & & & & & $\mathrm{X}$ \\
\hline
\end{tabular}

\section{Uncontrolled When Printed}


Table 1-1

Summary of Characterization Activities Conducted at CAUs 530-535 (Page 5 of 13)

\begin{tabular}{|c|c|c|c|c|c|c|c|}
\hline \multirow[b]{2}{*}{ CAU } & \multirow[b]{2}{*}{ CAS } & \multirow[b]{2}{*}{$\begin{array}{l}\text { FFACO } \\
\text { Name }^{a}\end{array}$} & \multicolumn{3}{|c|}{ Preliminary Assessment Activities } & \multicolumn{2}{|c|}{ SAFER Closure Activities } \\
\hline & & & $\begin{array}{l}\text { Preliminary } \\
\text { Assessment } \\
\text { Sampling }\end{array}$ & $\begin{array}{l}\text { Radiological } \\
\text { Survey }\end{array}$ & $\begin{array}{l}\text { Assessment of } \\
\text { Mud Pit CASs } \\
\text { Potentially } \\
\text { Contaminated with } \\
\text { Radionuclides }\end{array}$ & $\begin{array}{l}\text { Closure } \\
\text { Sampling }\end{array}$ & $\begin{array}{l}\text { Visual Habitat } \\
\text { SurveysOnly }\end{array}$ \\
\hline \multirow{20}{*}{$\begin{array}{c}532 \\
\text { (cont.) }\end{array}$} & $02-09-23$ & U-2cw Mud Pit (1) & $\bar{X}$ & $\bar{X}$ & & & \\
\hline & $02-09-24$ & U-2dd \#1 Mud Pit (2) & & & & & $\mathrm{X}$ \\
\hline & $02-09-25$ & U-2fg Mud Pit (1) & & & & & $\mathrm{X}$ \\
\hline & $02-09-26$ & U-2cv Mud Pit (1) & & & & $\mathrm{X}$ & \\
\hline & 04-09-07 & U-4ag Mud Pit (1) & $\mathrm{X}$ & $\mathrm{X}$ & & & \\
\hline & 04-09-08 & U-4ad Mud Pit (1) & & & & $x$ & \\
\hline & $04-09-10$ & U-4ap Mud Pit (1) & $x$ & $\mathrm{x}$ & & & \\
\hline & $04-09-12$ & U-4ae Mud Pit (1) & & & & & $x$ \\
\hline & 04-09-13 & U-4aq Mud Pit (1) & $x$ & $x$ & & & \\
\hline & $05-09-01$ & U-5e Mud Pit (1) & & & & & $\bar{x}$ \\
\hline & $06-09-03$ & U-6e Mud Pit (2) & & & & & $\mathrm{x}$ \\
\hline & $07-09-26$ & U-7ar Mud Pit (2) & $x$ & $\mathrm{x}$ & & & \\
\hline & $08-09-04$ & UE-8f Mud Pit (1) & $x$ & $x$ & & & \\
\hline & 09-09-01 & U-9 ITS V-26 Mud Pit (2) & & & & & $\mathrm{X}$ \\
\hline & $09-09-02$ & U-9 ITS X-24 Mud Pit (2) & $x$ & $X$ & & & \\
\hline & $09-09-03$ & U-9 ITS Z-26 Mud Pit (2) & & & & & $\bar{x}$ \\
\hline & 09-09-04 & U-9W-24.5 Mud Pit (2) & & & & & $x$ \\
\hline & $09-09-05$ & U-9 ITS AA-25 Mud Pit (2) & & & & & $x$ \\
\hline & 09-09-06 & U-9ch Mud Pit (1) & & & & & $x$ \\
\hline & $09-09-07$ & U-9 ITS XY-31 Mud Pit (2) & & & & & $\mathrm{X}$ \\
\hline
\end{tabular}

\section{Uncontrolled When Printed}


Table 1-1

Summary of Characterization Activities Conducted at CAUs 530-535 (Page 6 of 13)

\begin{tabular}{|c|c|c|c|c|c|c|c|}
\hline \multirow[b]{2}{*}{ CAU } & \multirow[b]{2}{*}{ CAS } & \multirow[b]{2}{*}{$\begin{array}{l}\text { FFACO } \\
\text { Name }^{a}\end{array}$} & \multicolumn{3}{|c|}{ Preliminary Assessment Activities } & \multicolumn{2}{|c|}{ SAFER Closure Activities } \\
\hline & & & $\begin{array}{c}\text { Preliminary } \\
\text { Assessment } \\
\text { Sampling }\end{array}$ & $\begin{array}{l}\text { Radiological } \\
\text { Survey }\end{array}$ & $\begin{array}{l}\text { Assessment of } \\
\text { Mud Pit CASs } \\
\text { Potentially } \\
\text { Contaminated with } \\
\text { Radionuclides }\end{array}$ & $\begin{array}{l}\text { Closure } \\
\text { Sampling }\end{array}$ & $\begin{array}{l}\text { Visual Habitat } \\
\text { SurveysOnly }\end{array}$ \\
\hline \multirow{20}{*}{$\begin{array}{c}532 \\
\text { (cont.) }\end{array}$} & $09-09-08$ & U-9yz-26 Mud Pit (2) & & & & & $x$ \\
\hline & 09-09-09 & U-9sS Mud Pit (2) & & & & & $x$ \\
\hline & $09-09-10$ & U-9 ITS S-25 Mud Pit (2) & & & & $\mathrm{X}$ & \\
\hline & 09-09-11 & U-9bi \#2 Zero Station Mud Pit (2) & & & & & $x$ \\
\hline & $09-09-12$ & U-9cm Mud Pit (2) & & & & & $\mathrm{X}$ \\
\hline & $09-09-13$ & U-9 ITS X-27 Mud Pit (2) & & & & & $\mathrm{X}$ \\
\hline & $09-09-14$ & U-9 ITS U-24 Mud Pit (2) & & & & & $\mathrm{X}$ \\
\hline & 09-09-15 & U-9 ITS X-22 Mud Pit (2) & & & & $\mathrm{X}$ & \\
\hline & $09-09-16$ & U-9 ITS Z-21 Mud Pit (2) & $\mathrm{X}$ & $\mathrm{x}$ & & $\mathrm{x}$ & \\
\hline & $09-09-17$ & U-9 ITS W-21 Mud Pit (2) & & & & & $\mathrm{X}$ \\
\hline & $09-09-18$ & U-9bz Mud Pit (1) & & & $\bar{x}$ & & \\
\hline & 09-09-19 & U-9 ITS X-28 Mud Pit (2) & & & & & $\mathrm{X}$ \\
\hline & $09-09-20$ & U-9 ITS Z-24 Mud Pit (2) & & & & $\mathrm{x}$ & \\
\hline & $09-09-21$ & U-9co Mud Pit (1) & & & & & $\mathrm{X}$ \\
\hline & $09-09-22$ & U-9cp Mud Pit (1) & & & & & $\mathrm{x}$ \\
\hline & $09-09-23$ & U-9 ITS Y-30 Mud Pit (2) & & & & $x$ & \\
\hline & $10-09-07$ & U-10an Mud Pit (2) & & & & & $\mathrm{X}$ \\
\hline & $10-09-08$ & U-10bg Mud Pit (1) & $\mathrm{X}$ & $\mathrm{X}$ & & & \\
\hline & $10-09-09$ & U-10ca Mud Pit (1) & & & & & $x$ \\
\hline & $10-09-11$ & U-10bb Mud Pit (1) & & & & & $x$ \\
\hline
\end{tabular}

\section{Uncontrolled When Printed}


Table 1-1

Summary of Characterization Activities Conducted at CAUs 530-535 (Page 7 of 13)

\begin{tabular}{|c|c|c|c|c|c|c|c|}
\hline \multirow[b]{2}{*}{ CAU } & \multirow[b]{2}{*}{ CAS } & \multirow[b]{2}{*}{$\begin{array}{l}\text { FFACO } \\
\text { Name }^{a}\end{array}$} & \multicolumn{3}{|c|}{ Preliminary Assessment Activities } & \multicolumn{2}{|c|}{ SAFER Closure Activities } \\
\hline & & & $\begin{array}{l}\text { Preliminary } \\
\text { Assessment } \\
\text { Sampling }\end{array}$ & $\begin{array}{l}\text { Radiological } \\
\text { Survey }\end{array}$ & $\begin{array}{l}\text { Assessment of } \\
\text { Mud Pit CASs } \\
\text { Potentially } \\
\text { Contaminated with } \\
\text { Radionuclides }\end{array}$ & $\begin{array}{l}\text { Closure } \\
\text { Sampling }\end{array}$ & $\begin{array}{l}\text { Visual Habitat } \\
\text { SurveysOnly }\end{array}$ \\
\hline \multirow{18}{*}{$\begin{array}{c}532 \\
\text { (cont.) }\end{array}$} & $10-09-12$ & U-10d Mud Pit (2) & $\bar{X}$ & $\bar{X}$ & & $\bar{X}$ & \\
\hline & $10-09-26$ & U-10aj Mud Pit (1) & & & & $\mathrm{X}$ & \\
\hline & $19-09-21$ & U-19ac Mud Pit (2) & & & & & $\mathrm{X}$ \\
\hline & $19-09-22$ & U-19q Mud Pit (2) & & & & & $\mathrm{X}$ \\
\hline & $19-09-23$ & U-19ai Mud Pit (1) & & & & & $\mathrm{X}$ \\
\hline & $19-09-24$ & U-19t Mud Pit (2) & & & & & $\mathrm{X}$ \\
\hline & $19-09-25$ & U-19e Mud Pit (1) & & & & & $\mathrm{X}$ \\
\hline & $20-09-12$ & U-20ah Mud Pit (1) & & & & & $\mathrm{X}$ \\
\hline & $20-09-13$ & U-20ar Mud Pit (1) & & & & & $\mathrm{X}$ \\
\hline & $20-09-14$ & U-20e Mud Pit (1) & & & & & $\mathrm{X}$ \\
\hline & $20-09-15$ & U-20au Mud Pit (1) & & & & $\bar{x}$ & \\
\hline & $20-09-16$ & U-20ag Mud Pit (2) & & & & & $\bar{x}$ \\
\hline & $20-09-17$ & U-20af Mud Pit (2) & & & & & $\mathrm{x}$ \\
\hline & $20-09-18$ & U-20g Mud Pit (1) & & & & & $\mathrm{X}$ \\
\hline & $20-09-19$ & U-20ba Mud Pit (1) & $\bar{x}$ & $\bar{x}$ & & & \\
\hline & $20-09-20$ & U-20n Mud Pit (1) & & & & & $x$ \\
\hline & $20-09-21$ & U-20c Mud Pit (2) & & & & & $\mathrm{X}$ \\
\hline & $20-09-22$ & U-20v Mud Pit (1) & & & & & $x$ \\
\hline \multirow{3}{*}{533} & $02-09-27$ & U-2e PS \#1A Mud Pit (1) & $x$ & $\mathrm{x}$ & $x$ & & \\
\hline & $02-09-28$ & U-2bq \#1 PS \#1A Mud Pit (1) & & & & & $\mathrm{X}$ \\
\hline & $02-09-29$ & U-2bq \#2 PS \#1A Mud Pit (1) & & & & & $\mathrm{X}$ \\
\hline
\end{tabular}

\section{Uncontrolled When Printed}


Table 1-1

Summary of Characterization Activities Conducted at CAUs 530-535 (Page 8 of 13)

\begin{tabular}{|c|c|c|c|c|c|c|c|}
\hline \multirow[b]{2}{*}{ CAU } & \multirow[b]{2}{*}{ CAS } & \multirow[b]{2}{*}{$\begin{array}{l}\text { FFACO } \\
\text { Name }^{a}\end{array}$} & \multicolumn{3}{|c|}{ Preliminary Assessment Activities } & \multicolumn{2}{|c|}{ SAFER Closure Activities } \\
\hline & & & $\begin{array}{l}\text { Preliminary } \\
\text { Assessment } \\
\text { Sampling }\end{array}$ & $\begin{array}{l}\text { Radiological } \\
\text { Survey }\end{array}$ & $\begin{array}{l}\text { Assessment of } \\
\text { Mud Pit CASs } \\
\text { Potentially } \\
\text { Contaminated with } \\
\text { Radionuclides }\end{array}$ & $\begin{array}{l}\text { Closure } \\
\text { Sampling }\end{array}$ & $\begin{array}{l}\text { Visual Habitat } \\
\text { SurveysOnly }\end{array}$ \\
\hline \multirow{21}{*}{$\begin{array}{l}533 \\
\text { (cont.) }\end{array}$} & $02-09-30$ & U-2dp PS \#1A Mud Pit (1) & & & & $\overline{\bar{X}}$ & \\
\hline & $02-09-31$ & U-2f PS \#1 Mud Pit (1) & & & & & $\mathrm{X}$ \\
\hline & $02-09-32$ & U-2ce PS \#1A Mud Pit (1) & $\bar{x}$ & $\mathrm{X}$ & & & \\
\hline & $02-09-33$ & U-2er PS \#1A Covered Mud Pit (1) & & & & $\mathrm{x}$ & \\
\hline & $02-09-34$ & U-2gg PS \#2A Mud Pit (1) & $\mathrm{x}$ & $\mathrm{X}$ & & & \\
\hline & $02-09-35$ & U-2fc PS \#1A Mud Pit (1) & & & & & $\mathrm{X}$ \\
\hline & $02-09-36$ & U-2gf PS \#1A Mud Pit (1) & & & & & $\bar{x}$ \\
\hline & $02-09-37$ & U-2q PS \#1A Mud Pit (1) & $\mathrm{X}$ & $\mathrm{X}$ & & & \\
\hline & $02-09-38$ & U-2ew PS \#2A Mud Pit (1) & & & & & $\mathrm{x}$ \\
\hline & $02-09-39$ & U-2ew PS \#1A Mud Pit (1) & $\mathrm{X}$ & $\bar{x}$ & & & \\
\hline & $02-09-40$ & U-2ge PS \#1A Mud Pit (1) & & & & & $\mathrm{X}$ \\
\hline & $02-09-41$ & U-2ev PS \#1A Mud Pit (1) & & & & & $\mathrm{X}$ \\
\hline & $02-09-42$ & U-2L PS \#5 Mud Pit (1) & & & & & $\mathrm{X}$ \\
\hline & $02-09-43$ & U-2dc \#6 PS \#1AMud Pit (1) & & & & & $\mathrm{X}$ \\
\hline & $02-09-50$ & U-2bz PS \#1A Mud Pit (1) & & & & & $\mathrm{X}$ \\
\hline & 02-09-51 & $\begin{array}{l}\text { U-2bp \#1 Zero Station } \\
\text { Covered Mud Pit (1) }\end{array}$ & & & $x$ & & \\
\hline & $02-09-52$ & U-2dc \#1 PS \#1A Mud Pit (1) & & & & $\mathrm{x}$ & \\
\hline & $02-09-53$ & U-2bg PS \#1A Mud Pit (1) & & & & & $\mathrm{X}$ \\
\hline & $02-09-54$ & U-2be PS \#1A Mud Pit (1) & & & & & $\mathrm{x}$ \\
\hline & $02-09-55$ & U-2L Mud Pit (1) & & & & & $\mathrm{X}$ \\
\hline & $02-09-56$ & U-2L PS \#3 Mud Pit (1) & & & & & $\mathrm{X}$ \\
\hline
\end{tabular}

\section{Uncontrolled When Printed}


Table 1-1

Summary of Characterization Activities Conducted at CAUs 530-535 (Page 9 of 13)

\begin{tabular}{|c|c|c|c|c|c|c|c|}
\hline \multirow[b]{2}{*}{ CAU } & \multirow[b]{2}{*}{ CAS } & \multirow[b]{2}{*}{$\begin{array}{l}\text { FFACO } \\
\text { Name }^{a}\end{array}$} & \multicolumn{3}{|c|}{ Preliminary Assessment Activities } & \multicolumn{2}{|c|}{ SAFER Closure Activities } \\
\hline & & & $\begin{array}{l}\text { Preliminary } \\
\text { Assessment } \\
\text { Sampling }\end{array}$ & $\begin{array}{l}\text { Radiological } \\
\text { Survey }\end{array}$ & $\begin{array}{l}\text { Assessment of } \\
\text { Mud Pit CASs } \\
\text { Potentially } \\
\text { Contaminated with } \\
\text { Radionuclides }\end{array}$ & $\begin{array}{l}\text { Closure } \\
\text { Sampling }\end{array}$ & $\begin{array}{l}\text { Visual Habitat } \\
\text { SurveysOnly }\end{array}$ \\
\hline \multirow{21}{*}{$\begin{array}{c}533 \\
\text { (cont.) }\end{array}$} & $04-09-14$ & U-4av PS \#1A Covered Mud Pit (1) & & & & $\overline{\bar{X}}$ & \\
\hline & $04-09-15$ & U-4am PS \#1A Covered Mud Pit (1) & $\mathrm{X}$ & $\mathrm{X}$ & & & \\
\hline & $09-09-24$ & U-9 ITS V-24 PS \#1A Mud Pit (2) & $\mathrm{X}$ & $\mathrm{X}$ & & & \\
\hline & $09-09-25$ & U-9 ITS V-27 PS \#1A Mud Pit (1) & & & & & $\bar{x}$ \\
\hline & $09-09-26$ & U-9cv PS \#1A Covered Mud Pit (1) & & & & & $\mathrm{X}$ \\
\hline & $09-09-27$ & U-9yz-26 PS \#1A Mud Pit (1) & & & & $\mathrm{X}$ & \\
\hline & $09-09-28$ & U-9bn PS \#2A Mud Pit (1) & $x$ & $\mathrm{X}$ & & & \\
\hline & $09-09-29$ & U-9 ITS X-28 PS \#1A Mud Pit (1) & & & & & $\mathrm{X}$ \\
\hline & $09-09-30$ & U-9k PS \#1 Mud Pit (1) & & & & & $\mathrm{x}$ \\
\hline & $09-09-31$ & $\begin{array}{l}\text { U-9cr PS \#1A } \\
\text { Covered Mud Pit (1) }\end{array}$ & & & & & $x$ \\
\hline & $09-09-32$ & U-9W-24.5 PS \#1A Mud Pit (1) & $\bar{x}$ & $\mathrm{x}$ & & & \\
\hline & $09-09-33$ & U-9cL PS \#1A Mud Pit (1) & $\bar{x}$ & $\mathrm{x}$ & & & \\
\hline & $09-09-34$ & U-9bu PS \#1A Mud Pit (1) & & & & & $\mathrm{X}$ \\
\hline & $09-09-35$ & U-9bi \#1 PS \#1A Mud Pit (1) & & & & $x$ & \\
\hline & $09-09-36$ & U-9cn PS \#1A Mud Pit (1) & & & & & $\mathrm{x}$ \\
\hline & $09-09-42$ & U-9bm PS \#1A Mud Pit (1) & & & & $\mathrm{X}$ & \\
\hline & $09-09-43$ & U-9bi \#2 PS \#1A Mud Pit (1) & & & $\mathrm{X}$ & & \\
\hline & $09-09-44$ & U-9c PS \#2 Mud Pit (1) & & & & & $\mathrm{X}$ \\
\hline & $10-09-13$ & U-10aq PS \#1A Mud Pit (1) & $\mathrm{x}$ & $\mathrm{X}$ & & & \\
\hline & $10-09-14$ & U-10bg PS \#1A Covered Mud Pit (1) & & & & & $\mathrm{X}$ \\
\hline & $10-09-15$ & U-10ap \#1 PS \#1A Mud Pit (1) & & & & & $\mathrm{X}$ \\
\hline
\end{tabular}

\section{Uncontrolled When Printed}


Table 1-1

Summary of Characterization Activities Conducted at CAUs 530-535

(Page 10 of 13)

\begin{tabular}{|c|c|c|c|c|c|c|c|}
\hline \multirow[b]{2}{*}{ CAU } & \multirow[b]{2}{*}{ CAS } & \multirow[b]{2}{*}{$\begin{array}{l}\text { FFACO } \\
\text { Name }^{a}\end{array}$} & \multicolumn{3}{|c|}{ Preliminary Assessment Activities } & \multicolumn{2}{|c|}{ SAFER Closure Activities } \\
\hline & & & $\begin{array}{l}\text { Preliminary } \\
\text { Assessment } \\
\text { Sampling }\end{array}$ & $\begin{array}{l}\text { Radiological } \\
\text { Survey }\end{array}$ & $\begin{array}{l}\text { Assessment of } \\
\text { Mud Pit CASs } \\
\text { Potentially } \\
\text { Contaminated with } \\
\text { Radionuclides }\end{array}$ & $\begin{array}{l}\text { Closure } \\
\text { Sampling }\end{array}$ & $\begin{array}{l}\text { Visual Habitat } \\
\text { SurveysOnly }\end{array}$ \\
\hline \multirow{21}{*}{$\begin{array}{c}533 \\
\text { (cont.) }\end{array}$} & $\overline{10-09-16}$ & $\overline{\text { U-10as PS \#1A Mud Pit (1) }}$ & & & & & $\overline{\bar{X}}$ \\
\hline & $10-09-17$ & U-10a PS \#2V Mud Pit (1) & & & & & $\mathrm{X}$ \\
\hline & $10-09-18$ & U-10ap \#3 PS \#1A Mud Pit (1) & $\bar{x}$ & $\mathrm{X}$ & & $\mathrm{X}$ & \\
\hline & $10-09-19$ & U-10ax PS \#1A Mud Pit (1) & & & & & $\bar{x}$ \\
\hline & $10-09-20$ & U-10ag PS \#1A Mud Pit (1) & $\mathrm{X}$ & $\mathrm{X}$ & & & \\
\hline & $10-09-21$ & U-10ar PS \#1A Covered Mud Pit (1) & & & & & $\mathrm{X}$ \\
\hline & $19-09-26$ & U-19ai PS \#1A Covered Mud Pit (1) & & & & & $\mathrm{x}$ \\
\hline & $19-09-27$ & U-19zS PS \#1D Covered Mud Pit (1) & & & & $\mathrm{X}$ & \\
\hline & $19-09-28$ & U-19ac PS \#1A Covered Mud Pit (1) & & & & & $\mathrm{X}$ \\
\hline & $20-09-23$ & U-20i PS \#1D Mud Pit (2) & $\bar{X}$ & $\mathrm{X}$ & & & \\
\hline & $20-09-24$ & U-20bb PS \#1A Covered Mud Pit (1) & & & & & $\mathrm{X}$ \\
\hline & $20-09-25$ & U-20c PS \#1D Mud Pit (1) & $\mathrm{X}$ & $\mathrm{X}$ & & & \\
\hline & $20-09-26$ & U-20bd PS \#1A Mud Pit (1) & & & $x$ & & \\
\hline & $20-09-27$ & U-20aj PS \#1A Mud Pit (1) & & & & $\mathrm{X}$ & \\
\hline & $20-09-28$ & U-20an PS \#1A Covered Mud Pit (1) & $\mathrm{X}$ & $\mathrm{X}$ & & & \\
\hline & $20-09-29$ & U-20v PS \#1D Mud Pit (1) & & & & & $\bar{X}$ \\
\hline & $20-09-30$ & U-20ay PS \#1A Covered Mud Pit (1) & & & & & $\bar{X}$ \\
\hline & $20-09-31$ & U-20aq PS \#1A Covered Mud Pit (1) & & & & $\mathrm{X}$ & \\
\hline & $20-09-32$ & U-20aL PS \#1A Covered Mud Pit (1) & $\mathrm{X}$ & $\mathrm{X}$ & & & \\
\hline & $20-09-33$ & U-20d PS \#1D Mud Pit (1) & $\mathrm{X}$ & $\mathrm{X}$ & & & \\
\hline & $20-09-34$ & U-20e PS \#1D Mud Pit (1) & $\bar{X}$ & $\mathrm{X}$ & & & $\bar{X}$ \\
\hline
\end{tabular}

\section{Uncontrolled When Printed}


Table 1-1

Summary of Characterization Activities Conducted at CAUs 530-535

(Page 11 of 13)

\begin{tabular}{|c|c|c|c|c|c|c|c|}
\hline \multirow[b]{2}{*}{ CAU } & \multirow[b]{2}{*}{ CAS } & \multirow[b]{2}{*}{$\begin{array}{l}\text { FFACO } \\
\text { Name }^{a}\end{array}$} & \multicolumn{3}{|c|}{ Preliminary Assessment Activities } & \multicolumn{2}{|c|}{ SAFER Closure Activities } \\
\hline & & & $\begin{array}{l}\text { Preliminary } \\
\text { Assessment } \\
\text { Sampling }\end{array}$ & $\begin{array}{l}\text { Radiological } \\
\text { Survey }\end{array}$ & $\begin{array}{l}\text { Assessment of } \\
\text { Mud Pit CASs } \\
\text { Potentially } \\
\text { Contaminated with } \\
\text { Radionuclides }\end{array}$ & $\begin{array}{l}\text { Closure } \\
\text { Sampling }\end{array}$ & $\begin{array}{l}\text { Visual Habitat } \\
\text { SurveysOnly }\end{array}$ \\
\hline \multirow{3}{*}{$\begin{array}{c}533 \\
\text { (cont.) }\end{array}$} & $20-09-35$ & U-20ax PPS \#1A Mud Pit (1) & & & & $\overline{\bar{X}}$ & \\
\hline & $20-09-36$ & U-20av PS \#1A Mud Pit (1) & $\mathrm{X}$ & $\mathrm{X}$ & & & \\
\hline & $20-09-37$ & U-20n PS \#1D Covered Mud Pit (1) & $\bar{x}$ & $\mathrm{X}$ & & & \\
\hline \multirow{18}{*}{534} & $01-09-06$ & UE-1r Mud Pit (1) & $\mathrm{X}$ & $\mathrm{X}$ & & & \\
\hline & 01-09-07 & UE-1p Eleana Mud Pit (1) & $\bar{x}$ & $\mathrm{X}$ & & & \\
\hline & 01-09-09 & UE-1L Mud Pits (2) & & & & & $\bar{X}$ \\
\hline & $02-09-44$ & UE-2co Mud Pit (1) & & & & & $\mathrm{X}$ \\
\hline & $02-09-45$ & UE-2eu Mud Pit (1) & & & & & $\mathrm{X}$ \\
\hline & $02-09-46$ & UE-2ad Mud Pit (1) & & & & & $\mathrm{X}$ \\
\hline & $02-09-47$ & UE-2ac Mud Pit (1) & $\mathrm{X}$ & $\mathrm{X}$ & & & \\
\hline & $03-09-30$ & UE-3Lj/Inst. Mud Pit (1) & & & & $\mathrm{X}$ & \\
\hline & $04-09-16$ & UE-4af Mud Pit (1) & & & & & $\mathrm{x}$ \\
\hline & $04-09-17$ & UE-4aa Mud Pit (1) & & & & & $\mathrm{X}$ \\
\hline & $04-09-18$ & UE-4ai Mud Pit (1) & & & & $\bar{x}$ & \\
\hline & 04-09-19 & U-4ao CDS Test Mud Pit (1) & $\bar{x}$ & $\bar{X}$ & & & \\
\hline & $04-09-21$ & UE-4ac Mud Pit (1) & & & & & $\bar{x}$ \\
\hline & 05-09-02 & RNM \#1 Mud Pit (1) & & & & $\bar{x}$ & \\
\hline & $05-09-03$ & UE-5n Mud Pits (2) & & & & & $\mathrm{X}$ \\
\hline & $05-09-04$ & RNM \#2s Mud Pit (2) & & & & & $\mathrm{X}$ \\
\hline & 06-09-04 & UE-6e Mud Pit (2) & & & & & $\mathrm{X}$ \\
\hline & $07-09-27$ & UE-7k Mud Pit (1) & & & & $\mathrm{X}$ & \\
\hline
\end{tabular}

\section{Uncontrolled When Printed}


Table 1-1

Summary of Characterization Activities Conducted at CAUs 530-535

(Page 12 of 13)

\begin{tabular}{|c|c|c|c|c|c|c|c|}
\hline \multirow[b]{2}{*}{ CAU } & \multirow[b]{2}{*}{ CAS } & \multirow[b]{2}{*}{$\begin{array}{l}\text { FFACO } \\
\text { Name }^{a}\end{array}$} & \multicolumn{3}{|c|}{ Preliminary Assessment Activities } & \multicolumn{2}{|c|}{ SAFER Closure Activities } \\
\hline & & & $\begin{array}{l}\text { Preliminary } \\
\text { Assessment } \\
\text { Sampling }\end{array}$ & $\begin{array}{l}\text { Radiological } \\
\text { Survey }\end{array}$ & $\begin{array}{l}\text { Assessment of } \\
\text { Mud Pit CASs } \\
\text { Potentially } \\
\text { Contaminated with } \\
\text { Radionuclides }\end{array}$ & $\begin{array}{l}\text { Closure } \\
\text { Sampling }\end{array}$ & $\begin{array}{l}\text { Visual Habitat } \\
\text { SurveysOnly }\end{array}$ \\
\hline \multirow{21}{*}{$\begin{array}{c}534 \\
\text { (cont.) }\end{array}$} & $08-09-05$ & UE-8o Mud Pit (1) & $\bar{x}$ & $\overline{\mathrm{X}}$ & & & $\overline{\bar{X}}$ \\
\hline & $08-09-06$ & UE-8e \#2 Mud Pit (1) & & & & $\mathrm{X}$ & \\
\hline & $09-09-37$ & U-9 ITS UE-S-17 Mud Pit (1) & & & $\mathrm{X}$ & & \\
\hline & $09-09-38$ & U-9 ITS UE-U-22 Mud Pit (1) & $\mathrm{X}$ & $\mathrm{x}$ & $\mathrm{X}$ & & \\
\hline & $09-09-39$ & U-9 ITS UE-U-29 \#2 Mud Pit (1) & & & & & $\mathrm{X}$ \\
\hline & $09-09-40$ & U-9cu Grout Test Mud Pit (1) & & & & $\mathrm{X}$ & \\
\hline & $10-09-22$ & UE-10 ITS \#2 Mud Pit (1) & & & & & $\mathrm{X}$ \\
\hline & $10-09-23$ & UE-10 ITS \#3 Mud Pit (1) & $\mathrm{X}$ & $\mathrm{X}$ & & & $\mathrm{X}$ \\
\hline & $10-09-24$ & UE-10 ITS \#1 Mud Pit (1) & & & & & $\mathrm{X}$ \\
\hline & $10-09-25$ & UE-10 ITS \#6 Mud Pit (1) & $\mathrm{X}$ & $\bar{x}$ & & & \\
\hline & $14-09-01$ & UE-14b Mud Pit (1) & & & & & $\mathrm{X}$ \\
\hline & $14-09-02$ & UE-14a Mud Pit (1) & & & & $\mathrm{x}$ & \\
\hline & $17-09-01$ & UE-17f Eleana Mud Pit (2) & $x$ & $\mathrm{X}$ & & & \\
\hline & $19-09-29$ & U-19g Sandia Inst. Mud Pit (1) & $\mathrm{X}$ & $\mathrm{X}$ & & & \\
\hline & $19-09-30$ & UE-19h Mud Pit (2) & & & & & $\mathrm{x}$ \\
\hline & $20-09-38$ & UE-20d Mud Pit (1) & & & $\bar{x}$ & & $\mathrm{X}$ \\
\hline & $20-09-39$ & UE-20bh \#1 Mud Pit (1) & $\mathrm{X}$ & $\mathrm{x}$ & & & \\
\hline & $20-09-40$ & UE-20n \#1 Mud Pit (1) & & & & $\mathrm{X}$ & \\
\hline & $20-09-41$ & UE-20ae Mud Pit (1) & & & & & $\mathrm{X}$ \\
\hline & $20-09-42$ & UE-20av Mud Pit (1) & & & & & $\mathrm{X}$ \\
\hline & $20-09-43$ & UE-20p Mud Pit (1) & & & & & $\bar{x}$ \\
\hline
\end{tabular}

\section{Uncontrolled When Printed}


Table 1-1

Summary of Characterization Activities Conducted at CAUs 530-535

(Page 13 of 13)

\begin{tabular}{|c|c|c|c|c|c|c|c|}
\hline \multirow[b]{2}{*}{ CAU } & \multirow[b]{2}{*}{ CAS } & \multirow[b]{2}{*}{$\begin{array}{l}\text { FFACO } \\
\text { Name }^{a}\end{array}$} & \multicolumn{3}{|c|}{ Preliminary Assessment Activities } & \multicolumn{2}{|c|}{ SAFER Closure Activities } \\
\hline & & & $\begin{array}{l}\text { Preliminary } \\
\text { Assessment } \\
\text { Sampling }\end{array}$ & $\begin{array}{l}\text { Radiological } \\
\text { Survey }\end{array}$ & $\begin{array}{l}\text { Assessment of } \\
\text { Mud Pit CASs } \\
\text { Potentially } \\
\text { Contaminated with } \\
\text { Radionuclides }\end{array}$ & $\begin{array}{l}\text { Closure } \\
\text { Sampling }\end{array}$ & $\begin{array}{l}\text { Visual Habitat } \\
\text { SurveysOnly }\end{array}$ \\
\hline \multirow{15}{*}{535} & $\overline{001-09-04}$ & UE-1L Mud Pit (1) & & & & $\overline{\bar{X}}$ & \\
\hline & $03-09-29$ & U-3me Mud Spill & & & & & $\mathrm{X}$ \\
\hline & $04-09-09$ & U-4aj Mud Spill & & & & & $\mathrm{X}$ \\
\hline & $04-09-11$ & U-4ac Mud Spill & & & & & $\mathrm{X}$ \\
\hline & $04-09-22$ & Unknown \#11 Mud Pit/Disposal Area & & & & & $\mathrm{X}$ \\
\hline & $07-09-28$ & Unknown \#12 Mud Pit/Disposal Area & & & & $\mathrm{X}$ & \\
\hline & $07-09-29$ & Unknown \#13 Mud Pit/Disposal Area & & & & & $\mathrm{X}$ \\
\hline & $10-09-10$ & U-10bh Mud Spill & & & & & $\mathrm{X}$ \\
\hline & $19-09-31$ & Unknown \#10 Mud Pit/Disposal Area & $\mathrm{X}$ & $\mathrm{X}$ & & & \\
\hline & $19-09-32$ & $\begin{array}{l}\text { Unknown \#7 Covered Mud Pit/Disposal } \\
\text { Area }\end{array}$ & $x$ & $x$ & & & \\
\hline & $19-09-33$ & Unknown \#8 Mud Pit/Disposal Area & & & & & $\mathrm{X}$ \\
\hline & $19-09-34$ & Unknown \#9 Mud Pit/Disposal Area & & & & & $\mathrm{X}$ \\
\hline & $20-09-44$ & Unknown \#4 Mud Pit/Disposal Area & $\mathrm{X}$ & $\mathrm{X}$ & & & \\
\hline & $20-09-45$ & Unknown \#5 Mud Pit/Disposal Area & $\mathrm{X}$ & $\mathrm{X}$ & & & \\
\hline & $20-09-46$ & Unknown \#14 Mud Pit/Disposal Area & & & & $\mathrm{X}$ & \\
\hline
\end{tabular}

a Numbers in parentheses indicate the number of mud pits at each CAS.

CAS $=$ Corrective Action Site

$\mathrm{CAU}=$ Corrective Action Unit

FFACO = Federal Facility Agreement and Consent Order

SAFER $=$ Streamlined Approach for Environmental Restoration 


\subsection{Closure Report Contents}

This CR is divided into the following sections and appendices:

Section 1.0 - Introduction: Summarizes the purpose, scope, and contents of this CR.

Section 2.0 - Closure Activities: Summarizes the closure activities and schedule as well as deviation from the SAFER Plan.

Section 3.0 - Waste Disposition: Discusses the wastes generated and entered into an approved waste management system.

Section 4.0 - Closure Verification Results: Describes verification activities and the results.

Section 5.0 - Conclusions and Recommendations: Recommends no further action for CAUs 530-535 and provides the supporting rationale.

Section 6.0 - References: Provides a list of all referenced documents used in the preparation of this CR.

Appendix A- Data Quality Objectives as Developed in the SAFER Plan for CAUs 530-535: NTS Mud Pits, Nevada Test Site, Nevada: Discusses results of the data quality assessment (DQA) and evaluates the outcome of the decision statements as developed in the data quality objectives (DQOs) of the SAFER Plan.

Appendix B - Closure Certification for CAUs 530-535: NTS Mud Pits, Nevada Test Site, Nevada: Documents housekeeping and debris removal activities.

Appendix C - As-Built Documentation for CAUs 530-535: NTS Mud Pits, Nevada Test Site, Nevada: Contains site plans for all sampled CASs that show sample locations and provide sample coordinates.

Appendix D - Confirmation Sampling Test Results for CAUs 530-535: NTS Mud Pits, Nevada Test Site, Nevada: Provides the analytical data used in evaluating the DQO decision statements. 
Appendix E - Waste Disposition Documentation for CAUs 530-535: NTS Mud Pits, Nevada Test Site, Nevada: Provides documentation for the waste generated as a result of closure investigation activities and housekeeping activities at CAS 09-09-08.

Appendix F - Modifications to the Post Closure Plan for CAUs 530-535: NTS Mud Pits, Nevada Test Site, Nevada: Documents that there are no modifications to the post-closure plan.

Appendix G - Evaluation of Risk for CAUs 530-535: NTS Mud Pits, Nevada Test Site, Nevada:

Documents that CAUs 530-535 do not pose an unacceptable risk to human or ecological receptors.

To ensure all project objectives, health and safety requirements, and quality control procedures were adhered to, the closure activities were performed in accordance with the following documents:

- $\quad$ Mud Pit Risk-Based Closure Strategy Report for CAUs 530, 531, 532, 533, 534, and 535 , Nevada Test Site Mud Pits, Nevada Test Site, Nevada (NNSA/NSO, 2004)

- $\quad$ SAFER Plan for CAUs 530, 531, 532, 533, 534, and 535, Nevada Test Site Mud Pits, Nevada Test Site, Nevada (NNSA/NSO, 2005b)

- $\quad$ Record of Technical Change (ROTC) No. 1 for the SAFER Plan for CAUs 530, 531, 532, 533, 534, and 535, Nevada Test Site Mud Pits, Nevada Test Site, Nevada. This ROTC changed the collection frequency of the field blanks from one per CAS to one per day-additional if field conditions change.

- Record of Technical Change (ROTC) No. 2 for the SAFER Plan for CAUs 530, 531, 532, 533, 534, and 535, Nevada Test Site Mud Pits, Nevada Test Site, Nevada. This ROTC revised the methods available for sample collection and changed the sampling depth for covered mud pit CASs.

- $\quad$ Industrial Sites Quality Assurance Project Plan (QAPP) (NNSA/NV, 2002)

- Federal Facility Agreement and Consent Order (1996)

- $\quad$ Project Execution Plan (SNJV, 2005)

- Standards-Based Management System (SBMS) Subject Areas and Procedures 


\subsection{Closure Activities}

The following sections summarize the CAUs 530-535 closure activities and any deviations from the original scope of work. Appendix A and Appendix B provide details and results of the closure activities.

\subsection{Description of Corrective Action Activities}

Field activities, which did not include corrective actions, were performed as set forth in the CAUs 530-535 SAFER Plan from September 6, 2005, through April 12, 2006. The purpose of the field activities was to sample a statistically representative number of the 268 mud pit CASs in CAUs 530-535 and evaluate the potential risk to human health and the environment in order to confirm the closure strategy proposed in the RBCSR. This closure strategy, which is the basis of the DQO decision statements governing this closure investigation (Appendix A), is confirmed if none of the representative CASs pose an unacceptable risk to human health or the environment and, therefore, CAUs 530-535 can be closed via the no further action alternative. The scope of field activities, which included environmental sample collection and visual habitat surveys, are discussed in detail in the following subsections.

\subsubsection{Environmental Sample Collection}

Following a probabilistic sampling design, samples were collected from 52 CASs to represent the entire population of 268 CASs in CAUs 530-535. Ten samples were collected from the surface of each mud pit CAS ( 0 to 6 inches below soil cover if the mud pit is covered) to determine a characteristic TPH-DRO concentration for each CAS (see Appendix A). The characteristic TPH-DRO concentration is defined as the 95 percent upper confidence limit (UCL) of the mean. Sample locations were determined prior to sampling efforts using the Visual Sample Plan (VSP) model (PNNL, 2002) and were configured in a triangular grid pattern with the location of the initial sample being randomly chosen. Activities in support of collecting these environmental samples are considered standard activities conducted at all 52 CASs with slight variations depending upon if the CASs were uncovered or covered. The SAFER Plan also called for additional activities to be conducted on an as-needed basis at CASs where radiological field-screening results (FSRs) exceeded field-screening levels (FSLs), where obvious spills or staining was present, or where predetermined 
sample locations did not satisfy the DQOs. Both standard and as-needed (or CAS-specific) activities are discussed below.

\subsubsection{Standard Activities}

Visual Inspections. Prior to sampling activities at each CAS, the CAS was inspected for threatened or endangered species habitat, areas of obvious spills or staining, and debris. No threatened or endangered species habitat was identified during these inspections. Biased samples were collected from spills and stains and are discussed in Section 2.1.1.2.3.

Establishment of Radiological FSLs and FSRs. Prior to sampling activities, FSL were established by collecting 10 soil samples from outside of the CAS area that are representative of the local area. These samples were homogenized in a single collection pan and given 10 one-minute counts. The alpha and beta/gamma results of each one-minute count were recorded and processed by using the Chi-Square test. The FSL is the sum of the mean of the 10 counts plus two standard deviations. The FSL served two purposes. It is the criteria by which samples were submitted for analysis of radionuclides and to meet sample shipping requirements. Field-screening results were obtained for all samples within a CAS by surveying each soil sample within the collection pan using a handheld alpha and beta/gamma survey instruments (e.g., NE Electra). If any of these FSRs exceeded the FSLs, then all samples from the CAS were submitted for radiological analysis. Samples from four CASs were submitted for radiological analyses as discussed in Section 2.1.1.2.2.

Collection of Quality Control (QC) Samples. Additional samples were collected according to the SAFER Plan and submitted for laboratory analyses to ensure that data generated from the analysis of environmental samples met the requirements of the data quality indicators (DQIs). Discussion of the QC results is provided in Section 4.1 and Appendix A.

\subsection{Uncovered CASs}

Of the 52 CASs that were sampled, 45 were uncovered. The standard activities conducted at these CASs are discussed below.

Vegetation Removal. At those CASs where vegetation interfered with sampling activities, the vegetation was removed prior to sampling. Vegetation removal consisted of clearing tumble weeds 
that had accumulated on the bottom of the mud pits. Care was taken during the removal to ensure that the sampling locations were not adversely impacted.

Surface Sample Collection. Samples from uncovered CASs were collected using disposable scoops to dig up to six inches below the surface and retrieve the sample.

\subsection{Covered CASs}

Of the 52 CASs that were sampled, seven were covered. The standard activities conducted at these CASs are discussed below.

Utility Clearance Surveys. A utility clearance survey was completed at each of the covered CASs. One underground electric utility was found within CAS 07-09-25, but none of the sample locations needed to be moved to avoid this utility. Extra caution was used during backhoe operations at this CAS to ensure that the utility was not disturbed. No utilities were identified at the remaining six covered CASs.

Subsurface Sample Collection. Samples from covered CASs were collected using a backhoe to remove the soil cover down to the mud/soil cover interface. Once at the interface, the backhoe retrieved a bucket of mud from which the environmental sample was taken while attempting to capture just the first six inches of mud below the interface.

Organic Vapor Monitoring. As samples were brought to the surface, they were monitored using a photoionization detector (PID) for organic vapors to ensure worker health and safety. No organic vapors were detected during sampling.

\subsubsection{Corrective Action Site-Specific Activities}

The following activities were conducted at the mud pit CASs, where necessary.

\subsection{Determination of New Sample Coordinates}

Field activities revealed that pre-determined sample locations at fifteen CASs were not adequate to meet the DQO requirements. Typically, this was due to the fact that the sample locations fell on the berm of the mud pit rather than within the residual mud on the bottom of the pit. This situation 
occurred more at CASs that were heavily covered with tumble weeds than at CASs that were clear of vegetation. CASs where new sample locations had to be determined using VSP after the CAS boundary had been re-established using Global Positioning System (GPS) included: 02-09-52; 03-09-17; 03-09-30; 04-09-18; 07-09-27; 09-09-15; 09-09-20; 09-09-23; 09-09-24; 09-09-27; 09-09-35; 10-09-12; 10-09-18; 10-09-26; 19-09-12. New sample locations for these CASs are shown in Appendix C.

\subsection{Samples Submitted for Radiological Analyses}

Radiological analyses were routinely conducted for samples that came from a CAS where the FSLs were exceeded. According to the SAFER Plan, analytical results of radiological samples were compared to the preliminary action levels (PALs) that are based on a 25 millirem per year (mrem/yr) dose. These PALs are as follows:

- $\quad$ Sr-90, 838 picocuries per gram (pCi/g)

- $\quad \mathrm{Pu}-238,13.0 \mathrm{pCi} / \mathrm{g}$

- $\quad \mathrm{Pu}-239,12.7 \mathrm{pCi} / \mathrm{g}$

- $\mathrm{U}-234,143 \mathrm{pCi} / \mathrm{g}$

- $\quad \mathrm{U}-235,17.5 \mathrm{pCi} / \mathrm{g}$

- U-238, $105 \mathrm{pCi} / \mathrm{g}$

- $\quad$ Cesium (Cs)-137, 12.2 pCi/g

- $\quad$ Europium (Eu)-152, 5.7 pCi/g

- $\quad$ Lead (Pb)-212, 5.0 pCi/g

CAS 01-09-02. Samples MPXA001, MPXA002, MPXA003, MPXA004, MPXA005, MPXA009, MPXA0010, and MPXA201 exceeded the FSL at this CAS for beta radiation. Therefore, all samples from this CAS were submitted for gamma spectroscopy, isotopic U, isotopic Pu, and Sr-90 analysis. None of the results exceeded the PALs.

CAS 02-09-26. Although the FSRs from the initial screening of sample MPXH010 did not exceed either of the FSLs for this CAS, the FSRs were approaching the FSLs. To confirm the initial FSRs were accurate, a second screening of this sample was conducted and resulted in a FSR that exceeded the FSL for beta radiation. To be conservative, this sample was submitted for gamma spectroscopy, isotopic U, isotopic Pu, and Sr-90 analysis. None of the results exceeded the PALs. 
CAS 02-09-52. Sample MPXK005 exceed the FSL at this CAS for beta radiation. Therefore, all samples from this CAS were submitted for gamma spectroscopy, isotopic U, isotopic Pu, and Sr-90 analysis. None of the results exceeded the PALs.

CAS 09-09-24. During field activities, it was realized that this CAS resides within a large radioactive materials area (RMA), which is not consistent with the rest of the mud pit CASs in CAUs 530-535. This RMA was established as a result of atmospheric tests conducted from June 1957 to October 1958 using balloons launched from site B-9a, which was located in the area of this CAS. None of the samples exceeded the FSLs for this CAS; however, due to its location within an RMA, all of the samples were submitted for gamma spectroscopy, isotopic U, isotopic Pu, and Sr-90 analysis.

The evaluation of the radionuclides determined to be present in the mud pit CAS 09-09-24 were evaluated using the Residual Radioactive computer code (RESRAD) and Scenario B, which evaluates the potential dose for the remote use scenario. Europium-152 was the greatest contributor representing 96.0 percent of the total dose potential of $0.77 \mathrm{mrem} / \mathrm{yr}$ which does not pose an unacceptable risk under Scenario B. None of the other six detected radionuclides contributed more than 4.0 percent to the total dose. Appendix G presents details of the RESRAD model and computer code calculations and results for CAS 09-09-24.

The primary radionuclide present in this mud pit was Eu-152, which is considered a soil activation product of the atmospheric testing era at the NTS. Although this radionuclide is considered to be entrained throughout the mud (i.e., present in the surface and subsurface), it is not considered to have originated from the drilling activities nor considered to be associated with the drilling activities. The CAS is located in a large RMA that encompasses much of the area identified to be affected by the historic atmospheric testing at the NTS and this RMA posting will not be removed in the foreseeable future.

\subsection{Collection of Biased Samples}

CAS 01-09-04. At this uncovered CAS, one biased sample was collected in a potential mud spill of crushed black volcanic rock to the east of sample location B10 and submitted for TPH-DRO analysis (see Figure C.1-2). No other process knowledge or site properties suggested analyses for additional 
parameters were necessary. Concentrations of TPH-DRO did not exceed the minimum detection concentration (MDC).

CAS 07-09-13. At this uncovered CAS, one biased sample was collected from a greyish-black colored grout pile or potential mud spill from just outside the east end of the pit and submitted for TPH-DRO analysis (see Figure C.1-23). No other process knowledge or site properties suggested analyses for additional parameters were necessary. Concentrations of TPH-DRO did not exceed the MDC.

CAS 20-09-31. This CAS was covered making the boundaries of the CAS rather arbitrary. However, a wash area was noted along the east end of the former pit area. The wash contained a greyish material, which was distinguishable from the surrounding soil and was thought to be a potential mud spill. A sample was collected from this greyish material in the wash and submitted for TPH-DRO analysis (see Figure C.1-49). No other process knowledge or site properties suggested analyses for additional parameters were necessary. Concentrations of TPH-DRO did not exceed the MDC.

\subsection{Samples Submitted for SVOC and VOC Analysis}

CAS 03-09-17. This CAS is a two-pit system having a larger return pit and smaller suction pit. During the original sample collection activities, a black substance identified as coal tar epoxy (CTE) debris was encountered at the bottom of the suction pit. Samples collected from this suction pit had a noticeable organic odor and therefore submitted for SVOC analysis. Results confirmed SVOCs were present above the PALs, but this can be attributed to the presence of the CTE. Because the CTE debris is an anomaly and interfered with the collection of representative sample locations at the base of the suction pit, the CTE debris and soil directly in contact with the debris was removed by excavation and disposed. See Section 2.2.2 below for discussion of deviations from the SAFER Plan.

Three pre-determined, random soil sample locations originally within or adjacent to the CTE debris (M02, M03, and M04) were re-collected after the CTE debris was removed. These samples were analyzed for VOCs and SVOCs in addition to the TPH-DRO. Concentrations of VOCs and SVOCs did not exceed the MDC, with the exception of one SVOC constituent (Di-n-butylphthlate), which is well below the PAL, and confirms no remaining constituents associated with the CTE debris are present at this CAS. 


\subsubsection{Visual Habitat Surveys}

Additional information to confirm the lack of habitat for threatened and endangered species was collected during visual surveys. These surveys were conducted at 149 CASs not visited previously during any of the historical characterization efforts of CAUs 530-535 (Table 1-1). This activity confirmed that no threatened or endangered species were present in any of the CASs, and none of the surveyed CASs are likely to serve as habitat for threatened or endangered species. A standardized form was created and used to document the results of each habitat survey. Original survey forms, along with photodocumentation of debris encountered at these CASs, are located in the project files for future reference.

\subsubsection{Waste Characterization}

Waste characterization activities were conducted to gather sufficient information and data to support waste disposal decisions. These results are discussed in Sections 3.1.1 and 3.1.3.

\subsubsection{Conceptual Site Model Validation}

A conceptual site model (CSM) was developed to represent the release mechanisms and potential migration pathways for contaminant releases at CAUs 530-535. The CSM and detailed discussion of the potential pathways are provided in the SAFER Plan. The CSM addressed surface and shallow subsurface soils potentially impacted by releases of TPH-DRO from historical drilling operations conducted during underground nuclear testing at the NTS. The release mechanisms include the addition of diesel fuel to the drilling mud as well as spills/leaks from equipment brought on site.

The CSM assumed that the residual mud in the pits would have been homogenized during drilling operations, TPH-DRO was the only COPC, contaminant migration would be minimal, and that no threatened and endangered species inhabited the mud pits. These assumptions are supported by the consistently low levels of TPH-DRO found in each of the mud pits, the levels of radiological COPCs that were below the FALs, and the lack of suitable threatened or endangered species habitat. Therefore, information gathered during field activities of this closure investigation validates the CSM as presented in the SAFER Plan. 


\subsubsection{Housekeeping}

In addition to these SAFER Plan activities, housekeeping debris was removed from CAS 09-09-08 on February 21, 2006. The debris consisted of two lead-acid batteries located on the northeast corner of the mud pit berm. The batteries were removed from the CAS for recycling. Soil just below the battery was excavated and drummed. Finally, verification samples were collected under the former battery locations.

At CAS 02-09-30, a legacy Cs-137 radioactive source was identified near but outside the CAS boundary during sampling activities. The source was containerized and removed from the site by appropriate personnel. Handheld radiological screening instruments confirmed no elevated readings were present on the ground surface; therefore, no soil samples were collected. Additional details of these activities are discussed in Appendix B.

\subsection{Deviations from SAFER Plan as Approved}

This section provides a summary of the deviations that were made during SAFER Plan activities.

\subsubsection{CAU 532, CAS 09-09-05 and CAS 09-09-15}

Corrective Action Site 09-09-05 was identified in the SAFER Plan as one of the 52 CASs for environmental sampling. However, CAS 09-09-15 was mistaken for CAS 09-09-05 and was sampled on September 22, 2005. This was discovered on November 11, 2005 during the habitat survey visit to CAS 09-09-15 where the CAS had already been sampled. As such, CAS 09-09-05 was identified for a habitat survey instead of sampling. Since both CASs are from the same CAU and same NTS Area and since selection of CASs for sampling was randomly conducted, this deviation does not impact the sampling design or influence the results of this closure investigation.

\subsubsection{CAU 530, CAS 03-09-17}

This CAS is a two-pit system having a larger return pit and smaller suction pit. During the collection of the 10 random surface samples, a black substance identified as CTE debris was encountered at the bottom of the suction pit. Samples collected from this suction pit had a noticeable organic odor and were therefore submitted for SVOC analysis. Results confirmed SVOCs were present above the 
PALs, but subsequent analyses attributed the presence of organics to the CTE. The presence of the CTE is not related to drilling operations conducted at the mud pit and the practice of lining a pit was not observed during other field activities conducted for this investigation suggesting that CTE debris is an anomaly. Because the CTE debris is anomalous and interfered with the collection of representative residual mud at the base of the suction pit, the CTE debris and soil directly in contact with the debris was removed by excavation and disposed on April 11 and 12, 2006. Additional details of the CTE debris excavation and waste management activities are provided in Appendix B and Appendix E.

Three pre-determined, random soil sample locations originally above or adjacent to the CTE debris (M02, M03, and M04) were re-collected after the CTE debris was removed to provide representative TPH-DRO sample results for the CAS. These three samples were analyzed for TPH-DRO as well as VOCs and SVOCs. The TPH-DRO results of sample numbers MPXM012, MPXM013, and MPXM014 have replaced the original three samples in calculating the 95 percent UCL of the mean DRO concentration for risk-based closure. The VOC and SVOC results confirm no CTE constituents remain at the CAS. This deviation does not impact the sampling design or influence the results of this closure investigation.

\subsection{Corrective Action Schedule as Completed}

The schedule of activities for the CAUs 530-535 SAFER investigation are summarized in Table 2-1.

\subsection{Site Plan/Survey Plat}

Figure 2-1 shows an example of how samples were located within a one- and two-pit system. Site plans for each CAS and sample locations are shown in Appendix C. 
Table 2-1

CAUs 530-535 SAFER Investigation Schedule as Completed

\begin{tabular}{|c|c|c|c|}
\hline Activity & Task & Start Date & End Date \\
\hline \multirow{8}{*}{$\begin{array}{c}\text { Site } \\
\text { Preparation }\end{array}$} & $\begin{array}{l}\text { Underground Utility Clearance Surveys and } \\
\text { Underground/Overhead Utility Checklists }\end{array}$ & $8 / 31 / 2005$ & 9/26/2005 \\
\hline & Vegetation Removal & $9 / 6 / 2005$ & $9 / 28 / 2005$ \\
\hline & Debris Removal & 9/6/2005 & 9/28/2005 \\
\hline & Sample Location Identification & 9/6/2005 & 9/28/2005 \\
\hline & Construction of Temporary EZ & $9 / 7 / 2005$ & 11/1/2005 \\
\hline & $\begin{array}{l}\text { Visual Inspections for Threatened and Endangered } \\
\text { Species Habitat and Spills or Soil Stains }\end{array}$ & 9/7/2005 & $11 / 1 / 2005$ \\
\hline & Establish Field-Screening Levels & 9/7/2005 & $11 / 1 / 2005$ \\
\hline & Spill Prevention (required at covered CASs only) & 9/27/2005 & $11 / 1 / 2005$ \\
\hline \multirow{4}{*}{$\begin{array}{l}\text { Site } \\
\text { Investigation }\end{array}$} & Surface Sample Collection & 9/7/2005 & $10 / 12 / 2005$ \\
\hline & $\begin{array}{l}\text { Subsurface Sample Collection } \\
\text { (required at covered CASs only) }\end{array}$ & 9/27/2005 & $11 / 1 / 2005$ \\
\hline & Radiological Field Screening & 9/7/2005 & $11 / 1 / 2005$ \\
\hline & Organic Vapor Monitoring (required at covered CASs only) & 9/27/2005 & $11 / 1 / 2005$ \\
\hline \multirow{7}{*}{$\begin{array}{c}\text { Post } \\
\text { Investigation }\end{array}$} & Visual Habitat Surveys & 10/13/2005 & $12 / 8 / 2005$ \\
\hline & Data Verification & $10 / 3 / 2005$ & $1 / 25 / 2006$ \\
\hline & Risk Assessment & $1 / 27 / 2006$ & $1 / 31 / 2006$ \\
\hline & Debris Disposal in Rolloff & $9 / 28 / 2005$ & $11 / 18 / 2005$ \\
\hline & Rinsate Disposal at HAA (required for covered CASs only) & $\mathrm{N} / \mathrm{A}$ & $11 / 1 / 2005$ \\
\hline & Rolloff Disposal at Landfill & $N / A$ & $2 / 02 / 2006$ \\
\hline & Rinsate Disposal & N/A & $6 / 16 / 2006$ \\
\hline \multirow{3}{*}{$\begin{array}{l}\text { Housekeeping } \\
\text { at } \\
\text { CAS 09-09-08 }\end{array}$} & Battery Removal for Recycling & \multirow{3}{*}{$\mathrm{N} / \mathrm{A}$} & 2/21/2006 \\
\hline & Soil Excavation and Verification Sampling & & $2 / 21 / 2006$ \\
\hline & Disposal of Excavated Soil & & $6 / 16 / 2006$ \\
\hline \multirow{2}{*}{$\begin{array}{c}\text { Debris } \\
\text { Removal at } \\
\text { CAS 03-09-17 }\end{array}$} & CTE Debris and Soil Removal & $4 / 11 / 2006$ & $4 / 12 / 2006$ \\
\hline & Verification Sampling & $\mathrm{N} / \mathrm{A}$ & 4/12/2006 \\
\hline
\end{tabular}

CAS $=$ Corrective action site

CTE = Coal tar epoxy

$E Z=$ Exclusion zone

HAA = Hydrocarbon accumulation area

N/A = Not applicable 


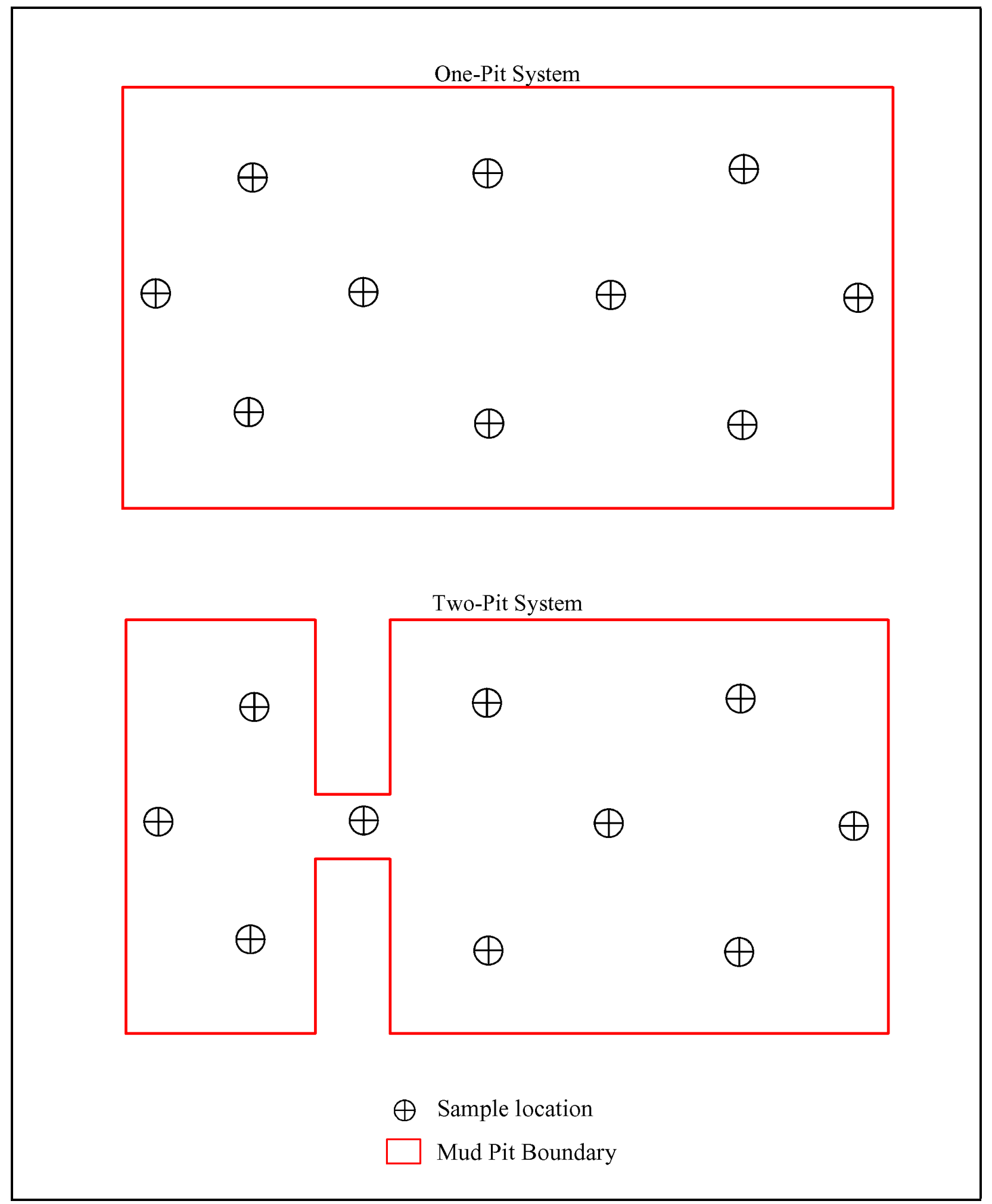

Figure 2-1

Example Mud Pit Sample Distribution for a One- and Two-Pit System 


\subsection{Waste Disposition}

Investigation-derived waste (IDW) was generated during the SAFER closure investigation activities at CAUs 530-535. The waste streams included debris, decontamination rinsate liquid, disposable personal protection equipment (PPE), and disposable sampling equipment. The types, amounts, and disposal of the wastes are detailed in the following subsections.

\subsection{Waste Minimization}

CAUs 530-535 integrated waste minimization into the field activities. The IDW was segregated to the extent possible. Controls were in place to avoid the unnecessary generation of hazardous and/or mixed waste. Decontamination procedures were established for covered and uncovered CASs to minimize the amount of waste generated. For uncovered CASs, disposable aluminum collection pans were dry decontaminated by swiping clean with a kemwipe between samples locations at the same CAS to minimize the amount of IDW generated. For covered CASs, the backhoe bucket was dry decontaminated, by brushing off excess dirt and wiping with a kemwipe between sample locations at the same CAS, and wet decontaminated between CASs to minimize the amount of rinsate generated. Quality assurance samples proved that these decontamination procedures did not affect the representativeness of the dataset.

\subsubsection{Characterization}

The only COPC for this investigation was TPH-DRO. Wastes such as the decontamination rinsate and PPE/sampling debris were characterized based on the associated soil samples and knowledge of the waste generation process. The decontamination rinsate and CTE debris were also sampled for waste characterization data. Where required, direct sampling of debris and/or associated excavated soil was conducted for waste determination. These data were reviewed against federal regulations; state regulations; DOE Directives, Policies, and Guidance; Waste Disposal Criteria; and Stoller-Navarro Joint Venture (SNJV) SBMS procedures. Analytical data were reviewed through Tier I, II, and III validation. 


\subsubsection{Waste Streams}

The IDW generated was segregated into the following waste streams:

- Personal protective equipment and disposable sampling equipment

- Debris determined to be non-hazardous, easily manageable (i.e., less than $50 \mathrm{lb}$ ), and not contaminated with either fixed or removable radiological contamination

- Decontamination rinsate

- Coal tar epoxy debris and underlying soil

- Housekeeping waste of two lead batteries

\subsubsection{Waste Sampling}

Waste determinations were made utilizing process knowledge and media sample association. Direct sampling was performed on the decontamination rinsate, drummed soil associated with the lead battery removal, and CTE debris and associated soil to confirm the regulatory status of the IDW.

\subsection{Storage}

The IDW generated was managed within one Hydrocarbon Accumulation Area (HAA), one Satellite Accumulation Area (SAA), and one roll-off container. Twenty six gallons (gal) of rinsate were generated during decontamination activities stored in one 55-gal, U.S. Department of Transportation (DOT) approved steel drum, labeled as "Hydrocarbon Waste," and stored in a HAA within the former Area 6 Decon Facility, CAU 543, CAS 06-17-01. The easily manageable debris collected was surveyed and swiped for radiation and placed into the roll-off container, also located within the former Area 6 Decon Facility. Personal protective equipment and disposable sampling equipment was disposed of in the roll-off at Building 153 in Mercury. For each waste stream, the amount, type, and source were recorded in the appropriate waste management logbooks. All waste is traceable to associated media samples. Waste accumulation areas were inspected regularly as required by federal regulation and internal procedures. The CTE debris and underlying soil were directly loaded into dump trucks and disposed at the Area 6 Hydrocarbon Landfill; therefore, waste storage was not necessary. 


\subsection{Waste Disposal}

Appendix $\mathrm{E}$ of this $\mathrm{CR}$ provides additional details regarding the disposition and volume of each waste stream generated during the closure activities. The disposition of each waste stream is summarized as follows:

- Personal protective equipment and disposable sampling equipment was disposed as solid waste in the 10C Landfill. The individual bags of waste were documented in a sanitary waste logbook at the end of each field work day. Approximately 550 gal of PPE and disposable equipment were disposed.

- Non-hazardous, easily manageable debris (i.e., less than $50 \mathrm{lb}$ ) was disposed as solid waste in the 10C Landfill. Table 3-1 summarizes the debris that was disposed of in the 10C Landfill. The number of items translated into approximately 2 cubic yards $\left(\mathrm{yd}^{3}\right)$ with a total weight of $200 \mathrm{lb}$ as documented in the Landfill Load Verification Form.

- Decontamination rinsate was disposed as sanitary waste into the Area 23 Mercury Lagoons. A total volume of 26 gal of rinsate was disposed.

- Coal tar epoxy debris and associated soil was disposed as hydrocarbon waste to the Area 6 Hydrocarbon Landfill. The Landfill Load Verification Form documents that a total of $75,000 \mathrm{lb}$ of CTE was disposed, which translates into approximately $30 \mathrm{yd}^{3}$.

- Lead batteries were turned in for recycling at the NTS Fleet Operations yard. The excavated and drummed soil beneath the batteries was approximately 5 gal and was disposed as sanitary waste.

- The Cs-137 radioactive source is securely stored at Building 153. Final characterization and disposal as low-level waste (LLW) will occur independently from the CAU 530-535 CR as this waste stream is not associated with the mud pit CAS and was outside the CAS boundary. 
Table 3-1

Non-Hazardous Debris Removed During SAFER Activities

\begin{tabular}{|c|c|c|}
\hline CAU & CAS & Debris Removed \\
\hline \multirow{2}{*}{530} & $03-09-15$ & 1 soda can, 1 Folgers coffee can \\
\hline & 07-09-10 & 2 metal cables, 1 small fuse, 1 boot \\
\hline \multirow{2}{*}{532} & $02-09-18$ & Office trash can \\
\hline & $02-09-26$ & Rubber gaskets, spatula \\
\hline \multirow{4}{*}{533} & $02-09-30$ & $\begin{array}{l}3 \text { glass Mason jars, a metal frame, } 2 \text {-ft long small } \\
\text { diameter rods }\end{array}$ \\
\hline & $02-09-52$ & 7 T-posts, 1 3-gal pail \\
\hline & $09-09-27$ & $\begin{array}{l}\text { barbed wire, } 2 \text {-ft long small diameter rods, metal } \\
\text { tie, light bulb socket }\end{array}$ \\
\hline & $10-09-18$ & Rusted metal pail, crushed soda can \\
\hline \multirow{2}{*}{534} & $03-09-30$ & 2 ends of a spool, glass bottle, Pepsi can \\
\hline & $07-09-27$ & Drill rod \\
\hline 535 & 07-09-28 & $\begin{array}{l}\text { 5-gal water jug, } 2 \text { T-posts, plastic scoop, food and } \\
\text { drink containers, metal grate, metal pipe, circular } \\
\text { metal plate }\end{array}$ \\
\hline
\end{tabular}

\subsection{Photodocumentation}

Debris that could not be easily removed from a CAS during environmental sample collection was photodocumented and left in place for potential future disposal. Debris or spills that were encountered during the visual habitat surveys were also photodocumented and left in place for potential future disposal. Information on the type of debris, CAS, and photo documentation has been tabulated and is available in the project files for future reference.

\subsection{Housekeeping Activities}

The following additional waste was generated during housekeeping activities at CAS 09-09-08 and 02-09-30. These activities are documented in detail in Appendix B:

- Two batteries were found during visual habitat surveys at CAS 09-09-08 and transported to the management and operating (M\&O) fleet operations yard for recycling. 
- One drum of approximately 5 gal of excavated soil was sampled and characterized as solid waste for 09-09-08. This drum was picked up by the NTS M\&O Contractor for disposal at the 10C Landfill. The load verification form was misplaced; however, documentation of the disposal is included in Appendix E.

- At CAS 02-09-30, a legacy Cs-137 radioactive source was identified, containerized, and removed from the site, securely stored at Building 153 and is pending final characterization and disposal as LLW independent of this CR as the source is not considered a mud pit CAS waste stream. 


\subsection{Closure Verification Results}

The CAUs 530-535 SAFER Plan identified that the right type, quality, and quantity of data were available to resolve the DQO decision statements, at the agreed to level of confidence, so that CAUs 530-535 may be closed with no further action. To verify the dataset supports the DQO decisions, a data quality assessment (DQA) was conducted (Section 4.1 and Appendix A). Results from the DQA were used to determine the acceptable closure recommendations and if use restrictions are necessary for CAUs 530-535 (Section 4.2). The following section summarizes the assessment.

\subsection{Data Quality Assessment}

The DQA is a scientific evaluation of the investigation results to determine if the: (1) DQOs established in the CAUs 530-535 SAFER Plan were met and (2) DQO decision statements can be resolved at the desired level of confidence. Results from the five steps of the assessment (detailed in Appendix A) to evaluate the DQIs, the hypothesis tests supporting Decision A and Decision B, and the assumptions underlying these hypothesis tests are as follows:

- Data quality indicators - For the data used in making Decision A and Decision B, all performance criteria specified in the SAFER Plan were satisfied.

- Hypothesis tests for Decision A and Decision B - In satisfying the specified decision errors, results from both of these tests confirm that CAUs 530-535 do not pose an unacceptable risk to human health or ecological receptors.

- Assumptions underlying the hypothesis tests - Results from these tests resulted in the need to increase the variance used in the Decision A hypothesis test but did not impact the outcome of Decision A or Decision B.

These evaluations concluded that the DQOs established in the SAFER Plan (summarized in Appendix A) were met. In addition, as discussed in Section 2.1.4, these results validate the CSM as presented in the SAFER Plan. Further, the data support that mud pit CASs not currently included in, but that meet the criteria of, CAU 530-535 can be moved from Appendix II to Appendix IV of the FFACO without further investigation (Section 5.2). 


\subsection{Use Restriction}

Data collected from representative CASs determined that TPH-DRO levels in CAUs 530-535 do not pose an unacceptable risk to human or ecological receptors. Therefore, no further action is necessary for the soil at these CAUs and no use restrictions are required. 


\subsection{Conclusions and Recommendations}

Based on the results of the closure investigation activities discussed in Section 2.0 and Appendix A, no further cleanup activities or use restrictions are necessary for CAUs 530-535. Therefore, the U.S. Department of Energy, National Nuclear Security Administration Nevada Site Office (NNSA/NSO) provides the following recommendations:

- $\quad$ No corrective actions are required at CAUs 530-535.

- $\quad$ No Corrective Action Plan is required at CAUs 530-535.

- No use restrictions are required at CAUs 530-535.

- No further action is required at CAUs 530-535.

- A Notice of Completion is requested from NDEP for closure of CAUs 530-535.

- CAUs 530-535 should be moved from Appendix III to Appendix IV of the FFACO.

\subsection{Justification for No Further Action}

Samples collected from 52 CASs were shown to be representative of the entire population of CASs within CAUs 530-535 where the only COPC identified was TPH-DRO. This analyte was detected in 22 percent of the soil samples, but the risk assessment (Appendix G) confirmed that the reported levels did not pose an unacceptable risk to human receptors. Visual habitat surveys as well as preliminary assessment activities also confirmed that the mud pit CASs are not suitable habitat for threatened or endangered species. Therefore, there is also no unacceptable risk to ecological receptors. Data quality objective decision statements were satisfied within the acceptable criteria specified in the SAFER Plan. Additional biased samples also confirmed the boundaries of the conceptual site model. Therefore, no further action is the recommended closure alternative for the 268 CASs within CAUs 530-535, and all CASs within these CAUs should be transferred to Appendix IV of the FFACO.

Housekeeping debris in CAUs 530-535 was removed or left in place and photodocumented for future disposal. This documentation is located in the project files for future reference.

\subsection{Future Applications of Mud Pit Risk-Based Closure Strategy}

The investigations conducted CAUs 530-535 supported the recommended closure strategy provided in the RBCSR and SAFER Plan. This closure investigation has shown that TPH-DRO is not a 
contaminant of concern (COC) at NTS mud pit CASs. Therefore, consistent with the conclusions and recommendations in the RBCSR and SAFER Plan, non-radioactive mud pit CASs identified in the future should be transferred directly from Appendix II to Appendix IV of the FFACO, provided they meet the following criteria:

- The CAS is either a single mud pit or a system of mud pits.

- The CAS is not located in a radiological or radioactive material posted area.

- The CAS does not serve as habitat for threatened and endangered species.

- There are no biasing factors evident based on a visual inspection. 


\subsection{References}

DOE/NV, see U.S. Department of Energy, Nevada Operations Office.

Federal Facility Agreement and Consent Order. 1996 (as amended). Agreed to by the State of Nevada, the U.S. Department of Energy, and the U.S. Department of Defense.

Nicosia, W.C., Shaw Environmental, Inc. 2003. Memo to M. England entitled, "Radiological Land Area Surveys of Summer 2003 Mud Pit Project at the Nevada Test Site,” 1 August.

Las Vegas, NV.

NNSA/NSO, see U.S. Department of Energy, National Nuclear Security Administration Nevada Site Office.

NNSA/NV, see U.S. Department of Energy, National Nuclear Security Administration Nevada Operations Office.

Pacific Northwest National Laboratory. 2002. Visual Sample Plan, Version 2.0, User’s Guide, September, PNNL-14002. Richland, WA.

PNNL, see Pacific Northwest National Laboratory.

REECo, see Reynolds Electrical \& Engineering Co., Inc.

Reynolds Electrical \& Engineering Co., Inc. 1994. Area 3 Waste Impoundment-Historical Information. Prepared by C.G. Postle. Las Vegas, NV.

SNJV, see Stoller-Navarro Joint Venture.

Stoller-Navarro Joint Venture. 2005. Project Execution Plan, S-N/99205--048. Las Vegas, NV.

U.S. Department of Energy, National Nuclear Security Administration Nevada Operations Office. 2002. Industrial Sites Quality Assurance Project Plan, Nevada Test Site, Nevada, Rev. 3, DOE/NV--372. Las Vegas, NV.

U.S. Department of Energy, National Nuclear Security Administration Nevada Site Office. 2004. Mud Pit Risk-Based Closure Strategy Report, Nevada Test Site, Nevada, DOE/NV--991. Las Vegas, NV.

U.S. Department of Energy, National Nuclear Security Administration Nevada Site Office. 2005a. Assessment of NTS Mud Pit CASs in CAUs 530-535 that are Potentially Contaminated with Radionuclides, July. Las Vegas, NV. 
U.S. Department of Energy, National Nuclear Security Administration Nevada Site Office. 2005b. Streamlined Approach for Environmental Restoration Plan for Corrective Action Units 530, 531, 532, 533, 534, and 535, Nevada Test Site Mud Pits, Nevada Test Site, Nevada, July, DOE/NV--1057. Las Vegas, NV.

U.S. Department of Energy, Nevada Operations Office. 2001. Mud Pit Strategy, Nevada Test Site, Nevada, DOE/NV--684. Las Vegas, NV.

U.S. Environmental Protection Agency. 1996. Test Methods for Evaluating Solid Waste, Physical/Chemical Methods, SW-846, ${ }^{\text {rd }}$ Edition (which includes updates to 1986, 1992, and 1994 revisions), CD-ROM PB97-501928GEI. Washington, DC.

Witt, J.W., Science Applications International Corporation. 2000. Record of meeting with B. Bailey (IT Corporation) regarding NTS Mud Pits. Las Vegas, NV. 


\section{Appendix A}

Data Quality Objectives as Developed in the SAFER Plan for CAUs 530-535:

Nevada Test Site Mud Pits,

Nevada Test Site, Nevada 


\section{A.1.0 Data Quality Assessment}

The Data Quality Assessment (DQA) process described in this appendix is a five-step scientific and statistical evaluation to determine if the data collected during the SAFER closure investigation are of the correct type, quality, and quantity to satisfy the CAUs 530-535 DQOs. The five steps of the DQA process presented in Sections A.1.1 through A.1.5 were developed in accordance with EPA Guidance for Data Quality Assessment (EPA, 2000). Employing the DQO and DQA process ensures that closure decisions are sound and defensible and establishes a systematic method for conducting future investigations of a similar scope.

\section{A.1.1 Step 1 - Review the DQOs and the Sampling Design}

The CAUs 530-535 DQOs provided the context for understanding the purpose of the closure investigation, dictated the sampling design for the investigation, and established the qualitative and quantitative criteria for assessing the quality of the data. Reviewing key outputs from the DQOs as well as the sampling design lays the foundation for the DQA process and facilitates a comparison between the dataset and criteria (or assumptions) used in developing the DQOs.

\section{A.1.1.1 Review Closure Investigation Objectives}

The problem statement for CAUs 530-535 is: "Existing data is insufficient to determine whether the preferred closure alternative (i.e., no further action) is acceptable for the 268 CASs within the six CAUs, 530-535.” To resolve the problem, two sequential decision statements, Decision A followed by Decision B, must be answered. The Decision A statement is: "Determine whether the characteristic TPH-DRO concentrations for a representative number of sampled CASs pose an unacceptable risk to human health or the environment.” The characteristic TPH-DRO concentration is defined as the 95 percent UCL of the mean. As determined in the RBCSR, the number of mud pits necessary to represent all 268 CASs in CAUs 530-535 is 52 (NNSA/NSO, 2004). The Decision B statement is: "Determine whether CAUs 530-535 can be closed via the no further action alternative." There are no alternative actions to Decision A; however, the cumulative results from each application of Decision A are utilized in Decision B. The alternative actions to Decision B are: "If none of the sampled mud pit CASs produce an unacceptable risk, then the 268 CASs in CAUs 530-535 will be 
closed via the no further action alternative. If any of the sampled CASs demonstrate an unacceptable risk, then additional evaluation will be required in consultation with the NDEP.”

To make these decisions, two types of information were missing, environmental samples and visual habitat surveys. To resolve Decision A, environmental samples were collected and analyzed following two criteria: (1) samples must be distributed throughout each of the 52 representative mud pit CASs to provide an unbiased characteristic TPH-DRO concentration, and (2) the analytical method selected must be of sufficient sensitivity to accurately quantify the TPH-DRO concentration present in the samples. To resolve Decision B, the lack of suitable habitat for threatened and endangered species must be confirmed by conducting visual habitat surveys at CASs not characterized during any of the preliminary assessments of CAUs 530-535.

The scale of decision making for Decision A is an individual CAS. The scale of decision making for Decision B is the entire population of mud pit CASs in CAUs 530-535. The population of interest is the residual drilling fluid contained in the mud pits. For uncovered mud pits, the drilling fluid is the surface material, defined as 0 to 6 inches in depth. For covered mud pits, the drilling fluid resides within the first 6 inches directly below the soil cover. Spatial boundaries are the expected maximum lateral and vertical extent of contamination. For this closure investigation, the lateral boundaries are the boundaries of each mud pit and, if a mud spill is present, the vertical boundaries will be the depth of the drilling fluid in each mud pit.

\section{A.1.1.2 Translate Objectives into Statistical Hypotheses}

In hypothesis testing, the null hypothesis (Ho) is considered to be true unless the data conclusively provide evidence that it is false. If the null hypothesis can be proven false, then it may be rejected in favor of the alternative hypothesis (Ha). Therefore, the following hypotheses are structured to protect human health and the environment by placing the burden of proof on demonstrating that CAUs 530-535 do not pose an unacceptable risk to human health.

Decision A. The hypothesis for Decision A compares the mean TPH-DRO concentration calculated for each sample set (i.e., for one CAS) to the maximum allowable mean concentration (MAMC) of TPH-DRO. The MAMC is a benchmark quantity equivalent to the mean TPH-DRO concentration for a scenario where the Hazard Index (HI) is 1.0. It is calculated from the equation to find a 
95 percent UCL by solving for the mean concentration as a function of the maximum allowable characteristic concentration (MACC) of TPH-DRO, the population standard deviation $(\sigma)$, and population size $(N)$. The MACC was previously calculated as 61,558 milligrams per kilogram (mg/kg) TPH-DRO in the SAFER Plan using the Future Industrial Worker exposure scenario (NNSA/NSO, 2005a). Since then, new exposure scenarios with site-specific input parameter values for the NTS have been proposed, and the most conservative of these scenarios is the Industrial Area exposure scenario (NNSA/NSO, 2006). Because the ingestion and inhalation rates are higher for this new exposure scenario than the former Future Industrial Worker exposure scenario, the MACC associated with this exposure scenario is $14,301 \mathrm{mg} / \mathrm{kg}$, which is lower than the $61,558 \mathrm{mg} / \mathrm{kg}$ originally calculated in the SAFER Plan. The population standard deviation and population size are discussed further in Section A.1.2.2. The MAMC is calculated using the formula:

$$
\text { MAMC }=\operatorname{MACC}-\mathrm{Z}_{0.02}(\sigma / \sqrt{N}) .
$$

Table A.1-1 summarizes the inputs and results for the calculation of the MAMC.

Table A.1-1

Calculation of the Maximum Allowable Mean TPH-DRO Concentration

\begin{tabular}{|c|c|c|c|}
\hline Input/Output & Variable & Symbol & Value \\
\hline \multirow{4}{*}{ Input } & $\begin{array}{c}\text { Maximum Allowable } \\
\text { Characteristic } \\
\text { TPH-DRO } \\
\text { Concentration }\end{array}$ & MACC & $14,300 \mathrm{mg} / \mathrm{kg}$ \\
\hline & $\begin{array}{c}\text { Population Standard } \\
\text { Deviation }\end{array}$ & $\sigma$ & $42 \mathrm{mg} / \mathrm{kg}$ \\
\hline & Population Size & $N$ & 521 \\
\hline & z-value for $95 \%$ UCL & $\mathrm{z}_{0.025}$ & 1.96 \\
\hline Output & $\begin{array}{c}\text { Maximum Allowable } \\
\text { Mean TPH-DRO } \\
\text { Concentration }\end{array}$ & MAMC & $14,296 \mathrm{mg} / \mathrm{kg}$ \\
\hline
\end{tabular}

$\mathrm{mg} / \mathrm{kg}=$ Milligrams per kilograms

TPH-DRO = Total petroleum hydrocarbons, diesel-range organics

$\mathrm{UCL}=$ Upper confidence level 
A mean TPH-DRO concentration of 14,296 mg/kg will result in an HI of 1.0 and pose an unacceptable risk to human health. To be conservative, sample means will be compared to a MAMC of 14,000 mg/kg. Table A.1-2 presents the Ho and Ha for Decision A in both a narrative and standard statistical form.

Table A.1-2

Hypotheses Statements for Decision A

\begin{tabular}{||c|c|c|}
\hline Hypothesis & Narrative Statement & Statistical Statement \\
\hline \hline $\begin{array}{c}\text { Null } \\
(\mathrm{Ho})\end{array}$ & $\begin{array}{c}\text { The mean TPH-DRO concentration for any given CAS } \\
\text { equals or exceeds the maximum mean concentration of } \\
14,000 \mathrm{mg} / \mathrm{kg} \text { indicating the CAS poses an unacceptable } \\
\text { risk to human health. }\end{array}$ & $\bar{\chi} \geq 14,000 \mathrm{mg} / \mathrm{kg}$ \\
$\begin{array}{c}\text { Alternative } \\
(\mathrm{Ha})\end{array}$ & $\begin{array}{c}\text { The mean TPH-DRO concentration for any given CAS is } \\
\text { less than the maximum mean concentration of } 14,000 \mathrm{mg} / \mathrm{kg}\end{array}$ & $\bar{\chi}<14,000 \mathrm{mg} / \mathrm{kg}$ \\
\hline
\end{tabular}

$\bar{\chi}=$ Mean TPH concentration for a single CAS

CAS $=$ Corrective action site

$\mathrm{mg} / \mathrm{kg}=$ Milligrams per kilogram

$\mathrm{TPH}-\mathrm{DRO}=$ Total petroleum hydrocarbons, diesel-range organics

These hypotheses statements satisfy the objectives of Decision A. However, they are a slight departure from the ones originally presented in the CAUs 530-535 SAFER Plan. The original hypotheses statements called for a direct comparison of the HI to a value of 1.0 (see Appendix G), but because that approach requires the data first be evaluated through a risk assessment, the statistical test of the hypotheses statements becomes unnecessarily complex. The new hypotheses statements proposed here offer a more straight-forward and robust statistical evaluation of the Decision A hypotheses.

Decision B. The hypotheses for Decision B compare number of mud pit CASs that pose an unacceptable risk (as determined by Decision A) to the critical value. Critical value, as discussed in the SAFER Plan and the RBCSR, is defined as the acceptable number of NTS Mud Pit CASs that have an $\mathrm{HI}$ greater than 1.0 or that serve as habitats for threatened or endangered species. For this SAFER closure investigation, the critical value was calculated to be zero (NNSA/NSO, 2005a). Table A.1-3 presents the Ho and Ha for Decision B in both the narrative and standard statistical form. 
Table A.1-3

Hypotheses Statements for Decision B

\begin{tabular}{||c|c|c||}
\hline Hypothesis & Narrative Statement & Statistical Statement $^{\mathbf{a}}$ \\
\hline \hline $\begin{array}{c}\text { Null } \\
\text { (Ho) }\end{array}$ & $\begin{array}{c}\text { At least one of the 52 sampled CASs poses an unacceptable } \\
\text { risk to human health or threatened or endangered species } \\
\text { habitat is present. Therefore, CAUs 530-535 cannot be } \\
\text { closed via the no further action alternative. }\end{array}$ & $X>0$ \\
\hline $\begin{array}{c}\text { Alternative } \\
\text { (Ha) }\end{array}$ & $\begin{array}{c}\text { None of the 52 sampled CASs poses an unacceptable risk to } \\
\text { human health and no viable habitat for threatened and } \\
\text { endangered species is present. Therefore, CAUs 530-535 } \\
\text { can be closed via the no further action alternative. }\end{array}$ & $X=0$ \\
\hline
\end{tabular}

${ }^{\mathrm{a}} X=$ Number of mud pit CASs that pose an unacceptable risk.

$\mathrm{CAS}=$ Corrective Action Site

$\mathrm{CAU}=$ Corrective Action Unit

\section{A.1.1.3 Develop Limits on Decision Errors}

The DQO decisions have a probability of making a decision error, either false negative (Type I) or false positive (Type II). The false negative decision error would mean deciding that a CAS does not pose an unacceptable risk when it actually does (Decision A) or deciding that CAUs 530-535 can be closed via the no further action alternative when they cannot (Decision B); for both decisions, the potential consequence is an increased risk to human health and the environment. The false positive decision error would mean deciding that a CAS poses an unacceptable risk when it actually does not (Decision A), or unnecessarily notifying NDEP that additional evaluation is necessary when it actually is not (Decision B).

Decision A. As agreed to by the planning team, the false negative and false positive decision errors for Decision A are 0.05 and 0.20, respectively. The false negative decision error (where consequences are more severe) is controlled by using the 95 percent UCL of the mean TPH-DRO concentration as the exposure point concentration in the risk assessment and ensuring the data meets the following criteria:

- Data was collected from a minimum number of sample locations to satisfy the decision errors.

- Analytical methods were of adequate sensitivity to detect TPH-DRO in the samples.

- Dataset meets the quality and completeness requirements specified in the DQOs. 
The false positive decision error is typically attributed to laboratory and/or sampling/handling errors that could cause cross contamination. Therefore, this type of decision error is controlled by implementing the same criteria to protect against false negative error and ensures the decontamination process is effective. To determine whether a false positive analytical result may have occurred, the following quality control samples were collected:

- $\quad$ Source blanks (1 per source lot per sampling event)

- $\quad$ Field blanks (1 per day - additional if field conditions changed)

To assess precision and accuracy as well as provide information regarding matrix interference, matrix spike/matrix spike duplicate (1 per CAS per matrix; not required for all radionuclide measurements) quality control samples were collected.

To measure the quality of the laboratory results and protect against decision errors for Decision A, precision, accuracy, sensitivity, comparability, representativeness, and completeness DQIs are presented in Section A.1.2.1.

Decision B. The planning team also established the false negative and false positive decision errors for Decision B to be 0.05 and 0.20 , respectively. Both errors are controlled by meeting the following criteria:

- Data used in Decision A meets all quality criteria.

- $\quad$ The assumed failure rate (i.e., portion of mud pit CASs that pose an unacceptable risk) underlying the Decision B hypothesis test is justified.

Closure Investigation. The overall false negative error for this investigation is approximately 0.10 calculated from the cumulative errors of both decisions, the 0.05 error of Decision A multiplied by the 0.05 error of Decision B. In other words, the closure strategy for this investigation is applied with 90 percent confidence. The overall false positive error for this investigation is 0.20 ; thus, a decision to engage in further consultation with NDEP before closure of CAUs 530-535 will be made with 80 percent confidence. 


\section{A.1.1.4 Review Sampling Design}

Based on an estimated variance, the RBCSR determined that a minimum of 10 samples from the surface of each mud pit CAS ( 0 to 6 inches below soil cover if the mud pit is covered) were adequate to meet the decision errors of Decision A (NNSA/NSO, 2004). To ensure the sample locations are evenly dispersed throughout the mud pit, they were determined prior to sampling efforts using the VSP model (PNNL, 2002) and configured in a triangular grid pattern with the location of the initial sample chosen randomly. Additional biased samples were collected in areas of obvious spills or staining, located within or adjacent to the mud pit(s), to ensure the CAS was adequately characterized. In addition, the RBCSR determined that 52 CASs constitute a sample of adequate size to statistically represent the entire population of 268 CASs in CAUs 530-535 with 90 percent confidence.

Additional information to confirm the lack of habitat for threatened or endangered species was collected during visual surveys conducted at CASs not previously visited during any of the preliminary assessments of CAUs 530-535. This information was taken into consideration for resolving Decision B. Additionally, if radiological field screening indicated radioactivity greater then the background, then samples were also analyzed for gamma spectroscopy, isotopic uranium, isotopic plutonium, and strontium-90 as specified in the SAFER Plan.

\section{A.1.2 Step 2 - Conduct a Preliminary Data Review}

In performing a preliminary data review, the quality and "structure" of the data is examined revealing anomalies or unexpected results which may influence further data analyses or limit the usefulness of the data.

\section{A.1.2.1 Review Quality Assurance Reports}

Data verification and validation was performed in accordance with the Industrial Sites QAPP (NNSA/NV, 2002). Chemical laboratory data was evaluated for data quality according to EPA Functional Guidelines (EPA, 1999 and 2002a). Radiological laboratory data was evaluated for quality according to industry standards, reviewed to ensure that all samples were appropriately collected and analyzed, and that the results met the validation criteria. As discussed in the following 
section, validated data was assessed to determine whether they met the DQO requirements of the investigation as measured by the performance criteria for the DQIs.

\section{A.1.2.1.1 Data Quality Indicators}

The DQIs are qualitative and quantitative descriptors used to: (1) interpret the degree of acceptability or utility of data, (2) evaluate the entire measurement system and laboratory measurement processes (i.e., analytical method performance), and (3) evaluate individual analytical results (i.e., parameter performance). The quality and usability of the data used for supporting DQO decisions is assessed by employing the DQIs discussed in the following subsections.

\section{A.1.2.1.1.1 Precision}

Precision is used to assess the variability between two equal samples. This is a measure of the repeatability of the analysis process from sample collection through analysis results. Precision is evaluated using the relative percent difference (RPD) or normalized difference. For the purpose of determining the data precision of chemical analyses, the RPD between duplicate analyses was calculated. For radionuclides, the RPD was not calculated unless both the sample and its duplicate had concentrations of the target radionuclide exceeding five times the MDC. Otherwise radionuclide, duplicate results were evaluated using the normalized difference. Table A.1-4 provides the precision analysis results for all constituents that were qualified. No chemical analytes were qualified for precision (i.e., the precision rate for all other constituents is 100 percent). The only radionuclide qualified for precision was $\mathrm{Pu}-239$, but because radionuclides were not considered target analytes and used primarily to support health and safety decisions, it does not affect either DQO decision.

Table A.1-4

Precision Measurements

\begin{tabular}{|c|c|c|c|c|c|}
\hline Constituent & $\begin{array}{c}\text { CAS } \\
\text { Number }\end{array}$ & Analysis & $\begin{array}{c}\text { Number of } \\
\text { Analytes } \\
\text { Qualified }\end{array}$ & $\begin{array}{c}\text { Number of } \\
\text { Measurements } \\
\text { Performed }\end{array}$ & $\begin{array}{c}\text { Percent } \\
\text { within } \\
\text { Criteria }\end{array}$ \\
\hline \hline Pu-239 & $15117-48-3$ & Plutonium & 10 & 32 & 68.8 \\
\hline
\end{tabular}

CAS $=$ Chemical Abstracts Service 


\section{A.1.2.1.1.2 Accuracy}

Accuracy is a measure of the closeness of an individual measurement or the average of a number of measurements to the true value. It is used to assess the performance of laboratory measurement processes as well as to evaluate individual groups of analyses (i.e., sample delivery groups). For the purpose of determining accuracy of sample analyses, environmental soil samples were evaluated and incorporated into the accuracy calculation. The results qualified for accuracy are provided in Table A.1-5 and were associated with matrix spike recoveries that were outside control limits and could potentially be reported at concentrations lower or higher than actual concentrations (i.e., biased low or high). No radiological data were qualified for accuracy. The number of TPH-DRO data that were within the accuracy control limits exceed the 80 percent criterion identified in the SAFER Plan. Therefore, the dataset is determined to be acceptable for the DQI of accuracy.

Table A.1-5

\section{Accuracy Measurements}

\begin{tabular}{|c|c|c|c|c|c||}
\hline Constituent & $\begin{array}{c}\text { CAS } \\
\text { Number }\end{array}$ & Analysis & $\begin{array}{c}\text { Number } \\
\text { of } \\
\text { Analytes } \\
\text { Qualified }\end{array}$ & $\begin{array}{c}\text { Number of } \\
\text { Measurements } \\
\text { Performed }\end{array}$ & $\begin{array}{c}\text { Percent } \\
\text { within } \\
\text { Criteria }\end{array}$ \\
\hline \hline Diesel-Range Organics & $68334-30-5$ & DRO & 3 & 538 & 99.4 \\
\hline
\end{tabular}

CAS $=$ Chemical Abstracts Service

$\mathrm{DRO}=$ Diesel-range organics

\section{A.1.2.1.1.3 Sensitivity}

Sensitivity is the capability of a method or instrument to discriminate between measurement responses representing different levels of the variable of interest (EPA, 2002b). Sample results were assessed against the acceptance criterion for the DQI of sensitivity as defined in the Industrial Sites QAPP (NNSA/NV, 2002). The sensitivity acceptance criterion defined in the SAFER Plan is that analytical detection limits will be less than the corresponding action level. Results not meeting the sensitivity acceptance criterion were obtained from those samples submitted for SVOC analysis as listed in Table A.1-6. Because this closure investigation is not based on satisfying an action level, the 2004 preliminary remediation goals (PRGs) were utilized as the action level instead to measure sensitivity. The samples submitted for SVOC analysis came from the suction pit at CAS 03-09-17 that contained CTE debris. The analytical results reported constituents consistent with organic 
constituents in CTE. However, these SVOC data were not utilized in supporting the DQO decisions, because the CTE debris and affected soil were subsequently excavated and removed from the suction pit to gain access to representative mud pit sample locations. Therefore, all the TPH-DRO results used in the DQO decisions met the sensitivity criterion.

Table A.1-6

Analytes Failing Sensitivity Criteria

\begin{tabular}{|c|c|c|c|}
\hline $\begin{array}{l}\text { Sample } \\
\text { Number }\end{array}$ & Constituent & $\begin{array}{c}\text { Minimum } \\
\text { Detection } \\
\text { Concentration } \\
(\mu \mathrm{g} / \mathrm{kg})\end{array}$ & $\begin{array}{c}2004 \text { PRG } \\
(\mu \mathrm{g} / \mathrm{kg})\end{array}$ \\
\hline \multirow{2}{*}{ MPXM002 } & Dibenzo(a,h)anthracene & 1,300 & 210 \\
\hline & N-nitroso-di-n-propylamine & 320 & 250 \\
\hline \multirow{4}{*}{ MPXM003 } & Dibenzo(a,h)anthracene & 11,000 & 210 \\
\hline & Hexachlorobenzene & 2,200 & 1,100 \\
\hline & N-nitroso-di-n-propylamine & 2,600 & 250 \\
\hline & Pentachlorophenol & 20,000 & 9,000 \\
\hline \multirow{4}{*}{ MPXM201 } & Dibenzo(a,h)anthracene & 27,000 & 210 \\
\hline & Hexachlorobenzene & 5,600 & 1,100 \\
\hline & N-nitroso-di-n-propylamine & 6,700 & 250 \\
\hline & Pentachlorophenol & 50,000 & 9,000 \\
\hline
\end{tabular}

$\mu \mathrm{g} / \mathrm{kg}=$ Micrograms per kilogram

\section{A.1.2.1.1.4 Comparability}

Comparability is a qualitative parameter expressing the confidence with which one dataset can be compared to another (EPA, 2002b). Field sampling, as described in the SAFER Plan, was performed and documented in accordance with approved procedures comparable to standard industry practices. Approved analytical methods and procedures were used to analyze, report, and validate the data. These are comparable to other methods used in industry and government investigations and are comparable to other investigations conducted for the NTS. Therefore, project datasets are considered comparable to other datasets generated using these same standardized U.S. Department of Energy (DOE) procedures, thereby meeting the DQO requirements of comparability. 


\section{A.1.2.1.1.5 Representativeness}

Representativeness is the degree to which sample characteristics accurately and precisely represent characteristics of a population or an environmental condition (ANSI/ASQC, 1995). The three criteria for representativeness, which are similar to the criteria used to limit the decision errors, include:

- Samples be collected from locations evenly dispersed throughout a CAS to identify TPH-DRO, if it is present anywhere within the CAS. This also includes the collection of biased samples from areas of obvious staining or spills.

- Analytical methods were of adequate sensitivity to detect TPH-DRO in the samples.

- The dataset meets the quality and completeness requirements specified in the DQOs.

Criterion 1 ensures the sample locations selected will identify COCs, if present, anywhere within the CAS. This criterion was met by using VSP software to identify sample locations (Section A.1.1.4). When possible, vegetation or debris was moved to avoid interfering with the sample locations. Alternatively, the sampling process allowed for the movement of up to and including three sample locations, no more than one foot from their original location, while satisfying this criterion. If locations needed to be moved more than one foot, new GPS coordinates were collected for the entire CAS boundary and VSP was re-run to determine new sample locations. Adherence to this guideline ensured that unbiased samples were collected. Criterion 1 was also met by collecting biased samples as needed from areas of obvious spills or staining located either within or adjacent to the mud pit CAS (Section 2.1.1.2.3). Criterion 2 ensures that the analyses are capable of detecting TPH-DRO present in the samples. This criterion was met as addressed by the sensitivity DQI discussed in Section A.1.2.1.1.3. Criterion 3 ensures the data set is off sufficient quality and completeness. This criterion has been met as discussed in Section A.1.2.1.1.6. Therefore, the analytical data acquired during the CAUs 530-535 closure investigation are considered representative of the population of interest.

\section{A.1.2.1.1.6 Completeness}

Completeness is defined as generating sufficient data of the appropriate quality to satisfy the data needs identified in the DQOs. The SAFER Plan defines acceptable criteria for completeness to be a sufficient number of valid analytical results to satisfy the false positive and false negative error rates. 
Rejected data (qualified as rejected or data that failed the criterion of sensitivity) are not used in the resolution of DQO decisions and are not counted toward meeting the completeness acceptance criterion. However, no data was rejected; meaning the data set is 100 percent complete. Further, it was determined that the 10 samples collected were more than sufficient to characterize TPH-DRO at a mud pit (Section A.1.4.2). Therefore, the dataset satisfies the completeness criteria.

\section{A.1.2.1.2 Statement of Acceptability and Usability}

The DQIs precision, accuracy, sensitivity, comparability, representativeness, and completeness were all evaluated for quality and impact to the data. This evaluation determined that all data can be used to support the DQO decisions.

\section{A.1.2.2 Calculate Basic Statistical Quantities}

As stated in the SAFER Plan, mud pits in CAUs 530-535 are considered to have resulted from essentially the same process. This assumption implies that all samples were collected from the same group, which in statistical terms means the unbiased samples collectively represent the entire mud pit population. By examining 10 samples at a time from each CAS, essentially a sample of the population is being considered. This section focuses on statistical quantities that describe the population data.

Number of Observations. For this closure investigation, a total of 521 TPH-DRO sample results were used to calculate the population mean and standard deviation. None of the biased sample results were considered for this closure investigation because no TPH-DRO was detected in any of the biased samples.

Population Mean. The mean TPH-DRO concentration for the mud pit population is $11.93 \mathrm{mg} / \mathrm{kg}$. This number is representative of all mud pits in CAUs 530-535 but was not used in any risk assessments.

Population Variance and Standard Deviation. The population variance of the TPH-DRO concentrations is $1,732 \mathrm{mg} / \mathrm{kg}$. This statistic is representative of the spread of the data with a higher variance indicating more spread. The standard deviation, equal to the square root of the variance, is $42 \mathrm{mg} / \mathrm{kg}$. 
Percentage of Non-detects. The data used for Decision A and Decision B consisted of 411 non-detects. This equates to 78 percent of the dataset. However, for calculating the potential risk to human health, a conservative value of half of the MDC was used to estimate the TPH-DRO concentration.

\section{A.1.2.3 Graph the Data}

Figure A.1-1 presents the cumulative probability distribution for the data set used in Decision A and Decision B. The TPH-DRO concentrations range from non-detect to $420 \mathrm{mg} / \mathrm{kg}$. As seen in Figure A.1-1 the data is spread over a wide concentration range, but the majority of the data is less than the mean. The population mean $(11.93 \mathrm{mg} / \mathrm{kg})$ and its associated probability of 0.5 indicate that, on average, a TPH-DRO concentration of $11.93 \mathrm{mg} / \mathrm{kg}$ or less will be detected in half the samples collected. The Figure A.1-1 also shows a 98 percent probability of detecting TPH-DRO concentrations less than the $100 \mathrm{mg} / \mathrm{kg}$ screening level.

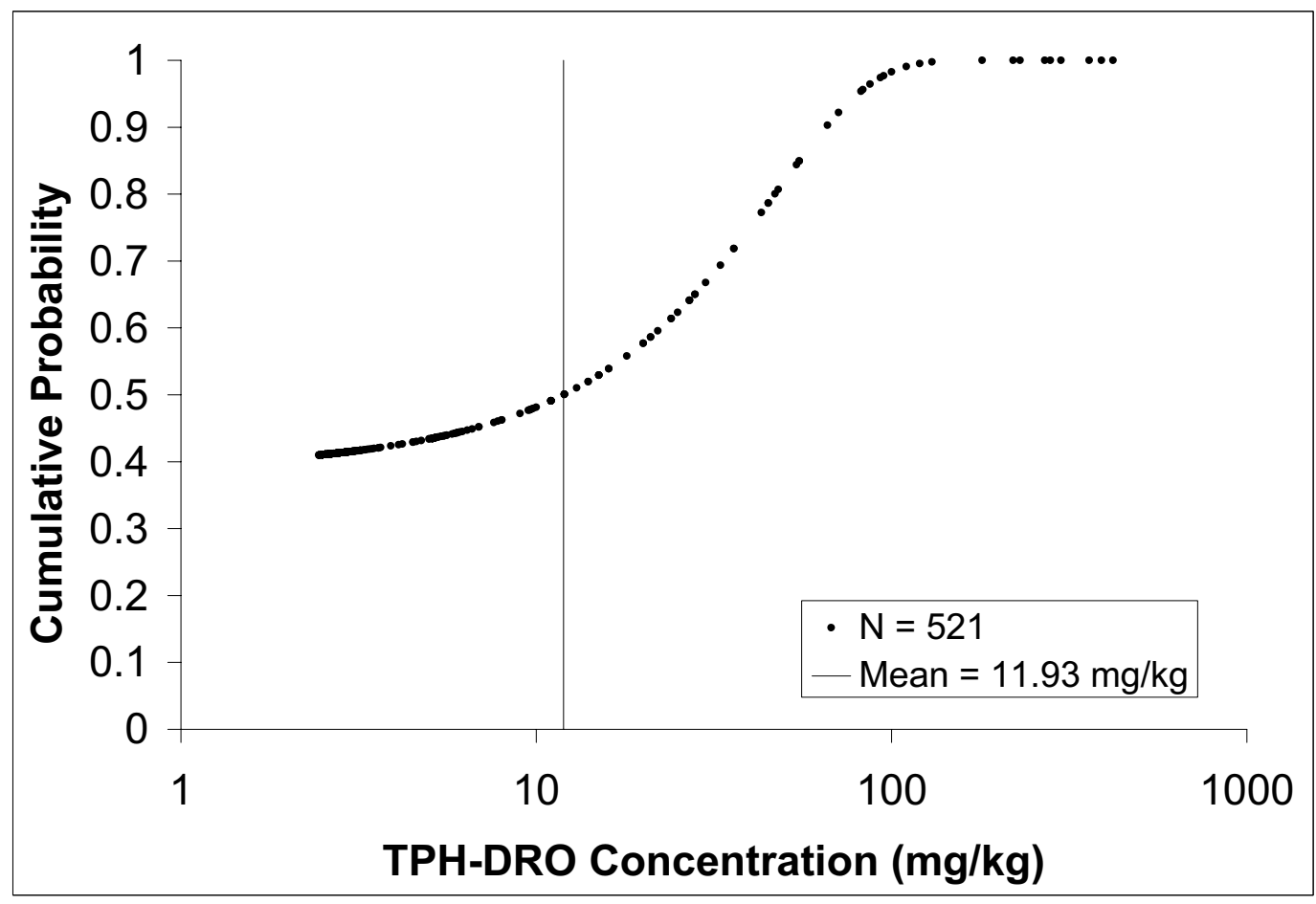

Figure A.1-1

Cumulative Probability Distribution for TPH-DRO Concentrations at CAUs 530-535 


\section{A.1.3 Step 3 - Select the Statistical Test}

This step selects the appropriate statistical hypothesis tests to be used to draw conclusions from the data and identifies the underlying assumptions to determine if the test conclusions drawn are valid.

\section{A.1.3.1 Select Statistical Hypothesis Test}

Decision A. This decision calls for a series of 52 hypothesis tests, one for each CAS. For each of the 52 tests, if a sample mean is significantly less than the $14,000 \mathrm{mg} / \mathrm{kg}$ threshold, then the corresponding HI will be significantly less than 1.0 and the mud pit CAS is not expected to pose an unacceptable risk. Each sample mean will be normally distributed according to the Central Limit Theorem: If a random sample consisting of $n$ observations is taken from a distribution with mean $\mu$ and variance $\sigma^{2}$, then $\bar{\chi}$ is distributed approximately normally with mean $\mu$ and variance $\sigma^{2} / n$ for large values of $n$.

In statistical notation, this is written as:

$$
\bar{\chi} \sim \mathrm{N}\left(\mu=14,000 \mathrm{mg} / \mathrm{kg}, \operatorname{var}(\bar{\chi})=\sigma^{2} / n=175.8 \mathrm{mg} / \mathrm{kg}\right.
$$

For the purpose of conducting this hypothesis test, the threshold value of $14,000 \mathrm{mg} / \mathrm{kg}$ is presumed to be the "true" mean. This logic is consistent with assuming the null hypothesis is true until it is rejected. The result from this hypothesis test is presented in Step 5 of the DQA (Section A.1.5.1).

Decision B. This decision calls for a single hypothesis test to compare the number of CASs found to pose an unacceptable risk (represented by the test statistic $X$ ) to the critical value of zero. If none of the sampled CASs are found to pose an unacceptable risk, then CAUs 530-535 may be closed via the no further action alternative. Since the 52 CASs were randomly selected, without replacement to represent the entire population of 268 CASs, the test statistic $X$ will be distributed according to a hypergeometric distribution. In statistical notation this is written as:

$$
X \sim \mathrm{H}(f=0, N=268, n=52)
$$

where $f$ is the failure rate (i.e., portion of mud pit CASs that pose an unacceptable risk), $N$ is the population size, and $n$ is the sample size. If the probability of the null hypothesis being true is less than the false negative decision error (0.05) then, the null hypothesis may be rejected for the 
alternative hypothesis. The result from this hypothesis test is presented in Step 5 of the DQA (Section A.1.5.1).

\section{A.1.3.2 Identify Assumptions Underlying the Statistical Test}

Decision A. This decision assumes the following:

- Samples that comprise the population are independent from each other. This is the fundamental assumption on which all the statistical tests rely. If the samples are not independent, then the calculated population variance may be understated. This would impact the value of the calculated test statistics.

- Ten samples are sufficient to accurately characterize a mud pit CAS. If 10 samples are not sufficient, then the mud pit CASs may not have been correctly characterized and additional sampling is warranted.

Decision B. The failure rate $(f)$ used in the hypothesis test for this decision is zero. Therefore, it assumes that none of the 268 CASs will pose an unacceptable risk.

\section{A.1.4 Step 4 - Verify the Assumptions of the Statistical Test}

Methods to verify the assumptions of Decision A and Decision B are discussed below. They utilize the statistical quantities determined in Section A.1.2.2.

\section{A.1.4.1 Determine an Approach for Verifying Assumptions}

Decision A. To test the first assumption of independence, a Rank von Neumann test was performed in accordance with EPA Guidance for Data Quality Assessment (EPA, 2000) on the entire data set. To confirm the second assumption that 10 samples are sufficient to characterize a mud pit CAS, the one-sample Sign test was used to confirm the minimum number of samples required (EPA et. al., 2000).

Decision B. To justify using a failure rate of zero in this hypothesis test, the probability of a CAS having a mean TPH-DRO concentration greater than the MAMC is calculated using a normal distribution. If the probability of exceeding the MAMC is zero, then the failure rate must also be zero. 


\section{A.1.4.2 Perform Tests of Assumptions}

Decision A. The result from the Rank von Neumann test for independence suggests the dataset is not independent. This result is not entirely unexpected, because the sample locations were configured in a triangular grid pattern instead of being chosen completely randomly. Also, the TPH-DRO levels are inherently low in CAUs 530-535 resulting in a majority of the data being less than the MDCs. The lack of independence between samples does not adversely impact the integrity of the hypothesis tests for Decision A as long as the corrective action discussed in Section A.1.4.3 is applied.

Using an estimated population variance, results from the Sign test in the RBCSR stated that 10 samples were sufficient to characterize each CAS. To confirm this assumption and perform the Sign test, it was necessary to develop Figure A.1.2 to show how $n$ varies with different values of uncertainty, which is equivalent to the width of the gray region commonly used in statistically-based site investigations (EPA et. al., 2000). Because an acceptable level of uncertainty was not specified for this investigation, the Sign test confirms a minimum of seven samples are necessary to characterize a mud pit at higher levels of uncertainty. This is less than the initial estimate of 10 samples necessary, because the calculated population variance is less than the estimated variance used in the RBCSR. By collecting 10 samples from each CAS, the uncertainty associated with this closure investigation has been reduced by approximately 62 percent. It should be noted that results from biased samples were not considered, because TPH-DRO was detected in the biased samples.

Decision B. With $\bar{\chi}$ as the test statistic to represent the mean TPH-DRO concentration of a CAS, the probability of $\bar{\chi}$ exceeding $14,000 \mathrm{mg} / \mathrm{kg}$ (i.e., the failure rate exceeding zero) when the population mean is $11.93 \mathrm{mg} / \mathrm{kg}$ and the variance of $\bar{\chi}$ is $175.8 \mathrm{mg} / \mathrm{kg}$ was calculated as follows:

$$
\mathrm{P}\left[\bar{\chi}>14,000 \mathrm{mg} / \mathrm{kg} \mid \mu=12.18 \mathrm{mg} / \mathrm{kg}, \operatorname{var}(\bar{\chi})=\sigma^{2} / n=175.8 \mathrm{mg} / \mathrm{kg}\right]=0
$$

Where: $\mathrm{P}=$ probability; $\bar{\chi}=$ sample mean; $\mu=$ population mean; and $\sigma^{2} / n=$ sample variance

This means the probability of a mud pit CAS having a mean TPH-DRO concentration that exceeds the MAMC is zero. Therefore, using a failure rate of zero is justified. 


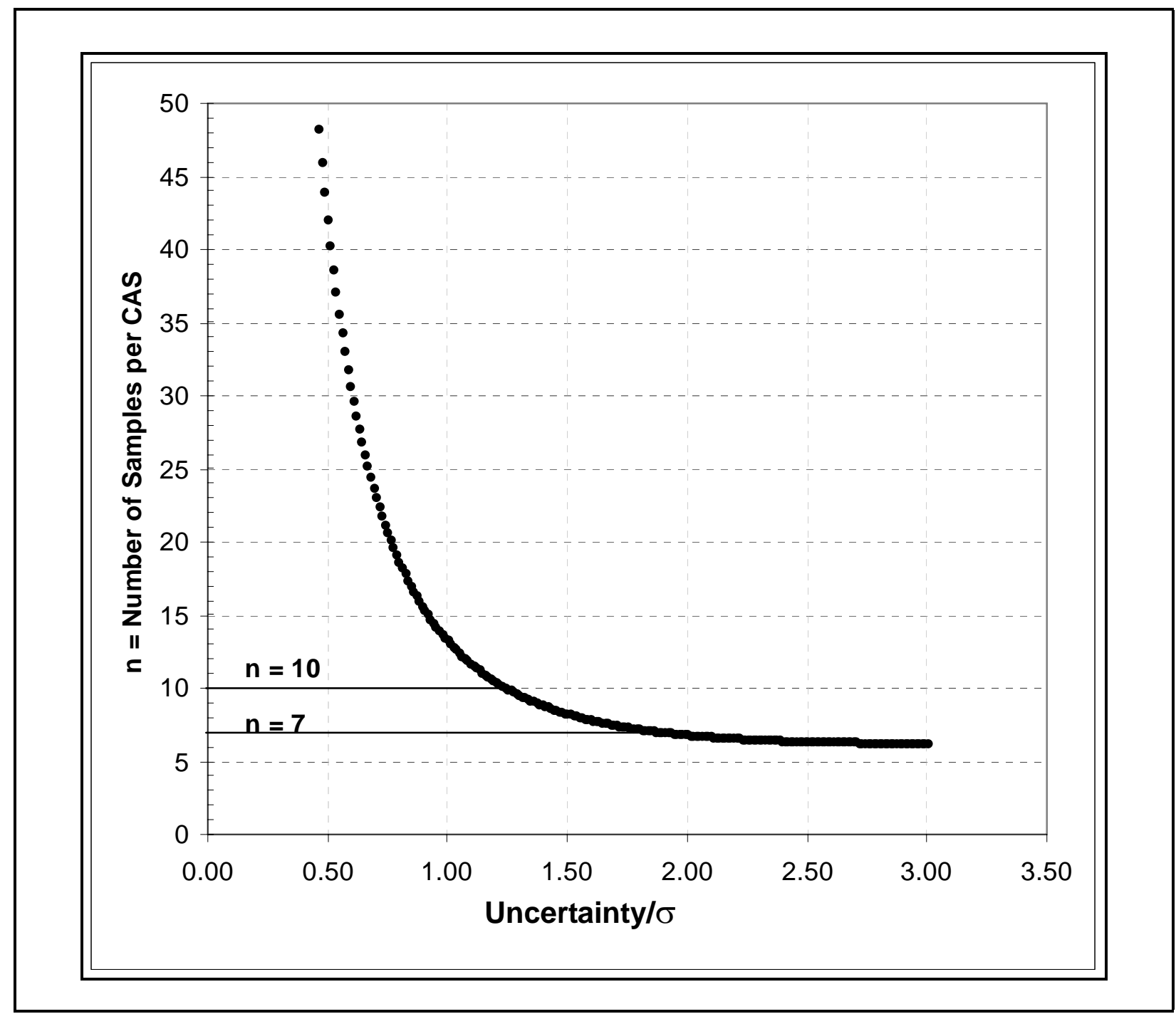

Figure A.1-2

Sign Test to Determine the Number of Samples Required for Decision A

\section{A.1.4.3 Determine Corrective Actions}

Decision A. Because the data is not independent, the variance used in the hypothesis test for Decision A is larger than $\sigma^{2} / n$, which equals $175.8 \mathrm{mg} / \mathrm{kg}$. The revised variance $\left(\sigma^{2}\right)$ is calculated to be $1,732 \mathrm{mg} / \mathrm{kg}$, which equals the population variance, and the revised standard deviation ( $\sigma$ ) is $42 \mathrm{mg} / \mathrm{kg}$ (EPA, 2000). This considered, equation A-2 is rewritten as:

$$
\bar{\chi} \sim \mathrm{N}\left(\mu=14,000 \mathrm{mg} / \mathrm{kg}, \operatorname{var}(\bar{\chi})=\sigma^{2}=1,732 \mathrm{mg} / \mathrm{kg}\right)
$$


Decision B. The test to justify the assumption used in Decision B is also affected by the change in variance. However, using $\sigma^{2}$ in equation A-4 also results in a probability of zero. Therefore, no corrective action is required, and the original assumptions regarding the failure rate used in developing the SAFER Plan DQOs are valid.

\section{A.1.5 Step 5 - Draw Conclusions from the Data}

\section{A.1.5.1 Perform the Statistical Hypothesis Test}

Decision A. The first step of the hypothesis test is to calculate the sample means for each CAS, $\bar{\chi}$. Next the normalized test statistic, $z_{\text {test }}$, is calculated according to the following equation:

$$
z_{\text {test }}=(\bar{\chi}-\mu) / \sigma^{\prime}
$$

where $\mu=14,000 \mathrm{mg} / \mathrm{kg}$ and $\sigma^{\prime}$ equals $42 \mathrm{mg} / \mathrm{kg}$. The test statistic, $z_{\text {test }}$, is associated with a probability of observing a lower sample mean. This probability is known as a p-value. Similarly, the false negative decision error has a z-value of -1.64 associated with its probability of 0.05 . In order to reject the null hypothesis, $z_{\text {test }}$ must be less than -1.64 or, alternatively, the p-value must be less than 0.05 .

These statistical quantities for each CAS are presented in Table A.1-7. The p-values associated with all tests are zero, meaning that the null hypothesis ( $\bar{\chi} \geq 14,000 \mathrm{mg} / \mathrm{kg}$ ) can be rejected for all 52 sampled mud pit CASs. This concludes that all CAS means are below the MAMC and none of the CASs pose an unacceptable risk. Furthermore, the failure rate of mud pit CASs in CAUs 530-535 is zero.

Decision B. With the failure rate of zero found in Decision A, the probability that the null hypothesis is true $(X>0)$ is equal to zero. This is less than the false negative rejection error (0.05) and, therefore, the null hypothesis can be rejected.

\section{A.1.5.2 Draw Closure Investigation Conclusions}

This DQA has confirmed that the hypotheses tests used in this closure investigation and their underlying assumptions satisfy Decision A and Decision B of the DQOs. Based on the Decision A 
and Decision B results, it is concluded that none of the sampled mud pit CASs pose an unacceptable risk and CAUs 530-535 may be closed via the no further action alternative.

Table A.1-7

Hypothesis Test Results Supporting Decision A

\begin{tabular}{|c|c|c|c|c|c|c|c|}
\hline CAS & $\bar{\chi}$ & $\mathbf{z}_{\text {test }}$ & p-vaule & CAS & $\bar{\chi}$ & $\mathbf{z}_{\text {test }}$ & p-value \\
\hline 01-09-02 & 2.75 & -336.332 & 0 & $07-09-28$ & 29.96 & -335.679 & 0 \\
\hline 01-09-04 & 2.88 & -336.329 & 0 & 08-09-06 & 2.53 & -336.338 & 0 \\
\hline 02-09-03 & 7.67 & -336.214 & 0 & 09-09-15 & 3.11 & -336.324 & 0 \\
\hline 02-09-09 & 2.79 & -336.331 & 0 & 09-09-10 & 54.21 & -335.096 & 0 \\
\hline $02-09-12$ & 2.52 & -336.338 & 0 & 09-09-16 & 2.65 & -336.335 & 0 \\
\hline 02-09-15 & 2.72 & -336.333 & 0 & $09-09-20$ & 2.71 & -336.334 & 0 \\
\hline 02-09-18 & 2.52 & -336.338 & 0 & $09-09-23$ & 2.53 & -336.338 & 0 \\
\hline $02-09-26$ & 2.55 & -336.337 & 0 & $09-09-24$ & 2.64 & -336.335 & 0 \\
\hline 02-09-30 & 4.05 & -336.301 & 0 & $09-09-27$ & 6.55 & -336.241 & 0 \\
\hline $02-09-33$ & 2.84 & -336.33 & 0 & 09-09-35 & 2.84 & -336.33 & 0 \\
\hline $02-09-52$ & 8.48 & -336.195 & 0 & $09-09-40$ & 2.52 & -336.338 & 0 \\
\hline 03-09-15 & 2.71 & -336.333 & 0 & $09-09-42$ & 2.51 & -336.338 & 0 \\
\hline 03-09-17 & 12.33 & -336.102 & 0 & $10-09-12$ & 5.50 & -336.266 & 0 \\
\hline 03-09-21 & 4.80 & -336.283 & 0 & 10-09-18 & 24.31 & -335.814 & 0 \\
\hline 03-09-30 & 7.24 & -336.225 & 0 & $10-09-26$ & 3.35 & -336.318 & 0 \\
\hline 04-09-06 & 2.68 & -336.334 & 0 & $14-09-02$ & 2.79 & -336.332 & 0 \\
\hline 04-09-08 & 3.00 & -336.327 & 0 & $19-09-12$ & 99.93 & -333.997 & 0 \\
\hline 04-09-14 & 31.79 & -335.635 & 0 & $19-09-17$ & 10.34 & -336.15 & 0 \\
\hline 04-09-18 & 9.95 & -336.16 & 0 & $19-09-19$ & 3.07 & -336.325 & 0 \\
\hline 05-09-02 & 74.07 & -334.619 & 0 & $19-09-27$ & 2.89 & -336.329 & 0 \\
\hline $06-09-02$ & 2.93 & -336.328 & 0 & $20-09-15$ & 2.82 & -336.331 & 0 \\
\hline 07-09-10 & 15.81 & -336.019 & 0 & $20-09-27$ & 99.33 & -334.012 & 0 \\
\hline 07-09-13 & 2.84 & -336.33 & 0 & $20-09-31$ & 4.39 & -336.293 & 0 \\
\hline 07-09-22 & 2.73 & -336.333 & 0 & $20-09-35$ & 2.91 & -336.329 & 0 \\
\hline 07-09-25 & 2.67 & -336.334 & 0 & $20-09-40$ & 2.83 & -336.331 & 0 \\
\hline $07-09-27$ & 20.74 & -335.9 & 0 & $20-09-46$ & 3.09 & -336.324 & 0 \\
\hline
\end{tabular}




\section{A.1.5.3 Evaluate Performance of the Sampling Design}

Because all decision error criteria were met (Section A.1.1.3) and the number of samples collected was adequate to characterize a mud pit CAS (Section A.1.4.2), the sampling design was conducive to meeting the performance standards established by the DQOs and the SAFER Plan. Further, this sampling design may be applied to future NTS mud pit closure investigations. 


\section{A.2.0 References}

ANSI/ASQC, see American National Standards Institute/American Society for Quality Control.

American National Standards Institute/American Society for Quality Control. 1995. Specifications and Guidelines for Quality Systems for Environmental Data Collection and Environmental Technology Programs (E4-1994). American National Standard.

EPA, see U.S. Environmental Protection Agency.

EPA et. al., see U.S. Environmental Protection Agency, U.S. Department of Defense, U.S. Department of Energy, and U.S. Nuclear Regulatory Commission.

NNSA/NSO, see U.S. Department of Energy, National Nuclear Security Administration Nevada Site Office.

NNSA/NV, see U.S. Department of Energy, National Nuclear Security Administration Nevada Operations Office.

Pacific Northwest National Laboratory. 2002. Visual Sample Plan, Version 2.0, User’s Guide, September, PNNL-14002. Richland, WA.

PNNL, see Pacific Northwest National Laboratory.

U.S. Department of Energy, National Nuclear Security Administration Nevada Operations Office. 2002. Industrial Sites Quality Assurance Project Plan, Nevada Test Site, Nevada, Rev. 3, DOE/NV--372. Las Vegas, NV.

U.S. Department of Energy, National Nuclear Security Administration Nevada Site Office. 2004. Mud Pit Risk-Based Closure Strategy Report, Nevada Test Site, Nevada, DOE/NV--991.

Las Vegas, NV.

U.S. Department of Energy, National Nuclear Security Administration Nevada Site Office. 2005a. Streamlined Approach for Environmental Restoration Plan for Corrective Action Units 530, 531, 532, 533, 534, and 535, Nevada Test Site Mud Pits, Nevada Test Site, Nevada, July, DOE/NV--1057. Las Vegas, NV.

U.S. Department of Energy, National Nuclear Security Administration Nevada Site Office. 2006. Industrial Sites Project Establishment of Final Action Levels, February. Las Vegas, NV.

U.S. Environmental Protection Agency. 1999. Contract Laboratory Program National Functional Guidelines for Organic Data Review, EPA 540/R-99/008. Washington, DC. 
U.S. Environmental Protection Agency. 2000. Guidance for Data Quality Assessment, EPA QA/G-9, EPA/600/R-96/084. Washington, DC.

U.S. Environmental Protection Agency, U.S. Department of Defense, U.S. Department of Energy, and U.S. Nuclear Regulatory Commission. 2000. Multi-Agency Radiation Survey and Site Investigation Manual (MARSSIM), Rev 1, EPA-402-R-97-016, DOE/EH-0624, NUREG-1575. Washington, DC.

U.S. Environmental Protection Agency. 2002a. Contract Laboratory Program National Functional Guidelines for Inorganic Data Review, EPA 540-R-01-008. Washington, DC.

U.S. Environmental Protection Agency. 2002b. Guidance for Quality Assurance Project Plans, EPA QA/G-5, EPA/240/R-02/009. Washington, DC. 


\section{Appendix B}

\section{Closure Certification \\ for CAUs 530-535: Nevada Test Site Mud Pits, Nevada Test Site, Nevada}




\section{B.1.0 Closure Certification}

This appendix documents additional housekeeping and debris removal activities completed at CAS 09-09-08 in CAU 532, CAS 03-09-17 in CAU 530, and CAS 02-09-30 in CAU 533.

\section{B.1.1 CAS 09-09-08, CAU 532}

On February 21, 2006, two lead-acid batteries were removed from the northeast berm of CAS 09-09-08 and transported to the M\&O fleet operations yard for recycling. The area was photodocumented before and after the removal (Figure B.1-1). Soil below the former battery locations was removed and placed in a 55-gal DOT specification steel drum and labeled as “Hazardous Waste - Pending Analysis.” The drum was stored in an SAA established near the CAS. The excavated soil was characterized as solid waste and was picked up by the NTS M\&O contractor for disposal at the 10C Landfill.

Verification samples (MPXAB001 and MPXAB002) were collected from under each of the former battery locations after the overlying soil had been removed. By process knowledge, the only COPC associated with the battery was lead. Verification sample analytical results for CAS 09-09-08 are provided in Table B.1-1 and show that no residual lead contamination remains.

\section{B.1.2 CAS 03-09-17, CAU 530}

Coal tar epoxy debris was initially identified within the northern suction pit at CAS 03-09-17 during the original closure sampling activities in September 2005. Based on process knowledge documented in the SAFER Plan, the presence of the CTE was determined to be an anomaly not directly related to mud pit construction or drilling mud disposal. Therefore, the CTE was considered to be debris within the suction pit that can be removed in order to access the underlying drilling mud. The area was photodocumented before and after the removal (Figure B.1-2). On April 11 and 12, 2006, CTE debris and potentially affected soil were excavated and removed from the bottom of northern suction pit. Soil directly in contact with, and up to 8 to 12 inches beneath, the CTE was removed in the excavation process. The debris and soil were directly loaded into $15-\mathrm{yd}^{3}$ end-dump trucks and transported to the Area 6 Hydrocarbon Landfill. Three truck loads, with a total weight of 75,000 lb of 


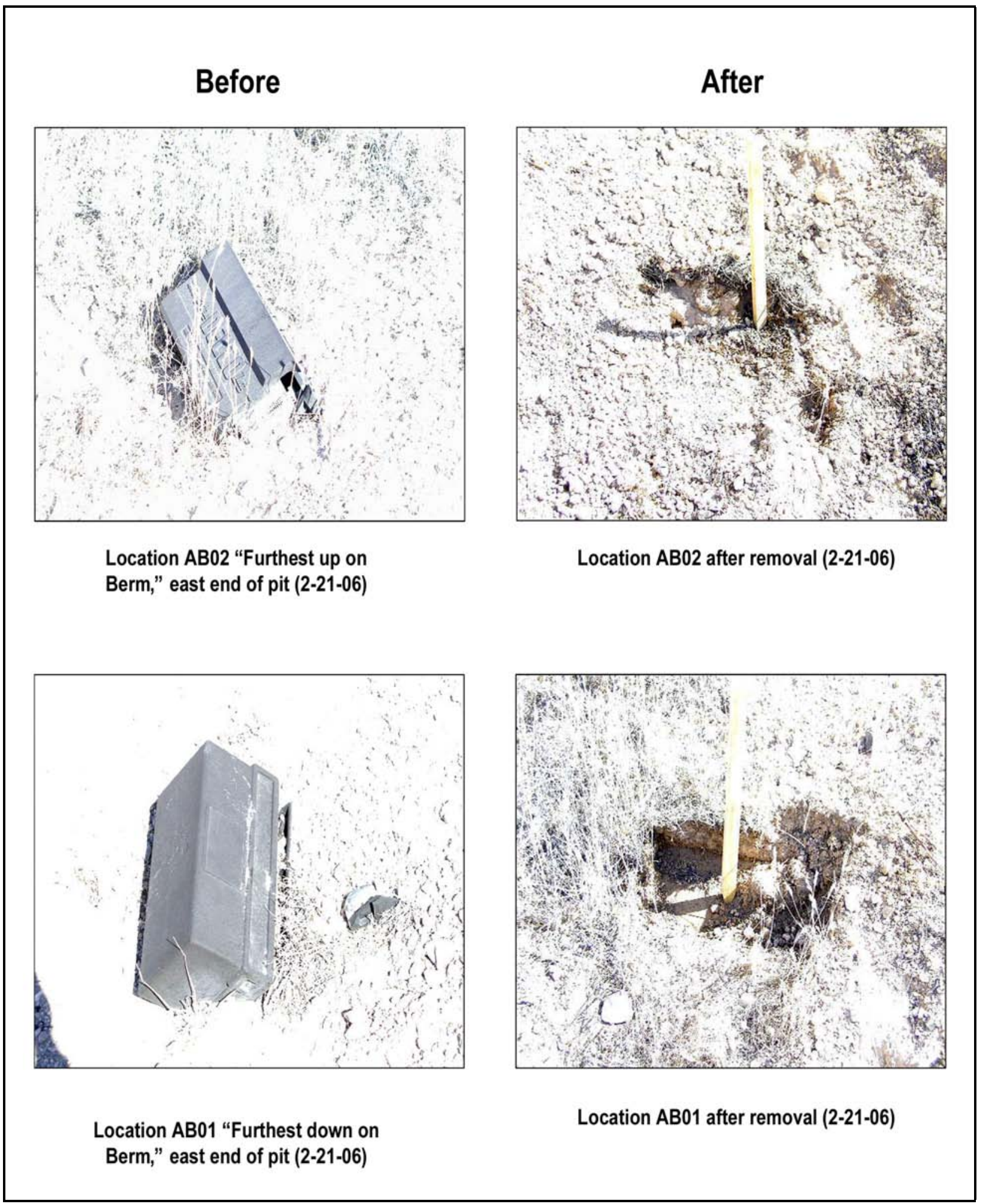

Figure B.1-1

Housekeeping Debris Removal CAS 09-09-08 
Table B.1-1

Soil Waste Results for TCLP Lead Detected above Minimum Detectable Concentration Limits at CAS 09-09-08, U-9yz-26 Mud Pit (2)

\begin{tabular}{|c|c|c|c|c|c||}
\hline $\begin{array}{c}\text { Sample } \\
\text { Location }\end{array}$ & $\begin{array}{c}\text { Sample } \\
\text { Number }\end{array}$ & $\begin{array}{c}\text { Depth } \\
\text { (ft bgs) }\end{array}$ & Parameter & $\begin{array}{c}\text { Result } \\
\text { (mg/L) }\end{array}$ & $\begin{array}{c}\text { Detection } \\
\text { Limit (mg/L) }\end{array}$ \\
\hline \hline $\mathrm{AB} 01$ & $\mathrm{MPXAB001}$ & $0.0-0.5$ & Lead & 4 & 0.03 \\
\hline $\mathrm{AB} 01$ & $\mathrm{MPXAB001}$ & $0.0-0.5$ & Arsenic & 0.21 & 0.03 \\
\hline $\mathrm{AB} 02$ & $\mathrm{MPXAB002}$ & $0.0-0.5$ & Lead & 0.053 & 0.1 \\
\hline $\mathrm{AB} 02$ & $\mathrm{MPXAB002}$ & $0.0-0.5$ & Arsenic & 0.027 & 0.1 \\
\hline
\end{tabular}

$\mathrm{ft}$ bgs $=$ Feet below ground surface $\mathrm{mg} / \mathrm{L}=$ Milligrams per Liter

debris/soil were transported and disposed in the Area 6 Hydrocarbon Landfill between April 11 and 12, 2006. The Landfill Load Verification Form for this waste is provided in Appendix E.

Before removal of the CTE, samples were collected of the CTE and soil adjacent to the CTE to make a waste determination of the CTE and to determine whether constituents of the debris were leachable. The CTE sample (MPXM301) was collected in the suction pit and analyzed for TPH-DRO, both total and Toxicity Characteristics Leaching Procedure (TCLP) VOCs, SVOCs, Resource Conservation Recovery Act (RCRA) metals, gamma spectrometry, isotopic Pu and U, and Sr-90. Soil sample MPXM302 was only analyzed for total VOCs, total SVOCs, and TPH-DRO. The CTE and affected soil were determined to be non-hazardous and designated as hydrocarbon/sanitary waste. The TCLP analysis also indicated that the CTE in its hardened form is not leachable. Following the excavation and removal of the CTE debris/soil, soil samples MPXM012, MPXM013, and MPXM014 were re-collected beneath the removed CTE at locations M04, M02, and M03, respectively, and analyzed for total VOCs, total SVOCs, and TPH-DRO. The purpose for sampling was twofold: first, provide verification that all the CTE debris and affected soil had been removed from the suction pit; and second, to provide new analytical results for determining the 95 percent UCL of the mean TPH-DRO soil concentration for the CAS. Analytical results above MDC limits for soil samples associated with closure verification are presented in this appendix in Table B.1-2. Results of the samples re-collected at locations M02, M03, and M04 show that no residual CTE remains as only one SVOC (Di-n-butylphthalate) was detected at a concentration of $43 \mu \mathrm{g} / \mathrm{kg}$ and is well below the PAL. 


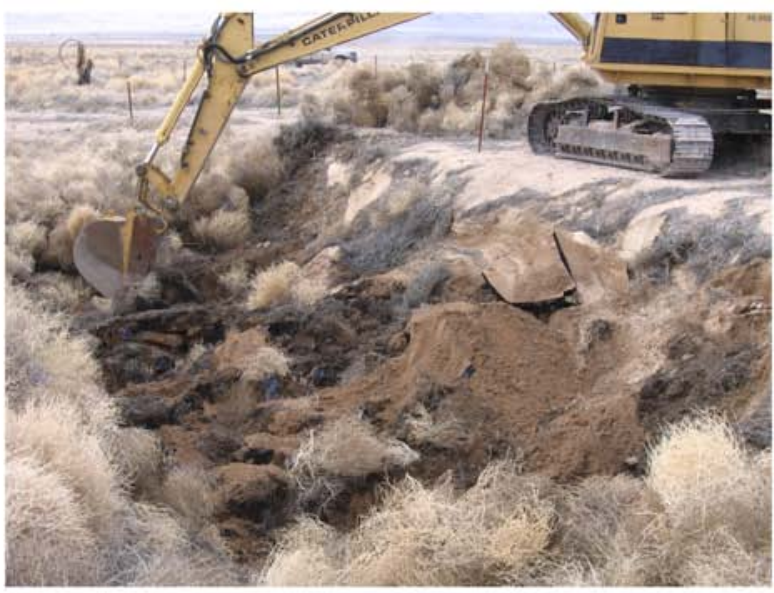

Start of coal tar epoxy removal (April 11,2006)

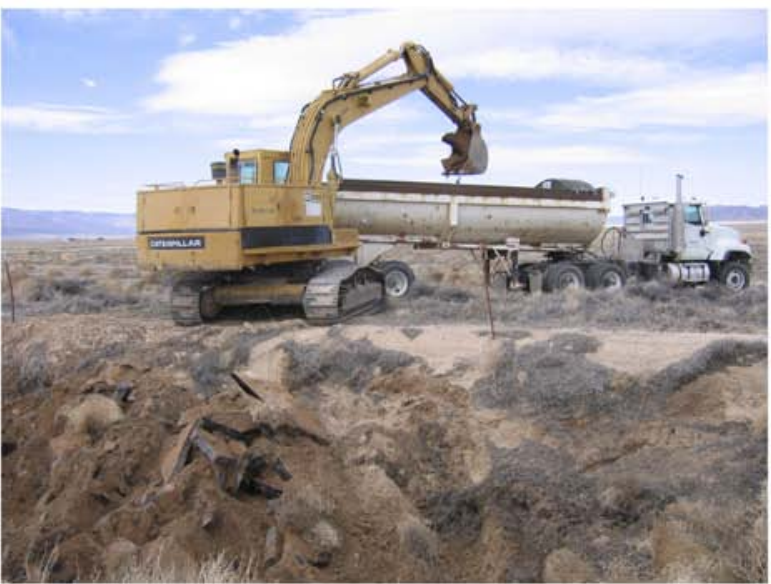

Loading coal tar epoxy for disposal (April 11,2006)

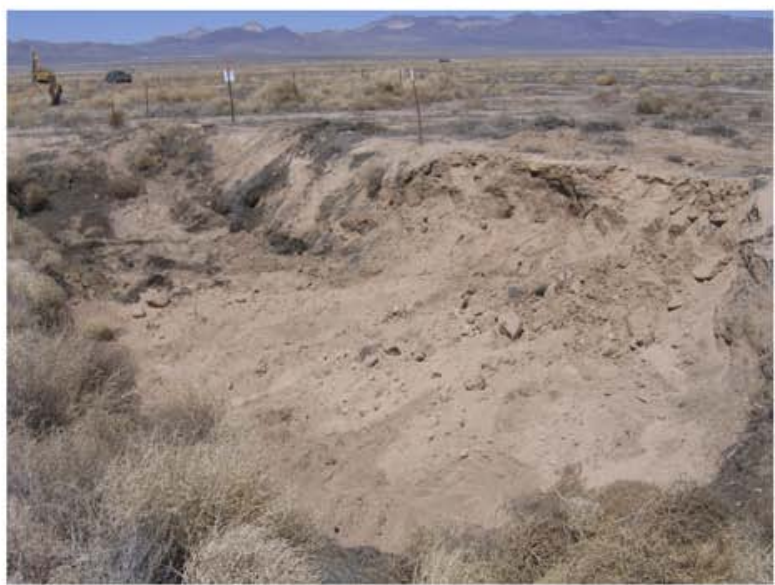

CAS after removal of coal tar epoxy (April 12,2006)

Figure B.1-2

Coal Tar Epoxy Debris Removal, CAS 03-09-17 
Table B.1-2

Soil Sample Results for SVOCs Detected Above Minimum Detectable Concentration Limits at CAS 03-09-17, U-3hc Mud Pit (2)

\begin{tabular}{||c|c|c|c|c|c|}
\hline $\begin{array}{c}\text { Sample } \\
\text { Location }\end{array}$ & $\begin{array}{c}\text { Sample } \\
\text { Number }\end{array}$ & $\begin{array}{c}\text { Depth } \\
\text { (ft bgs) }\end{array}$ & Parameter & $\begin{array}{c}\text { Result } \\
(\mu \mathbf{g} / \mathbf{k g})\end{array}$ & $\begin{array}{c}\text { Detection } \\
\text { Limit }(\mu \mathbf{g} / \mathbf{k g})\end{array}$ \\
\hline \hline $\mathrm{M} 03$ & MPXM014 & $0.0-0.5$ & Di-n-butylphthalate & 43 & 380 \\
\hline
\end{tabular}

$\mathrm{ft}$ bgs $=$ Feet below ground surface

$\mu \mathrm{g} / \mathrm{kg}=$ Micrograms per kilogram

Additional analytical results for non-detect DRO and SVOCs are provided in Appendix D, Tables D.1-34 and D.1-35.

\section{B.1.3 CAS 02-09-30, CAU 533}

During SAFER closure sampling activities at CAS 02-09-30 on September 26, 2005, a legacy nine microcurie Cs-137 radioactive source was discovered on the ground near but outside the CAS boundary. The source was reported to the appropriate personnel as dictated by NTS policy. Radiological screening of the ground surface did not indicate elevated readings; therefore, soil samples were not collected. The source was containerized and removed from the CAS on December 16, 2005, by Radiological Control personnel and has been placed into secure storage. Final characterization and disposal as LLW will be completed independently of the CAU 530-535 CR as this waste stream is not related to mud pits. 


\section{Appendix C}

\section{As-Built Documentation \\ for CAUs 530-535: Nevada Test Site Mud Pits, Nevada Test Site, Nevada}




\section{C.1.0 Introduction}

As-built drawings for mud pit CASs do not exist. Instead, site sketches serve as as-built drawings.

The sketches for mud pit CASs sampled as part of this closure investigation are indexed in

Table C.1-1.

Table C.1-1

As-Built Drawings for CAU 530-535 Corrective Action Sites (Page 1 of 2)

\begin{tabular}{|c|c|}
\hline Corrective Action Site & As-Built Drawing \\
\hline CAS 01-09-02 & See Figure C.1-1 \\
\hline CAS 01-09-04 & See Figure C.1-2 \\
\hline CAS 02-09-03 & See Figure C.1-3 \\
\hline CAS 02-09-09 & See Figure C.1-4 \\
\hline CAS 02-09-12 & See Figure C.1-5 \\
\hline CAS 02-09-15 & See Figure C.1-6 \\
\hline CAS 02-09-18 & See Figure C.1-7 \\
\hline CAS 02-09-26 & See Figure C.1-8 \\
\hline CAS 02-09-30 & See Figure C.1-9 \\
\hline CAS 02-09-33 & See Figure C.1-10 \\
\hline CAS 02-09-52 & See Figure C.1-11 \\
\hline CAS 03-09-15 & See Figure C.1-12 \\
\hline CAS 03-09-17 & See Figure C.1-13 \\
\hline CAS 03-09-21 & See Figure C.1-14 \\
\hline CAS 03-09-30 & See Figure C.1-15 \\
\hline CAS 04-09-06 & See Figure C.1-16 \\
\hline CAS 04-09-08 & See Figure C.1-17 \\
\hline CAS 04-09-14 & See Figure C.1-18 \\
\hline CAS 04-09-18 & See Figure C.1-19 \\
\hline CAS 05-09-02 & See Figure C.1-20 \\
\hline CAS 06-09-02 & See Figure C.1-21 \\
\hline CAS 07-09-10 & See Figure C.1-22 \\
\hline CAS 07-09-13 & See Figure C.1-23 \\
\hline CAS 07-09-22 & See Figure C.1-24 \\
\hline CAS 07-09-25 & See Figure C.1-25 \\
\hline
\end{tabular}


Table C.1-1

As-Built Drawings for CAU 530-535 Corrective Action Sites (Page 2 of 2)

\begin{tabular}{|c|c|}
\hline Corrective Action Site & As-Built Drawing \\
\hline CAS 07-09-27 & See Figure C.1-26 \\
\hline CAS 07-09-28 & See Figure C.1-27 \\
\hline CAS 08-09-06 & See Figure C.1-28 \\
\hline CAS 09-09-15 & See Figure C.1-29 \\
\hline CAS 09-09-10 & See Figure C.1-30 \\
\hline CAS 09-09-16 & See Figure C.1-31 \\
\hline CAS 09-09-20 & See Figure C.1-32 \\
\hline CAS 09-09-23 & See Figure C.1-33 \\
\hline CAS 09-09-24 & See Figure C.1-34 \\
\hline CAS 09-09-27 & See Figure C.1-35 \\
\hline CAS 09-09-35 & See Figure C.1-36 \\
\hline CAS 09-09-40 & See Figure C.1-37 \\
\hline CAS 09-09-42 & See Figure C.1-38 \\
\hline CAS 10-09-12 & See Figure C.1-39 \\
\hline CAS 10-09-18 & See Figure C.1-40 \\
\hline CAS 10-09-26 & See Figure C.1-41 \\
\hline CAS 14-09-02 & See Figure C.1-42 \\
\hline CAS 19-09-12 & See Figure C.1-43 \\
\hline CAS 19-09-17 & See Figure C.1-44 \\
\hline CAS 19-09-19 & See Figure C.1-45 \\
\hline CAS 19-09-27 & See Figure C.1-46 \\
\hline CAS 20-09-15 & See Figure C.1-47 \\
\hline CAS 20-09-27 & See Figure C.1-48 \\
\hline CAS 20-09-31 & See Figure C.1-49 \\
\hline CAS 20-09-35 & See Figure C.1-50 \\
\hline CAS 20-09-40 & See Figure C.1-51 \\
\hline CAS 20-09-46 & See Figure C.1-52 \\
\hline
\end{tabular}




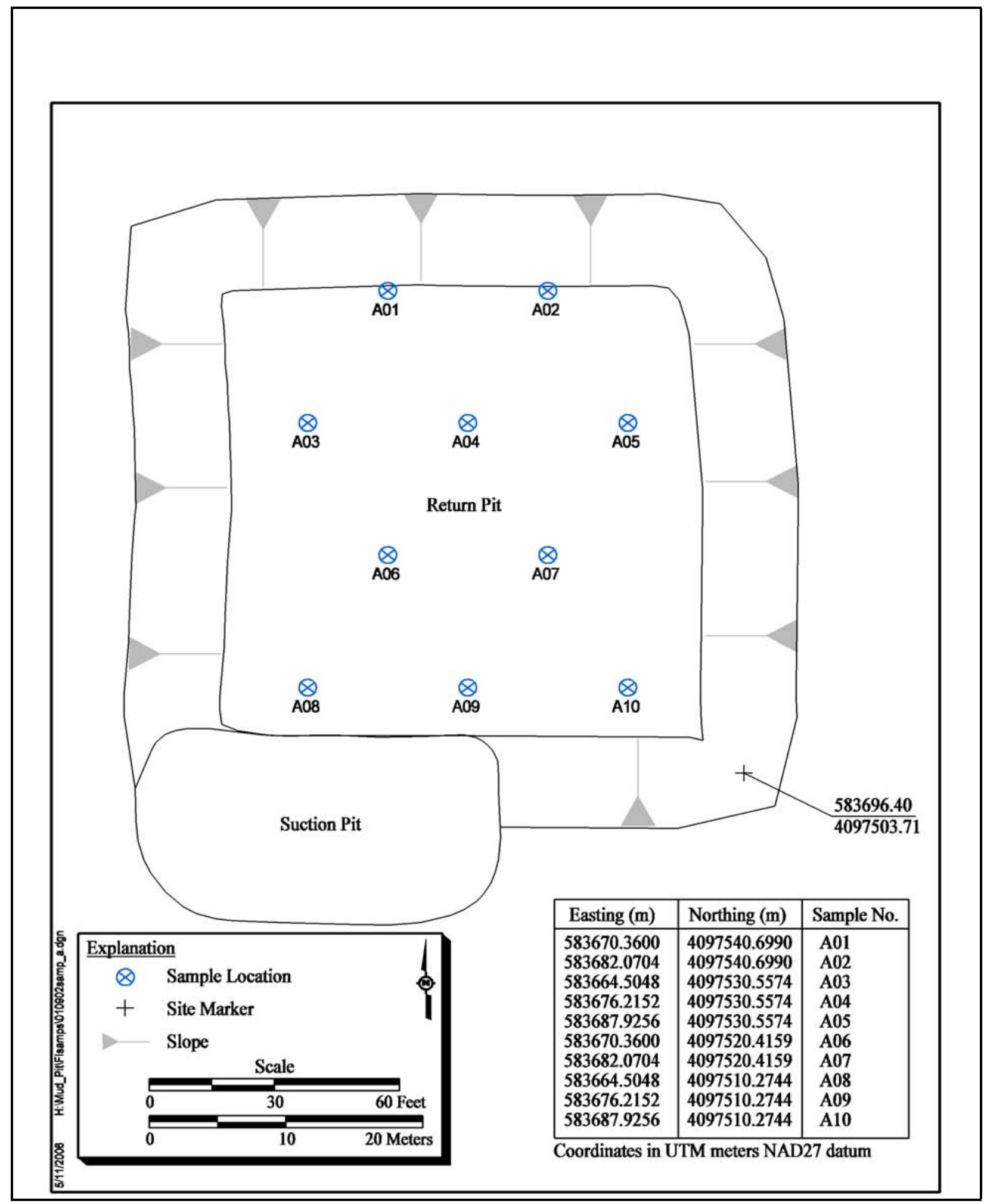

Figure C.1-1

CAS 01-09-02 Sample Locations 


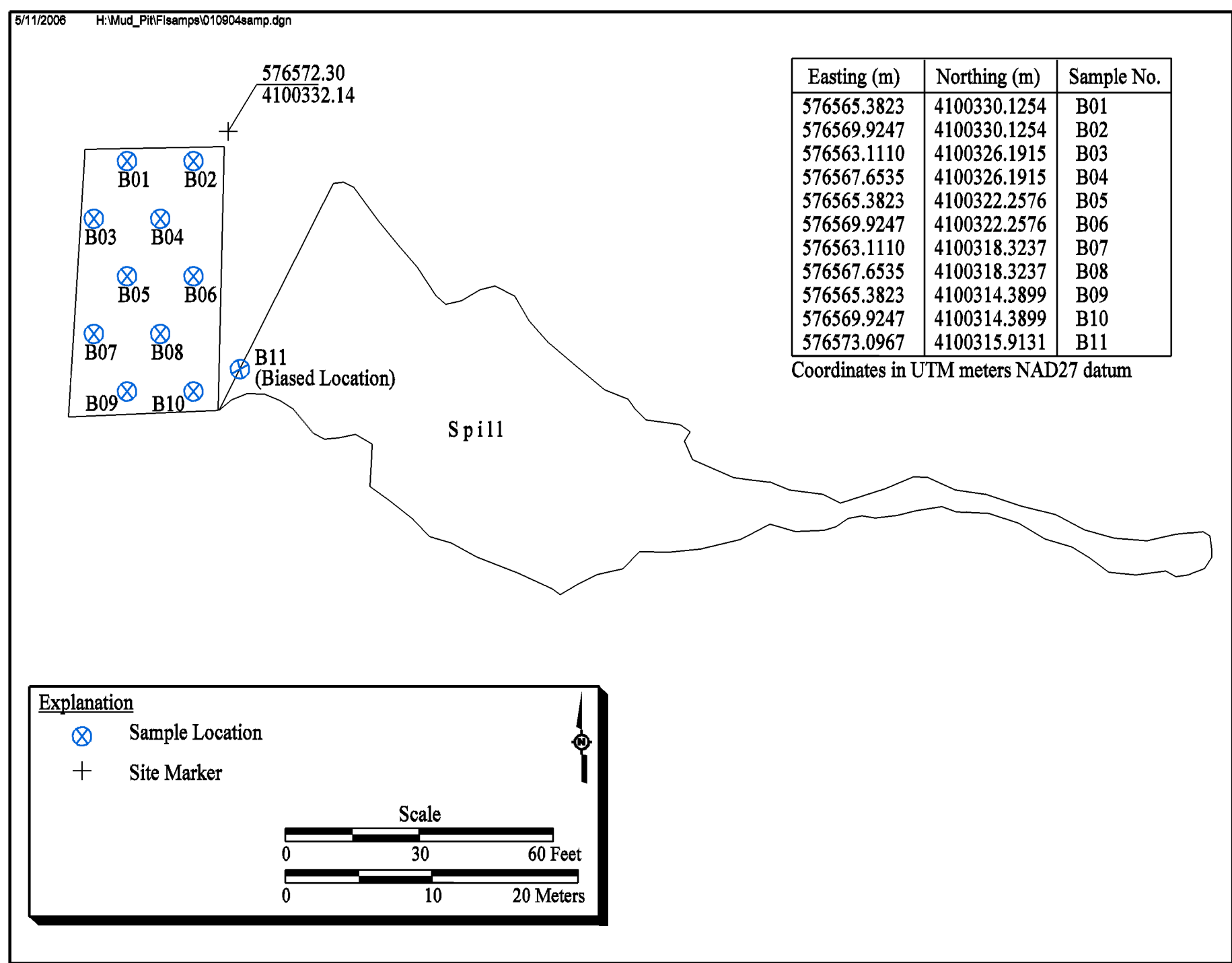

Figure C.1-2

CAS 01-09-04 Sample Locations

\section{Uncontrolled When Printed}




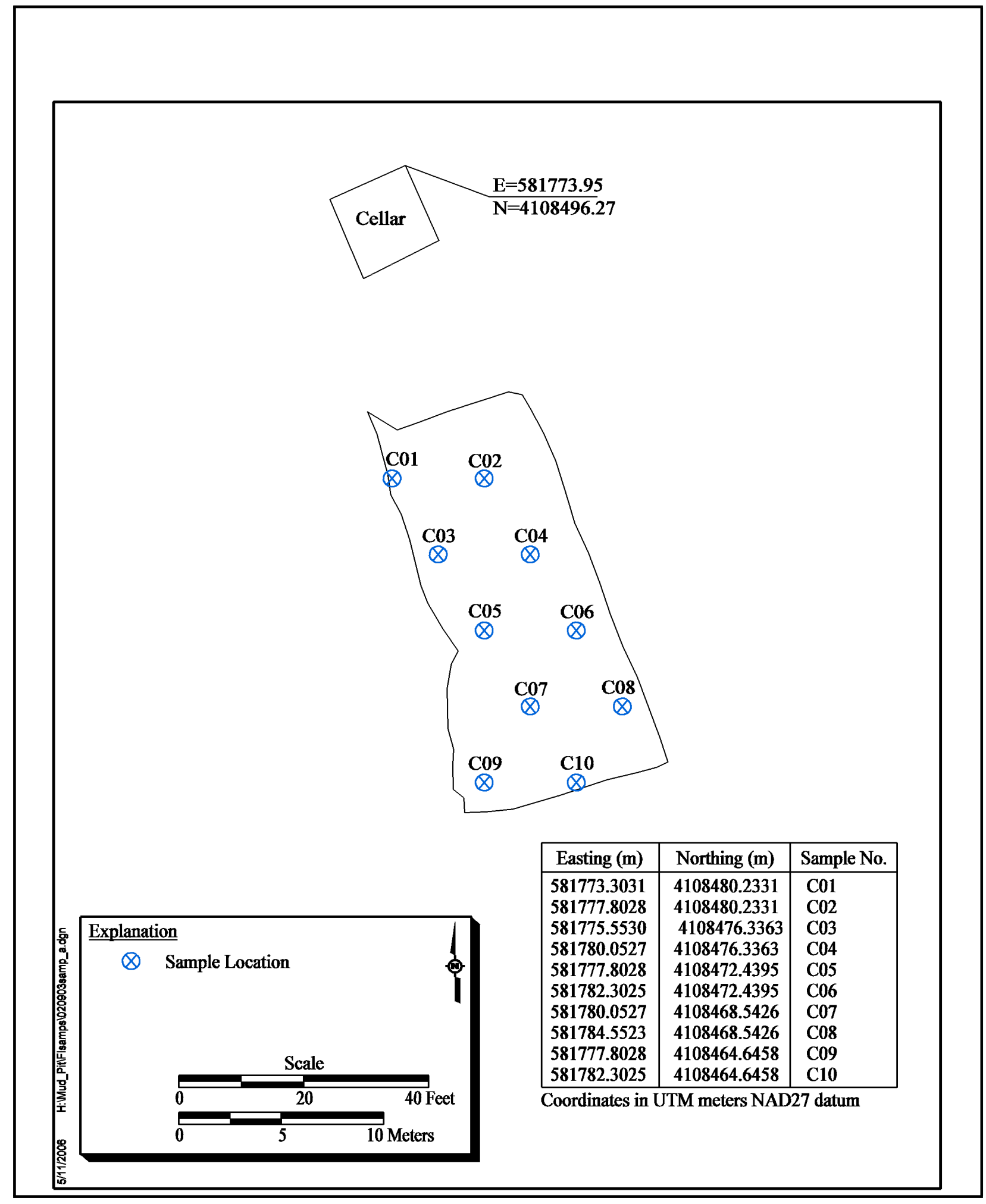

Figure C.1-3

CAS 02-09-03 Sample Locations 


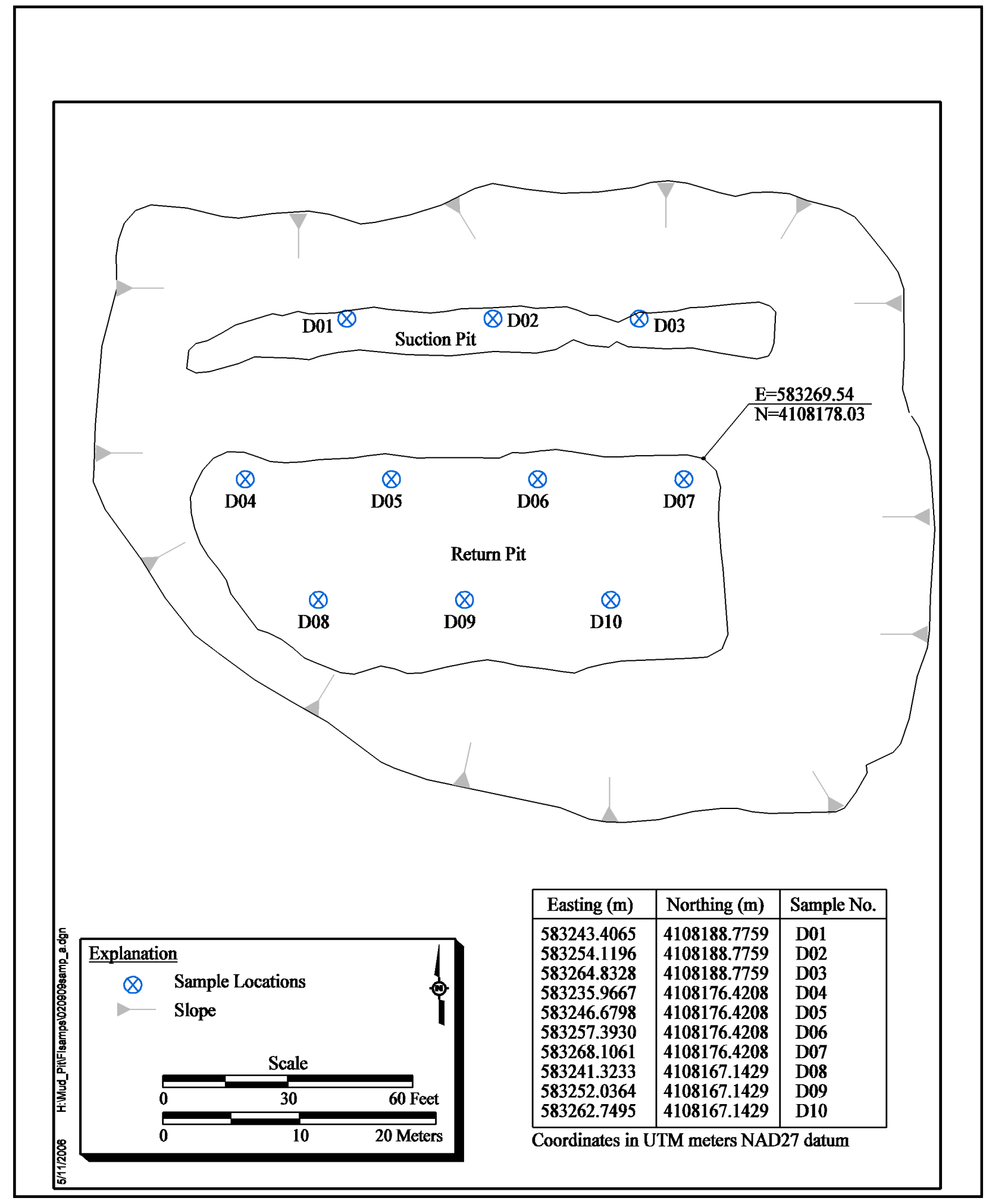

Figure C.1-4

CAS 02-09-09 Sample Locations 


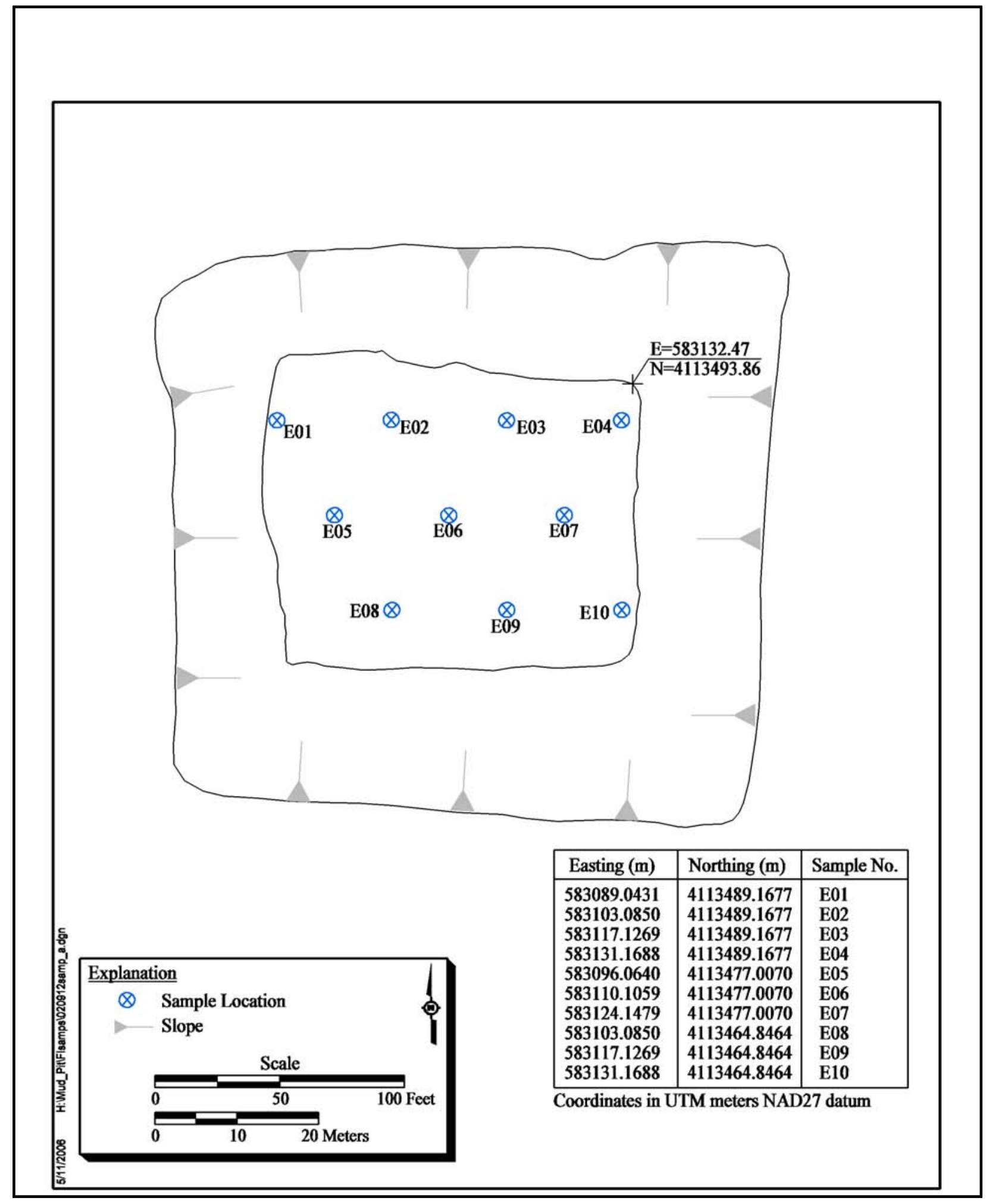

Figure C.1-5

CAS 02-09-12 Sample Locations 


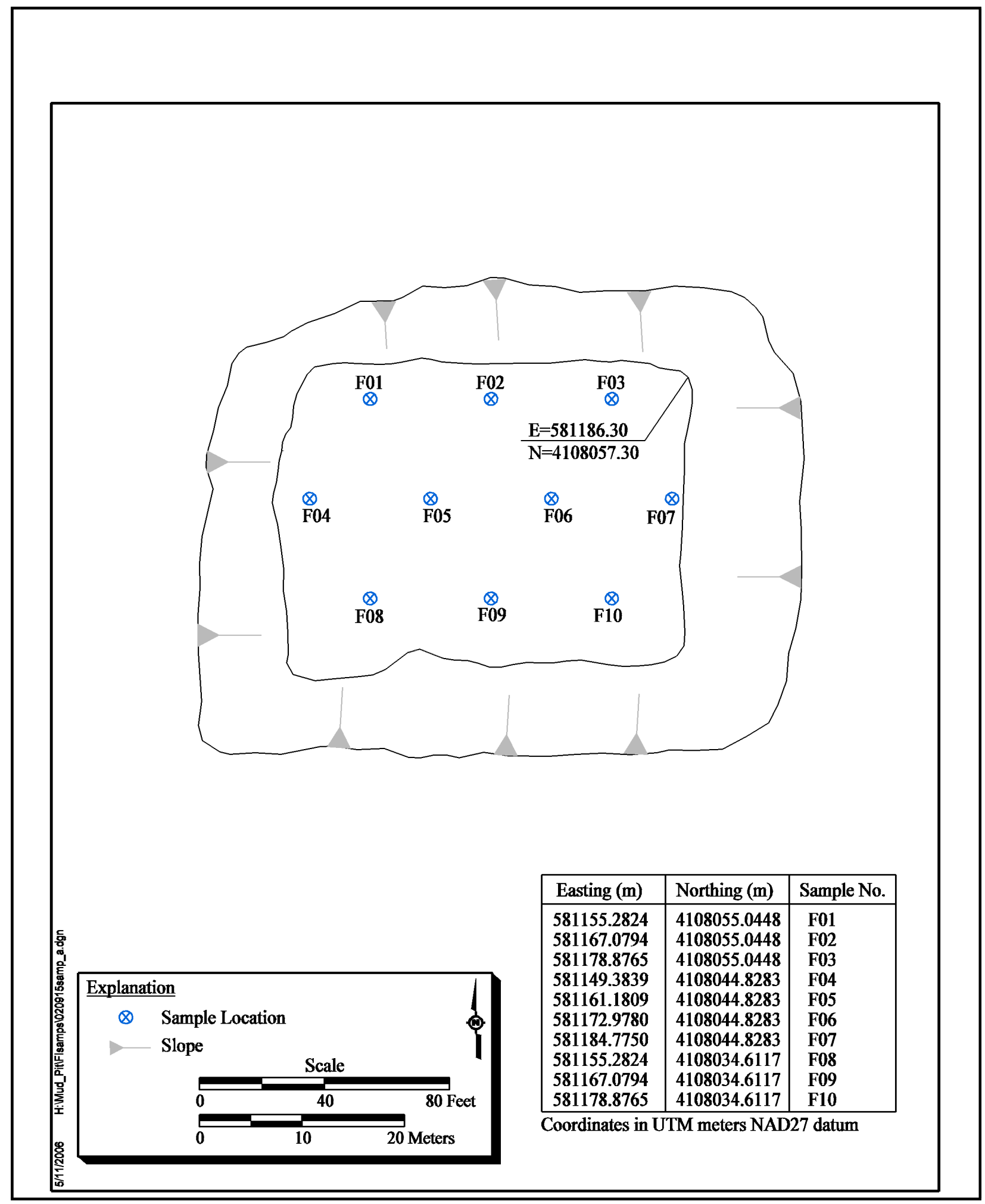

Figure C.1-6

CAS 02-09-15 Sample Locations 


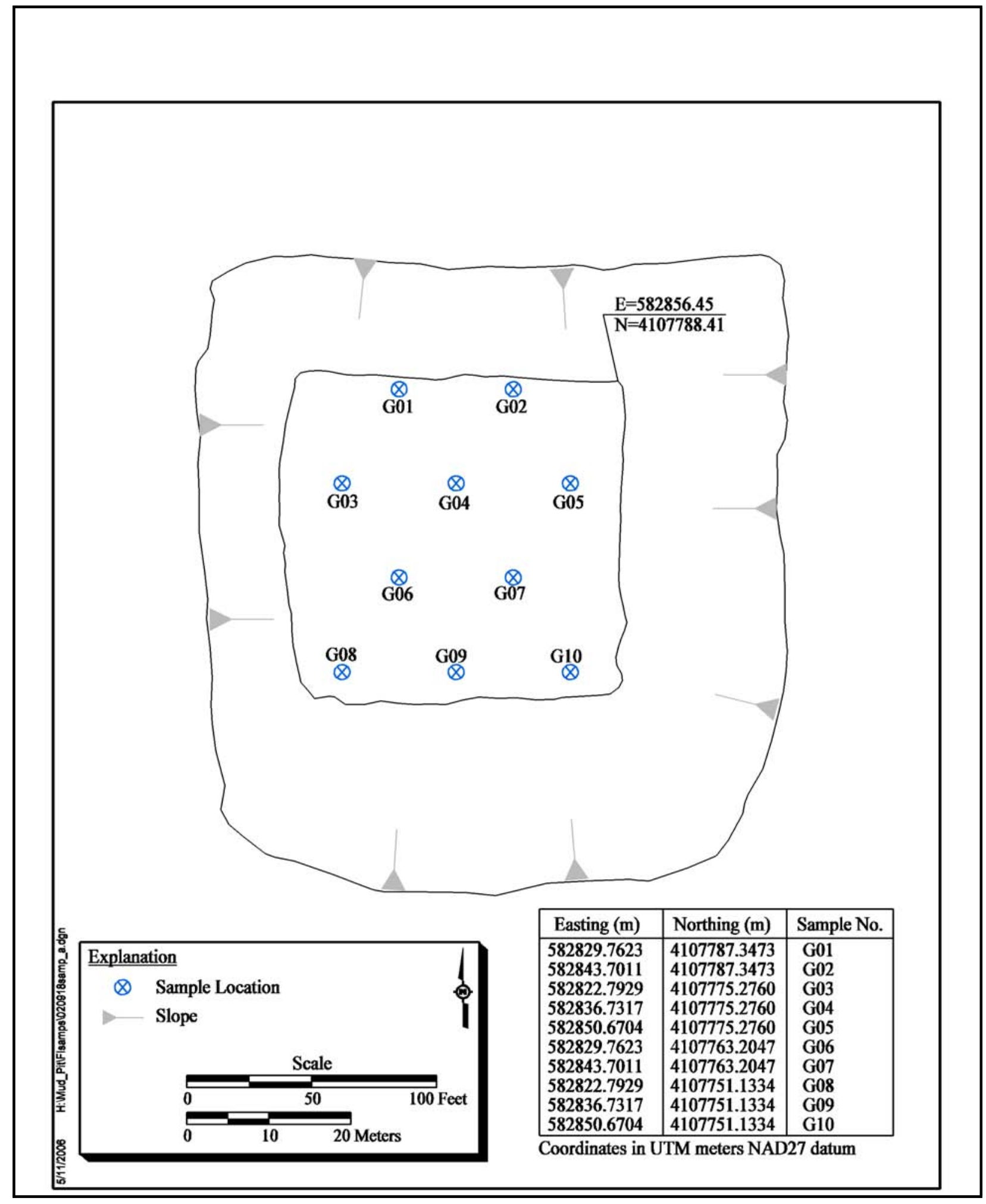

Figure C.1-7

CAS 02-09-18 Sample Locations 


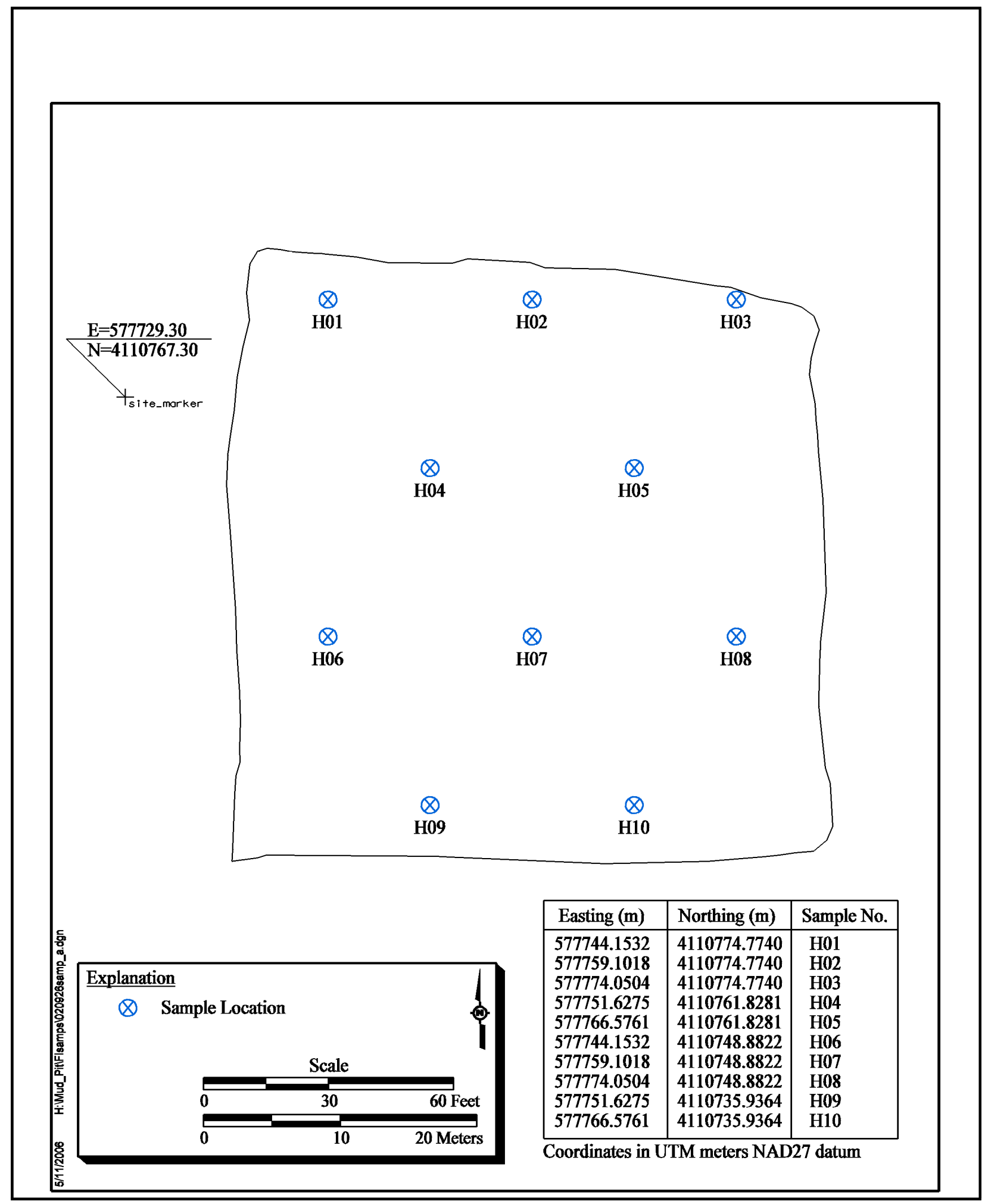

Figure C.1-8

CAS 02-09-26 Sample Locations 


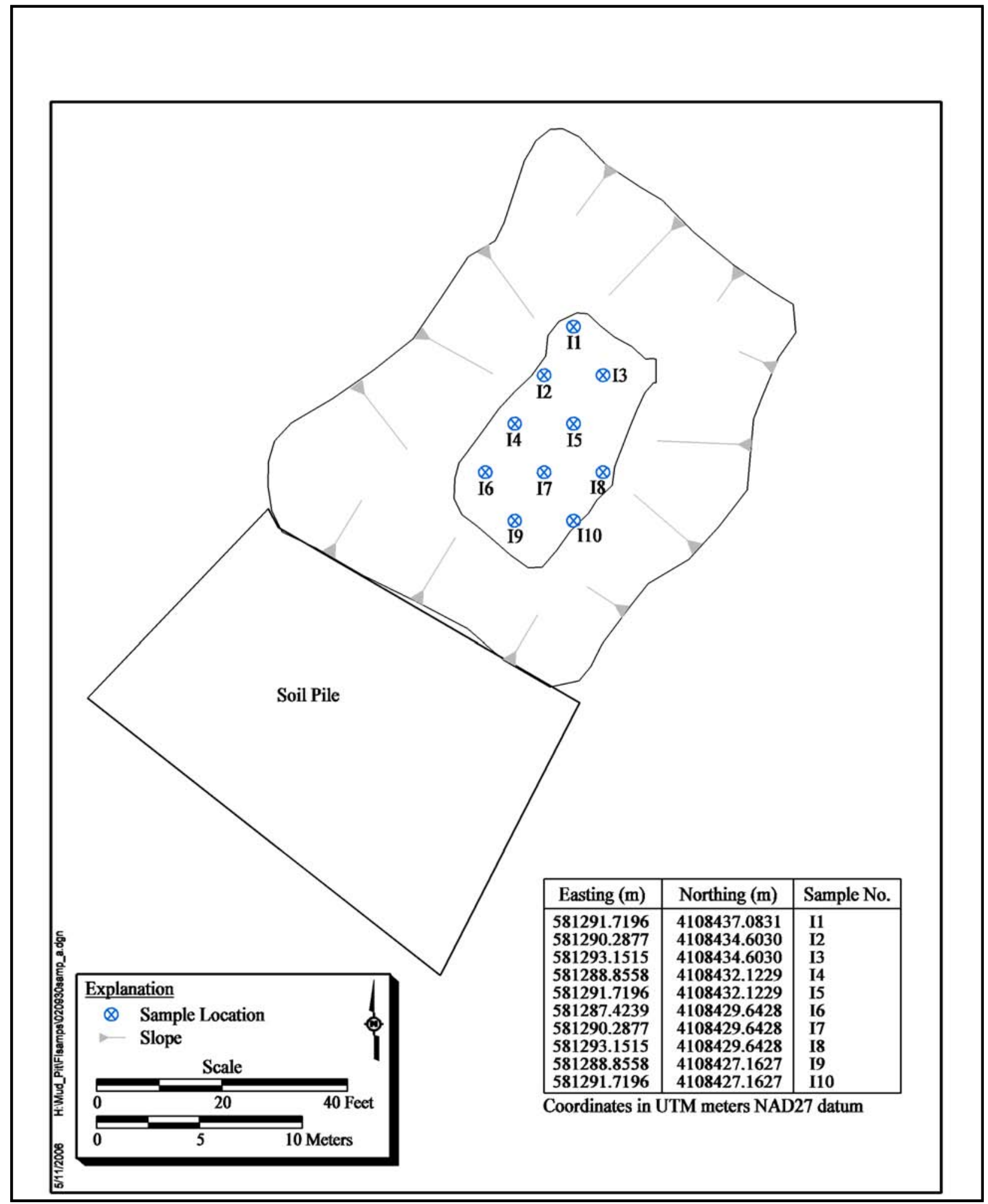

Figure C.1-9

CAS 02-09-30 Sample Locations 


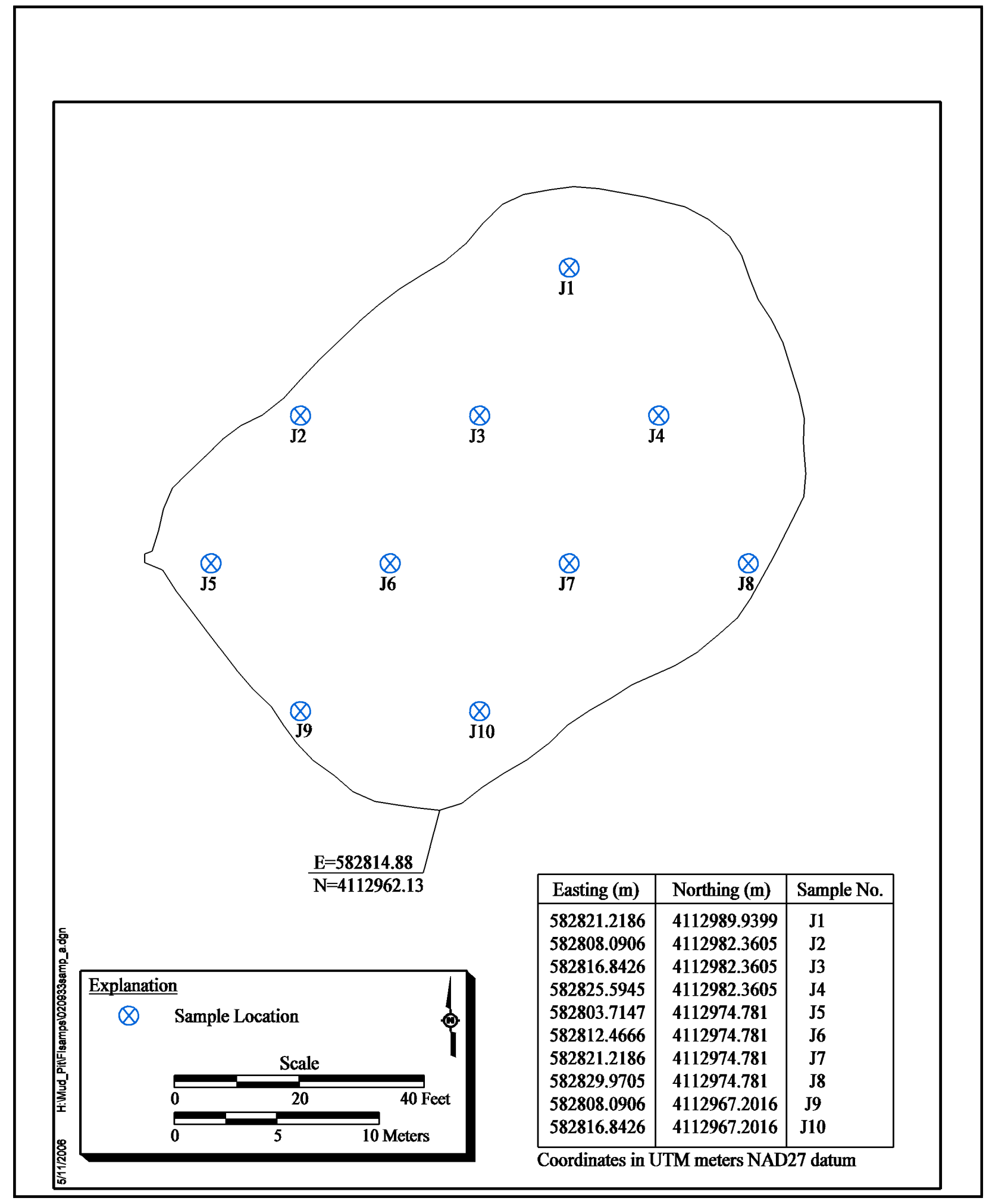

Figure C.1-10

CAS 02-09-33 Sample Locations 


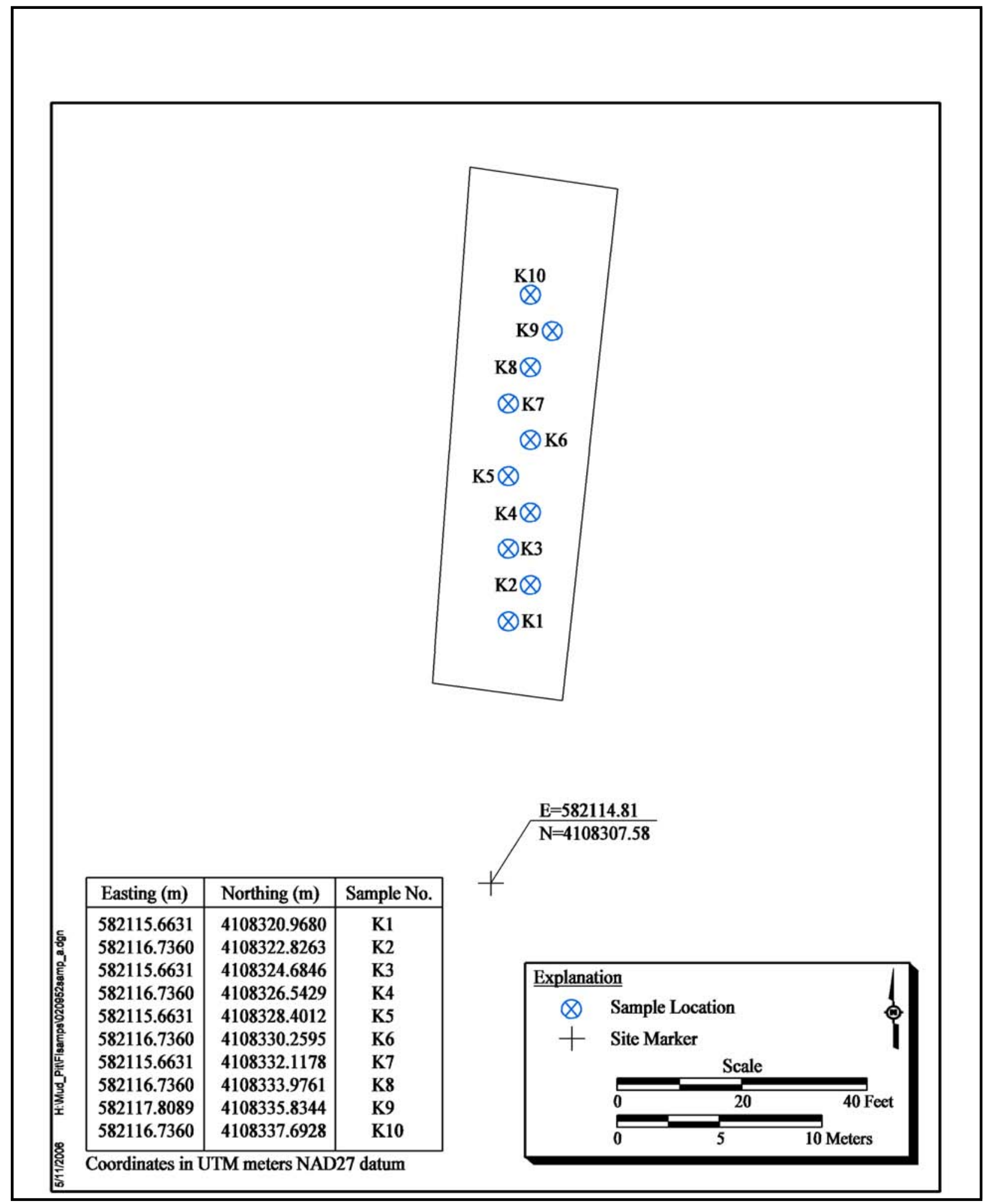

Figure C.1-11

CAS 02-09-52 Sample Locations 


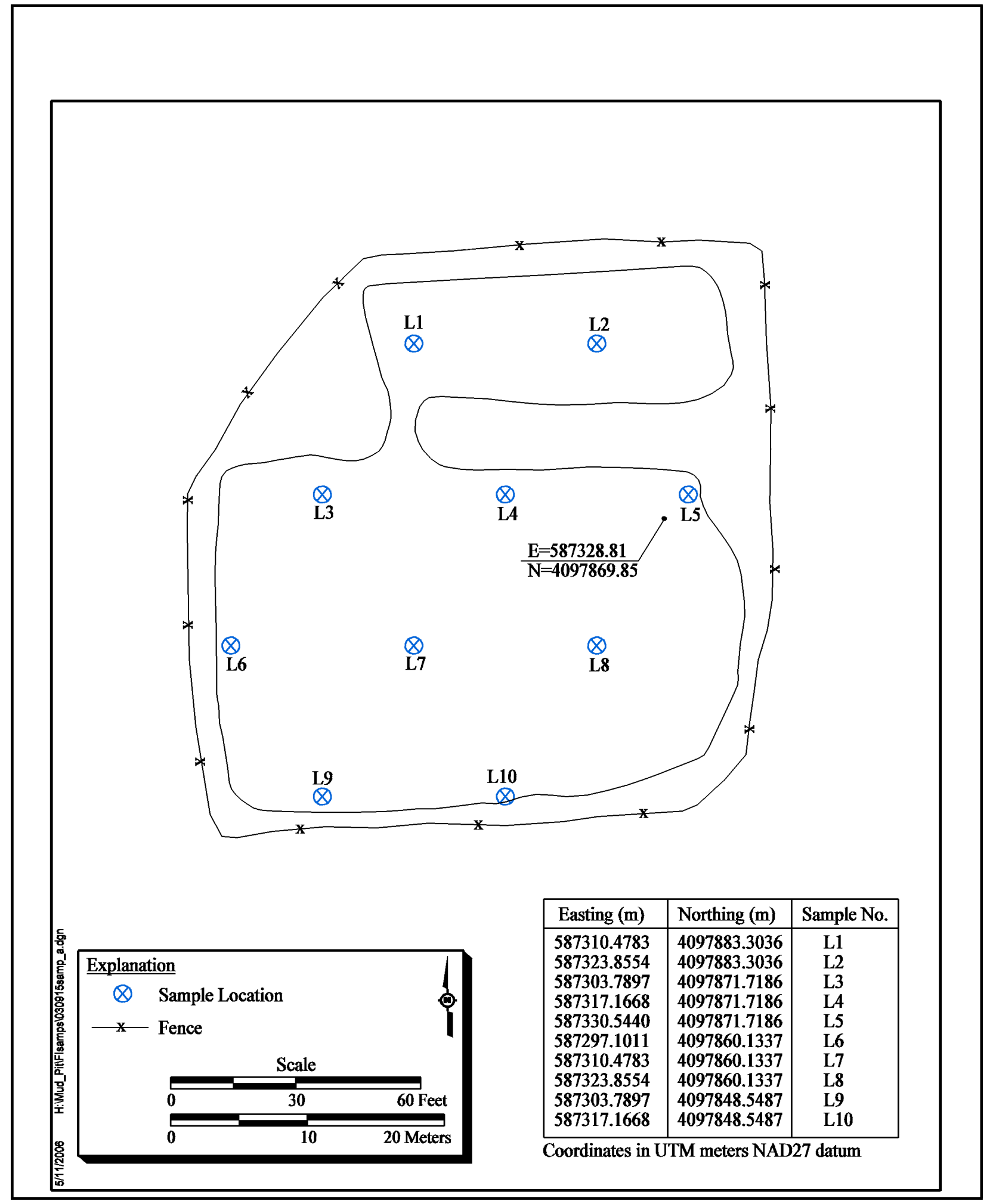

Figure C.1-12

CAS 03-09-15 Sample Locations 


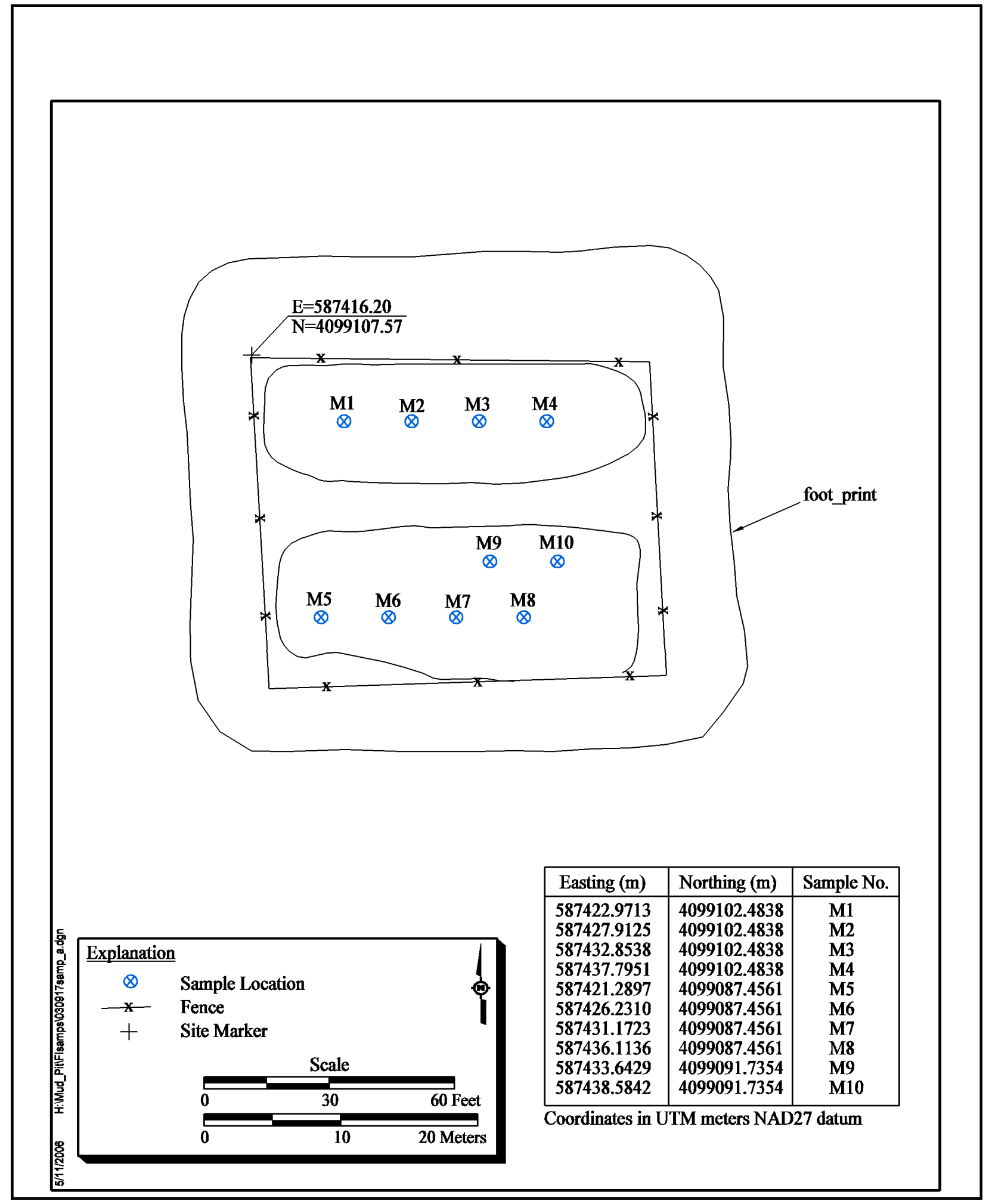

Figure C.1-13

CAS 03-09-17 Sample Locations 


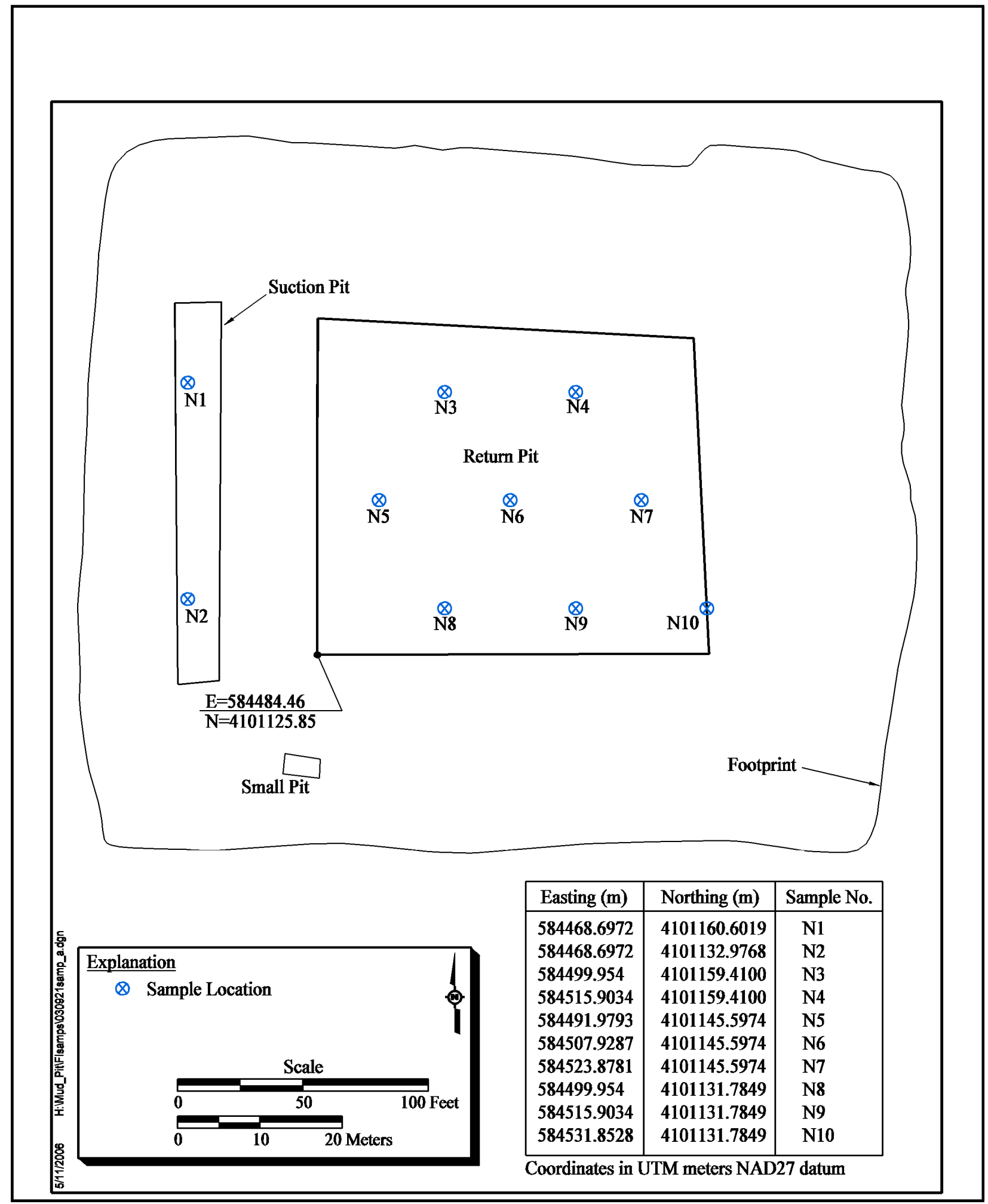

Figure C.1-14

CAS 03-09-21 Sample Locations 


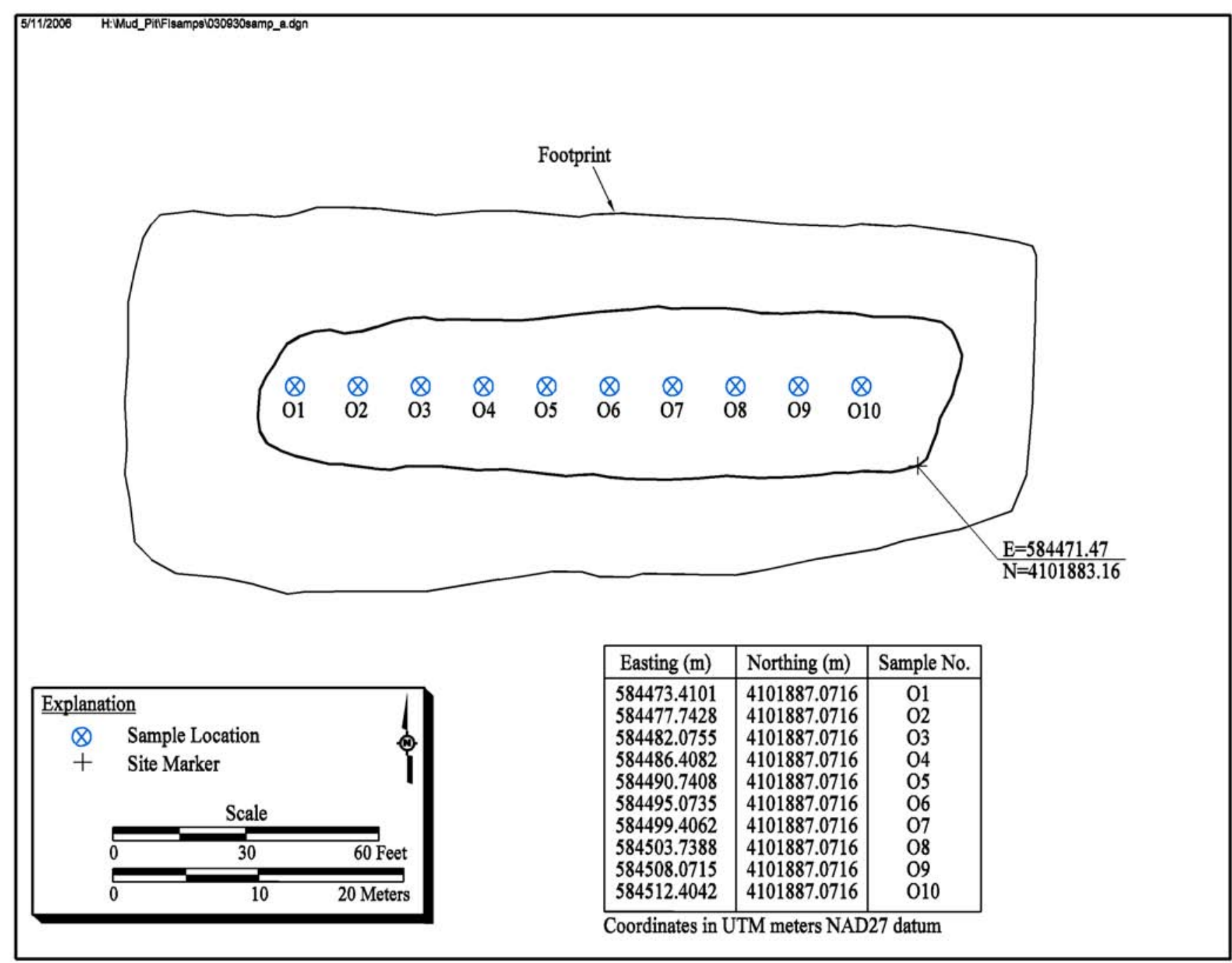

Figure C.1-15

CAS 03-09-30 Sample Locations

\section{Uncontrolled When Printed}




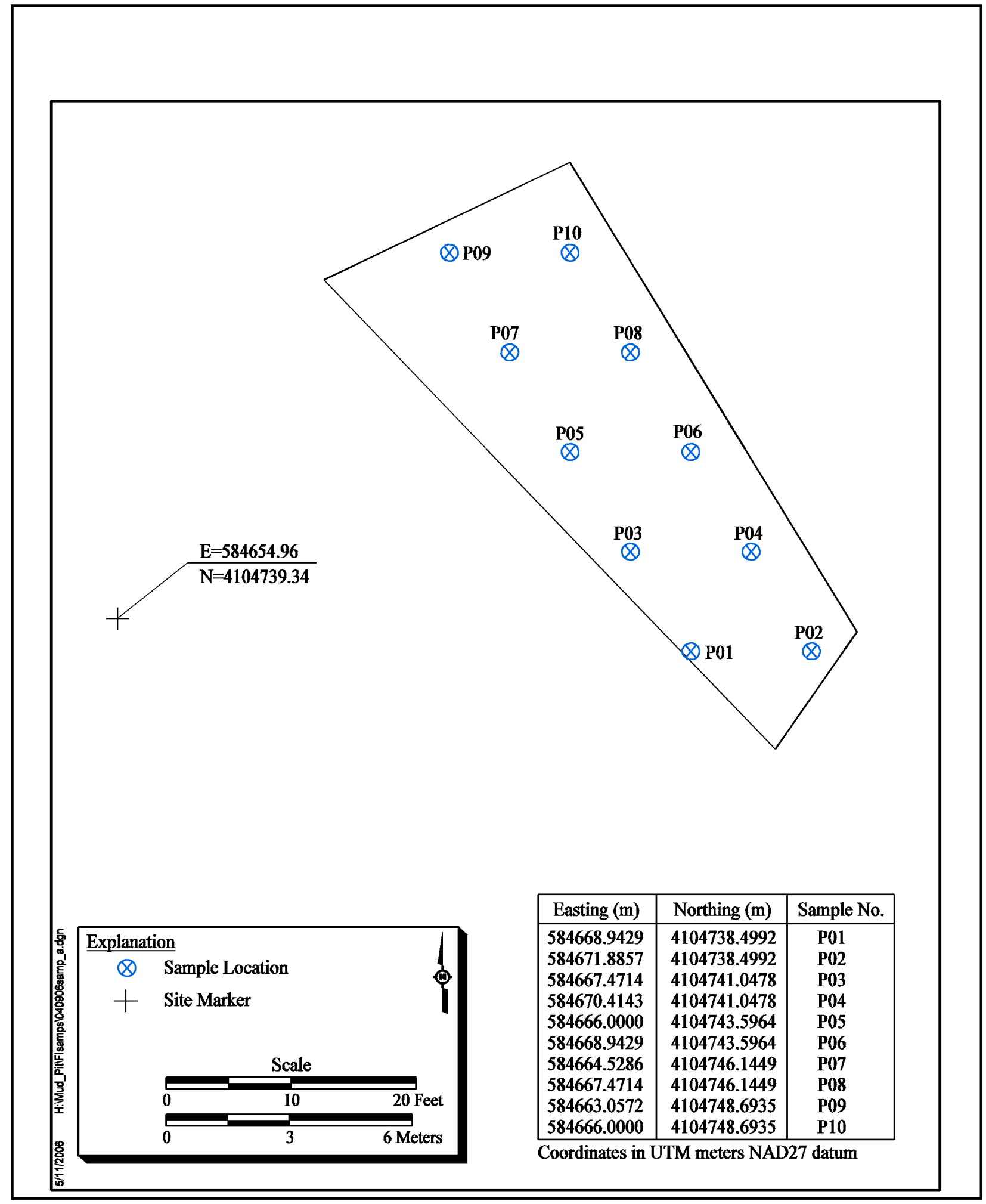

Figure C.1-16

CAS 04-09-06 Sample Locations 


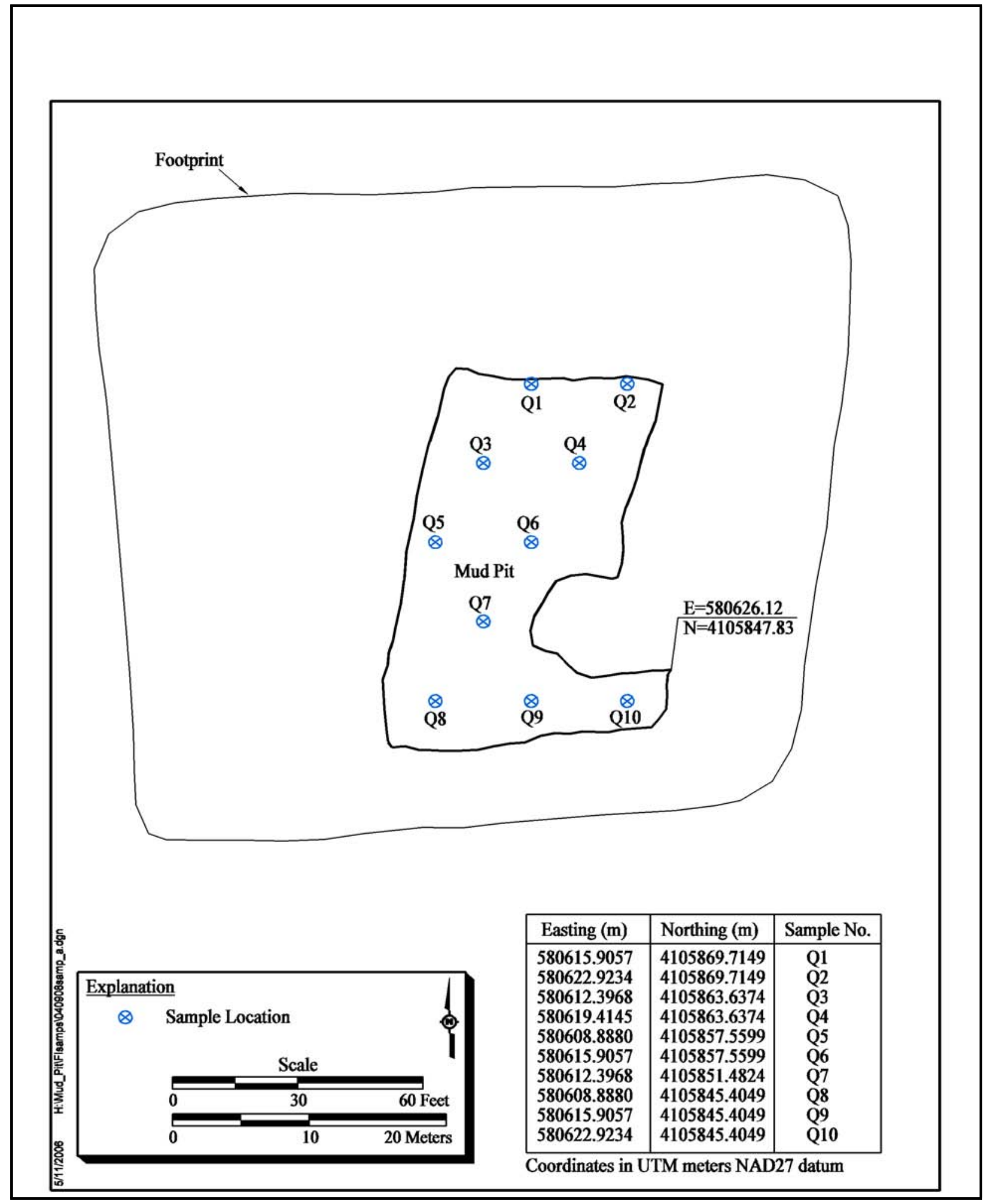

Figure C.1-17

CAS 04-09-08 Sample Locations 


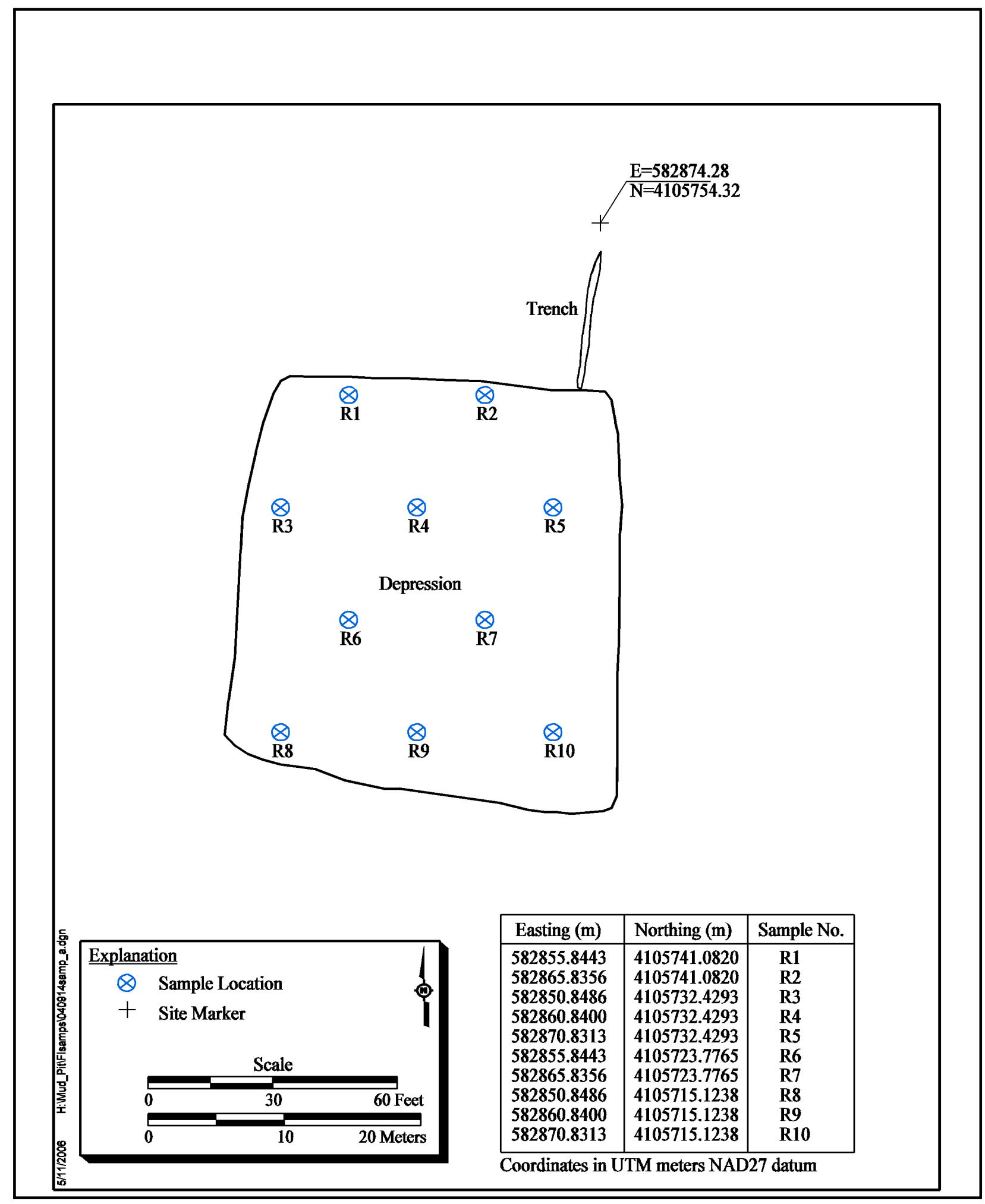

Figure C.1-18

CAS 04-09-14 Sample Locations 


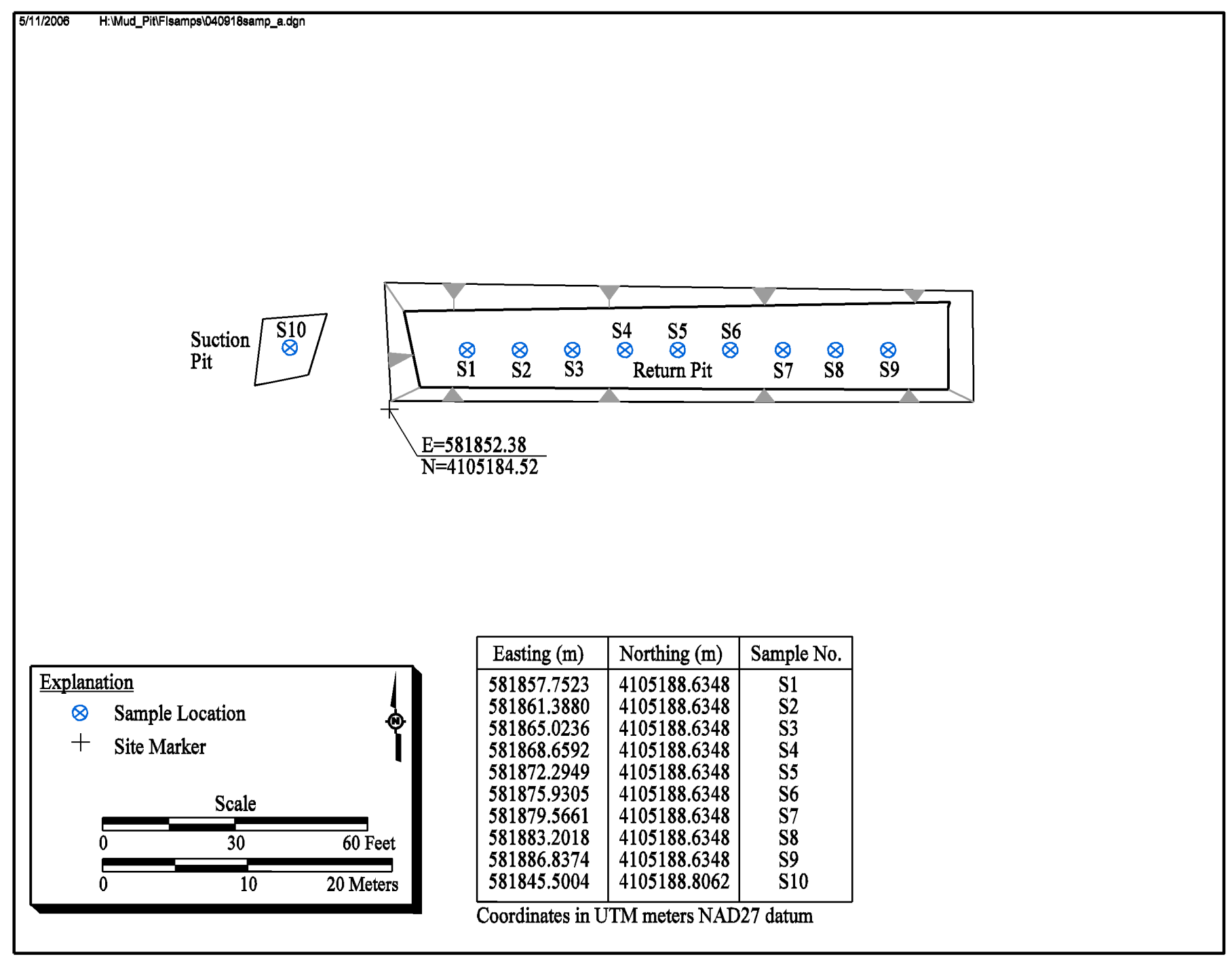

Figure C.1-19

CAS 04-09-18 Sample Locations

\section{Uncontrolled When Printed}




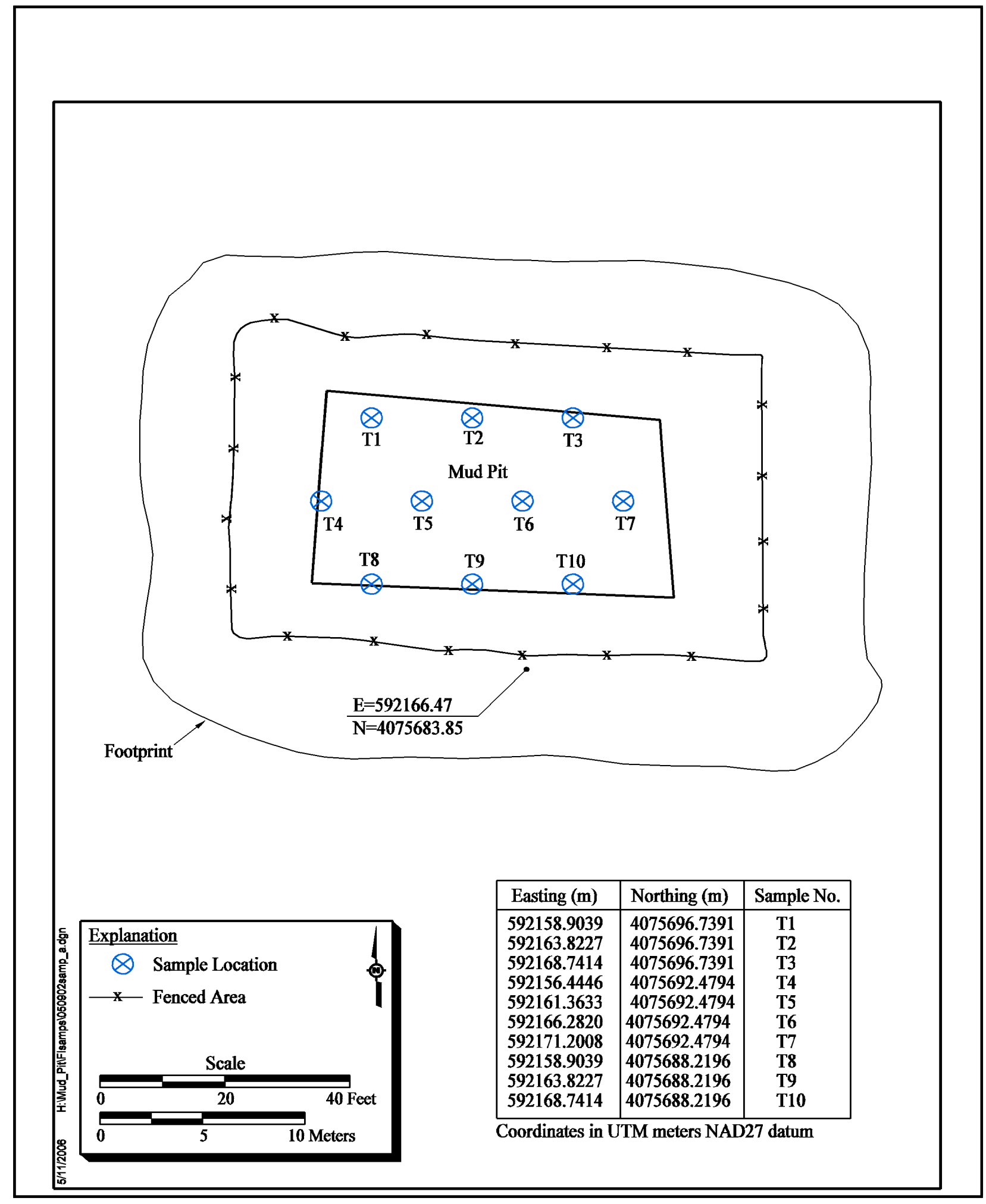

Figure C.1-20

CAS 05-09-02 Sample Locations 


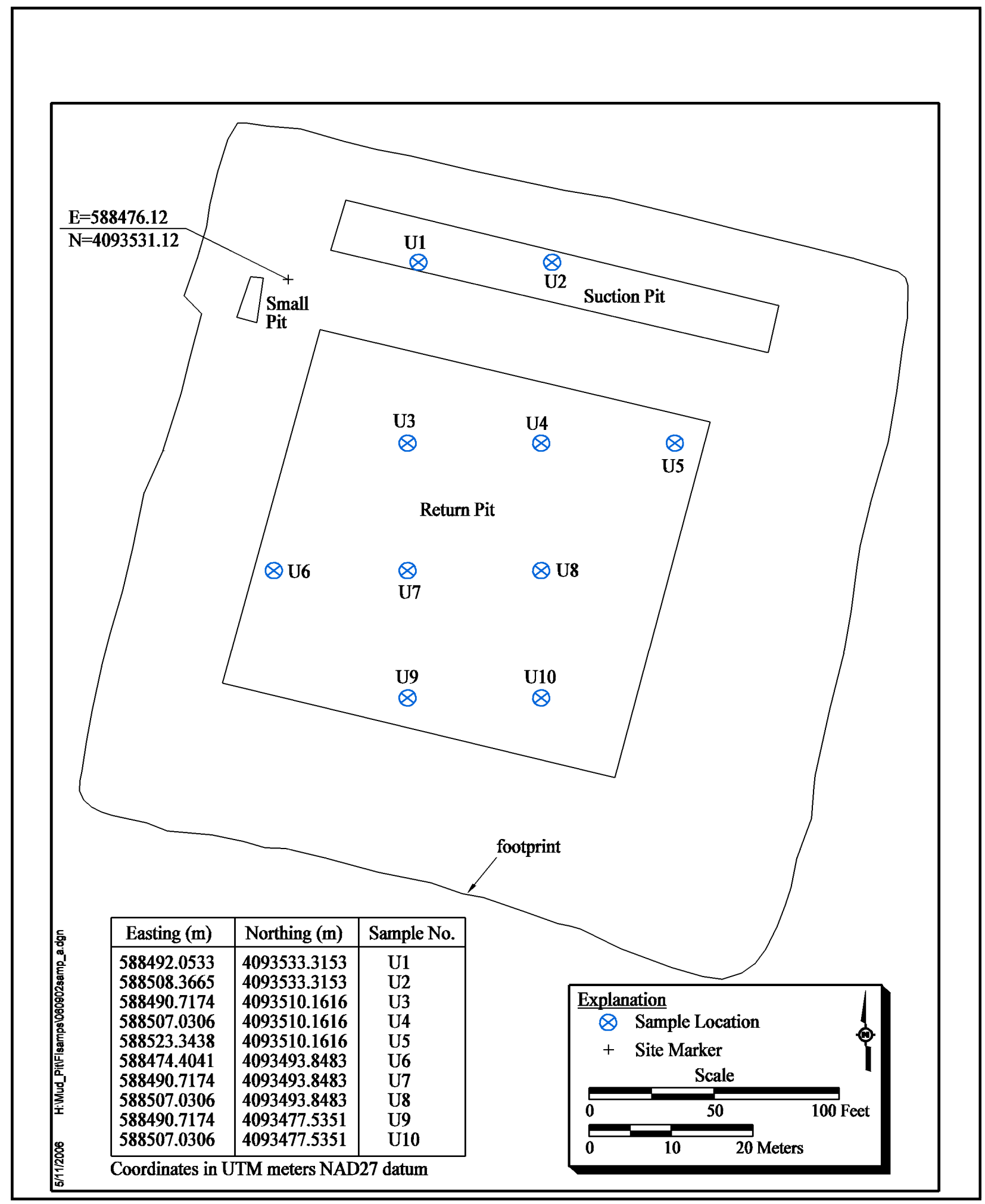

Figure C.1-21

CAS 06-09-02 Sample Locations 


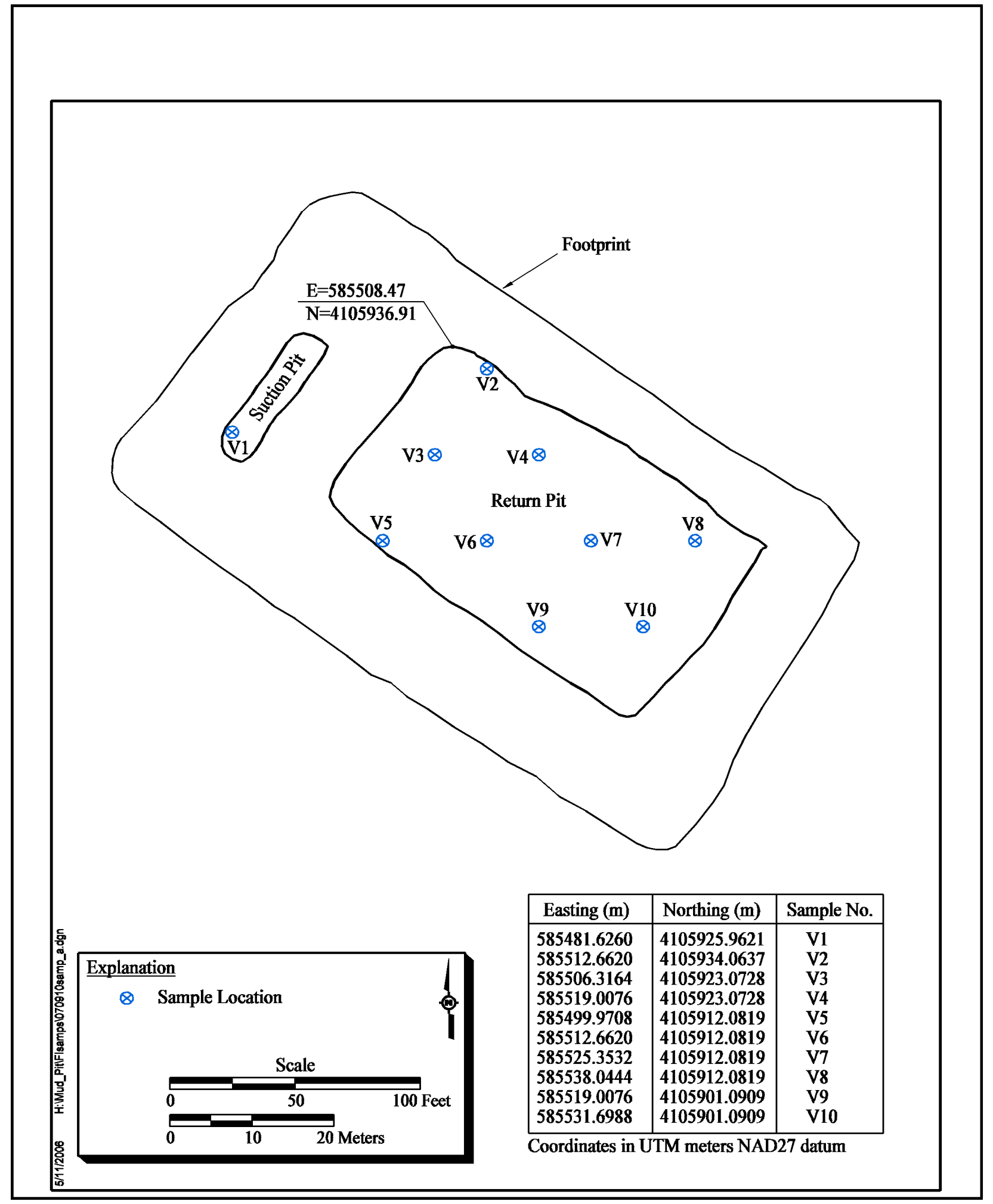

Figure C.1-22

CAS 07-09-10 Sample Locations 


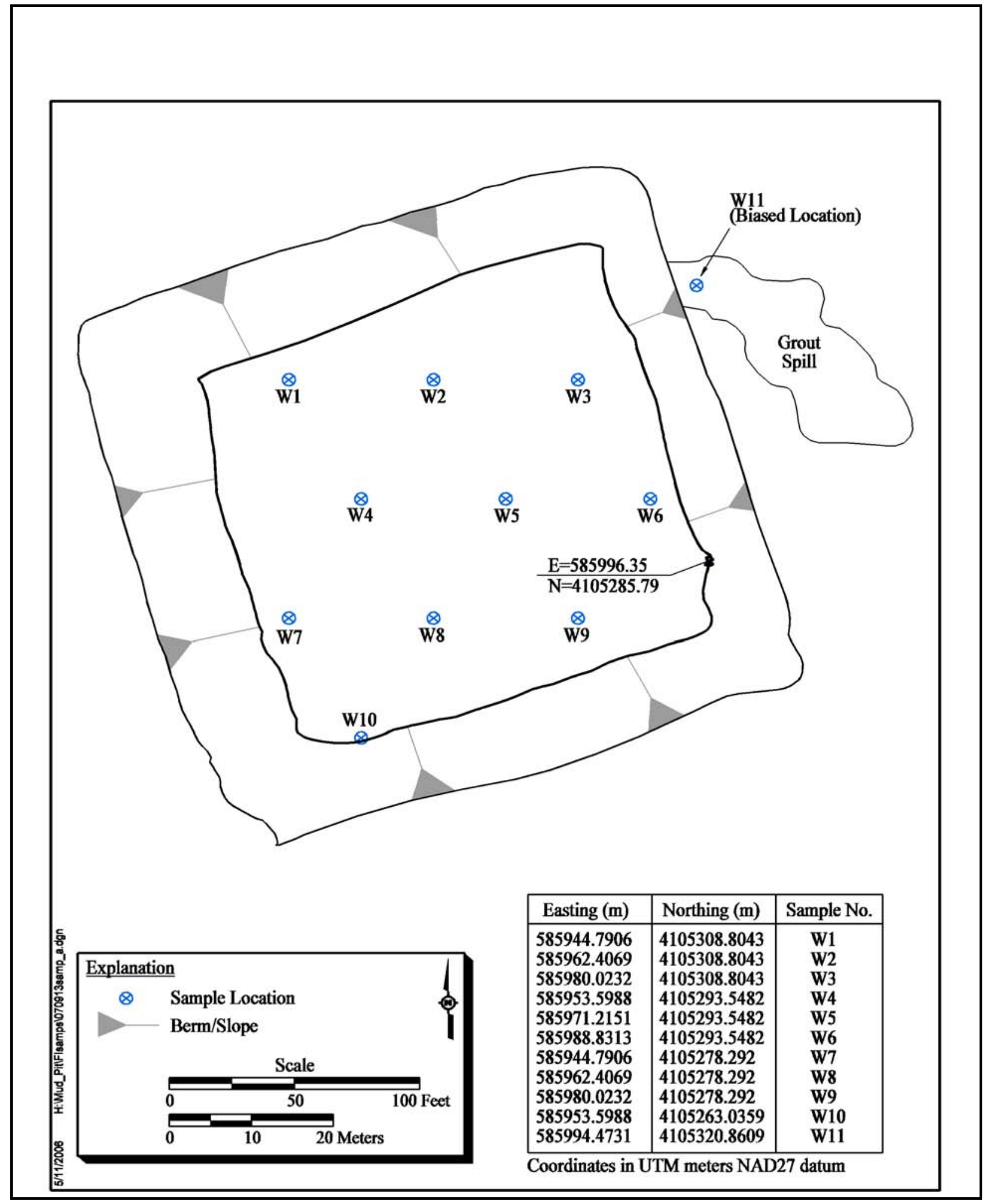

Figure C.1-23

CAS 07-09-13 Sample Locations 


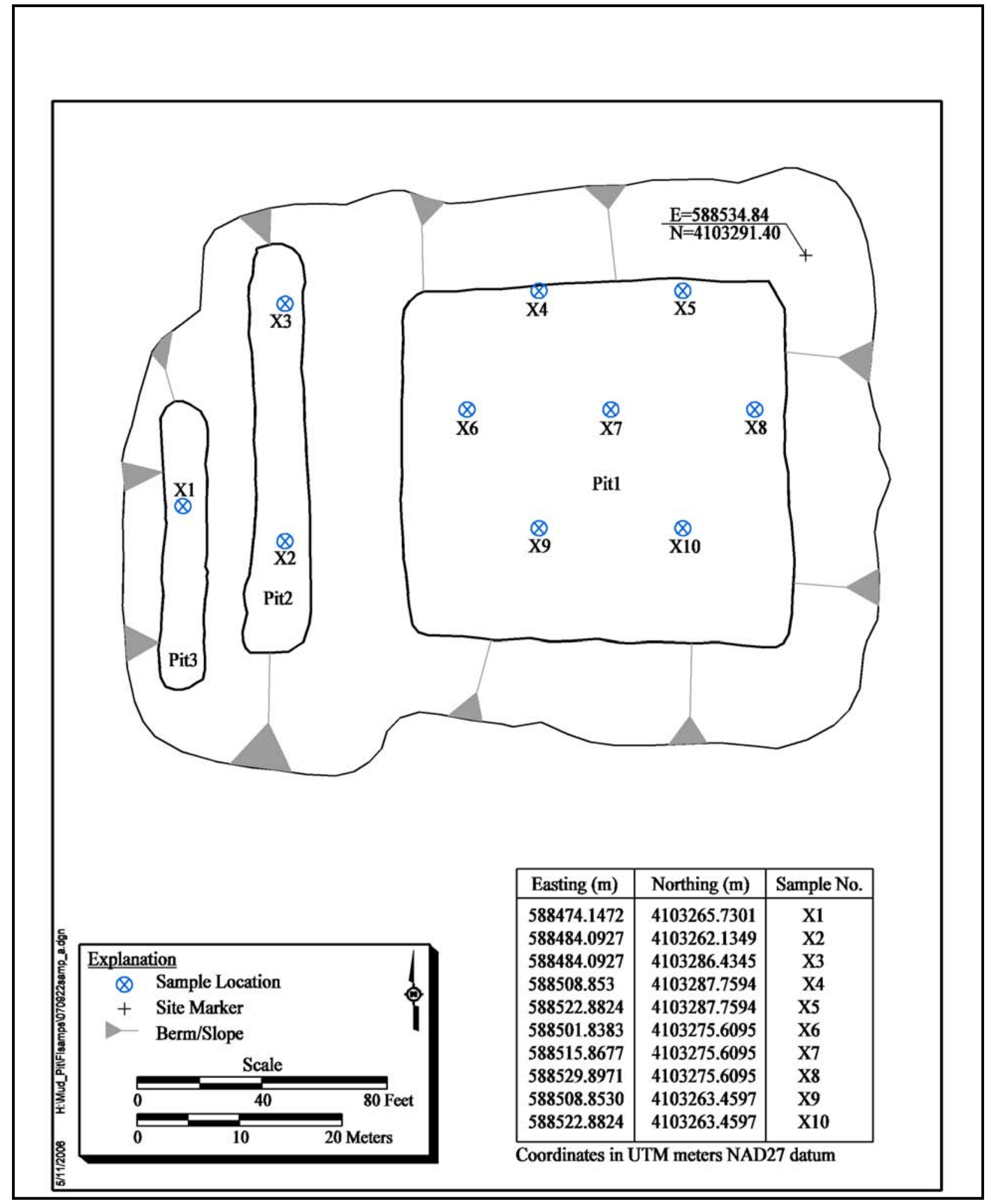

Figure C.1-24

CAS 07-09-22 Sample Locations 


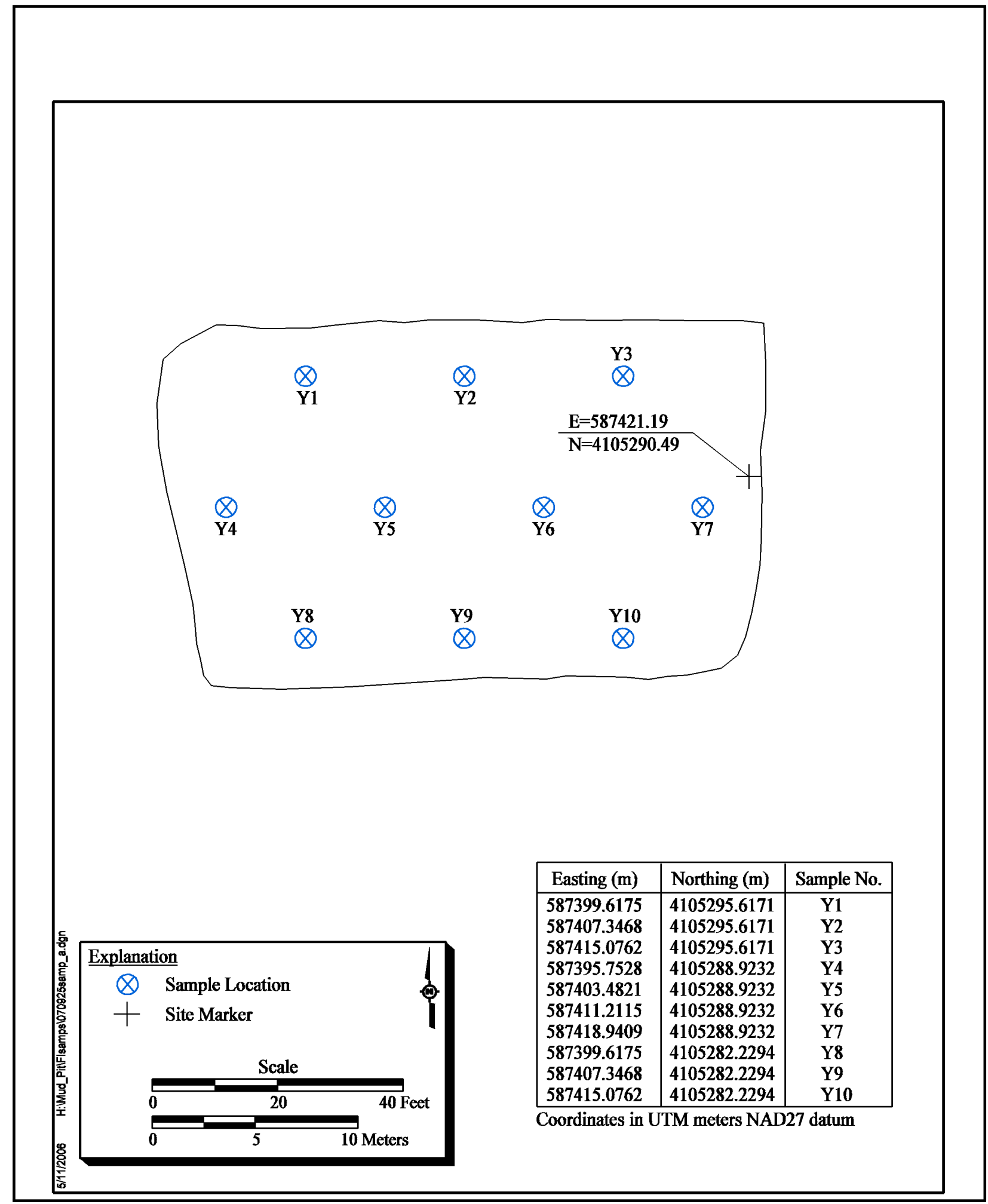

Figure C.1-25

CAS 07-09-25 Sample Locations 


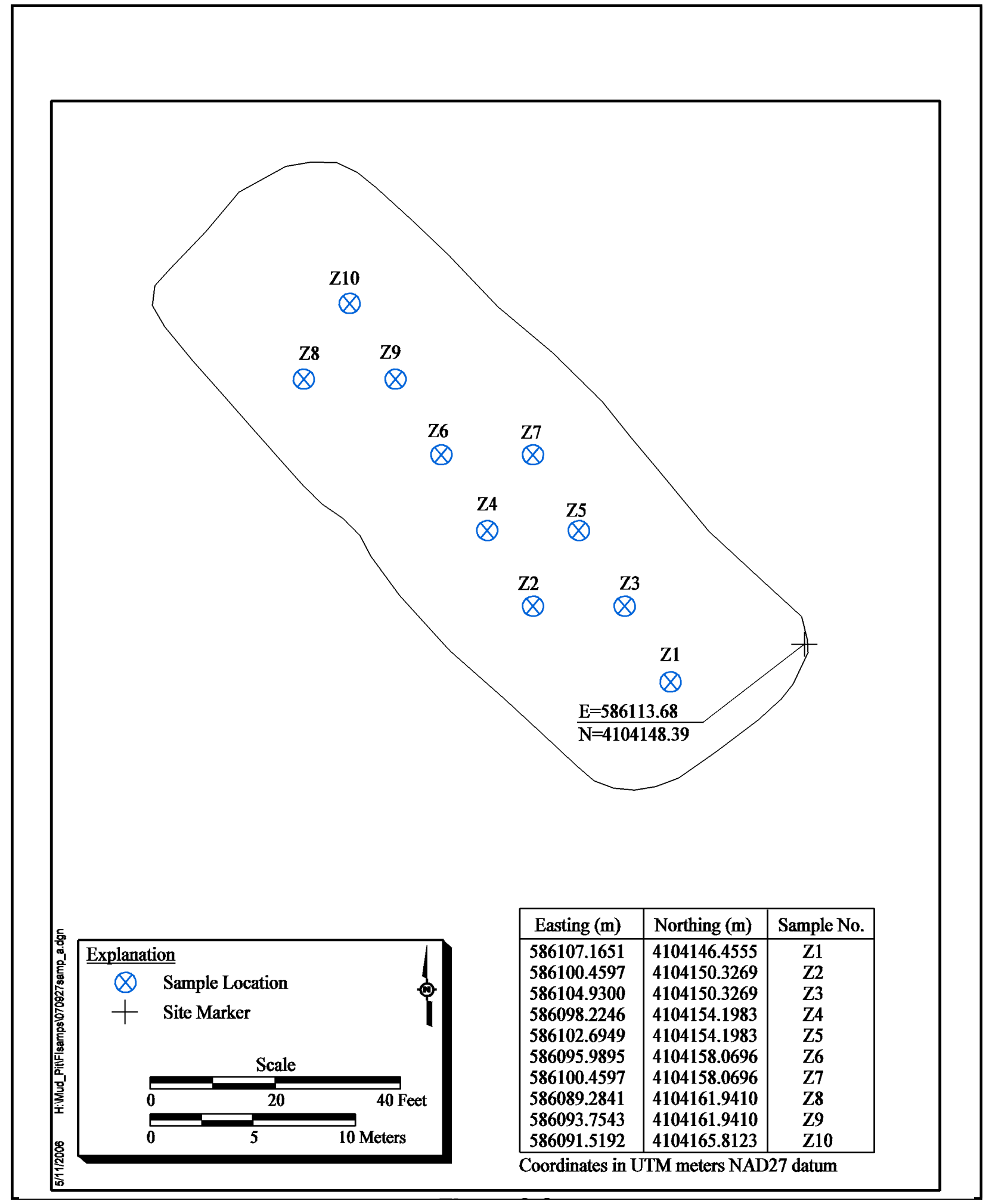

Figure C.1-26

CAS 07-09-27 Sample Locations 


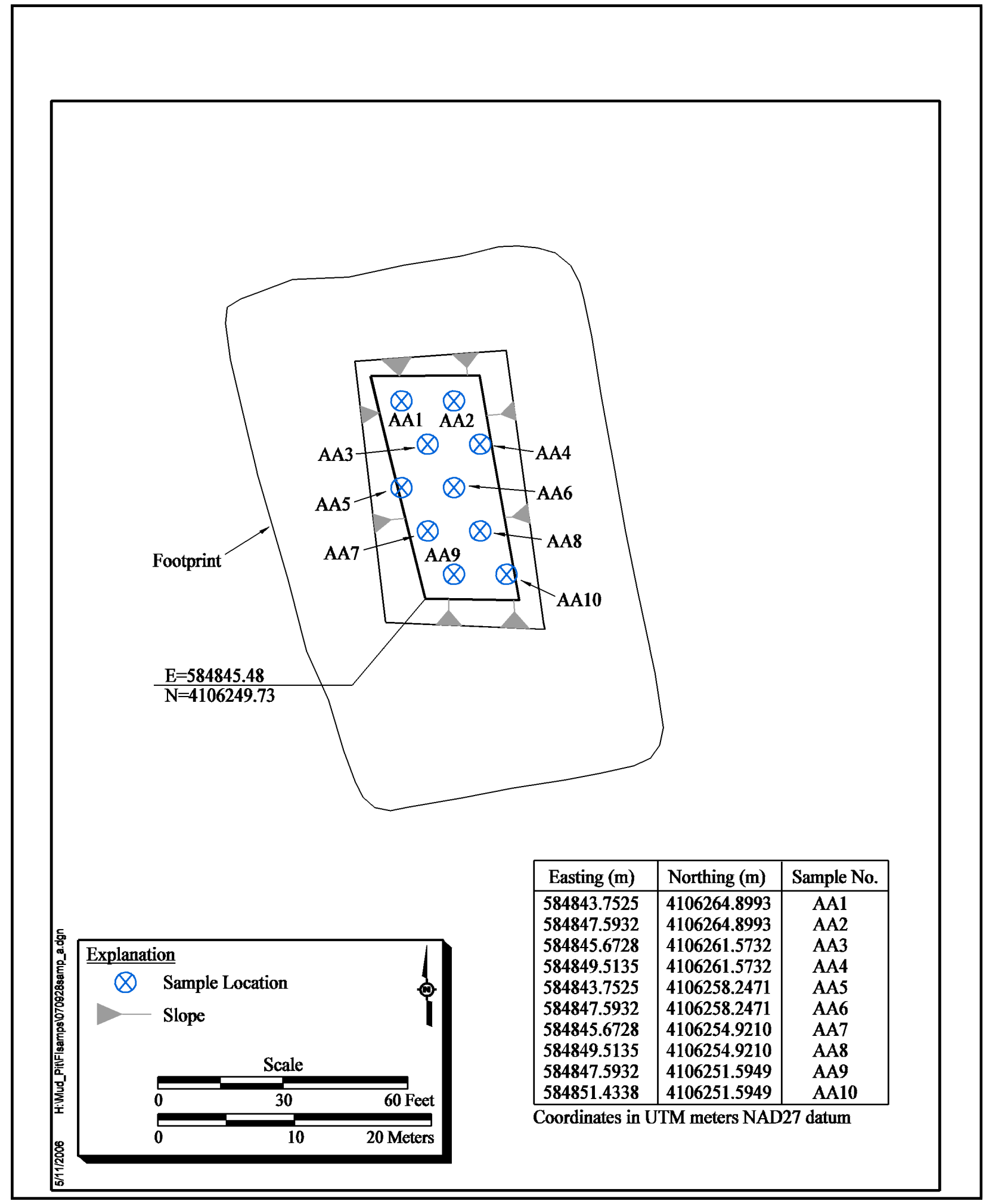

Figure C.1-27

CAS 07-09-28 Sample Locations 


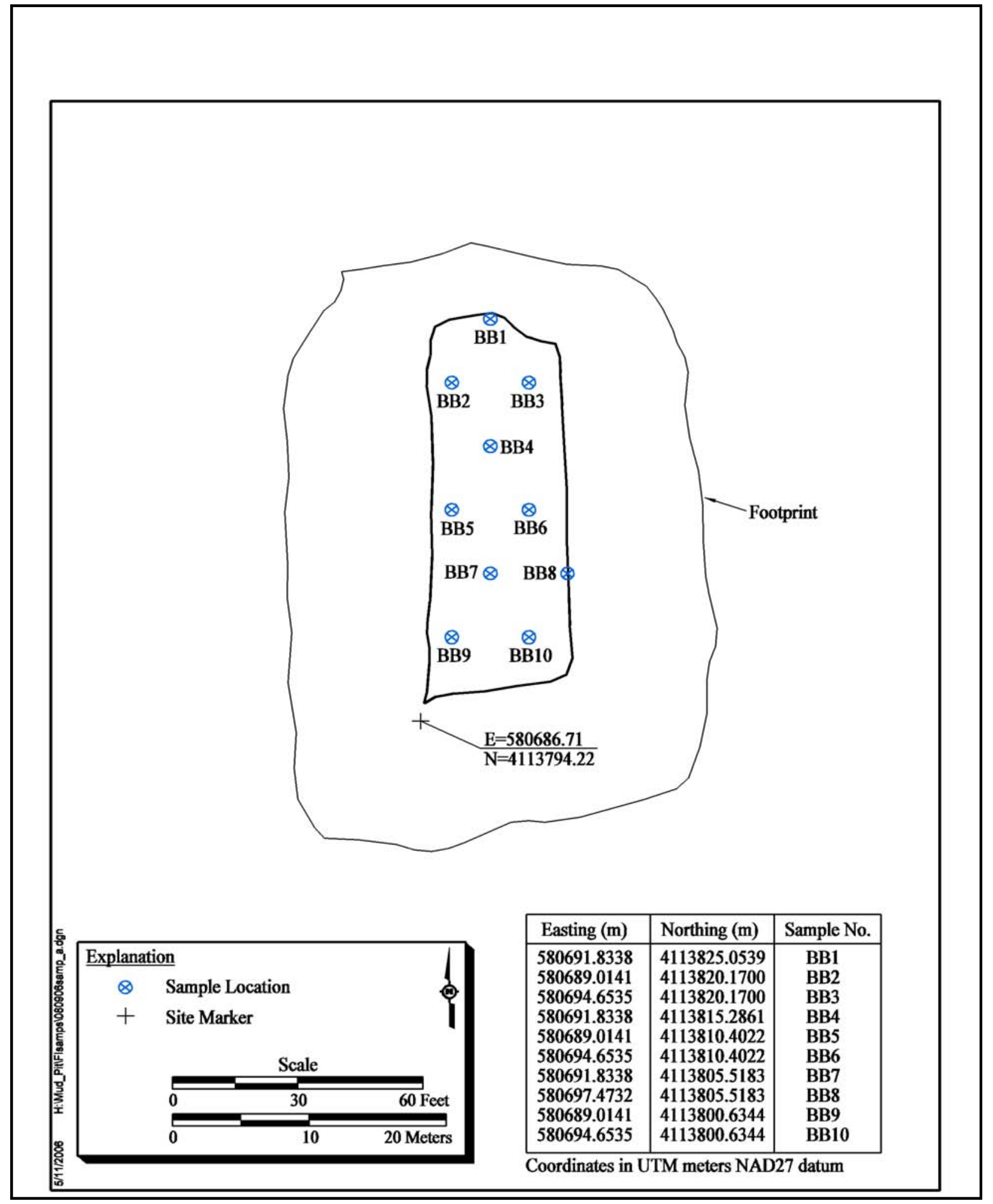

Figure C.1-28

CAS 08-09-06 Sample Locations 


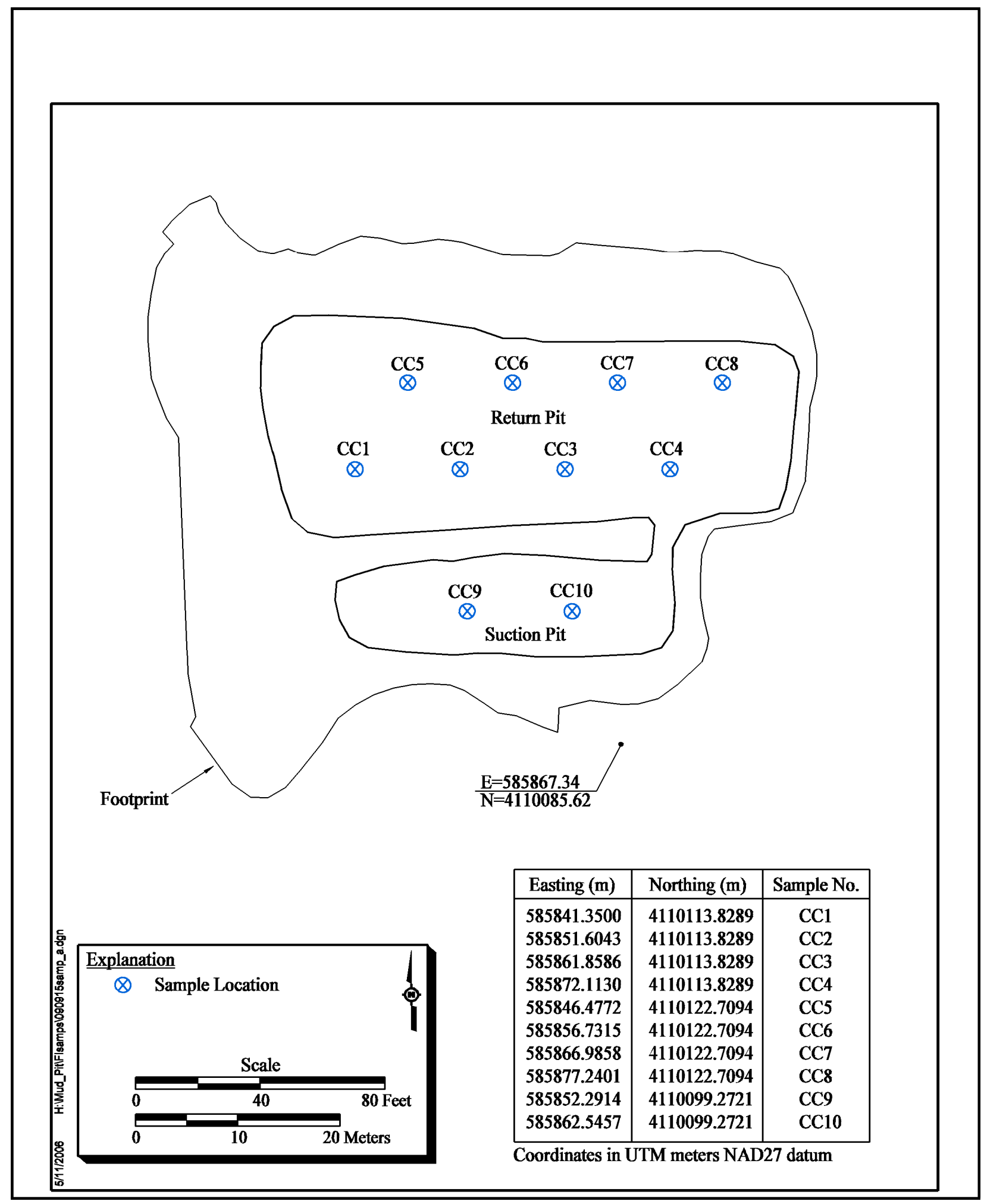

Figure C.1-29

CAS 09-09-15 Sample Locations 


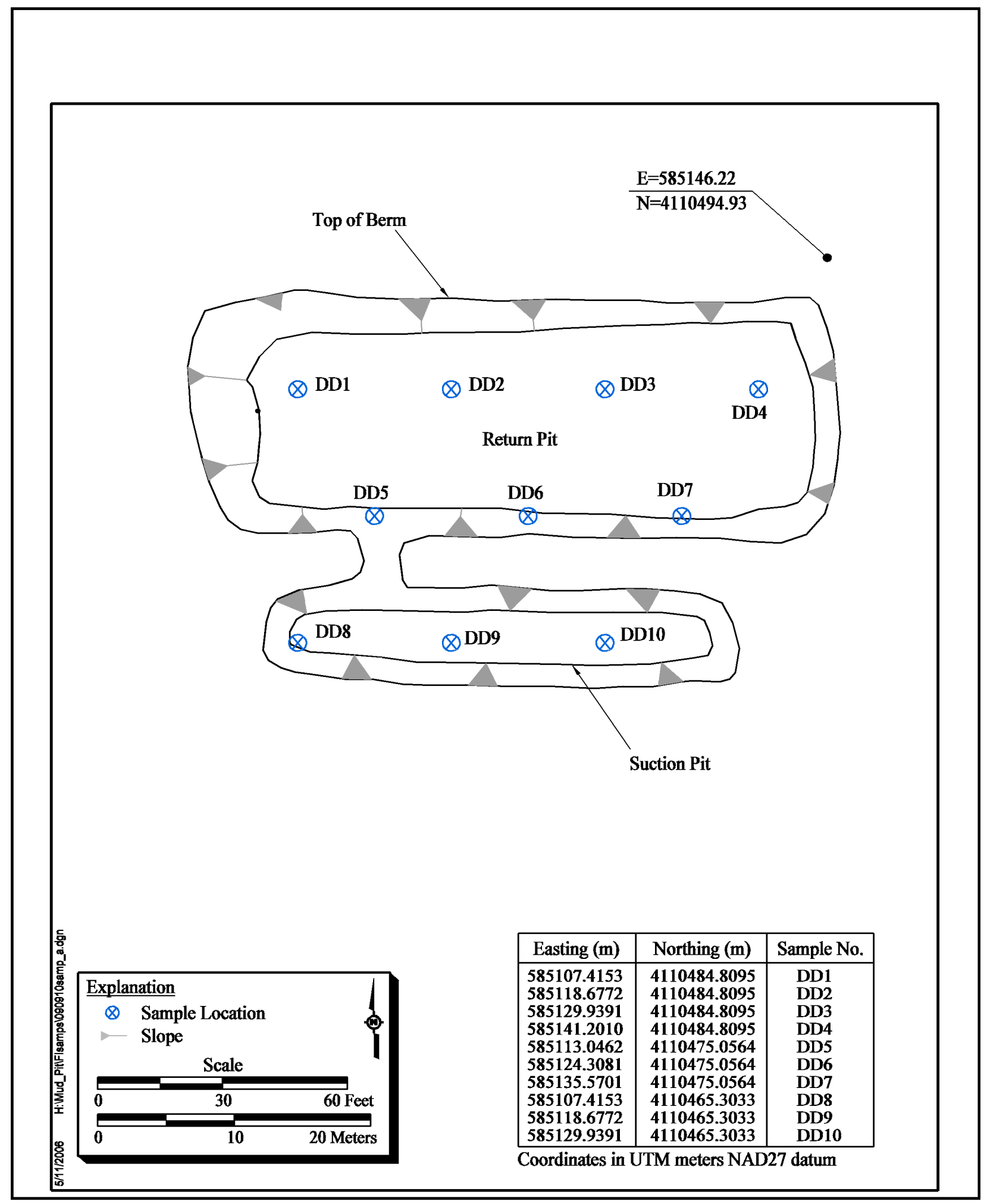

Figure C.1-30

CAS 09-09-10 Sample Locations 


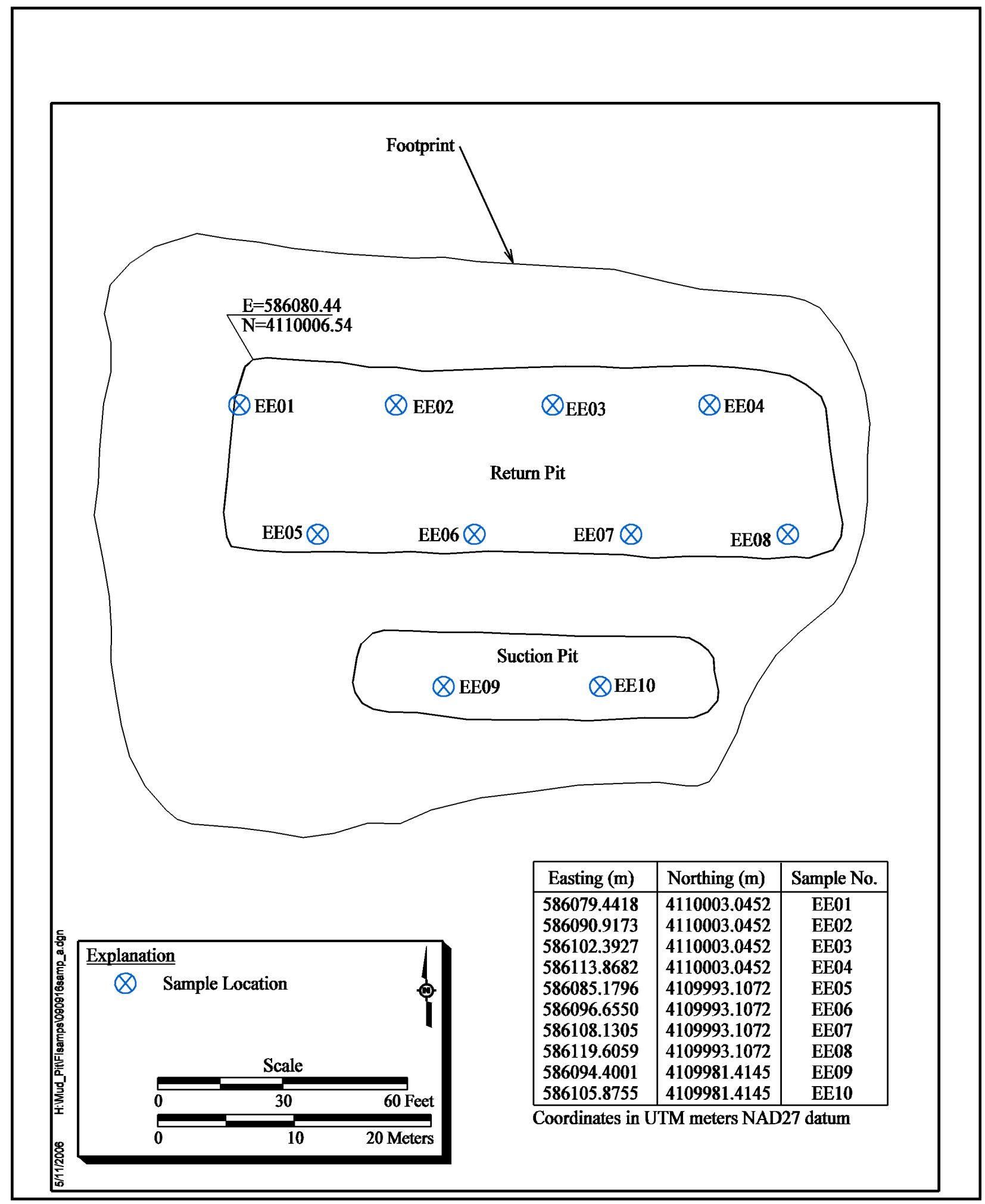

Figure C.1-31

CAS 09-09-16 Sample Locations 


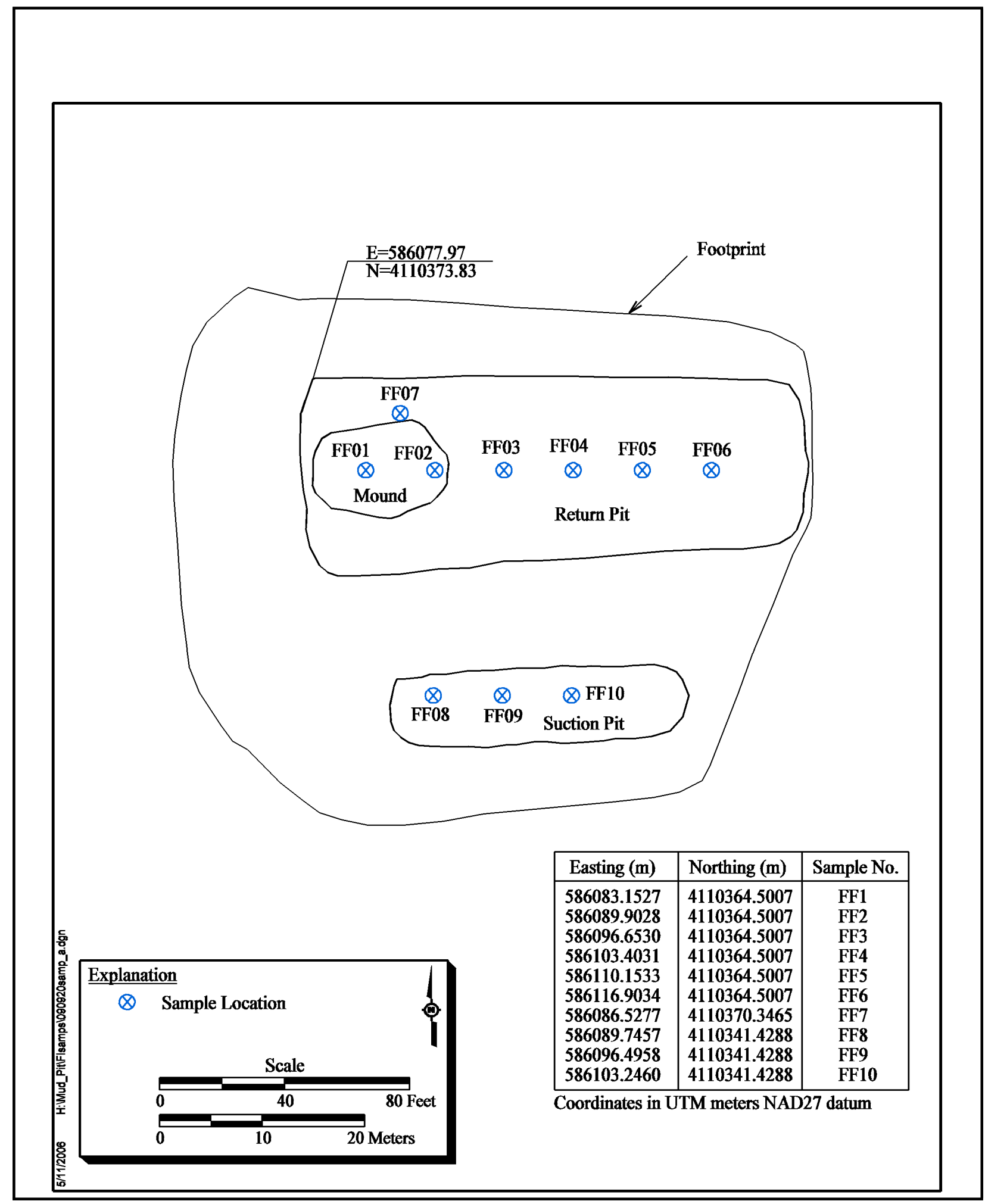

Figure C.1-32

CAS 09-09-20 Sample Locations 


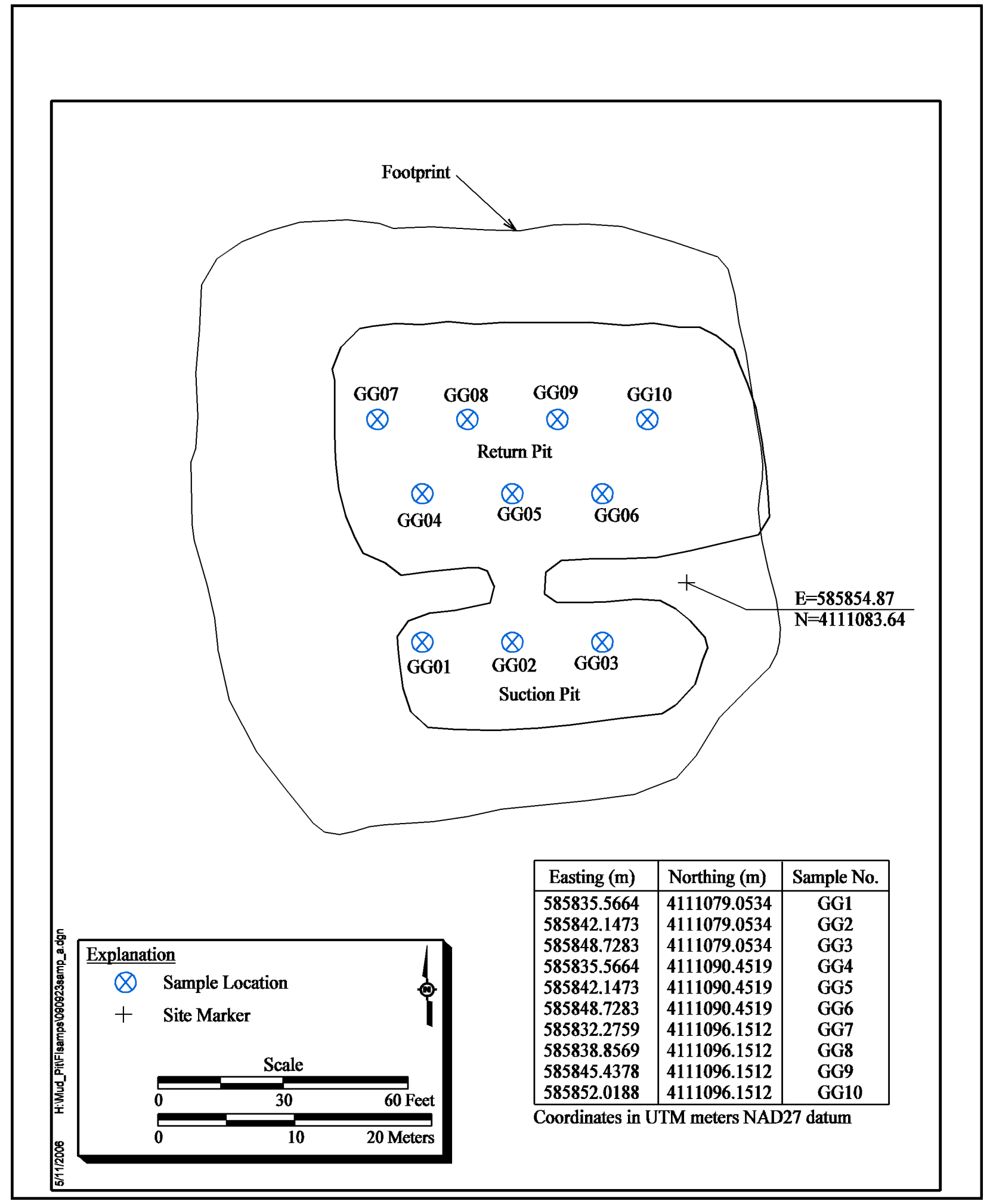

Figure C.1-33

CAS 09-09-23 Sample Locations 


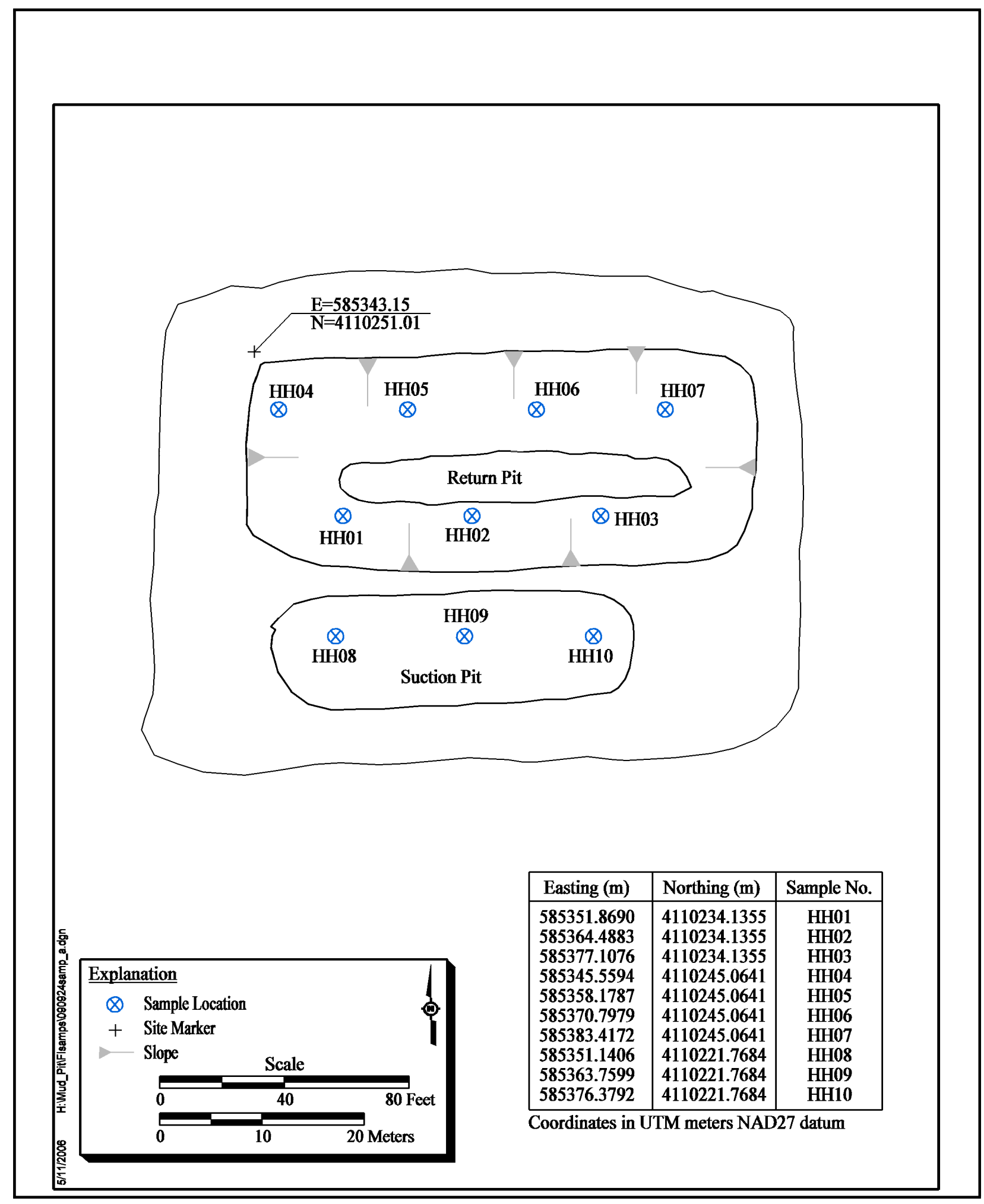

Figure C.1-34

CAS 09-09-24 Sample Locations 


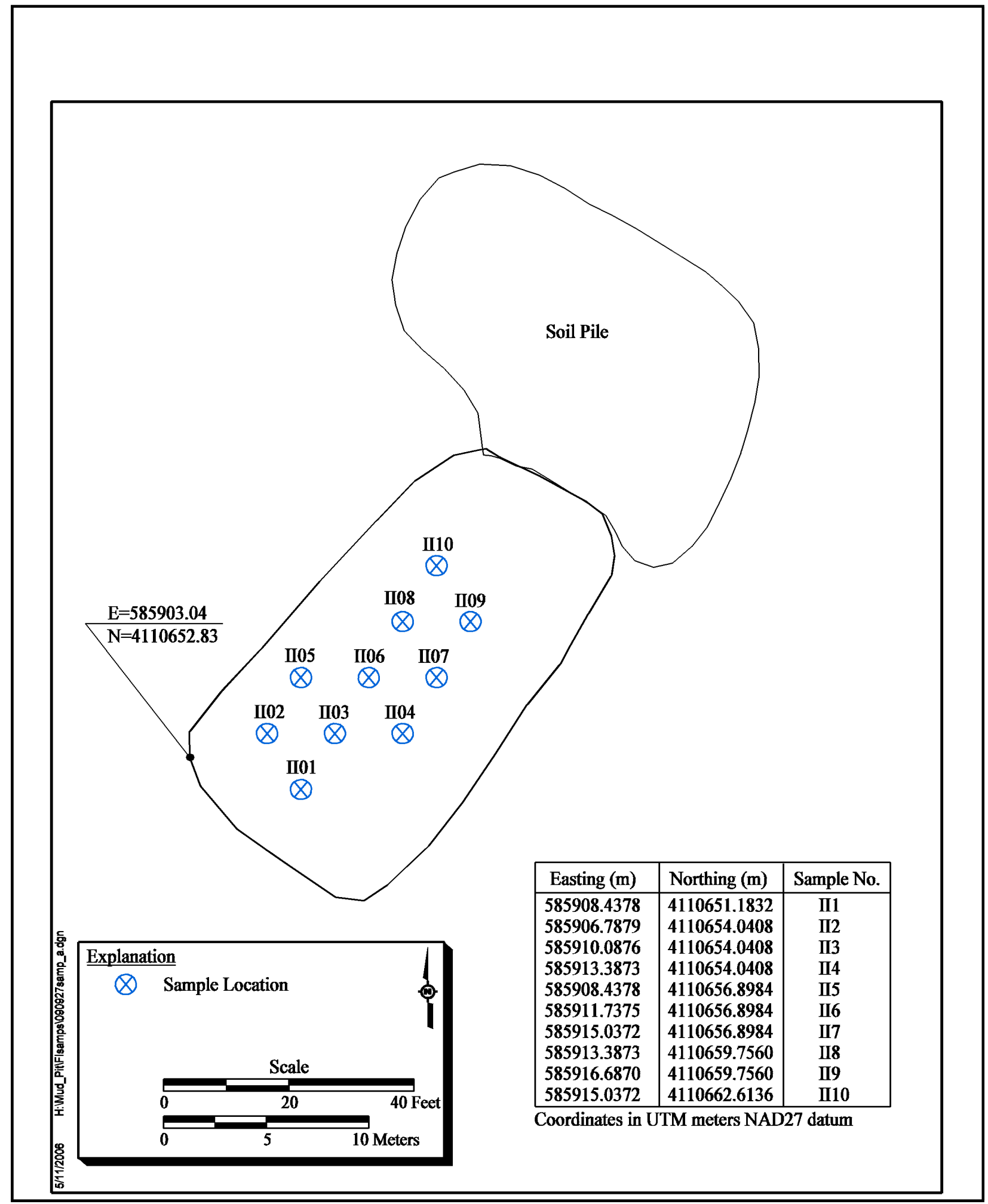

Figure C.1-35

CAS 09-09-27 Sample Locations 


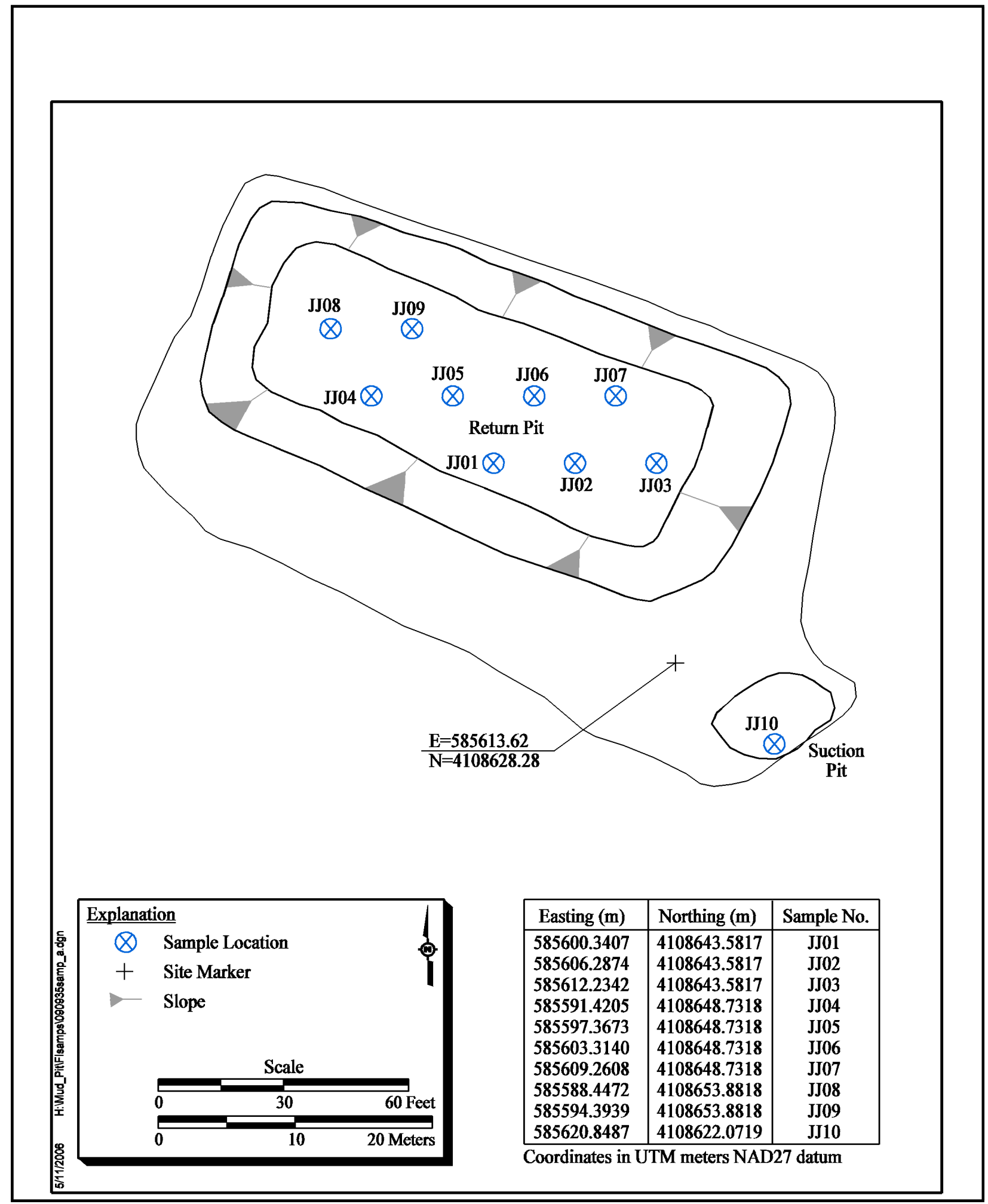

Figure C.1-36

CAS 09-09-35 Sample Locations 


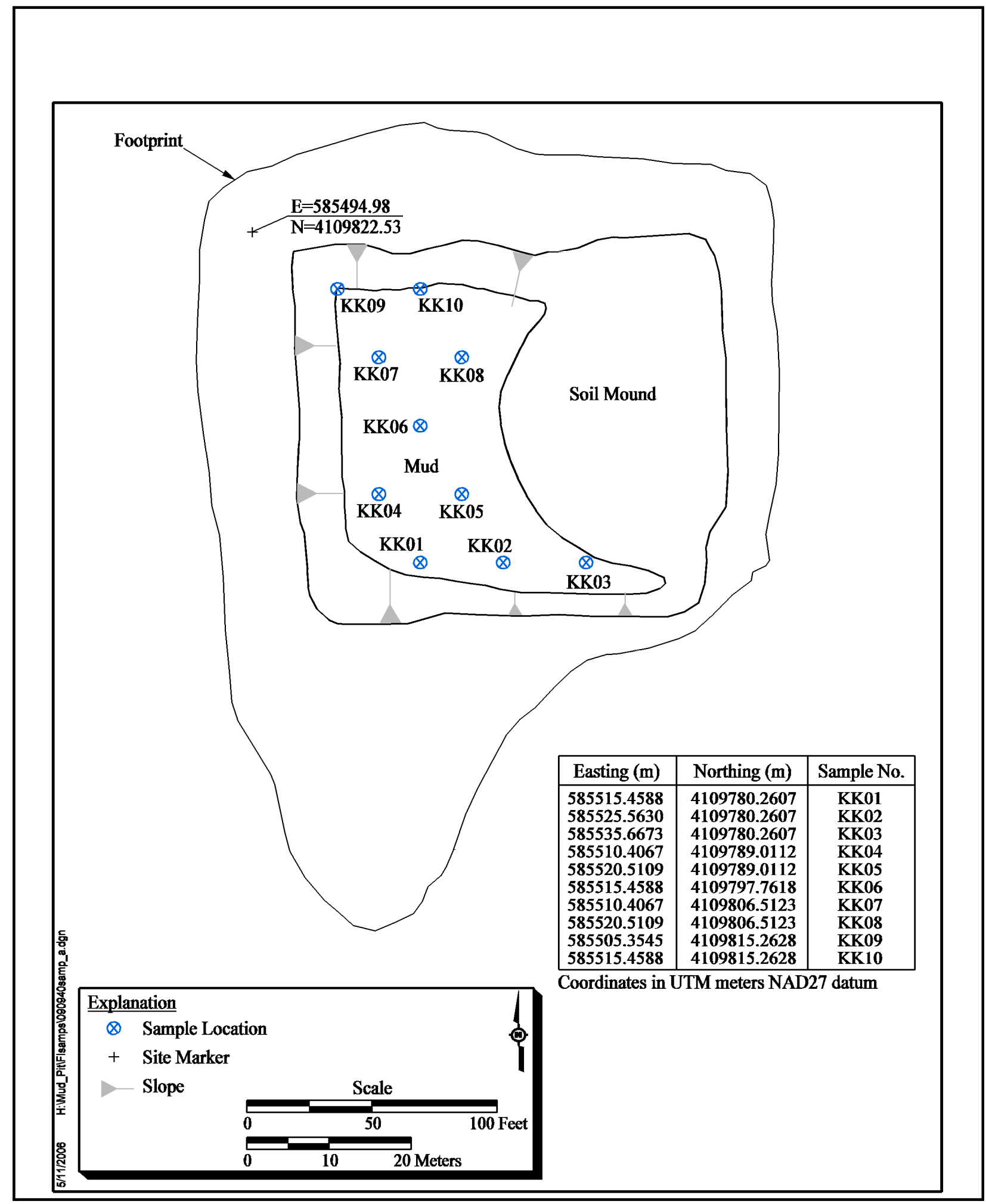

Figure C.1-37

CAS 09-09-40 Sample Locations 


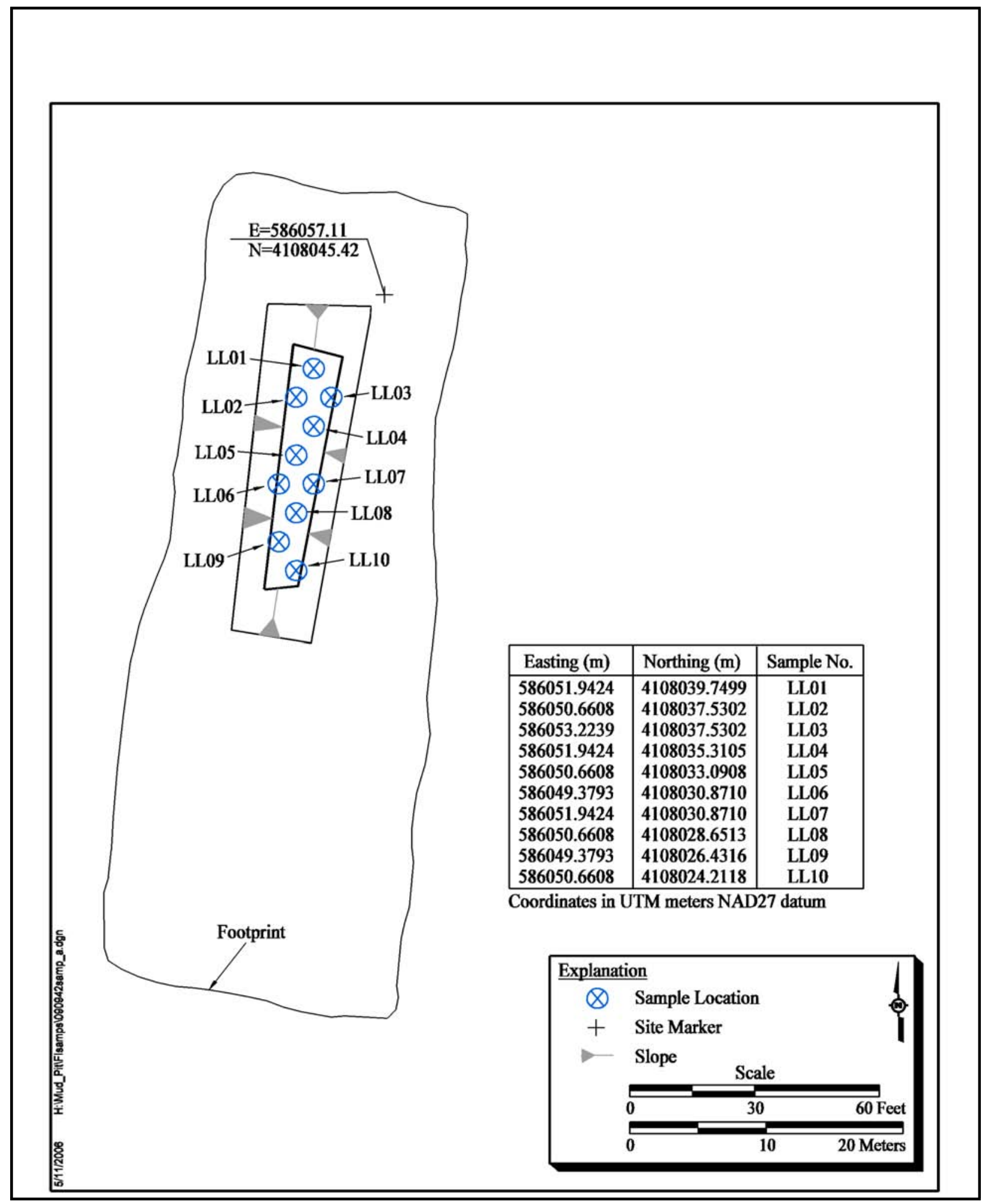

Figure C.1-38

CAS 09-09-42 Sample Locations 


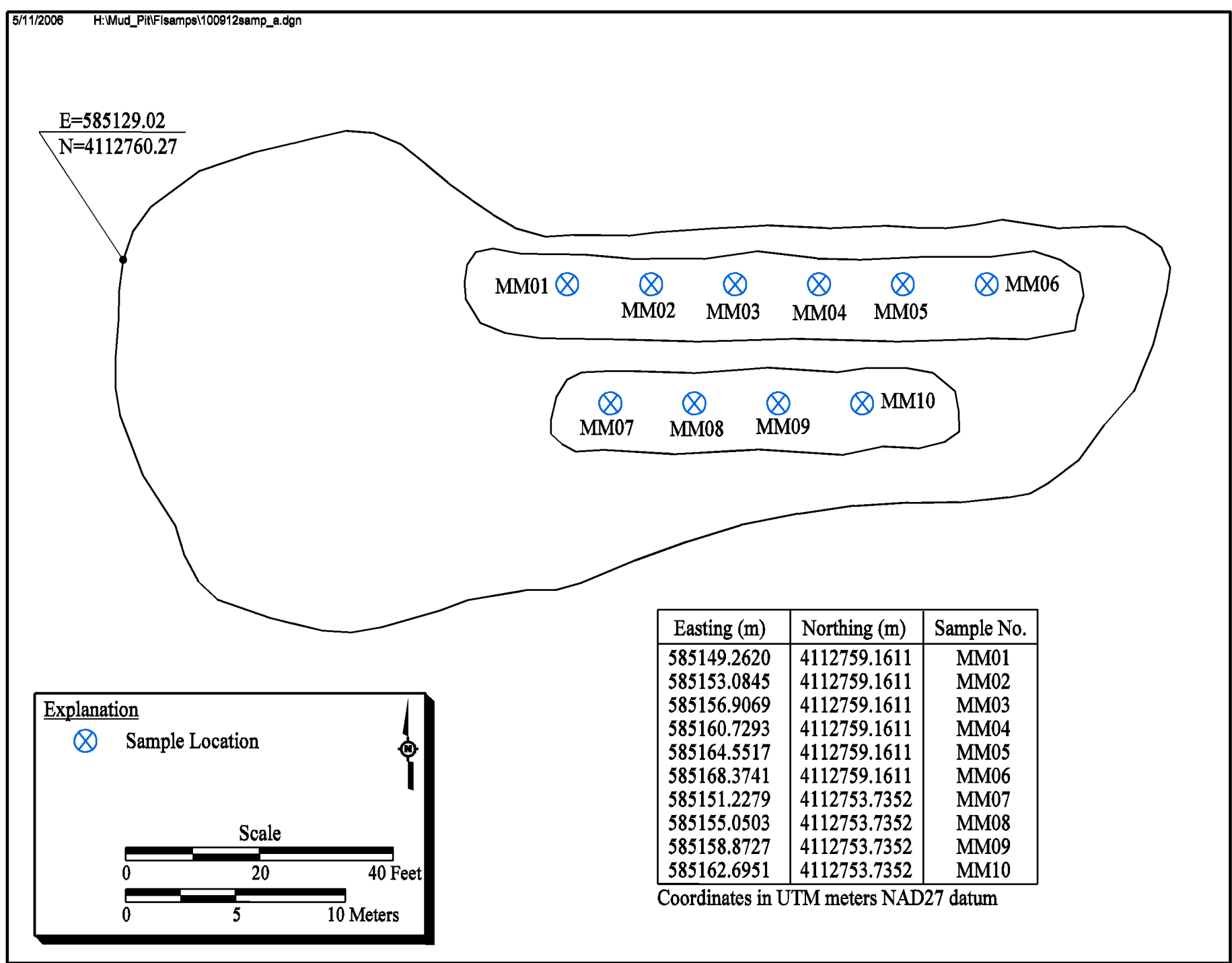

Figure C.1-39

CAS 10-09-12 Sample Locations

\section{Uncontrolled When Printed}




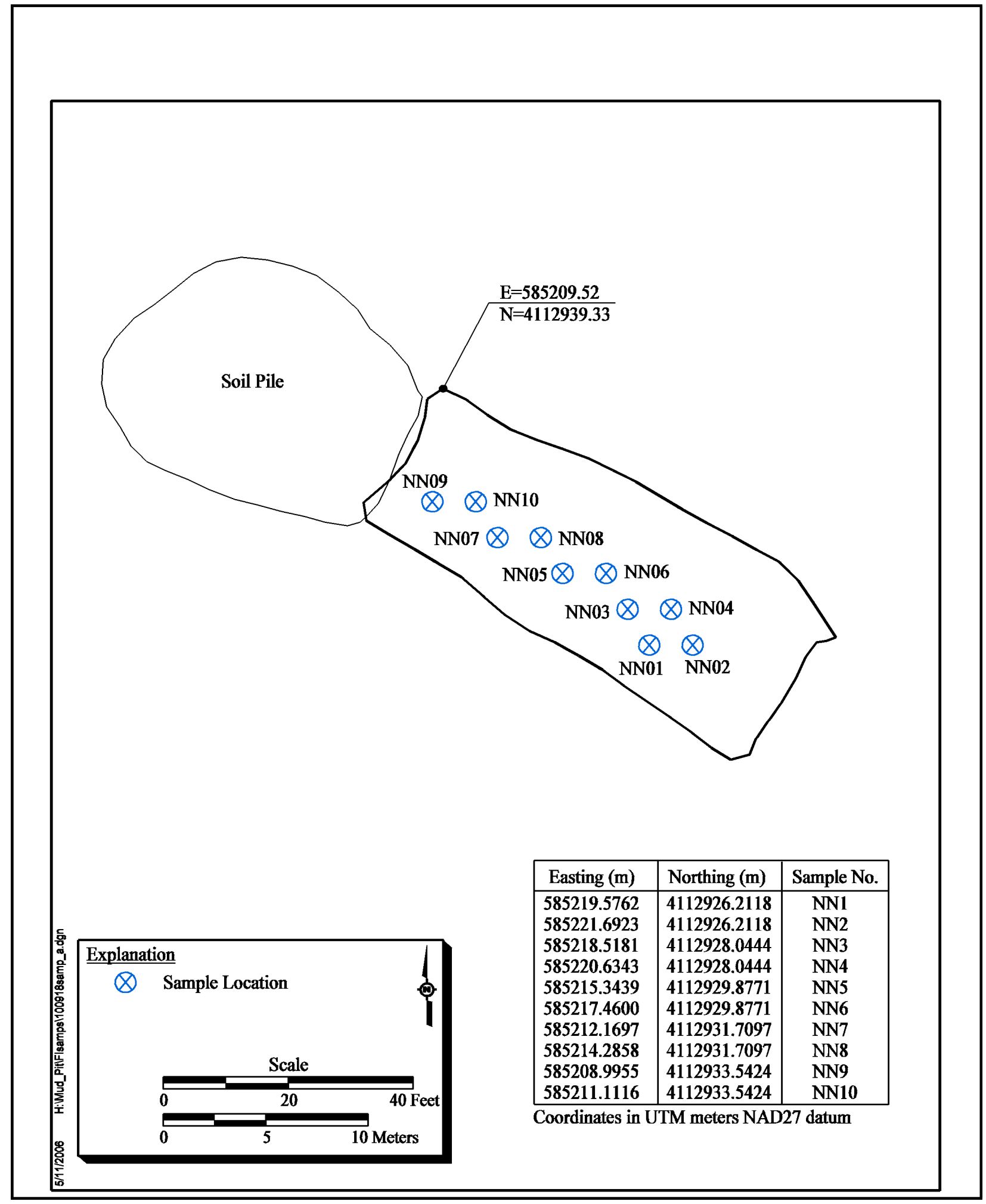

Figure C.1-40

CAS 10-09-18 Sample Locations 


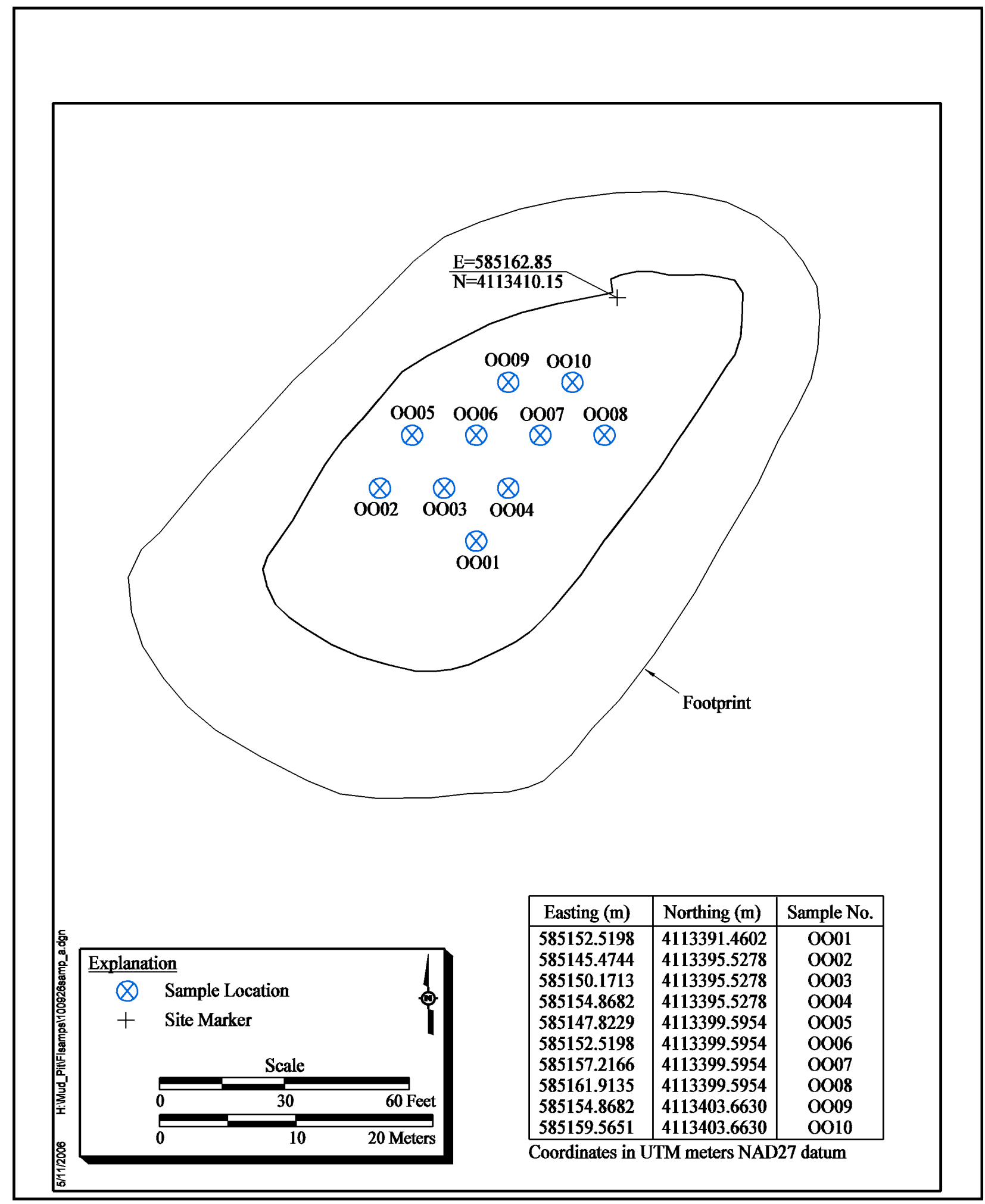

Figure C.1-41

CAS 10-09-26 Sample Locations 


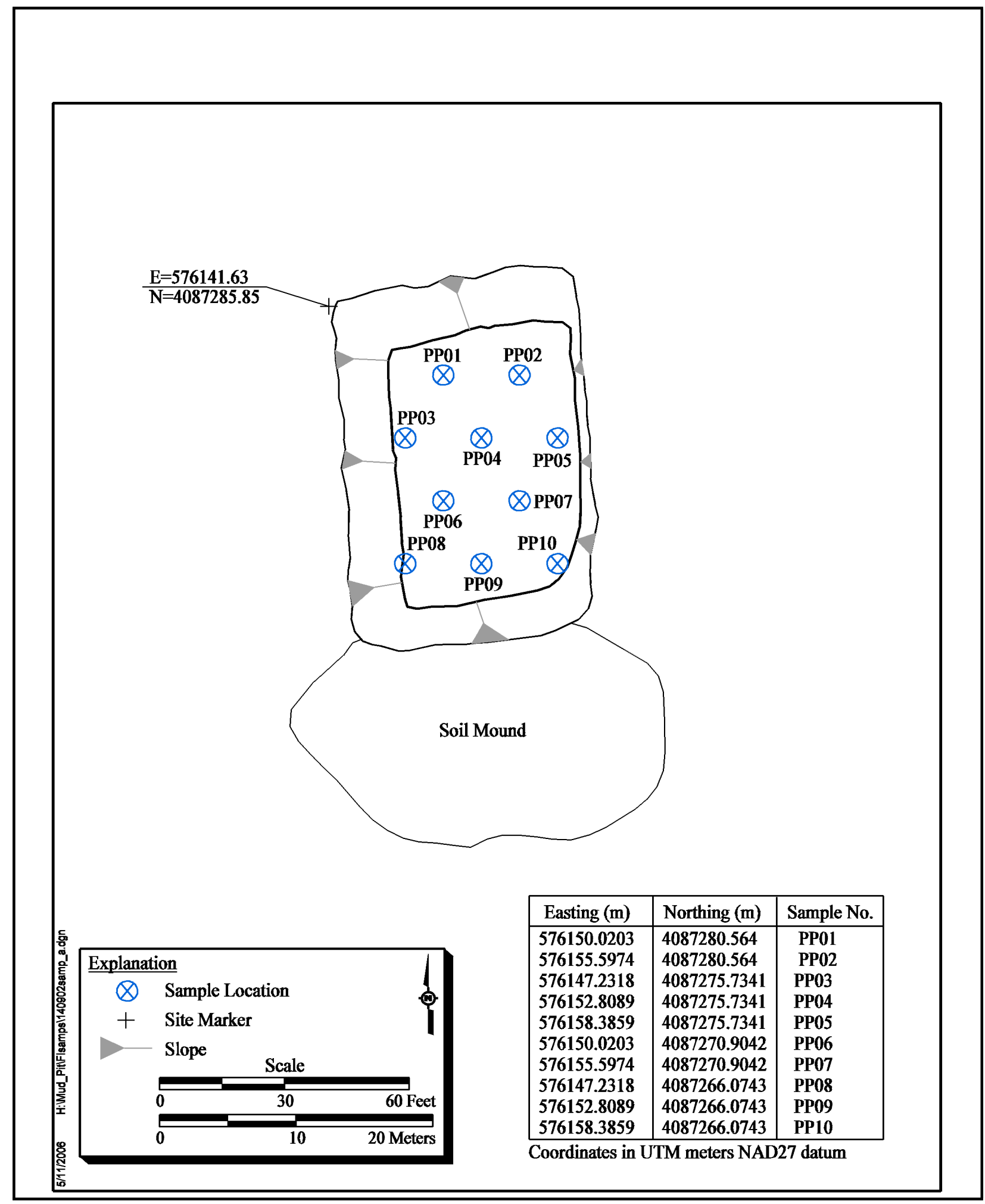

Figure C.1-42

CAS 14-09-02 Sample Locations 


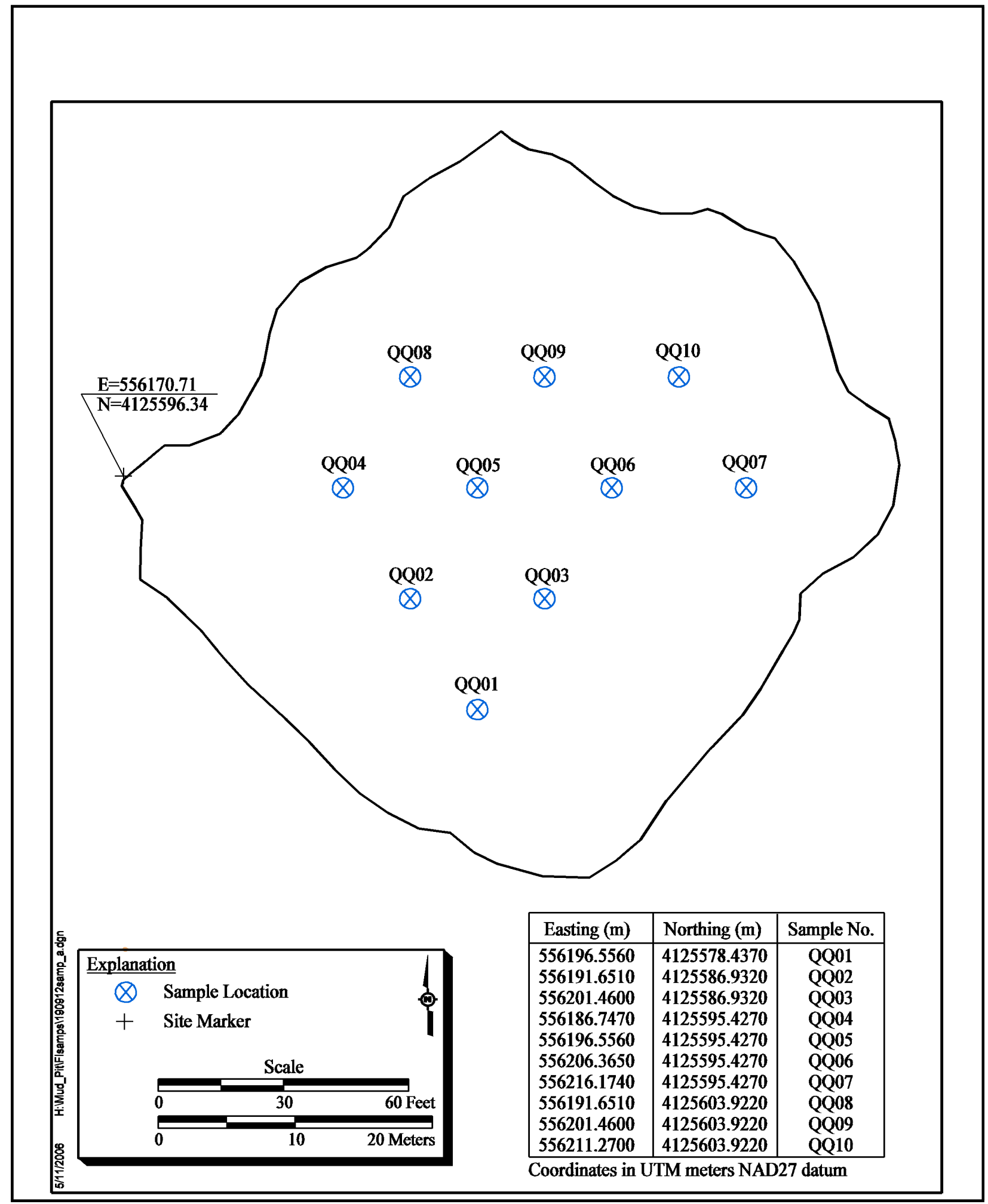

Figure C.1-43

CAS 19-09-12 Sample Locations 


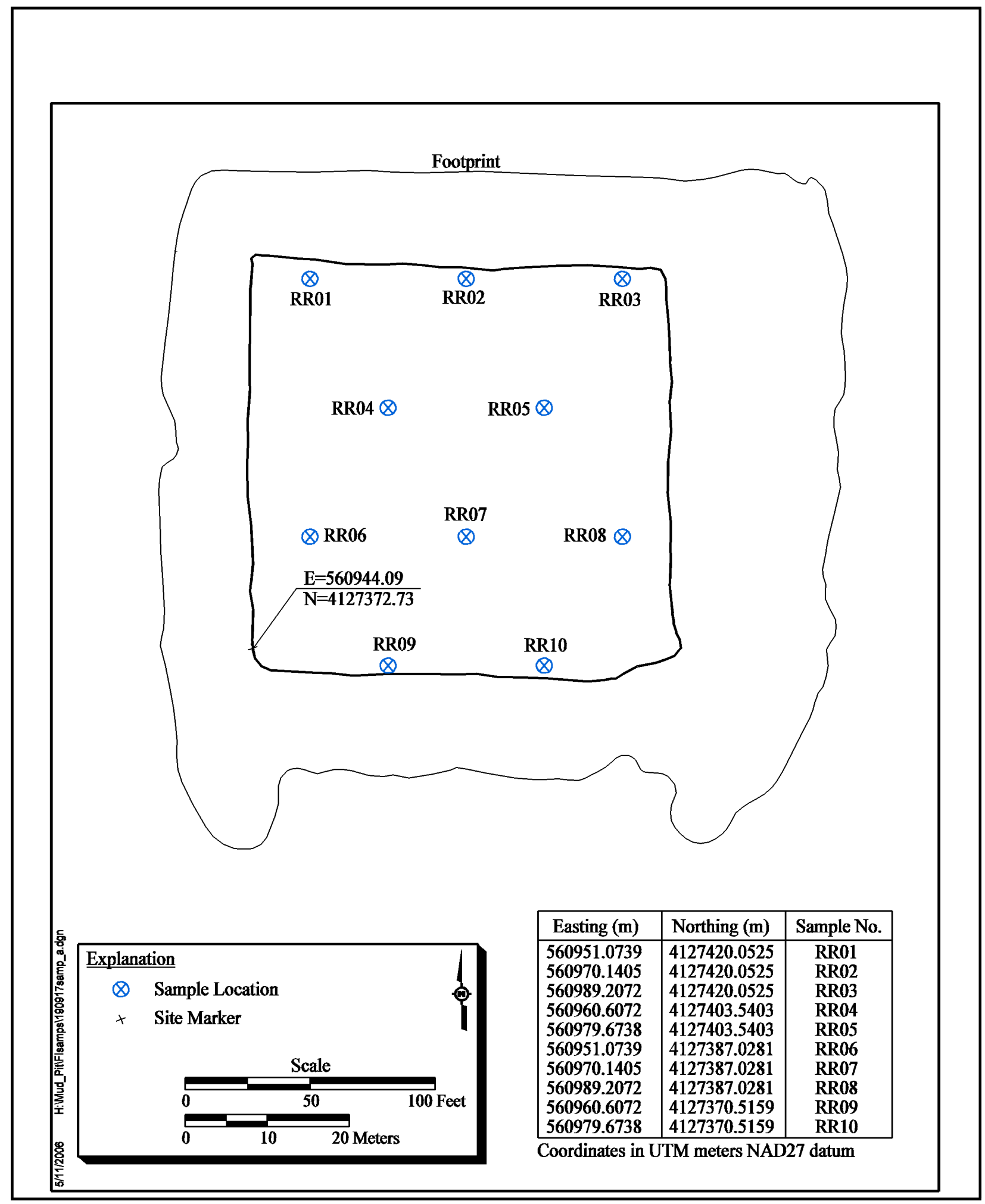

Figure C.1-44

CAS 19-09-17 Sample Locations 


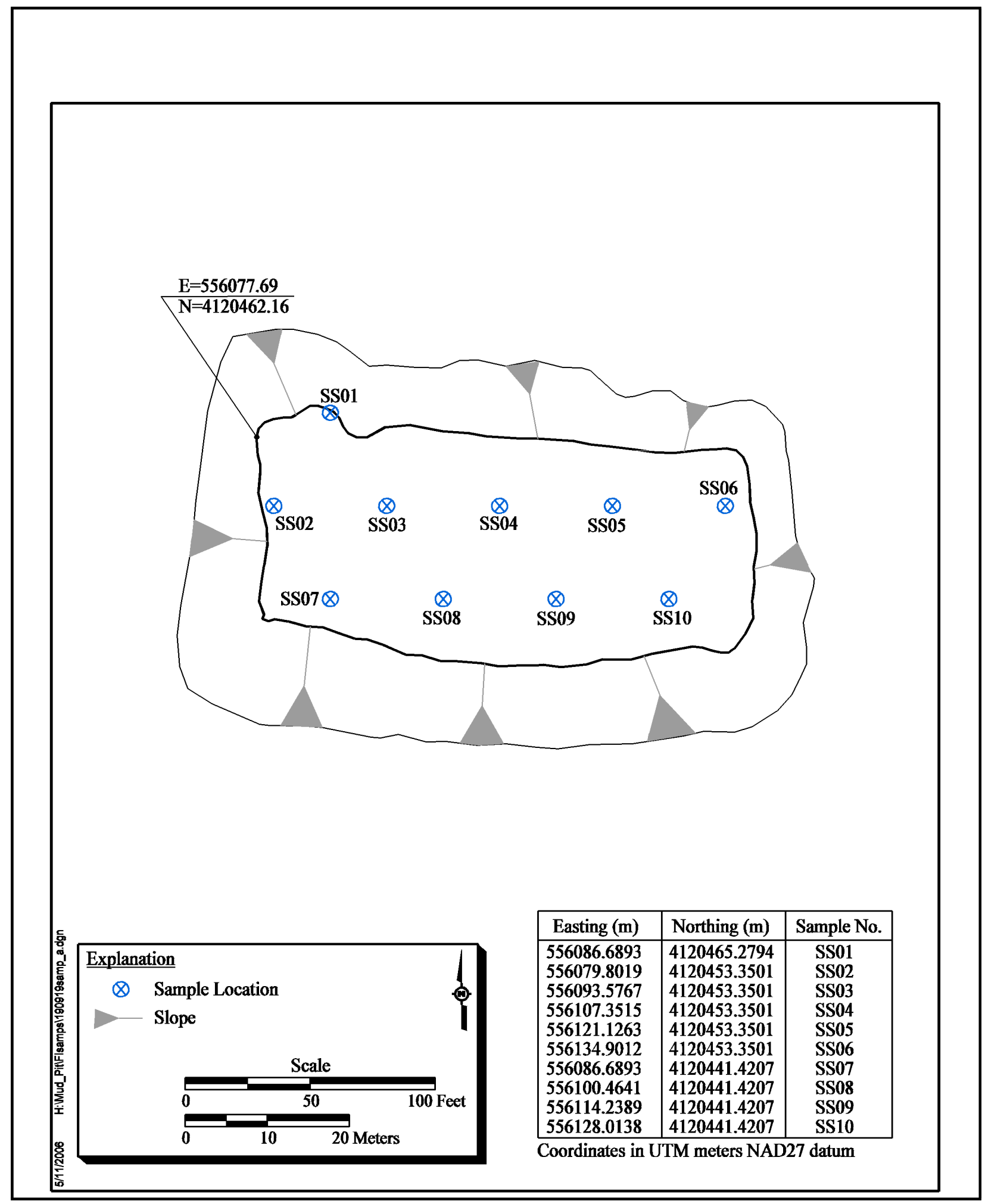

Figure C.1-45

CAS 19-09-19 Sample Locations 


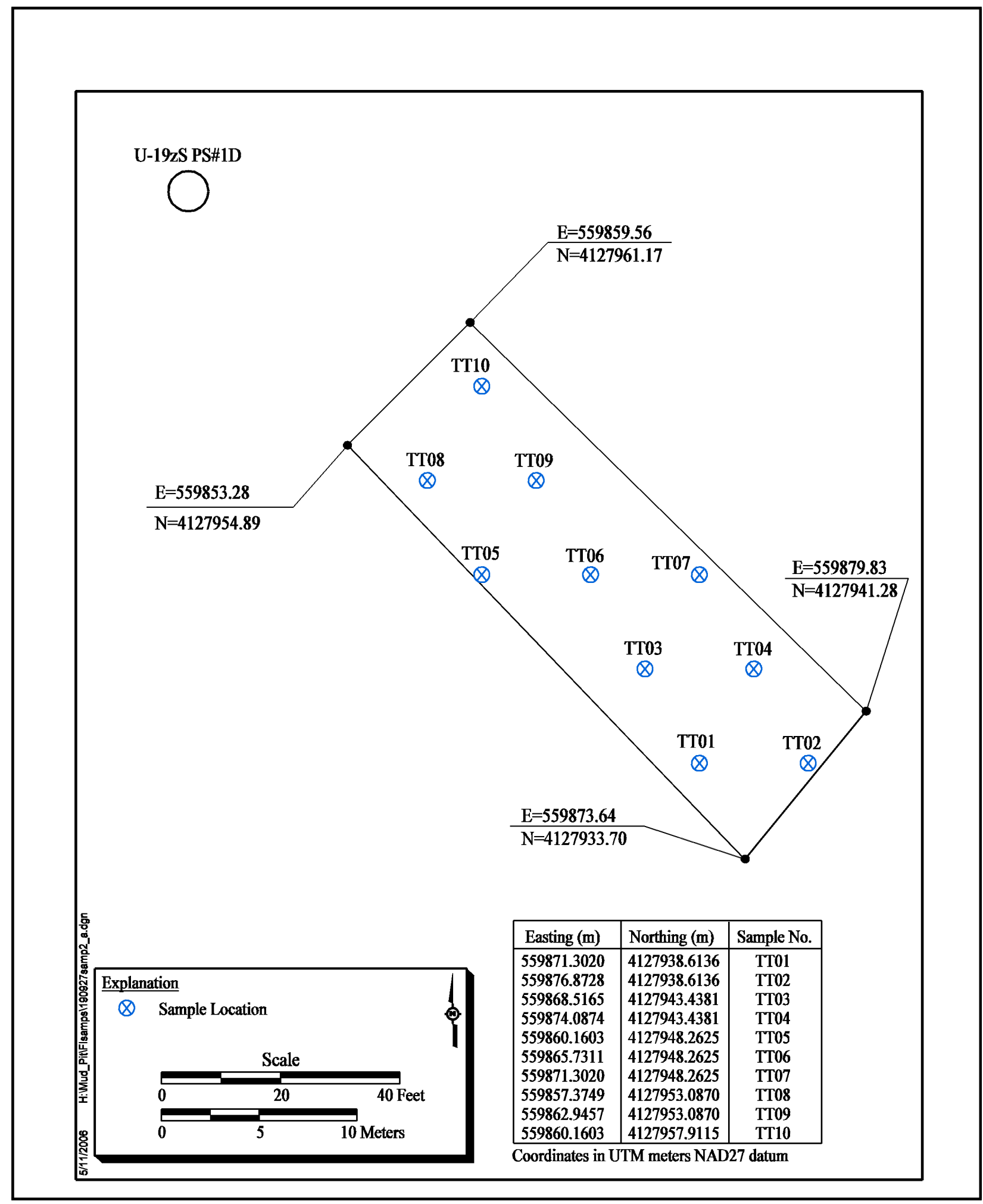

Figure C.1-46

CAS 19-09-27 Sample Locations 


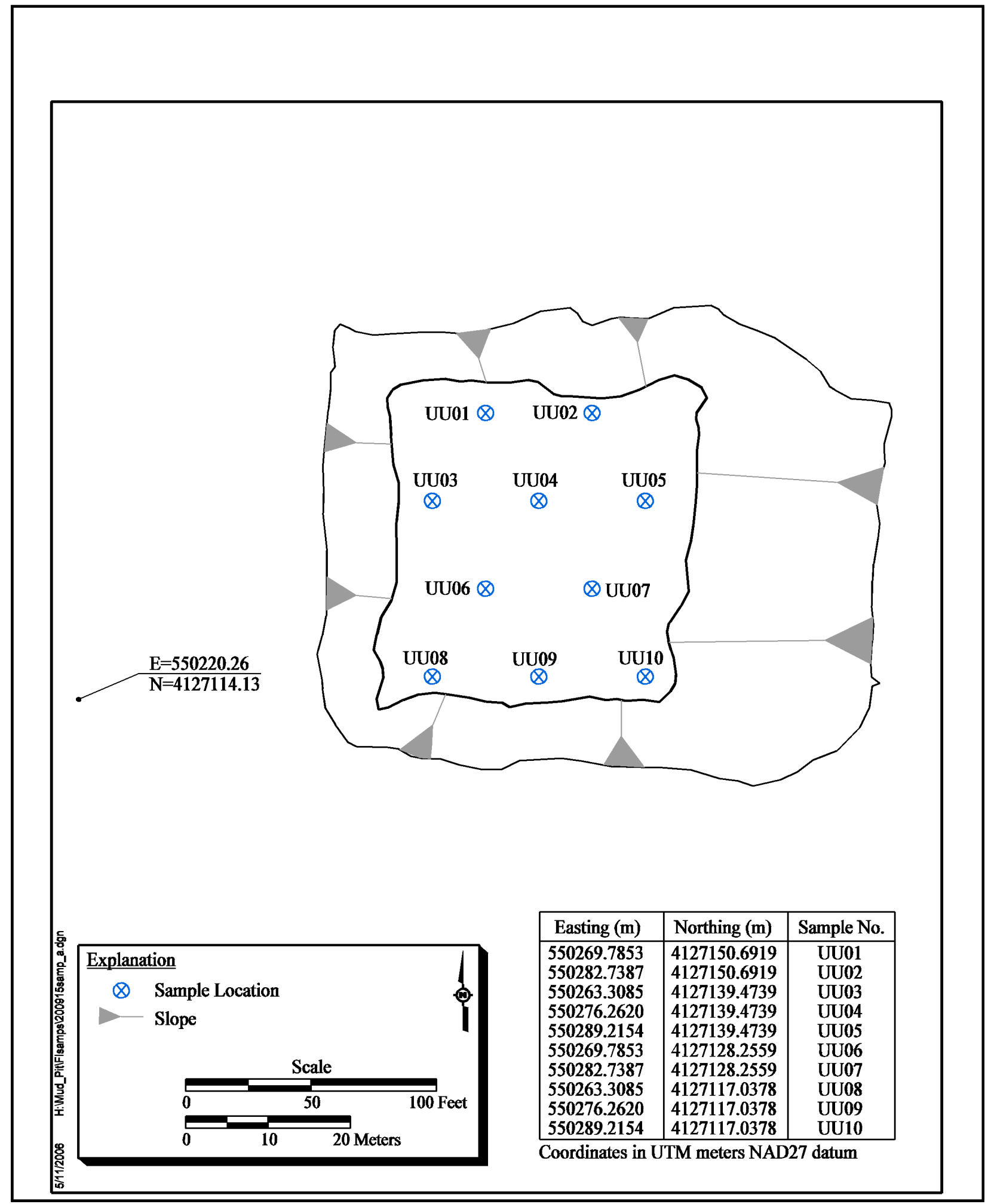

Figure C.1-47

CAS 20-09-15 Sample Locations 


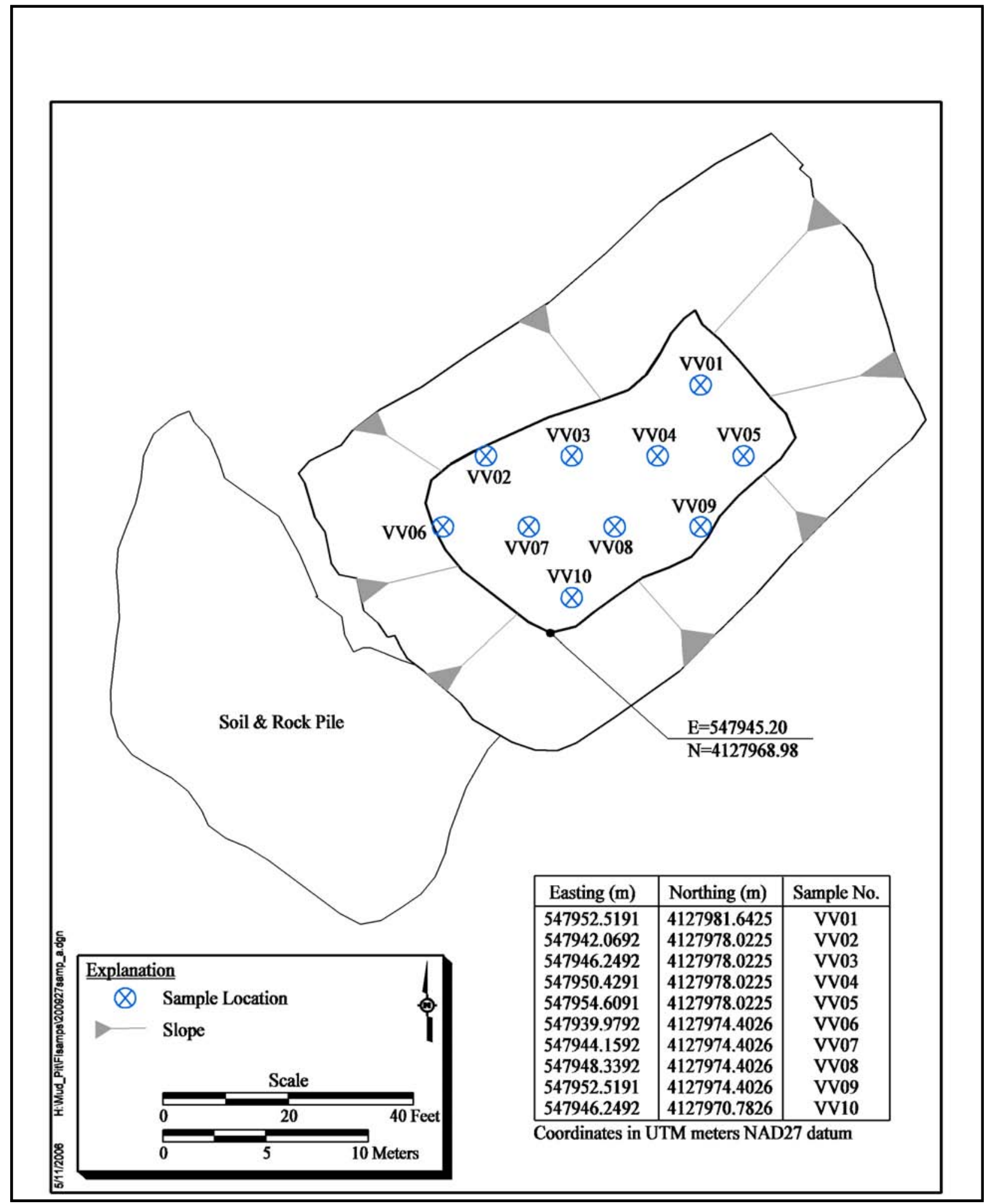

Figure C.1-48

CAS 20-09-27 Sample Locations 


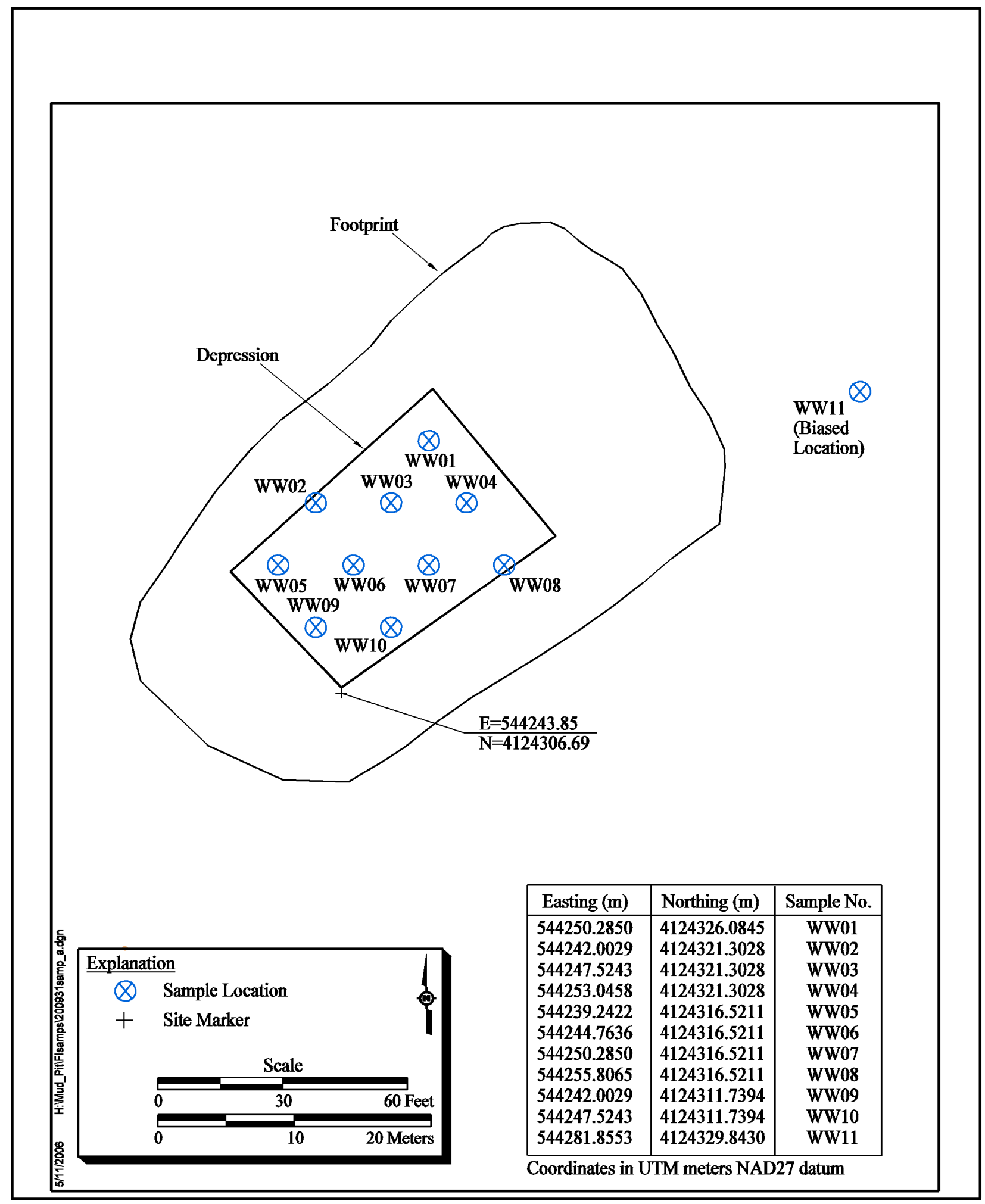

Figure C.1-49

CAS 20-09-31 Sample Locations 


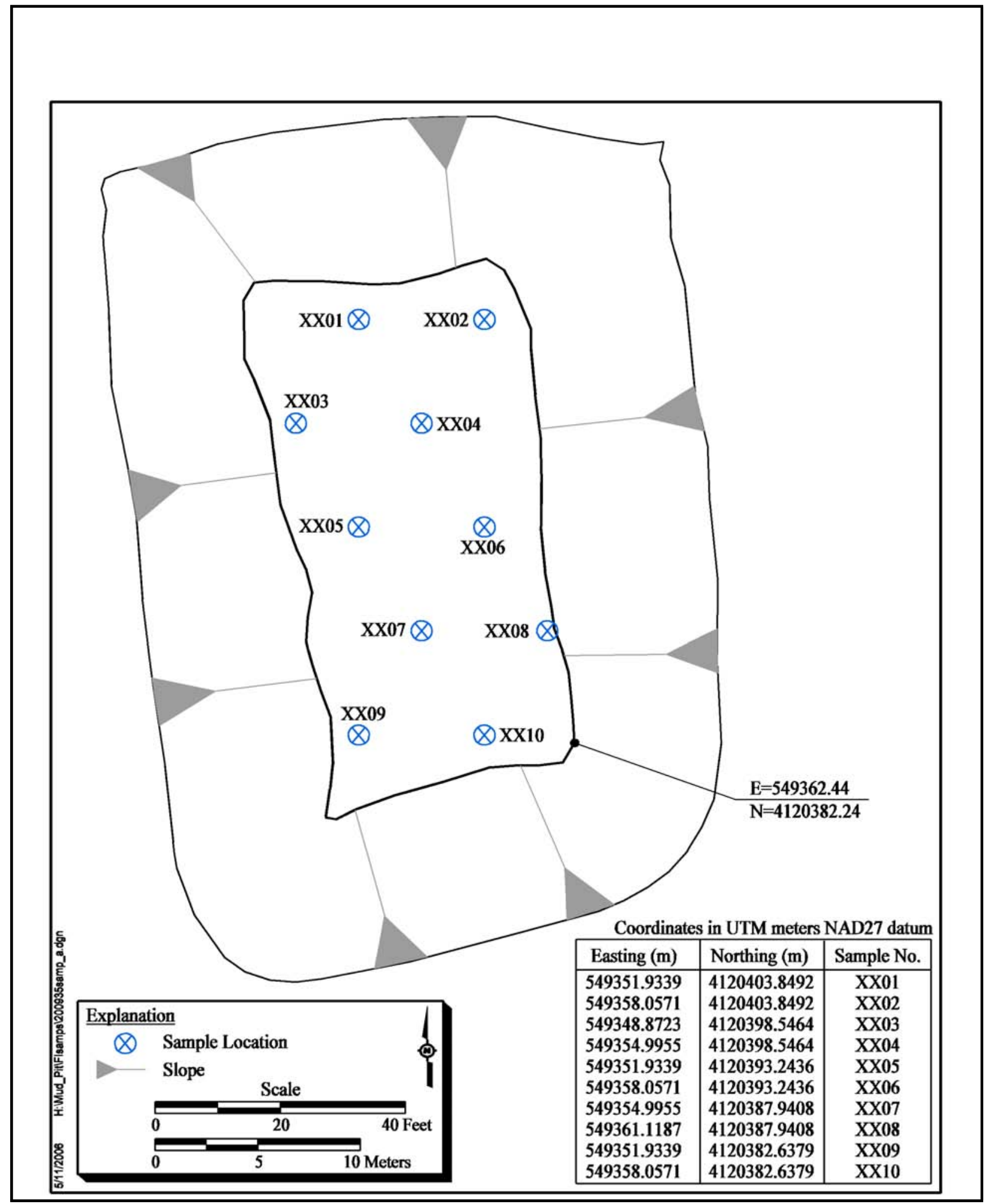

Figure C.1-50

CAS 20-09-35 Sample Locations 


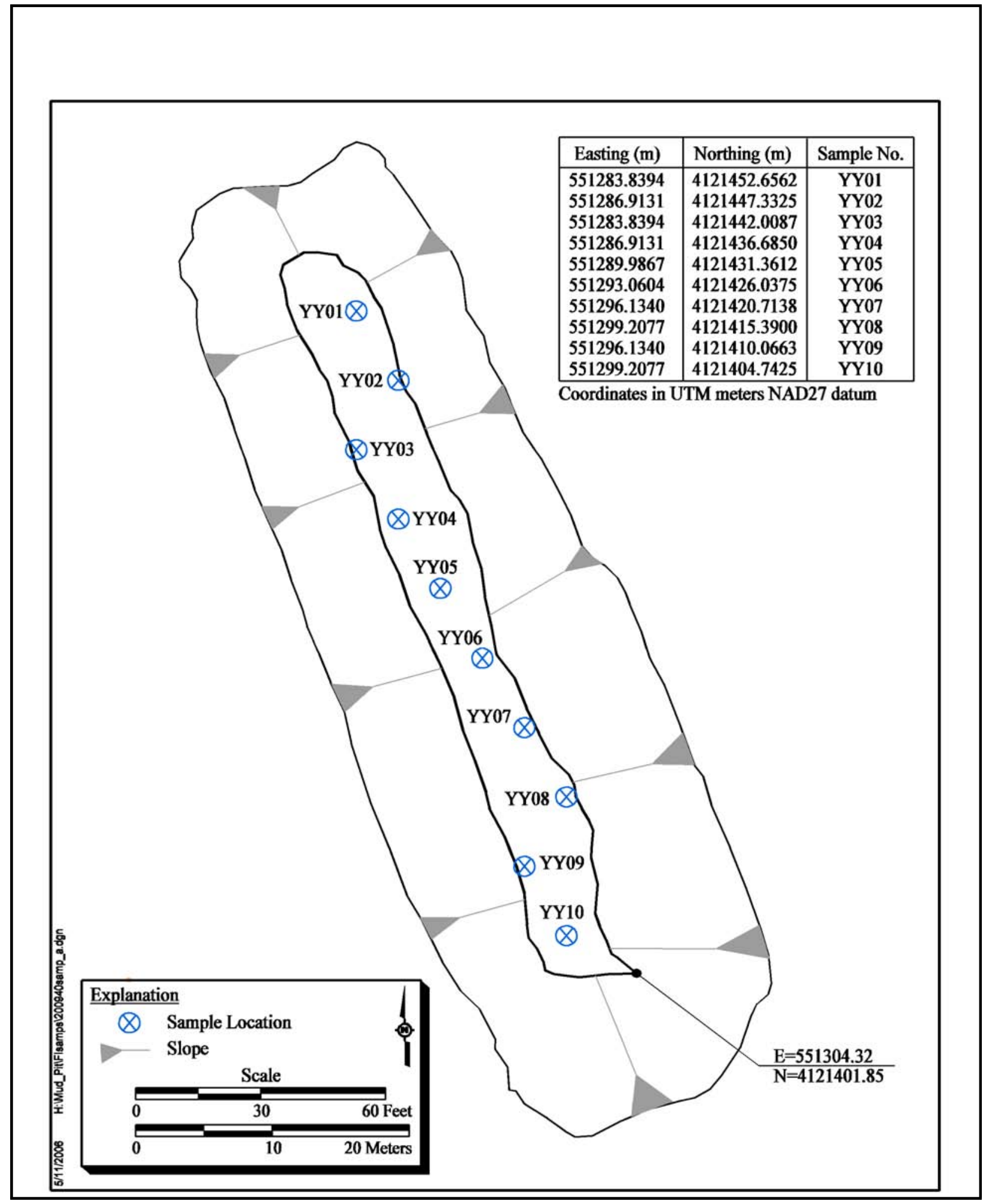

Figure C.1-51

CAS 20-09-40 Sample Locations 


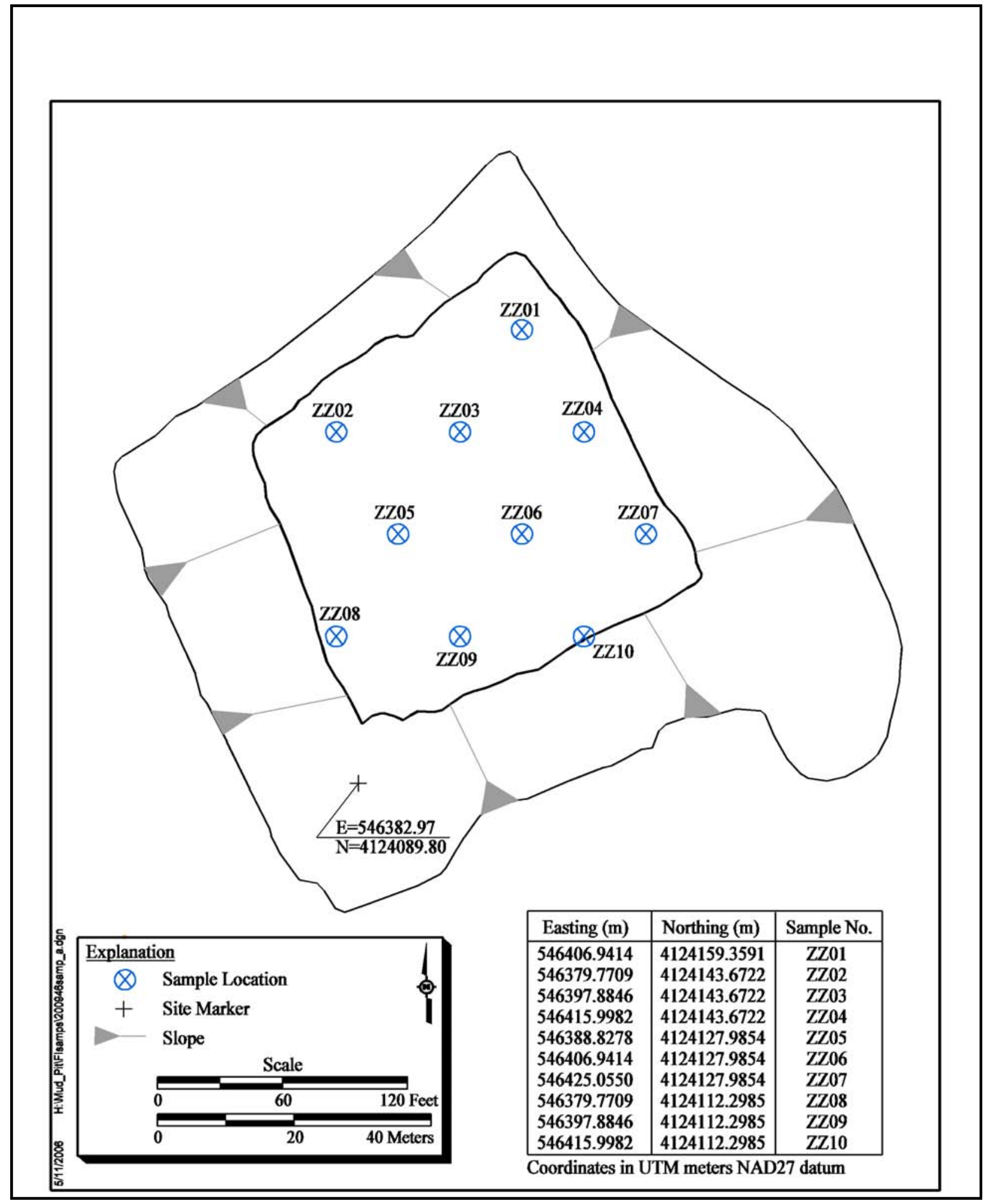

Figure C.1-52

CAS 20-09-46 Sample Locations 


\section{Appendix D}

\section{Confirmation Sampling Test Results for CAUs 530-535: Nevada Test Site Mud Pits, Nevada Test Site, Nevada}




\section{D.1.0 Introduction}

This appendix details the analytical results for CAUs 530-535. Both soil and aqueous samples were collected during the field activities of this closure investigation. Aqueous samples were collected for QA/QC purposes only.

\section{D.1.1 Soil Samples}

A minimum of 10 soil samples were collected from each CAS at locations configured in a triangular grid pattern with the location of the initial sample being randomly chosen (the coordinates of each sample location are provided in the site sketch drawings in Appendix C). Additional biased soil samples were taken in areas of obvious staining located either within or near the mud pit CAS. All soil samples were collected, screened for radiation (to protect worker health and safety), and analyzed for TPH-DRO. Both the MDCs and results above the MDCs are provided, because DQO Decision A utilized half the MDC for samples where TPH-DRO was not detected above the reporting limit. At CASs where radiation FSRs exceeded the FSLs, soil samples were also analyzed for isotopic U, isotopic Pu, gamma spectroscopy, and Sr-90. Soil samples submitted for SVOC analyses are also indicated in the following tables. Although a limited number of samples were submitted for VOC analysis, all the sample results were non-detect; therefore, results are not presented in this appendix.

\section{D.1.2 Aqueous Samples}

All aqueous samples were collected and analyzed for TPH-DRO. At CASs where radiation FSRs exceeded the FSLs, additional aqueous samples were collected and analyzed for isotopic U, isotopic $\mathrm{Pu}$, gamma spectroscopy, and Sr-90. Aqueous samples were used strictly for QA/QC purposes (i.e., equipment blanks and field blanks). 
Table D.1-1

Samples Collected at CAS 01-09-02, U-1e Mud Pit (2)

\begin{tabular}{||c|c|c|c|c|c||}
\hline $\begin{array}{c}\text { Sample } \\
\text { Location }\end{array}$ & $\begin{array}{c}\text { Sample } \\
\text { Number }\end{array}$ & $\begin{array}{c}\text { Depth } \\
\mathbf{f f t} \text { bgs) }\end{array}$ & Matrix & Purpose & Analyses \\
\hline \hline A01 & MPXA001 & $0.0-0.5$ & Soil & Environmental & Set 1 \\
\hline A02 & MPXA002 & $0.0-0.5$ & Soil & Environmental & Set 1 \\
\hline A03 & MPXA003 & $0.0-0.5$ & Soil & Environmental & Set 1 \\
\hline A04 & MPXA004 & $0.0-0.5$ & Soil & Environmental & Set 1 \\
\hline A05 & MPXA005 & $0.0-0.5$ & Soil & $\begin{array}{c}\text { Environmental, } \\
\text { MS/MSD }\end{array}$ & Set 1 \\
\hline A06 & MPXA006 & $0.0-0.5$ & Soil & Environmental & Set 1 \\
\hline A07 & MPXA007 & $0.0-0.5$ & Soil & Environmental & Set 1 \\
\hline A08 & MPXA008 & $0.0-0.5$ & Soil & Environmental & Set 1 \\
\hline A09 & MPXA009 & $0.0-0.5$ & Soil & Environmental & Set 1 \\
\hline \multirow{2}{*}{ A10 } & MPXA010 & $0.0-0.5$ & Soil & Environmental & Set 1 \\
\cline { 2 - 6 } & MPXA201 & $0.0-0.5$ & Soil & $\begin{array}{l}\text { Field Duplicate } \\
\text { of \#MPXA010 }\end{array}$ & Set 1 \\
\hline
\end{tabular}

Set 1 = TPH-DRO, gamma spectroscopy, isotopic uranium, isotopic plutonium, strontium-90

$\mathrm{ft}$ bgs = Feet below ground surface

MS/MSD = Matrix spike/matrix spike duplicate

TPH-DRO = Total petroleum hydrocarbons, diesel-range organics 
Table D.1-2

Soil Samples Results for TPH-DRO at CAS 01-09-02, U-1e Mud Pit (2)

\begin{tabular}{|c|c|c|c|c|}
\hline \multirow{2}{*}{$\begin{array}{c}\text { Sample } \\
\text { Location }\end{array}$} & \multirow{2}{*}{$\begin{array}{c}\text { Sample } \\
\text { Number }\end{array}$} & $\begin{array}{c}\text { Depth } \\
\text { ft bgs) }\end{array}$ & \multicolumn{2}{|c|}{ Contaminants of Potential Concern (mg/kg) } \\
\cline { 3 - 5 } & & & $5.4(\mathrm{U})$ & 5.4 \\
\hline \hline A01 & MPXA001 & $0.0-0.5$ & $5.7(\mathrm{U})$ & 5.7 \\
\hline A02 & MPXA002 & $0.0-0.5$ & $5.9(U)$ & 5.9 \\
\hline A03 & MPXA003 & $0.0-0.5$ & $5.5(U)$ & 5.5 \\
\hline A04 & MPXA004 & $0.0-0.5$ & $5.3(U)$ & 5.3 \\
\hline A05 & MPXA005 & $0.0-0.5$ & $5.9(U)$ & 5.9 \\
\hline A06 & MPXA006 & $0.0-0.5$ & $5.1(U)$ & 5.1 \\
\hline A07 & MPXA007 & $0.0-0.5$ & $5.8(U)$ & 5.8 \\
\hline A08 & MPXA008 & $0.0-0.5$ & $5.4(U)$ & 5.4 \\
\hline A09 & MPXA009 & $0.0-0.5$ & $5(U)$ & 5 \\
\hline \multirow{2}{*}{ A10 } & MPXA010 & $0.0-0.5$ & $5.3(U)$ & 5.3 \\
\cline { 3 - 5 } & MPXA201 & $0.0-0.5$ & & \\
\hline
\end{tabular}

$\mathrm{ft}$ bgs = Feet below ground surface

$\mathrm{mg} / \mathrm{kg}=$ Milligrams per kilogram

$\mathrm{U}=$ Compound was analyzed for, but not detected ("non-detect") 
Table D.1-3

Soil Sample Results for Gamma-Emitting Radionuclides Detected Above Minimum Detectable Concentration Limits at CAS 01-09-02, U-1e Mud Pit (2)

\begin{tabular}{|c|c|c|c|c|c|c|c|}
\hline \multirow[b]{2}{*}{$\begin{array}{l}\text { Sample } \\
\text { Location }\end{array}$} & \multirow[b]{2}{*}{$\begin{array}{l}\text { Sample } \\
\text { Number }\end{array}$} & \multirow[b]{2}{*}{$\begin{array}{l}\text { Depth } \\
\text { (ft bgs) }\end{array}$} & \multicolumn{5}{|c|}{ Contaminants of Potential Concern (pCi/g) } \\
\hline & & & 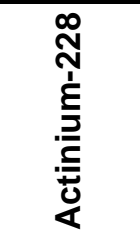 & 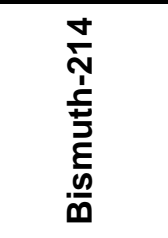 & 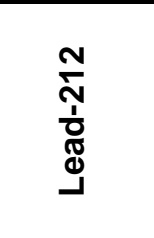 & 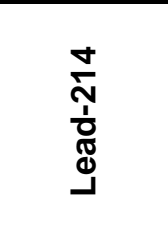 & 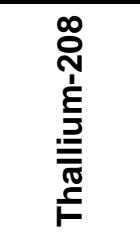 \\
\hline \multicolumn{3}{|c|}{ Final Action Levels ${ }^{a}$} & 5 & 5 & 5 & 5 & 5 \\
\hline \multicolumn{3}{|c|}{ Depths bgs (cm) } & $<15$ & $<15$ & $<15$ & $<15$ & $<15$ \\
\hline A01 & MPXA001 & $0.0-0.5$ & -- & -- & $1.43(\mathrm{~J})^{\mathrm{b}}$ & $0.82(G, J)$ & $0.67(\mathrm{G})$ \\
\hline A02 & MPXA002 & $0.0-0.5$ & -- & -- & $1.97(\mathrm{~J})^{\mathrm{b}}$ & $1.16(G, J)$ & $0.66(\mathrm{G})$ \\
\hline A03 & MPXA003 & $0.0-0.5$ & -- & -- & $1.73(\mathrm{~J})^{\mathrm{b}}$ & -- & $0.72(G)$ \\
\hline A04 & MPXA004 & $0.0-0.5$ & $2.28(\mathrm{G})$ & $1.01(\mathrm{G}, \mathrm{J})$ & $1.84(\mathrm{~J})^{\mathrm{b}}$ & $0.81(G, J)$ & $0.43(\mathrm{G})$ \\
\hline \multirow{2}{*}{ A05 } & MPXA005 & $0.0-0.5$ & 1.68 & $0.91(\mathrm{~J})$ & 1.32 & $1.17(\mathrm{~J})$ & 0.44 \\
\hline & MPXA201 & $0.0-0.5$ & -- & -- & 0.92 & $0.7(\mathrm{~J})$ & 0.48 \\
\hline A06 & MPXA006 & $0.0-0.5$ & $2.51(\mathrm{G})$ & -- & $1.72(\mathrm{~J})^{\mathrm{b}}$ & $1.28(G, J)$ & $0.64(G)$ \\
\hline A07 & MPXA007 & $0.0-0.5$ & $2.14(\mathrm{TI})$ & -- & 1.55 & $0.95(\mathrm{~J})$ & -- \\
\hline A08 & MPXA008 & $0.0-0.5$ & -- & -- & $1.38(\mathrm{~J})^{\mathrm{b}}$ & -- & $0.78(\mathrm{G})$ \\
\hline A09 & MPXA009 & $0.0-0.5$ & -- & $1.08(G, J)$ & $1.47(\mathrm{~J})^{\mathrm{b}}$ & $0.95(G, J)$ & $0.48(G)$ \\
\hline A10 & MPXA010 & $0.0-0.5$ & 1.48 & $0.87(\mathrm{~J})$ & 1.26 & $1(\mathrm{~J})$ & -- \\
\hline
\end{tabular}

aTaken from the generic guidelines for residual concentrations of actinium-228, bismuth-214, lead-212, lead-214, thallium-208, and thorium-232, as found in Chapter IV of DOE Order 5400.5, Change 2, "Radiation Protection of the Public and Environment." (DOE, 1993). The PALs for these isotopes is specified as $5 \mathrm{pCi} / \mathrm{g}$ averaged over the first $15 \mathrm{~cm}$ of soil and $15 \mathrm{pCi} / \mathrm{g}$ for deeper soils (DOE, 1993). For purposes of this document, $15 \mathrm{~cm}$ is assumed to be equivalent to $0.5 \mathrm{ft}$ ( 6 inches); therefore, $5 \mathrm{pCi} / \mathrm{g}$ represents the PALs for these radionuclides in the surface soil ( 0 to $0.5 \mathrm{ft}$ depth).

${ }^{b}$ Qualifier added to laboratory data; record accepted. Sample does not meet counting geometry requirements.

$\mathrm{cm}=$ Centimeter

$\mathrm{ft}$ bgs $=$ Feet below ground surface

$\mathrm{PAL}=$ Preliminary action level

$\mathrm{pCi} / \mathrm{g}=$ Picocuries per gram

$--=$ Not detected above minimum reporting limits

$<=$ Less than

$\mathrm{G}=$ Sample density differs by more than 15 percent of laboratory control sample density.

$\mathrm{J}=$ Estimated value.

$\mathrm{TI}=$ Nuclide identification is tentative. 
Table D.1-4

Soil Sample Results for Isotopic Uranium Detected Above Minimum Detectable Concentration Limits at CAS 01-09-02, U-1e Mud Pit (2)

\begin{tabular}{||c|c|c|c|c|c||}
\hline \multirow{2}{*}{$\begin{array}{c}\text { Sample } \\
\text { Location }\end{array}$} & \multirow{2}{*}{$\begin{array}{c}\text { Sample } \\
\text { Number }\end{array}$} & \multirow{2}{*}{$\begin{array}{c}\text { Depth } \\
\text { ft bgs) }\end{array}$} & \multicolumn{3}{c|}{ Contaminants of Potential Concern (pCi/g) } \\
\cline { 5 - 6 } & & & Uranium-234 & Uranium-235 & Uranium-238 \\
\hline \multicolumn{3}{|c|}{ Final Action Levels ${ }^{\mathrm{a}}$} & $\mathbf{1 4 3}$ & $\mathbf{1 7 . 5}$ & 105 \\
\hline \hline A01 & MPXA001 & $0.0-0.5$ & 1.27 & 0.084 & 1.3 \\
\hline A02 & MPXA002 & $0.0-0.5$ & 1.28 & -- & 1.32 \\
\hline A03 & MPXA003 & $0.0-0.5$ & 1.14 & 0.066 & 1.31 \\
\hline A04 & MPXA004 & $0.0-0.5$ & 1.01 & 0.068 & 1.28 \\
\hline \multirow{2}{*}{ A05 } & MPXA005 & $0.0-0.5$ & 1.04 & 0.059 & 1.09 \\
\cline { 4 - 6 } & MPXA201 & $0.0-0.5$ & 0.97 & 0.060 & 1.02 \\
\hline A06 & MPXA006 & $0.0-0.5$ & 1.11 & 0.074 & 1.22 \\
\hline A07 & MPXA007 & $0.0-0.5$ & 0.97 & -- & 0.97 \\
\hline A08 & MPXA008 & $0.0-0.5$ & 1.26 & 0.068 & 1.4 \\
\hline A09 & MPXA009 & $0.0-0.5$ & 1.14 & 0.089 & 1.33 \\
\hline A10 & MPXA010 & $0.0-0.5$ & 0.95 & -- & 1.03 \\
\hline
\end{tabular}

${ }^{a}$ Taken from the construction, commercial, industrial land use scenario in Table 2.1 of the NCRP Report No. 129, Recommended Screening Limits for Contaminated Surface Soil and Review Factors Relevant to Site-Specific Studies (NCRP, 1999). The values provided in this source document were scaled to a $25-\mathrm{mrem} / \mathrm{yr}$ dose.

$\mathrm{ft}$ bgs $=$ Feet below ground surface

$\mathrm{mrem} / \mathrm{yr}=$ Millirem per year

$\mathrm{pCi} / \mathrm{g}=$ Picocuries per gram

-- = Not detected above minimum reporting limits 
Table D.1-5

Samples Collected at CAS 01-09-04, UE-1L Mud Pit (1)

\begin{tabular}{|c|c|c|c|c|c|}
\hline $\begin{array}{l}\text { Sample } \\
\text { Location }\end{array}$ & $\begin{array}{l}\text { Sample } \\
\text { Number }\end{array}$ & $\begin{array}{l}\text { Depth } \\
\text { (ft bgs) }\end{array}$ & Matrix & Purpose & Analyses \\
\hline B01 & MPXB001 & $0.0-0.5$ & Soil & Environmental & TPH-DRO \\
\hline B02 & MPXB002 & $0.0-0.5$ & Soil & Environmental & TPH-DRO \\
\hline B03 & MPXB003 & $0.0-0.5$ & Soil & Environmental & TPH-DRO \\
\hline \multirow[b]{2}{*}{ B04 } & MPXB004 & $0.0-0.5$ & Soil & Environmental & TPH-DRO \\
\hline & MPXB201 & $0.0-0.5$ & Soil & $\begin{array}{c}\text { Field Duplicate } \\
\text { of \#MPXB004 }\end{array}$ & TPH-DRO \\
\hline B05 & MPXB005 & $0.0-0.5$ & Soil & $\begin{array}{c}\text { Environmental, } \\
\text { MS/MSD }\end{array}$ & TPH-DRO \\
\hline B06 & MPXB006 & $0.0-0.5$ & Soil & Environmental & TPH-DRO \\
\hline B07 & MPXB007 & $0.0-0.5$ & Soil & Environmental & TPH-DRO \\
\hline B08 & MPXB008 & $0.0-0.5$ & Soil & Environmental & TPH-DRO \\
\hline B09 & MPXB009 & $0.0-0.5$ & Soil & Environmental & TPH-DRO \\
\hline B10 & MPXB010 & $0.0-0.5$ & Soil & Environmental & TPH-DRO \\
\hline B11 & MPXB301 & $0.0-0.5$ & Soil & Environmental & Set 1 \\
\hline N/A & MPXB401 & N/A & Water & Field Blank & TPH-DRO \\
\hline
\end{tabular}

Set 1 = TPH-DRO, gamma spectroscopy, isotopic uranium, isotopic plutonium, strontium-90

$\mathrm{ft}$ bgs = Feet below ground surface

MS/MSD = Matrix spike/matrix spike duplicate

N/A = Not applicable

TPH-DRO = Total petroleum hydrocarbons, diesel-range organics 
Table D.1-6

Soil Sample Results for TPH-DRO at CAS 01-09-04, UE-1L Mud Pit (1)

\begin{tabular}{|c|c|c|c|c|}
\hline \multirow{2}{*}{$\begin{array}{l}\text { Sample } \\
\text { Location }\end{array}$} & \multirow{2}{*}{$\begin{array}{l}\text { Sample } \\
\text { Number }\end{array}$} & \multirow{2}{*}{$\begin{array}{l}\text { Depth } \\
\text { (ft bgs) }\end{array}$} & \multicolumn{2}{|c|}{ Contaminants of Potential Concern $(\mathrm{mg} / \mathrm{kg})$} \\
\hline & & & Result & Detection Limit \\
\hline B01 & MPXB001 & $0.0-0.5$ & $5.3(U)$ & 5.3 \\
\hline B02 & MPXB002 & $0.0-0.5$ & $5.4(U)$ & 5.4 \\
\hline B03 & MPXB003 & $0.0-0.5$ & $5.5(U)$ & 5.5 \\
\hline \multirow{2}{*}{ B04 } & MPXB004 & $0.0-0.5$ & $5.5(U)$ & 5.5 \\
\hline & MPXB201 & $0.0-0.5$ & $5.5(\cup)$ & 5.5 \\
\hline B05 & MPXB005 & $0.0-0.5$ & $5.5(U)$ & 5.5 \\
\hline B06 & MPXB006 & $0.0-0.5$ & $6.4(U)$ & 6.4 \\
\hline B07 & MPXB007 & $0.0-0.5$ & $5.9(U)$ & 5.9 \\
\hline B08 & MPXB008 & $0.0-0.5$ & $6.2(U)$ & 6.2 \\
\hline B09 & MPXB009 & $0.0-0.5$ & $5.8(U)$ & 5.8 \\
\hline B10 & MPXB010 & $0.0-0.5$ & $6(U)$ & 6 \\
\hline B11 & MPXВ301 & $0.0-0.5$ & $5.1(U)$ & 5.1 \\
\hline
\end{tabular}

$\mathrm{ft}$ bgs = Feet below ground surface

$\mathrm{mg} / \mathrm{kg}=$ Milligrams per kilogram

$\mathrm{U}=$ Compound was analyzed for, but not detected ("non-detect"). 
Table D.1-7

Soil Sample Results for Gamma-Emitting Radionuclides Detected Above
Minimum Detectable Concentration Limits at CAS 01-09-04, UE-1L Mud Pit (1)

\begin{tabular}{||c|c|c|c|c|c|c||}
\hline \multirow{2}{*}{$\begin{array}{c}\text { Sample } \\
\text { Location }\end{array}$} & \multirow{2}{*}{$\begin{array}{c}\text { Sample } \\
\text { Number }\end{array}$} & $\begin{array}{c}\text { Depth } \\
\text { (ft bgs) }\end{array}$ & \multicolumn{3}{c|}{ Contaminants of Potential Concern (pCi/g) } \\
\cline { 4 - 7 } & & Actinium-228 & Bismuth-214 & Lead-212 & Lead-214 \\
\hline \multicolumn{3}{|c|}{ Final Action Levels } \\
\end{tabular}

aTaken from the generic guidelines for residual concentrations of actinium-228, bismuth-214, lead-212, lead-214, thallium-208, and thorium-232, as found in Chapter IV of DOE Order 5400.5, Change 2, "Radiation Protection of the Public and Environment."

(DOE, 1993). The PALs for these isotopes is specified as $5 \mathrm{pCi} / \mathrm{g}$ averaged over the first $15 \mathrm{~cm}$ of soil and $15 \mathrm{pCi} / \mathrm{g}$ for deeper soils (DOE, 1993). For purposes of this document, $15 \mathrm{~cm}$ is assumed to be equivalent to $0.5 \mathrm{ft}$ ( 6 inches); therefore, 5 pCi/g represents the PALs for these radionuclides in the surface soil ( 0 to $0.5 \mathrm{ft}$ depth).

$\mathrm{cm}=$ Centimeter

$\mathrm{ft}$ bgs $=$ Feet below ground surface

$\mathrm{PAL}=$ Preliminary action level

$\mathrm{pCi} / \mathrm{g}=$ Picocuries per gram

$<=$ Less than

$\mathrm{J}=$ Estimated value.

Table D.1-8

Soil Sample Results for Isotopic Uranium Detected Above

Minimum Detectable Concentration Limits at CAS 01-09-04, UE-1L Mud Pit (1)

\begin{tabular}{|c|c|c|c|c|c||}
\hline \multirow{2}{*}{$\begin{array}{c}\text { Sample } \\
\text { Location }\end{array}$} & \multirow{2}{*}{$\begin{array}{c}\text { Sample } \\
\text { Number }\end{array}$} & \multirow{2}{*}{$\begin{array}{c}\text { Depth } \\
\text { (ft bgs) }\end{array}$} & \multicolumn{3}{c|}{ Contaminants of Potential Concern (pCi/g) } \\
\cline { 4 - 6 } & & & Uranium-234 & Uranium-235 & Uranium-238 \\
\hline \multicolumn{3}{|c|}{ Final Action Levels } & 143 & 17.5 & 105 \\
\hline \hline B11 & MPXB301 & $0.0-0.5$ & 1.18 & 0.075 & 1.29 \\
\hline
\end{tabular}

${ }^{a}$ Taken from the construction, commercial, industrial land use scenario in Table 2.1 of the NCRP Report No. 129, Recommended Screening Limits for Contaminated Surface Soil and Review Factors Relevant to Site-Specific Studies (NCRP, 1999). The values provided in this source document were scaled to a $25-\mathrm{mrem} / \mathrm{yr}$ dose.

$\mathrm{ft}$ bgs = Feet below ground surface

$\mathrm{mrem} / \mathrm{yr}=$ Millirem per year

$\mathrm{pCi} / \mathrm{g}=$ Picocuries per gram 
Table D.1-9

Samples Collected at CAS 02-09-03, U-2dc \#4 PS \#1A Covered Mud Pit (1)

\begin{tabular}{|c|c|c|c|c|c|}
\hline $\begin{array}{c}\text { Sample } \\
\text { Location }\end{array}$ & $\begin{array}{l}\text { Sample } \\
\text { Number }\end{array}$ & $\begin{array}{c}\text { Depth } \\
\text { (ft bgs) }\end{array}$ & Matrix & Purpose & Analyses \\
\hline \multirow{2}{*}{ C01 } & MPXC001 & $2.0-2.5$ & Soil & Environmental & TPH-DRO \\
\hline & MPXC001A & $2.5-3.0$ & Soil & Environmental & TPH-DRO \\
\hline \multirow{2}{*}{$\mathrm{C} 02$} & MPXC002 & $2.0-2.5$ & Soil & Environmental & TPH-DRO \\
\hline & MPXC002A & $2.0-2.5$ & Soil & Environmental & TPH-DRO \\
\hline \multirow{3}{*}{$\mathrm{CO3}$} & MPXC003 & $4.5-5.0$ & Soil & Environmental & TPH-DRO \\
\hline & MPXC201 & $4.5-5.0$ & Soil & $\begin{array}{l}\text { Field Duplicate } \\
\text { of \#MPXC003 }\end{array}$ & TPH-DRO \\
\hline & MPXC003A & $4.0-4.5$ & Soil & Environmental & TPH-DRO \\
\hline \multirow[t]{2}{*}{$\mathrm{CO4}$} & MPXC004 & $3.0-3.5$ & Soil & $\begin{array}{c}\text { Environmental, } \\
\text { MS/MSD }\end{array}$ & TPH-DRO \\
\hline & MPXC004A & $3.5-4.0$ & Soil & Environmental & TPH-DRO \\
\hline \multirow[b]{2}{*}{$\mathrm{C} 05$} & MPXC005A & $3.5-4.0$ & Soil & Environmental & TPH-DRO \\
\hline & MPXC201A & $3.5-4.0$ & Soil & $\begin{array}{l}\text { Field Duplicate } \\
\text { of \#MPXC005A }\end{array}$ & TPH-DRO \\
\hline $\mathrm{CO6}$ & MPXC006A & $5.5-6.0$ & Soil & Environmental & TPH-DRO \\
\hline $\mathrm{C} 07$ & MPXC007A & $5.0-5.5$ & Soil & $\begin{array}{c}\text { Environmental, } \\
\text { MS/MSD }\end{array}$ & TPH-DRO \\
\hline 08 & MPXC008A & $4.5-5.0$ & Soil & Environmental & TPH-DRO \\
\hline $\mathrm{CO9}$ & MPXC009A & $5.0-5.5$ & Soil & Environmental & TPH-DRO \\
\hline C10 & MPXC010A & $4.5-5.0$ & Soil & Environmental & TPH-DRO \\
\hline$N / A$ & MPXC401A & N/A & Water & Field Blank & TPH-DRO \\
\hline
\end{tabular}

$\mathrm{ft}$ bgs = Feet below ground surface

MS/MSD = Matrix spike/matrix spike duplicate

N/A = Not applicable

$\mathrm{TPH}-\mathrm{DRO}=$ Total petroleum hydrocarbons, diesel-range organics 
Table D.1-10

Soil Sample Results for TPH-DRO at

CAS 02-09-03, U-2dc \#4 PS \#1A Covered Mud Pit (1)

\begin{tabular}{|c|c|c|c|c|}
\hline \multirow{2}{*}{$\begin{array}{c}\text { Sample } \\
\text { Location }\end{array}$} & \multirow{2}{*}{$\begin{array}{l}\text { Sample } \\
\text { Number }\end{array}$} & \multirow{2}{*}{$\begin{array}{c}\text { Depth } \\
\text { (ft bgs) }\end{array}$} & \multicolumn{2}{|c|}{ Contaminants of Potential Concern (mg/kg) } \\
\hline & & & Result & Detection Limit \\
\hline \multirow{2}{*}{$\mathrm{C01}$} & MPXC001 & $2.0-2.5$ & $5.2(U)$ & 5.2 \\
\hline & MPXC001A & $2.5-3.0$ & $5.2(U)$ & 5.2 \\
\hline \multirow{2}{*}{$\mathrm{C} 02$} & MPXC002 & $2.0-2.5$ & $4(J)$ & 5.2 \\
\hline & MPXC002A & $2.0-2.5$ & $10(\mathrm{M}, \mathrm{Z})$ & 5.3 \\
\hline \multirow{3}{*}{$\mathrm{CO3}$} & MPXC003 & $4.5-5.0$ & $5.2(U)$ & 5.2 \\
\hline & MPXC201 & $4.5-5.0$ & $5.2(U)$ & 5.2 \\
\hline & MPXC003A & $4.0-4.5$ & $5.3(U)$ & 5.3 \\
\hline \multirow{2}{*}{$\mathrm{CO4}$} & MPXC004 & $3.0-3.5$ & $5.3(U)$ & 5.3 \\
\hline & MPXC004A & $3.5-4.0$ & $6(U)$ & 6 \\
\hline \multirow{2}{*}{ C05 } & MPXC005A & $3.5-4.0$ & $5.5(U)$ & 5.5 \\
\hline & MPXC201A & $3.5-4.0$ & $5.7(U)$ & 5.7 \\
\hline $\mathrm{C} 06$ & MPXC006A & $5.5-6.0$ & $5.3(U)$ & 5.3 \\
\hline $\mathrm{C} 07$ & MPXC007A & $5.0-5.5$ & $45(H)$ & 7.6 \\
\hline $\mathrm{C} 08$ & MPXC008A & $4.5-5.0$ & $5.3(U)$ & 5.3 \\
\hline Co9 & MPXC009A & $5.0-5.5$ & $5.3(U)$ & 5.3 \\
\hline C10 & MPXC010A & $4.5-5.0$ & $5.4(U)$ & 5.4 \\
\hline
\end{tabular}

$\mathrm{ft}$ bgs $=$ Feet below ground surface

$\mathrm{mg} / \mathrm{kg}=$ Milligrams per kilogram

$\mathrm{H}=$ Fuel pattern in the heavier end of retention time window.

$\mathrm{J}=$ Estimated value.

$\mathrm{M}=\mathrm{A}$ pattern resembling motor oil was detected.

$U$ = Compound was analyzed for, but not detected ("non-detect").

$Z=$ Result did not resemble any common total petroleum hydrocarbons products. 
Table D.1-11

Samples Collected at CAS 02-09-09, U-2az \#2 Mud Pit (2)

\begin{tabular}{|c|c|c|c|c|c|}
\hline $\begin{array}{l}\text { Sample } \\
\text { Location }\end{array}$ & $\begin{array}{l}\text { Sample } \\
\text { Number }\end{array}$ & $\begin{array}{l}\text { Depth } \\
\text { (ft bgs) }\end{array}$ & Matrix & Purpose & Analyses \\
\hline D01 & MPXD001 & $0.0-0.5$ & Soil & Environmental & TPH-DRO \\
\hline D02 & MPXD002 & $0.0-0.5$ & Soil & Environmental & TPH-DRO \\
\hline D03 & MPXD003 & $0.0-0.5$ & Soil & Environmental & TPH-DRO \\
\hline D04 & MPXD004 & $0.0-0.5$ & Soil & Environmental & TPH-DRO \\
\hline D05 & MPXD005 & $0.0-0.5$ & Soil & Environmental & TPH-DRO \\
\hline D06 & MPXD006 & $0.0-0.5$ & Soil & Environmental & TPH-DRO \\
\hline \multirow[b]{2}{*}{ D07 } & MPXD007 & $0.0-0.5$ & Soil & Environmental & TPH-DRO \\
\hline & MPXD201 & $0.0-0.5$ & Soil & $\begin{array}{l}\text { Field Duplicate } \\
\text { of \#MPXD007 }\end{array}$ & TPH-DRO \\
\hline D08 & MPXD008 & $0.0-0.5$ & Soil & Environmental & TPH-DRO \\
\hline D09 & MPXD009 & $0.0-0.5$ & Soil & Environmental & TPH-DRO \\
\hline D10 & MPXD010 & $0.0-0.5$ & Soil & $\begin{array}{c}\text { Environmental, } \\
\text { MS/MSD }\end{array}$ & TPH-DRO \\
\hline
\end{tabular}

$\mathrm{ft}$ bgs = Feet below ground surface MS/MSD = Matrix spike/matrix spike duplicate

$\mathrm{TPH}-\mathrm{DRO}=$ Total petroleum hydrocarbons, diesel-range organics 
Table D.1-12

Soil Sample Results for TPH-DRO at CAS 02-09-09, U-2az \#2 Mud Pit (2)

\begin{tabular}{|c|c|c|c|c||}
\hline \multirow{2}{*}{$\begin{array}{c}\text { Sample } \\
\text { Location }\end{array}$} & \multirow{2}{*}{$\begin{array}{c}\text { Sample } \\
\text { Number }\end{array}$} & \multirow{2}{*}{$\begin{array}{c}\text { Depth } \\
\text { ft bgs) }\end{array}$} & \multicolumn{2}{|c|}{ Contaminants of Potential Concern (mg/kg) } \\
\cline { 4 - 5 } & & Result & Detection Limit \\
\hline \hline D01 & MPXD001 & $0.0-0.5$ & $5(\mathrm{U})$ & 5 \\
\hline D02 & MPXD002 & $0.0-0.5$ & $2.1(\mathrm{~J})$ & 5.1 \\
\hline D03 & MPXD003 & $0.0-0.5$ & $5.2(\mathrm{U})$ & 5.2 \\
\hline D04 & MPXD004 & $0.0-0.5$ & $5(\mathrm{U})$ & 5 \\
\hline D05 & MPXD005 & $0.0-0.5$ & $5(\mathrm{U})$ & 5 \\
\hline D06 & MPXD006 & $0.0-0.5$ & $5.1(\mathrm{U})$ & 5.1 \\
\hline \multirow{2}{*}{ D07 } & MPXD007 & $0.0-0.5$ & $5.2(\mathrm{U})$ & 5.2 \\
\cline { 3 - 5 } & MPXD201 & $0.0-0.5$ & $5.1(\mathrm{U})$ & 5.1 \\
\hline D08 & MPXD008 & $0.0-0.5$ & $5(\mathrm{U})$ & 5 \\
\hline D09 & MPXD009 & $0.0-0.5$ & $4.9(\mathrm{U})$ & 4.9 \\
\hline D10 & MPXD010 & $0.0-0.5$ & $5.2(\mathrm{U})$ & 5.2 \\
\hline
\end{tabular}

$\mathrm{ft}$ bgs = Feet below ground surface

$\mathrm{mg} / \mathrm{kg}=$ Milligrams per kilogram

$\mathrm{J}=$ Estimated value.

$\mathrm{U}=$ Compound was analyzed for, but not detected ("non-detect"). 
Table D.1-13

Samples Collected at CAS 02-09-12, U-2gd Mud Pit (1)

\begin{tabular}{|c|c|c|c|c|c|}
\hline $\begin{array}{c}\text { Sample } \\
\text { Location }\end{array}$ & $\begin{array}{l}\text { Sample } \\
\text { Number }\end{array}$ & $\begin{array}{l}\text { Depth } \\
\text { (ft bgs) }\end{array}$ & Matrix & Purpose & Analyses \\
\hline E01 & MPXE001 & $0.0-0.5$ & Soil & Environmental & TPH-DRO \\
\hline E02 & MPXE002 & $0.0-0.5$ & Soil & Environmental & TPH-DRO \\
\hline \multirow[b]{2}{*}{ E03 } & MPXE003 & $0.0-0.5$ & Soil & Environmental & TPH-DRO \\
\hline & MPXE201 & $0.0-0.5$ & Soil & $\begin{array}{l}\text { Field Duplicate } \\
\text { of \#MPXE003 }\end{array}$ & TPH-DRO \\
\hline E04 & MPXE004 & $0.0-0.5$ & Soil & Environmental & TPH-DRO \\
\hline E05 & MPXE005 & $0.0-0.5$ & Soil & Environmental & TPH-DRO \\
\hline E06 & MPXE006 & $0.0-0.5$ & Soil & Environmental & TPH-DRO \\
\hline E07 & MPXE007 & $0.0-0.5$ & Soil & $\begin{array}{c}\text { Environmental, } \\
\text { MS/MSD }\end{array}$ & TPH-DRO \\
\hline E08 & MPXE008 & $0.0-0.5$ & Soil & Environmental & TPH-DRO \\
\hline E09 & MPXE009 & $0.0-0.5$ & Soil & Environmental & TPH-DRO \\
\hline E10 & MPXE010 & $0.0-0.5$ & Soil & Environmental & TPH-DRO \\
\hline
\end{tabular}

$\mathrm{ft}$ bgs = Feet below ground surface MS/MSD = Matrix spike/matrix spike duplicate

$\mathrm{TPH}-\mathrm{DRO}=$ Total petroleum hydrocarbons, diesel-range organics 
Table D.1-14

Soil Sample Results for TPH-DRO at CAS 02-09-12, U-2gd Mud Pit (1)

\begin{tabular}{|c|c|c|c|c|}
\hline \multirow{2}{*}{$\begin{array}{c}\text { Sample } \\
\text { Location }\end{array}$} & \multirow{2}{*}{$\begin{array}{l}\text { Sample } \\
\text { Number }\end{array}$} & \multirow{2}{*}{$\begin{array}{l}\text { Depth } \\
\text { (ft bgs) }\end{array}$} & \multicolumn{2}{|c|}{ Contaminants of Potential Concern (mg/kg) } \\
\hline & & & Result & Detection Limit \\
\hline E01 & MPXE001 & $0.0-0.5$ & $5(U)$ & 5 \\
\hline E02 & MPXE002 & $0.0-0.5$ & $5(U)$ & 5 \\
\hline \multirow{2}{*}{ E03 } & MPXE003 & $0.0-0.5$ & $5.1(U)$ & 5.1 \\
\hline & MPXE201 & $0.0-0.5$ & $5.1(U)$ & 5.1 \\
\hline E04 & MPXE004 & $0.0-0.5$ & $5(U)$ & 5 \\
\hline E05 & MPXE005 & $0.0-0.5$ & $5(U)$ & 5 \\
\hline E06 & MPXE006 & $0.0-0.5$ & $5(U)$ & 5 \\
\hline E07 & MPXE007 & $0.0-0.5$ & $5.3(U)$ & 5.3 \\
\hline E08 & MPXE008 & $0.0-0.5$ & $5(U)$ & 5 \\
\hline E09 & MPXE009 & $0.0-0.5$ & $4.9(U)$ & 4.9 \\
\hline E10 & MPXE010 & $0.0-0.5$ & $5(U)$ & 5 \\
\hline
\end{tabular}

$\mathrm{ft}$ bgs $=$ Feet below ground surface $\mathrm{mg} / \mathrm{kg}=$ Milligrams per kilogram TPH-DRO = Total petroleum hydrocarbons, diesel-range organics $\mathrm{U}=$ Compound was analyzed for, but not detected ("non-detect"). 
Table D.1-15

Samples Collected at CAS 02-09-15, U-2do Mud Pit (1)

\begin{tabular}{|c|c|c|c|c|c|}
\hline $\begin{array}{c}\text { Sample } \\
\text { Location }\end{array}$ & $\begin{array}{l}\text { Sample } \\
\text { Number }\end{array}$ & $\begin{array}{c}\text { Depth } \\
\text { (ft bgs) }\end{array}$ & Matrix & Purpose & Analyses \\
\hline F01 & MPXF001 & $0.0-0.5$ & Soil & Environmental & TPH-DRO \\
\hline F02 & MPXF002 & $0.0-0.5$ & Soil & Environmental & TPH-DRO \\
\hline F03 & MPXF003 & $0.0-0.5$ & Soil & Environmental & TPH-DRO \\
\hline F04 & MPXF004 & $0.0-0.5$ & Soil & $\begin{array}{c}\text { Environmental, } \\
\text { MS/MSD }\end{array}$ & TPH-DRO \\
\hline F05 & MPXF005 & $0.0-0.5$ & Soil & Environmental & TPH-DRO \\
\hline F06 & MPXF006 & $0.0-0.5$ & Soil & Environmental & TPH-DRO \\
\hline \multirow[b]{2}{*}{ F07 } & MPXF007 & $0.0-0.5$ & Soil & Environmental & TPH-DRO \\
\hline & MPXF201 & $0.0-0.5$ & Soil & $\begin{array}{l}\text { Field Duplicate } \\
\text { of \#MPXF007 }\end{array}$ & TPH-DRO \\
\hline F08 & MPXF008 & $0.0-0.5$ & Soil & Environmental & TPH-DRO \\
\hline F09 & MPXF009 & $0.0-0.5$ & Soil & Environmental & TPH-DRO \\
\hline F10 & MPXF010 & $0.0-0.5$ & Soil & Environmental & TPH-DRO \\
\hline
\end{tabular}

$\mathrm{ft}$ bgs = Feet below ground surface MS/MSD = Matrix spike/matrix spike duplicate

$\mathrm{TPH}-\mathrm{DRO}=$ Total petroleum hydrocarbons, diesel-range organics 
Table D.1-16

Soil Sample Results for TPH-DRO at CAS 02-09-15, U-2do Mud Pit (1)

\begin{tabular}{|c|c|c|c|c|}
\hline \multirow{2}{*}{$\begin{array}{c}\text { Sample } \\
\text { Location }\end{array}$} & \multirow{2}{*}{$\begin{array}{c}\text { Sample } \\
\text { Number }\end{array}$} & $\begin{array}{c}\text { Depth } \\
\text { (ft bgs) }\end{array}$ & \multicolumn{2}{|c|}{ Contaminants of Potential Concern (mg/kg) } \\
\cline { 4 - 5 } & & & Result & Detection Limit \\
\hline \hline F01 & MPXF001 & $0.0-0.5$ & $5.1(U)$ & 5.1 \\
\hline F02 & MPXF002 & $0.0-0.5$ & $5.6(U)$ & 5.1 \\
\hline F03 & MPXF003 & $0.0-0.5$ & $5.1(U)$ & 5.1 \\
\hline F04 & MPXF004 & $0.0-0.5$ & $5.1(U)$ & 5.1 \\
\hline F05 & MPXF005 & $0.0-0.5$ & $5.1(U)$ & 5.3 \\
\hline F06 & MPXF006 & $0.0-0.5$ & $5.3(U)$ & 5.5 \\
\hline \multirow{2}{*}{ F07 } & MPXF007 & $0.0-0.5$ & $5.5(U)$ & 5.8 \\
\cline { 3 - 5 } & MPXF201 & $0.0-0.5$ & $5.8(U)$ & 5.1 \\
\hline F08 & MPXF008 & $0.0-0.5$ & $5.1(U)$ & 6.3 \\
\hline F09 & MPXF009 & $0.0-0.5$ & $6.3(U)$ & $6.2(U)$ \\
\hline F10 & MPXF010 & $0.0-0.5$ & & 6.2 \\
\hline
\end{tabular}

$\mathrm{ft}$ bgs = Feet below ground surface

$\mathrm{mg} / \mathrm{kg}=$ Milligrams per kilogram

$\mathrm{U}=$ Compound was analyzed for, but not detected ("non-detect"). 
Table D.1-17

Samples Collected at CAS 02-09-18, U-2ez Mud Pit (1)

\begin{tabular}{|c|c|c|c|c|c||}
\hline $\begin{array}{c}\text { Sample } \\
\text { Location }\end{array}$ & $\begin{array}{c}\text { Sample } \\
\text { Number }\end{array}$ & $\begin{array}{c}\text { Depth } \\
\mathbf{f t} \text { bgs })\end{array}$ & Matrix & Purpose & Analyses \\
\hline \hline G01 & MPXG001 & $0.0-0.5$ & Soil & Environmental & TPH-DRO \\
\hline G02 & MPXG002 & $0.0-0.5$ & Soil & Environmental & TPH-DRO \\
\hline G03 & MPXG003 & $0.0-0.5$ & Soil & Environmental & TPH-DRO \\
\hline G04 & MPXG004 & $0.0-0.5$ & Soil & Environmental & TPH-DRO \\
\hline G05 & MPXG005 & $0.0-0.5$ & Soil & Field Duplicate & of \#MPXG005 \\
\hline MPXG201 & $0.0-0.5$ & Soil & Environmental & TPH-DRO \\
\hline G06 & MPXG006 & $0.0-0.5$ & Soil & Environmental & TPH-DRO \\
\hline G08 & MPXG007 & $0.0-0.5$ & Soil & Environmental & TPH-DRO \\
\hline G09 & MPXG009 & $0.0-0.5$ & Soil & Environmental, \\
MPS/MSD & TPH-DRO \\
\hline
\end{tabular}

$\mathrm{ft}$ bgs = Feet below ground surface MS/MSD = Matrix spike/matrix spike duplicate

$\mathrm{TPH}-\mathrm{DRO}=$ Total petroleum hydrocarbons, diesel-range organics 
Table D.1-18

Soil Sample Results for TPH-DRO at CAS 02-09-18, U-2ez Mud Pit (1)

\begin{tabular}{|c|c|c|c|c|}
\hline \multirow{2}{*}{$\begin{array}{c}\text { Sample } \\
\text { Location }\end{array}$} & \multirow{2}{*}{$\begin{array}{l}\text { Sample } \\
\text { Number }\end{array}$} & \multirow{2}{*}{$\begin{array}{l}\text { Depth } \\
\text { (ft bgs) }\end{array}$} & \multicolumn{2}{|c|}{ Contaminants of Potential Concern (mg/kg) } \\
\hline & & & Result & Detection Limit \\
\hline G01 & MPXG001 & $0.0-0.5$ & $5.1(U)$ & 5.1 \\
\hline G02 & MPXG002 & $0.0-0.5$ & $5(U)$ & 5 \\
\hline G03 & MPXG003 & $0.0-0.5$ & $5(U)$ & 5 \\
\hline G04 & MPXG004 & $0.0-0.5$ & $5.1(U)$ & 5.1 \\
\hline \multirow{2}{*}{ G05 } & MPXG005 & $0.0-0.5$ & $5.1(U)$ & 5.1 \\
\hline & MPXG201 & $0.0-0.5$ & $5.1(U)$ & 5.1 \\
\hline G06 & MPXG006 & $0.0-0.5$ & $5(U)$ & 5 \\
\hline G07 & MPXG007 & $0.0-0.5$ & $5.1(U)$ & 5.1 \\
\hline G08 & MPXG008 & $0.0-0.5$ & $5(U)$ & 5 \\
\hline G09 & MPXG009 & $0.0-0.5$ & $4.9(U)$ & 4.9 \\
\hline G10 & MPXG010 & $0.0-0.5$ & $5.1(U)$ & 5.1 \\
\hline
\end{tabular}

$\mathrm{ft}$ bgs $=$ Feet below ground surface

$\mathrm{mg} / \mathrm{kg}=$ Milligrams per kilogram

$\mathrm{U}=$ Compound was analyzed for, but was not detected ("non-detect"). 
Table D.1-19

Samples Collected at CAS 02-09-26, U-2cv Mud Pit (1)

\begin{tabular}{|c|c|c|c|c|c|}
\hline $\begin{array}{l}\text { Sample } \\
\text { Location }\end{array}$ & $\begin{array}{l}\text { Sample } \\
\text { Number }\end{array}$ & $\begin{array}{l}\text { Depth } \\
\text { (ft bgs) }\end{array}$ & Matrix & Purpose & Analyses \\
\hline $\mathrm{H} 01$ & MPXH001 & $0.0-0.5$ & Soil & Environmental & TPH-DRO \\
\hline H02 & MPXH002 & $0.0-0.5$ & Soil & Environmental & TPH-DRO \\
\hline $\mathrm{HO3}$ & MPXH003 & $0.0-0.5$ & Soil & Environmental & TPH-DRO \\
\hline H04 & MPXH004 & $0.0-0.5$ & Soil & Environmental & TPH-DRO \\
\hline \multirow[b]{2}{*}{ H05 } & MPXH005 & $0.0-0.5$ & Soil & Environmental & TPH-DRO \\
\hline & MPXH201 & $0.0-0.5$ & Soil & $\begin{array}{l}\text { Field Duplicate } \\
\text { of \#MPXH005 }\end{array}$ & TPH-DRO \\
\hline H06 & MPXH006 & $0.0-0.5$ & Soil & Environmental & TPH-DRO \\
\hline $\mathrm{H} 07$ & MPXH007 & $0.0-0.5$ & Soil & Environmental & TPH-DRO \\
\hline H08 & MPXH008 & $0.0-0.5$ & Soil & $\begin{array}{l}\text { Environmental, } \\
\text { MS/MSD }\end{array}$ & TPH-DRO \\
\hline HO9 & MPXH009 & $0.0-0.5$ & Soil & Environmental & TPH-DRO \\
\hline $\mathrm{H} 10$ & MPXH010 & $0.0-0.5$ & Soil & Environmental & Set 1 \\
\hline N/A & MPXH401 & N/A & Water & Field Blank & TPH-DRO \\
\hline
\end{tabular}

Set 1 = TPH-DRO, gamma spectroscopy, isotopic uranium, isotopic plutonium, strontium-90

$\mathrm{ft}$ bgs = Feet below ground surface

MS/MSD = Matrix spike/matrix spike duplicate

N/A = Not applicable

TPH-DRO = Total petroleum hydrocarbons, diesel-range organics 
Table D.1-20

Soil Sample Results for TPH-DRO at CAS 02-09-26, U-2cv Mud Pit (1)

\begin{tabular}{|c|c|c|c|c|}
\hline \multirow{2}{*}{$\begin{array}{l}\text { Sample } \\
\text { Location }\end{array}$} & \multirow{2}{*}{$\begin{array}{l}\text { Sample } \\
\text { Number }\end{array}$} & \multirow{2}{*}{$\begin{array}{l}\text { Depth } \\
\text { (ft bgs) }\end{array}$} & \multicolumn{2}{|c|}{ Contaminants of Potential Concern (mg/kg) } \\
\hline & & & Result & Detection Limit \\
\hline $\mathrm{HO1}$ & MPXH001 & $0.0-0.5$ & $5(U)$ & 5 \\
\hline $\mathrm{H} 02$ & MPXH002 & $0.0-0.5$ & $5.1(U)$ & 5.1 \\
\hline $\mathrm{HO3}$ & MPXH003 & $0.0-0.5$ & $5.2(U)$ & 5.2 \\
\hline $\mathrm{H} 04$ & MPXH004 & $0.0-0.5$ & $5.1(U)$ & 5.1 \\
\hline \multirow{2}{*}{$\mathrm{H} 05$} & MPXH005 & $0.0-0.5$ & $5.1(U)$ & 5.1 \\
\hline & MPXH201 & $0.0-0.5$ & $5.2(U)$ & 5.2 \\
\hline $\mathrm{H} 06$ & MPXH006 & $0.0-0.5$ & $5(U)$ & 5 \\
\hline $\mathrm{H} 07$ & MPXH007 & $0.0-0.5$ & $5(U)$ & 5 \\
\hline $\mathrm{H} 08$ & MPXH008 & $0.0-0.5$ & $5.2(U)$ & 5.2 \\
\hline H09 & MPXH009 & $0.0-0.5$ & $5.1(U)$ & 5.1 \\
\hline $\mathrm{H} 10$ & MPXH010 & $0.0-0.5$ & $5.1(U)$ & 5.1 \\
\hline
\end{tabular}

$\mathrm{ft}$ bgs $=$ Feet below ground surface $\mathrm{mg} / \mathrm{kg}=$ Milligrams per kilogram

$\mathrm{U}=$ Compound was analyzed for, but not detected ("non-detect"). 
Table D.1-21

Soil Sample Results for Gamma-Emitting Radionuclides Detected Above Minimum Detectable Concentration Limits at CAS 02-09-26, U-2cv Mud Pit (1)

\begin{tabular}{|c|c|c|c|c|c|c|c|}
\hline \multirow[b]{2}{*}{$\begin{array}{l}\text { Sample } \\
\text { Location }\end{array}$} & \multirow[b]{2}{*}{$\begin{array}{l}\text { Sample } \\
\text { Number }\end{array}$} & \multirow[b]{2}{*}{$\begin{array}{c}\text { Depth } \\
\text { (ft bgs) }\end{array}$} & \multicolumn{5}{|c|}{ Contaminants of Potential Concern (pCi/g) } \\
\hline & & & 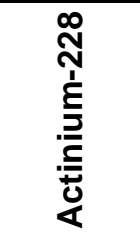 & 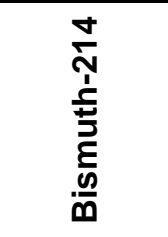 & 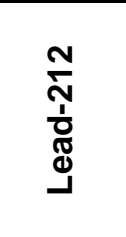 & 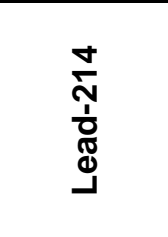 & 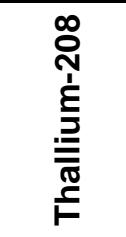 \\
\hline \multicolumn{3}{|c|}{ Final Action Levels ${ }^{a}$} & 5 & 5 & 5 & 5 & 5 \\
\hline \multicolumn{3}{|c|}{ Depths bgs (cm) } & $<15$ & $<15$ & $<15$ & $<15$ & $<15$ \\
\hline $\mathrm{H} 10$ & MPXH010 & $0.0-0.5$ & $2.16(\mathrm{G})$ & $0.95(G, J)$ & $2.2(\mathrm{~J})^{\mathrm{b}}$ & $1.07(\mathrm{G}, \mathrm{J})$ & $0.78(G)$ \\
\hline
\end{tabular}

aTaken from the generic guidelines for residual concentrations of actinium-228, bismuth-214, lead-212, lead-214, thallium-208, and thorium-232, as found in Chapter IV of DOE Order 5400.5, Change 2, "Radiation Protection of the Public and Environment."

(DOE, 1993). The PALs for these isotopes is specified as $5 \mathrm{pCi} / \mathrm{g}$ averaged over the first $15 \mathrm{~cm}$ of soil and $15 \mathrm{pCi} / \mathrm{g}$ for deeper soils (DOE, 1993). For purposes of this document, $15 \mathrm{~cm}$ is assumed to be equivalent to $0.5 \mathrm{ft}$ ( 6 inches); therefore, $5 \mathrm{pCi} / \mathrm{g}$ represents the PALs for these radionuclides in the surface soil ( 0 to $0.5 \mathrm{ft}$ depth).

${ }^{b}$ Qualifier added to laboratory data; record accepted. Sample does not meet counting geometry requirements.

$\mathrm{cm}=$ Centimeters

$\mathrm{ft}$ bgs $=$ Feet below ground surface

$\mathrm{PAL}=$ Preliminary action level

$\mathrm{pCi} / \mathrm{g}=$ Picocuries per gram

$<=$ Less than

$\mathrm{G}=$ Sample density differs by more than $15 \%$ of laboratory control sample density.

$\mathrm{J}=$ Estimated value.

Table D.1-22

Soil Sample Results for Isotopic Uranium Detected Above Minimum Detectable Concentration Limits at CAS 02-09-26, U-2cv Mud Pit (1)

\begin{tabular}{|c|c|c|c|c|c|}
\hline \multirow{2}{*}{$\begin{array}{c}\text { Sample } \\
\text { Location }\end{array}$} & $\begin{array}{c}\text { Sample } \\
\text { Number }\end{array}$ & $\begin{array}{c}\text { Depth } \\
\text { (ft bgs) }\end{array}$ & \multicolumn{3}{c|}{ Contaminants of Potential Concern (pCi/g) } \\
\cline { 4 - 6 } & Uranium-234 & Uranium-235 & Uranium-238 \\
\hline \multicolumn{3}{|c|}{ Final Action Levels } & 173.5 & 105 \\
\hline \hline $\mathrm{H} 10$ & MPXH010 & $0.0-0.5$ & 1.06 & 0.132 & 1.2 \\
\hline
\end{tabular}

${ }^{a}$ Taken from the construction, commercial, industrial land use scenario in Table 2.1 of the NCRP Report No. 129, Recommended Screening Limits for Contaminated Surface Soil and Review Factors Relevant to Site-Specific Studies (NCRP, 1999). The values provided in this source document were scaled to a 25-mrem/yr dose.

$\mathrm{ft}$ bgs $=$ Feet below ground surface

$\mathrm{mrem} / \mathrm{yr}=$ Millirem per year

$\mathrm{pCi} / \mathrm{g}=$ Picocuries per gram 
Table D.1-23

Samples Collected at CAS 02-09-30, U-2dp PS \#1A Mud Pit (1)

\begin{tabular}{|c|c|c|c|c|c|}
\hline $\begin{array}{l}\text { Sample } \\
\text { Location }\end{array}$ & $\begin{array}{l}\text { Sample } \\
\text { Number }\end{array}$ & $\begin{array}{l}\text { Depth } \\
\text { (ft bgs) }\end{array}$ & Matrix & Purpose & Analyses \\
\hline 101 & MPXI001 & $0.0-0.5$ & Soil & Environmental & TPH-DRO \\
\hline 102 & MPXI002 & $0.0-0.5$ & Soil & Environmental & TPH-DRO \\
\hline \multirow[b]{2}{*}{103} & MPXI003 & $0.0-0.5$ & Soil & Environmental & TPH-DRO \\
\hline & MPXI201 & $0.0-0.5$ & Soil & $\begin{array}{c}\text { Field Duplicate } \\
\text { of \#MPXI003 }\end{array}$ & TPH-DRO \\
\hline 104 & MPXI004 & $0.0-0.5$ & Soil & Environmental & TPH-DRO \\
\hline 105 & MPXI005 & $0.0-0.5$ & Soil & Environmental & TPH-DRO \\
\hline 106 & MPXI006 & $0.0-0.5$ & Soil & Environmental & TPH-DRO \\
\hline 107 & MPXI007 & $0.0-0.5$ & Soil & Environmental & TPH-DRO \\
\hline 108 & MPXI008 & $0.0-0.5$ & Soil & $\begin{array}{c}\text { Environmental, } \\
\text { MS/MSD }\end{array}$ & TPH-DRO \\
\hline 109 & MPXI009 & $0.0-0.5$ & Soil & Environmental & TPH-DRO \\
\hline 110 & MPXI010 & $0.0-0.5$ & Soil & Environmental & TPH-DRO \\
\hline
\end{tabular}

$\mathrm{ft}$ bgs = Feet below ground surface MS/MSD = Matrix spike/matrix spike duplicate

$\mathrm{TPH}-\mathrm{DRO}=$ Total petroleum hydrocarbons, diesel-range organics 
Table D.1-24

Soil Sample Results for TPH-DRO at CAS 02-09-30, U-2dp PS \#1A Mud Pit (1)

\begin{tabular}{|c|c|c|c|c||}
\hline \multirow{2}{*}{$\begin{array}{c}\text { Sample } \\
\text { Location }\end{array}$} & \multirow{2}{*}{$\begin{array}{c}\text { Sample } \\
\text { Number }\end{array}$} & \multirow{2}{*}{$\begin{array}{c}\text { Depth } \\
\text { ff bgs) }\end{array}$} & \multicolumn{2}{|c|}{ Contaminants of Potential Concern (mg/kg) } \\
\cline { 4 - 5 } & & & Result & Detection Limit \\
\hline \hline 101 & MPXI001 & $0.0-0.5$ & $6.2(\mathrm{U})$ & 6.2 \\
\hline 102 & MPXI002 & $0.0-0.5$ & $2.9(\mathrm{~J})$ & 5.9 \\
\hline \multirow{2}{*}{103} & MPXI003 & $0.0-0.5$ & $5.9(\mathrm{U})$ & 5.9 \\
\cline { 3 - 5 } & MPXI201 & $0.0-0.5$ & $6.1(\mathrm{U})$ & 6.1 \\
\hline 104 & MPXI004 & $0.0-0.5$ & $11(\mathrm{M})$ & 5.7 \\
\hline 105 & MPXI005 & $0.0-0.5$ & $6.4(\mathrm{U})$ & 6.4 \\
\hline 106 & MPXI006 & $0.0-0.5$ & $6.7(\mathrm{U})$ & 6.7 \\
\hline 107 & MPXI007 & $0.0-0.5$ & $5.7(\mathrm{U})$ & 5.7 \\
\hline 108 & MPXI008 & $0.0-0.5$ & $5.8(\mathrm{U})$ & 5.8 \\
\hline 109 & MPXI009 & $0.0-0.5$ & $5.3(\mathrm{U})$ & 5.3 \\
\hline 110 & MPXI010 & $0.0-0.5$ & $5.2(\mathrm{U})$ & 5.2 \\
\hline
\end{tabular}

$\mathrm{ft}$ bgs $=$ Feet below ground surface $\mathrm{mg} / \mathrm{kg}=$ Milligrams per kilogram $\mathrm{J}=$ Estimated value.

$\mathrm{M}=\mathrm{A}$ pattern resembling motor oil was detected.

$\mathrm{U}=$ Compound was analyzed for, but not detected ("non-detect"). 
Table D.1-25

Samples Collected at CAS 02-09-33, U-2er PS \#1A Covered Mud Pit (1)

\begin{tabular}{|c|c|c|c|c|c|}
\hline $\begin{array}{l}\text { Sample } \\
\text { Location }\end{array}$ & $\begin{array}{l}\text { Sample } \\
\text { Number }\end{array}$ & $\begin{array}{c}\text { Depth } \\
\text { (ft bgs) }\end{array}$ & Matrix & Purpose & Analyses \\
\hline \multirow{2}{*}{ J01 } & MPXJ001 & $4.0-4.5$ & Soil & Environmental & TPH-DRO \\
\hline & MPXJ001A & $5.0-5.5$ & Soil & Environmental & TPH-DRO \\
\hline \multirow{2}{*}{$\mathrm{J} 02$} & MPXJ002 & $3.0-3.5$ & Soil & Environmental & TPH-DRO \\
\hline & MPXJ002A & $5.5-6.0$ & Soil & Environmental & TPH-DRO \\
\hline \multirow{3}{*}{ J03 } & MPXJ003 & $4.0-4.5$ & Soil & Environmental & TPH-DRO \\
\hline & MPXJ201 & $4.0-4.5$ & Soil & $\begin{array}{l}\text { Field Duplicate } \\
\text { of \#MPXJ003 }\end{array}$ & TPH-DRO \\
\hline & MPXJ003A & $4.5-5.0$ & Soil & Environmental & TPH-DRO \\
\hline \multirow{2}{*}{$\mathrm{J} 04$} & MPXJ004 & $4.0-4.5$ & Soil & Environmental & TPH-DRO \\
\hline & MPXJ004A & $4.5-5.0$ & Soil & $\begin{array}{c}\text { Environmental, } \\
\text { MS/MSD }\end{array}$ & TPH-DRO \\
\hline \multirow{2}{*}{$\mathrm{J} 05$} & MPXJ005 & $3.0-3.5$ & Soil & Environmental & TPH-DRO \\
\hline & MPXJ005A & $5.5-6.0$ & Soil & Environmental & TPH-DRO \\
\hline \multirow{2}{*}{ J06 } & MPXJ006 & $3.5-4.0$ & Soil & $\begin{array}{c}\text { Environmental, } \\
\text { MS/MSD }\end{array}$ & TPH-DRO \\
\hline & MPXJ006A & $4.0-4.5$ & Soil & Environmental & TPH-DRO \\
\hline \multirow{2}{*}{$\mathrm{J} 07$} & MPXJ007 & $3.5-4.0$ & Soil & Environmental & TPH-DRO \\
\hline & MPXJ007A & $5.5-6.0$ & Soil & Environmental & TPH-DRO \\
\hline \multirow{2}{*}{ J08 } & MPXJ008 & $3.5-4.0$ & Soil & Environmental & TPH-DRO \\
\hline & MPXJ008A & $5.0-5.5$ & Soil & Environmental & TPH-DRO \\
\hline \multirow{2}{*}{ J09 } & MPXJ009 & $3.5-4.0$ & Soil & Environmental & TPH-DRO \\
\hline & MPXJ009A & $5.5-6.0$ & Soil & Environmental & TPH-DRO \\
\hline \multirow{3}{*}{$\mathrm{J} 10$} & MPXJ010 & $3.5-4.0$ & Soil & Environmental & TPH-DRO \\
\hline & MPXJ010A & $5.5-6.0$ & Soil & Environmental & TPH-DRO \\
\hline & MPXJ201A & $5.5-6.0$ & Soil & $\begin{array}{l}\text { Field Duplicate } \\
\text { of \#MPXJ010A }\end{array}$ & TPH-DRO \\
\hline N/A & MPXJ401 & N/A & Water & Field Blank & TPH-DRO \\
\hline N/A & MPXJ401A & $N / A$ & Water & Field Blank & TPH-DRO \\
\hline
\end{tabular}

$\mathrm{ft}$ bgs $=$ Feet below ground surface

MS/MSD = Matrix spike/matrix spike duplicate

N/A = Not applicable

TPH-DRO = Total petroleum hydrocarbons, diesel-range organics 
Table D.1-26

Soil Sample Results for TPH-DRO at

CAS 02-09-33, U-2er PS \#1A Covered Mud Pit (1)

\begin{tabular}{|c|c|c|c|c|}
\hline \multirow{2}{*}{$\begin{array}{l}\text { Sample } \\
\text { Location }\end{array}$} & \multirow{2}{*}{$\begin{array}{l}\text { Sample } \\
\text { Number }\end{array}$} & \multirow{2}{*}{$\begin{array}{l}\text { Depth } \\
\text { (ft bgs) }\end{array}$} & \multicolumn{2}{|c|}{ Contaminants of Potential Concern $(\mathrm{mg} / \mathrm{kg})$} \\
\hline & & & Result & Detection Limit \\
\hline \multirow{2}{*}{$\mathrm{J} 01$} & MPXJ001 & $4.0-4.5$ & $5.8(U)$ & 5.8 \\
\hline & MPXJ001A & $5.0-5.5$ & $5.6(U)$ & 5.6 \\
\hline \multirow{2}{*}{$\mathrm{J} 02$} & MPXJ002 & $3.0-3.5$ & $5.8(U)$ & 5.8 \\
\hline & MPXJ002A & $5.5-6.0$ & $5.4(U)$ & 5.4 \\
\hline \multirow{3}{*}{ J03 } & MPXJ003 & $4.0-4.5$ & $5.9(U)$ & 5.9 \\
\hline & MPXJ201 & $4.0-4.5$ & $4.3(\mathrm{~J})$ & 5.3 \\
\hline & MPXJ003A & $4.5-5.0$ & $5.7(U)$ & 5.7 \\
\hline \multirow{2}{*}{$\mathrm{J} 04$} & MPXJ004 & $4.0-4.5$ & $5.2(U)$ & 5.2 \\
\hline & MPXJ004A & $4.5-5.0$ & $5.9(U)$ & 5.9 \\
\hline \multirow{2}{*}{ J05 } & MPXJ005 & $3.0-3.5$ & $5.4(U)$ & 5.4 \\
\hline & MPXJ005A & $5.5-6.0$ & $5.4(U)$ & 5.4 \\
\hline \multirow{2}{*}{ J06 } & MPXJ006 & $3.5-4.0$ & $5.4(U)$ & 5.4 \\
\hline & MPXJ006A & $4.0-4.5$ & $5.8(U)$ & 5.8 \\
\hline \multirow{2}{*}{$\mathrm{J} 07$} & MPXJ007 & $3.5-4.0$ & $5.3(U)$ & 5.3 \\
\hline & MPXJ007A & $5.5-6.0$ & $5.6(U)$ & 5.6 \\
\hline \multirow{2}{*}{ J08 } & MPXJ008 & $3.5-4.0$ & $5.4(U)$ & 5.4 \\
\hline & MPXJ008A & $5.0-5.5$ & $5.4(U)$ & 5.4 \\
\hline \multirow{2}{*}{ J09 } & MPXJ009 & $3.5-4.0$ & $5.4(U)$ & 5.4 \\
\hline & MPXJ009A & $5.5-6.0$ & $6.8(U)$ & 6.8 \\
\hline \multirow{3}{*}{$\mathrm{J} 10$} & MPXJ010 & $3.5-4.0$ & $5.8(U)$ & 5.8 \\
\hline & MPXJ010A & $5.5-6.0$ & $5.2(U)$ & 5.2 \\
\hline & MPXJ201A & $5.5-6.0$ & $5.3(U)$ & 5.3 \\
\hline
\end{tabular}

$\mathrm{ft}$ bgs = Feet below ground surface $\mathrm{mg} / \mathrm{kg}=$ Milligrams per kilogram

$\mathrm{J}=$ Estimated value.

$\mathrm{U}=$ Compound was analyzed for, but not detected ("non-detect"). 
Table D.1-27

Samples Collected at CAS 02-09-52, U-2dc \#1 PS \#1A Mud Pit (1)

\begin{tabular}{|c|c|c|c|c|c|}
\hline $\begin{array}{l}\text { Sample } \\
\text { Location }\end{array}$ & $\begin{array}{l}\text { Sample } \\
\text { Number }\end{array}$ & $\begin{array}{l}\text { Depth } \\
\text { (ft bgs) }\end{array}$ & Matrix & Purpose & Analyses \\
\hline K01 & MPXK001 & $0.0-0.5$ & Soil & Environmental & Set 1 \\
\hline K02 & MPXK002 & $0.0-0.5$ & Soil & Environmental & Set 1 \\
\hline \multirow[b]{2}{*}{ K03 } & MPXK003 & $0.0-0.5$ & Soil & Environmental & Set 1 \\
\hline & MPXK201 & $0.0-0.5$ & Soil & $\begin{array}{l}\text { Field Duplicate } \\
\text { of \#MPXK003 }\end{array}$ & Set 1 \\
\hline K04 & MPXK004 & $0.0-0.5$ & Soil & Environmental & Set 1 \\
\hline K05 & MPXK005 & $0.0-0.5$ & Soil & Environmental & Set 1 \\
\hline K06 & MPXK006 & $0.0-0.5$ & Soil & Environmental & Set 1 \\
\hline K07 & MPXK007 & $0.0-0.5$ & Soil & Environmental & Set 1 \\
\hline K08 & MPXK008 & $0.0-0.5$ & Soil & Environmental & Set 1 \\
\hline K09 & MPXK009 & $0.0-0.5$ & Soil & $\begin{array}{c}\text { Environmental, } \\
\text { MS/MSD }\end{array}$ & Set 1 \\
\hline K10 & MPXK010 & $0.0-0.5$ & Soil & Environmental & Set 1 \\
\hline
\end{tabular}

Set 1 = TPH-DRO, gamma spectroscopy, isotopic uranium, isotopic plutonium, strontium-90

$\mathrm{ft}$ bgs = Feet below ground surface

MS/MSD = Matrix spike/matrix spike duplicate 
Table D.1-28

Soil Sample Results for TPH-DRO at CAS 02-09-52, U-2dc \#1 PS \#1A Mud Pit (1)

\begin{tabular}{|c|c|c|c|c||}
\hline \multirow{2}{*}{$\begin{array}{c}\text { Sample } \\
\text { Location }\end{array}$} & \multirow{2}{*}{$\begin{array}{c}\text { Sample } \\
\text { Number }\end{array}$} & $\begin{array}{c}\text { Depth } \\
\text { ff bgs) }\end{array}$ & \multicolumn{2}{|c|}{ Contaminants of Potential Concern (mg/kg) } \\
\cline { 4 - 5 } & & & $2(\mathrm{~J})$ & Detection Limit \\
\hline \hline K01 & MPXK001 & $0.0-0.5$ & $5.2(\mathrm{U})$ & 5.1 \\
\hline K02 & MPXK002 & $0.0-0.5$ & $45(\mathrm{M}, \mathrm{Z})$ & 5.1 \\
\hline \multirow{2}{*}{ K03 } & MPXK003 & $0.0-0.5$ & $4.6(\mathrm{~J})$ & 5 \\
\cline { 3 - 5 } & MPXK201 & $0.0-0.5$ & $7.8(\mathrm{M})$ & 5.1 \\
\hline K04 & MPXK004 & $0.0-0.5$ & $5.1(\mathrm{U})$ & 5.1 \\
\hline K05 & MPXK005 & $0.0-0.5$ & $4.6(\mathrm{~J})$ & 5 \\
\hline K06 & MPXK006 & $0.0-0.5$ & $5(\mathrm{U})$ & 5 \\
\hline K07 & MPXK007 & $0.0-0.5$ & $2.5(\mathrm{~J})$ & 5.1 \\
\hline K08 & MPXK008 & $0.0-0.5$ & $6.6(\mathrm{M})$ & 5.2 \\
\hline K09 & MPXK009 & $0.0-0.5$ & $5(\mathrm{U})$ & 5 \\
\hline K10 & MPXK010 & $0.0-0.5$ & & \\
\hline \hline
\end{tabular}

$\mathrm{ft}$ bgs = Feet below ground surface

$\mathrm{mg} / \mathrm{kg}=$ Milligrams per kilogram

$\mathrm{J}=$ Estimated value.

$\mathrm{M}=\mathrm{A}$ pattern resembling motor oil was detected.

$\mathrm{U}=$ Compound was analyzed for, but not detected ("non-detect").

$Z=$ Result did not resemble any common total petroleum hydrocarbons products. 
Table D.1-29

Soil Sample Results for Gamma-Emitting Radionuclides Detected Above Minimum Detectable Concentration Limits at CAS 02-09-52, U-2dc \#1 PS \#1A Mud Pit (1)

\begin{tabular}{|c|c|c|c|c|c|c|c|c|}
\hline \multirow[b]{2}{*}{$\begin{array}{l}\text { Sample } \\
\text { Location }\end{array}$} & \multirow[b]{2}{*}{$\begin{array}{l}\text { Sample } \\
\text { Number }\end{array}$} & \multirow[b]{2}{*}{$\begin{array}{c}\text { Depth } \\
\text { (ft bgs) }\end{array}$} & \multicolumn{6}{|c|}{ Contaminants of Potential Concern (pCi/g) } \\
\hline & & & 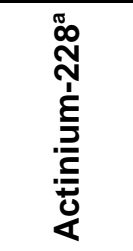 & 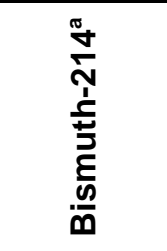 & 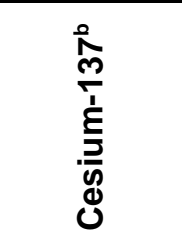 & 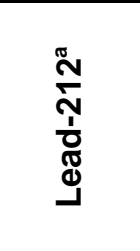 & 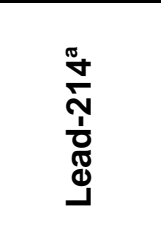 & 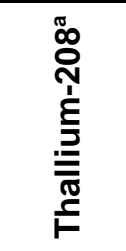 \\
\hline \multicolumn{3}{|c|}{ Final Action Levels } & 5 & 5 & \multirow{2}{*}{12.2} & 5 & 5 & 5 \\
\hline \multicolumn{3}{|c|}{ Depths bgs (cm) } & $<15$ & $<15$ & & $<15$ & $<15$ & $<15$ \\
\hline K01 & MPXK001 & $0.0-0.5$ & -- & $1.19(\mathrm{G}, \mathrm{J})$ & -- & $1.7(\mathrm{~J})^{\mathrm{C}}$ & -- & $0.59(\mathrm{G})$ \\
\hline K02 & MPXK002 & $0.0-0.5$ & -- & -- & $2.05(\mathrm{G})$ & $1.59(\mathrm{~J})^{\mathrm{c}}$ & $1.17(\mathrm{G}, \mathrm{J})$ & $0.53(G)$ \\
\hline \multirow{2}{*}{ K03 } & MPXK003 & $0.0-0.5$ & $1.47(\mathrm{G})$ & $1.01(G, J)$ & $0.62(\mathrm{G})$ & $1.66(\mathrm{~J})^{\mathrm{c}}$ & $0.87(\mathrm{G}, \mathrm{J})$ & $0.46(G)$ \\
\hline & MPXK201 & $0.0-0.5$ & $1.83(\mathrm{G})$ & -- & $0.57(\mathrm{G})$ & $1.57(\mathrm{~J})^{\mathrm{c}}$ & $0.94(G, J)$ & $0.71(G)$ \\
\hline K04 & MPXK004 & $0.0-0.5$ & -- & $1.19(\mathrm{G}, \mathrm{J})$ & $4.48(\mathrm{G})$ & $2.01(\mathrm{~J})^{\mathrm{c}}$ & $1.17(\mathrm{G}, \mathrm{J})$ & $0.72(G)$ \\
\hline K05 & MPXK005 & $0.0-0.5$ & -- & -- & $0.77(\mathrm{G})$ & $1.82(\mathrm{~J})^{\mathrm{c}}$ & $0.9(\mathrm{G}, \mathrm{J})$ & $0.54(G)$ \\
\hline K06 & MPXK006 & $0.0-0.5$ & -- & $1.18(\mathrm{G}, \mathrm{J})$ & $4.98(\mathrm{G})$ & $1.71(\mathrm{~J})^{\mathrm{c}}$ & -- & -- \\
\hline K07 & MPXK007 & $0.0-0.5$ & $1.8(\mathrm{G})$ & $0.77(\mathrm{G}, \mathrm{J})$ & $0.65(G)$ & $2.16(\mathrm{~J})^{\mathrm{c}}$ & $1.07(\mathrm{G}, \mathrm{J})$ & $0.59(G)$ \\
\hline K08 & MPXK008 & $0.0-0.5$ & -- & -- & $8.4(G)$ & $1.62(\mathrm{~J})^{\mathrm{c}}$ & -- & -- \\
\hline K09 & MPXK009 & $0.0-0.5$ & -- & -- & $4.01(\mathrm{G})$ & $1.64(\mathrm{~J})^{\mathrm{c}}$ & $0.94(G, J)$ & -- \\
\hline K10 & MPXK010 & $0.0-0.5$ & $1.61(\mathrm{G})$ & $0.74 \mathrm{G}, \mathrm{J})$ & $0.36(\mathrm{G}, \mathrm{LT})$ & $2.03(\mathrm{~J})^{\mathrm{c}}$ & $1.1(\mathrm{G}, \mathrm{J})$ & $0.53(G)$ \\
\hline
\end{tabular}

aTaken from the generic guidelines for residual concentrations of actinium-228, bismuth-214, lead-212, lead-214, thallium-208, and thorium-232, as found in Chapter IV of DOE Order 5400.5, Change 2, "Radiation Protection of the Public and Environment." (DOE, 1993). The PALs for these isotopes is specified as $5 \mathrm{pCi} / \mathrm{g}$ averaged over the first $15 \mathrm{~cm}$ of soil and $15 \mathrm{pCi} / \mathrm{g}$ for deeper soils (DOE, 1993). For purposes of this document, $15 \mathrm{~cm}$ is assumed to be equivalent to $0.5 \mathrm{ft}$ ( 6 inches); therefore, $5 \mathrm{pCi} / \mathrm{g}$ represents the PALs for these radionuclides in the surface soil (0 to $0.5 \mathrm{ft}$ depth).

${ }^{\mathrm{b}}$ Taken from the construction, commercial, industrial land use scenario in Table 2.1 of the NCRP Report No. 129, Recommended Screening Limits for Contaminated Surface Soil and Review Factors Relevant to Site-Specific Studies (NCRP, 1999). The values provided in this source document were scaled to a 25-mrem/yr dose.

${ }^{\circ} Q$ ualifier added to laboratory data; record accepted. Sample does not meet counting geometry requirements.

$\mathrm{cm}=$ Centimeters

$\mathrm{ft}$ bgs $=$ Feet below ground surface

$\mathrm{mrem} / \mathrm{yr}=$ Millirem per year

$\mathrm{pCi} / \mathrm{g}=$ Picocuries per gram

$--=$ Not detected above minimum reporting limits

$<=$ Less than

$\mathrm{G}=$ Sample density differs by more than $15 \%$ of laboratory control sample density.

$\mathrm{J}=$ Estimated value.

$\mathrm{LT}=$ Result is less than the requested minimum detectable concentration, greater than sample specific minimum detectable concentration. 
Table D.1-30

Soil Sample Results for Isotopes Detected Above Minimum

Detectable Concentration Limits at CAS 02-09-52, U-2dc \#1 PS \#1A Mud Pit (1)

\begin{tabular}{||c|c|c|c|c|c|c|c||}
\hline \multirow{2}{*}{$\begin{array}{c}\text { Sample } \\
\text { Location }\end{array}$} & \multirow{2}{*}{$\begin{array}{c}\text { Sample } \\
\text { Number }\end{array}$} & \multirow{2}{*}{$\begin{array}{c}\text { Depth } \\
\text { ft bgs) }\end{array}$} & \multicolumn{5}{|c||}{ Contaminants of Potential Concern (pCi/g) } \\
\cline { 5 - 8 } & & & Plutonium-238 & Plutonium-239 & Uranium-234 & Uranium-235 & Uranium-238 \\
\hline \multicolumn{2}{|c|}{ Final Action Levels } & & 13 & 12.7 & 143 & 17.5 & 105 \\
\hline \hline K01 & MPXK001 & $0.0-0.5$ & -- & 0.47 & 1.1 & 0.076 & 1.18 \\
\hline K02 & MPXK002 & $0.0-0.5$ & 0.324 & 1.32 & 0.86 & -- & 1.04 \\
\hline \multirow{2}{*}{ K03 } & MPXK003 & $0.0-0.5$ & -- & 0.082 & 1.02 & 0.065 & 1 \\
\cline { 2 - 8 } & MPXK201 & $0.0-0.5$ & 0.222 & 2.58 & 0.98 & 0.051 & 1.04 \\
\hline K04 & MPXK004 & $0.0-0.5$ & 0.162 & 0.93 & 1.08 & 0.062 & 1.07 \\
\hline K05 & MPXK005 & $0.0-0.5$ & -- & 0.56 & 1.14 & 0.172 & 1.09 \\
\hline K06 & MPXK006 & $0.0-0.5$ & 0.215 & 1.46 & 1.24 & 0.125 & 1.15 \\
\hline K07 & MPXK007 & $0.0-0.5$ & 0.056 & 0.281 & 0.96 & -- & 1.14 \\
\hline K08 & MPXK008 & $0.0-0.5$ & 0.25 & 2.05 & 0.98 & -- & 1.03 \\
\hline K09 & MPXK009 & $0.0-0.5$ & 0.321 & 2.08 & 1.27 & 0.045 (LT) & 1.37 \\
\hline K10 & MPXK010 & $0.0-0.5$ & 0.212 & 5.32 & 1.12 & 0.138 & 1 \\
\hline \hline
\end{tabular}

${ }^{\text {a } T a k e n ~ f r o m ~ t h e ~ c o n s t r u c t i o n, ~ c o m m e r c i a l, ~ i n d u s t r i a l ~ l a n d ~ u s e ~ s c e n a r i o ~ i n ~ T a b l e ~} 2.1$ of the NCRP Report No. 129, Recommended Screening Limits for Contaminated Surface Soil and Review Factors Relevant to Site-Specific Studies (NCRP, 1999). The values provided in this source document were scaled to a $25-\mathrm{mrem} / \mathrm{yr}$ dose.

$\mathrm{ft}$ bgs $=$ Feet below ground surface

$\mathrm{mrem} / \mathrm{yr}=$ Millirem per year

$\mathrm{pCi} / \mathrm{g}=$ Picocuries per gram

-- = Not detected above minimum reporting limits

$\mathrm{LT}=$ Result is less than requested minimum detectable concentration, greater than sample specific minimum detectable concentration . 
Table D.1-31

Samples Collected at CAS 03-09-15, U-3kL Mud Pit (2)

\begin{tabular}{|c|c|c|c|c|c|}
\hline $\begin{array}{l}\text { Sample } \\
\text { Location }\end{array}$ & $\begin{array}{l}\text { Sample } \\
\text { Number }\end{array}$ & $\begin{array}{l}\text { Depth } \\
\text { (ft bgs) }\end{array}$ & Matrix & Purpose & Analyses \\
\hline L01 & MPXL001 & $0.0-0.5$ & Soil & Environmental & TPH-DRO \\
\hline L02 & MPXL002 & $0.0-0.5$ & Soil & Environmental & TPH-DRO \\
\hline L03 & MPXL003 & $0.0-0.5$ & Soil & Environmental & TPH-DRO \\
\hline L04 & MPXL004 & $0.0-0.5$ & Soil & Environmental & TPH-DRO \\
\hline L05 & MPXL005 & $0.0-0.5$ & Soil & Environmental & TPH-DRO \\
\hline \multirow[b]{2}{*}{ L06 } & MPXL006 & $0.0-0.5$ & Soil & Environmental & TPH-DRO \\
\hline & MPXL201 & $0.0-0.5$ & Soil & $\begin{array}{c}\text { Field Duplicate } \\
\text { of \#MPXL006 }\end{array}$ & TPH-DRO \\
\hline L07 & MPXL007 & $0.0-0.5$ & Soil & Environmental & TPH-DRO \\
\hline L08 & MPXL008 & $0.0-0.5$ & Soil & $\begin{array}{c}\text { Environmental, } \\
\text { MS/MSD }\end{array}$ & TPH-DRO \\
\hline L09 & MPXL009 & $0.0-0.5$ & Soil & Environmental & TPH-DRO \\
\hline L10 & MPXL010 & $0.0-0.5$ & Soil & Environmental & TPH-DRO \\
\hline
\end{tabular}

$\mathrm{ft}$ bgs = Feet below ground surface MS/MSD = Matrix spike/matrix spike duplicate

$\mathrm{TPH}-\mathrm{DRO}=$ Total petroleum hydrocarbons, diesel-range organics 
Table D.1-32

Soil Sample Results for TPH-DRO at CAS 03-09-15, U-3kL Mud Pit (2)

\begin{tabular}{|c|c|c|c|c|}
\hline \multirow{2}{*}{$\begin{array}{c}\text { Sample } \\
\text { Location }\end{array}$} & \multirow{2}{*}{$\begin{array}{c}\text { Sample } \\
\text { Number }\end{array}$} & \multirow{2}{*}{$\begin{array}{c}\text { Depth } \\
\text { (ft bgs) }\end{array}$} & \multicolumn{2}{|c|}{ Contaminants of Potential Concern (mg/kg) } \\
\hline & & & Result & Detection Limit \\
\hline L01 & MPXL001 & $0.0-0.5$ & $5.6(U)$ & 5.6 \\
\hline L02 & MPXL002 & $0.0-0.5$ & $7(U)$ & 7 \\
\hline L03 & MPXL003 & $0.0-0.5$ & $5.1(U)$ & 5.1 \\
\hline L04 & MPXL004 & $0.0-0.5$ & $5.2(U)$ & 5.2 \\
\hline L05 & MPXL005 & $0.0-0.5$ & $5.1(U)$ & 5.1 \\
\hline \multirow{2}{*}{ L06 } & MPXL006 & $0.0-0.5$ & $5.5(U)$ & 5.5 \\
\hline & MPXL201 & $0.0-0.5$ & $5.6(U)$ & 5.6 \\
\hline L07 & MPXL007 & $0.0-0.5$ & $5.2(U)$ & 5.2 \\
\hline L08 & MPXL008 & $0.0-0.5$ & $5.1(U)$ & 5.1 \\
\hline L09 & MPXL009 & $0.0-0.5$ & $5.2(U)$ & 5.2 \\
\hline L10 & MPXL010 & $0.0-0.5$ & $5.2(\mathrm{U})$ & 5.2 \\
\hline
\end{tabular}

$\mathrm{ft}$ bgs = Feet below ground surface

$\mathrm{mg} / \mathrm{kg}=$ Milligrams per kilogram

TPH-DRO = Total petroleum hydrocarbons, diesel-range organics

$\mathrm{U}=$ Compound was analyzed for, but not detected ("non-detect"). 
Table D.1-33

Samples Collected at CAS 03-09-17, U-3hc Mud Pit (2)

\begin{tabular}{|c|c|c|c|c|c|}
\hline $\begin{array}{l}\text { Sample } \\
\text { Location }\end{array}$ & $\begin{array}{l}\text { Sample } \\
\text { Number }\end{array}$ & $\begin{array}{c}\text { Depth } \\
\text { (ft bgs) }\end{array}$ & Matrix & Purpose & Analyses \\
\hline M01 & MPXM001 & $0.0-0.5$ & Soil & Environmental & TPH-DRO \\
\hline \multirow{2}{*}{ M02 } & MPXM002 & $0.0-0.5$ & Soil & Environmental & Set 2 \\
\hline & MPXM013 & $0.0-0.5$ & Soil & Environmental & Set 5 \\
\hline \multirow{3}{*}{ M03 } & MPXM003 & $0.0-0.5$ & Soil & Environmental & Set 2 \\
\hline & MPXM201 & $0.0-0.5$ & Soil & $\begin{array}{l}\text { Field Duplicate } \\
\text { of \#MPXM003 }\end{array}$ & Set 2 \\
\hline & MPXM014 & $0.0-0.5$ & Soil & Environmental & Set 5 \\
\hline \multirow{2}{*}{ M04 } & MPXM004 & $0.0-0.5$ & Soil & Environmental & Set 2 \\
\hline & MPXM012 & $0.0-0.5$ & Soil & Environmental & Set 5 \\
\hline M05 & MPXM005 & $0.0-0.5$ & Soil & Environmental & TPH-DRO \\
\hline M06 & MPXM006 & $0.0-0.5$ & Soil & Environmental & TPH-DRO \\
\hline M07 & MPXM007 & $0.0-0.5$ & Soil & Environmental & TPH-DRO \\
\hline M08 & MPXM008 & $0.0-0.5$ & Soil & $\begin{array}{c}\text { Environmental, } \\
\text { MS/MSD }\end{array}$ & TPH-DRO \\
\hline M09 & MPXM009 & $0.0-0.5$ & Soil & Environmental & TPH-DRO \\
\hline M10 & MPXM010 & $0.0-0.5$ & Soil & Environmental & TPH-DRO \\
\hline M11 & MPXM301 & $0.0-0.5$ & CTE & $\begin{array}{c}\text { Waste } \\
\text { Management }\end{array}$ & Set 4 \\
\hline M12 & MPXM302 & 0.05 & Soil & $\begin{array}{c}\text { Waste } \\
\text { Management }\end{array}$ & Set 5 \\
\hline M13 & MPXM011 & $0.0-0.5$ & Soil & Environmental & TPH-DRO \\
\hline $\mathrm{N} / \mathrm{A}$ & MPXM303 & N/A & Water & Trip Blank & VOCs \\
\hline N/A & MPXM401 & N/A & Water & Field Blank & Set 3 \\
\hline N/A & MPXM402 & $\mathrm{N} / \mathrm{A}$ & Water & Trip Blank & VOCs \\
\hline
\end{tabular}

Set $2=$ TPH-DRO, SVOCs

Set $3=$ TPH-DRO, SVOCs, gamma spectroscopy, isotopic uranium, isotopic plutonium, strontium-90

Set 4 = TPH-DRO, SVOCs, VOCs, RCRA Metals, TCLP VOC, TCLP SVOC, TCLP RCRA metals, gamma spectroscopy, isotopic uranium, isotopic plutonium, strontium-90

Set $5=$ TPH-DRO, VOCs, SVOCs

CTE = Coal tar epoxy

$\mathrm{ft}$ bgs $=$ Feet below ground surface

MS/MSD = Matrix spike/matrix spike duplicate

N/A = Not applicable

RCRA = Resource Conservation and Recovery Act

SVOC $=$ Semivolatile organic compound

TCLP $=$ Toxicity characteristic leaching procedure

TPH-DRO = Total petroleum hydrocarbons, diesel-range organics

VOC $=$ Volatile organic compound 
Table D.1-34

Soil Sample Results for TPH-DRO at CAS 03-09-17, U-3hc Mud Pit (2)

\begin{tabular}{|c|c|c|c|c|}
\hline \multirow{2}{*}{$\begin{array}{c}\text { Sample } \\
\text { Location }\end{array}$} & \multirow{2}{*}{$\begin{array}{l}\text { Sample } \\
\text { Number }\end{array}$} & \multirow{2}{*}{$\begin{array}{l}\text { Depth } \\
\text { (ft bgs) }\end{array}$} & \multicolumn{2}{|c|}{ Contaminants of Potential Concern $(\mathrm{mg} / \mathrm{kg})$} \\
\hline & & & Result & Detection Limit \\
\hline M01 & MPXM001 & $0.0-0.5$ & $82(H)$ & 5.7 \\
\hline \multirow{2}{*}{ M02 } & MPXM002 & $0.0-0.5$ & $120(H, Z)$ & 6 \\
\hline & MPXM013* & $0.0-0.5$ & $5.7(U)$ & 5.7 \\
\hline \multirow{3}{*}{ M03 } & MPXM003 & $0.0-0.5$ & $6.2(U)$ & 6.2 \\
\hline & MPXM201 & $0.0-0.5$ & $210(H, Z)$ & 6.1 \\
\hline & MPXM014* & $0.0-0.5$ & $5.6(U)$ & 5.6 \\
\hline \multirow{2}{*}{ M04 } & MPXM004 & $0.0-0.5$ & $6.4(\mathrm{M}, \mathrm{Z})$ & 6 \\
\hline & MPXM012* & $0.0-0.5$ & $5.9(U)$ & 5.9 \\
\hline M05 & MPXM005 & $0.0-0.5$ & $28(\mathrm{M})$ & 5.4 \\
\hline M06 & MPXM006 & $0.0-0.5$ & $5.3(U)$ & 5.3 \\
\hline M07 & MPXM007 & $0.0-0.5$ & $5.8(U)$ & 5.8 \\
\hline M08 & MPXM008 & $0.0-0.5$ & $5.8(U)$ & 5.8 \\
\hline M09 & MPXM009 & $0.0-0.5$ & $5.8(U)$ & 5.8 \\
\hline M10 & MPXM010 & $0.0-0.5$ & $5.7(U)$ & 5.7 \\
\hline M13 & MPXM011 & $0.0-0.5$ & $5.8(U)$ & 5.8 \\
\hline
\end{tabular}

DRO = Diesel-range organics

$\mathrm{ft}$ bgs $=$ Feet below ground surface

$\mathrm{mg} / \mathrm{kg}=$ Milligrams per kilogram

$\mathrm{H}=$ Fuel pattern in the heavier end of retention time window.

$\mathrm{M}=\mathrm{A}$ pattern resembling motor oil was detected.

$\mathrm{U}=$ Compound was analyzed for, but not detected ("non-detect").

$\mathrm{UCL}=$ Upper confidence limit

$Z=$ Result did not resemble any common TPH products.

*The DRO result for this sample replaces the previous result in calculating the 95\% UCL of the mean DRO concentration for risk-based closure. Previous sample results at this location were not representative of the mud pit due to the presence of anomalous coal tar epoxy debris, which has since been removed from the CAS. 
Table D.1-35

Soil Sample Results for Total SVOCs Detected Above Minimum Reporting Limits at CAS 03-09-17, U-3hc Mud Pit (2)

\begin{tabular}{|c|c|c|c|c|c|c|c|c|c|c|c|c|c|c|c|c|c|c|c|c|}
\hline \multirow[b]{2}{*}{ 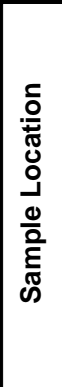 } & \multirow[b]{2}{*}{ 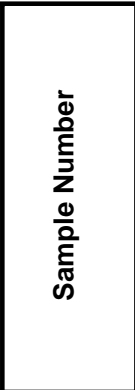 } & \multirow[b]{2}{*}{ 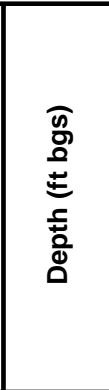 } & \multicolumn{18}{|c|}{ Contaminants of Potential Concern $(\mu \mathrm{g} / \mathrm{kg})$} \\
\hline & & & 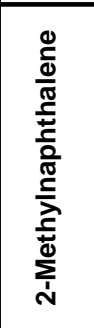 & 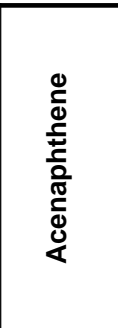 & 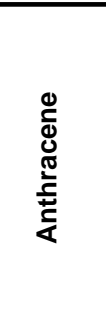 & 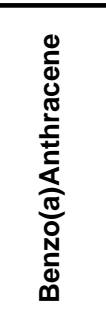 & 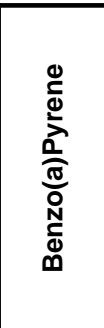 & 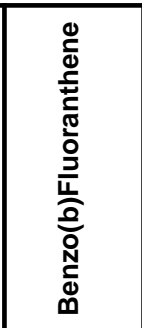 & 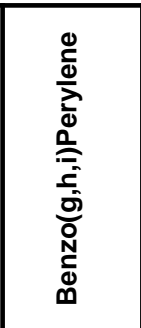 & 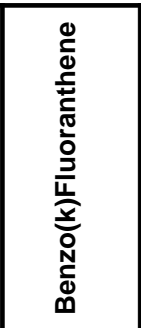 & 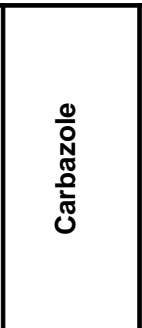 & 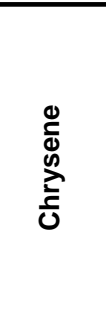 & 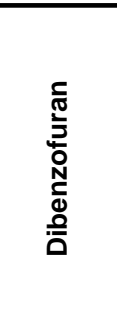 & 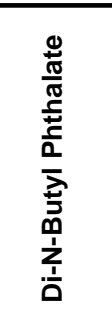 & 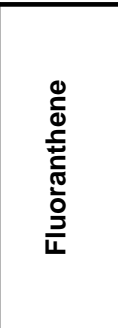 & $\begin{array}{l}\frac{0}{0} \\
\frac{0}{0} \\
\text { 은 }\end{array}$ & 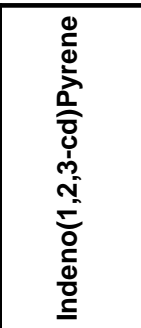 & 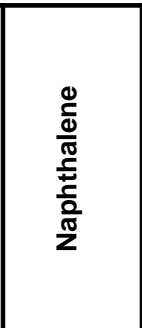 & 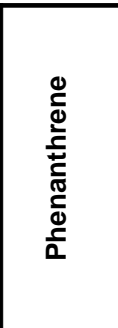 & 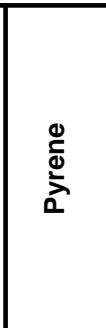 \\
\hline \multicolumn{3}{|c|}{ Final Action Levels ${ }^{a}$} & 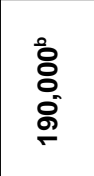 & 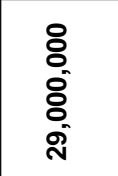 & $\begin{array}{l}8 \\
8 \\
8 \\
8 \\
8 \\
8 \\
8 \\
\end{array}$ & $\underset{\sim}{\stackrel{9}{+}}$ & 옥 & 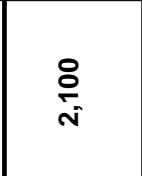 & 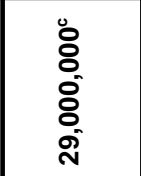 & $\begin{array}{l}\text { ¿ } \\
\text { ì }\end{array}$ & $\begin{array}{l}\text { ¿ } \\
\text { ¿. } \\
\infty\end{array}$ & $\begin{array}{l}8 \\
8 \\
0 \\
\text { ㄱ. }\end{array}$ & $\begin{array}{l}8 \\
8 \\
8 \\
8 \\
\end{array}$ & 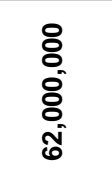 & 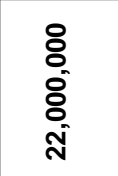 & 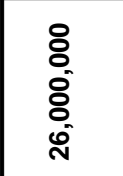 & 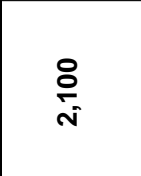 & 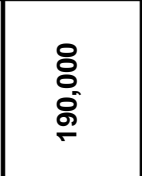 & $\begin{array}{l}\text { ¿े } \\
8 \\
8 \\
8 \\
8 \\
8 \\
8\end{array}$ & 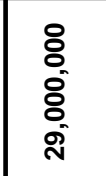 \\
\hline \multirow[t]{2}{*}{ M02 } & MPXM002 & $0.0-0.5$ & 6,100 & $2,700(\mathrm{~J})$ & $\begin{array}{c}2,600 \\
(\mathrm{~J})\end{array}$ & 5,100 & 4,300 & 5,700 & $1,500(\mathrm{~J})^{\mathrm{e}}$ & $2,900(\mathrm{~J})$ & $1,800(\mathrm{~J})$ & 4,600 & $3,000(\mathrm{~J})$ & 26,000 & 15,000 & $3,100(\mathrm{~J})$ & $1,700(\mathrm{~J})$ & $2,500(\mathrm{~J})$ & 15,000 & 13,000 \\
\hline & MPXM013 & $0.0-0.5$ & $\overline{--}$ & $\overline{--}$ & $\overline{--}$ & $\overline{--}$ & $\overline{--}$ & $\overline{--}$ & $\overline{--}$ & $\overline{--}$ & $\overline{--}$ & $\overline{--}$ & $\overline{--}$ & $\overline{--}$ & $\overline{--}$ & $\overline{--}$ & $\overline{--}$ & $\overline{--}$ & $\overline{--}$ & $\overline{--}$ \\
\hline \multirow{3}{*}{ M03 } & MPXM003 & $0.0-0.5$ & $\begin{array}{c}41,000 \\
(\mathrm{~J})^{\mathrm{f}}\end{array}$ & $\begin{array}{c}31,000 \\
(J)^{\mathrm{f}}\end{array}$ & $\begin{array}{c}34,000 \\
(\mathrm{~J})^{\mathrm{f}}\end{array}$ & $\begin{array}{c}50,000 \\
(\mathrm{~J})^{\dagger}\end{array}$ & $\begin{array}{c}39,000 \\
(\mathrm{~J})^{\mathrm{f}}\end{array}$ & $44,000(J)^{f}$ & $12,000(\mathrm{~J})^{\mathrm{g}}$ & $26,000(\mathrm{~J})^{\dagger}$ & $21,000(\mathrm{~J})^{\mathrm{f}}$ & $\begin{array}{c}46,000 \\
(\mathrm{~J})^{\dagger}\end{array}$ & $\begin{array}{c}29,000 \\
(\mathrm{~J})^{\dagger}\end{array}$ & $\begin{array}{c}290,000 \\
(\mathrm{~J})^{\dagger}\end{array}$ & $\begin{array}{c}160,000 \\
(\mathrm{~J})^{\mathrm{f}}\end{array}$ & $\begin{array}{c}34,000 \\
(\mathrm{~J})^{\dagger}\end{array}$ & $16,000(\mathrm{~J})^{f}$ & $11,000(\mathrm{~J})^{\mathrm{f}}$ & $\begin{array}{c}160,000 \\
(\mathrm{~J})^{\mathrm{f}}\end{array}$ & $\begin{array}{c}130,000 \\
(\mathrm{~J})^{\dagger}\end{array}$ \\
\hline & MPXM201 & $0.0-0.5$ & $\begin{array}{c}130,00 \\
0(\mathrm{~J})^{\dagger}\end{array}$ & $\begin{array}{c}67,000 \\
(\mathrm{~J})^{\mathrm{t}}\end{array}$ & $\begin{array}{c}70,000 \\
(\mathrm{~J})^{f}\end{array}$ & $\begin{array}{c}92,000 \\
(\mathrm{~J})^{\dagger}\end{array}$ & $\begin{array}{c}68,000 \\
(\mathrm{~J})^{f}\end{array}$ & $78,000(\mathrm{~J})^{\dagger}$ & $20,000(\mathrm{~J})^{\mathrm{g}}$ & $49,000(\mathrm{~J})^{f}$ & $40,000(\mathrm{~J})^{\dagger}$ & $\begin{array}{c}79,000 \\
(\mathrm{~J})^{\dagger}\end{array}$ & $\begin{array}{c}63,000 \\
(J)^{t}\end{array}$ & $\begin{array}{c}540,000 \\
(\mathrm{~J})^{\dagger}\end{array}$ & $\begin{array}{c}280,000 \\
(\mathrm{~J})^{f}\end{array}$ & $\begin{array}{c}70,000 \\
(\mathrm{~J})^{\dagger}\end{array}$ & $30,000(\mathrm{~J})^{\dagger}$ & $46,000(\mathrm{~J})^{\dagger}$ & $\begin{array}{c}310,000 \\
(\mathrm{~J})^{f}\end{array}$ & $\begin{array}{c}190,000 \\
(\mathrm{~J})^{f}\end{array}$ \\
\hline & MPXM014 & $0.0-0.5$ & $\overline{--}$ & $\overline{--}$ & -- & -- & -- & -- & -- & -- & -- & $\overline{--}$ & -- & $43(\mathrm{~J})$ & -- & -- & -- & -- & -- & $\overline{--}$ \\
\hline \multirow{2}{*}{ M04 } & MPXM004 & $0.0-0.5$ & $\overline{--}$ & $\overline{--}$ & $\overline{--}$ & -- & $\overline{--}$ & -- & -- & 740 & $\overline{--}$ & -- & -- & $73(\mathrm{~J})$ & $36(\mathrm{~J})$ & $\overline{--}$ & -- & $\overline{--}$ & $38(\mathrm{~J})$ & $27(\mathrm{~J})$ \\
\hline & MPXM012 & $0.0-0.5$ & -- & -- & -- & -- & -- & -- & -- & -- & -- & -- & -- & -- & -- & -- & -- & -- & -- & -- \\
\hline
\end{tabular}

aBased on U.S. Environmental Protection Agency, Region 9 Preliminary Remediation Goals (PRGs) (EPA, 2002)

${ }^{\mathrm{b}}$ The PAL is a surrogate PRG using 91-20-3 naphthalene

'The PAL is a surrogate PRG using 129-00-0 pyrene

The PAL is a surrogate PRG using 120-12-7 anthracene

eQualifier added to laboratory data; record accepted. Calibration verification did not meet criteria or was not performed.

Qualifier added to laboratory data; record accepted. Surrogates diluted out.

${ }^{9}$ Qualifier added to laboratory data; record accepted. Calibration verification did not meet criteria or was not performed. Surrogates diluted out.

$\mathrm{ft}$ bgs $=$ Feet below ground surface

$\mu \mathrm{g} / \mathrm{kg}=$ Micrograms per kilogram

-- = Not detected above minimum reporting limits. 
Table D.1-36

Samples Collected at CAS 03-09-21, U-3gv Mud Pit (2)

\begin{tabular}{|c|c|c|c|c|c|}
\hline $\begin{array}{c}\text { Sample } \\
\text { Location }\end{array}$ & $\begin{array}{l}\text { Sample } \\
\text { Number }\end{array}$ & $\begin{array}{l}\text { Depth } \\
\text { (ft bgs) }\end{array}$ & Matrix & Purpose & Analyses \\
\hline N01 & MPXN001 & $0.0-0.5$ & Soil & Environmental & TPH-DRO \\
\hline N02 & MPXN002 & $0.0-0.5$ & Soil & Environmental & TPH-DRO \\
\hline N03 & MPXN003 & $0.0-0.5$ & Soil & Environmental & TPH-DRO \\
\hline N04 & MPXN004 & $0.0-0.5$ & Soil & Environmental & TPH-DRO \\
\hline \multirow[b]{2}{*}{ N05 } & MPXN005 & $0.0-0.5$ & Soil & Environmental & TPH-DRO \\
\hline & MPXN201 & $0.0-0.5$ & Soil & $\begin{array}{l}\text { Field Duplicate } \\
\text { of \#MPXN005 }\end{array}$ & TPH-DRO \\
\hline N06 & MPXN006 & $0.0-0.5$ & Soil & $\begin{array}{c}\text { Environmental, } \\
\text { MS/MSD }\end{array}$ & TPH-DRO \\
\hline N07 & MPXN007 & $0.0-0.5$ & Soil & Environmental & TPH-DRO \\
\hline N08 & MPXN008 & $0.0-0.5$ & Soil & Environmental & TPH-DRO \\
\hline N09 & MPXN009 & $0.0-0.5$ & Soil & Environmental & TPH-DRO \\
\hline N10 & MPXN010 & $0.0-0.5$ & Soil & Environmental & TPH-DRO \\
\hline
\end{tabular}

$\mathrm{ft}$ bgs $=$ Feet below ground surface

MS/MSD = Matrix spike/matrix spike duplicate

TPH-DRO = Total petroleum hydrocarbons, diesel-range organics 
Table D.1-37

Soil Sample Results for TPH-DRO at CAS 03-09-21, U-3gv Mud Pit (2)

\begin{tabular}{|c|c|c|c|c|}
\hline \multirow{2}{*}{$\begin{array}{c}\text { Sample } \\
\text { Location }\end{array}$} & \multirow{2}{*}{$\begin{array}{l}\text { Sample } \\
\text { Number }\end{array}$} & \multirow{2}{*}{$\begin{array}{c}\text { Depth } \\
\text { (ft bgs) }\end{array}$} & \multicolumn{2}{|c|}{ Contaminants of Potential Concern (mg/kg) } \\
\hline & & & Result & Detection Limit \\
\hline N01 & MPXN001 & $0.0-0.5$ & $11(\mathrm{M})$ & 5.3 \\
\hline N02 & MPXN002 & $0.0-0.5$ & $15(\mathrm{M}, \mathrm{Z})$ & 5.3 \\
\hline \multirow{2}{*}{ N03 } & MPXN003 & $0.0-0.5$ & $5.7(U)$ & 5.7 \\
\hline & MPXN201 & $0.0-0.5$ & $5.5(U)$ & 5.5 \\
\hline N04 & MPXN004 & $0.0-0.5$ & $5.5(U)$ & 5.5 \\
\hline N05 & MPXN005 & $0.0-0.5$ & $5.6(U)$ & 5.6 \\
\hline N06 & MPXN006 & $0.0-0.5$ & $5.4(U)$ & 5.4 \\
\hline N07 & MPXN007 & $0.0-0.5$ & $5.4(U)$ & 5.4 \\
\hline N08 & MPXN008 & $0.0-0.5$ & $5.6(U)$ & 5.6 \\
\hline N09 & MPXN009 & $0.0-0.5$ & $5.5(U)$ & 5.5 \\
\hline N10 & MPXN010 & $0.0-0.5$ & $5.3(U)$ & 5.3 \\
\hline
\end{tabular}

$\mathrm{ft}$ bgs $=$ Feet below ground surface

$\mathrm{mg} / \mathrm{kg}=$ Milligrams per kilogram

$\mathrm{M}=\mathrm{A}$ pattern resembling motor oil was detected.

$\mathrm{U}=$ Compound was analyzed for, but not detected ("non-detect").

$Z=$ Result did not resemble any common total petroleum hydrocarbons products. 
Table D.1-38

Samples Collected at CAS 03-09-30, UE-3Lj/Inst. Mud Pit (1)

\begin{tabular}{|c|c|c|c|c|c|}
\hline $\begin{array}{c}\text { Sample } \\
\text { Location }\end{array}$ & $\begin{array}{l}\text { Sample } \\
\text { Number }\end{array}$ & $\begin{array}{c}\text { Depth } \\
\text { (ft bgs) }\end{array}$ & Matrix & Purpose & Analyses \\
\hline $\mathrm{O} 01$ & MPXO001 & $0.0-0.5$ & Soil & Environmental & TPH-DRO \\
\hline $\mathrm{O} 02$ & MPX0002 & $0.0-0.5$ & Soil & $\begin{array}{c}\text { Environmental, } \\
\text { MS/MSD }\end{array}$ & TPH-DRO \\
\hline $\mathrm{O} 03$ & MPX0003 & $0.0-0.5$ & Soil & Environmental & TPH-DRO \\
\hline O04 & MPX0004 & $0.0-0.5$ & Soil & Environmental & TPH-DRO \\
\hline O05 & MPX0005 & $0.0-0.5$ & Soil & Environmental & TPH-DRO \\
\hline 006 & MPX0006 & $0.0-0.5$ & Soil & Environmental & TPH-DRO \\
\hline 007 & MPXO007 & $0.0-0.5$ & Soil & Environmental & TPH-DRO \\
\hline O08 & MPX0008 & $0.0-0.5$ & Soil & Environmental & TPH-DRO \\
\hline \multirow[b]{2}{*}{ O09 } & MPX0009 & $0.0-0.5$ & Soil & Environmental & TPH-DRO \\
\hline & MPXO201 & $0.0-0.5$ & Soil & $\begin{array}{l}\text { Field Duplicate } \\
\text { of \#MPXO009 }\end{array}$ & TPH-DRO \\
\hline O10 & MPX0010 & $0.0-0.5$ & Soil & Environmental & TPH-DRO \\
\hline
\end{tabular}

$\mathrm{ft}$ bgs = Feet below ground surface MS/MSD = Matrix spike/matrix spike duplicate

$\mathrm{TPH}-\mathrm{DRO}=$ Total petroleum hydrocarbons, diesel-range organics 
Table D.1-39

Soil Sample Results for TPH-DRO at CAS 03-09-30, UE-3Lj/Inst. Mud Pit (1)

\begin{tabular}{||c|c|c|c|c||}
\hline \multirow{2}{*}{$\begin{array}{c}\text { Sample } \\
\text { Location }\end{array}$} & \multirow{2}{*}{$\begin{array}{c}\text { Sample } \\
\text { Number }\end{array}$} & \multirow{2}{*}{$\begin{array}{c}\text { Depth } \\
\text { ft bgs) }\end{array}$} & \multicolumn{2}{|c|}{ Contaminants of Potential Concern (mg/kg) } \\
\cline { 4 - 5 } & & Result & Detection Limit \\
\hline \hline O01 & MPXO001 & $0.0-0.5$ & $5.6(\mathrm{UJ})$ & 5.6 \\
\hline O02 & MPXO002R1 & $0.0-0.5$ & $21(\mathrm{~B}, \mathrm{M})$ & 5.7 \\
\hline O03 & MPXO003 & $0.0-0.5$ & $4.3(\mathrm{~J})$ & 5.8 \\
\hline O04 & MPXO004R1 & $0.0-0.5$ & $11(\mathrm{~B}, \mathrm{M})$ & 5.7 \\
\hline O05 & MPXO005R1 & $0.0-0.5$ & $16(\mathrm{~B}, \mathrm{M})$ & 5.8 \\
\hline O06 & MPXO006 & $0.0-0.5$ & $6.4(\mathrm{UJ})$ & 6.4 \\
\hline O07 & MPXO007 & $0.0-0.5$ & $7.8(\mathrm{UJ})$ & 7.8 \\
\hline O08 & MPXO008 & $0.0-0.5$ & $5.8(\mathrm{UJ})$ & 5.8 \\
\hline \multirow{2}{*}{ O09 } & MPXO009 & $0.0-0.5$ & $5.7(\mathrm{UJ})$ & 5.7 \\
\cline { 2 - 5 } & MPXO201 & $0.0-0.5$ & $5.6(\mathrm{U})$ & 5.6 \\
\hline O10 & MPXO010 & $0.0-0.5$ & $5.9(\mathrm{U})$ & 5.9 \\
\hline
\end{tabular}

$\mathrm{ft}$ bgs $=$ Feet below ground surface

$\mathrm{mg} / \mathrm{kg}=$ Milligrams per kilogram

$B=$ Value less than the contract required detection limit, but greater than or equal to the instrument detection limit.

$\mathrm{J}=$ Estimated value.

$\mathrm{M}=\mathrm{A}$ pattern resembling motor oil was detected.

$\mathrm{U}=$ Compound was analyzed for, but not detected ("non-detect").

$\mathrm{R} 1=\mathrm{Re}$-run of original sample and has its own unique results and qualifiers. 
Table D.1-40

Samples Collected at CAS 04-09-06, U-4uPS \#1A Covered Mud Pit (1)

\begin{tabular}{|c|c|c|c|c|c|}
\hline $\begin{array}{c}\text { Sample } \\
\text { Location }\end{array}$ & $\begin{array}{l}\text { Sample } \\
\text { Number }\end{array}$ & $\begin{array}{l}\text { Depth } \\
\text { (ft bgs) }\end{array}$ & Matrix & Purpose & Analyses \\
\hline P01 & MPXP001 & $4.5-5.0$ & Soil & Environmental & TPH-DRO \\
\hline P02 & MPXP002 & $5.0-5.5$ & Soil & Environmental & TPH-DRO \\
\hline \multirow[b]{2}{*}{ P03 } & MPXP003 & $4.5-5.0$ & Soil & Environmental & TPH-DRO \\
\hline & MPXP201 & $4.5-5.0$ & Soil & $\begin{array}{c}\text { Field Duplicate } \\
\text { of \#MPXP003 }\end{array}$ & TPH-DRO \\
\hline P04 & MPXP004 & $4.5-5.0$ & Soil & $\begin{array}{c}\text { Environmental, } \\
\text { MS/MSD }\end{array}$ & TPH-DRO \\
\hline P05 & MPXP005 & $4.5-5.0$ & Soil & Environmental & TPH-DRO \\
\hline P06 & MPXP006 & $4.5-5.0$ & Soil & Environmental & TPH-DRO \\
\hline P07 & MPXP007 & $4.5-5.0$ & Soil & Environmental & TPH-DRO \\
\hline P08 & MPXР008 & $4.5-5.0$ & Soil & Environmental & TPH-DRO \\
\hline P09 & MPXP009 & $4.5-5.0$ & Soil & Environmental & TPH-DRO \\
\hline P10 & MPXP010 & $4.5-5.0$ & Soil & Environmental & TPH-DRO \\
\hline N/A & MPXP401 & N/A & Water & Field Blank & TPH-DRO \\
\hline
\end{tabular}

$\mathrm{ft}$ bgs $=$ Feet below ground surface

MS/MSD = Matrix spike/matrix spike duplicate

N/A $=$ Not applicable

TPH-DRO = Total petroleum hydrocarbons, diesel-range organics 
Table D.1-41

Soil Sample Results for TPH-DRO at CAS 04-09-06, U-4uPS \#1A Covered Mud Pit (1)

\begin{tabular}{||c|c|c|c|c||}
\hline \multirow{2}{*}{$\begin{array}{c}\text { Sample } \\
\text { Location }\end{array}$} & \multirow{2}{*}{$\begin{array}{c}\text { Sample } \\
\text { Number }\end{array}$} & \multirow{2}{*}{$\begin{array}{c}\text { Depth } \\
\text { ff bgs) }\end{array}$} & \multicolumn{2}{|c|}{ Contaminants of Potential Concern (mg/kg) } \\
\cline { 4 - 5 } & & & Result & Detection Limit \\
\hline \hline P01 & MPXP001 & $4.5-5.0$ & $5.3(U)$ & 5.3 \\
\hline P02 & MPXP002 & $5.0-5.5$ & $5.3(U)$ & 5.3 \\
\hline \multirow{2}{*}{ P03 } & MPXP003 & $4.5-5.0$ & $5.4(U)$ & 5.4 \\
\cline { 3 - 5 } & MPXP201 & $4.5-5.0$ & $5.5(U)$ & 5.5 \\
\hline P04 & MPXP004 & $4.5-5.0$ & $5.2(U)$ & 5.2 \\
\hline P05 & MPXP005 & $4.5-5.0$ & $5.3(U)$ & 5.3 \\
\hline P06 & MPXP006 & $4.5-5.0$ & $5.3(U)$ & 5.3 \\
\hline P07 & MPXP007 & $4.5-5.0$ & $5.3(U)$ & 5.3 \\
\hline P08 & MPXP008 & $4.5-5.0$ & $5.3(U)$ & 5.9 \\
\hline P09 & MPXP009 & $4.5-5.0$ & $5.9(U)$ & 5.3 \\
\hline P10 & MPXP010 & $4.5-5.0$ & $5.3(U)$ & \\
\hline
\end{tabular}

$\mathrm{ft}$ bgs $=$ Feet below ground surface

$\mathrm{mg} / \mathrm{kg}=$ Milligrams per kilogram

$\mathrm{U}=$ Compound was analyzed for, but not detected ("non-detect"). 
Table D.1-42

Samples Collected at CAS 04-09-08, U-4ad Mud Pit (1)

\begin{tabular}{||c|c|c|c|c|c||}
\hline $\begin{array}{c}\text { Sample } \\
\text { Location }\end{array}$ & $\begin{array}{c}\text { Sample } \\
\text { Number }\end{array}$ & $\begin{array}{c}\text { Depth } \\
\text { (ft bgs) }\end{array}$ & Matrix & Purpose & Analyses \\
\hline \hline Q01 & MPXQ001 & $0.0-0.5$ & Soil & Environmental & TPH-DRO \\
\hline Q02 & MPXQ002 & $0.0-0.5$ & Soil & Environmental & TPH-DRO \\
\hline Q03 & MPXQ003 & $0.0-0.5$ & Soil & Environmental & TPH-DRO \\
\hline Q04 & MPXQ004 & $0.0-0.5$ & Soil & Environmental & TPH-DRO \\
\hline Q05 & MPXQ005 & $0.0-0.5$ & Soil & $\begin{array}{c}\text { Environmental, } \\
\text { MS/MSD }\end{array}$ & TPH-DRO \\
\hline Q06 & MPXQ006 & $0.0-0.5$ & Soil & Environmental & TPH-DRO \\
\hline Q07 & MPXQ007 & $0.0-0.5$ & Soil & Environmental & TPH-DRO \\
\hline & MPXQ008 & $0.0-0.5$ & Soil & Environmental & TPH-DRO \\
\cline { 2 - 6 } Q08 & MPXQ201 & $0.0-0.5$ & Soil & $\begin{array}{c}\text { Field Duplicate } \\
\text { of \#MPXQ008 }\end{array}$ & TPH-DRO \\
\hline Q09 & MPXQ009 & $0.0-0.5$ & Soil & Environmental & TPH-DRO \\
\hline Q10 & MPXQ010 & $0.0-0.5$ & Soil & Environmental & TPH-DRO \\
\hline N/A & MPXQ401 & N/A & Water & Field Blank & TPH-DRO \\
\hline
\end{tabular}

$\mathrm{ft}$ bgs $=$ Feet below ground surface

MS/MSD = Matrix spike/matrix spike duplicate

N/A = Not applicable

TPH-DRO = Total petroleum hydrocarbons, diesel-range organics 
Table D.1-43

Soil Sample Results for TPH-DRO at CAS 04-09-08, U-4ad Mud Pit (1)

\begin{tabular}{|c|c|c|c|c|}
\hline \multirow{2}{*}{$\begin{array}{l}\text { Sample } \\
\text { Location }\end{array}$} & \multirow{2}{*}{$\begin{array}{l}\text { Sample } \\
\text { Number }\end{array}$} & \multirow{2}{*}{$\begin{array}{l}\text { Depth } \\
\text { (ft bgs) }\end{array}$} & \multicolumn{2}{|c|}{ Contaminants of Potential Concern (mg/kg) } \\
\hline & & & Result & Detection Limit \\
\hline Q01 & MPXQ001 & $0.0-0.5$ & $5.8(U)$ & 5.8 \\
\hline Q02 & MPXQ002 & $0.0-0.5$ & $6(U)$ & 6 \\
\hline Q03 & MPXQ003 & $0.0-0.5$ & $6.4(U)$ & 6.4 \\
\hline Q04 & MPXQ004 & $0.0-0.5$ & $6.2(U)$ & 6.2 \\
\hline Q05 & MPXQ005 & $0.0-0.5$ & $5.7(U)$ & 5.7 \\
\hline Q06 & MPXQ006 & $0.0-0.5$ & $6(U)$ & 6 \\
\hline Q07 & MPXQ007 & $0.0-0.5$ & $5.9(\mathrm{U})$ & 5.9 \\
\hline \multirow{2}{*}{ Q08 } & MPXQ008 & $0.0-0.5$ & $6(U)$ & 6 \\
\hline & MPXQ201 & $0.0-0.5$ & $6(U)$ & 6 \\
\hline Q09 & MPXQ009 & $0.0-0.5$ & $6.4(U)$ & 6.4 \\
\hline Q10 & MPXQ010 & $0.0-0.5$ & $5.5(U)$ & 5.5 \\
\hline
\end{tabular}

$\mathrm{ft}$ bgs $=$ Feet below ground surface

$\mathrm{mg} / \mathrm{kg}=$ Milligrams per kilogram

$\mathrm{U}=$ Compound was analyzed for, but not detected ("non-detect"). 
Table D.1-44

Samples Collected at CAS 04-09-14, U-4av PS \#1A Covered Mud Pit (1)

\begin{tabular}{|c|c|c|c|c|c|}
\hline $\begin{array}{c}\text { Sample } \\
\text { Location }\end{array}$ & $\begin{array}{l}\text { Sample } \\
\text { Number }\end{array}$ & $\begin{array}{c}\text { Depth } \\
\text { (ft bgs) }\end{array}$ & Matrix & Purpose & Analyses \\
\hline R01 & MPXR001 & $4.5-5.0$ & Soil & Environmental & TPH-DRO \\
\hline R02 & MPXR002 & $5.5-6.0$ & Soil & Environmental & TPH-DRO \\
\hline R03 & MPXR003 & $3.0-3.5$ & Soil & Environmental & TPH-DRO \\
\hline \multirow[b]{2}{*}{ R04 } & MPXR004 & $5.0-5.5$ & Soil & Environmental & TPH-DRO \\
\hline & MPXR201 & $5.0-5.5$ & Soil & $\begin{array}{l}\text { Field Duplicate } \\
\text { of \#MPXR004 }\end{array}$ & TPH-DRO \\
\hline R05 & MPXR005 & $5.0-5.5$ & Soil & Environmental & TPH-DRO \\
\hline R06 & MPXR006 & $2.5-3.0$ & Soil & Environmental & TPH-DRO \\
\hline R07 & MPXR007 & $5.0-5.5$ & Soil & Environmental & TPH-DRO \\
\hline R08 & MPXR008 & $2.5-3.0$ & Soil & Environmental & TPH-DRO \\
\hline R09 & MPXR009 & $4.5-5.0$ & Soil & $\begin{array}{l}\text { Environmental, } \\
\text { MS/MSD }\end{array}$ & TPH-DRO \\
\hline R10 & MPXR010 & $5.0-5.5$ & Soil & Environmental & TPH-DRO \\
\hline N/A & MPXR401 & $N / A$ & Water & Field Blank & TPH-DRO \\
\hline
\end{tabular}

$\mathrm{ft}$ bgs $=$ Feet below ground surface

MS/MSD = Matrix spike/matrix spike duplicate

N/A = Not applicable

TPH-DRO = Total petroleum hydrocarbons, diesel-range organics 
Table D.1-45

Soil Sample Results for TPH-DRO at CAS 04-09-14, U-4av PS \#1A Covered Mud Pit (1)

\begin{tabular}{|c|c|c|c|c|}
\hline \multirow{2}{*}{$\begin{array}{l}\text { Sample } \\
\text { Location }\end{array}$} & \multirow{2}{*}{$\begin{array}{l}\text { Sample } \\
\text { Number }\end{array}$} & \multirow{2}{*}{$\begin{array}{c}\text { Depth } \\
\text { (ft bgs) }\end{array}$} & \multicolumn{2}{|c|}{ Contaminants of Potential Concern (mg/kg) } \\
\hline & & & Result & Detection Limit \\
\hline $\mathrm{R} 01$ & MPXR001 & $4.5-5.0$ & $5.4(U)$ & 5.4 \\
\hline $\mathrm{R} 02$ & MPXR002 & $5.5-6.0$ & $5.5(U)$ & 5.5 \\
\hline R03 & MPXR003 & $3.0-3.5$ & $5.6(U)$ & 5.6 \\
\hline \multirow{2}{*}{ R04 } & MPXR004 & $5.0-5.5$ & $83(\mathrm{M})$ & 5.5 \\
\hline & MPXR201 & $5.0-5.5$ & $83(\mathrm{M})$ & 5.6 \\
\hline R05 & MPXR005 & $5.0-5.5$ & $27(\mathrm{M})$ & 5.6 \\
\hline R06 & MPXR006 & $2.5-3.0$ & $5.8(U)$ & 5.8 \\
\hline R07 & MPXR007 & $5.0-5.5$ & $95(\mathrm{M})$ & 5.5 \\
\hline R08 & MPXR008 & $2.5-3.0$ & $5.5(U)$ & 5.5 \\
\hline R09 & MPXR009 & $4.5-5.0$ & $93(\mathrm{~J})$ & 5.7 \\
\hline R10 & MPXR010 & $5.0-5.5$ & $4.2(\mathrm{~J})$ & 6 \\
\hline
\end{tabular}

$\mathrm{ft}$ bgs $=$ Feet below ground surface

$\mathrm{mg} / \mathrm{kg}=$ Milligrams per kilogram

$\mathrm{J}=$ Estimated value.

$\mathrm{M}=\mathrm{A}$ pattern resembling motor oil was detected.

$\mathrm{U}=$ Compound was analyzed for, but not detected ("non-detect"). 
Table D.1-46

Samples Collected at CAS 04-09-18, UE-4ai Mud Pit (1)

\begin{tabular}{||c|c|c|c|c|c||}
\hline $\begin{array}{c}\text { Sample } \\
\text { Location }\end{array}$ & $\begin{array}{c}\text { Sample } \\
\text { Number }\end{array}$ & $\begin{array}{c}\text { Depth } \\
\text { (ft bgs) }\end{array}$ & Matrix & Purpose & Analyses \\
\hline \hline S01 & MPXS001 & $0.0-0.5$ & Soil & Environmental & TPH-DRO \\
\hline S02 & MPXS002 & $0.0-0.5$ & Soil & Environmental & TPH-DRO \\
\hline S03 & MPXS003 & $0.0-0.5$ & Soil & Environmental & TPH-DRO \\
\hline S04 & MPXS004 & $0.0-0.5$ & Soil & $\begin{array}{c}\text { Environmental, } \\
\text { MS/MSD }\end{array}$ & TPH-DRO \\
\hline S05 & MPXS005 & $0.0-0.5$ & Soil & Environmental & TPH-DRO \\
\hline S06 & MPXS006 & $0.0-0.5$ & Soil & Environmental & TPH-DRO \\
\hline S07 & MPXS007 & $0.0-0.5$ & Soil & Environmental & TPH-DRO \\
\cline { 2 - 6 } & MPXS201 & $0.0-0.5$ & Soil & $\begin{array}{c}\text { Field Duplicate } \\
\text { of \#MPXSO07 }\end{array}$ & TPH-DRO \\
\hline S08 & MPXS008 & $0.0-0.5$ & Soil & Environmental & TPH-DRO \\
\hline S09 & MPXS009 & $0.0-0.5$ & Soil & Environmental & TPH-DRO \\
\hline S10 & MPXS010 & $0.0-0.5$ & Soil & Environmental & TPH-DRO \\
\hline
\end{tabular}

$\mathrm{ft}$ bgs = Feet below ground surface MS/MSD = Matrix spike/matrix spike duplicate

TPH-DRO = Total petroleum hydrocarbons, diesel-range organics 
Table D.1-47

Soil Sample Results for TPH-DRO at CAS 04-09-18, UE-4ai Mud Pit (1)

\begin{tabular}{||c|c|c|c|c||}
\hline \multirow{2}{*}{$\begin{array}{c}\text { Sample } \\
\text { Location }\end{array}$} & \multirow{2}{*}{$\begin{array}{c}\text { Sample } \\
\text { Number }\end{array}$} & \multirow{2}{*}{$\begin{array}{c}\text { Depth } \\
\text { ft bgs) }\end{array}$} & \multicolumn{2}{|c|}{ Contaminants of Potential Concern (mg/kg) } \\
\cline { 4 - 5 } & & & Result & Detection Limit \\
\hline \hline S01 & MPXS001 & $0.0-0.5$ & $5.2(\mathrm{U})$ & 5.2 \\
\hline S02 & MPXS002 & $0.0-0.5$ & $2.4(\mathrm{~J})$ & 5.2 \\
\hline S03 & MPXS003 & $0.0-0.5$ & $5.3(\mathrm{U})$ & 5.3 \\
\hline S04 & MPXS004 & $0.0-0.5$ & $27(\mathrm{H})$ & 5.3 \\
\hline S05 & MPXS005 & $0.0-0.5$ & $9.5(\mathrm{M})$ & 5.2 \\
\hline S06 & MPXS006 & $0.0-0.5$ & $24(\mathrm{H}, \mathrm{M})$ & 5.2 \\
\hline \multirow{2}{*}{ S07 } & MPXS007 & $0.0-0.5$ & $12(\mathrm{H}, \mathrm{M})$ & 5.3 \\
\cline { 3 - 5 } & MPXS201 & $0.0-0.5$ & $17(\mathrm{H}, \mathrm{M})$ & 5.3 \\
\hline S08 & MPXS008 & $0.0-0.5$ & $6(\mathrm{M}, \mathrm{Z})$ & 5.2 \\
\hline S09 & MPXS009 & $0.0-0.5$ & $3(\mathrm{~J})$ & 5.3 \\
\hline S10 & MPXS010 & $0.0-0.5$ & $2.1(\mathrm{~J})$ & 5.2 \\
\hline \hline
\end{tabular}

$\mathrm{ft}$ bgs $=$ Feet below ground surface

$\mathrm{mg} / \mathrm{kg}=$ Milligrams per kilogram

$\mathrm{H}=$ Fuel pattern in the heavier end of retention time window.

$\mathrm{J}=$ Estimated value.

$\mathrm{M}=\mathrm{A}$ pattern resembling motor oil was detected.

$U=$ Compound was analyzed for, but not detected ("non-detect").

$\mathrm{Z}=$ Result did not resemble any common TPH products. 
Table D.1-48

Samples Collected at CAS 05-09-02, RNM \#1 Mud Pit (1)

\begin{tabular}{||c|c|c|c|c|c||}
\hline $\begin{array}{c}\text { Sample } \\
\text { Location }\end{array}$ & $\begin{array}{c}\text { Sample } \\
\text { Number }\end{array}$ & $\begin{array}{c}\text { Depth } \\
\text { (ft bgs) }\end{array}$ & Matrix & Purpose & Analyses \\
\hline \hline T01 & MPXT001 & $0.0-0.5$ & Soil & Environmental & TPH-DRO \\
\hline T02 & MPXT002 & $0.0-0.5$ & Soil & Environmental & TPH-DRO \\
\hline T03 & MPXT003 & $0.0-0.5$ & Soil & Environmental & TPH-DRO \\
\hline T04 & MPXT004 & $0.0-0.5$ & Soil & Environmental & TPH-DRO \\
\hline T05 & MPXT005 & $0.0-0.5$ & Soil & $\begin{array}{c}\text { Environmental, } \\
\text { MS/MSD }\end{array}$ & TPH-DRO \\
\hline T06 & MPXT006 & $0.0-0.5$ & Soil & Environmental & TPH-DRO \\
\cline { 2 - 6 } & MPXT201 & $0.0-0.5$ & Soil & $\begin{array}{c}\text { Field Duplicate } \\
\text { of \#MPXT006 }\end{array}$ & TPH-DRO \\
\hline T07 & MPXT007 & $0.0-0.5$ & Soil & Environmental & TPH-DRO \\
\hline T08 & MPXT008 & $0.0-0.5$ & Soil & Environmental & TPH-DRO \\
\hline T09 & MPXT009 & $0.0-0.5$ & Soil & Environmental & TPH-DRO \\
\hline T10 & MPXT010 & $0.0-0.5$ & Soil & Environmental & TPH-DRO \\
\hline N/A & MPXT401 & N/A & Water & Field Blank & TPH-DRO \\
\hline
\end{tabular}

$\mathrm{ft}$ bgs = Feet below ground surface

MS/MSD = Matrix spike/matrix spike duplicate

N/A = Not applicable

TPH-DRO = Total petroleum hydrocarbons, diesel-range organics 
Table D.1-49

Soil Sample Results for TPH-DRO at CAS 05-09-02, RNM \#1 Mud Pit (1)

\begin{tabular}{|c|c|c|c|c|}
\hline \multirow{2}{*}{$\begin{array}{l}\text { Sample } \\
\text { Location }\end{array}$} & \multirow{2}{*}{$\begin{array}{l}\text { Sample } \\
\text { Number }\end{array}$} & \multirow{2}{*}{$\begin{array}{c}\text { Depth } \\
\text { (ft bgs) }\end{array}$} & \multicolumn{2}{|c|}{ Contaminants of Potential Concern (mg/kg) } \\
\hline & & & Result & Detection Limit \\
\hline T01 & MPXT001 & $0.0-0.5$ & $12(\mathrm{M})$ & 5 \\
\hline T02 & MPXT002 & $0.0-0.5$ & $2.7(\mathrm{~J})$ & 5.2 \\
\hline T03 & MPXT003 & $0.0-0.5$ & $6.4(\mathrm{M})$ & 5 \\
\hline T04 & MPXT004 & $0.0-0.5$ & $270(\mathrm{M})$ & 5.3 \\
\hline T05 & MPXT005 & $0.0-0.5$ & $4.8(\mathrm{~J})$ & 5.4 \\
\hline \multirow{2}{*}{ T06 } & MPXT006 & $0.0-0.5$ & $6.2(\mathrm{M})$ & 5.1 \\
\hline & MPXT201 & $0.0-0.5$ & $8.6(\mathrm{M})$ & 5.1 \\
\hline T07 & MPXT007 & $0.0-0.5$ & $5.3(\mathrm{M})$ & 5.1 \\
\hline T08 & MPXT008 & $0.0-0.5$ & $420(M)$ & 5.3 \\
\hline T09 & MPXT009 & $0.0-0.5$ & $7.6(\mathrm{M})$ & 5.2 \\
\hline T10 & MPXT010 & $0.0-0.5$ & $5.1(U)$ & 5.1 \\
\hline
\end{tabular}

$\mathrm{ft}$ bgs $=$ Feet below ground surface

$\mathrm{mg} / \mathrm{kg}=$ Milligrams per kilogram

$\mathrm{J}=$ Estimated value.

$\mathrm{M}=\mathrm{A}$ pattern resembling motor oil was detected.

$\mathrm{U}=$ Compound was analyzed for, but not detected ("non-detect"). 
Table D.1-50

Samples Collected at CAS 06-09-02, U-6f Mud Pit (2)

\begin{tabular}{||c|c|c|c|c|c||}
\hline $\begin{array}{c}\text { Sample } \\
\text { Location }\end{array}$ & $\begin{array}{c}\text { Sample } \\
\text { Number }\end{array}$ & $\begin{array}{c}\text { Depth } \\
\text { (ft bgs) }\end{array}$ & Matrix & Purpose & Analyses \\
\hline \hline U01 & MPXU001 & $0.0-0.5$ & Soil & Environmental & TPH-DRO \\
\hline U02 & MPXU002 & $0.0-0.5$ & Soil & Environmental & TPH-DRO \\
\hline \multirow{2}{*}{$\cup 03$} & MPXU003 & $0.0-0.5$ & Soil & Environmental & TPH-DRO \\
\cline { 2 - 6 } & MPXU201 & $0.0-0.5$ & Soil & $\begin{array}{c}\text { Field Duplicate } \\
\text { of \#MPXU003 }\end{array}$ & TPH-DRO \\
\hline U04 & MPXU004 & $0.0-0.5$ & Soil & Environmental & TPH-DRO \\
\hline U05 & MPXU005 & $0.0-0.5$ & Soil & Environmental & TPH-DRO \\
\hline U06 & MPXU006 & $0.0-0.5$ & Soil & Environmental & TPH-DRO \\
\hline U07 & MPXU007 & $0.0-0.5$ & Soil & Environmental & TPH-DRO \\
\hline U08 & MPXU008 & $0.0-0.5$ & Soil & $\begin{array}{c}\text { Environmental, } \\
\text { MS/MSD }\end{array}$ & TPH-DRO \\
\hline U09 & MPXU009 & $0.0-0.5$ & Soil & Environmental & TPH-DRO \\
\hline U10 & MPXU010 & $0.0-0.5$ & Soil & Environmental & TPH-DRO \\
\hline N/A & MPXU401 & N/A & Water & Field Blank & TPH-DRO \\
\hline
\end{tabular}

$\mathrm{ft}$ bgs = Feet below ground surface

MS/MSD = Matrix spike/matrix spike duplicate

N/A = Not applicable

TPH-DRO = Total petroleum hydrocarbons, diesel-range organics 
Table D.1-51

Soil Sample Results for TPH-DRO at CAS 06-09-02, U-6f Mud Pit (2)

\begin{tabular}{|c|c|c|c|c|}
\hline \multirow{2}{*}{$\begin{array}{l}\text { Sample } \\
\text { Location }\end{array}$} & \multirow{2}{*}{$\begin{array}{l}\text { Sample } \\
\text { Number }\end{array}$} & \multirow{2}{*}{$\begin{array}{l}\text { Depth } \\
\text { (ft bgs) }\end{array}$} & \multicolumn{2}{|c|}{ Contaminants of Potential Concern $(\mathrm{mg} / \mathrm{kg})$} \\
\hline & & & Result & Detection Limit \\
\hline U01 & MPXU001 & $0.0-0.5$ & $5.3(U)$ & 5.3 \\
\hline U02 & MPXU002 & $0.0-0.5$ & $3.3(\mathrm{~J})$ & 6 \\
\hline \multirow{2}{*}{ U03 } & MPXU003 & $0.0-0.5$ & $5.2(U)$ & 5.2 \\
\hline & MPXU201 & $0.0-0.5$ & $5.2(U)$ & 5.2 \\
\hline U04 & MPXU004 & $0.0-0.5$ & $5.1(U)$ & 5.1 \\
\hline U05 & MPXU005 & $0.0-0.5$ & $5.1(U)$ & 5.1 \\
\hline U06 & MPXU006 & $0.0-0.5$ & $5.2(U)$ & 5.2 \\
\hline U07 & MPXU007 & $0.0-0.5$ & $5.2(U)$ & 5.2 \\
\hline U08 & MPXU008 & $0.0-0.5$ & $5.1(U)$ & 5.1 \\
\hline U09 & MPXU009 & $0.0-0.5$ & $5(U)$ & 5 \\
\hline U10 & MPXU010 & $0.0-0.5$ & $5.3(U)$ & 5.3 \\
\hline
\end{tabular}

$\mathrm{ft}$ bgs = Feet below ground surface

$\mathrm{mg} / \mathrm{kg}=$ Milligrams per kilogram

$\mathrm{J}=$ Estimated value.

$\mathrm{U}=$ Compound was analyzed for, but not detected ("non-detect"). 
Table D.1-52

Samples Collected at CAS 07-09-10, U-7aw Mud Pit (2)

\begin{tabular}{|c|c|c|c|c|c|}
\hline $\begin{array}{l}\text { Sample } \\
\text { Location }\end{array}$ & $\begin{array}{l}\text { Sample } \\
\text { Number }\end{array}$ & $\begin{array}{c}\text { Depth } \\
\text { (ft bgs) }\end{array}$ & Matrix & Purpose & Analyses \\
\hline V01 & MPXV001 & $0.0-0.5$ & Soil & Environmental & TPH-DRO \\
\hline V02 & MPXV002 & $0.0-0.5$ & Soil & Environmental & TPH-DRO \\
\hline \multirow[b]{2}{*}{ V03 } & MPXV003 & $0.0-0.5$ & Soil & Environmental & TPH-DRO \\
\hline & MPXV201 & $0.0-0.5$ & Soil & $\begin{array}{l}\text { Field Duplicate } \\
\text { of \#MPXV003 }\end{array}$ & TPH-DRO \\
\hline V04 & MPXV004 & $0.0-0.5$ & Soil & Environmental & TPH-DRO \\
\hline V05 & MPXV005 & $0.0-0.5$ & Soil & Environmental & TPH-DRO \\
\hline V06 & MPXV006 & $0.0-0.5$ & Soil & Environmental & TPH-DRO \\
\hline V07 & MPXV007 & $0.0-0.5$ & Soil & Environmental & TPH-DRO \\
\hline V08 & MPXV008 & $0.0-0.5$ & Soil & Environmental & TPH-DRO \\
\hline V09 & MPXV009 & $0.0-0.5$ & Soil & $\begin{array}{c}\text { Environmental, } \\
\text { MS/MSD }\end{array}$ & TPH-DRO \\
\hline V10 & MPXV010 & $0.0-0.5$ & Soil & Environmental & TPH-DRO \\
\hline
\end{tabular}

$\mathrm{ft}$ bgs = Feet below ground surface MS/MSD = Matrix spike/matrix spike duplicate

TPH-DRO = Total petroleum hydrocarbons, diesel-range organics 
Table D.1-53

Soil Sample Results for TPH-DRO at CAS 07-09-10, U-7aw Mud Pit (2)

\begin{tabular}{||c|c|c|c|c||}
\hline \multirow{2}{*}{$\begin{array}{c}\text { Sample } \\
\text { Location }\end{array}$} & \multirow{2}{*}{$\begin{array}{c}\text { Sample } \\
\text { Number }\end{array}$} & $\begin{array}{c}\text { Depth } \\
\text { (ft bgs) }\end{array}$ & \multicolumn{2}{|c|}{ Contaminants of Potential Concern (mg/kg) } \\
\cline { 4 - 5 } & & & Result & Detection Limit \\
\hline \hline V01 & MPXV001 & $0.0-0.5$ & $130(\mathrm{M})$ & 5.1 \\
\hline V02 & MPXV002 & $0.0-0.5$ & $2.2(\mathrm{~J})$ & 5.1 \\
\hline \multirow{2}{*}{ V03 } & MPXV003 & $0.0-0.5$ & $5.1(\mathrm{U})$ & 5.1 \\
\cline { 3 - 5 } & MPXV201 & $0.0-0.5$ & $5.1(\mathrm{U})$ & 5.1 \\
\hline V04 & MPXV004 & $0.0-0.5$ & $5.1(\mathrm{U})$ & 5.1 \\
\hline V05 & MPXV005 & $0.0-0.5$ & $5.1(\mathrm{U})$ & 5.1 \\
\hline V06 & MPXV006 & $0.0-0.5$ & $2.5(\mathrm{~J})$ & 5.1 \\
\hline V07 & MPXV007 & $0.0-0.5$ & $5.1(\mathrm{U})$ & 5.1 \\
\hline V08 & MPXV008 & $0.0-0.5$ & $5.1(\mathrm{U})$ & 5.1 \\
\hline V09 & MPXV009 & $0.0-0.5$ & $5.1(\mathrm{U})$ & 5.1 \\
\hline V10 & MPXV010 & $0.0-0.5$ & $5.1(\mathrm{U})$ & \\
\hline
\end{tabular}

$\mathrm{ft}$ bgs = Feet below ground surface

$\mathrm{mg} / \mathrm{kg}=$ Milligrams per kilogram

$\mathrm{J}=$ Estimated value.

$\mathrm{M}=\mathrm{A}$ pattern resembling motor oil was detected.

$\mathrm{U}=$ Compound was analyzed for, but not detected ("non-detect"). 
Table D.1-54

Samples Collected at CAS 07-09-13, U-7bz Mud Pit (2)

\begin{tabular}{|c|c|c|c|c|c|}
\hline $\begin{array}{c}\text { Sample } \\
\text { Location }\end{array}$ & $\begin{array}{l}\text { Sample } \\
\text { Number }\end{array}$ & $\begin{array}{c}\text { Depth } \\
\text { (ft bgs) }\end{array}$ & Matrix & Purpose & Analyses \\
\hline W01 & MPXW001 & $0.0-0.5$ & Soil & Environmental & TPH-DRO \\
\hline W02 & MPXW002 & $0.0-0.5$ & Soil & Environmental & TPH-DRO \\
\hline \multirow[b]{2}{*}{ W03 } & MPXW003 & $0.0-0.5$ & Soil & Environmental & TPH-DRO \\
\hline & MPXW201 & $0.0-0.5$ & Soil & $\begin{array}{l}\text { Field Duplicate } \\
\text { of \#MPXW003 }\end{array}$ & TPH-DRO \\
\hline W04 & MPXW004 & $0.0-0.5$ & Soil & Environmental & TPH-DRO \\
\hline W05 & MPXW005 & $0.0-0.5$ & Soil & Environmental & TPH-DRO \\
\hline W06 & MPXW006 & $0.0-0.5$ & Soil & Environmental & TPH-DRO \\
\hline W07 & MPXW007 & $0.0-0.5$ & Soil & Environmental & TPH-DRO \\
\hline W08 & MPXW008 & $0.0-0.5$ & Soil & $\begin{array}{l}\text { Environmental, } \\
\text { MS/MSD }\end{array}$ & TPH-DRO \\
\hline W09 & MPXW009 & $0.0-0.5$ & Soil & Environmental & TPH-DRO \\
\hline W10 & MPXW010 & $0.0-0.5$ & Soil & Environmental & TPH-DRO \\
\hline W11 & MPXW301 & $0.0-0.5$ & Soil & Environmental & TPH-DRO \\
\hline
\end{tabular}

$\mathrm{ft}$ bgs = Feet below ground surface MS/MSD = Matrix spike/matrix spike duplicate

$\mathrm{TPH}-\mathrm{DRO}=$ Total petroleum hydrocarbons, diesel-range organics 
Table D.1-55

Soil Sample Results for TPH-DRO at CAS 07-09-13, U-7bz Mud Pit (2)

\begin{tabular}{||c|c|c|c|c||}
\hline \multirow{2}{*}{$\begin{array}{c}\text { Sample } \\
\text { Location }\end{array}$} & \multirow{2}{*}{$\begin{array}{c}\text { Sample } \\
\text { Number }\end{array}$} & $\begin{array}{c}\text { Depth } \\
\text { (ft bgs) }\end{array}$ & \multicolumn{2}{|c||}{ Contaminants of Potential Concern (mg/kg) } \\
\cline { 4 - 5 } & & & Result & Detection Limit \\
\hline \hline W01 & MPXW001 & $0.0-0.5$ & $5.7(U)$ & 5.7 \\
\hline W02 & MPXW002 & $0.0-0.5$ & $5.7(U)$ & 5.7 \\
\hline \multirow{2}{*}{ W03 } & MPXW003 & $0.0-0.5$ & $5.3(U)$ & 5.3 \\
\cline { 3 - 5 } & MPXW201 & $0.0-0.5$ & $5.3(U)$ & 5.3 \\
\hline W04 & MPXW004 & $0.0-0.5$ & $5.5(U)$ & 5.5 \\
\hline W05 & MPXW005 & $0.0-0.5$ & $5.9(U)$ & 5.9 \\
\hline W06 & MPXW006 & $0.0-0.5$ & $5.2(U)$ & 5.2 \\
\hline W07 & MPXW007 & $0.0-0.5$ & $6(U)$ & 6 \\
\hline W08 & MPXW008 & $0.0-0.5$ & $5.8(U)$ & 5.8 \\
\hline W09 & MPXW009 & $0.0-0.5$ & $5.6(U)$ & 5.6 \\
\hline W10 & MPXW010 & $0.0-0.5$ & $6.1(U)$ & 6.1 \\
\hline W11 & MPXW01 & $0.0-0.5$ & $5.6(U)$ & 5.6 \\
\hline
\end{tabular}

$\mathrm{ft}$ bgs = Feet below ground surface

$\mathrm{mg} / \mathrm{kg}=$ Milligrams per kilogram

$\mathrm{U}=$ Compound was analyzed for, but not detected ("non-detect"). 
Table D.1-56

Samples Collected at CAS 07-09-22, U-7bw Mud Pit (3)

\begin{tabular}{|c|c|c|c|c|c|}
\hline $\begin{array}{l}\text { Sample } \\
\text { Location }\end{array}$ & $\begin{array}{l}\text { Sample } \\
\text { Number }\end{array}$ & $\begin{array}{c}\text { Depth } \\
\text { (ft bgs) }\end{array}$ & Matrix & Purpose & Analyses \\
\hline \multirow[b]{2}{*}{ X01 } & MPXX001 & $0.0-0.5$ & Soil & Environmental & TPH-DRO \\
\hline & MPXX201 & $0.0-0.5$ & Soil & $\begin{array}{l}\text { Field Duplicate } \\
\text { of \#MPXX001 }\end{array}$ & TPH-DRO \\
\hline $\mathrm{X} 02$ & MPXX002 & $0.0-0.5$ & Soil & Environmental & TPH-DRO \\
\hline $\mathrm{X03}$ & MPXX003 & $0.0-0.5$ & Soil & Environmental & TPH-DRO \\
\hline X04 & MPXX004 & $0.0-0.5$ & Soil & Environmental & TPH-DRO \\
\hline $\mathrm{X} 05$ & MPXX005 & $0.0-0.5$ & Soil & Environmental & TPH-DRO \\
\hline $\mathrm{X} 06$ & MPXX006 & $0.0-0.5$ & Soil & Environmental & TPH-DRO \\
\hline X07 & MPXX007 & $0.0-0.5$ & Soil & Environmental & TPH-DRO \\
\hline $\mathrm{X} 08$ & MPXX008 & $0.0-0.5$ & Soil & Environmental & TPH-DRO \\
\hline X09 & MPXX009 & $0.0-0.5$ & Soil & Environmental & TPH-DRO \\
\hline X10 & MPXX010 & $0.0-0.5$ & Soil & $\begin{array}{l}\text { Environmental, } \\
\text { MS/MSD }\end{array}$ & TPH-DRO \\
\hline N/A & MPXX401 & N/A & Water & Field Blank & TPH-DRO \\
\hline
\end{tabular}

$\mathrm{ft}$ bgs = Feet below ground surface

MS/MSD = Matrix spike/matrix spike duplicate

N/A = Not applicable

TPH-DRO = Total petroleum hydrocarbons, diesel-range organics 
Table D.1-57

Soil Sample Results for TPH-DRO at CAS 07-09-22, U-7bw Mud Pit (3)

\begin{tabular}{|c|c|c|c|c|}
\hline \multirow{2}{*}{$\begin{array}{l}\text { Sample } \\
\text { Location }\end{array}$} & \multirow{2}{*}{$\begin{array}{l}\text { Sample } \\
\text { Number }\end{array}$} & \multirow{2}{*}{$\begin{array}{c}\text { Depth } \\
\text { (ft bgs) }\end{array}$} & \multicolumn{2}{|c|}{ Contaminants of Potential Concern (mg/kg) } \\
\hline & & & Result & Detection Limit \\
\hline \multirow{2}{*}{ X01 } & MPXX001 & $0.0-0.5$ & $5.8(U)$ & 5.8 \\
\hline & MPXX201 & $0.0-0.5$ & $5.9(U)$ & 5.9 \\
\hline X02 & MPXX002 & $0.0-0.5$ & $5.8(U)$ & 5.8 \\
\hline X03 & MPXX003 & $0.0-0.5$ & $5.3(U)$ & 5.3 \\
\hline X04 & MPXX004 & $0.0-0.5$ & $5.4(U)$ & 5.4 \\
\hline X05 & MPXX005 & $0.0-0.5$ & $5.3(U)$ & 5.3 \\
\hline X06 & MPXX006 & $0.0-0.5$ & $5.6(U)$ & 5.6 \\
\hline X07 & MPXX007 & $0.0-0.5$ & $5.3(U)$ & 5.3 \\
\hline X08 & MPXX008 & $0.0-0.5$ & $5.3(U)$ & 5.3 \\
\hline X09 & MPXX009 & $0.0-0.5$ & $5.5(U)$ & 5.5 \\
\hline X10 & MPXX010 & $0.0-0.5$ & $5.3(U)$ & 5.3 \\
\hline
\end{tabular}

$\mathrm{ft}$ bgs $=$ Feet below ground surface

$\mathrm{mg} / \mathrm{kg}=$ Milligrams per kilogram

$\mathrm{U}=$ Compound was analyzed for, but not detected ("non-detect"). 
Table D.1-58

Samples Collected at CAS 07-09-25, U-7i PS \#2D Covered Mud Pit (1)

\begin{tabular}{||c|c|c|c|c|c|}
\hline $\begin{array}{c}\text { Sample } \\
\text { Location }\end{array}$ & $\begin{array}{c}\text { Sample } \\
\text { Number }\end{array}$ & $\begin{array}{c}\text { Depth } \\
\mathbf{f f t} \text { bgs })\end{array}$ & Matrix & Purpose & Analyses \\
\hline \hline Y01 & MPXY001 & $4.5-5.0$ & Soil & Environmental & TPH-DRO \\
\hline Y02 & MPXY002 & $8.0-8.5$ & Soil & Environmental & TPH-DRO \\
\hline Y03 & MPXY003 & $4.5-5.0$ & Soil & $\begin{array}{c}\text { Field Duplicate } \\
\text { of \#MPXY003 }\end{array}$ & TPH-DRO \\
\cline { 2 - 6 } & MPXY201 & $4.5-5.0$ & Soil & Environmental & TPH-DRO \\
\hline Y04 & MPXY004 & $5.5-6.0$ & Soil & Environmental & TPH-DRO \\
\hline Y05 & MPXY005 & $7.5-8.0$ & Soil & Environmental & TPH-DRO \\
\hline Y06 & MPXY006 & $7.5-8.0$ & Soil & Environmental, & MS/MSD \\
\hline Y08 & MPXY008 & $7.5-8.0$ & Soil & Environmental & TPH-DRO \\
\hline Y09 & MPXY009 & $5.0-5.5$ & Soil & Environmental & TPH-DRO \\
\hline Y10 & MPXY010 & $5.5-6.0$ & Soil & Environmental & TPH-DRO \\
\hline
\end{tabular}

$\mathrm{ft}$ bgs = Feet below ground surface MS/MSD = Matrix spike/matrix spike duplicate

TPH-DRO = Total petroleum hydrocarbons, diesel-range organics 
Table D.1-59

Soil Sample Results for TPH-DRO at CAS 07-09-25,

U-7i PS \#2D Covered Mud Pit (1)

\begin{tabular}{||c|c|c|c|c||}
\hline \multirow{2}{*}{$\begin{array}{c}\text { Sample } \\
\text { Location }\end{array}$} & \multirow{2}{*}{$\begin{array}{c}\text { Sample } \\
\text { Number }\end{array}$} & $\begin{array}{c}\text { Depth } \\
\text { (ft bgs) }\end{array}$ & \multicolumn{2}{|c||}{ Contaminants of Potential Concern (mg/kg) } \\
\cline { 4 - 6 } & & Result & Detection Limit \\
\hline \hline Y01 & MPXY001 & $4.5-5.0$ & $5.3(\mathrm{U})$ & 5.3 \\
\hline Y02 & MPXY002 & $8.0-8.5$ & $5.3(\mathrm{U})$ & 5.3 \\
\hline \multirow{2}{*}{ Y03 } & MPXY003 & $4.5-5.0$ & $5.3(\mathrm{U})$ & 5.3 \\
\cline { 3 - 5 } & MPXY01 & $4.5-5.0$ & $5.3(\mathrm{U})$ & 5.3 \\
\hline Y04 & MPXY004 & $5.5-6.0$ & $5.3(\mathrm{U})$ & 5.3 \\
\hline Y05 & MPXY005 & $7.5-8.0$ & $5.2(\mathrm{U})$ & 5.2 \\
\hline Y06 & MPXY006 & $7.5-8.0$ & $5.4(\mathrm{U})$ & 5.4 \\
\hline Y07 & MPXY007 & $4.5-5.0$ & $5.4(\mathrm{U})$ & 5.4 \\
\hline Y08 & MPXY008 & $7.5-8.0$ & $5.3(\mathrm{U})$ & 5.3 \\
\hline Y09 & MPXY009 & $5.0-5.5$ & $5.4(\mathrm{U})$ & 5.4 \\
\hline Y10 & MPXY010 & $5.5-6.0$ & $5.4(\mathrm{U})$ & 5.4 \\
\hline
\end{tabular}

$\mathrm{ft}$ bgs $=$ Feet below ground surface

$\mathrm{mg} / \mathrm{kg}=$ Milligrams per kilogram

$\mathrm{U}=$ Compound was analyzed for, but not detected ("non-detect"). 
Table D.1-60

Samples Collected at CAS 07-09-27, UE-7k Mud Pit (1)

\begin{tabular}{|c|c|c|c|c|c|}
\hline $\begin{array}{l}\text { Sample } \\
\text { Location }\end{array}$ & $\begin{array}{l}\text { Sample } \\
\text { Number }\end{array}$ & $\begin{array}{c}\text { Depth } \\
\text { (ft bgs) }\end{array}$ & Matrix & Purpose & Analyses \\
\hline Z01 & MPXZ001 & $0.0-0.5$ & Soil & Environmental & TPH-DRO \\
\hline Z02 & MPXZ002 & $0.0-0.5$ & Soil & Environmental & TPH-DRO \\
\hline Z03 & MPXZ003 & $0.0-0.5$ & Soil & Environmental & TPH-DRO \\
\hline \multirow[b]{2}{*}{ Z04 } & MPXZ004 & $0.0-0.5$ & Soil & Environmental & TPH-DRO \\
\hline & MPXZ201 & $0.0-0.5$ & Soil & $\begin{array}{l}\text { Field Duplicate } \\
\text { of \#MPXZ004 }\end{array}$ & TPH-DRO \\
\hline Z05 & MPXZ005 & $0.0-0.5$ & Soil & Environmental & TPH-DRO \\
\hline Z06 & MPXZ006 & $0.0-0.5$ & Soil & Environmental & TPH-DRO \\
\hline Z07 & MPXZ007 & $0.0-0.5$ & Soil & Environmental & TPH-DRO \\
\hline Z08 & MPXZ008 & $0.0-0.5$ & Soil & Environmental & TPH-DRO \\
\hline Z09 & MPXZ009 & $0.0-0.5$ & Soil & Environmental & TPH-DRO \\
\hline Z10 & MPXZ010 & $0.0-0.5$ & Soil & $\begin{array}{c}\text { Environmental, } \\
\text { MS/MSD }\end{array}$ & TPH-DRO \\
\hline
\end{tabular}

$\mathrm{ft}$ bgs = Feet below ground surface MS/MSD = Matrix spike/matrix spike duplicate

$\mathrm{TPH}-\mathrm{DRO}=$ Total petroleum hydrocarbons, diesel-range organics 
Table D.1-61

Soil Sample Results for TPH-DRO at CAS 07-09-27, UE-7k Mud Pit (1)

\begin{tabular}{||c|c|c|c|c||}
\hline \multirow{2}{*}{$\begin{array}{c}\text { Sample } \\
\text { Location }\end{array}$} & \multirow{2}{*}{$\begin{array}{c}\text { Sample } \\
\text { Number }\end{array}$} & $\begin{array}{c}\text { Depth } \\
\text { (ft bgs) }\end{array}$ & \multicolumn{2}{|c|}{ Contaminants of Potential Concern (mg/kg) } \\
\cline { 4 - 6 } & & & Result & Detection Limit \\
\hline \hline Z01 & MPXZ001 & $0.0-0.5$ & $5.7(\mathrm{U})$ & 5.7 \\
\hline Z02 & MPXZ002 & $0.0-0.5$ & $33(\mathrm{M})$ & 6.4 \\
\hline Z03 & MPXZ003 & $0.0-0.5$ & $5.3(\mathrm{U})$ & 5.3 \\
\hline \multirow{2}{*}{ Z04 } & MPXZ004 & $0.0-0.5$ & $20(\mathrm{M})$ & 6.8 \\
\cline { 3 - 5 } & MPXZ201 & $0.0-0.5$ & $37(\mathrm{M})$ & 7.5 \\
\hline Z05 & MPXZ005 & $0.0-0.5$ & $20(\mathrm{M})$ & 6.3 \\
\hline Z06 & MPXZ006 & $0.0-0.5$ & $22(\mathrm{M})$ & 6.9 \\
\hline Z07 & MPXZ007 & $0.0-0.5$ & $21(\mathrm{M})$ & 5.7 \\
\hline Z08 & MPXZ008 & $0.0-0.5$ & $3.4(\mathrm{~J})$ & 6.9 \\
\hline Z09 & MPXZ009 & $0.0-0.5$ & $54(\mathrm{M})$ & 8.4 \\
\hline Z10 & MPXZ010 & $0.0-0.5$ & $25(\mathrm{M})$ & 6.6 \\
\hline
\end{tabular}

$\mathrm{ft}$ bgs = Feet below ground surface

$\mathrm{mg} / \mathrm{kg}=$ Milligrams per kilogram

$\mathrm{J}=$ Estimated value.

$\mathrm{M}=\mathrm{A}$ pattern resembling motor oil was detected.

$\mathrm{U}=$ Compound was analyzed for, but not detected ("non-detect"). 
Table D.1-62

Samples Collected at CAS 07-09-28, Unknown \#12 Mud Pit/Disposal Area

\begin{tabular}{|c|c|c|c|c|c|}
\hline $\begin{array}{l}\text { Sample } \\
\text { Location }\end{array}$ & $\begin{array}{l}\text { Sample } \\
\text { Number }\end{array}$ & $\begin{array}{c}\text { Depth } \\
\text { (ft bgs) }\end{array}$ & Matrix & Purpose & Analyses \\
\hline AA01 & MPXAA001 & $0.0-0.5$ & Soil & Environmental & TPH-DRO \\
\hline AA02 & MPXAA002 & $0.0-0.5$ & Soil & Environmental & TPH-DRO \\
\hline AA03 & MPXAA003 & $0.0-0.5$ & Soil & Environmental & TPH-DRO \\
\hline AA04 & MPXAA004 & $0.0-0.5$ & Soil & Environmental & TPH-DRO \\
\hline \multirow[b]{2}{*}{ AA05 } & MPXAA005 & $0.0-0.5$ & Soil & Environmental & TPH-DRO \\
\hline & MPXAA201 & $0.0-0.5$ & Soil & $\begin{array}{l}\text { Field Duplicate } \\
\text { of \#MPXAA005 }\end{array}$ & TPH-DRO \\
\hline AA06 & MPXAA006 & $0.0-0.5$ & Soil & Environmental & TPH-DRO \\
\hline AA07 & MPXAA007 & $0.0-0.5$ & Soil & Environmental & TPH-DRO \\
\hline AA08 & MPXAA008 & $0.0-0.5$ & Soil & Environmental & TPH-DRO \\
\hline AA09 & MPXAA009 & $0.0-0.5$ & Soil & Environmental & TPH-DRO \\
\hline AA10 & MPXAA010 & $0.0-0.5$ & Soil & $\begin{array}{c}\text { Environmental, } \\
\text { MS/MSD }\end{array}$ & TPH-DRO \\
\hline N/A & MPXAA401 & $N / A$ & Water & Field Blank & TPH-DRO \\
\hline
\end{tabular}

$\mathrm{ft}$ bgs $=$ Feet below ground surface

MS/MSD = Matrix spike/matrix spike duplicate

N/A = Not applicable

TPH-DRO = Total petroleum hydrocarbons, diesel-range organics 
Table D.1-63

Soil Sample Results for TPH-DRO at CAS 07-09-28, Unknown \#12 Mud Pit/Disposal Area

\begin{tabular}{||c|c|c|c|c||}
\hline \multirow{2}{*}{$\begin{array}{c}\text { Sample } \\
\text { Location }\end{array}$} & \multirow{2}{*}{$\begin{array}{c}\text { Sample } \\
\text { Number }\end{array}$} & $\begin{array}{c}\text { Depth } \\
\text { ft bgs) }\end{array}$ & \multicolumn{2}{|c|}{ Contaminants of Potential Concern (mg/kg) } \\
\cline { 4 - 5 } & & & Result & Detection Limit \\
\hline \hline AA01 & MPXAA001 & $0.0-0.5$ & $4.7(\mathrm{~J})$ & 5.2 \\
\hline AA02 & MPXAA002 & $0.0-0.5$ & $5.2(\mathrm{~J})$ & 5.2 \\
\hline AA03 & MPXAA003 & $0.0-0.5$ & $11(\mathrm{M})$ & 5.1 \\
\hline AA04 & MPXAA004 & $0.0-0.5$ & $2.2(\mathrm{~J})$ & 5.1 \\
\hline \multirow{2}{*}{ AA05 } & MPXAA005 & $0.0-0.5$ & $6.9(\mathrm{~J})$ & 5.1 \\
\cline { 4 - 5 } & MPXAA201 & $0.0-0.5$ & $5.3(\mathrm{M}, \mathrm{Z})$ & 5.1 \\
\hline AA06 & MPXAA006 & $0.0-0.5$ & $4.1(\mathrm{~J})$ & 5.1 \\
\hline AA07 & MPXAA007 & $0.0-0.5$ & $27(\mathrm{M})$ & 5.1 \\
\hline AA08 & MPXAA008 & $0.0-0.5$ & $47(\mathrm{M})$ & 5.1 \\
\hline AA09 & MPXAA009 & $0.0-0.5$ & $180(\mathrm{M}, \mathrm{Z})$ & $5(\mathrm{U})$ \\
\hline AA10 & MPXAA010 & $0.0-0.5$ & & 5.1 \\
\hline
\end{tabular}

$\mathrm{ft}$ bgs $=$ Feet below ground surface

$\mathrm{mg} / \mathrm{kg}=$ Milligrams per kilogram

$\mathrm{J}=$ Estimated value.

$\mathrm{M}=\mathrm{A}$ pattern resembling motor oil was detected.

$\mathrm{U}=$ Compound was analyzed for, but not detected ("non-detect").

$\mathrm{Z}=$ Result did not resemble any common total petroleum hydrocarbons products. 
Table D.1-64

Samples Collected at CAS 08-09-06, UE-8e \#2 Mud Pit (1)

\begin{tabular}{|c|c|c|c|c|c|}
\hline $\begin{array}{l}\text { Sample } \\
\text { Location }\end{array}$ & $\begin{array}{l}\text { Sample } \\
\text { Number }\end{array}$ & $\begin{array}{c}\text { Depth } \\
\text { (ft bgs) }\end{array}$ & Matrix & Purpose & Analyses \\
\hline BB01 & MPXBB001 & $0.0-0.5$ & Soil & Environmental & TPH-DRO \\
\hline BB02 & MPXBB002 & $0.0-0.5$ & Soil & Environmental & TPH-DRO \\
\hline \multirow[b]{2}{*}{ BВ03 } & MPХBВ003 & $0.0-0.5$ & Soil & Environmental & TPH-DRO \\
\hline & MPXBB201 & $0.0-0.5$ & Soil & $\begin{array}{l}\text { Field Duplicate } \\
\text { of \#MPXBB003 }\end{array}$ & TPH-DRO \\
\hline BB04 & MPXBB004 & $0.0-0.5$ & Soil & Environmental & TPH-DRO \\
\hline BB05 & MPХBB005 & $0.0-0.5$ & Soil & Environmental & TPH-DRO \\
\hline BB06 & MPXBB006 & $0.0-0.5$ & Soil & Environmental & TPH-DRO \\
\hline BB07 & MPXBB007 & $0.0-0.5$ & Soil & Environmental & TPH-DRO \\
\hline BВ08 & МРХВВ008 & $0.0-0.5$ & Soil & Environmental & TPH-DRO \\
\hline BB09 & MPXBB009 & $0.0-0.5$ & Soil & Environmental & TPH-DRO \\
\hline BB10 & MPXBB010 & $0.0-0.5$ & Soil & $\begin{array}{c}\text { Environmental, } \\
\text { MS/MSD }\end{array}$ & TPH-DRO \\
\hline
\end{tabular}

$\mathrm{ft}$ bgs $=$ Feet below ground surface MS/MSD = Matrix spike/matrix spike duplicate

$\mathrm{TPH}-\mathrm{DRO}=$ Total petroleum hydrocarbons, diesel-range organics 
Table D.1-65

Soil Sample Results for TPH-DRO at CAS 08-09-06, UE-8e \#2 Mud Pit (1)

\begin{tabular}{|c|c|c|c|c|}
\hline \multirow{2}{*}{$\begin{array}{c}\text { Sample } \\
\text { Location }\end{array}$} & \multirow{2}{*}{$\begin{array}{l}\text { Sample } \\
\text { Number }\end{array}$} & \multirow{2}{*}{$\begin{array}{l}\text { Depth } \\
\text { (ft bgs) }\end{array}$} & \multicolumn{2}{|c|}{ Contaminants of Potential Concern (mg/kg) } \\
\hline & & & Result & Detection Limit \\
\hline BB01 & MPXBB001 & $0.0-0.5$ & $5.1(U)$ & 5.1 \\
\hline BB02 & MPXBB002 & $0.0-0.5$ & $5(U)$ & 5 \\
\hline \multirow{2}{*}{ BB03 } & MPXBB003 & $0.0-0.5$ & $5.2(U)$ & 5.2 \\
\hline & MPXBB201 & $0.0-0.5$ & $5.2(U)$ & 5.2 \\
\hline BB04 & MPXBB004 & $0.0-0.5$ & $5(U)$ & 5 \\
\hline BB05 & MPXBB005 & $0.0-0.5$ & $5.2(U)$ & 5.2 \\
\hline BB06 & MPXBB006 & $0.0-0.5$ & $5(U)$ & 5 \\
\hline BB07 & MPXВB007 & $0.0-0.5$ & $5.1(U)$ & 5.1 \\
\hline BB08 & МРХВВ008 & $0.0-0.5$ & $5(U)$ & 5 \\
\hline BB09 & MPXBB009 & $0.0-0.5$ & $5(U)$ & 5 \\
\hline BB10 & MPXBB010 & $0.0-0.5$ & $4.9(U)$ & 4.9 \\
\hline
\end{tabular}

$\mathrm{ft}$ bgs $=$ Feet below ground surface $\mathrm{mg} / \mathrm{kg}=$ Milligrams per kilogram

$\mathrm{U}=$ Compound was analyzed for, but not detected ("non-detect"). 
Table D.1-66

Samples Collected at CAS 09-09-10, U-9 ITS S-25 Mud Pit (2)

\begin{tabular}{|c|c|c|c|c|c|}
\hline $\begin{array}{c}\text { Sample } \\
\text { Location }\end{array}$ & $\begin{array}{l}\text { Sample } \\
\text { Number }\end{array}$ & $\begin{array}{l}\text { Depth } \\
\text { (ft bgs) }\end{array}$ & Matrix & Purpose & Analyses \\
\hline DD01 & MPXDD001 & $0.0-0.5$ & Soil & Environmental & TPH-DRO \\
\hline \multirow[b]{2}{*}{ DD02 } & MPXDD002 & $0.0-0.5$ & Soil & Environmental & TPH-DRO \\
\hline & MPXDD201 & $0.0-0.5$ & Soil & $\begin{array}{l}\text { Field Duplicate } \\
\text { of \#MPXDD002 }\end{array}$ & TPH-DRO \\
\hline DD03 & MPXDD003 & $0.0-0.5$ & Soil & Environmental & TPH-DRO \\
\hline DD04 & MPXDD004 & $0.0-0.5$ & Soil & Environmental & TPH-DRO \\
\hline DD05 & MPXDD005 & $0.0-0.5$ & Soil & Environmental & TPH-DRO \\
\hline DD06 & MPXDD006 & $0.0-0.5$ & Soil & Environmental & TPH-DRO \\
\hline DD07 & MPXDD007 & $0.0-0.5$ & Soil & $\begin{array}{c}\text { Environmental, } \\
\text { MS/MSD }\end{array}$ & TPH-DRO \\
\hline DD08 & MPXDD008 & $0.0-0.5$ & Soil & Environmental & TPH-DRO \\
\hline DD09 & MPXDD009 & $0.0-0.5$ & Soil & Environmental & TPH-DRO \\
\hline DD10 & MPXDD010 & $0.0-0.5$ & Soil & Environmental & TPH-DRO \\
\hline
\end{tabular}

$\mathrm{ft}$ bgs $=$ Feet below ground surface MS/MSD = Matrix spike/matrix spike duplicate

$\mathrm{TPH}-\mathrm{DRO}=$ Total petroleum hydrocarbons, diesel-range organics 
Table D.1-67

Soil Sample Results for TPH-DRO at CAS 09-09-10, U-9 ITS S-25 Mud Pit (2)

\begin{tabular}{|c|c|c|c|c|}
\hline \multirow{2}{*}{$\begin{array}{l}\text { Sample } \\
\text { Location }\end{array}$} & \multirow{2}{*}{$\begin{array}{l}\text { Sample } \\
\text { Number }\end{array}$} & \multirow{2}{*}{$\begin{array}{c}\text { Depth } \\
\text { (ft bgs) }\end{array}$} & \multicolumn{2}{|c|}{ Contaminants of Potential Concern $(\mathrm{mg} / \mathrm{kg})$} \\
\hline & & & Result & Detection Limit \\
\hline DD01 & MPXDD001 & $0.0-0.5$ & $390(\mathrm{H}, \mathrm{L}, \mathrm{Z})$ & 51 \\
\hline \multirow{2}{*}{ DD02 } & MPXDD002 & $0.0-0.5$ & $28(\mathrm{H})$ & 5 \\
\hline & MPXDD201 & $0.0-0.5$ & $27(\mathrm{H})$ & 5 \\
\hline DD03 & MPXDD003 & $0.0-0.5$ & $5.1(U)$ & 5.1 \\
\hline DD04 & MPXDD004 & $0.0-0.5$ & $5(U)$ & 5 \\
\hline DD05 & MPXDD005 & $0.0-0.5$ & $18(H)$ & 5.1 \\
\hline DD06 & MPXDD006 & $0.0-0.5$ & $5(U)$ & 5 \\
\hline DD07 & MPXDD007 & $0.0-0.5$ & $5.1(\mathrm{U})$ & 5.1 \\
\hline DD08 & MPXDD008 & $0.0-0.5$ & $30(\mathrm{H})$ & 5.3 \\
\hline DD09 & MPXDD009 & $0.0-0.5$ & $55(\mathrm{H})$ & 5.6 \\
\hline DD10 & MPXDD010 & $0.0-0.5$ & $11(\mathrm{M})$ & 5.1 \\
\hline
\end{tabular}

$\mathrm{ft}$ bgs $=$ Feet below ground surface

$\mathrm{mg} / \mathrm{kg}=$ Milligrams per kilogram

$\mathrm{H}=$ Fuel pattern in the heavier end of retention time window.

$L=$ Fuel pattern in the lighter end of retention time window.

$\mathrm{M}=\mathrm{A}$ pattern resembling motor oil was detected.

$\mathrm{U}=$ Compound was analyzed for, but not detected ("non-detect").

$Z=$ Result did not resemble any common total petroleum hydrocarbons products. 
Table D.1-68

Samples Collected at CAS 09-09-15, U-9 ITS X-22 Mud Pit (2)

\begin{tabular}{|c|c|c|c|c|c|}
\hline $\begin{array}{c}\text { Sample } \\
\text { Location }\end{array}$ & $\begin{array}{c}\text { Sample } \\
\text { Number }\end{array}$ & $\begin{array}{c}\text { Depth } \\
\text { (ft bgs) }\end{array}$ & Matrix & Purpose Analyses \\
\hline \hline CC01 & MPXCC001 & $0.0-0.5$ & Soil & Environmental & TPH-DRO \\
\hline CC02 & MPXCC002 & $0.0-0.5$ & Soil & Environmental & TPH-DRO \\
\hline CC03 & MPXCC003 & $0.0-0.5$ & Environmental, & MS/MSD & TPH-DRO \\
\hline CC04 & MPXCC004 & $0.0-0.5$ & Soil & Environmental & TPH-DRO \\
\hline CC05 & MPXCC005 & $0.0-0.5$ & Soil & Environmental & TPH-DRO \\
\hline CC06 & MPXCC006 & $0.0-0.5$ & Soil & Field Duplicate & of \#MPXCC006 \\
\cline { 2 - 5 } & MPXCC201 & $0.0-0.5$ & TPH-DRO \\
\hline CC07 & MPXCC007 & $0.0-0.5$ & Soil & Environmental & TPH-DRO \\
\hline CC08 & MPXCC008 & $0.0-0.5$ & Soil & Environmental & TPH-DRO \\
\hline CC09 & MPXCC009 & $0.0-0.5$ & Soil & Environmental & TPH-DRO \\
\hline CC10 & MPXCC010 & $0.0-0.5$ & Soil & Environmental & TPH-DRO \\
\hline
\end{tabular}

$\mathrm{ft}$ bgs $=$ Feet below ground surface MS/MSD = Matrix spike/matrix spike duplicate

$\mathrm{TPH}-\mathrm{DRO}=$ Total petroleum hydrocarbons, diesel-range organics 
Table D.1-69

Soil Sample Results for TPH-DRO at CAS 09-09-15, U-9 ITS X-22 Mud Pit (2)

\begin{tabular}{|c|c|c|c|c|}
\hline \multirow{2}{*}{$\begin{array}{l}\text { Sample } \\
\text { Location }\end{array}$} & \multirow{2}{*}{$\begin{array}{l}\text { Sample } \\
\text { Number }\end{array}$} & \multirow{2}{*}{$\begin{array}{l}\text { Depth } \\
\text { (ft bgs) }\end{array}$} & \multicolumn{2}{|c|}{ Contaminants of Potential Concern (mg/kg) } \\
\hline & & & Result & Detection Limit \\
\hline $\mathrm{CC01}$ & MPXCC001 & $0.0-0.5$ & $5.3(U)$ & 5.3 \\
\hline $\mathrm{CCO} 2$ & MPXCC002 & $0.0-0.5$ & $5.4(U)$ & 5.4 \\
\hline $\mathrm{CCO} 3$ & MPXCC003 & $0.0-0.5$ & $5.3(U)$ & 5.3 \\
\hline $\mathrm{CCO} 4$ & MPXCC004 & $0.0-0.5$ & $5.4(U)$ & 5.4 \\
\hline CC05 & MPXCC005 & $0.0-0.5$ & $5.5(U)$ & 5.5 \\
\hline \multirow{2}{*}{$\mathrm{CCO6}$} & MPXCC006 & $0.0-0.5$ & $5.3(U)$ & 5.3 \\
\hline & MPXCC201 & $0.0-0.5$ & $5.4(U)$ & 5.4 \\
\hline $\mathrm{CCO} 7$ & MPXCC007 & $0.0-0.5$ & $5.5(U)$ & 5.5 \\
\hline CC08 & MPXCC008 & $0.0-0.5$ & $5.3(U)$ & 5.3 \\
\hline CC09 & MPXCC009 & $0.0-0.5$ & $8.2(U)$ & 8.2 \\
\hline CC10 & MPXCC010 & $0.0-0.5$ & $11(U)$ & 11 \\
\hline
\end{tabular}

$\mathrm{ft}$ bgs $=$ Feet below ground surface

$\mathrm{mg} / \mathrm{kg}=$ Milligrams per kilogram

$\mathrm{U}=$ Compound was analyzed for, but not detected ("non-detect"). 
Table D.1-70

Samples Collected at CAS 09-09-16, U-9 ITS Z-21 Mud Pit (2)

\begin{tabular}{|c|c|c|c|c|c|}
\hline $\begin{array}{c}\text { Sample } \\
\text { Location }\end{array}$ & $\begin{array}{l}\text { Sample } \\
\text { Number }\end{array}$ & $\begin{array}{c}\text { Depth } \\
\text { (ft bgs) }\end{array}$ & Matrix & Purpose & Analyses \\
\hline EE01 & MPXEE001 & $0.0-0.5$ & Soil & Environmental & TPH-DRO \\
\hline EE02 & MPXEE002 & $0.0-0.5$ & Soil & Environmental & TPH-DRO \\
\hline EE03 & MPXEE003 & $0.0-0.5$ & Soil & Environmental & TPH-DRO \\
\hline \multirow{2}{*}{ EE04 } & MPXEE004 & $0.0-0.5$ & Soil & Environmental & TPH-DRO \\
\hline & MPXEE201 & $0.0-0.5$ & Soil & $\begin{array}{l}\text { Field Duplicate } \\
\text { of \#MPXEE004 }\end{array}$ & TPH-DRO \\
\hline EE05 & MPXEE005 & $0.0-0.5$ & Soil & Environmental & TPH-DRO \\
\hline EE06 & MPXEE006 & $0.0-0.5$ & Soil & Environmental & TPH-DRO \\
\hline EE07 & MPXEE007 & $0.0-0.5$ & Soil & Environmental & TPH-DRO \\
\hline EE08 & MPXEE008 & $0.0-0.5$ & Soil & Environmental & TPH-DRO \\
\hline EE09 & MPXEE009 & $0.0-0.5$ & Soil & $\begin{array}{c}\text { Environmental, } \\
\text { MS/MSD }\end{array}$ & TPH-DRO \\
\hline EE10 & MPXEE010 & $0.0-0.5$ & Soil & Environmental & TPH-DRO \\
\hline
\end{tabular}

$\mathrm{ft}$ bgs $=$ Feet below ground surface MS/MSD = Matrix spike/matrix spike duplicate

$\mathrm{TPH}-\mathrm{DRO}=$ Total petroleum hydrocarbons, diesel-range organics 
Table D.1-71

Soil Sample Results for TPH-DRO at CAS 09-09-16, U-9 ITS Z-21 Mud Pit (2)

\begin{tabular}{|c|c|c|c|c||}
\hline \multirow{2}{*}{$\begin{array}{c}\text { Sample } \\
\text { Location }\end{array}$} & \multirow{2}{*}{$\begin{array}{c}\text { Sample } \\
\text { Number }\end{array}$} & $\begin{array}{c}\text { Depth } \\
\text { ft bgs) }\end{array}$ & \multicolumn{2}{|c||}{ Contaminants of Potential Concern (mg/kg) } \\
\cline { 4 - 5 } & & Result & Detection Limit \\
\hline \hline EE01 & MPXEE001 & $0.0-0.5$ & $5(\mathrm{U})$ & 5 \\
\hline EE02 & MPXEE002 & $0.0-0.5$ & $5(\mathrm{U})$ & 5 \\
\hline EE03 & MPXEE003 & $0.0-0.5$ & $5.1(\mathrm{U})$ & 5.1 \\
\hline \multirow{2}{*}{ EE04 } & MPXEE004 & $0.0-0.5$ & $5.6(U)$ & 5.6 \\
\cline { 3 - 5 } & MPXEE201 & $0.0-0.5$ & $5.5(U)$ & 5.5 \\
\hline EE05 & MPXEE005 & $0.0-0.5$ & $4.9(U)$ & 4.9 \\
\hline EE06 & MPXEE006 & $0.0-0.5$ & $5.1(U)$ & 5.1 \\
\hline EE07 & MPXEE007 & $0.0-0.5$ & $5.1(U)$ & 5.1 \\
\hline EE08 & MPXEE008 & $0.0-0.5$ & $5.5(U)$ & 5.5 \\
\hline EE09 & MPXEE009 & $0.0-0.5$ & $5.9(U)$ & 5.9 \\
\hline EE10 & MPXEE010 & $0.0-0.5$ & $5.8(U)$ & 5.8 \\
\hline
\end{tabular}

$\mathrm{ft}$ bgs $=$ Feet below ground surface

$\mathrm{mg} / \mathrm{kg}=$ Milligrams per kilogram

$\mathrm{U}=$ Compound was analyzed for, but not detected ("non-detect"). 
Table D.1-72

Samples Collected at CAS 09-09-20, U-9 ITS Z-24 Mud Pit (2)

\begin{tabular}{|c|c|c|c|c|c|}
\hline $\begin{array}{c}\text { Sample } \\
\text { Location }\end{array}$ & $\begin{array}{c}\text { Sample } \\
\text { Number }\end{array}$ & $\begin{array}{c}\text { Depth } \\
\text { (ft bgs) }\end{array}$ & Matrix & Purpose Analyses \\
\hline \hline FF01 & MPXFF001 & $0.0-0.5$ & Soil & Environmental & TPH-DRO \\
\hline FF02 & MPXFF002 & $0.0-0.5$ & Soil & MS/MSD & TPH-DRO \\
\hline FF03 & MPXFF003 & $0.0-0.5$ & Soil & Environmental & TPH-DRO \\
\hline FF04 & MPXFF004 & $0.0-0.5$ & Soil & Environmental & TPH-DRO \\
\cline { 2 - 5 } & MPXFF201 & $0.0-0.5$ & Soil & of \#MPXFF004 & TPH-DRO \\
\hline FF05 & MPXFF005 & $0.0-0.5$ & Soil & Environmental & TPH-DRO \\
\hline FF06 & MPXFF006 & $0.0-0.5$ & Soil & Environmental & TPH-DRO \\
\hline FF07 & MPXFF007 & $0.0-0.5$ & Soil & Environmental & TPH-DRO \\
\hline FF08 & MPXFF008 & $0.0-0.5$ & Soil & Environmental & TPH-DRO \\
\hline FF09 & MPXFF009 & $0.0-0.5$ & Soil & Environmental & TPH-DRO \\
\hline FF10 & MPXFF010 & $0.0-0.5$ & Soil & Environmental & TPH-DRO \\
\hline
\end{tabular}

$\mathrm{ft}$ bgs $=$ Feet below ground surface MS/MSD = Matrix spike/matrix spike duplicate

$\mathrm{TPH}-\mathrm{DRO}=$ Total petroleum hydrocarbons, diesel-range organics 
Table D.1-73

Soil Sample Results for TPH-DRO at CAS 09-09-20, U-9 ITS Z-24 Mud Pit (2)

\begin{tabular}{|c|c|c|c|c|}
\hline \multirow{2}{*}{$\begin{array}{c}\text { Sample } \\
\text { Location }\end{array}$} & \multirow{2}{*}{$\begin{array}{l}\text { Sample } \\
\text { Number }\end{array}$} & \multirow{2}{*}{$\begin{array}{l}\text { Depth } \\
\text { (ft bgs) }\end{array}$} & \multicolumn{2}{|c|}{ Contaminants of Potential Concern (mg/kg) } \\
\hline & & & Result & Detection Limit \\
\hline FF01 & MPXFF001 & $0.0-0.5$ & $5.3(U)$ & 5.3 \\
\hline FF02 & MPXFF002 & $0.0-0.5$ & $5.1(U)$ & 5.1 \\
\hline FF03 & MPXFF003 & $0.0-0.5$ & $5.2(U)$ & 5.2 \\
\hline \multirow{2}{*}{ FF04 } & MPXFF004 & $0.0-0.5$ & $5.2(U)$ & 5.2 \\
\hline & MPXFF201 & $0.0-0.5$ & $5.2(\mathrm{U})$ & 5.2 \\
\hline FF05 & MPXFF005 & $0.0-0.5$ & $5.2(U)$ & 5.2 \\
\hline FF06 & MPXFF006 & $0.0-0.5$ & $5.2(U)$ & 5.2 \\
\hline FF07 & MPXFF007 & $0.0-0.5$ & $5.2(U)$ & 5.2 \\
\hline FF08 & MPXFF008 & $0.0-0.5$ & $6.1(\mathrm{U})$ & 6.1 \\
\hline FF09 & MPXFF009 & $0.0-0.5$ & $5.9(U)$ & 5.9 \\
\hline FF10 & MPXFF010 & $0.0-0.5$ & $5.7(U)$ & 5.7 \\
\hline
\end{tabular}

$\mathrm{ft}$ bgs $=$ Feet below ground surface

$\mathrm{mg} / \mathrm{kg}=$ Milligrams per kilogram

$\mathrm{U}=$ Compound was analyzed for, but not detected ("non-detect"). 
Table D.1-74

Samples Collected at CAS 09-09-23, U-9 ITS Y-30 Mud Pit (2)

\begin{tabular}{|c|c|c|c|c|c|}
\hline $\begin{array}{c}\text { Sample } \\
\text { Location }\end{array}$ & $\begin{array}{l}\text { Sample } \\
\text { Number }\end{array}$ & $\begin{array}{l}\text { Depth } \\
\text { (ft bgs) }\end{array}$ & Matrix & Purpose & Analyses \\
\hline GG01 & MPXGG001 & $0.0-0.5$ & Soil & Environmental & TPH-DRO \\
\hline GG02 & MPXGG002 & $0.0-0.5$ & Soil & Environmental & TPH-DRO \\
\hline GG03 & MPXGG003 & $0.0-0.5$ & Soil & Environmental & TPH-DRO \\
\hline GG04 & MPXGG004 & $0.0-0.5$ & Soil & Environmental & TPH-DRO \\
\hline \multirow{2}{*}{ GG05 } & MPXGG005 & $0.0-0.5$ & Soil & Environmental & TPH-DRO \\
\hline & MPXGG201 & $0.0-0.5$ & Soil & $\begin{array}{l}\text { Field Duplicate } \\
\text { of \#MPXGG005 }\end{array}$ & TPH-DRO \\
\hline GG06 & MPXGG006 & $0.0-0.5$ & Soil & Environmental & TPH-DRO \\
\hline GG07 & MPXGG007 & $0.0-0.5$ & Soil & Environmental & TPH-DRO \\
\hline GG08 & MPXGG008 & $0.0-0.5$ & Soil & Environmental & TPH-DRO \\
\hline GG09 & MPXGG009 & $0.0-0.5$ & Soil & $\begin{array}{c}\text { Environmental, } \\
\text { MS/MSD }\end{array}$ & TPH-DRO \\
\hline GG10 & MPXGG010 & $0.0-0.5$ & Soil & Environmental & TPH-DRO \\
\hline
\end{tabular}

$\mathrm{ft}$ bgs $=$ Feet below ground surface MS/MSD = Matrix spike/matrix spike duplicate

$\mathrm{TPH}-\mathrm{DRO}=$ Total petroleum hydrocarbons, diesel-range organics 
Table D.1-75

Soil Sample Results for TPH-DRO at CAS 09-09-23, U-9 ITS Y-30 Mud Pit (2)

\begin{tabular}{|c|c|c|c|c|}
\hline \multirow{2}{*}{$\begin{array}{l}\text { Sample } \\
\text { Location }\end{array}$} & \multirow{2}{*}{$\begin{array}{l}\text { Sample } \\
\text { Number }\end{array}$} & \multirow{2}{*}{$\begin{array}{l}\text { Depth } \\
\text { (ft bgs) }\end{array}$} & \multicolumn{2}{|c|}{ Contaminants of Potential Concern (mg/kg) } \\
\hline & & & Result & Detection Limit \\
\hline GG01 & MPXGG001 & $0.0-0.5$ & $5.1(U)$ & 5.1 \\
\hline GG02 & MPXGG002 & $0.0-0.5$ & $5.1(U)$ & 5.1 \\
\hline GG03 & MPXGG003 & $0.0-0.5$ & $5.1(U)$ & 5.1 \\
\hline GG04 & MPXGG004 & $0.0-0.5$ & $5(U)$ & 5 \\
\hline \multirow{2}{*}{ GG05 } & MPXGG005 & $0.0-0.5$ & $5.1(U)$ & 5.1 \\
\hline & MPXGG201 & $0.0-0.5$ & $5(U)$ & 5 \\
\hline GG06 & MPXGG006 & $0.0-0.5$ & $5(U)$ & 5 \\
\hline GG07 & MPXGG007 & $0.0-0.5$ & $5.1(U)$ & 5.1 \\
\hline GG08 & MPXGG008 & $0.0-0.5$ & $5(U)$ & 5 \\
\hline GG09 & MPXGG009 & $0.0-0.5$ & $5(U)$ & 5 \\
\hline GG10 & MPXGG010 & $0.0-0.5$ & $5.1(U)$ & 5.1 \\
\hline
\end{tabular}

$\mathrm{ft}$ bgs $=$ Feet below ground surface

$\mathrm{mg} / \mathrm{kg}=$ Milligrams per kilogram

$\mathrm{U}=$ Compound was analyzed for, but not detected ("non-detect"). 
Table D.1-76

Samples Collected at CAS 09-09-24, U-9 ITS V-24 PS \#1A Mud Pit (2)

\begin{tabular}{|c|c|c|c|c|c|}
\hline $\begin{array}{c}\text { Sample } \\
\text { Location }\end{array}$ & $\begin{array}{l}\text { Sample } \\
\text { Number }\end{array}$ & $\begin{array}{l}\text { Depth } \\
\text { (ft bgs) }\end{array}$ & Matrix & Purpose & Analyses \\
\hline $\mathrm{HH} 01$ & MPXHH001 & $0.0-0.5$ & Soil & Environmental & Set 1 \\
\hline $\mathrm{HH} 02$ & MPXHH002 & $0.0-0.5$ & Soil & Environmental & Set 1 \\
\hline $\mathrm{HH} 03$ & MPXHH0O3 & $0.0-0.5$ & Soil & Environmental & Set 1 \\
\hline $\mathrm{HH} 04$ & MPXHH0O4 & $0.0-0.5$ & Soil & Environmental & Set 1 \\
\hline $\mathrm{HH} 05$ & MPXHH005 & $0.0-0.5$ & Soil & $\begin{array}{c}\text { Environmental, } \\
\text { MS/MSD }\end{array}$ & Set 1 \\
\hline $\mathrm{HH} 06$ & MPXHH006 & $0.0-0.5$ & Soil & Environmental & Set 1 \\
\hline \multirow[b]{2}{*}{$\mathrm{HH} 07$} & MPXHH007 & $0.0-0.5$ & Soil & Environmental & Set 1 \\
\hline & MPXHH201 & $0.0-0.5$ & Soil & $\begin{array}{l}\text { Field Duplicate } \\
\text { of \#MPXHH007 }\end{array}$ & Set 1 \\
\hline $\mathrm{HH} 08$ & MPХHH0O8 & $0.0-0.5$ & Soil & Environmental & Set 1 \\
\hline $\mathrm{HH} 09$ & MPXHH0O9 & $0.0-0.5$ & Soil & Environmental & Set 1 \\
\hline $\mathrm{HH} 10$ & MPXHH010 & $0.0-0.5$ & Soil & Environmental & Set 1 \\
\hline$N / A$ & MPXHH401 & $N / A$ & Water & Field Blank & Set 1 \\
\hline
\end{tabular}

Set 1 = TPH-DRO, gamma spectroscopy, isotopic uranium, isotopic plutonium, strontium-90

$\mathrm{ft}$ bgs = Feet below ground surface

MS/MSD = Matrix spike/matrix spike duplicate

N/A = Not applicable

TPH-DRO = Total petroleum hydrocarbons, diesel-range organics 
Table D.1-77

Soil Sample Results for TPH-DRO at CAS 09-09-24, U-9 ITS V-24 PS \#1A Mud Pit (2)

\begin{tabular}{|c|c|c|c|c|}
\hline \multirow{2}{*}{$\begin{array}{c}\text { Sample } \\
\text { Location }\end{array}$} & \multirow{2}{*}{$\begin{array}{l}\text { Sample } \\
\text { Number }\end{array}$} & \multirow{2}{*}{$\begin{array}{l}\text { Depth } \\
\text { (ft bgs) }\end{array}$} & \multicolumn{2}{|c|}{ Contaminants of Potential Concern $(\mathrm{mg} / \mathrm{kg})$} \\
\hline & & & Result & Detection Limit \\
\hline $\mathrm{HHO1}$ & MPXHH001 & $0.0-0.5$ & $5.1(U)$ & 5.1 \\
\hline $\mathrm{HHO2}$ & MPXHH0O2 & $0.0-0.5$ & $5.3(U)$ & 5.3 \\
\hline $\mathrm{HHO3}$ & MPXHН003 & $0.0-0.5$ & $5.3(U)$ & 5.3 \\
\hline $\mathrm{HH} 04$ & MPXHH004 & $0.0-0.5$ & $5.3(U)$ & 5.3 \\
\hline $\mathrm{HH} 05$ & MPXHH005 & $0.0-0.5$ & $5.4(U)$ & 5.4 \\
\hline $\mathrm{HH} 06$ & MPXHH006 & $0.0-0.5$ & $5.4(\mathrm{U})$ & 5.4 \\
\hline \multirow{2}{*}{$\mathrm{HH} 07$} & MPXHH007 & $0.0-0.5$ & $5.4(U)$ & 5.4 \\
\hline & MPXHH201 & $0.0-0.5$ & $5.4(U)$ & 5.4 \\
\hline $\mathrm{HH} 08$ & MPXHН008 & $0.0-0.5$ & $5.1(U)$ & 5.1 \\
\hline HH09 & MPXHH009 & $0.0-0.5$ & $5.2(U)$ & 5.2 \\
\hline $\mathrm{HH} 10$ & MPXНH010 & $0.0-0.5$ & $5.3(U)$ & 5.3 \\
\hline
\end{tabular}

$\mathrm{ft}$ bgs $=$ Feet below ground surface

$\mathrm{mg} / \mathrm{kg}=$ Milligrams per kilogram

$\mathrm{U}=$ Compound was analyzed for, but not detected ("non-detect"). 
Table D.1-78

Soil Sample Results for Gamma-Emitting Radionuclides Detected Above Minimum Detectable Concentration Limits at CAS 09-09-24, U-9 ITS V-24 PS \#1A Mud Pit (2)

\begin{tabular}{|c|c|c|c|c|c|c|c|}
\hline \multirow[b]{2}{*}{$\begin{array}{l}\text { Sample } \\
\text { Location }\end{array}$} & \multirow[b]{2}{*}{$\begin{array}{l}\text { Sample } \\
\text { Number }\end{array}$} & \multirow[b]{2}{*}{$\begin{array}{c}\text { Depth } \\
\text { (ft bgs) }\end{array}$} & \multicolumn{5}{|c|}{ Contaminants of Potential Concern (pCi/g) } \\
\hline & & & 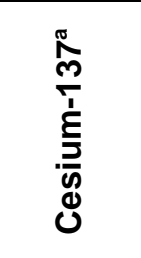 & 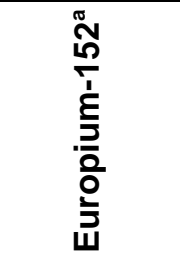 & 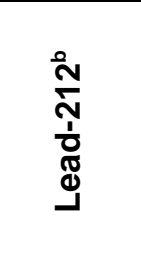 & 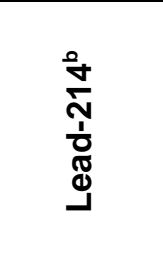 & 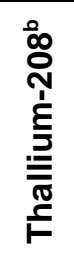 \\
\hline \multicolumn{3}{|c|}{ Final Action Levels } & \multirow{2}{*}{12.2} & \multirow{2}{*}{5.7} & 5 & 5 & 5 \\
\hline \multicolumn{3}{|c|}{ Depths bgs (cm) } & & & $<15$ & $<15$ & $<15$ \\
\hline $\mathrm{HHO1}$ & MPXHH001 & $0.0-0.5$ & -- & 16.1 & 1.08 & -- & -- \\
\hline $\mathrm{HHO2}$ & MPXHH002 & $0.0-0.5$ & -- & $16.5(\mathrm{G})$ & $1.26(\mathrm{~J})^{\mathrm{c}}$ & -- & -- \\
\hline $\mathrm{HH} 03$ & MPXHH003 & $0.0-0.5$ & $0.78(\mathrm{G})$ & $13.6(\mathrm{G})$ & $1.03(\mathrm{~J})^{\mathrm{c}}$ & -- & -- \\
\hline $\mathrm{HH} 04$ & MPXHH004 & $0.0-0.5$ & -- & 3.33 & 1.32 & $0.73(\mathrm{~J})$ & 0.38 \\
\hline HH05 & MPXHH005 & $0.0-0.5$ & -- & $1.24(\mathrm{G}, \mathrm{TI})$ & $1.01(\mathrm{~J})^{\mathrm{c}}$ & $0.76(G, J)$ & -- \\
\hline $\mathrm{HH} 06$ & MPXHH006 & $0.0-0.5$ & -- & 6.7 & 0.94 & -- & -- \\
\hline \multirow{2}{*}{$\mathrm{HH} 07$} & MPXHH007 & $0.0-0.5$ & -- & $5.36(\mathrm{G})$ & $0.83(\mathrm{~J})^{\mathrm{c}}$ & $0.89(G, J)$ & -- \\
\hline & MPXHH201 & $0.0-0.5$ & -- & $5.45(G)$ & $0.96(\mathrm{~J})^{\mathrm{c}}$ & -- & -- \\
\hline HH08 & MPXHH008 & $0.0-0.5$ & -- & $9.4(\mathrm{G})$ & $1.36(J)^{c}$ & $0.79(\mathrm{G}, \mathrm{J})$ & -- \\
\hline HH09 & MPXHH009 & $0.0-0.5$ & -- & 12.6 & 1.24 & -- & -- \\
\hline $\mathrm{HH} 10$ & MPXHН010 & $0.0-0.5$ & -- & $11.5(\mathrm{G})$ & $1.37(\mathrm{~J})^{\mathrm{c}}$ & -- & -- \\
\hline
\end{tabular}

${ }^{a}$ Taken from the construction, commercial, industrial land use scenario in Table 2.1 of the NCRP Report No. 129, Recommended Screening Limits for Contaminated Surface Soil and Review Factors Relevant to Site-Specific Studies (NCRP, 1999). The values provided in this source document were scaled to a 25-mrem/yr dose.

${ }^{\text {b} T a k e n ~ f r o m ~ t h e ~ g e n e r i c ~ g u i d e l i n e s ~ f o r ~ r e s i d u a l ~ c o n c e n t r a t i o n s ~ o f ~ a c t i n i u m-228, ~ b i s m u t h-214, ~ l e a d-212, ~ l e a d-214, ~ t h a l l i u m-208, ~}$ and thorium-232, as found in Chapter IV of DOE Order 5400.5, Change 2, "Radiation Protection of the Public and Environment." (DOE, 1993). The PALs for these isotopes is specified as $5 \mathrm{pCi} / \mathrm{g}$ averaged over the first $15 \mathrm{~cm}$ of soil and $15 \mathrm{pCi} / \mathrm{g}$ for deeper soils (DOE, 1993). For purposes of this document, $15 \mathrm{~cm}$ is assumed to be equivalent to $0.5 \mathrm{ft}$ ( 6 inches); therefore, $5 \mathrm{pCi} / \mathrm{g}$ represents the PALs for these radionuclides in the surface soil (0 to $0.5 \mathrm{ft}$ depth).

${ }^{\circ} Q u a l i f i e r$ added to laboratory data; record accepted. Sample does not meet counting geometry requirements.

$\mathrm{cm}=$ Centimeter

$\mathrm{ft}$ bgs $=$ Feet below ground surface

$\mathrm{mrem} / \mathrm{yr}=$ Millirem per year

$\mathrm{pCi} / \mathrm{g}=$ Picocuries per gram

$--=$ Not detected above minimum reporting limits

$<=$ Less than

$\mathrm{G}=$ Sample density differs by more than $15 \%$ of laboratory control sample density.

$\mathrm{J}=$ Estimated value.

$\mathrm{TI}=$ Nuclide identification is tentative . 
Table D.1-79

Soil Sample Results for Isotopes Detected Above Minimum Detectable Concentration Limits at CAS 09-09-24, U-9 ITS V-24 PS \#1A Mud Pit (2)

\begin{tabular}{|c|c|c|c|c|c|c|c|c|}
\hline \multirow[b]{2}{*}{$\begin{array}{l}\text { Sample } \\
\text { Location }\end{array}$} & \multirow[b]{2}{*}{$\begin{array}{l}\text { Sample } \\
\text { Number }\end{array}$} & \multirow[b]{2}{*}{$\begin{array}{l}\text { Depth } \\
\text { (ft bgs) }\end{array}$} & \multicolumn{6}{|c|}{ Contaminants of Potential Concern (pCi/g) } \\
\hline & & & 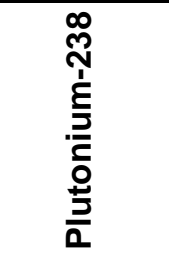 & 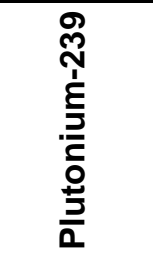 & 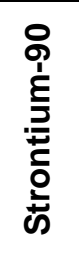 & 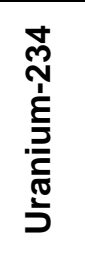 & 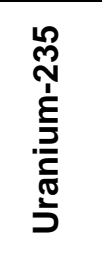 & 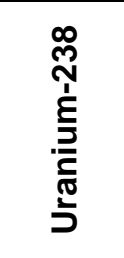 \\
\hline \multicolumn{3}{|c|}{ Final Action Levels ${ }^{a}$} & 13 & 12.7 & 838 & 143 & 17.5 & 105 \\
\hline $\mathrm{HH} 01$ & MPXHH001 & $0.0-0.5$ & -- & $0.15(\mathrm{~J})^{\mathrm{b}}$ & -- & 0.8 & -- & 0.81 \\
\hline $\mathrm{HHO} 2$ & MPXHH002 & $0.0-0.5$ & $0.037(\mathrm{LT})$ & $1.58(\mathrm{~J})^{\mathrm{b}}$ & -- & 0.83 & -- & 0.81 \\
\hline $\mathrm{HH} 03$ & MPXHH0O3 & $0.0-0.5$ & $0.039(\mathrm{LT})$ & $1.25(\mathrm{~J})^{\mathrm{b}}$ & -- & 0.94 & -- & 0.82 \\
\hline $\mathrm{HH} 04$ & MPXHH004 & $0.0-0.5$ & -- & $0.334(\mathrm{~J})^{\mathrm{b}}$ & -- & 0.94 & -- & 0.98 \\
\hline $\mathrm{HH} 05$ & MPXHH005 & $0.0-0.5$ & -- & $0.52(\mathrm{~J})^{\mathrm{b}}$ & -- & 1.01 & 0.058 & 0.94 \\
\hline $\mathrm{HH} 06$ & MPХHH006 & $0.0-0.5$ & -- & $0.65(\mathrm{~J})^{\mathrm{b}}$ & -- & 0.8 & -- & 0.85 \\
\hline \multirow{2}{*}{$\mathrm{HH} 07$} & MPXHH0O7 & $0.0-0.5$ & 0.054 & $4.56(J)^{b}$ & -- & 0.96 & -- & 0.86 \\
\hline & MPXHH201 & $0.0-0.5$ & 0.059 & $4.25(J)^{\mathrm{b}}$ & 0.6 & 1.05 & -- & $0.9(\mathrm{M} 3)$ \\
\hline $\mathrm{HH} 08$ & MPXHН008 & $0.0-0.5$ & 0.074 & $4.73(\mathrm{~J})^{\mathrm{b}}$ & -- & 0.82 & -- & 0.82 \\
\hline $\mathrm{HH} 09$ & MPХHН009 & $0.0-0.5$ & 0.077 & $4.75(\mathrm{~J})^{\mathrm{b}}$ & -- & 0.88 & -- & 0.94 \\
\hline $\mathrm{HH} 10$ & MPXНH010 & $0.0-0.5$ & -- & $1.5(\mathrm{~J})^{\mathrm{b}}$ & -- & 0.96 & -- & 0.75 \\
\hline
\end{tabular}

${ }^{a}$ Taken from the construction, commercial, industrial land use scenario in Table 2.1 of the NCRP Report No. 129, Recommended Screening Limits for Contaminated Surface Soil and Review Factors Relevant to Site-Specific Studies (NCRP, 1999). The values provided in this source document were scaled to a 25-mrem/yr dose.

${ }^{\mathrm{b}} \mathrm{Qualifier}$ added to laboratory data; record accepted. Duplicate precision analysis (relative percent difference) exceeds control limits.

$\mathrm{ft}$ bgs $=$ Feet below ground surface

MDC = Minimum detectable concentration

$\mathrm{mrem} / \mathrm{yr}=$ Millirem per year

$\mathrm{pCi} / \mathrm{g}=$ Picocuries per gram

$\mathrm{J}=$ Estimated value

$\mathrm{LT}=$ Result is less than requested minimum detectable concentration, but greater than sample specific minimum concentration .

M3 = The requested MDC was not met, but the reported activity is greater than the reported MDC.

$--=$ Not detected above minimum reporting limits 
Table D.1-80

Samples Collected at CAS 09-09-27, U-9yz-26 PS \#1A Mud Pit (1)

\begin{tabular}{|c|c|c|c|c|c|}
\hline $\begin{array}{c}\text { Sample } \\
\text { Location }\end{array}$ & $\begin{array}{l}\text { Sample } \\
\text { Number }\end{array}$ & $\begin{array}{l}\text { Depth } \\
\text { (ft bgs) }\end{array}$ & Matrix & Purpose & Analyses \\
\hline II01 & MPXII001 & $0.0-0.5$ & Soil & Environmental & TPH-DRO \\
\hline IIO2 & MPXII002 & $0.0-0.5$ & Soil & Environmental & TPH-DRO \\
\hline 1103 & MPXII003 & $0.0-0.5$ & Soil & Environmental & TPH-DRO \\
\hline 1104 & MPXII004 & $0.0-0.5$ & Soil & Environmental & TPH-DRO \\
\hline II05 & MPXII005 & $0.0-0.5$ & Soil & Environmental & TPH-DRO \\
\hline 1106 & MPXII006 & $0.0-0.5$ & Soil & Environmental & TPH-DRO \\
\hline 1107 & MPXII007 & $0.0-0.5$ & Soil & $\begin{array}{c}\text { Environmental, } \\
\text { MS/MSD }\end{array}$ & TPH-DRO \\
\hline 1108 & MPXII008 & $0.0-0.5$ & Soil & Environmental & TPH-DRO \\
\hline \multirow[b]{2}{*}{1109} & MPXII009 & $0.0-0.5$ & Soil & Environmental & TPH-DRO \\
\hline & MPXII201 & $0.0-0.5$ & Soil & $\begin{array}{l}\text { Field Duplicate of } \\
\text { \#MPXII009 }\end{array}$ & TPH-DRO \\
\hline II10 & MPXII010 & $0.0-0.5$ & Soil & Environmental & TPH-DRO \\
\hline
\end{tabular}

$\mathrm{ft}$ bgs = Feet below ground surface MS/MSD = Matrix spike/matrix spike duplicate

$\mathrm{TPH}-\mathrm{DRO}=$ Total petroleum hydrocarbons, diesel-range organics 
Table D.1-81

Soil Sample Results for TPH-DRO at CAS 09-09-27, U-9yz-26 PS \#1A Mud Pit (1)

\begin{tabular}{||c|c|c|c|c||}
\hline \multirow{2}{*}{$\begin{array}{c}\text { Sample } \\
\text { Location }\end{array}$} & \multirow{2}{*}{$\begin{array}{c}\text { Sample } \\
\text { Number }\end{array}$} & \multirow{2}{*}{$\begin{array}{c}\text { Depth } \\
\text { ft bgs) }\end{array}$} & \multicolumn{2}{|c|}{ Contaminants of Potential Concern (mg/kg) } \\
\cline { 4 - 5 } & & Result & Detection Limit \\
\hline \hline II01 & MPXII001 & $0.0-0.5$ & $11(\mathrm{M})$ & 5.2 \\
\hline II02 & MPXII002 & $0.0-0.5$ & $7.2(\mathrm{U})$ & 7.2 \\
\hline II03 & MPXII003 & $0.0-0.5$ & $3.5(\mathrm{~J})$ & 5.4 \\
\hline II04 & MPXII004 & $0.0-0.5$ & $5.2(\mathrm{U})$ & 5.2 \\
\hline II05 & MPXII005 & $0.0-0.5$ & $10(\mathrm{U})$ & 10 \\
\hline II06 & MPXII006 & $0.0-0.5$ & $5.6(\mathrm{M})$ & 5.3 \\
\hline II07 & MPXII007 & $0.0-0.5$ & $4.1(\mathrm{~J})$ & 5.2 \\
\hline II08 & MPXII008 & $0.0-0.5$ & $8(\mathrm{M})$ & 5.2 \\
\hline \multirow{2}{*}{ II09 } & MPXII009 & $0.0-0.5$ & $3.6(\mathrm{~J})$ & 5.1 \\
\cline { 2 - 5 } & MPXII201 & $0.0-0.5$ & $4.2(\mathrm{~J})$ & 5.1 \\
\hline II10 & MPXII010 & $0.0-0.5$ & $14(\mathrm{M})$ & 6.1 \\
\hline \hline
\end{tabular}

$\mathrm{ft}$ bgs $=$ Feet below ground surface

$\mathrm{mg} / \mathrm{kg}=$ Milligrams per kilogram

$\mathrm{J}=$ Estimated value.

$\mathrm{M}=\mathrm{A}$ pattern resembling motor oil was detected.

$\mathrm{U}=$ Compound was analyzed for, but not detected ("non-detect"). 
Table D.1-82

Samples Collected at CAS 09-09-35, U-9bi \#1 PS \#1A Mud Pit (1)

\begin{tabular}{|c|c|c|c|c|c|}
\hline $\begin{array}{c}\text { Sample } \\
\text { Location }\end{array}$ & $\begin{array}{l}\text { Sample } \\
\text { Number }\end{array}$ & $\begin{array}{l}\text { Depth } \\
\text { (ft bgs) }\end{array}$ & Matrix & Purpose & Analyses \\
\hline JJ01 & MPXJJ001 & $0.0-0.5$ & Soil & Environmental & TPH-DRO \\
\hline JJ02 & MPXJJ002 & $0.0-0.5$ & Soil & Environmental & TPH-DRO \\
\hline JJ03 & MPXJJ003 & $0.0-0.5$ & Soil & Environmental & TPH-DRO \\
\hline \multirow[b]{2}{*}{ JJ04 } & MPXJJ004 & $0.0-0.5$ & Soil & Environmental & TPH-DRO \\
\hline & MPXJJ201 & $0.0-0.5$ & Soil & $\begin{array}{l}\text { Field Duplicate } \\
\text { of \#MPXJJ004 }\end{array}$ & TPH-DRO \\
\hline JJ05 & MPXJJ005 & $0.0-0.5$ & Soil & Environmental & TPH-DRO \\
\hline JJ06 & MPXJJ006 & $0.0-0.5$ & Soil & Environmental & TPH-DRO \\
\hline JJ07 & MPXJJ007 & $0.0-0.5$ & Soil & Environmental & TPH-DRO \\
\hline JJ08 & MPXJJ008 & $0.0-0.5$ & Soil & $\begin{array}{c}\text { Environmental, } \\
\text { MS/MSD }\end{array}$ & TPH-DRO \\
\hline JJ09 & MPXJJ009 & $0.0-0.5$ & Soil & Environmental & TPH-DRO \\
\hline JJ10 & MPXJJ010 & $0.0-0.5$ & Soil & Environmental & TPH-DRO \\
\hline
\end{tabular}

$\mathrm{ft}$ bgs = Feet below ground surface MS/MSD = Matrix spike/matrix spike duplicate

$\mathrm{TPH}-\mathrm{DRO}=$ Total petroleum hydrocarbons, diesel-range organics 
Table D.1-83

Soil Sample Results for TPH-DRO at CAS 09-09-35, U-9bi \#1 PS \#1A Mud Pit (1)

\begin{tabular}{|c|c|c|c|c|}
\hline \multirow{2}{*}{$\begin{array}{c}\text { Sample } \\
\text { Location }\end{array}$} & \multirow{2}{*}{$\begin{array}{l}\text { Sample } \\
\text { Number }\end{array}$} & \multirow{2}{*}{$\begin{array}{l}\text { Depth } \\
\text { (ft bgs) }\end{array}$} & \multicolumn{2}{|c|}{ Contaminants of Potential Concern (mg/kg) } \\
\hline & & & Result & Detection Limit \\
\hline JJ01 & MPXJJ001 & $0.0-0.5$ & $5.2(U)$ & 5.2 \\
\hline $\mathrm{JJ02}$ & MPXJJ002 & $0.0-0.5$ & $5.3(U)$ & 5.3 \\
\hline JJ03 & MPXJJ003 & $0.0-0.5$ & $5.3(U)$ & 5.3 \\
\hline \multirow{2}{*}{ JJ04 } & MPXJJ004 & $0.0-0.5$ & $5.4(U)$ & 5.4 \\
\hline & MPXJJ201 & $0.0-0.5$ & $5.3(U)$ & 5.3 \\
\hline JJ05 & MPXJJ005 & $0.0-0.5$ & $5.2(U)$ & 5.2 \\
\hline JJ06 & MPXJJ006 & $0.0-0.5$ & $5.2(U)$ & 5.2 \\
\hline $\mathrm{JJ07}$ & MPXJJ007 & $0.0-0.5$ & $5.3(U)$ & 5.3 \\
\hline JJ08 & MPXJJ008 & $0.0-0.5$ & $5.3(U)$ & 5.3 \\
\hline JJ09 & MPXJJ009 & $0.0-0.5$ & $5.4(U)$ & 5.4 \\
\hline JJ10 & MPXJJ010 & $0.0-0.5$ & $9.2(U)$ & 9.2 \\
\hline
\end{tabular}

$\mathrm{ft}$ bgs $=$ Feet below ground surface

$\mathrm{mg} / \mathrm{kg}=$ Milligrams per kilogram

$\mathrm{U}=$ Compound was analyzed for, but not detected ("non-detect"). 
Table D.1-84

Samples Collected at CAS 09-09-40, U-9cu Grout Test Mud Pit (1)

\begin{tabular}{|c|c|c|c|c|c|}
\hline $\begin{array}{c}\text { Sample } \\
\text { Location }\end{array}$ & $\begin{array}{l}\text { Sample } \\
\text { Number }\end{array}$ & $\begin{array}{c}\text { Depth } \\
\text { (ft bgs) }\end{array}$ & Matrix & Purpose & Analyses \\
\hline KK01 & MPXKK001 & $0.0-0.5$ & Soil & Environmental & TPH-DRO \\
\hline \multirow[b]{2}{*}{ KK02 } & MPXKK002 & $0.0-0.5$ & Soil & Environmental & TPH-DRO \\
\hline & MPXKK201 & $0.0-0.5$ & Soil & $\begin{array}{l}\text { Field Duplicate } \\
\text { of \#MPXKK002 }\end{array}$ & TPH-DRO \\
\hline KK03 & MPXKK003 & $0.0-0.5$ & Soil & Environmental & TPH-DRO \\
\hline KK04 & MPXKK004 & $0.0-0.5$ & Soil & Environmental & TPH-DRO \\
\hline KK05 & MPXKK005 & $0.0-0.5$ & Soil & $\begin{array}{c}\text { Environmental, } \\
\text { MS/MSD }\end{array}$ & TPH-DRO \\
\hline KK06 & MPXKK006 & $0.0-0.5$ & Soil & Environmental & TPH-DRO \\
\hline KK07 & MPXKK007 & $0.0-0.5$ & Soil & Environmental & TPH-DRO \\
\hline KK08 & MPXKК008 & $0.0-0.5$ & Soil & Environmental & TPH-DRO \\
\hline KK09 & MPXKK009 & $0.0-0.5$ & Soil & Environmental & TPH-DRO \\
\hline KK10 & MPXKK010 & $0.0-0.5$ & Soil & Environmental & TPH-DRO \\
\hline
\end{tabular}

$\mathrm{ft}$ bgs $=$ Feet below ground surface MS/MSD = Matrix spike/matrix spike duplicate

$\mathrm{TPH}-\mathrm{DRO}=$ Total petroleum hydrocarbons, diesel-range organics 
Table D.1-85

Soil Sample Results for TPH-DRO at CAS 09-09-40, U-9cu Grout Test Mud Pit (1)

\begin{tabular}{||c|c|c|c|c||}
\hline \multirow{2}{*}{$\begin{array}{c}\text { Sample } \\
\text { Location }\end{array}$} & \multirow{2}{*}{$\begin{array}{c}\text { Sample } \\
\text { Number }\end{array}$} & \multirow{2}{*}{$\begin{array}{c}\text { Depth } \\
\text { ft bgs) }\end{array}$} & \multicolumn{2}{|c|}{ Contaminants of Potential Concern (mg/kg) } \\
\cline { 4 - 5 } & & Result & Detection Limit \\
\hline \hline KK01 & MPXKK001 & $0.0-0.5$ & $5(U)$ & 5 \\
\hline \multirow{2}{*}{ KK02 } & MPXKK002 & $0.0-0.5$ & $5(U)$ & 5 \\
\cline { 3 - 5 } & MPXKK201 & $0.0-0.5$ & $5.1(U)$ & 5.1 \\
\hline KK03 & MPXKK003 & $0.0-0.5$ & $4.9(U)$ & 4.9 \\
\hline KK04 & MPXKK004 & $0.0-0.5$ & $5(U)$ & 5 \\
\hline KK05 & MPXKK005 & $0.0-0.5$ & $5(U)$ & 5 \\
\hline KK06 & MPXKK006 & $0.0-0.5$ & $5.1(U)$ & 5.1 \\
\hline KK07 & MPXKK007 & $0.0-0.5$ & $5.1(U)$ & 5 \\
\hline KK08 & MPXKK008 & $0.0-0.5$ & $5(U)$ & 5.1 \\
\hline KK09 & MPXKK009 & $0.0-0.5$ & $5.1(U)$ & 5.1 \\
\hline KK10 & MPXKK010 & $0.0-0.5$ & $5.1(U)$ & 5.1 \\
\hline \hline
\end{tabular}

$\mathrm{ft}$ bgs = Feet below ground surface

$\mathrm{mg} / \mathrm{kg}=$ Milligrams per kilogram

$\mathrm{U}=$ Compound was analyzed for, but not detected ("non-detect"). 
Table D.1-86

Samples Collected at CAS 09-09-42, U-9bm PS \#1A Mud Pit (1)

\begin{tabular}{|c|c|c|c|c|c|}
\hline $\begin{array}{c}\text { Sample } \\
\text { Location }\end{array}$ & $\begin{array}{l}\text { Sample } \\
\text { Number }\end{array}$ & $\begin{array}{c}\text { Depth } \\
\text { (ft bgs) }\end{array}$ & Matrix & Purpose & Analyses \\
\hline LL01 & MPXLL001 & $0.0-0.5$ & Soil & Environmental & TPH-DRO \\
\hline LL02 & MPXLL002 & $0.0-0.5$ & Soil & Environmental & TPH-DRO \\
\hline LL03 & MPXLL003 & $0.0-0.5$ & Soil & Environmental & TPH-DRO \\
\hline LL04 & MPXLL004 & $0.0-0.5$ & Soil & Environmental & TPH-DRO \\
\hline LL05 & MPXLL005 & $0.0-0.5$ & Soil & Environmental & TPH-DRO \\
\hline LL06 & MPXLL006 & $0.0-0.5$ & Soil & Environmental & TPH-DRO \\
\hline \multirow{2}{*}{ LL07 } & MPXLL007 & $0.0-0.5$ & Soil & Environmental & TPH-DRO \\
\hline & MPXLL201 & $0.0-0.5$ & Soil & $\begin{array}{l}\text { Field Duplicate } \\
\text { of \#MPXLL007 }\end{array}$ & TPH-DRO \\
\hline LL08 & MPXLL008 & $0.0-0.5$ & Soil & Environmental & TPH-DRO \\
\hline LL09 & MPXLL009 & $0.0-0.5$ & Soil & Environmental & TPH-DRO \\
\hline LL10 & MPXLL010 & $0.0-0.5$ & Soil & $\begin{array}{c}\text { Environmental, } \\
\text { MS/MSD }\end{array}$ & TPH-DRO \\
\hline$N / A$ & MPXLL401 & N/A & Water & Field Blank & TPH-DRO \\
\hline
\end{tabular}

$\mathrm{ft}$ bgs $=$ Feet below ground surface

MS/MSD = Matrix spike/matrix spike duplicate

N/A $=$ Not applicable

TPH-DRO = Total petroleum hydrocarbons, diesel-range organics 
Table D.1-87

Soil Sample Results for TPH-DRO at CAS 09-09-42, U-9bm PS \#1A Mud Pit (1)

\begin{tabular}{|c|c|c|c|c|}
\hline \multirow{2}{*}{$\begin{array}{l}\text { Sample } \\
\text { Location }\end{array}$} & \multirow{2}{*}{$\begin{array}{l}\text { Sample } \\
\text { Number }\end{array}$} & \multirow{2}{*}{$\begin{array}{l}\text { Depth } \\
\text { (ft bgs) }\end{array}$} & \multicolumn{2}{|c|}{ Contaminants of Potential Concern $(\mathrm{mg} / \mathrm{kg})$} \\
\hline & & & Result & Detection Limit \\
\hline LL01 & MPXLL001 & $0.0-0.5$ & $5(U)$ & 5 \\
\hline LL02 & MPXLL002 & $0.0-0.5$ & $5.1(U)$ & 5.1 \\
\hline LL03 & MPXLL003 & $0.0-0.5$ & $5(U)$ & 5 \\
\hline LL04 & MPXLL004 & $0.0-0.5$ & $5(U)$ & 5 \\
\hline LL05 & MPXLL005 & $0.0-0.5$ & $5(U)$ & 5 \\
\hline LL06 & MPXLL006 & $0.0-0.5$ & $5(U)$ & 5 \\
\hline \multirow{2}{*}{ LL07 } & MPXLL007 & $0.0-0.5$ & $5(U)$ & 5 \\
\hline & MPXLL201 & $0.0-0.5$ & $5(U)$ & 5 \\
\hline LL08 & MPXLL008 & $0.0-0.5$ & $5(U)$ & 5 \\
\hline LL09 & MPXLL009 & $0.0-0.5$ & $5(U)$ & 5 \\
\hline LL10 & MPXLL010 & $0.0-0.5$ & $5(U)$ & 5 \\
\hline
\end{tabular}

$\mathrm{ft}$ bgs $=$ Feet below ground surface $\mathrm{mg} / \mathrm{kg}=$ Milligrams per kilogram

$\mathrm{U}=$ Compound was analyzed for, but not detected ("non-detect"). 
Table D.1-88

Samples Collected at CAS 10-09-12, U-10d Mud Pit (2)

\begin{tabular}{|c|c|c|c|c|c|}
\hline $\begin{array}{l}\text { Sample } \\
\text { Location }\end{array}$ & $\begin{array}{l}\text { Sample } \\
\text { Number }\end{array}$ & $\begin{array}{l}\text { Depth } \\
\text { (ft bgs) }\end{array}$ & Matrix & Purpose & Analyses \\
\hline MM01 & MPXMM001 & $0.0-0.5$ & Soil & Environmental & TPH-DRO \\
\hline MM02 & MPXMM002 & $0.0-0.5$ & Soil & Environmental & TPH-DRO \\
\hline \multirow[b]{2}{*}{ MM03 } & MPXMM003 & $0.0-0.5$ & Soil & Environmental & TPH-DRO \\
\hline & MPXMM201 & $0.0-0.5$ & Soil & $\begin{array}{l}\text { Field Duplicate } \\
\text { of \#MPXMM003 }\end{array}$ & TPH-DRO \\
\hline MM04 & MPXMM004 & $0.0-0.5$ & Soil & Environmental & TPH-DRO \\
\hline MM05 & MPXMM005 & $0.0-0.5$ & Soil & Environmental & TPH-DRO \\
\hline MM06 & MPXMM006 & $0.0-0.5$ & Soil & $\begin{array}{c}\text { Environmental, } \\
\text { MS/MSD }\end{array}$ & TPH-DRO \\
\hline MM07 & MPXMM007 & $0.0-0.5$ & Soil & Environmental & TPH-DRO \\
\hline MM08 & MPXMM008 & $0.0-0.5$ & Soil & Environmental & TPH-DRO \\
\hline MM09 & MPXMM009 & $0.0-0.5$ & Soil & Environmental & TPH-DRO \\
\hline MM10 & MPXMM010 & $0.0-0.5$ & Soil & Environmental & TPH-DRO \\
\hline N/A & MPXMM401 & $N / A$ & Water & Field Blank & Set 1 \\
\hline
\end{tabular}

Set 1 = TPH-DRO, gamma spectroscopy, isotopic uranium, isotopic plutonium, strontium-90

$\mathrm{ft}$ bgs = Feet below ground surface

MS/MSD = Matrix spike/matrix spike duplicate

N/A = Not applicable

TPH-DRO = Total petroleum hydrocarbons, diesel-range organics 
Table D.1-89

Soil Sample Results for TPH-DRO at CAS 10-09-12, U-10d Mud Pit (2)

\begin{tabular}{|c|c|c|c|c|}
\hline \multirow{2}{*}{$\begin{array}{l}\text { Sample } \\
\text { Location }\end{array}$} & \multirow{2}{*}{$\begin{array}{l}\text { Sample } \\
\text { Number }\end{array}$} & \multirow{2}{*}{$\begin{array}{l}\text { Depth } \\
\text { (ft bgs) }\end{array}$} & \multicolumn{2}{|c|}{ Contaminants of Potential Concern $(\mathrm{mg} / \mathrm{kg})$} \\
\hline & & & Result & Detection Limit \\
\hline MM01 & MPXMM001 & $0.0-0.5$ & $5.4(U)$ & 5.4 \\
\hline MM02 & MPXMM002 & $0.0-0.5$ & $9(U)$ & 9 \\
\hline \multirow{2}{*}{ MM03 } & MPXMM003 & $0.0-0.5$ & $9.5(U)$ & 9.5 \\
\hline & MPXMM201 & $0.0-0.5$ & $8.1(U)$ & 8.1 \\
\hline MM04 & MPXMM004 & $0.0-0.5$ & $8.4(U)$ & 8.4 \\
\hline MM05 & MPXMM005 & $0.0-0.5$ & $9(U)$ & 9 \\
\hline MM06 & MPXMM006 & $0.0-0.5$ & $6.3(U)$ & 6.3 \\
\hline MM07 & MPXMM007 & $0.0-0.5$ & $5.2(U)$ & 5.2 \\
\hline MM08 & MPXMM008 & $0.0-0.5$ & $11(\mathrm{M})$ & 5.7 \\
\hline MM09 & MPXMM009 & $0.0-0.5$ & $12(\mathrm{M})$ & 5.9 \\
\hline MM10 & MPXMM010 & $0.0-0.5$ & $2.8(\mathrm{~J})$ & 5.6 \\
\hline
\end{tabular}

$\mathrm{ft}$ bgs $=$ Feet below ground surface

$\mathrm{mg} / \mathrm{kg}=$ Milligrams per kilogram

$\mathrm{J}=$ Estimated value.

$\mathrm{M}=\mathrm{A}$ pattern resembling motor oil was detected.

$\mathrm{U}=$ Compound was analyzed for, but not detected ("non-detect"). 
Table D.1-90

Samples Collected at CAS 10-09-18, U-10ap \#3 PS \#1A Mud Pit (1)

\begin{tabular}{|c|c|c|c|c|c|}
\hline $\begin{array}{c}\text { Sample } \\
\text { Location }\end{array}$ & $\begin{array}{l}\text { Sample } \\
\text { Number }\end{array}$ & $\begin{array}{l}\text { Depth } \\
\text { (ft bgs) }\end{array}$ & Matrix & Purpose & Analyses \\
\hline NN01 & MPXNN001 & $0.0-0.5$ & Soil & Environmental & TPH-DRO \\
\hline NN02 & MPXNN002 & $0.0-0.5$ & Soil & Environmental & TPH-DRO \\
\hline \multirow[b]{2}{*}{ NN03 } & MPXNN003 & $0.0-0.5$ & Soil & Environmental & TPH-DRO \\
\hline & MPXNN201 & $0.0-0.5$ & Soil & $\begin{array}{l}\text { Field Duplicate } \\
\text { of \#MPXNN003 }\end{array}$ & TPH-DRO \\
\hline NN04 & MPXNN004A & $0.0-0.5$ & Soil & Environmental & TPH-DRO \\
\hline NN05 & MPXNN005A & $0.0-0.5$ & Soil & Environmental & TPH-DRO \\
\hline NN06 & MPXNN006A & $0.0-0.5$ & Soil & Environmental & TPH-DRO \\
\hline NN07 & MPXNN007 & $0.0-0.5$ & Soil & Environmental & TPH-DRO \\
\hline NN08 & MPXNN008 & $0.0-0.5$ & Soil & $\begin{array}{c}\text { Environmental, } \\
\text { MS/MSD }\end{array}$ & TPH-DRO \\
\hline NN09 & MPXNN009 & $0.0-0.5$ & Soil & Environmental & TPH-DRO \\
\hline NN10 & MPXNN010 & $0.0-0.5$ & Soil & Environmental & TPH-DRO \\
\hline
\end{tabular}

$\mathrm{ft}$ bgs = Feet below ground surface MS/MSD = Matrix spike/matrix spike duplicate

$\mathrm{TPH}-\mathrm{DRO}=$ Total petroleum hydrocarbons, diesel-range organics 
Table D.1-91

Soil Sample Results for TPH-DRO at CAS 10-09-18, U-10ap \#3 PS \#1A Mud Pit (1)

\begin{tabular}{|c|c|c|c|c|}
\hline \multirow{2}{*}{$\begin{array}{l}\text { Sample } \\
\text { Location }\end{array}$} & \multirow{2}{*}{$\begin{array}{l}\text { Sample } \\
\text { Number }\end{array}$} & \multirow{2}{*}{$\begin{array}{l}\text { Depth } \\
\text { (ft bgs) }\end{array}$} & \multicolumn{2}{|c|}{ Contaminants of Potential Concern (mg/kg } \\
\hline & & & Result & Detection Limit \\
\hline NN01 & MPXNN001 & $0.0-0.5$ & $120(\mathrm{M})$ & 5.6 \\
\hline NN02 & MPXNN002 & $0.0-0.5$ & $43(L, M)$ & 5.5 \\
\hline \multirow{2}{*}{ NN03 } & MPXNN003 & $0.0-0.5$ & $13(\mathrm{~L}, \mathrm{M})$ & 6 \\
\hline & MPXNN201 & $0.0-0.5$ & $4.6(\mathrm{~J})$ & 5.7 \\
\hline NN04 & MPXNN004A & $0.0-0.5$ & $6(\mathrm{~J})$ & 6.1 \\
\hline NN05 & MPXNN005A & $0.0-0.5$ & $8(\mathrm{M})$ & 5.3 \\
\hline NN06 & MPXNN006A & $0.0-0.5$ & $9.6(\mathrm{M}, \mathrm{Z})$ & 5.7 \\
\hline NN07 & MPXNN007 & $0.0-0.5$ & $14(\mathrm{~L}, \mathrm{M})$ & 5.7 \\
\hline NN08 & MPXNN008 & $0.0-0.5$ & $24(\mathrm{M}, \mathrm{Z})$ & 5.6 \\
\hline NN09 & MPXNN009 & $0.0-0.5$ & $5.2(\mathrm{U})$ & 5.2 \\
\hline NN10 & MPXNN010 & $0.0-0.5$ & $5.6(U)$ & 5.6 \\
\hline
\end{tabular}

$\mathrm{ft}$ bgs $=$ Feet below ground surface

$\mathrm{mg} / \mathrm{kg}=$ Milligrams per kilogram

$\mathrm{J}=$ Estimated value.

$\mathrm{L}=$ Fuel pattern in the lighter end of retention time window.

$\mathrm{M}=\mathrm{A}$ pattern resembling motor oil was detected.

$\mathrm{U}=$ Compound was analyzed for, but not detected ("non-detect").

$Z=$ Result did not resemble any common total petroleum hydrocarbons products. 
Table D.1-92

Samples Collected at CAS 10-09-26, U-10aj Mud Pit (1)

\begin{tabular}{|c|c|c|c|c|c|}
\hline $\begin{array}{c}\text { Sample } \\
\text { Location }\end{array}$ & $\begin{array}{l}\text { Sample } \\
\text { Number }\end{array}$ & $\begin{array}{l}\text { Depth } \\
\text { (ft bgs) }\end{array}$ & Matrix & Purpose & Analyses \\
\hline 0001 & MPXOO001 & $0.0-0.5$ & Soil & Environmental & TPH-DRO \\
\hline 0002 & MPXOO002 & $0.0-0.5$ & Soil & Environmental & TPH-DRO \\
\hline 0003 & MPX00003 & $0.0-0.5$ & Soil & Environmental & TPH-DRO \\
\hline 0004 & MPXOO004 & $0.0-0.5$ & Soil & $\begin{array}{l}\text { Environmental, } \\
\text { MS/MSD }\end{array}$ & TPH-DRO \\
\hline 0005 & MPXOO005 & $0.0-0.5$ & Soil & Environmental & TPH-DRO \\
\hline \multirow[b]{2}{*}{0006} & MPX00006 & $0.0-0.5$ & Soil & Environmental & TPH-DRO \\
\hline & MPXOO201 & $0.0-0.5$ & Soil & $\begin{array}{l}\text { Field Duplicate } \\
\text { of \#MPXOO006 }\end{array}$ & TPH-DRO \\
\hline 0007 & MPXOO007 & $0.0-0.5$ & Soil & Environmental & TPH-DRO \\
\hline 0008 & MPXOO008 & $0.0-0.5$ & Soil & Environmental & TPH-DRO \\
\hline 0009 & MPXOO009 & $0.0-0.5$ & Soil & Environmental & TPH-DRO \\
\hline 0010 & MPX00010 & $0.0-0.5$ & Soil & Environmental & TPH-DRO \\
\hline N/A & MPX00401 & N/A & Water & Field Blank & TPH-DRO \\
\hline
\end{tabular}

$\mathrm{ft}$ bgs = Feet below ground surface

MS/MSD = Matrix spike/matrix spike duplicate

N/A = Not applicable

TPH-DRO = Total petroleum hydrocarbons, diesel-range organics 
Table D.1-93

Soil Sample Results for TPH-DRO at CAS 10-09-26, U-10aj Mud Pit (1)

\begin{tabular}{|c|c|c|c|c|}
\hline \multirow{2}{*}{$\begin{array}{c}\text { Sample } \\
\text { Location }\end{array}$} & \multirow{2}{*}{$\begin{array}{l}\text { Sample } \\
\text { Number }\end{array}$} & \multirow{2}{*}{$\begin{array}{c}\text { Depth } \\
\text { (ft bgs) }\end{array}$} & \multicolumn{2}{|c|}{ Contaminants of Potential Concern (mg/kg) } \\
\hline & & & Result & Detection Limit \\
\hline 0001 & MPXOO001 & $0.0-0.5$ & $9(\mathrm{M})$ & 5.4 \\
\hline 0002 & MPXOO002 & $0.0-0.5$ & $5.3(U)$ & 5.3 \\
\hline 0003 & MPXOO003 & $0.0-0.5$ & $5.8(U)$ & 5.8 \\
\hline 0004 & MPXOO004 & $0.0-0.5$ & $5.4(U)$ & 5.4 \\
\hline 0005 & MPXOO005 & $0.0-0.5$ & $5.3(U)$ & 5.3 \\
\hline \multirow{2}{*}{0006} & MPXOO006 & $0.0-0.5$ & $5.9(U)$ & 5.9 \\
\hline & MPXOO201 & $0.0-0.5$ & $5.9(U)$ & 5.9 \\
\hline 0007 & MPXOO007 & $0.0-0.5$ & $5.3(U)$ & 5.3 \\
\hline 0008 & MPXOO008 & $0.0-0.5$ & $5.2(U)$ & 5.2 \\
\hline 0009 & MPXOO009 & $0.0-0.5$ & $5.4(U)$ & 5.4 \\
\hline 0010 & MPX00010 & $0.0-0.5$ & $5.3(U)$ & 5.3 \\
\hline
\end{tabular}

$\mathrm{ft}$ bgs $=$ Feet below ground surface

$\mathrm{mg} / \mathrm{kg}=$ Milligrams per kilogram

$\mathrm{M}=\mathrm{A}$ pattern resembling motor oil was detected.

$\mathrm{U}=$ Compound was analyzed for, but not detected ("non-detect"). 
Table D.1-94

Samples Collected at CAS 14-09-02, UE-14a Mud Pit (1)

\begin{tabular}{|c|c|c|c|c|c|}
\hline $\begin{array}{l}\text { Sample } \\
\text { Location }\end{array}$ & $\begin{array}{l}\text { Sample } \\
\text { Number }\end{array}$ & $\begin{array}{l}\text { Depth } \\
\text { (ft bgs) }\end{array}$ & Matrix & Purpose & Analyses \\
\hline PP01 & MPXPP001 & $0.0-0.5$ & Soil & Environmental & TPH-DRO \\
\hline PP02 & MPXPP002 & $0.0-0.5$ & Soil & Environmental & TPH-DRO \\
\hline PP03 & MPXPP003 & $0.0-0.5$ & Soil & Environmental & TPH-DRO \\
\hline PP04 & MPXPP004 & $0.0-0.5$ & Soil & Environmental & TPH-DRO \\
\hline PP05 & MPXPP005 & $0.0-0.5$ & Soil & $\begin{array}{l}\text { Environmental, } \\
\text { MS/MSD }\end{array}$ & TPH-DRO \\
\hline PP06 & MPXPP006 & $0.0-0.5$ & Soil & Environmental & TPH-DRO \\
\hline \multirow[b]{2}{*}{ PP07 } & MPXPP007 & $0.0-0.5$ & Soil & Environmental & TPH-DRO \\
\hline & MPXPP201 & $0.0-0.5$ & Soil & $\begin{array}{l}\text { Field Duplicate } \\
\text { of \#MPXPP007 }\end{array}$ & TPH-DRO \\
\hline PP08 & MPXPP008 & $0.0-0.5$ & Soil & Environmental & TPH-DRO \\
\hline PP09 & MPXPP009 & $0.0-0.5$ & Soil & Environmental & TPH-DRO \\
\hline PP10 & MPXPP010 & $0.0-0.5$ & Soil & Environmental & TPH-DRO \\
\hline
\end{tabular}

$\mathrm{ft}$ bgs = Feet below ground surface MS/MSD = Matrix spike/matrix spike duplicate

$\mathrm{TPH}-\mathrm{DRO}=$ Total petroleum hydrocarbons, diesel-range organics 
Table D.1-95

Soil Sample Results for TPH-DRO at CAS 14-09-02, UE-14a Mud Pit (1)

\begin{tabular}{|c|c|c|c|c|}
\hline \multirow{2}{*}{$\begin{array}{c}\text { Sample } \\
\text { Location }\end{array}$} & \multirow{2}{*}{$\begin{array}{l}\text { Sample } \\
\text { Number }\end{array}$} & \multirow{2}{*}{$\begin{array}{l}\text { Depth } \\
\text { (ft bgs) }\end{array}$} & \multicolumn{2}{|c|}{ Contaminants of Potential Concern (mg/kg) } \\
\hline & & & Result & Detection Limit \\
\hline PP01 & MPXPP001 & $0.0-0.5$ & $5.4(U)$ & 5.4 \\
\hline PP02 & MPXPP002 & $0.0-0.5$ & $5.7(U)$ & 5.7 \\
\hline PP03 & MPXPP003 & $0.0-0.5$ & $5.5(U)$ & 5.5 \\
\hline PP04 & MPXPP004 & $0.0-0.5$ & $5.8(U)$ & 5.8 \\
\hline PP05 & MPXPP005 & $0.0-0.5$ & $5.5(U)$ & 5.5 \\
\hline PP06 & MPXPP006 & $0.0-0.5$ & $5.6(U)$ & 5.6 \\
\hline \multirow{2}{*}{ PP07 } & MPXPP007 & $0.0-0.5$ & $6(U)$ & 6 \\
\hline & MPXPP201 & $0.0-0.5$ & $6.7(\mathrm{U})$ & 6.7 \\
\hline PP08 & MPXРP008 & $0.0-0.5$ & $5.5(U)$ & 5.5 \\
\hline PP09 & MPXPP009 & $0.0-0.5$ & $5.4(U)$ & 5.4 \\
\hline PP10 & MPXPP010 & $0.0-0.5$ & $5.3(U)$ & 5.3 \\
\hline
\end{tabular}

$\mathrm{ft}$ bgs $=$ Feet below ground surface

$\mathrm{mg} / \mathrm{kg}=$ Milligrams per kilogram

$\mathrm{U}=$ Compound was analyzed for, but not detected ("non-detect"). 
Table D.1-96

Samples Collected at CAS 19-09-12, U-19q Mud Pit (1)

\begin{tabular}{|c|c|c|c|c|c||}
\hline $\begin{array}{c}\text { Sample } \\
\text { Location }\end{array}$ & $\begin{array}{c}\text { Sample } \\
\text { Number }\end{array}$ & $\begin{array}{c}\text { Depth } \\
\text { (ft bgs) }\end{array}$ & Matrix & Purpose & Analyses \\
\hline \hline QQ01 & MPXQQ001 & $0.0-0.5$ & Soil & Environmental & TPH-DRO \\
\hline QQ02 & MPXQQ002 & $0.0-0.5$ & Soil & $\begin{array}{c}\text { Environmental, } \\
\text { MS/MSD }\end{array}$ & TPH-DRO \\
\hline QQ03 & MPXQQ003 & $0.0-0.5$ & Soil & Environmental & TPH-DRO \\
\hline QQ04 & MPXQQ004 & $0.0-0.5$ & Soil & Environmental & TPH-DRO \\
\hline QQ05 & MPXQQ005 & $0.0-0.5$ & Soil & Environmental & TPH-DRO \\
\hline & MPXQQ006 & $0.0-0.5$ & Soil & Environmental & TPH-DRO \\
\cline { 2 - 6 } QQ06 & MPXQQ201 & $0.0-0.5$ & Soil & $\begin{array}{c}\text { Field Duplicate } \\
\text { of \#MPXQQ006 }\end{array}$ & TPH-DRO \\
\hline QQ07 & MPXQQ007 & $0.0-0.5$ & Soil & Environmental & TPH-DRO \\
\hline QQ08 & MPXQQ008 & $0.0-0.5$ & Soil & Environmental & TPH-DRO \\
\hline QQ09 & MPXQQ009A & $0.0-0.5$ & Soil & Environmental & TPH-DRO \\
\hline QQ10 & MPXQQ010 & $0.0-0.5$ & Soil & Environmental & TPH-DRO \\
\hline
\end{tabular}

$\mathrm{ft}$ bgs = Feet below ground surface MS/MSD = Matrix spike/matrix spike duplicate

$\mathrm{TPH}-\mathrm{DRO}=$ Total petroleum hydrocarbons, diesel-range organics 
Table D.1-97

Soil Sample Results for TPH-DRO at CAS 19-09-12, U-19q Mud Pit (1)

\begin{tabular}{|c|c|c|c|c|}
\hline \multirow{2}{*}{$\begin{array}{c}\text { Sample } \\
\text { Location }\end{array}$} & \multirow{2}{*}{$\begin{array}{c}\text { Sample } \\
\text { Number }\end{array}$} & $\begin{array}{c}\text { Depth } \\
\text { (ft bgs) }\end{array}$ & \multicolumn{2}{|c|}{ Contaminants of Potential Concern (mg/kg) } \\
\cline { 4 - 5 } & & & $5.9(\mathrm{H}, \mathrm{Z})$ & Detection Limit \\
\hline \hline QQ01 & MPXQQ001 & $0.0-0.5$ & $12(\mathrm{H})$ & 5.7 \\
\hline QQ02 & MPXQQ002 & $0.0-0.5$ & $300(\mathrm{H})$ & 5.9 \\
\hline QQ03 & MPXQQ003 & $0.0-0.5$ & $5.7(\mathrm{U})$ & 5.7 \\
\hline QQ04 & MPXQQ004 & $0.0-0.5$ & $2.5(\mathrm{~J})$ & 5.5 \\
\hline QQ05 & MPXQQ005 & $0.0-0.5$ & $230(\mathrm{H})$ & 6.8 \\
\hline \multirow{2}{*}{ QQ06 } & MPXQQ006 & $0.0-0.5$ & $240(\mathrm{H})$ & 6.5 \\
\cline { 3 - 5 } & MPXQQ201 & $0.0-0.5$ & $100(\mathrm{H})$ & 6 \\
\hline QQ07 & MPXQQ007 & $0.0-0.5$ & $15(\mathrm{H}, \mathrm{M})$ & 5.7 \\
\hline QQ08 & MPXQQ008 & $0.0-0.5$ & $280(\mathrm{H}, \mathrm{Z})$ & 5.4 \\
\hline QQ09 & MPXQQ009A & $0.0-0.5$ & $48(\mathrm{H}, \mathrm{L}, \mathrm{Z})$ & 5.4 \\
\hline QQ10 & MPXQQ010 & $0.0-0.5$ & & 6 \\
\hline
\end{tabular}

$\mathrm{ft}$ bgs $=$ Feet below ground surface

$\mathrm{mg} / \mathrm{kg}=$ Milligrams per kilogram

$\mathrm{J}=$ Estimated value.

$\mathrm{H}=$ Fuel pattern in the heavier end of retention time window.

$\mathrm{L}=$ Fuel pattern in the lighter end of retention time window.

$\mathrm{M}=\mathrm{A}$ pattern resembling motor oil was detected.

$\mathrm{U}=$ Compound was analyzed for, but not detected ("non-detect").

$Z=$ Result did not resemble any common total petroleum hydrocarbons products. 
Table D.1-98

Samples Collected at CAS 19-09-17, U-19bj Mud Pit (1)

\begin{tabular}{||c|c|c|c|c|c||}
\hline $\begin{array}{c}\text { Sample } \\
\text { Location }\end{array}$ & $\begin{array}{c}\text { Sample } \\
\text { Number }\end{array}$ & $\begin{array}{c}\text { Depth } \\
\mathbf{f t} \text { bgs })\end{array}$ & Matrix & Purpose & Analyses \\
\hline \hline RR01 & MPXRR001 & $0.0-0.5$ & Soil & Environmental & TPH-DRO \\
\hline RR02 & MPXRR002 & $0.0-0.5$ & Soil & Environmental & TPH-DRO \\
\cline { 2 - 6 } & MPXRR201 & $0.0-0.5$ & Field Duplicate & of \#MPXRR002 \\
\hline RR03 & MPXRR003 & $0.0-0.5$ & Soil & Environmental, & MS/MSD \\
\hline RR04 & MPXRR004 & $0.0-0.5$ & Soil & Environmental & TPH-DRO \\
\hline RR05 & MPXRR005 & $0.0-0.5$ & Soil & Environmental & TPH-DRO \\
\hline RR06 & MPXRR006 & $0.0-0.5$ & Soil & Environmental & TPH-DRO \\
\hline RR07 & MPXRR007 & $0.0-0.5$ & Soil & Environmental & TPH-DRO \\
\hline RR08 & MPXRR008 & $0.0-0.5$ & Soil & Environmental & TPH-DRO \\
\hline RR09 & MPXRR009 & $0.0-0.5$ & Soil & Environmental & TPH-DRO \\
\hline RR10 & MPXRR010 & $0.0-0.5$ & Soil & Environmental & TPH-DRO \\
\hline
\end{tabular}

$\mathrm{ft}$ bgs = Feet below ground surface MS/MSD = Matrix spike/matrix spike duplicate

$\mathrm{TPH}-\mathrm{DRO}=$ Total petroleum hydrocarbons, diesel-range organics 
Table D.1-99

Soil Sample Results for TPH-DRO at CAS 19-09-17, U-19bj Mud Pit (1)

\begin{tabular}{||c|c|c|c|c||}
\hline \multirow{2}{*}{$\begin{array}{c}\text { Sample } \\
\text { Location }\end{array}$} & \multirow{2}{*}{$\begin{array}{c}\text { Sample } \\
\text { Number }\end{array}$} & $\begin{array}{c}\text { Depth } \\
\text { (ft bgs) }\end{array}$ & \multicolumn{2}{|c|}{ Contaminants of Potential Concern (mg/kg) } \\
\cline { 4 - 5 } & & Result & Detection Limit \\
\hline \hline RR01 & MPXRR001 & $0.0-0.5$ & $5.2(\mathrm{U})$ & 5.2 \\
\hline \multirow{2}{*}{ RR02 } & MPXRR002 & $0.0-0.5$ & $16(\mathrm{M})$ & 5.5 \\
\cline { 2 - 5 } & MPXRR201 & $0.0-0.5$ & $13(\mathrm{M})$ & 5.5 \\
\hline RR03 & MPXRR003 & $0.0-0.5$ & $5.5(\mathrm{U})$ & 5.5 \\
\hline RR04 & MPXRR004 & $0.0-0.5$ & $5.2(\mathrm{U})$ & 5.2 \\
\hline RR05 & MPXRR005 & $0.0-0.5$ & $5.1(\mathrm{U})$ & 5.1 \\
\hline RR06 & MPXRR006 & $0.0-0.5$ & $5.2(\mathrm{U})$ & 5.2 \\
\hline RR07 & MPXRR007 & $0.0-0.5$ & $5.2(\mathrm{U})$ & 5.2 \\
\hline RR08 & MPXRR008 & $0.0-0.5$ & $66(\mathrm{M})$ & 5.2 \\
\hline RR09 & MPXRR009 & $0.0-0.5$ & $5.6(\mathrm{U})$ & 5.6 \\
\hline RR10 & MPXRR010 & $0.0-0.5$ & $5.8(\mathrm{U})$ & 5.8 \\
\hline \hline
\end{tabular}

$\mathrm{ft}$ bgs $=$ Feet below ground surface

$\mathrm{mg} / \mathrm{kg}=$ Milligrams per kilogram

$\mathrm{M}=\mathrm{A}$ pattern resembling motor oil was detected.

$\mathrm{U}=$ Compound was analyzed for, but not detected ("non-detect"). 
Table D.1-100

Samples Collected at CAS 19-09-19, U-19x PS \#1D Mud Pit (1)

\begin{tabular}{|c|c|c|c|c|c|}
\hline $\begin{array}{c}\text { Sample } \\
\text { Location }\end{array}$ & $\begin{array}{l}\text { Sample } \\
\text { Number }\end{array}$ & $\begin{array}{l}\text { Depth } \\
\text { (ft bgs) }\end{array}$ & Matrix & Purpose & Analyses \\
\hline SS01 & MPXSS001 & $0.0-0.5$ & Soil & Environmental & TPH-DRO \\
\hline SS02 & MPXSS002 & $0.0-0.5$ & Soil & Environmental & TPH-DRO \\
\hline SS03 & MPXSS003 & $0.0-0.5$ & Soil & Environmental & TPH-DRO \\
\hline \multirow[b]{2}{*}{ SSO4 } & MPXSS004 & $0.0-0.5$ & Soil & Environmental & TPH-DRO \\
\hline & MPXSS201 & $0.0-0.5$ & Soil & $\begin{array}{l}\text { Field Duplicate } \\
\text { of \#MPXSS004 }\end{array}$ & TPH-DRO \\
\hline SS05 & MPXSS005 & $0.0-0.5$ & Soil & Environmental & TPH-DRO \\
\hline SS06 & MPXSS006 & $0.0-0.5$ & Soil & Environmental & TPH-DRO \\
\hline SS07 & MPXSS007 & $0.0-0.5$ & Soil & Environmental & TPH-DRO \\
\hline SS08 & MPXSS008 & $0.0-0.5$ & Soil & $\begin{array}{l}\text { Environmental, } \\
\text { MS/MSD }\end{array}$ & TPH-DRO \\
\hline SSO9 & MPXSS009 & $0.0-0.5$ & Soil & Environmental & TPH-DRO \\
\hline SS10 & MPXSS010 & $0.0-0.5$ & Soil & Environmental & TPH-DRO \\
\hline N/A & MPXSS401 & N/A & Water & Field Blank & TPH-DRO \\
\hline
\end{tabular}

$\mathrm{ft}$ bgs = Feet below ground surface

MS/MSD = Matrix spike/matrix spike duplicate

N/A = Not applicable

TPH-DRO = Total petroleum hydrocarbons, diesel-range organics 
Table D.1-101

Soil Sample Results for TPH-DRO at CAS 19-09-19, U-19x PS \#1D Mud Pit (1)

\begin{tabular}{|c|c|c|c|c|}
\hline \multirow{2}{*}{$\begin{array}{l}\text { Sample } \\
\text { Location }\end{array}$} & \multirow{2}{*}{$\begin{array}{l}\text { Sample } \\
\text { Number }\end{array}$} & \multirow{2}{*}{$\begin{array}{c}\text { Depth } \\
\text { (ft bgs) }\end{array}$} & \multicolumn{2}{|c|}{ Contaminants of Potential Concern (mg/kg) } \\
\hline & & & Result & Detection Limit \\
\hline SS01 & MPXSS001 & $0.0-0.5$ & $5.7(U)$ & 5.7 \\
\hline SSO2 & MPXSS002 & $0.0-0.5$ & $6.9(U)$ & 6.9 \\
\hline SS03 & MPXSS003 & $0.0-0.5$ & $6.4(U)$ & 6.4 \\
\hline \multirow{2}{*}{ SS04 } & MPXSS004 & $0.0-0.5$ & $6(U)$ & 6 \\
\hline & MPXSS201 & $0.0-0.5$ & $6(U)$ & 6 \\
\hline SS05 & MPXSS005 & $0.0-0.5$ & $5.7(U)$ & 5.7 \\
\hline SS06 & MPXSS006 & $0.0-0.5$ & $6(U)$ & 6 \\
\hline SS07 & MPXSS007 & $0.0-0.5$ & $6.3(U)$ & 6.3 \\
\hline SS08 & MPXSS008 & $0.0-0.5$ & $6.6(U)$ & 6.6 \\
\hline SS09 & MPXSS009 & $0.0-0.5$ & $5.9(U)$ & 5.9 \\
\hline SS10 & MPXSS010 & $0.0-0.5$ & $5.9(U)$ & 5.9 \\
\hline
\end{tabular}

$\mathrm{ft}$ bgs = Feet below ground surface

$\mathrm{mg} / \mathrm{kg}=$ Milligrams per kilogram

$\mathrm{U}=$ Compound was analyzed for, but not detected ("non-detect"). 
Table D.1-102

Samples Collected at CAS 19-09-27, U-19zS PS \#1D Covered Mud Pit (1)

\begin{tabular}{|c|c|c|c|c|c|}
\hline $\begin{array}{c}\text { Sample } \\
\text { Location }\end{array}$ & $\begin{array}{l}\text { Sample } \\
\text { Number }\end{array}$ & $\begin{array}{l}\text { Depth } \\
\text { (ft bgs) }\end{array}$ & Matrix & Purpose & Analyses \\
\hline TT01 & MPXTT001 & $4.0-4.5$ & Soil & Environmental & TPH-DRO \\
\hline \multirow[b]{2}{*}{ TT02 } & MPXTT002 & $3.5-4.0$ & Soil & Environmental & TPH-DRO \\
\hline & MPXTT201 & $3.5-4.0$ & Soil & $\begin{array}{l}\text { Field Duplicate } \\
\text { of \#MPXTT002 }\end{array}$ & TPH-DRO \\
\hline TT03 & МРХTT003 & $2.5-3.0$ & Soil & Environmental & TPH-DRO \\
\hline TT04 & MPXTT004 & $4.0-4.5$ & Soil & Environmental & TPH-DRO \\
\hline TT05 & MPXTT005 & $3.5-4.0$ & Soil & $\begin{array}{c}\text { Environmental, } \\
\text { MS/MSD }\end{array}$ & TPH-DRO \\
\hline TT06 & MPXTT006 & $3.0-3.5$ & Soil & Environmental & TPH-DRO \\
\hline TT07 & MPXТT007 & $3.5-4.0$ & Soil & Environmental & TPH-DRO \\
\hline TT08 & MPXTT008 & $3.5-4.0$ & Soil & Environmental & TPH-DRO \\
\hline TT09 & MPХTT009 & $4.0-4.5$ & Soil & Environmental & TPH-DRO \\
\hline TT10 & MPXTT010 & $4.5-5.0$ & Soil & Environmental & TPH-DRO \\
\hline$N / A$ & MPXTT401 & $\mathrm{N} / \mathrm{A}$ & Water & Field Blank & TPH-DRO \\
\hline
\end{tabular}

$\mathrm{ft}$ bgs = Feet below ground surface

MS/MSD = Matrix spike/matrix spike duplicate

TPH-DRO = Total petroleum hydrocarbons, diesel-range organics 
Table D.1-103

Soil Sample Results for TPH-DRO at

CAS 19-09-27, U-19zS PS \#1D Covered Mud Pit (1)

\begin{tabular}{|c|c|c|c|c||}
\hline \multirow{2}{*}{$\begin{array}{c}\text { Sample } \\
\text { Location }\end{array}$} & \multirow{2}{*}{$\begin{array}{c}\text { Sample } \\
\text { Number }\end{array}$} & $\begin{array}{c}\text { Depth } \\
\text { (ft bgs) }\end{array}$ & \multicolumn{2}{|c|}{ Contaminants of Potential Concern (mg/kg) } \\
\cline { 4 - 5 } & & Result & Detection Limit \\
\hline \hline TT01 & MPXTT001 & $4.0-4.5$ & $5.3(\mathrm{U})$ & 5.3 \\
\hline \multirow{2}{*}{ TT02 } & MPXTT002 & $3.5-4.0$ & $5.9(\mathrm{U})$ & 5.9 \\
\cline { 2 - 5 } & MPXTT201 & $3.5-4.0$ & $5.5(\mathrm{U})$ & 5.5 \\
\hline TT03 & MPXTT003 & $2.5-3.0$ & $5.5(\mathrm{U})$ & 5.5 \\
\hline TT04 & MPXTT004 & $4.0-4.5$ & $5.3(\mathrm{U})$ & 5.3 \\
\hline TT05 & MPXTT005 & $3.5-4.0$ & $5.8(U)$ & 5.8 \\
\hline TT06 & MPXTT006 & $3.0-3.5$ & $5.7(U)$ & 5.7 \\
\hline TT07 & MPXTT007 & $3.5-4.0$ & $6(U)$ & 6 \\
\hline TT08 & MPXTT008 & $3.5-4.0$ & $6.4(U)$ & 6.4 \\
\hline TT09 & MPXTT009 & $4.0-4.5$ & $6.3(U)$ & 6.3 \\
\hline TT10 & MPXTT010 & $4.5-5.0$ & $5.6(U)$ & 5.6 \\
\hline
\end{tabular}

$\mathrm{ft}$ bgs = Feet below ground surface

$\mathrm{mg} / \mathrm{kg}=$ Milligrams per kilogram

$\mathrm{U}=$ Compound was analyzed for, but not detected ("non-detect"). 
Table D.1-104

Samples Collected at CAS 20-09-15, U-20au Mud Pit (1)

\begin{tabular}{|c|c|c|c|c|c|}
\hline $\begin{array}{c}\text { Sample } \\
\text { Location }\end{array}$ & $\begin{array}{l}\text { Sample } \\
\text { Number }\end{array}$ & $\begin{array}{l}\text { Depth } \\
\text { (ft bgs) }\end{array}$ & Matrix & Purpose & Analyses \\
\hline UU01 & MPXUU001 & $0.0-0.5$ & Soil & Environmental & TPH-DRO \\
\hline UU02 & MPXUU002 & $0.0-0.5$ & Soil & Environmental & TPH-DRO \\
\hline UU03 & MPXUU003 & $0.0-0.5$ & Soil & $\begin{array}{c}\text { Environmental, } \\
\text { MS/MSD }\end{array}$ & TPH-DRO \\
\hline UU04 & MPXUU004 & $0.0-0.5$ & Soil & Environmental & TPH-DRO \\
\hline UU05 & MPXUU005 & $0.0-0.5$ & Soil & Environmental & TPH-DRO \\
\hline UU05 & MPXUU006 & $0.0-0.5$ & Soil & Environmental & TPH-DRO \\
\hline UU07 & MPXUU007 & $0.0-0.5$ & Soil & Environmental & TPH-DRO \\
\hline UU08 & MPXUU008 & $0.0-0.5$ & Soil & Environmental & TPH-DRO \\
\hline UU09 & MPXUU009 & $0.0-0.5$ & Soil & Environmental & TPH-DRO \\
\hline \multirow{2}{*}{ UU10 } & MPXUU010 & $0.0-0.5$ & Soil & Environmental & TPH-DRO \\
\hline & MPXUU201 & $0.0-0.5$ & Soil & $\begin{array}{l}\text { Field Duplicate } \\
\text { of \#MPXUU010 }\end{array}$ & TPH-DRO \\
\hline
\end{tabular}

$\mathrm{ft}$ bgs = Feet below ground surface

MS/MSD = Matrix spike/matrix spike duplicate

TPH-DRO = Total petroleum hydrocarbons, diesel-range organics 
Table D.1-105

Soil Sample Results for TPH-DRO at CAS 20-09-15, U-20au Mud Pit (1)

\begin{tabular}{|c|c|c|c|c||}
\hline \multirow{2}{*}{$\begin{array}{c}\text { Sample } \\
\text { Location }\end{array}$} & \multirow{2}{*}{$\begin{array}{c}\text { Sample } \\
\text { Number }\end{array}$} & \multirow{2}{*}{$\begin{array}{c}\text { Depth } \\
\text { ft bgs) }\end{array}$} & \multicolumn{2}{|c|}{ Contaminants of Potential Concern (mg/kg) } \\
\cline { 4 - 5 } & & Result & Detection Limit \\
\hline \hline UU01 & MPXUU001 & $0.0-0.5$ & $5.1(\mathrm{UJ})$ & 5.1 \\
\hline UU02 & MPXUU002 & $0.0-0.5$ & $5.1(\mathrm{U})$ & 5.1 \\
\hline UU03 & MPXUU003 & $0.0-0.5$ & $5.2(\mathrm{U})$ & 5.2 \\
\hline UU04 & MPXUU004 & $0.0-0.5$ & $5.2(\mathrm{U})$ & 5.2 \\
\hline UU05 & MPXUU005 & $0.0-0.5$ & $5.1(\mathrm{U})$ & 5.1 \\
\hline UU06 & MPXUU006 & $0.0-0.5$ & $5.1(\mathrm{U})$ & 5.1 \\
\hline UU07 & MPXUU007 & $0.0-0.5$ & $5.1(\mathrm{U})$ & 5.1 \\
\hline UU08 & MPXUU008 & $0.0-0.5$ & $5.1(\mathrm{U})$ & 5.1 \\
\hline UU09 & MPXUU009 & $0.0-0.5$ & $5.1(\mathrm{U})$ & 5.1 \\
\hline \multirow{2}{*}{ UU10 } & MPXUU010 & $0.0-0.5$ & $5.1(\mathrm{U})$ & 5.1 \\
\cline { 2 - 5 } & MPXUU201 & $0.0-0.5$ & $5.1(\mathrm{U})$ & 5.1 \\
\hline
\end{tabular}

$\mathrm{ft}$ bgs = Feet below ground surface

$\mathrm{mg} / \mathrm{kg}=$ Milligrams per kilogram

$\mathrm{J}=$ Estimated value.

$\mathrm{U}=$ Compound was analyzed for, but not detected (“non-detect”). 
Table D.1-106

Samples Collected at CAS 20-09-27, U-20aj PS \#1A Mud Pit (1)

\begin{tabular}{|c|c|c|c|c|c||}
\hline $\begin{array}{c}\text { Sample } \\
\text { Location }\end{array}$ & $\begin{array}{c}\text { Sample } \\
\text { Number }\end{array}$ & $\begin{array}{c}\text { Depth } \\
\text { (ft bgs) }\end{array}$ & Matrix & Purpose & Analyses \\
\hline \hline VV01 & MPXVV001 & $0.0-0.5$ & Soil & Environmental & TPH-DRO \\
\hline VV02 & MPXVV002 & $0.0-0.5$ & Soil & Environmental & TPH-DRO \\
\hline VV03 & MPXVV003 & $0.0-0.5$ & Soil & Environmental & TPH-DRO \\
\hline VV04 & MPXVV004 & $0.0-0.5$ & Soil & $\begin{array}{c}\text { Environmental, } \\
\text { MS/MSD }\end{array}$ & TPH-DRO \\
\hline \multirow{2}{*}{ VV05 } & MPXVV05 & $0.0-0.5$ & Soil & Environmental & TPH-DRO \\
\cline { 2 - 6 } & MPXVV201 & $0.0-0.5$ & Soil & $\begin{array}{c}\text { Field Duplicate } \\
\text { of \#MPXVV005 }\end{array}$ & TPH-DRO \\
\hline VV06 & MPXVV006 & $0.0-0.5$ & Soil & Environmental & TPH-DRO \\
\hline VV07 & MPXVV007 & $0.0-0.5$ & Soil & Environmental & TPH-DRO \\
\hline VV08 & MPXVV008 & $0.0-0.5$ & Soil & Environmental & TPH-DRO \\
\hline VV09 & MPXVV009 & $0.0-0.5$ & Soil & Environmental & TPH-DRO \\
\hline VV10 & MPXVV010 & $0.0-0.5$ & Soil & Environmental & TPH-DRO \\
\hline
\end{tabular}

$\mathrm{ft}$ bgs $=$ Feet below ground surface MS/MSD = Matrix spike/matrix spike duplicate

$\mathrm{TPH}-\mathrm{DRO}=$ Total petroleum hydrocarbons, diesel-range organics 
Table D.1-107

Soil Sample Results for TPH-DRO at CAS 20-09-27, U-20aj PS \#1A Mud Pit (1)

\begin{tabular}{|c|c|c|c|c|}
\hline \multirow{2}{*}{$\begin{array}{l}\text { Sample } \\
\text { Location }\end{array}$} & \multirow{2}{*}{$\begin{array}{l}\text { Sample } \\
\text { Number }\end{array}$} & \multirow{2}{*}{$\begin{array}{c}\text { Depth } \\
\text { (ft bgs) }\end{array}$} & \multicolumn{2}{|c|}{ Contaminants of Potential Concern (mg/kg) } \\
\hline & & & Result & Detection Limit \\
\hline VV01 & MPXVV001 & $0.0-0.5$ & $36(L, M, Z)$ & 5.8 \\
\hline VV02 & MPXVV002 & $0.0-0.5$ & $71(\mathrm{H}, \mathrm{M})$ & 5.7 \\
\hline VV03 & MPXVV003 & $0.0-0.5$ & $36(\mathrm{H}, \mathrm{M})$ & 5.9 \\
\hline VV04 & MPXVV004 & $0.0-0.5$ & $87(\mathrm{~J})$ & 6.2 \\
\hline \multirow{2}{*}{ VV05 } & MPXVV005 & $0.0-0.5$ & $55(\mathrm{H}, \mathrm{M})$ & 6.6 \\
\hline & MPXVV201 & $0.0-0.5$ & $180(\mathrm{H}, \mathrm{M})$ & 6.7 \\
\hline VV06 & MPXVV006 & $0.0-0.5$ & $220(\mathrm{H}, \mathrm{M})$ & 5.9 \\
\hline VV07 & MPXVV007 & $0.0-0.5$ & $15(\mathrm{H}, \mathrm{M})$ & 5.8 \\
\hline VV08 & MPXVV008 & $0.0-0.5$ & $110(\mathrm{H}, \mathrm{M})$ & 6.5 \\
\hline VV09 & MPXVV009 & $0.0-0.5$ & $6.6(\mathrm{U})$ & 6.6 \\
\hline VV10 & MPXVV010 & $0.0-0.5$ & $360(\mathrm{H}, \mathrm{M})$ & 6.2 \\
\hline
\end{tabular}

$\mathrm{ft}$ bgs $=$ Feet below ground surface

$\mathrm{mg} / \mathrm{kg}=$ Milligrams per kilogram

$\mathrm{H}=$ Fuel pattern in the heavier end of retention time window.

$\mathrm{J}=$ Estimated value.

$\mathrm{L}=$ Fuel pattern in the lighter end of retention time window.

$\mathrm{M}=\mathrm{A}$ pattern resembling motor oil was detected.

$U=$ Compound was analyzed for, but not detected ("non-detect").

$Z=$ Result did not resemble any common total petroleum hydrocarbons products. 
Table D.1-108

Samples Collected at CAS 20-09-31, U-20aq PS \#1A Covered Mud Pit (1)

\begin{tabular}{|c|c|c|c|c|c|}
\hline $\begin{array}{l}\text { Sample } \\
\text { Location }\end{array}$ & $\begin{array}{l}\text { Sample } \\
\text { Number }\end{array}$ & $\begin{array}{l}\text { Depth } \\
\text { (ft bgs) }\end{array}$ & Matrix & Purpose & Analyses \\
\hline WW01 & MPXWW001 & $4.0-4.5$ & Soil & Environmental & TPH-DRO \\
\hline WW02 & MPXWW002 & $3.0-3.5$ & Soil & Environmental & TPH-DRO \\
\hline WW03 & MPXWW003 & $4.5-5.0$ & Soil & Environmental & TPH-DRO \\
\hline WW04 & MPXWW004 & $4.5-5.0$ & Soil & Environmental & TPH-DRO \\
\hline WW05 & MPXWW005 & $3.0-3.5$ & Soil & Environmental & TPH-DRO \\
\hline WW06 & MPXWW006 & $4.5-5.0$ & Soil & $\begin{array}{c}\text { Environmental, } \\
\text { MS/MSD }\end{array}$ & TPH-DRO \\
\hline WW07 & MPXWW007 & $4.5-5.0$ & Soil & Environmental & TPH-DRO \\
\hline \multirow[b]{2}{*}{ WW08 } & MPXWW008 & $4.0-4.5$ & Soil & Environmental & TPH-DRO \\
\hline & MPXWW201 & $4.0-4.5$ & Soil & $\begin{array}{l}\text { Field Duplicate } \\
\text { of \#MPXWW008 }\end{array}$ & TPH-DRO \\
\hline WW09 & MPXWW009 & $1.5-2.0$ & Soil & Environmental & TPH-DRO \\
\hline WW10 & MPXWW010 & $4.5-5.0$ & Soil & Environmental & TPH-DRO \\
\hline WW11 & MPXWW301 & $0.0-0.25$ & Soil & Environmental & TPH-DRO \\
\hline N/A & MPXWW401 & $\mathrm{N} / \mathrm{A}$ & Water & $\begin{array}{c}\text { Equipment } \\
\text { Rinsate Blank }\end{array}$ & TPH-DRO \\
\hline N/A & MPXWW402 & N/A & Water & $\begin{array}{c}\text { Equipment } \\
\text { Rinsate Blank }\end{array}$ & TPH-DRO \\
\hline
\end{tabular}

$\mathrm{ft}$ bgs = Feet below ground surface

MS/MSD = Matrix spike/matrix spike duplicate

$\mathrm{N} / \mathrm{A}=$ Not applicable

$\mathrm{TPH}-\mathrm{DRO}=$ Total petroleum hydrocarbons, diesel-range organics 
Table D.1-109

Soil Sample Results for TPH-DRO at

CAS 20-09-31, U-20aq PS \#1A Covered Mud Pit (1)

\begin{tabular}{||c|c|c|c|c||}
\hline \multirow{2}{*}{$\begin{array}{c}\text { Sample } \\
\text { Location }\end{array}$} & \multirow{2}{*}{$\begin{array}{c}\text { Sample } \\
\text { Number }\end{array}$} & $\begin{array}{c}\text { Depth } \\
\text { (ft bgs) }\end{array}$ & \multicolumn{2}{|c|}{ Contaminants of Potential Concern (mg/kg) } \\
\cline { 4 - 5 } & & Result & Detection Limit \\
\hline \hline WW01 & MPXWW001 & $4.0-4.5$ & $6.1(\mathrm{U})$ & 6.1 \\
\hline WW02 & MPXWW002 & $3.0-3.5$ & $5.5(\mathrm{U})$ & 5.5 \\
\hline WW03 & MPXWW003 & $4.5-5.0$ & $9.6(\mathrm{M})$ & 6.8 \\
\hline WW04 & MPXWW004 & $4.5-5.0$ & $7.3(\mathrm{U})$ & 7.3 \\
\hline WW05 & MPXWW005 & $3.0-3.5$ & $5.6(\mathrm{U})$ & 5.6 \\
\hline WW06 & MPXWW006 & $4.5-5.0$ & $7.2(\mathrm{U})$ & 7.2 \\
\hline WW07 & MPXWW007 & $4.5-5.0$ & $6(\mathrm{U})$ & 6 \\
\hline \multirow{2}{*}{ WW08 } & MPXWW008 & $4.0-4.5$ & $6.1(\mathrm{U})$ & 6.1 \\
\cline { 2 - 5 } & MPXWW201 & $4.0-4.5$ & $6.8(\mathrm{U})$ & 6.8 \\
\hline WW09 & MPXWW009 & $1.5-2.0$ & $5.3(\mathrm{U})$ & 6.7 \\
\hline WW10 & MPXWW010 & $4.5-5.0$ & $9.7(\mathrm{M})$ & 5.7 \\
\hline WW11 & MPXWW01 & $0.0-0.25$ & $5.7(\mathrm{U})$ & \\
\hline
\end{tabular}

$\mathrm{ft}$ bgs $=$ Feet below ground surface

$\mathrm{mg} / \mathrm{kg}=$ Milligrams per kilogram

$\mathrm{M}=\mathrm{A}$ pattern resembling motor oil was detected.

$\mathrm{U}=$ Compound was analyzed for, but not detected ("non-detect"). 
Table D.1-110

Samples Collected at CAS 20-09-35, U-20ax PPS \#1A Mud Pit (1)

\begin{tabular}{|c|c|c|c|c|c||}
\hline $\begin{array}{c}\text { Sample } \\
\text { Location }\end{array}$ & $\begin{array}{c}\text { Sample } \\
\text { Number }\end{array}$ & $\begin{array}{c}\text { Depth } \\
\text { (ft bgs) }\end{array}$ & Matrix & Purpose & Analyses \\
\hline \hline XX01 & MPXXX001 & $0.0-0.5$ & Soil & Environmental & TPH-DRO \\
\hline XX02 & MPXXX002 & $0.0-0.5$ & Soil & Environmental & TPH-DRO \\
\hline XX03 & MPXXX003 & $0.0-0.5$ & Soil & Environmental & TPH-DRO \\
\hline XX04 & MPXXX004 & $0.0-0.5$ & Soil & Environmental & TPH-DRO \\
\hline XX05 & MPXXX005 & $0.0-0.5$ & Soil & $\begin{array}{c}\text { Environmental, } \\
\text { MS/MSD }\end{array}$ & TPH-DRO \\
\hline & MPXXX006 & $0.0-0.5$ & Soil & Environmental & TPH-DRO \\
\cline { 2 - 6 } & MPXXX201 & $0.0-0.5$ & Soil & $\begin{array}{c}\text { Field Duplicate } \\
\text { of \#MPXXX006 }\end{array}$ & TPH-DRO \\
\hline XX07 & MPXXX007 & $0.0-0.5$ & Soil & Environmental & TPH-DRO \\
\hline XX08 & MPXXX008 & $0.0-0.5$ & Soil & Environmental & TPH-DRO \\
\hline XX09 & MPXXX009 & $0.0-0.5$ & Soil & Environmental & TPH-DRO \\
\hline XX10 & MPXXX010 & $0.0-0.5$ & Soil & Environmental & TPH-DRO \\
\hline N/A & MPXXX401 & N/A & Water & Field Blank & TPH-DRO \\
\hline
\end{tabular}

$\mathrm{ft}$ bgs = Feet below ground surface

MS/MSD = Matrix spike/matrix spike duplicate

TPH-DRO = Total petroleum hydrocarbons, diesel-range organics 
Table D.1-111

Soil Sample Results for TPH-DRO at

CAS 20-09-35, U-20ax PPS \#1A Mud Pit (1)

\begin{tabular}{|c|c|c|c|c||}
\hline \multirow{2}{*}{$\begin{array}{c}\text { Sample } \\
\text { Location }\end{array}$} & \multirow{2}{*}{$\begin{array}{c}\text { Sample } \\
\text { Number }\end{array}$} & $\begin{array}{c}\text { Depth } \\
\text { (ft bgs) }\end{array}$ & \multicolumn{2}{|c|}{ Contaminants of Potential Concern (mg/kg) } \\
\cline { 4 - 5 } & & & Result & Detection Limit \\
\hline \hline XX01 & MPXXX001 & $0.0-0.5$ & $5.2(\mathrm{U})$ & 5.2 \\
\hline XX02 & MPXXX002 & $0.0-0.5$ & $6(U)$ & 6 \\
\hline XX03 & MPXXX003 & $0.0-0.5$ & $5.7(U)$ & 5.7 \\
\hline XX04 & MPXXX004 & $0.0-0.5$ & $6(U)$ & 6 \\
\hline$X X 05$ & MPXXX005 & $0.0-0.5$ & $5.9(U)$ & 5.9 \\
\hline \multirow{2}{*}{ XX06 } & MPXXX006 & $0.0-0.5$ & $5.9(U)$ & 5.9 \\
\cline { 2 - 5 } & MPXXX201 & $0.0-0.5$ & $5.7(U)$ & 5.9 \\
\hline$X X 07$ & MPXXX007 & $0.0-0.5$ & $5.9(U)$ & 6 \\
\hline$X X 08$ & MPXXX008 & $0.0-0.5$ & $6(U)$ & 5.8 \\
\hline$X X 09$ & MPXXX009 & $0.0-0.5$ & $5.8(U)$ & 5.7 \\
\hline$X X 10$ & MPXXX010 & $0.0-0.5$ & $5.7(U)$ & \\
\hline
\end{tabular}

$\mathrm{ft}$ bgs = Feet below ground surface

$\mathrm{mg} / \mathrm{kg}=$ Milligrams per kilogram

$\mathrm{U}=$ Compound was analyzed for, but not detected ("non-detect"). 
Table D.1-112

Samples Collected at CAS 20-09-40, UE-20n \#1 Mud Pit (1)

\begin{tabular}{|c|c|c|c|c|c|}
\hline $\begin{array}{l}\text { Sample } \\
\text { Location }\end{array}$ & $\begin{array}{l}\text { Sample } \\
\text { Number }\end{array}$ & $\begin{array}{l}\text { Depth } \\
\text { (ft bgs) }\end{array}$ & Matrix & Purpose & Analyses \\
\hline YY01 & MPXYY001 & $0.0-0.5$ & Soil & Environmental & TPH-DRO \\
\hline YY02 & MPXYY002 & $0.0-0.5$ & Soil & Environmental & TPH-DRO \\
\hline YY03 & MPXYY003 & $0.0-0.5$ & Soil & Environmental & TPH-DRO \\
\hline YY04 & MPXYY004 & $0.0-0.5$ & Soil & $\begin{array}{c}\text { Environmental, } \\
\text { MS/MSD }\end{array}$ & TPH-DRO \\
\hline YY05 & MPXYY005 & $0.0-0.5$ & Soil & Environmental & TPH-DRO \\
\hline \multirow[b]{2}{*}{ YY06 } & MPXYY006 & $0.0-0.5$ & Soil & Environmental & TPH-DRO \\
\hline & MPXYY201 & $0.0-0.5$ & Soil & $\begin{array}{l}\text { Field Duplicate } \\
\text { of \#MPXYY006 }\end{array}$ & TPH-DRO \\
\hline YY07 & MPXYY007 & $0.0-0.5$ & Soil & Environmental & TPH-DRO \\
\hline YY08 & MPXYY008 & $0.0-0.5$ & Soil & Environmental & TPH-DRO \\
\hline YY09 & MPXYY009 & $0.0-0.5$ & Soil & Environmental & TPH-DRO \\
\hline YY10 & MPXYY010 & $0.0-0.5$ & Soil & Environmental & TPH-DRO \\
\hline
\end{tabular}

$\mathrm{ft}$ bgs = Feet below ground surface MS/MSD = Matrix spike/matrix spike duplicate

$\mathrm{TPH}-\mathrm{DRO}=$ Total petroleum hydrocarbons, diesel-range organics 
Table D.1-113

Soil Sample Results for TPH-DRO at CAS 20-09-40, UE-20n \#1 Mud Pit (1)

\begin{tabular}{|c|c|c|c|c||}
\hline \multirow{2}{*}{$\begin{array}{c}\text { Sample } \\
\text { Location }\end{array}$} & \multirow{2}{*}{$\begin{array}{c}\text { Sample } \\
\text { Number }\end{array}$} & \multirow{2}{*}{$\begin{array}{c}\text { Depth } \\
\text { ft bgs) }\end{array}$} & \multicolumn{2}{|c|}{ Contaminants of Potential Concern (mg/kg) } \\
\cline { 4 - 5 } & & & Result & Detection Limit \\
\hline \hline YY01 & MPXYY001 & $0.0-0.5$ & $5.1(\mathrm{U})$ & 5.1 \\
\hline YY02 & MPXYY002 & $0.0-0.5$ & $5.2(\mathrm{U})$ & 5.2 \\
\hline YY03 & MPXYY003 & $0.0-0.5$ & $5.2(\mathrm{U})$ & 5.2 \\
\hline YY04 & MPXYY004 & $0.0-0.5$ & $5.7(U)$ & 5.7 \\
\hline YY05 & MPXYY005 & $0.0-0.5$ & $6(U)$ & 6 \\
\hline \multirow{2}{*}{ YY06 } & MPXYY006 & $0.0-0.5$ & $5.7(U)$ & 5.7 \\
\cline { 2 - 5 } & MPXYY201 & $0.0-0.5$ & $5.6(U)$ & 5.6 \\
\hline YY07 & MPXYY007 & $0.0-0.5$ & $5.9(U)$ & 6.9 \\
\hline YY08 & MPXYY008 & $0.0-0.5$ & $6(U)$ & 5.8 \\
\hline YY09 & MPXYY009 & $0.0-0.5$ & $5.8(U)$ & 6 \\
\hline YY10 & MPXYY010 & $0.0-0.5$ & $6(U)$ & 6 \\
\hline \hline
\end{tabular}

$\mathrm{ft}$ bgs $=$ Feet below ground surface

$\mathrm{mg} / \mathrm{kg}=$ Milligrams per kilogram

$\mathrm{U}=$ Compound was analyzed for, but not detected ("non-detect"). 
Table D.1-114

Samples Collected at CAS 20-09-46, Unknown \#14 Mud Pit/Disposal Area

\begin{tabular}{|c|c|c|c|c|c|}
\hline $\begin{array}{c}\text { Sample } \\
\text { Location }\end{array}$ & $\begin{array}{l}\text { Sample } \\
\text { Number }\end{array}$ & $\begin{array}{l}\text { Depth } \\
\text { (ft bgs) }\end{array}$ & Matrix & Purpose & Analyses \\
\hline ZZ01 & MPXZZ001 & $0.0-0.5$ & Soil & Environmental & TPH-DRO \\
\hline ZZO2 & MPXZZ002 & $0.0-0.5$ & Soil & Environmental & TPH-DRO \\
\hline ZZ03 & MPXZZO003 & $0.0-0.5$ & Soil & Environmental & TPH-DRO \\
\hline \multirow[b]{2}{*}{ ZZO4 } & MPXZZO004 & $0.0-0.5$ & Soil & Environmental & TPH-DRO \\
\hline & MPXZZ201 & $0.0-0.5$ & Soil & $\begin{array}{l}\text { Field Duplicate } \\
\text { of \#MPXZZ004 }\end{array}$ & TPH-DRO \\
\hline ZZ05 & MPXZZ005 & $0.0-0.5$ & Soil & Environmental & TPH-DRO \\
\hline ZZ06 & MPXZZ006 & $0.0-0.5$ & Soil & Environmental & TPH-DRO \\
\hline ZZ07 & MPXZZ007 & $0.0-0.5$ & Soil & $\begin{array}{c}\text { Environmental, } \\
\text { MS/MSD }\end{array}$ & TPH-DRO \\
\hline ZZ08 & MPXZZO008 & $0.0-0.5$ & Soil & Environmental & TPH-DRO \\
\hline ZZO9 & MPXZZ009 & $0.0-0.5$ & Soil & Environmental & TPH-DRO \\
\hline ZZ10 & MPXZZ010 & $0.0-0.5$ & Soil & Environmental & TPH-DRO \\
\hline N/A & MPXZZ401 & N/A & Water & Field Blank & TPH-DRO \\
\hline
\end{tabular}

$\mathrm{ft}$ bgs $=$ Feet below ground surface

MS/MSD = Matrix spike/matrix spike duplicate

$\mathrm{N} / \mathrm{A}=$ Not applicable

TPH-DRO = Total petroleum hydrocarbons, diesel-range organics 
Table D.1-115

Soil Samples Results for TPH-DRO at CAS 20-09-46, Unknown \#14 Mud Pit/Disposal Area

\begin{tabular}{|c|c|c|c|c|}
\hline \multirow{2}{*}{$\begin{array}{l}\text { Sample } \\
\text { Location }\end{array}$} & \multirow{2}{*}{$\begin{array}{l}\text { Sample } \\
\text { Number }\end{array}$} & \multirow{2}{*}{$\begin{array}{c}\text { Depth } \\
\text { (ft bgs) }\end{array}$} & \multicolumn{2}{|c|}{ Contaminants of Potential Concern $(\mathrm{mg} / \mathrm{kg}$} \\
\hline & & & Result & Detection Limit \\
\hline ZZ01 & MPXZZ001 & $0.0-0.5$ & $6(U)$ & 6 \\
\hline ZZO2 & MPXZZOO2 & $0.0-0.5$ & $6.1(U)$ & 6.1 \\
\hline ZZ03 & MPXZZ003 & $0.0-0.5$ & $6.1(U)$ & 6.1 \\
\hline \multirow{2}{*}{ ZZ04 } & MPXZZ004 & $0.0-0.5$ & $6.5(U)$ & 6.5 \\
\hline & MPXZZ201 & $0.0-0.5$ & $6.5(U)$ & 6.5 \\
\hline ZZ05 & MPXZZ005 & $0.0-0.5$ & $6.3(U)$ & 6.3 \\
\hline ZZ06 & MPXZZO06 & $0.0-0.5$ & $6.1(U)$ & 6.1 \\
\hline ZZ07 & MPXZZ007 & $0.0-0.5$ & $6.1(\mathrm{U})$ & 6.1 \\
\hline ZZ08 & MPXZZ008 & $0.0-0.5$ & $6.1(U)$ & 6.1 \\
\hline ZZ09 & MPXZZ009 & $0.0-0.5$ & $6.2(\mathrm{U})$ & 6.2 \\
\hline ZZ10 & MPXZZ010 & $0.0-0.5$ & $6.3(\mathrm{U})$ & 6.3 \\
\hline
\end{tabular}

$\mathrm{ft}$ bgs $=$ Feet below ground surface

$\mathrm{mg} / \mathrm{kg}=$ Milligrams per kilogram

$\mathrm{U}=$ Compound was analyzed for, but not detected ("non-detect"). 


\section{D.2.0 References}

DOE, see U.S. Department of Energy.

NCRP, see National Council on Radiation Protection and Measurements.

National Council on Radiation Protection and Measurements. 1999. Recommended Screening Limits for Contaminated Surface Soil and Review Factors Relevant to Site-Specific Studies. Table 2.1 of the NCRP Report No. 129.

U.S. Department of Energy. 1993. "Radiation Protection of the Public and Environment. Chapter IV of DOE Order 5400.5, Change 2. 


\section{Appendix E}

\section{Waste Disposition Documentation for CAUs 530-535: Nevada Test Site Mud Pits, Nevada Test Site, Nevada}




\section{E.1.0 Waste Disposition}

Investigation-derived waste was generated during the field corrective actions activities of CAUs 530-535. The waste streams generated include decontamination rinse water, disposable PPE, disposable sampling equipment, hydrocarbon-contaminated soil and debris, and miscellaneous waste removed from various CASs as best management practice during the field activities. Investigation-derived waste was segregated to the greatest extent possible and waste minimization techniques were integrated into the field activities to reduce the amount of waste generated. Controls were in place to minimize the use of hazardous materials and the unnecessary generation of hazardous and/or mixed waste. Decontamination activities were planned and executed to minimize the volume of rinsate generated.

The amount, type, and source of waste placed into each drum and roll-off was recorded in waste management logbooks. Investigation-derived waste generated during the field activities that was known to be hazardous based on process knowledge and/or sample analytical results was placed in containers and labeled as “Hazardous Waste.” Potentially hazardous waste generated during the corrective actions was placed in containers and labeled as "Hazardous Waste - Pending Analysis.” One HAA and one SAA was established to manage hydrocarbon and potentially hazardous waste, respectively, generated during the corrective action sampling activity.

\section{E.1.1 Characterization}

Analytical results for each drum of waste or associated samples were reviewed to ensure compliance with federal regulations, state regulations, DOE directives/policies, guidance, and waste disposal criteria.

\section{E.1.2 Waste Streams}

Investigation-derived waste generated during the investigation was segregated into the following waste streams:

- Personal protective equipment and disposable sampling equipment

- Decontamination rinsate 
- Debris including, but not limited to: plastic sheeting, glass/plastic sample jars, PPE, soil, sampling scoops, and aluminum bowls

- Lead batteries and underlying soil

- Coal tar epoxy debris and underlying soil

\section{E.1.3 Investigation-Derived Waste Generated}

The following lists the types of IDW generated during the corrective actions:

- One drum with 26 gal of rinsate was characterized as sanitary waste and disposed at the NTS-permitted Area 23 Lagoon. The waste in this drum was generated from CASs 02-09-03, 02-09-33, 04-09-06, 04-09-14, 07-09-25, 19-09-27, 20-09-31.

- $\quad$ One drum with 5 gal of soil IDW was generated at CAS 09-09-08 and has been characterized as solid waste. This drum was disposed at the NTS-permitted 10C landfill.

- Several small pieces of debris totaling $200 \mathrm{lb}$ were removed from various CASs and contained in a roll-off container. This debris was characterized as solid waste and disposed at the NTS-permitted Area 23 sanitary landfill. The debris and associated CASs are detailed in Table 3-1 of this CR. The approximate volume of the debris was less than $2 \mathrm{yd}^{3}$.

- A total of 75,000 lb of CTE debris and associated soil was characterized as hydrocarbon waste exceeding the regulatory threshold established by State of Nevada regulations (NDEP, 1997a and b). The debris was loaded, transported, and disposed at the permitted NTS Hydrocarbon Landfill. The hydrocarbon waste was generated from CAS 03-09-17. Three truckloads, with a $10-\mathrm{yd}^{3}$ capacity each, were used to transport the 75,000 lb of CTE.

- Approximately 35 bags (or 550 gal) of PPE and disposable sampling equipment was disposed as solid waste at the NTS-permitted LOC landfill. An individual Landfill Verification Form is not available for this IDW as it was disposed with multiple CAU IDW.

During a habitat survey at CAS 09-09-08, two lead batteries were identified within the CAS boundary. The two batteries were deemed salvageable and turned in for recycling at the NTS Fleet Operations yard.

At CAS 02-09-30, a legacy nine microcurie Cs-137 radioactive source was discovered near the CAS boundary during corrective action sampling activities. The source has been containerized; removed from the site; and securley stored at Building 153, pending diposal as LLW independently from the CAU 530-535 CR, as this waste stream is not associated with the mud pit CAS. 


\section{E.1.4 Waste Characterization Samples}

Waste characterization samples were collected from the housekeeping waste (soil only) at CAS 09-09-08, of CTE debris removed from CAS 03-09-17, and from drummed waste, as necessary, to facilitate full characterization of the waste for disposal. Results of waste characterization samples are not presented in this document except as necessary to support site characterization decisions. Complete results for all samples are maintained in project files. The following sections describe the waste characterization samples collected during the corrective actions of CAUs 530-535. Samples were analyzed in accordance with the procedures specified in the CAUs 530-535 SAFER Plan. Analytical results are compared to the federal limits for hazardous waste, NDEP hydrocarbon action limit, landfill acceptance criteria, and the limits in the NTS Performance Objective for Certification of Nonradioactive Hazardous Waste (BN, 1995). The Performance Objective For Certification of Nonradioactive Hazardous Waste limits have been established for NTS hazardous waste generators to ensure that all hazardous waste being shipped off-site contains no "added radioactivity."

Specific waste characterization sampling and analysis was conducted on the following potential waste streams:

- Soil IDW excavated after the removal of the lead batteries at CAS 09-09-08

- Coal tar epoxy debris at CAS 03-09-17

- Rinsate generated during decontamination activities from covered CASs

\section{E.1.4.1 CAS 09-09-08, U-9yz-26 Mud Pit (2)}

One composite sample was collected of the soil excavated and drummed associated with the removal of two lead batteries. The soil was analyzed for TCLP RCRA metals, gamma spectrometry, isotopic Pu and U, and Sr-90 to determine a disposal path. Analytical results indicated the sample did not exceed the RCRA TCLP limit for any metal and was below the NTS landfill limits for disposal as non-radioactive waste. The lead batteries were not sampled; instead, the batteries were transported to the NTS Fleet Operations yard for recycling. 


\section{E.1.4.2 CAS 03-09-17, U-3hc Mud Pit (2)}

One sample of CTE and one sample of soil in contact with the CTE was collected directly and analyzed to determine a disposal path. The CTE was analyzed for TPH-DRO, and both total and TCLP VOCs, SVOCs, and RCRA metals, gamma spectrometry, isotopic Pu, isotopic U, and Sr-90. The soil was analyzed for total VOC, total SVOC, and TPH-DRO. Analytical results determined the CTE and all associated soils excavated with the debris removal are non-hazardous, non-leaching hydrocarbon/sanitary waste. No contaminants were identified above the RCRA TCLP limits for solid waste or above the NTS landfill limits for disposal as non-radioactive waste.

\section{E.1.4.3 Decontamination Rinsate, Multiple CASs}

One liquid sample was collected from the rinsate drum located at the Area 6 Decon Facility HAA. The rinsate was analyzed for gross alpha/beta and tritium. Site characterization soil samples were used to determine that the rinsate was sanitary waste and non-radioactive according to NTS Performance Objective for Certification of Nonradioactive Hazardous Waste (BN, 1995). 


\section{E.2.0 References}

BN, see Bechtel Nevada.

Bechtel Nevada. 1995. "Nevada Test Site Performance Objectives for Certification of Nonradioactive Hazardous Waste,” Rev. 0, G-E11/96. 01. Las Vegas, NV.

NDEP, see Nevada Division of Environmental Protection.

Nevada Division of Environmental Protection. 1997a. Class II Solid Waste Disposal Site for Municipal and Industrial Solid Waste, Area 23 of the NTS, Permit SW 13097 04. Carson City, NV.

Nevada Division of Environmental Protection. 1997b (as amended in August 2000). Class III Solid Waste Disposal Site for Hydrocarbon Burdened Soils, Area 6 of the NTS, Permit SW 1309702. Carson City, NV. 


\section{Attachment A}

\section{NTS Landfill Load Verification}




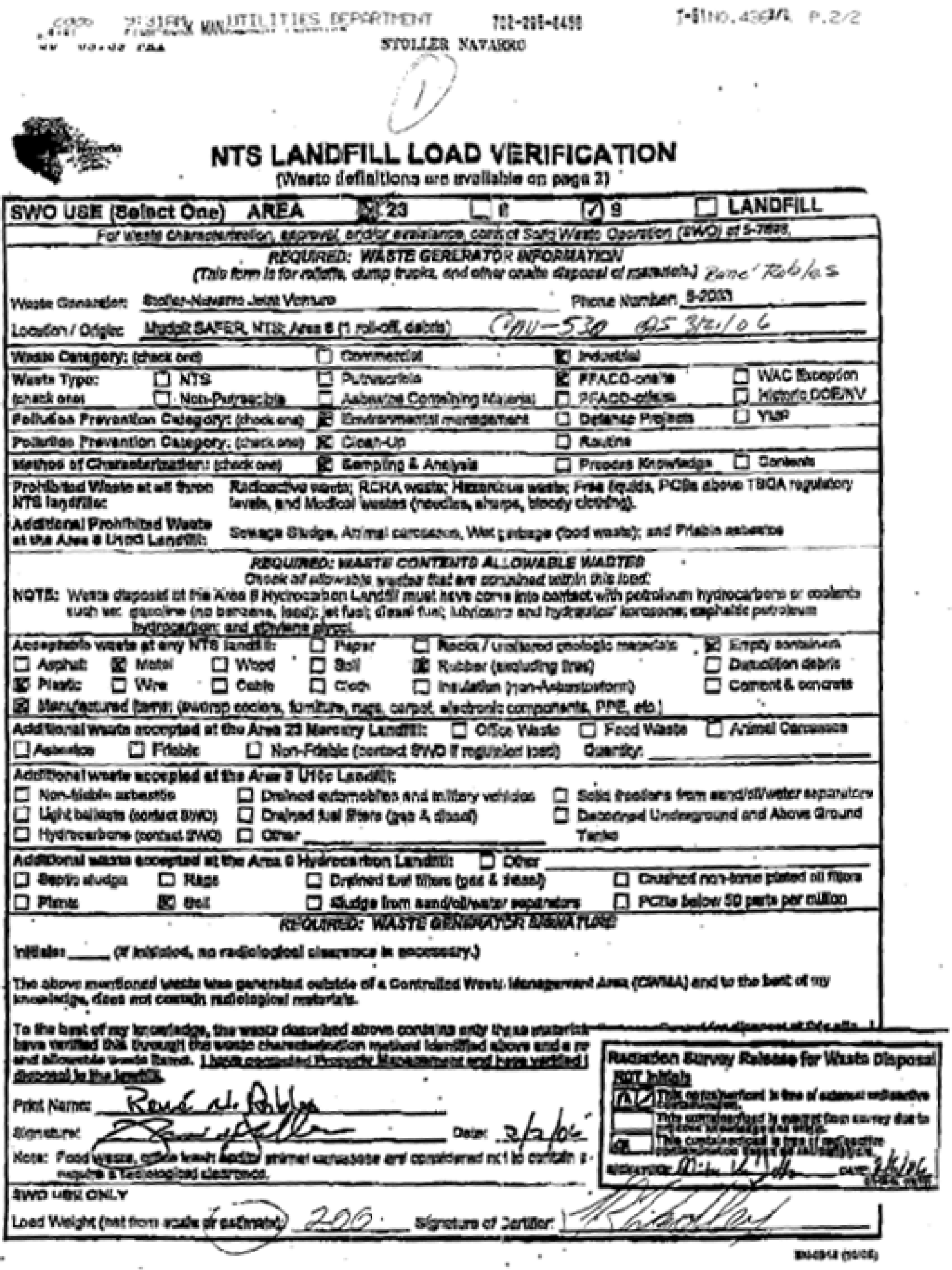




\section{NTS LANDFILL LOAD VERIFICATION}

(Waste definitions are available on page 2)

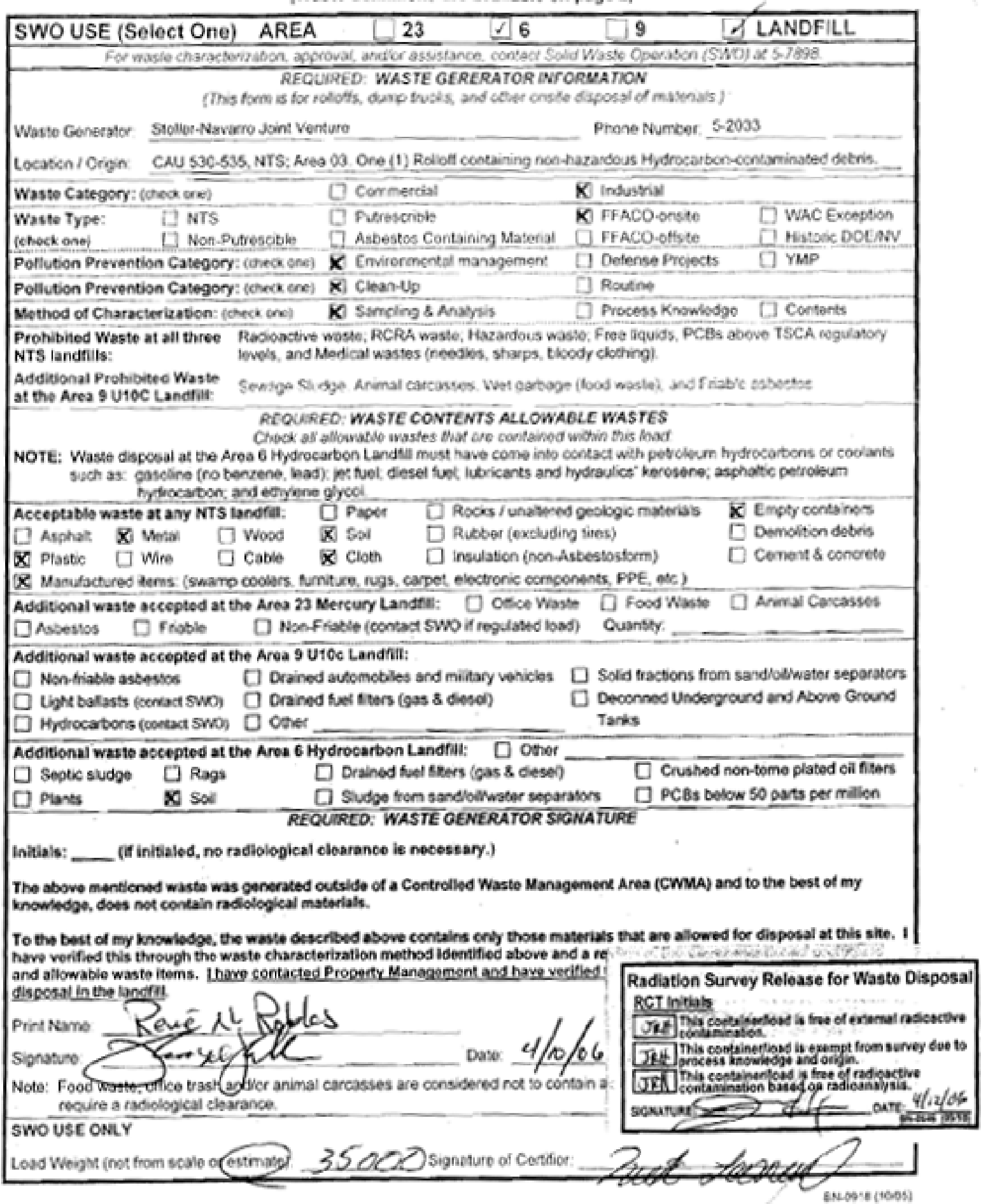


NTS LANDFILL LOAD VERIFICATION (Waste definitions are available on page 2)

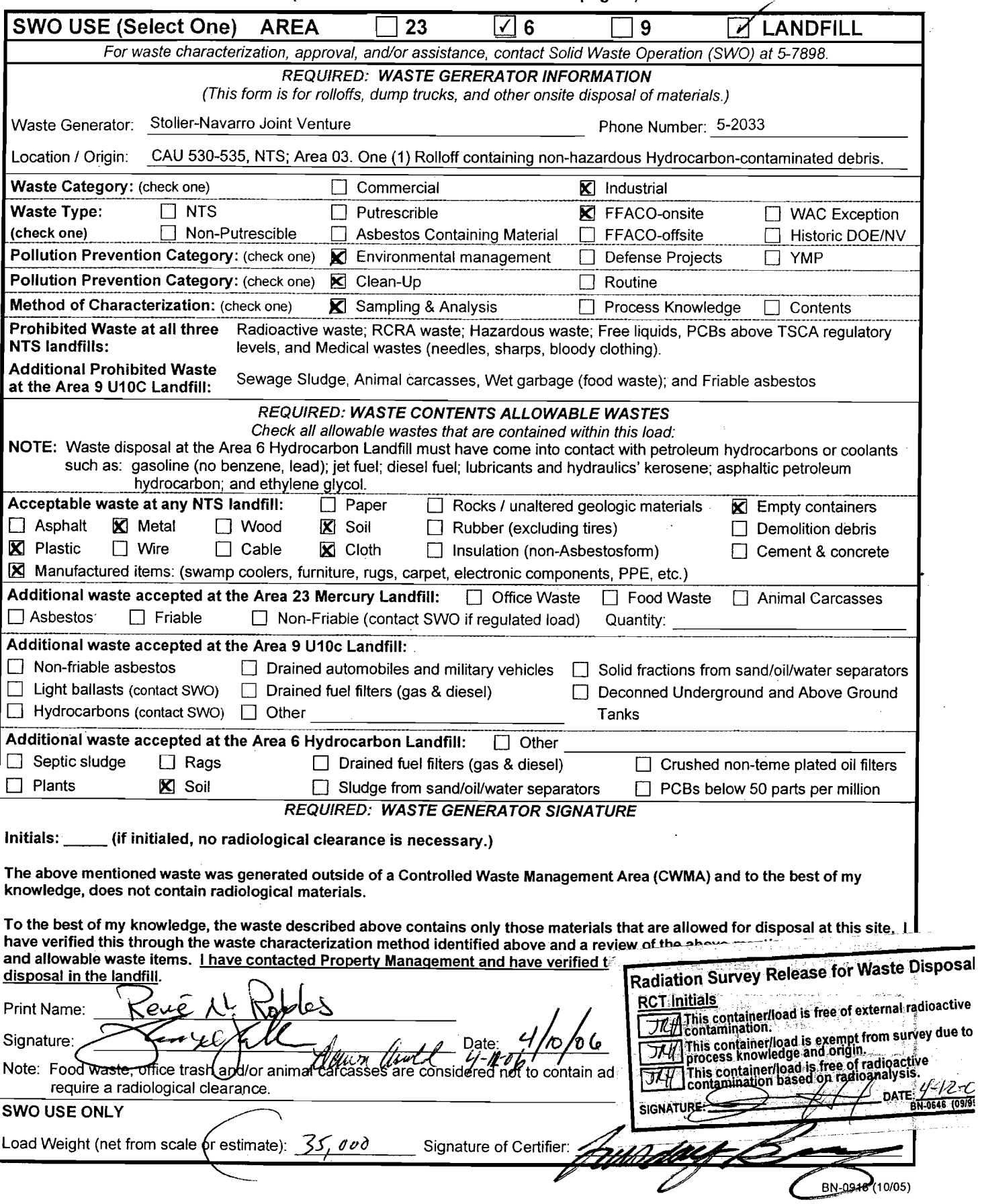




\section{NTS LANDFILL LOAD VERIFICATION} (Waste definitions are available on page 2)

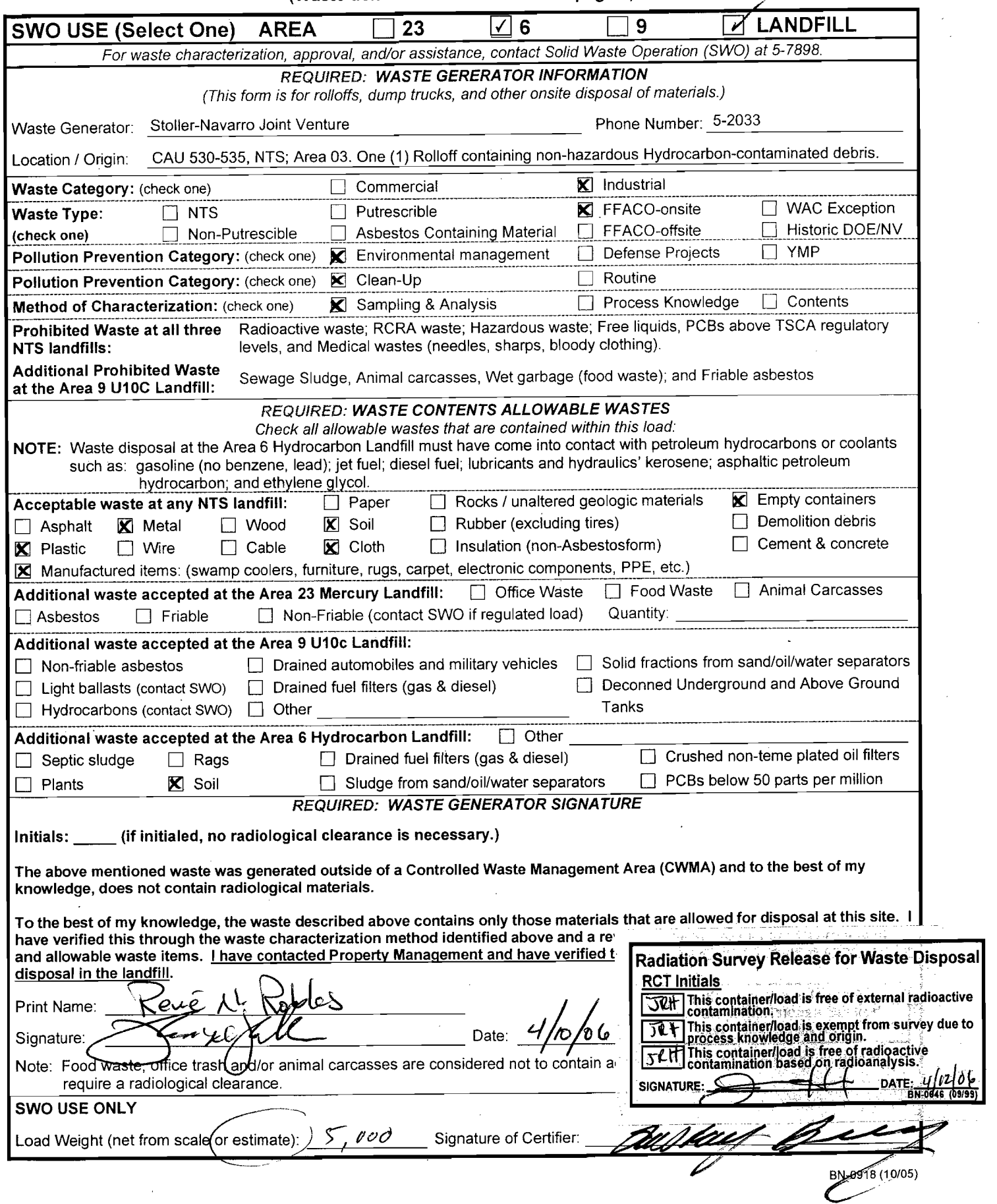


Enclosed is the Field Activity Daily Log of the SNJV, Environmental Compliance Technician who was present during pick up and delivery of drum SNN0612 to the Area 9, U10c Landfill.

In summary, the sanitary waste for CAUs 530-535 has been picked up and disposed of by BN Sanitary Operations, currently the paperwork is misplaced for drums SNN0612. When this paperwork is available it will be placed in SNJV Central Files with the CAU 530-535 waste files. 


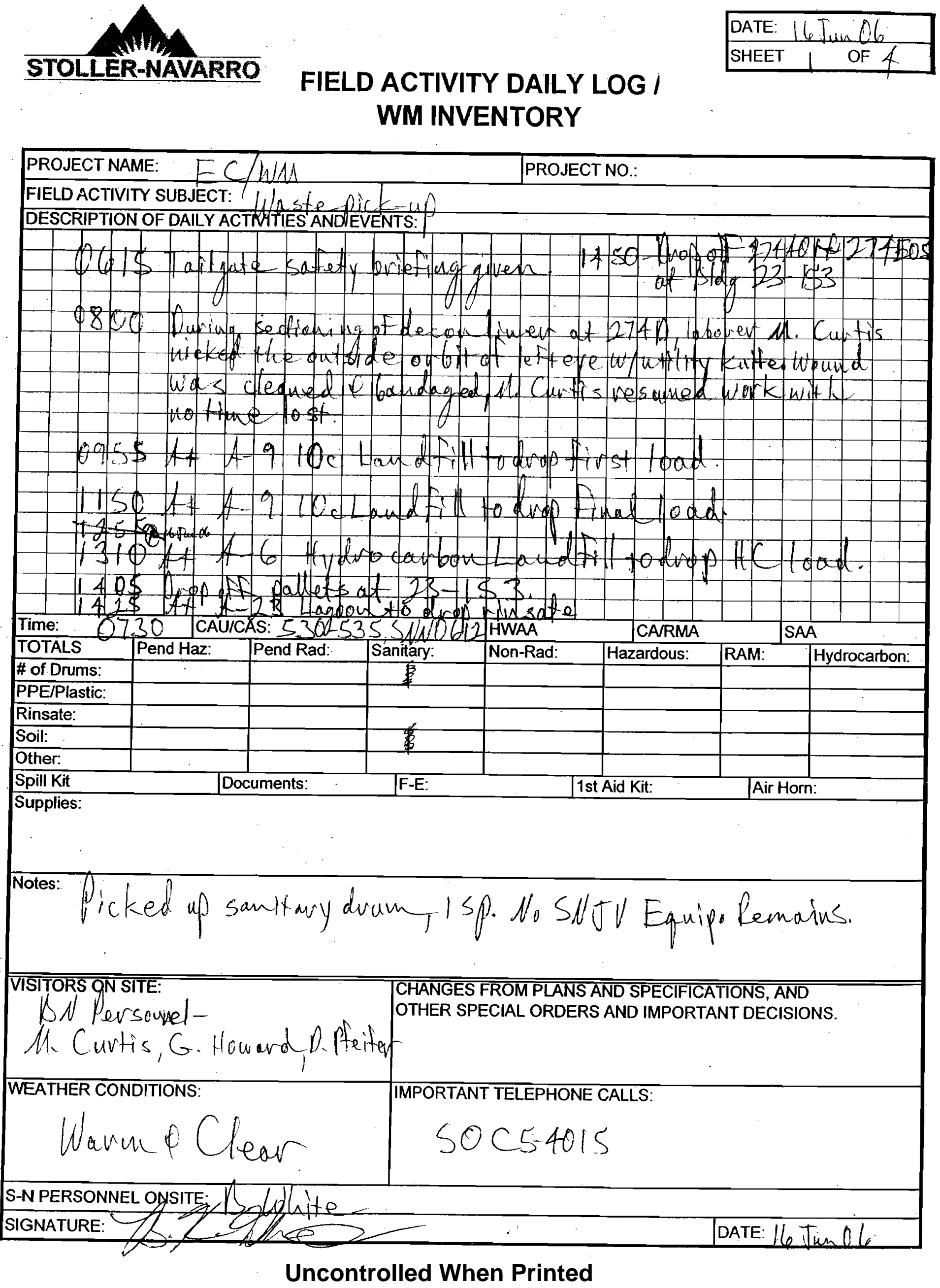


FIELD ACTIVITY DAILY LOG I

DATE: 16 Tun 06 SHEET 2 OF 4 WM INVENTORY (CONTINUATION SHEET)

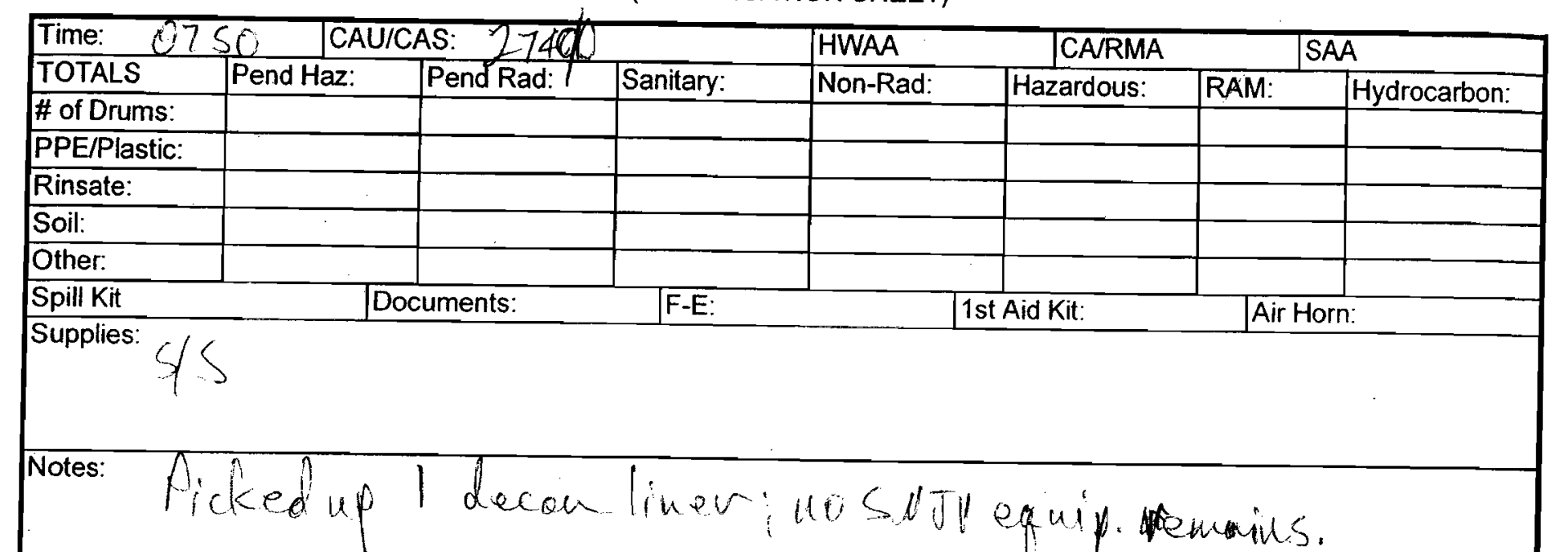

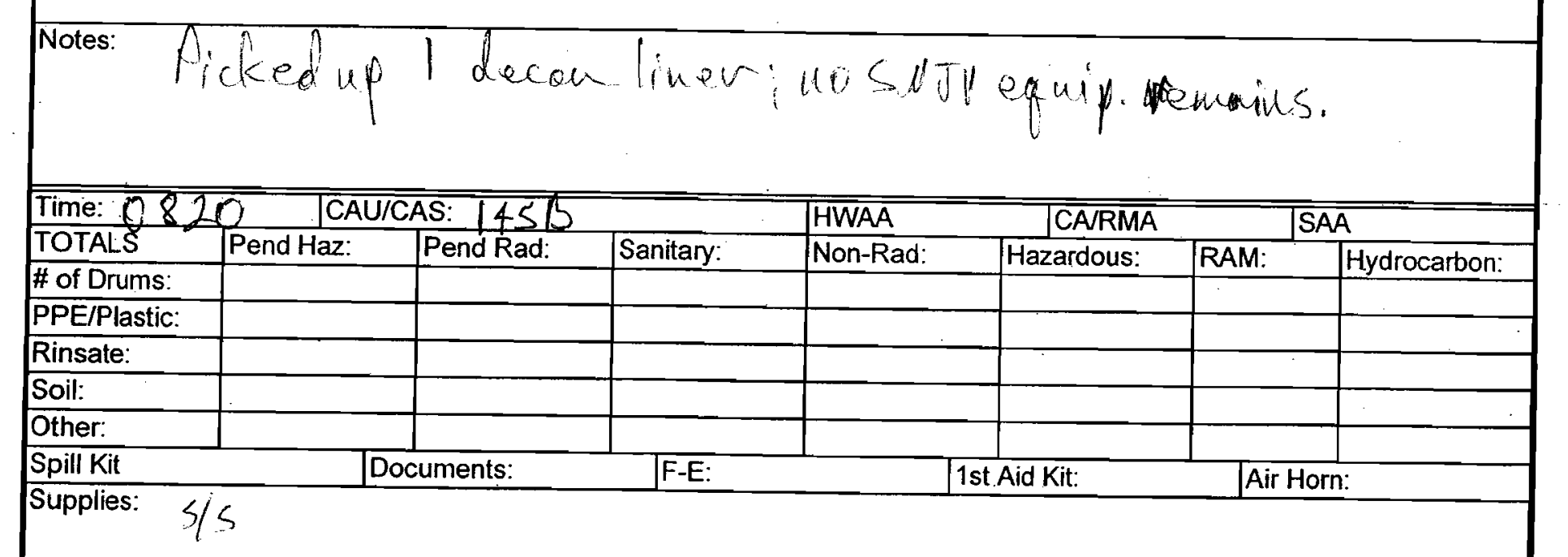

Notes: Picked up 3 sanitary drums, I deacon liner, Isp, I Wp.

No SN JV equip. remains.

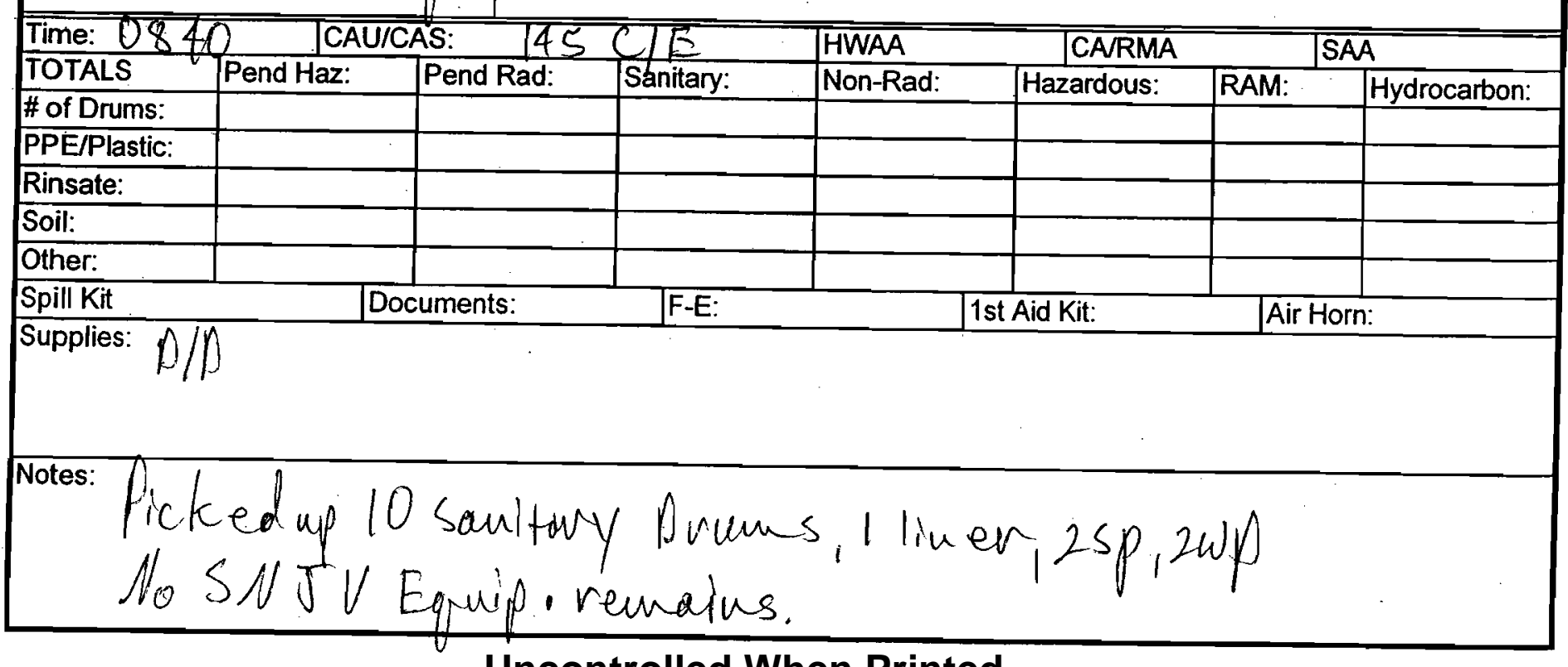

Uncontrolled When Printed 


\section{FIELD ACTIVITY DAILY LOG / WM INVENTORY}

(CONTINUATION SHEET)

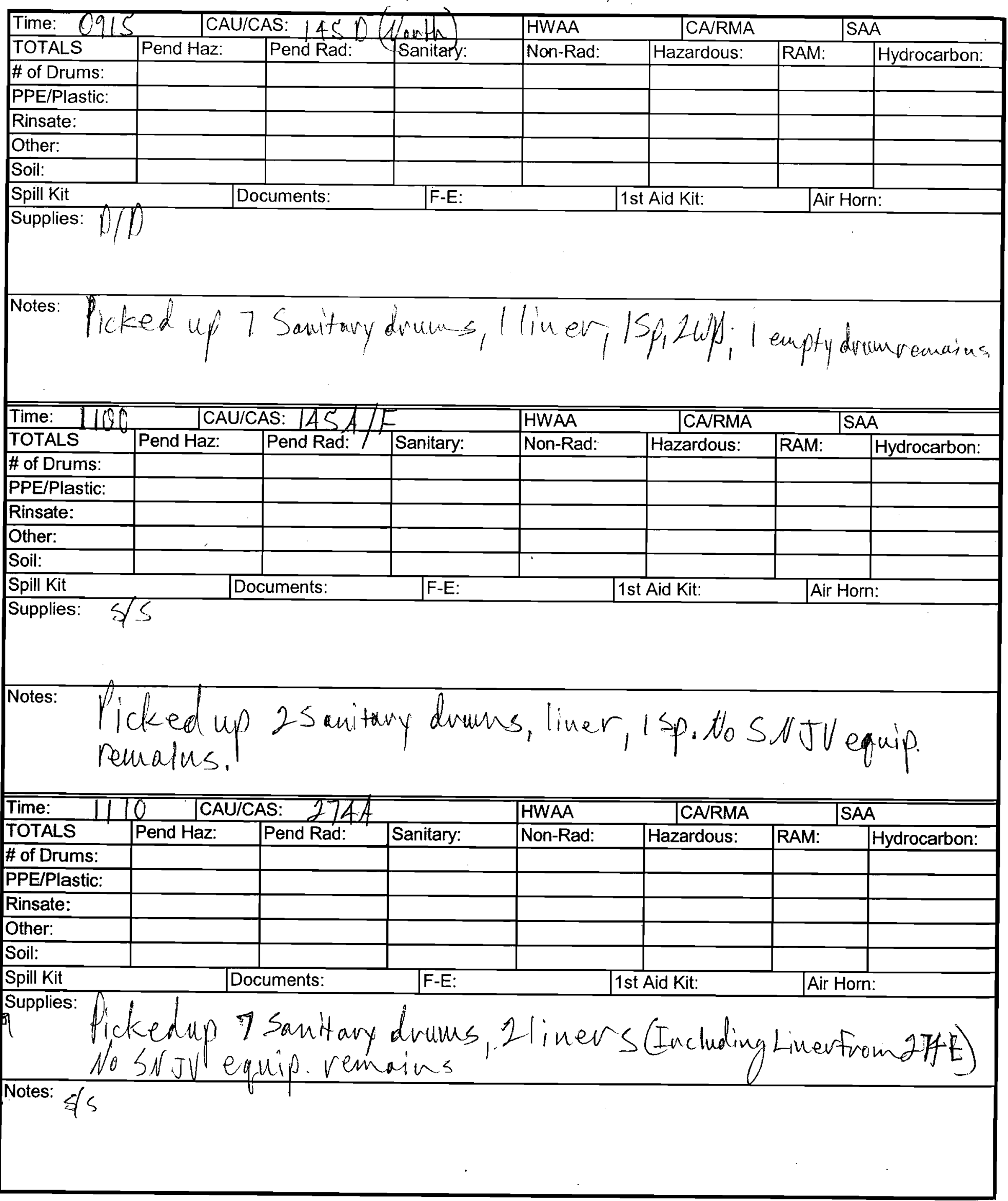




\section{FIELD ACTIVITY DAILY LOG / WM INVENTORY}

(CONTINUATION SHEET)

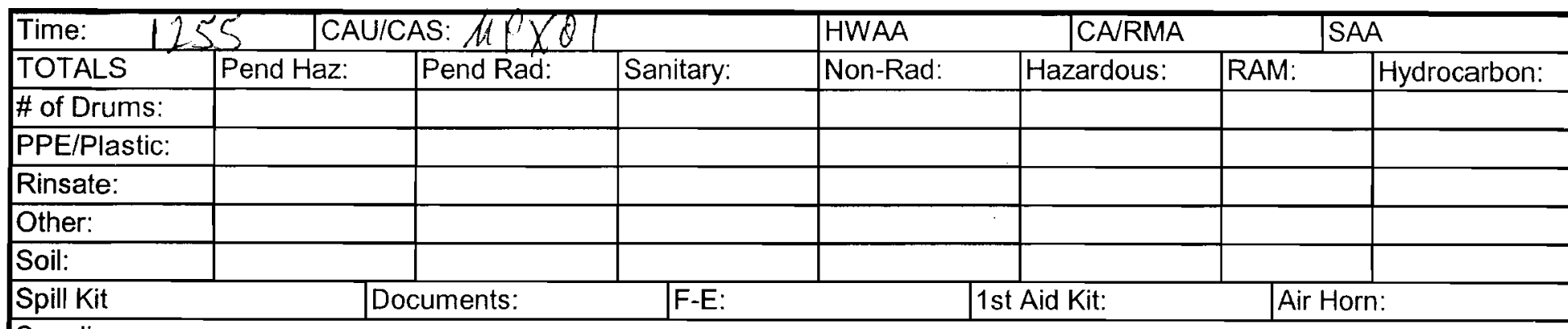

Supplies:

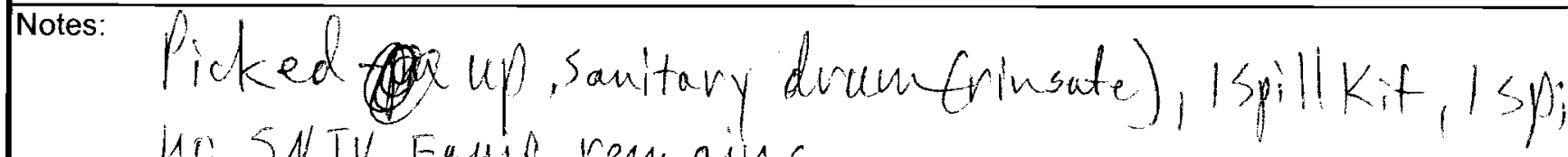
Mo SNJV Equip. remains.

\begin{tabular}{|l|l|l|l|l|l|l|l|l|}
\hline \hline Time: & \multicolumn{2}{l}{ CAU/CAS: } & HWAA & CARMA & SAA \\
\hline TOTALS & Pend Haz: & Pend Rad: & Sanitary: & Non-Rad: & Hazardous: & RAM: & Hydrocarbon: \\
\hline \# of Drums: & & & & & & & & \\
\hline PPE/Plastic: & & & & & & & & \\
\hline Rinsate: & & & & & & & & \\
\hline Other: & & & & & & & & \\
\hline Soil: & & & & & & & & \\
\hline Spill Kit & & & & & & & \\
\hline
\end{tabular}

Supplies:

Notes:

\begin{tabular}{|c|c|c|c|c|c|c|c|}
\hline Time: & \multicolumn{2}{|c|}{ CAU/CAS: } & & \multirow{2}{*}{\begin{tabular}{|l} 
HWAA \\
Non-Rad:
\end{tabular}} & \multicolumn{2}{|l|}{ CA/RMA } & SAA \\
\hline TOTALS & Pend Haz: & Pend Rad: & Sanitary: & & Hazardous: & RAM: & Hydrocarbon: \\
\hline \# of Drum & & & & & & & \\
\hline PPE/Plas & & & & & & & . \\
\hline Rinsate: & & & & & & & \\
\hline Other: & & & & & & & \\
\hline Soil: & & & & & & & \\
\hline Spill Kit & & cuments: & F-E: & & Aid Kit: & & \\
\hline
\end{tabular}

Supplies:

Notes: 


\title{
Appendix F
}

\author{
Modifications to the Post-Closure Plan \\ for CAUs 530-535: Nevada Test Site Mud Pits, \\ Nevada Test Site, Nevada
}




\section{F.1.0 Modifications to the Post-Closure Plan}

There are no modifications to the Post-Closure Plan. 


\section{Appendix G}

\section{Evaluation of Risk for CAUs 530-535: Nevada Test Site Mud Pits, Nevada Test Site, Nevada}




\section{G.1.0 Evaluation of Risk}

Section G.1.0 of this appendix addresses the risk to human and ecological receptors from exposure to TPH-DRO present in the mud pit CASs that comprise CAUs 530-535. Section G.2.0 of this appendix addresses the risk of human receptors from Eu-152 at CAS 09-09-24.

The RBCSR documented that TPH-DRO is the only COPC at these CASs and proposed basing the risk evaluation on the Massachusetts Department of Environmental Protection (MADEP) procedure for quantifying the human health risk associated with TPH-DRO (MADEP, 2003). Following the MADEP procedure, cancer effects are evaluated separately by quantifying specific hydrocarbon compounds, such as benzene and certain polycyclic aromatic hydrocarbons, that are designated carcinogens (MADEP, 2002); however, the RBCSR documented that these carcinogenic compounds are not present in CAUs 530-535 eliminating the need to perform a cancer risk assessment. This approach was agreed to during the planning stages of this closure investigation. Further details on the MADEP procedures are presented in the RBCSR and the SAFER Plan.

The human non-cancer risk posed by TPH-DRO concentrations in the 52 sampled mud pit CASs was quantified following Risk Assessment Guidance for Superfund (EPA, 1989). This is the guidance that was followed when developing the risk-based closure strategy for CAUs 530-535 (NNSA/NSO, 2004; NNSA/NSO, 2005a). After the approval of the CAUs 530-535 SAFER Plan, new procedures have been proposed for evaluating risk at sites throughout the NTS. These new procedures are consistent with the CAUs 530-535 SAFER Plan in their methods to evaluate risk to human receptors, but new exposure scenario is with site-specific input parameter values for the NTS have been proposed. The most conservative of these scenarios is the Industrial Area exposure scenario that assumes the NTS worker is regularly assigned to work within the area for his entire career (NNSA/NSO, 2005b). This scenario is improbable as a worker is neither likely to be assigned to work within a mud pit, nor is the mud likely to be used as fill material for construction of a work facility, but the new exposure scenario put forward to provide a conservative bounding case for the evaluation of risk. In addition to quantifying the risk to human receptors and according to the DQOs of the SAFER Plan, the absence of risk to ecological receptors from TPH-DRO was confirmed by conducting visual habitat surveys to verify the lack of threatened or endangered species or suitable habitat at the CASs in CAUs 530-535. 


\section{G.1.1 Human Receptors}

This section presents a discussion of how the human health risk assessment was conducted for the 52 mud pit CASs that were sampled during this closure investigation. The purpose of this risk assessment is to determine the TPH-DRO concentrations to which a potential receptor is exposed and quantify the toxicity of this exposure. The exposure a human receptor receives is evaluated through an exposure assessment that incorporates exposure point concentrations, with site-specific exposure parameters, to determine an estimate of the dosage or chronic daily intake (CDI) of TPH-DRO. This dosage is then compared to a reference dose as part of the toxicity assessment. The result is a HI, which quantifies the risk to a human receptor. For the risk to be acceptable, the HI must be less than 1.0.

\section{G.1.1.1 Exposure Assessment}

In a human health risk assessment, it is necessary to consider the additive hazards from all complete exposure routes for each of the 52 CASs sampled during this closure investigation. As shown in the CSM agreed to during the planning phase, the complete exposure routes identified for human receptors are ingestion, inhalation of dust, and dermal contact. Inputs to evaluate the collective hazards from these three exposure routes include estimates of the exposure point concentration $\left(\mathrm{EPC}_{\mathrm{Chem}}\right)$ and the exposure parameters; output includes the route-specific chronic daily intake $\left(\mathrm{CDI}_{\mathrm{i}}\right)$ for TPH-DRO. Equations used to calculate the CDI for the ingestion, inhalation, and dermal routes are presented in equations G-1, G-2, and G-3, respectively.

$$
\begin{aligned}
& C D I_{\text {Ing-nc }}=\frac{E P C_{\text {Chem-soil }} * I N G R * E F * E D}{B W^{*} A T} \\
& C D I_{\text {Inhl-nc }}=\frac{E P C_{\text {Chem }} * I N H R^{*} E F * E D}{B W^{*} A T}
\end{aligned}
$$




$$
C D I_{\text {Dermat nc }}=\frac{E P C_{\text {Chem }} * S A^{*} A F^{*} C F^{*} E F^{*} E D^{*} A C F}{B W^{*} A T}
$$

The correction factor (CF) variable in equation G-3 is a unit conversion factor equal to 0.001. Further explanation of the inputs and output to the exposure assessment is provided in the following sections.

\section{G.1.1.1.1 Exposure Point Concentrations}

The $\mathrm{EPC}_{\mathrm{Chem}}$ variable in the above equations is the characteristic TPH-DRO concentration for an individual mud pit CAS and represents the level of contamination to which a receptor is exposed. For this closure investigation, the $\mathrm{EPC}_{\mathrm{Chem}}$ is considered equal to the 95 percent UCL of the mean TPH-DRO concentration. The 95 percent UCL is calculated as:

$$
E P C_{\text {Chem }}=\bar{X}_{C A S}+1.96(\sigma / \sqrt{10})
$$

Where: $\bar{\chi}$ equals the mean TPH-DRO for a given CAS, $\sigma$ equals the population variance. (Table G.1-3 presents EPC $_{\text {Chem }}$ for each of the sampled CASs.)

\section{G.1.1.1.2 Exposure Parameters}

The remaining variables in each of the route-specific equations are exposure parameters. These parameters are presented in Table G.1-1 and are characteristic of the Industrial Area exposure scenario (NNSA/NSO, 2005b). Because the Industrial Area exposure scenario is the most conservative exposure scenario for an NTS worker, if the TPH-DRO concentrations from the mud pit CASs do not pose an unacceptable risk for this exposure scenario, then consideration of alternative scenarios requiring less exposure are not necessary and no use restrictions will be required. 
Table G.1-1

Exposure Parameters for the Risk Assessment

\begin{tabular}{|c|c|c|c|}
\hline $\begin{array}{c}\text { Exposure } \\
\text { Route }\end{array}$ & Exposure Parameter & Units & $\begin{array}{c}\text { Industrial } \\
\text { Area }\end{array}$ \\
\hline \hline \multirow{3}{*}{ All } & $\begin{array}{c}\text { Averaging Time (AT) } \\
\text { (non-carcinogen) (yr x day/yr) }\end{array}$ & days & ED x 365 \\
\cline { 2 - 4 } & Adult Body Weight (BW) & $\mathrm{kg}$ & 70 \\
\cline { 2 - 4 } & Exposure duration (ED) & $\mathrm{yr}$ & 25 \\
\cline { 2 - 4 } & Exposure frequency (EF) & days/yr & 225 \\
\hline Ingestion & Soil Ingestion Rate (INGR) & $\mathrm{kg} / \mathrm{day}$ & 0.0002 \\
\hline Inhalation & Adult Inhalation Rate (INHR) & $\mathrm{m}^{3} / \mathrm{day}$ & 20 \\
\hline \multirow{3}{*}{ Dermal } & Adult Adherence Factor (AF) & $\mathrm{mg} / \mathrm{cm}^{2}$ & 0.2 \\
\cline { 2 - 4 } & Absorption Fraction (ABS) & $\mathrm{unitless}^{\mathrm{b}}$ & $0.1^{\mathrm{c}}$ \\
\cline { 2 - 4 } & Adult Surface Area (SA) & $\mathrm{m}^{2} / \mathrm{day}$ & 0.33 \\
\hline
\end{tabular}

${ }^{\text {a }}$ Scaled based on time spent outdoors. Outdoor soil ingestion rate $480 \mathrm{mg} /$ day (Yu, et. al., 1993)

bEPA, 2001

'EPA Region 9 default for semivolatile organic compounds

days/yr = Days per year

$\mathrm{kg}=$ Kilogram

$\mathrm{kg} /$ day = Kilograms per day

$\mathrm{m}^{2} /$ day $=$ Square meters per day

$\mathrm{m}^{3} /$ day $=$ Cubic meters per day

$\mathrm{mg} / \mathrm{cm}^{2}=$ Milligrams per square centimeter

$\mathrm{yr}=$ Year

\section{G.1.1.1.3. Chronic Daily Intake Results}

The results of the exposure assessment are the estimation of the route-specific $\mathrm{CDI}_{\mathrm{i}}$ for TPH-DRO. Table G.1-3 presents the CDIs by CAS and exposure route for the Industrial Area exposure scenario. The dominant exposure pathways are dermal contact and ingestion. Exposure from inhalation of dust is approximately 10,000 times less than the other exposure pathways, which supports the CSM that inhalation of dust is an insignificant exposure pathway.

\section{G.1.1.2 Toxicity Assessment}

The primary objectives of the toxicity assessment are to evaluate the inherent toxicity of TPH-DRO and to identify the toxicity constants for characterizing the site-specific risks. The toxicity constants operate essentially as unit damage functions. They relate the amount of adverse biological effect delivered to an organism on a unit of exposure basis. 
Non-carcinogenic effects associated with each exposure route are gauged by the magnitude of the Hazard Quotient $\left(\mathrm{HQ}_{\mathrm{i}}\right)$, which is calculated as:

$$
H Q_{i}=\frac{C D I_{i}}{R f D_{T P H-D R O_{i}}}
$$

Here $\mathrm{CDI}_{\mathrm{i}}$ is the route-specific chronic daily intake to which a human receptor is exposed. The $\mathrm{RfD}_{\text {TPH-DROi }}$ is the reference dose, an estimate of a daily exposure level for the human population, including sensitive subpopulations, which are likely to be without appreciable risk of effects during a lifetime (EPA, 1989). The route-specific $\mathrm{RfD}_{\mathrm{TPH}-\mathrm{DROi}}$ are presented in Table G.1-2 (additional information regarding how these values were selected is discussed in the RBCSR [NNSA/NSO, 2004]). If the $\mathrm{CDI}_{\mathrm{i}}$ is greater than the $\mathrm{RfD}_{\mathrm{TPH}-\mathrm{DRO}}$, the $\mathrm{HQ}_{\mathrm{i}}$ will be greater than 1.0. Results are shown in Table G.1-3 for the Industrial Area exposure scenario. Because there are three exposure routes (ingestion, inhalation of dust, and dermal contact), there are three HQs associated with each CAS.

Table G.1-2

Reference Doses for TPH-DRO

\begin{tabular}{||c|c|c|c|c|c||}
\hline $\begin{array}{c}\text { Petroleum } \\
\text { Fraction }\end{array}$ & $\begin{array}{c}\text { Oral RfD } \\
\text { (mg/kg day) }\end{array}$ & $\begin{array}{c}\text { Inhalation } \\
\mathbf{R f D} \\
\text { (mg/kg day) }\end{array}$ & $\begin{array}{c}\text { Dermal } \\
\text { RfD } \\
\text { (mg/kg day) }\end{array}$ & Source & Remark \\
\hline \hline DRO & 0.1 & $0.057^{\mathrm{a}}$ & 0.1 & MADEP, 2002 & $\begin{array}{c}\text { For } \mathrm{C}_{9} \text { to } \mathrm{C}_{18} \\
\text { aliphatic } \\
\text { hydrocarbons }\end{array}$ \\
\hline
\end{tabular}

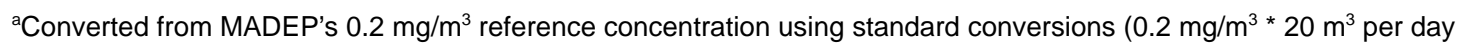
inhalation rate $/ 70 \mathrm{~kg}$ body weight)

${ }^{\mathrm{b}} \mathrm{No}$ information on Dermal RfDs, assumed the same as Oral

$C=$ Carbon

DRO = Diesel-range organics

$\mathrm{mg} / \mathrm{kg}=$ Milligrams per kilogram

Source: MADEP, 2002 


\section{G.1.1.3 Risk Assessment}

For each CAS, the collective hazard from all exposure routes - ingestion, inhalation of dust, plus dermal contact - is determined in equation G-6 by summing the $\mathrm{HQ}_{\mathrm{i}} \mathrm{s}$ as shown:

$$
H I=\sum_{i} H Q_{i}
$$

The resulting quantity is termed the HI, which is compared to the risk-based criteria of 1.0. If the HI for a CAS is less than or equal to 1.0, then the CAS does not pose an unacceptable risk to human health. The HIs for each CAS are presented in Table G.1-3 for the Industrial Area exposure scenario.

Because equation G-6 assumes proportional additivity, it may not accurately predict the occurrence of a chemical exposure related effect. However, it is considered a conservative value and is a useful metric in the regulatory decision-making process for gauging the potential threat posed by chemicals with associated non-cancer effects (EPA, 1989).

\section{G.1.2 Ecological Receptors}

To date, there have been no known federally listed threatened, endangered, or candidate plants identified within the boundaries of the mud pit CASs (DOE/NV, 1996); therefore, TPH-DRO within the CASs of CAUs 530-535 are not expected to affect sensitive plant species. There are two federally listed threatened species, the desert tortoise and bald eagle, and one federally listed endangered species, the peregrine falcon, known to inhabit the NTS (DOE/NV, 1996). As documented in the RBCSR, the habitat preferences for these species suggest they are not likely to frequent the mud pit CASs and, consequently, they are unlikely to receive direct exposure to TPH-DRO (NNSA/NSO, 2004). In following the DQOs of the SAFER Plan, visual habitat surveys were conducted as part of the field investigation to confirm the lack of risk to ecological receptors.

\section{G.1.3 Conclusions}

The risk assessment for human receptors using the Industrial Area exposure scenario resulted in HIs that ranged from 0.002 to 0.009 . The results for all 52 CASs that were sampled are part of this closure investigation are shown in Table G.1-3. All are less than 1.0 meaning none of the 52 sampled 
CASs pose an unacceptable risk to human receptors. Because this scenario represents the highest exposure to TPH-DRO an NTS worker would receive from a CAS in CAUs 530-535 and this exposure shows no unacceptable risk, no use restrictions are required.

To confirm the lack of risk to ecological receptors, visual habitat surveys were conducted at CASs that were not characterized during any of the preliminary assessments of CAUs 530-535 (see Table 1-1). These surveys confirmed that the mud pit CASs do not serve as suitable habitat for the threatened and endangered species and, therefore, TPH-DRO does not pose an unacceptable risk to ecological receptors. Documentation of the visual habitat surveys is located in the project files for future reference.

After evaluating the risk to human receptors and verifying the lack of risk to ecological receptors, it is concluded that mud pit CASs in CAUs 530-535 do not pose an unacceptable risk. According to the risk-based closure strategy, it is recommended to close these CAUs with no further action. 
Table G.1-3

Risk Assessment Results for the Industrial Area Reuse Scenario (Page 1 of 3)

\begin{tabular}{|c|c|c|c|c|c|c|c|c|c|}
\hline \multirow{3}{*}{ CAS } & \multirow{3}{*}{$\begin{array}{c}\text { 95\% UCL of the } \\
\text { Mean TPH-DRO } \\
\text { Soil Concentration } \\
\text { Csoil } \\
\text { mg/kg_soil }\end{array}$} & \multirow{3}{*}{$\begin{array}{c}\text { Air Concentration } \\
\text { Associated with } \\
\text { Characteristic Soil } \\
\text { Concentration }\end{array}$} & \multicolumn{7}{|c|}{$\begin{array}{c}\text { Scenario: Industrial Area } \\
\text { Non Cancer Effects: TPH-DRO }\end{array}$} \\
\hline & & & CDI_Ing-nc & CDI_Inhl-nc & CDI_Dermal-nc & \multirow{2}{*}{ HQ_Ing } & \multirow{2}{*}{ HQ_Inhl } & \multirow{2}{*}{ HQ_Dermal } & \multirow{2}{*}{ HI } \\
\hline & & & mg/kg-day & mg/kg-day & mg/kg-day & & & & \\
\hline 01-09-02 & 28.8 & 3.02E-08 & 5.07E-05 & $5.32 \mathrm{E}-09$ & $1.67 \mathrm{E}-05$ & $5.07 \mathrm{E}-04$ & $9.34 \mathrm{E}-08$ & 1.67E-04 & $6.74 \mathrm{E}-04$ \\
\hline 01-09-04 & 28.9 & 3.04E-08 & 5.09E-05 & 5.35E-09 & $1.68 \mathrm{E}-05$ & $5.09 \mathrm{E}-04$ & $9.38 \mathrm{E}-08$ & $1.68 \mathrm{E}-04$ & 6.77E-04 \\
\hline $02-09-03$ & 33.7 & 3.54E-08 & 5.94E-05 & $6.23 \mathrm{E}-09$ & $1.96 \mathrm{E}-05$ & 5.94E-04 & 1.09E-07 & 1.96E-04 & 7.90E-04 \\
\hline 02-09-09 & 28.8 & 3.03E-08 & 5.08E-05 & 5.33E-09 & $1.68 \mathrm{E}-05$ & 5.08E-04 & 9.35E-08 & $1.68 \mathrm{E}-04$ & $6.75 \mathrm{E}-04$ \\
\hline $02-09-12$ & 28.6 & $3.00 \mathrm{E}-08$ & 5.03E-05 & 5.28E-09 & $1.66 \mathrm{E}-05$ & 5.03E-04 & $9.26 \mathrm{E}-08$ & 1.66E-04 & 6.69E-04 \\
\hline 02-09-15 & 28.8 & 3.02E-08 & 5.06E-05 & 5.32E-09 & $1.67 \mathrm{E}-05$ & 5.06E-04 & 9.33E-08 & 1.67E-04 & $6.74 \mathrm{E}-04$ \\
\hline 02-09-18 & 28.6 & $3.00 \mathrm{E}-08$ & 5.03E-05 & 5.28E-09 & 1.66E-05 & 5.03E-04 & $9.27 \mathrm{E}-08$ & 1.66E-04 & 6.69E-04 \\
\hline $02-09-26$ & 28.6 & $3.00 \mathrm{E}-08$ & 5.03E-05 & 5.29E-09 & 1.66E-05 & 5.03E-04 & $9.27 \mathrm{E}-08$ & $1.66 \mathrm{E}-04$ & $6.70 \mathrm{E}-04$ \\
\hline 02-09-30 & 30.1 & $3.16 \mathrm{E}-08$ & 5.30E-05 & 5.56E-09 & 1.75E-05 & 5.30E-04 & 9.76E-08 & $1.75 \mathrm{E}-04$ & 7.05E-04 \\
\hline $02-09-33$ & 28.9 & 3.03E-08 & 5.09E-05 & 5.34E-09 & $1.68 \mathrm{E}-05$ & 5.09E-04 & 9.37E-08 & $1.68 \mathrm{E}-04$ & 6.77E-04 \\
\hline $02-09-52$ & 34.5 & $3.62 \mathrm{E}-08$ & $6.08 \mathrm{E}-05$ & $6.38 \mathrm{E}-09$ & $2.01 \mathrm{E}-05$ & $6.08 \mathrm{E}-04$ & 1.12E-07 & $2.01 \mathrm{E}-04$ & 8.09E-04 \\
\hline 03-09-15 & 28.7 & 3.02E-08 & 5.06E-05 & 5.32E-09 & $1.67 \mathrm{E}-05$ & $5.06 \mathrm{E}-04$ & 9.33E-08 & 1.67E-04 & 6.73E-04 \\
\hline 03-09-17 & 37.2 & 3.90E-08 & $6.55 \mathrm{E}-05$ & 6.87E-09 & $2.16 \mathrm{E}-05$ & $6.55 \mathrm{E}-04$ & 1.21E-07 & 2.16E-04 & 8.71E-04 \\
\hline 03-09-21 & 30.8 & $3.24 \mathrm{E}-08$ & 5.43E-05 & 5.70E-09 & $1.79 \mathrm{E}-05$ & 5.43E-04 & $1.00 \mathrm{E}-07$ & 1.79E-04 & $7.22 \mathrm{E}-04$ \\
\hline $03-09-30$ & 33.3 & $3.49 \mathrm{E}-08$ & 5.86E-05 & 6.15E-09 & 1.93E-05 & 5.86E-04 & $1.08 \mathrm{E}-07$ & 1.93E-04 & $7.80 \mathrm{E}-04$ \\
\hline 04-09-06 & 28.7 & 3.02E-08 & 5.06E-05 & 5.31E-09 & $1.67 \mathrm{E}-05$ & 5.06E-04 & $9.32 \mathrm{E}-08$ & 1.67E-04 & 6.73E-04 \\
\hline 04-09-08 & 29.0 & 3.05E-08 & 5.11E-05 & 5.37E-09 & 1.69E-05 & 5.11E-04 & $9.42 \mathrm{E}-08$ & 1.69E-04 & $6.80 \mathrm{E}-04$ \\
\hline 04-09-14 & 57.8 & 6.07E-08 & 1.02E-04 & 1.07E-08 & 3.36E-05 & 1.02E-03 & 1.88E-07 & 3.36E-04 & $1.35 \mathrm{E}-03$ \\
\hline
\end{tabular}

\section{Uncontrolled When Printed}


Table G.1-3

Risk Assessment Results for the Industrial Area Reuse Scenario

(Page 2 of 3 )

\begin{tabular}{|c|c|c|c|c|c|c|c|c|c|}
\hline \multirow{3}{*}{ CAS } & \multirow{3}{*}{$\begin{array}{c}\text { 95\% UCL of the } \\
\text { Mean TPH-DRO } \\
\text { Soil Concentration }\end{array}$} & \multirow{3}{*}{$\begin{array}{c}\text { Air Concentration } \\
\text { Associated with } \\
\text { Characteristic Soil } \\
\text { Concentration }\end{array}$} & \multicolumn{7}{|c|}{$\begin{array}{c}\text { Scenario: Industrial Area } \\
\text { Non Cancer Effects: TPH-DRO }\end{array}$} \\
\hline & & & CDI_Ing-nc & CDI_Inhl-nc & CDI_Dermal-nc & \multirow{2}{*}{ HQ_Ing } & \multirow{2}{*}{ HQ_Inhl } & \multirow{2}{*}{ HQ_Dermal } & \multirow{2}{*}{ HI } \\
\hline & & & mg/kg-day & mg/kg-day & mg/kg-day & & & & \\
\hline $04-09-18$ & 36.0 & $3.78 \mathrm{E}-08$ & $6.34 \mathrm{E}-05$ & 6.65E-09 & 2.09E-05 & 6.34E-04 & 1.17E-07 & 2.09E-04 & 8.43E-04 \\
\hline $05-09-02$ & 100.1 & $1.05 \mathrm{E}-07$ & 1.76E-04 & $1.85 \mathrm{E}-08$ & 5.82E-05 & 1.76E-03 & $3.25 \mathrm{E}-07$ & 5.82E-04 & 2.35E-03 \\
\hline 06-09-02 & 29.0 & $3.04 \mathrm{E}-08$ & 5.10E-05 & 5.36E-09 & $1.68 \mathrm{E}-05$ & 5.10E-04 & $9.40 \mathrm{E}-08$ & 1.68E-04 & 6.79E-04 \\
\hline 07-09-10 & 41.8 & 4.39E-08 & 7.37E-05 & 7.74E-09 & 2.43E-05 & 7.37E-04 & 1.36E-07 & 2.43E-04 & $9.80 \mathrm{E}-04$ \\
\hline $07-09-13$ & 28.9 & 3.03E-08 & 5.09E-05 & 5.34E-09 & $1.68 \mathrm{E}-05$ & 5.09E-04 & 9.37E-08 & $1.68 \mathrm{E}-04$ & 6.77E-04 \\
\hline $07-09-22$ & 28.8 & 3.02E-08 & 5.07E-05 & 5.32E-09 & 1.67E-05 & 5.07E-04 & 9.33E-08 & 1.67E-04 & $6.74 \mathrm{E}-04$ \\
\hline $07-09-25$ & 28.7 & 3.01E-08 & 5.06E-05 & 5.31E-09 & 1.67E-05 & 5.06E-04 & 9.31E-08 & 1.67E-04 & 6.72E-04 \\
\hline $07-09-27$ & 46.8 & 4.91E-08 & 8.24E-05 & 8.65E-09 & $2.72 \mathrm{E}-05$ & 8.24E-04 & $1.52 \mathrm{E}-07$ & $2.72 \mathrm{E}-04$ & 1.10E-03 \\
\hline $07-09-28$ & 56.0 & $5.88 \mathrm{E}-08$ & $9.86 \mathrm{E}-05$ & $1.04 \mathrm{E}-08$ & $3.25 \mathrm{E}-05$ & $9.86 \mathrm{E}-04$ & $1.82 \mathrm{E}-07$ & $3.25 \mathrm{E}-04$ & $1.31 \mathrm{E}-03$ \\
\hline 08-09-06 & 28.6 & 3.00E-08 & 5.03E-05 & 5.28E-09 & $1.66 \mathrm{E}-05$ & 5.03E-04 & $9.27 \mathrm{E}-08$ & 1.66E-04 & 6.69E-04 \\
\hline $09-09-10$ & 80.2 & 8.43E-08 & $1.41 \mathrm{E}-04$ & $1.48 \mathrm{E}-08$ & 4.66E-05 & $1.41 \mathrm{E}-03$ & $2.60 \mathrm{E}-07$ & 4.66E-04 & $1.88 \mathrm{E}-03$ \\
\hline 09-09-15 & 29.1 & 3.06E-08 & 5.13E-05 & 5.39E-09 & 1.69E-05 & 5.13E-04 & $9.46 \mathrm{E}-08$ & 1.69E-04 & $6.83 \mathrm{E}-04$ \\
\hline 09-09-16 & 28.7 & 3.01E-08 & 5.05E-05 & 5.31E-09 & 1.67E-05 & 5.05E-04 & 9.31E-08 & 1.67E-04 & 6.72E-04 \\
\hline $09-09-20$ & 28.7 & 3.02E-08 & 5.06E-05 & 5.32E-09 & 1.67E-05 & 5.06E-04 & 9.33E-08 & 1.67E-04 & 6.73E-04 \\
\hline $09-09-23$ & 28.6 & $3.00 \mathrm{E}-08$ & 5.03E-05 & 5.28E-09 & $1.66 \mathrm{E}-05$ & 5.03E-04 & $9.27 \mathrm{E}-08$ & $1.66 \mathrm{E}-04$ & $6.69 \mathrm{E}-04$ \\
\hline 09-09-24 & 28.7 & 3.01E-08 & 5.05E-05 & 5.30E-09 & 1.67E-05 & 5.05E-04 & $9.30 \mathrm{E}-08$ & 1.67E-04 & $6.72 \mathrm{E}-04$ \\
\hline $09-09-27$ & 32.6 & $3.42 \mathrm{E}-08$ & 5.74E-05 & 6.03E-09 & 1.89E-05 & 5.74E-04 & $1.06 \mathrm{E}-07$ & 1.89E-04 & 7.63E-04 \\
\hline
\end{tabular}

\section{Uncontrolled When Printed}


Table G.1-3

Risk Assessment Results for the Industrial Area Reuse Scenario

(Page 3 of 3 )

\begin{tabular}{|c|c|c|c|c|c|c|c|c|c|}
\hline \multirow{3}{*}{ CAS } & \multirow{3}{*}{$\begin{array}{c}\text { 95\% UCL of the } \\
\text { Mean TPH-DRO } \\
\text { Soil Concentration } \\
\text { Csoil } \\
\text { mg/kg_soil }\end{array}$} & \multirow{3}{*}{$\begin{array}{c}\text { Air Concentration } \\
\text { Associated with } \\
\text { Characteristic Soil } \\
\text { Concentration }\end{array}$} & \multicolumn{7}{|c|}{$\begin{array}{c}\text { Scenario: Industrial Area } \\
\text { Non Cancer Effects: TPH-DRO }\end{array}$} \\
\hline & & & CDI_Ing-nc & CDI_Inhl-nc & CDI_Dermal-nc & \multirow{2}{*}{ HQ_Ing } & \multirow{2}{*}{ HQ_Inhl } & \multirow{2}{*}{ HQ_Dermal } & \multirow{2}{*}{ HI } \\
\hline & & & mg/kg-day & mg/kg-day & mg/kg-day & & & & \\
\hline $09-09-35$ & 28.9 & 3.03E-08 & 5.09E-05 & 5.34E-09 & 1.68E-05 & 5.09E-04 & 9.37E-08 & $1.68 \mathrm{E}-04$ & $6.77 \mathrm{E}-04$ \\
\hline $09-09-40$ & 28.6 & 3.00E-08 & 5.03E-05 & 5.28E-09 & 1.66E-05 & 5.03E-04 & $9.26 \mathrm{E}-08$ & 1.66E-04 & $6.69 \mathrm{E}-04$ \\
\hline $09-09-42$ & 28.5 & 3.00E-08 & 5.03E-05 & 5.28E-09 & 1.66E-05 & 5.03E-04 & $9.26 \mathrm{E}-08$ & 1.66E-04 & $6.69 \mathrm{E}-04$ \\
\hline $10-09-12$ & 31.5 & 3.31E-08 & 5.55E-05 & 5.83E-09 & 1.83E-05 & 5.55E-04 & $1.02 \mathrm{E}-07$ & 1.83E-04 & 7.39E-04 \\
\hline $10-09-18$ & 50.3 & 5.29E-08 & 8.87E-05 & 9.31E-09 & 2.93E-05 & 8.87E-04 & 1.63E-07 & 2.93E-04 & $1.18 \mathrm{E}-03$ \\
\hline $10-09-26$ & 29.4 & 3.09E-08 & 5.17E-05 & 5.43E-09 & 1.71E-05 & 5.17E-04 & 9.53E-08 & 1.71E-04 & $6.88 \mathrm{E}-04$ \\
\hline $14-09-02$ & 28.8 & 3.03E-08 & $5.08 \mathrm{E}-05$ & 5.33E-09 & $1.68 \mathrm{E}-05$ & $5.08 \mathrm{E}-04$ & 9.35E-08 & $1.68 \mathrm{E}-04$ & $6.75 \mathrm{E}-04$ \\
\hline $19-09-12$ & 126.0 & 1.32E-07 & $2.22 \mathrm{E}-04$ & 2.33E-08 & 7.32E-05 & $2.22 \mathrm{E}-03$ & 4.09E-07 & 7.32E-04 & 2.95E-03 \\
\hline $19-09-17$ & 36.4 & 3.82E-08 & $6.41 \mathrm{E}-05$ & 6.73E-09 & 2.11E-05 & $6.41 \mathrm{E}-04$ & $1.18 \mathrm{E}-07$ & 2.11E-04 & $8.52 \mathrm{E}-04$ \\
\hline $19-09-19$ & 29.1 & 3.06E-08 & $5.13 \mathrm{E}-05$ & 5.38E-09 & 1.69E-05 & 5.13E-04 & $9.44 \mathrm{E}-08$ & 1.69E-04 & $6.82 \mathrm{E}-04$ \\
\hline $19-09-27$ & 28.9 & 3.04E-08 & 5.09E-05 & 5.35E-09 & 1.68E-05 & 5.09E-04 & 9.39E-08 & 1.68E-04 & $6.78 \mathrm{E}-04$ \\
\hline 20-09-15 & 28.9 & 3.03E-08 & $5.08 \mathrm{E}-05$ & 5.34E-09 & 1.68E-05 & $5.08 \mathrm{E}-04$ & 9.36E-08 & $1.68 \mathrm{E}-04$ & 6.76E-04 \\
\hline $20-09-27$ & 125.4 & $1.32 \mathrm{E}-07$ & $2.21 \mathrm{E}-04$ & 2.32E-08 & $7.29 \mathrm{E}-05$ & $2.21 \mathrm{E}-03$ & 4.07E-07 & 7.29E-04 & $2.94 \mathrm{E}-03$ \\
\hline $20-09-31$ & 30.4 & 3.19E-08 & 5.36E-05 & 5.63E-09 & 1.77E-05 & 5.36E-04 & 9.87E-08 & 1.77E-04 & 7.13E-04 \\
\hline $20-09-35$ & 28.9 & 3.04E-08 & $5.10 \mathrm{E}-05$ & 5.35E-09 & 1.68E-05 & 5.10E-04 & 9.39E-08 & $1.68 \mathrm{E}-04$ & $6.78 \mathrm{E}-04$ \\
\hline $20-09-40$ & 28.9 & 3.03E-08 & 5.08E-05 & 5.34E-09 & 1.68E-05 & 5.08E-04 & 9.37E-08 & 1.68E-04 & $6.76 \mathrm{E}-04$ \\
\hline $20-09-46$ & 29.1 & 3.06E-08 & $5.13 \mathrm{E}-05$ & 5.39E-09 & 1.69E-05 & 5.13E-04 & $9.45 \mathrm{E}-08$ & 1.69E-04 & $6.82 \mathrm{E}-04$ \\
\hline
\end{tabular}

\section{Uncontrolled When Printed}




\section{G.2.0 RESRAD Calculations for CAS 09-09-24}

This section discusses the Residual Radioactivity (RESRAD) model and computer code (ANL, 2001) calculations and results for the Mud pit CAS 09-09-24.

\section{Selection of RESRAD Exposure Scenario}

Remote Work Area Exposure Scenario (DOE, 2006) was selected as the exposure scenario for the CAS 09-09-24 because of the remote location of the site. Because the Remote Work Area Scenario parameters were used for these calculations, a re-evaluation will be necessary if the site use changes to Industrial Area Scenario.

\section{User Input Parameters}

The RESRAD default parameters were modified for the calculations for this CAS location in accordance with the Industrial Site Project Establishment of Final Action Levels (DOE, 2006). Radionuclide concentrations used for the calculations are reported in the Appendix A of this document.

\section{RESRAD Dose Estimates for CAS 09-09-24}

The detailed results for this RESRAD exposure scenario are provided in Exhibit 1, RESRAD Summary Report: CAS 09-09-24. The maximum dose of 0.77 mrem/yr occurs at year zero.

Uncertainty in the derivation of dose estimates and dose/source contribution ratios comes from the distribution of possible input parameter values, as well as uncertainty in the conceptual model used to represent the site. The pathway contributions to the total annual dose at time zero are 99.16 percent for external exposure, 0.81 percent for inhalation, and 0.03 percent for soil ingestion pathways. Therefore, uncertainties in the following parameters: Erosion rates, thickness of contaminated zone, occupancy factors, and wind speed have the greatest significance on the model predictions. However, the migration of radionuclides into this CAS is not considered in the calculations.

The maximum dose contributions and total dose/source concentration ratios for CAS 09-09-24 using Remote Work Area Scenario parameters have been predicted to occur at time zero. The calculated 
maximum dose contributions for all considered pathways are presented in Table 1, Maximum Dose Contributions for CAS 09-09-24 Using Remote Work Area Scenario and Figure 1 Dose Per Year, All Radionuclides Summed, All Pathways Summed, shows that at time zero, the total effective dose equivalent to the workers for the considered pathways is $0.77 \mathrm{mrem} / \mathrm{yr}$ and that the annual dose rate drops to zero at the year 300 .

Figure G.-1 CAS 09-09-24 Dose Per Year, All Radionuclides Nuclides Summed, Component Pathways shows the breakdown of the total dose into the component pathways. Together, Table G.2-1 and Figures G.2-1 and G.2-2 show that the dose from Eu-152 at time zero is $0.74 \mathrm{mrem} /$ year and decreases to zero after the 300-year time interval. This result also shows that the annual dose from external radiation (almost all from Eu-152) at time zero is $0.76 \mathrm{mrem} / \mathrm{year}$ and is reduced to zero mrem/yr within 300 years. Eu-152 has a half-life of 13.33 years, the concentration of Eu-152 at this site will decay to a minute level through the radioactive decay processes within the 300 -year time interval.

Table G.2-1

Maximum Annual Dose Contributions for CAS 09-09-24 Using Remote Work Area Scenario (occurs at year zero) (mrem/yr)

\begin{tabular}{||c|c|c|c|c|c|c|c|c||}
\hline \multirow{2}{*}{ Radionuclide } & \multicolumn{2}{|c|}{ Ground (external) } & \multicolumn{2}{c|}{ Inhalation } & \multicolumn{2}{|c|}{ Soil } & \multicolumn{3}{c|}{ Total } \\
\cline { 2 - 9 } & Dose & Fraction & Dose & Fraction & Dose & Fraction & Dose & Fraction \\
\hline Cesium-137 & 0.02 & 0.03 & 0.00 & 0.00 & 0.00 & 0.00 & 0.02 & 0.03 \\
\hline European-152 & 0.74 & 0.96 & 0.00 & 0.00 & 0.00 & 0.00 & 0.74 & 0.96 \\
\hline Plutonium-238 & 0.00 & 0.00 & 0.00 & 0.00 & 0.00 & 0.00 & 0.00 & 0.00 \\
\hline Plutonium-239 & 0.00 & 0.00 & 0.00 & 0.01 & 0.00 & 0.00 & 0.00 & 0.01 \\
\hline Strontium-90 & 0.00 & 0.00 & 0.00 & 0.00 & 0.00 & 0.00 & 0.00 & 0.00 \\
\hline Uranium-234 & 0.00 & 0.00 & 0.00 & 0.00 & 0.00 & 0.00 & 0.00 & 0.00 \\
\hline Uranium-238 & 0.00 & 0.00 & 0.00 & 0.00 & 0.00 & 0.00 & 0.00 & 0.00 \\
\hline Total & 0.76 & 0.99 & 0.00 & 0.01 & 0.00 & 0.00 & 0.77 & 1.00 \\
\hline
\end{tabular}

$\mathrm{mrem} / \mathrm{yr}=$ Millirem per year 


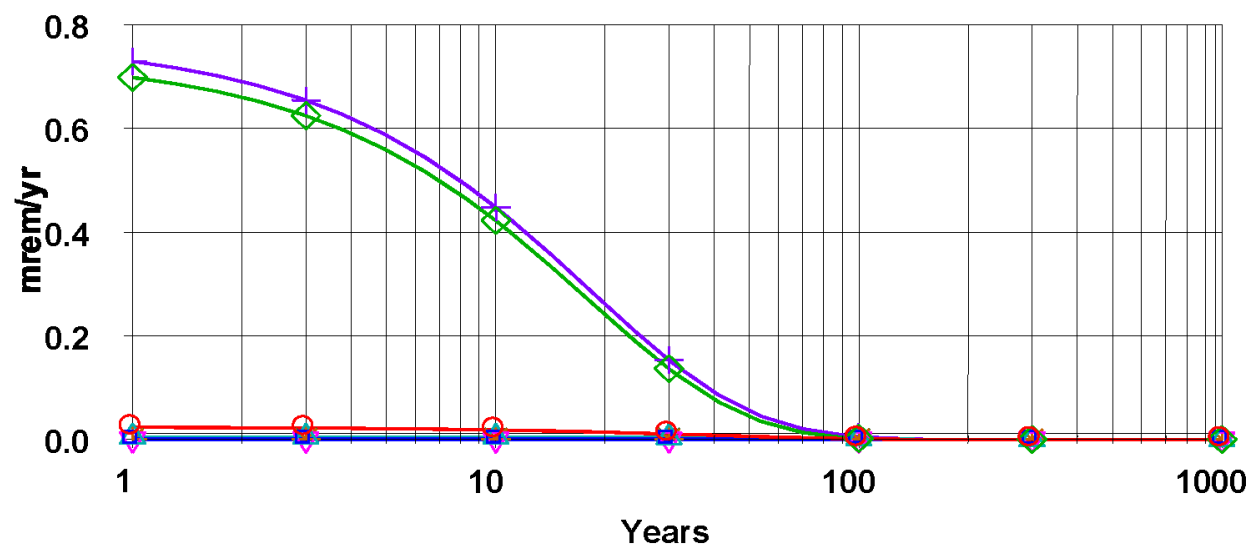

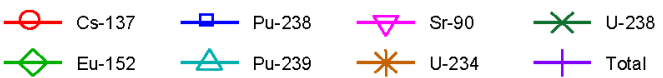

Figure G.2-1

CAS 09-09-24 Dose Contribution, All Radionulides Summed, All Pathways Summed
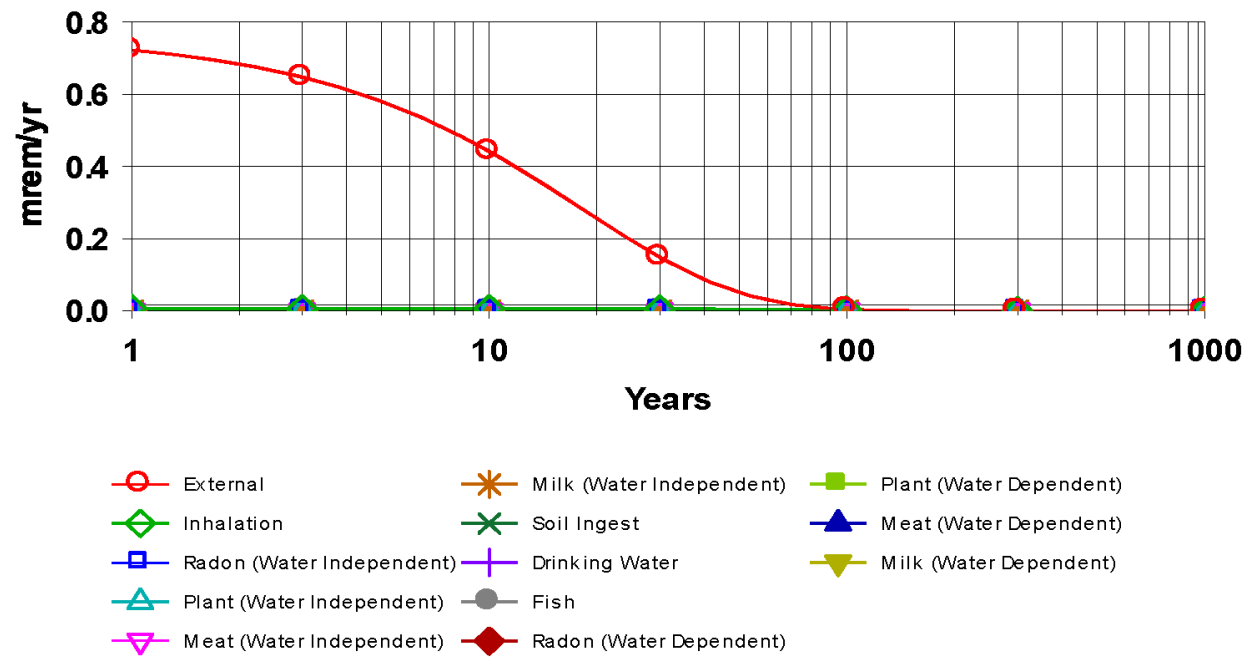

Figure G.2-2

CAS 09-09-24 Dose Contribution, All Radionulides Summed, All Component Pathways 


\section{Residual Radioactive Material Guidelines for CAS 09-09-24}

Because the sum of the ratios for CAS 09-09-24 did not exceed unity (Table G.2-2), residual radioactive guidelines for mixtures of radionuclides were not calculated for this CAS. Table G.2-2 presents the results for derived guidelines for single radionuclides for this CAS. The FALs for the CAS 09-09-24 Remote Work Area Scenario are the residual radioactive material guideline values for single radionuclides.

Table G.2-2

CAS 09-09-24 Sum of Fractions and Proportional Scaling (Single Radionuclide Guidelines)

\begin{tabular}{|c|c|c|c|c|}
\hline Radionuclide & $\begin{array}{c}\text { Initial } \\
\text { Radionuclide } \\
\text { Concentration } \\
\text { (pCi/g) }\end{array}$ & $\begin{array}{c}\text { \% } \\
\text { Contribution }\end{array}$ & $\begin{array}{c}\text { Single } \\
\text { Radionuclide } \\
\text { Guidelines } \\
\text { (pCi/g) }\end{array}$ & $\begin{array}{c}\text { Ratio for Single } \\
\text { Radionuclide } \\
\text { Guideline }\end{array}$ \\
\hline Cesium-137 & 0.78 & 0.04 & 817.2 & 0.03 \\
\hline European-152 & 12.34 & 0.69 & 417.9 & 0.96 \\
\hline Plutonium-238 & 0.06 & 0.00 & 12080 & 0.00 \\
\hline Plutonium-239 & 2.28 & 0.13 & 10990 & 0.01 \\
\hline Strontium-90 & 0.60 & 0.03 & 10330 & 0.00 \\
\hline Uranium-234 & 0.91 & 0.05 & 26710 & 0.00 \\
\hline Uranium-238 & 0.86 & 0.05 & 12490 & 0.00 \\
\hline Total & 17.83 & 1.00 & & 1.00 \\
\hline
\end{tabular}

$\mathrm{pCi} / \mathrm{g}=$ Picocuries per gram 


\section{G.3.0 References}

ANL, see Argonne National Laboratory

Argonne National Laboratory. 2001. User's Manual for RESRAD Version 6, ANL/EAD-4, Environmental Assessment Division, Argonne, IL.

DOE/NV, see U.S. Department of Energy, Nevada Operations Office.

EPA, see U.S. Environmental Protection Agency

MADEP, see Massachusetts Department of Environmental Protection.

Massachusetts Department of Environmental Protection. 2002. Implementation of the MADEP VPH/EPH Approach. Boston, MA.

Massachusetts Department of Environmental Protection. 2003. Updated Petroleum Hydrocarbon Fraction Toxicity Values for the VPH/EPH/APH Methodology. Boston, MA.

NNSA/NSO, see U.S. Department of Energy, National Nuclear Security Administration Nevada Site Office.

U.S. Department of Energy, National Nuclear Security Administration Nevada Site Office. 2004. Mud Pit Risk-Based Closure Strategy Report, Nevada Test Site, Nevada, DOE/NV--991. Las Vegas, NV.

U.S. Department of Energy, National Nuclear Security Administration Nevada Site Office. 2005a. Streamlined Approach for Environmental Restoration Plan for Corrective Action Units 530, 531, 532, 533, 534, and 535, Nevada Test Site Mud Pits, Nevada Test Site, Nevada, DOE/NV--1057. Las Vegas, NV.

U.S. Department of Energy, National Nuclear Security Administration Nevada Site Office. 2005b. Process to Move from Preliminary Action Levels to Final Action Levels (Draft), November. Las Vegas, NV.

U.S. Department of Energy, National Nuclear Security Administration Nevada Site Office. 2006. Industrial Sites Project Establishment of Final Action Levels, DOE/NV--1107. February. Las Vegas, NV.

U.S. Department of Energy, Nevada Operations Office. 1996. Final Environmental Impact Statement for the Nevada Test Site and Off-Site Location in the State of Nevada, DOE/EIS 0243. Las Vegas, NV. 
U.S. Environmental Protection Agency. 1989. Risk Assessment Guidance for Superfund, Vol. I: Human Health Evaluation Manual (Part A), Interim Final, EPA/540/1-89-002.

U.S. Environmental Protection Agency. 2001. Users Guide: Radionuclide Carcinogenicity, Office of Air and Radiation Protection, Las Vegas, NV.

Yu C., Loureiro C., Cheng C. C., Jones L. G., Wang Y. Y., Chia Y. P., and Faillace E. 1993. Manual for Data Collection Handbook to Support Modeling the Impacts of Radioactive Material in Soil, ANL/EAIS-8. Chicago, IL: Environmental Assessment Division, Argonne National Laboratory. 


\section{Attachment G}

\section{RESRAD Tables}

(24 Pages) 

1RESRAD, Version 6.3
T $\ll$ Limit $=180$ days
05/07/2006 17:31 Page
Summary : Mudpit Remote Work Area
File: Mudpit Remote.RAD

Table of Contents

ÄÄÄÄÄÄÄÄÄÄÄÄÄÄÄÄÄ

Part I: Mixture Sums and Single Radionuclide Guidelines

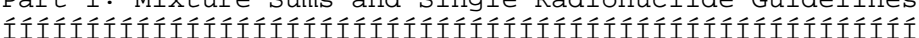

Dose Conversion Factor (and Related) Parameter Summary ...

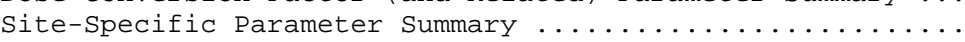
Summary of Pathway Selections $\ldots \ldots \ldots \ldots \ldots \ldots \ldots \ldots \ldots$

Contaminated Zone and Total Dose Summary

Total Dose Components

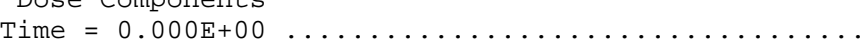

$\begin{array}{ll} & \\ & \end{array}$

.

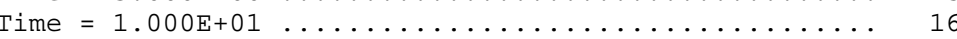

Time $=3.000 \mathrm{E}+01 \ldots \ldots \ldots \ldots \ldots \ldots \ldots \ldots \ldots \ldots \ldots \ldots, 17$

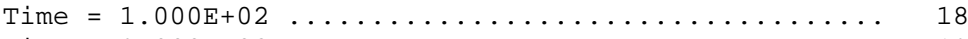

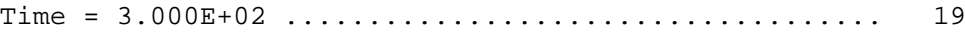

Time $=1.000 \mathrm{E}+03 \ldots \ldots \ldots \ldots \ldots \ldots \ldots \ldots \ldots \ldots \ldots, 20$

Dose/Source Ratios Summed Over All Pathways ........... 21

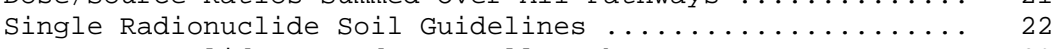

Dose Per Nuclide Summed Over All Pathways $\ldots \ldots \ldots \ldots \ldots .23$

Soil Concentration Per Nuclide ................ 24 

1RESRAD, Version 6.3
T« Limit $=180$ days
05/07/2006 17:31 Page 2
Summary : Mudpit Remote Work Area
File: Mudpit Remote.RAD

Dose Conversion Factor (and Related) Parameter Summary File: FGR 13 MORBIDITY

$\odot \quad 3$

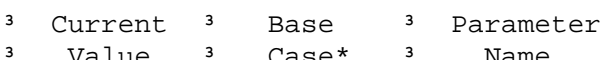
Parameter
Menu 3
Value
Name

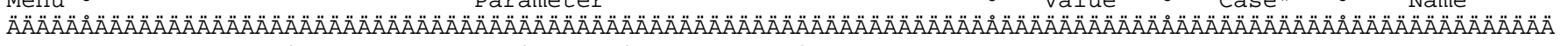

B-1 3 Dose conversion factors for inhalation, $\mathrm{mrem} / \mathrm{pCi}$ :

B-1 3 AC-227+D

$\mathrm{B}-1 \quad 3 \mathrm{CS}-137+\mathrm{D}$

$\mathrm{B}-1 \quad 3 \mathrm{Eu}-152$

B-1 3 Gd-152

$\mathrm{B}-1 \quad 3 \mathrm{~Pa}-231$

$\mathrm{B}-1 \quad 3 \mathrm{~Pb}-210+\mathrm{D}$

$\mathrm{B}-13 \mathrm{Pu}-238$

B-1 3 Pu-239

$\begin{array}{lll}\mathrm{B}-1 & 3 & \mathrm{Ra}-226+\mathrm{D} \\ \mathrm{B}-1 & 3 & \mathrm{Sr}-90+\mathrm{D}\end{array}$

B-1 3 Th -230

$\mathrm{B}-1 \quad 3 \mathrm{U}-234$

$B-1 \quad 3 \quad U-235+D$

B-1 3 U-238

B-1 3 U-238+D

3

D-1 3 Dose conversion factors for ingestion, $\mathrm{mrem} / \mathrm{pCi}$

D-1 3 AC-227+D

D-1 3 Cs $-137+D$

D-1 3 Eu-152

D-1 3 Gd-152

$\mathrm{D}-1 \quad 3 \mathrm{~Pa}-231$

$\mathrm{D}-1 \quad 3 \mathrm{~Pb}-210+\mathrm{D}$

$\mathrm{D}-1$ 3 $\mathrm{Pu}-239$

D-1 3 Ra-226+D

D-1 3 Sr $-90+D$

D-1 3 Th-230

D-1 3 U-234

D-1 $3 \quad \mathrm{U}-235+\mathrm{D}$

$D-1 \quad 3 \quad U-238$

$\mathrm{D}-1 \quad 3 \quad \mathrm{U}-238+\mathrm{D}$

D-34 3 Food transfer factors

D-34 3 AC-227+D, plant/soil concentration ratio, dimensionless $\mathrm{D}-34{ }^{3} \mathrm{AC}-227+\mathrm{D}$, beef/livestock-intake ratio, $(\mathrm{pCi} / \mathrm{kg}) /(\mathrm{pCi} / \mathrm{d})$

$D-34 \quad 3 \quad A C-227+$

D-34 3

D-34 3 Cs-137+D, plant/soil concentration ratio, dimensionless

$\mathrm{D}-34{ }^{3} \mathrm{Cs}-137+\mathrm{D}$, beef/livestock-intake ratio, (pCi/kg)/(pCi/d)

$\mathrm{D}-34{ }^{3} \mathrm{Cs}-137+\mathrm{D}$, milk/livestock-intake ratio, $(\mathrm{pCi} / \mathrm{L}) /(\mathrm{pCi} / \mathrm{d})$

$\mathrm{D}-344^{3}$

$\mathrm{D}-34{ }^{3} \mathrm{Eu}-152$

D-34 3 Eu-152

$\mathrm{D}-34{ }^{3} \mathrm{Eu}-152$

, plant/soil concentration ratio, dimensionless beef/livestock-intake ratio, $(\mathrm{pCi} / \mathrm{kg}) /(\mathrm{pCi} / \mathrm{d})$ $\mathrm{milk} /$ livestock-intake ratio, $(\mathrm{pCi} / \mathrm{L}) /(\mathrm{pCi} / \mathrm{d})$

D-34 $3 \mathrm{Gd}-152$

D-34 $3 \mathrm{Gd}-152$

$\mathrm{D}-34{ }^{3} \mathrm{Gd}-152$

plant/soil concentration ratio, dimensionless beef/livestock-intake ratio, $(\mathrm{pCi} / \mathrm{kg}) /(\mathrm{pCi} / \mathrm{d})$ milk/livestock-intake ratio, $(\mathrm{pCi} / \mathrm{L}) /(\mathrm{pCi} / \mathrm{d})$ $36.724 \mathrm{E}+00$ 3 $6.700 \mathrm{E}+003$ DCF2( 1$)$ $3 \quad 3.190 \mathrm{E}-05 \quad 3 \quad 3.190 \mathrm{E}-05$ 3 DCF2( (2) $2.210 E-04{ }^{3}$ 2.210E-04 3 DCF2( 3$)$ $2.430 \mathrm{E}-0132.430 \mathrm{~B}-01{ }^{3}$ DCF2( 5 ) $\begin{array}{llll}1.280 E+00 & 3 & 1.280 E+00 & 3 \\ \text { DCF2 } & 6\end{array}$ $3 \quad 2.320 E-0231.360 E-023 \operatorname{DCF} 2(7)$ 3 3.920E-01 3 3.920E-01 3 DCF2( 8 ) 3 4.290E-01 3 4.290E-01 3 DCF2( 10$)$ 3 8.594E-03 3 8.580E-03 3 DCF2( 11$)$ 3 1.308E-03 3 1.300E-03 3 DCF2( 12 ) 3 3.260E-01 3 3.260E-01 3 DCF2( 13 ) 3 1.320E-01 3 1.320E-01 3 DCF2 (14) $31.230 \mathrm{E}-0131.230 \mathrm{H}-013 \mathrm{DCF} 2(15)$ $1.230 E-013{ }^{3} 1.230 E-01$ 3 DCF2 (15)

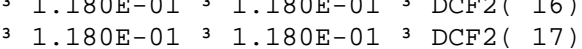
3 1.480E-02 3 1.410E-02 3 DCF3( 1$)$ 3 5.000E-05 3 5.000E-05 3 DCF3( 2) $36.480 \mathrm{E}-06$ 3 $6.480 \mathrm{E}-06$ 3 DCF3( 3 ) 1.610E-04 3 1.610E-04 3 DCF3( 5$)$ 3 1. $1.600 \mathrm{E}-022^{3} 1.010 \mathrm{E}-043 \mathrm{DCF}(\mathrm{5})$ $37.276 E-03$ 3 $5.370 E-03$ 3 DCF3 ( 7$)$ 3 3.276E-03 $3.370 \mathrm{E}-03$ DCF3( 7$)$ $3.200 \mathrm{E}-03$ 3 $3.200 \mathrm{E}-\mathrm{O3}$ - DCF3( 8$)$ 3 3.540E-03 3 3.540E-03 3 DCF3( 10$)$ $31.321 \mathrm{E}-03$ 3 $1.320 \mathrm{E}-03{ }^{3}$ DCF3( 11) $31.528 \mathrm{E}-04$ 3 $1.420 \mathrm{E}-04{ }^{3}$ DCF3( 12$)$ 3 5.480E-04 3 5.480E-04 3 DCF3( 13 ) $32.830 \mathrm{E}-04$ 3 $2.830 \mathrm{E}-043 \mathrm{DCF}(14)$ $32.673 E-0432.630 E-04{ }^{3}$ DCF3 (14) $32.673 E-0432.650 E-04$ 3 DCF3( 15$)$

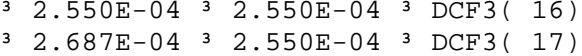

2.500E-03 3 2.500E-03 $3 \operatorname{RTF}(5,1)$ $32.000 \mathrm{E}-03 \quad 3 \quad 2.000 \mathrm{~B}-03 \quad 3 \operatorname{RTF}(5,2)$ $32.000 \mathrm{E}-05$ 3 $2.000 \mathrm{E}-053 \operatorname{RTF}(5,3)$ 
Dose Conversion Factor (and Related) Parameter Summary (continued)

File: FGR 13 MORBIDITY

$\odot^{\circ} \operatorname{Menu}^{3}$

Parameter

3 Current ${ }^{3}$ Base ${ }_{3}$ Parameter

ӒӒӒӒА

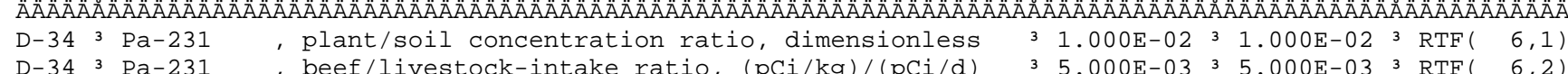

$\mathrm{D}-34 \quad \mathrm{~Pa}-231$

$\mathrm{D}-34$ 3 $\mathrm{Pa}-231$

$\mathrm{D}-344^{3}$

milk/livestock-intake ratio, $(\mathrm{pCi} / \mathrm{L}) /(\mathrm{pCi} / \mathrm{d})$

$\mathrm{D}-343 \mathrm{~Pb}-210+\mathrm{D}$

plant/soil concentration ratio, dimensionless beef/livestock-intake ratio, (pCi/kg)/(pCi/d)

$\mathrm{D}-343 \mathrm{~Pb}-210+\mathrm{D}$

$\mathrm{D}-343 \mathrm{~Pb}-210+\mathrm{D}, \mathrm{milk} /$ livestock-intake ratio, ( $\mathrm{pCi} / \mathrm{L}) /(\mathrm{pCi} / \mathrm{d})$

D- $344^{3}$

$\mathrm{D}-34$ 3 $\mathrm{Pu}-238$

$\mathrm{D}-34 \quad 3 \mathrm{Pu}-238$

$\mathrm{D}-34 \quad 3 \mathrm{Pu}-238$

$\mathrm{D}-34^{3}$

D-34 3 Pu-239

$\mathrm{D}-34$ 3 $\mathrm{PU}-239$

D-34 3 Pu-239

D-34 -34

$\mathrm{D}-34{ }^{3} \mathrm{Ra}-226+\mathrm{D}$

$\mathrm{D}-343 \mathrm{Ra}-226+\mathrm{D}$

$\mathrm{D}-344^{3} \mathrm{Ra}-226+\mathrm{D}$

$\mathrm{D}-344^{3}$

D-34 3 Sr-90+D

plant/soil concentration ratio, dimensionless

beef/livestock-intake ratio, $(\mathrm{pCi} / \mathrm{kg}) /(\mathrm{pCi} / \mathrm{d})$

milk/livestock-intake ratio, $(\mathrm{pCi} / \mathrm{L}) /(\mathrm{pCi} / \mathrm{d})$

plant/soil concentration ratio, dimensionless beef/livestock-intake ratio, $(\mathrm{pCi} / \mathrm{kg}) /(\mathrm{pCi} / \mathrm{d})$

$\mathrm{milk} /$ livestock-intake ratio, $(\mathrm{pCi} / \mathrm{L}) /(\mathrm{pCi} / \mathrm{d})$

D-34 3 Sr $-90+D$

D-34 3 Sr $-90+D$

D-34 3

D-34 3 Th -230

D-34 3 Th-230

D-34 3 Th -230

$\mathrm{D}-34^{3}$

$\mathrm{D}-34 \quad 3 \quad \mathrm{U}-234$

D-34 3 U -234

$\mathrm{D}-34 \quad 3 \quad \mathrm{U}-234$

D-34 3

$\mathrm{D}-34 \quad 3 \quad \mathrm{U}-235+\mathrm{D}$

$\mathrm{D}-34 \quad 3 \quad \mathrm{U}-235+\mathrm{D}$

$D-34 \quad 3 \quad U-235+D$

$\mathrm{D}-344^{3}$

D-34 3 U-238

$\mathrm{D}-34 \quad 3 \quad \mathrm{U}-238$

D-34 3 U-238

D-34 3

$\mathrm{D}-34 \quad 3 \quad \mathrm{U}-238+\mathrm{D}$

$\mathrm{D}-34 \quad 3 \quad \mathrm{U}-238+\mathrm{D}$

$\mathrm{D}-34$ 3 $\mathrm{U}-238+\mathrm{D}$

D-5 3 Bioaccumulation factors, fresh water, L/kg:

$D-5 \quad 3$ AC-227+D, fish

D-5 3 AC-227+D , crustacea and mollusks

$\begin{array}{ll}D-5 & 3 \\ D-5 & 3\end{array}$

D-5 3 Cs $-137+D$, fish

D-5 3 Cs $-137+D$, crustacea and mollusks

$\left.\begin{array}{llllll}3 & 5.000 \mathrm{-}-03 & 3 & 5.000 \mathrm{E}-03 & 3 & \operatorname{RTF}(6,2) \\ 3 & 5.000 \mathrm{E}-06 & 3 & 5.000 \mathrm{0}-06 & 3 & \operatorname{RTF}(6,3\end{array}\right)$

3 1.

3 8.

3 3. 000E-04 3 3.000E-04 3 RTF $(7,3)$

3

3 1. $1000 \mathrm{E}-03 \quad 3$ 1.000E-03 $3 \operatorname{RTF}(8,1)$

$31.000 \mathrm{E}-04$ 3 $1.000 \mathrm{E}-043 \operatorname{RTF}(8,2)$

3 1. $1.00 \mathrm{E}-063$ 1. $3000 \mathrm{E}-063 \operatorname{RTF}(8,3)$

31 1. 000E-๑3 3 1.000E-03 $3 \operatorname{RTF}(10,1)$

31 1.000E-04 3 1.000E-04 $3 \operatorname{RTF}(10,2)$

3 1. $000 \mathrm{E}-06$ 3 $1.000 \mathrm{E}-06{ }^{3} \operatorname{RTF}(10,3)$

beef/livestock-intake ratio, (pci/kg)/(pCi/d)

milk/livestock-intake ratio, $(\mathrm{pCi} / \mathrm{L}) /(\mathrm{pCi} / \mathrm{d})$

lant/soil concentration ratio, dimensionless beef/livestock-intake ratio, $(\mathrm{pCi} / \mathrm{kg}) /(\mathrm{pCi} / \mathrm{d})$ $\mathrm{milk} /$ livestock-intake ratio, $(\mathrm{pCi} / \mathrm{L}) /(\mathrm{pCi} / \mathrm{d})$

plant/soil concentration ratio, dimensionless beef/livestock-intake ratio, $(\mathrm{pCi} / \mathrm{kg}) /(\mathrm{pCi} / \mathrm{d})$

plant/soil concentration ratio, dimensionless beef/livestock-intake ratio, (pCi/kg)/(pCi/d) $\mathrm{milk} /$ livestock-intake ratio, $(\mathrm{pCi} / \mathrm{L}) /(\mathrm{pCi} / \mathrm{d})$

plant/soil concentration ratio, dimensionless beef/livestock-intake ratio, $(\mathrm{pCi} / \mathrm{kg}) /(\mathrm{pCi} / \mathrm{d})$ milk/livestock-intake ratio, $(\mathrm{pCi} / \mathrm{L}) /(\mathrm{pCi} / \mathrm{d})$

lant/soil concentration ratio, dimensionless beef/livestock-intake ratio, $(\mathrm{pCi} / \mathrm{kg}) /(\mathrm{pCi} / \mathrm{d})$ $\mathrm{milk} /$ livestock-intake ratio, $(\mathrm{pCi} / \mathrm{L}) /(\mathrm{pCi} / \mathrm{d})$

plant/soil concentration ratio, dimensionless beef/livestock-intake ratio, $(\mathrm{pCi} / \mathrm{kg}) /(\mathrm{pCi} / \mathrm{d})$ 4.000E-02 3 4.000E-02 $3 \operatorname{RTF}(11,1)$ 3 1. $000 \mathrm{E}-03$ 3 $1.000 \mathrm{E}-03$ 3 $\operatorname{RTF}(11,2)$ $31.000 \mathrm{E}-033^{3} 1.000 \mathrm{E}-033^{3} \operatorname{RTF}(11,3)$ $3 \quad 3.000 \mathrm{E}-01 \quad 3 \quad 3.000 \mathrm{E}-013 \operatorname{RTF}(12,1)$ 3 8. $00 \odot \mathrm{E}-03$ 3 $8.000 \mathrm{E}-03 \quad 3 \operatorname{RTF}(12,2)$ 3 2. $2.000 \mathrm{E}-03$ 3 $2.000 \mathrm{E}-03$ 3

31 1.000E-03 3 1.000E-03 $3 \operatorname{RTF}(13,1)$ $31.000 \mathrm{E}-043$ 1. $3000 \mathrm{E}-043 \operatorname{RTF}(13,2)$ 3 5.000E-06 3 5.000E-06 3 RTF $(13,3)$

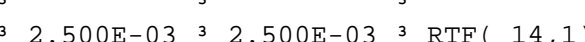
$3 \quad 3.400 \mathrm{E}-04 \quad 3 \quad 3.400 \mathrm{E}-04 \quad 3 \operatorname{RTF}(14,2)$ 3 6. ๑००E-๑4 3 6.00०E-๑4 $3 \operatorname{RTF}(14,3)$ 6.

2.500E-03 $32.500 \mathrm{E}-03 \quad 3 \operatorname{RTF}(15,1)$ 3 3.400E-04 3 3.400E-04 $3 \operatorname{RTF}(15,2)$ 3 6.000E-04 3 6.000E-04 ${ }^{3} \operatorname{RTF}(15,3)$

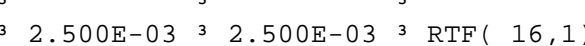
3. 400E-04 3 3.400E-04 $3 \operatorname{RTF}(16,2)$ 3 6. $000 \mathrm{E}-04$ 3 6.000E-04 $3 \operatorname{RTF}(16,3)$ 3

2.500E-03 3 2.500E-03 $3 \operatorname{RTF}(17,1)$ $3.400 \mathrm{E}-043 \quad 3.400 \mathrm{H}-043 \operatorname{RTF}(17,2)$ 6. $000 \mathrm{E}-044^{3} 6.000 \mathrm{E}-04{ }^{3} \operatorname{RTF}(17,3)$

$31.500 \mathrm{E}+0131.500 \mathrm{E}+013 \mathrm{BIOFAC}(1,1)$

$31.000 \mathrm{E}+03$ 3 $1.000 \mathrm{E}+03$ 3 $\operatorname{BIOFAC}(1,2)$

$32.000 \mathrm{E}+03 \quad 3 \quad 2.000 \mathrm{E}+03 \quad 3 \operatorname{BIOFAC}(2,1)$

$31.000 \mathrm{E}+02$ 3 $1.000 \mathrm{E}+023 \operatorname{BIOFAC}(2,2)$

\section{Uncontrolled When Printed}



1RESRAD, Version 6.3
T« Limit $=180$ days
05/07/2006 17:31 Page 4
Summary : Mudpit Remote Work Area
File: Mudpit Remote. RA

Dose Conversion Factor (and Related) Parameter Summary (continued)

File: FGR 13 MORBIDITY

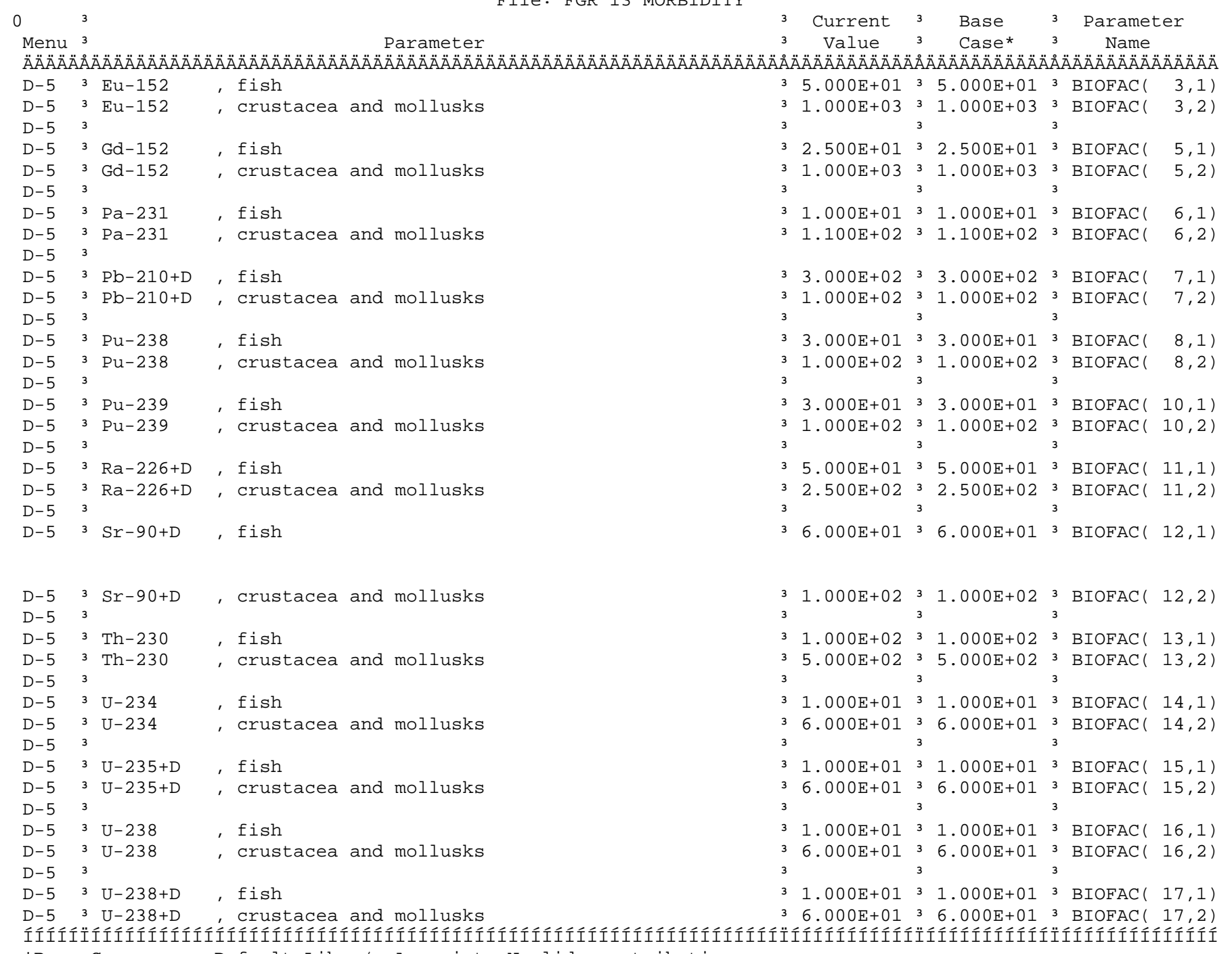

*Base Case means Default. Lib W/o Associate Nuclide contributions. 
R011 3 Area of contaminated zone $(m * * 2)$

R011 3 Thickness of contaminated zone $(\mathrm{m})$

R011 3 Length parallel to aquifer flow $(\mathrm{m})$

R011 3 Basic radiation dose limit (mrem/yr)

R011 3 Time since placement of material ( $\mathrm{yr}$ )

R011 3 Times for calculations ( $y r$ )

R011 3 Times for calculations ( $y r$ )

R011 3 Times for calculations ( $\mathrm{yr}$ )

R011 3 Times for calculations ( $\mathrm{yr}$ )

R011 3 Times for calculations ( $\mathrm{yr}$ )

R011 3 Times for calculations ( $y r$ )

R011 3 Times for calculations ( $y r$ )

R011 Times for calculations $(\mathrm{yr})$ 3

R012 3 Initial principal radionuclide ( $\mathrm{pCi} / \mathrm{g}$ ):

$\begin{array}{lllll}\mathrm{R} 012 & 3 & \text { Initial principal radionuclide }(\mathrm{pCi} / \mathrm{g}): & \mathrm{Cs}-137 \\ \mathrm{R} 012 & 3 & \text { Initial principal radionuclide }(\mathrm{pCi} / \mathrm{g}): & \mathrm{Eu}-152\end{array}$

$\mathrm{R} 012{ }^{3}$ Initial principal radionuclide ( $\left.\mathrm{pCi} / \mathrm{g}\right)$ : $\mathrm{Pu}-238$

$\mathrm{R} 0123$ Initial principal radionuclide (pCi/g): $\mathrm{Pu}-239$

$\mathrm{R} 0123$ Initial principal radionuclide $(\mathrm{pCi} / \mathrm{g}): \mathrm{Sr}-90$

$\mathrm{R} 0123$ Initial principal radionuclide ( $\mathrm{pCi} / \mathrm{g}): \mathrm{U}-234$

R012 3 Initial principal radionuclide $(\mathrm{pCi} / \mathrm{g})$ :

R012 3 Concentration in groundwater

R012 3 Concentration in groundwater

R012 3 Concentration in groundwater

R012 3 Concentration in groundwater

R012 3 Concentration in groundwater

R012 3 Concentration in groundwater

R012 3 Concentration in groundwater

(pCi/L): $\mathrm{Cs}-137$

$(\mathrm{pCi} / \mathrm{L}): \mathrm{Eu}-152$

$(\mathrm{pCi} / \mathrm{L}): \mathrm{Pu}-238$

$(\mathrm{pCi} / \mathrm{L}): \mathrm{Pu}-239$

$(\mathrm{pCi} / \mathrm{L}): \quad \mathrm{Sr}-90$

$(\mathrm{pCi} / \mathrm{L}): \quad \mathrm{U}-234$

$\mathrm{pCi} / \mathrm{L}): \mathrm{U}-238$

R013 3 Cover depth (m)

R013 3 Density of cover material $\left(\mathrm{g} / \mathrm{cm}^{* *} 3\right)$

$\mathrm{R} 0133$ Cover depth erosion rate $(\mathrm{m} / \mathrm{yr})$

R013 3 Density of contaminated zone $\left(\mathrm{g} / \mathrm{cm}^{* *} 3\right)$

R013 3 Contaminated zone erosion rate $(\mathrm{m} / \mathrm{yr})$

R013 3 Contaminated zone total porosity

R013 3 Contaminated zone field capacity

R013 3 Contaminated zone hydraulic conductivity (m/yr)

R013 3 Contaminated zone b parameter

R013 3 Average annual wind speed $(\mathrm{m} / \mathrm{sec}$ )

$\mathrm{R} 0133$ Humidity in air $\left(\mathrm{g} / \mathrm{m}^{* \star} 3\right)$

R013 3 Evapotranspiration coefficient

R013 3 Precipitation ( $\mathrm{m} / \mathrm{yr}$ )

R013 3 Irrigation ( $\mathrm{m} / \mathrm{yr}$ )

R013 3 Irrigation mode

R013 3 Runoff coefficient

R013 3 Watershed area for nearby stream or pond $\left(m^{* * 2}\right)$

R013 3 Accuracy for water/soil computations

R014 3 Density of saturated zone $(\mathrm{g} / \mathrm{cm} * * 3)$

R014 3 Saturated zone total porosity
3 1. $000 \mathrm{E}+02$ 2 3 1.

$1.500 \mathrm{E}-0132.000 \mathrm{E}+00$

3 not used $31.000 \mathrm{E}+02$

$\begin{array}{llll}3 & 2.500 \mathrm{E}+01^{3} & 3 & 3.000 \mathrm{E}+01^{3}\end{array}$

$3 \quad 0.000 \mathrm{E}+0 \odot \quad 3 \quad 0.000 \mathrm{E}+00$

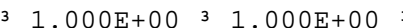

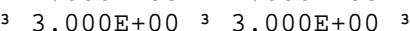

$\begin{array}{lll}3.000 \mathrm{E}+01 & 3 & 1.000 \mathrm{E}+01 \\ 3\end{array}$

$3.000 \mathrm{E}+01$ 3 $3.00 \ominus \mathrm{E}+01$

$1.000 \mathrm{E}+02$ 3 $1.000 \mathrm{E}+02$

3 3.

3 1.000E+03 3 1.000E+०3

3 not used $30.000 \mathrm{E}+0 \odot$

3 not used $30.0 \odot \odot E+\odot \odot{ }^{3}$

$7.800 \mathrm{E}-01 \quad 3 \quad 0.000 \mathrm{E}+00$

$1.234 \mathrm{E}+01 \quad 3 \quad 0.000 \mathrm{E}+0 \odot$

$6.000 \mathrm{E}-02$ 3 $0.000 \mathrm{E}+0 \odot$

$2.280 \mathrm{E}+\odot \odot 3 \quad \odot .00 \Theta \mathrm{E}+\Theta \odot$

$6.00 \odot \mathrm{E}-01{ }^{3} \quad 0.00 \odot \mathrm{E}+\odot \odot$

$9.100 \mathrm{E}-01$ 3 $0.000 \mathrm{E}+0 \odot$

$8.600 \mathrm{E}-013 \quad 0.000 \mathrm{E}+00$

not used $30.000 E+00$

not used 3 Q.000E+00

not used $3 \quad 0.000 \mathrm{E}+00$

3 not used 3 ๑. $000 \mathrm{E}+\odot{ }^{3}$

3 not used $3 \quad 0.000 \mathrm{E}+\odot \odot$

3 not used $30.000 \mathrm{E}+0 \odot$

not used 3 ०.000E+००

$30.000 \mathrm{E}+00 \quad 3 \quad 0.000 \mathrm{E}+0 \odot$

3 not used $31.500 E+00$

not used $1.500 E+00$

not used $31.000 \mathrm{E}-03$

$\begin{array}{lll}1.500 \mathrm{E}+0 \odot & 3 & 1.500 \mathrm{E}+\odot \odot \\ 1.000 \mathrm{E}-\odot 3 & 3 & 1.000 \mathrm{E}-\odot 3\end{array}$

4.000E-01 3 4.000E-01

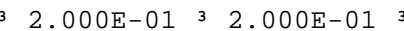

$1.000 \mathrm{E}+013 \quad 1.000 \mathrm{E}+01$

$35.300 \mathrm{E}+0 \odot \quad 3 \quad 5.300 \mathrm{E}+00$

$34.070 \mathrm{E}+003 \quad 2.000 \mathrm{E}+00$

3 not used 3 2.

5. $000 \mathrm{E}-013 \quad$ 5.000E-01

$1.900 \mathrm{E}-01$ 3 $1.000 \mathrm{E}+00$

$0.000 \mathrm{E}+00 \quad 3 \quad 2.000 \mathrm{E}-01$

3 overhead 3 overhead 3

$\begin{array}{llll}3 & 4.000 \mathrm{E}-01 & 3 & 2.000 \mathrm{E}-01\end{array}$

3 not used 3 1. $00 \odot E+06$

3 not used 3 1.000E-03

not used 3 1.500E+ $\odot \odot$

3 not used $34.000 \mathrm{E}-\odot 1$

\begin{tabular}{|c|c|c|}
\hline$\ldots$ & 3 & AREA \\
\hline$\ldots$ & 3 & THICKO \\
\hline - - - & 3 & LCZPAQ \\
\hline - - & 3 & BRDL \\
\hline - - & 3 & TI \\
\hline - - - & 3 & $\mathrm{~T}(\mathrm{2})$ \\
\hline - & 3 & $\mathrm{~T}(3)$ \\
\hline - - & 3 & $\mathrm{~T}(4)$ \\
\hline - & 3 & $\mathrm{~T}(5)$ \\
\hline - - - & 3 & $\mathrm{~T}(6)$ \\
\hline - & 3 & $\mathrm{~T}(7)$ \\
\hline - . - & 3 & $\mathrm{~T}(8)$ \\
\hline - & 3 & $\mathrm{~T}(9)$ \\
\hline - & $\begin{array}{l}3 \\
3\end{array}$ & $\mathrm{~T}(10)$ \\
\hline- & 3 & $\mathrm{~S} 1(2)$ \\
\hline- & 3 & $\mathrm{~S} 1(3)$ \\
\hline - - & 3 & S1( 8$)$ \\
\hline - & 3 & S1(10) \\
\hline - & 3 & $\mathrm{~S} 1(12)$ \\
\hline$\ldots$ & 3 & S1(14) \\
\hline - & 3 & S1(16) \\
\hline - & 3 & W1 ( 2) \\
\hline . - & 3 & W1( 3 ) \\
\hline- & 3 & W1( 8$)$ \\
\hline - & 3 & W1(10) \\
\hline-- & 3 & W1 (12) \\
\hline- & 3 & W1 (14) \\
\hline- & 3 & W1(16) \\
\hline & 3 & \\
\hline-- & 3 & COVERO \\
\hline- & 3 & DENSCV \\
\hline - & 3 & VCV \\
\hline- & 3 & DENSCZ \\
\hline - & 3 & VCZ \\
\hline & 3 & TPCZ \\
\hline- & 3 & $\mathrm{FCCZ}$ \\
\hline & 3 & $\mathrm{HCCZ}$ \\
\hline - & 3 & $\mathrm{BCZ}$ \\
\hline- & 3 & WIND \\
\hline & 3 & HUMID \\
\hline & 3 & EVAPTR \\
\hline- & 3 & PRECIP \\
\hline & 3 & RI \\
\hline & 3 & IDITCH \\
\hline & 3 & RUNOFF \\
\hline- & 3 & WAREA \\
\hline & 3 & EPS \\
\hline 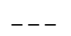 & 3 & DENSAQ \\
\hline & 3 & TPSZ \\
\hline
\end{tabular}



1RESRAD, Version 6.3

$0 \quad 3$

Site-Specific Parameter Summary (continued)

Menu 3

3 Default

Used by RESRAD

3 Parameter

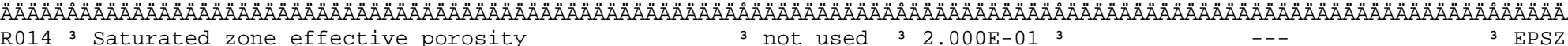

R014

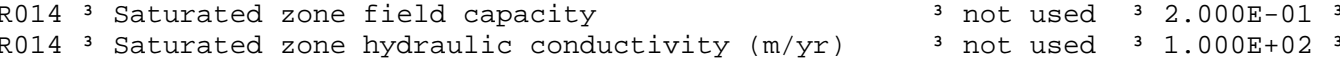

R014 3 Saturated zone hydraulic gradient

not used 3 1.000E+02

not used $35.300 \mathrm{E}+00^{\circ}$

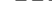

$\begin{array}{ll}3 & \text { EPSZ } \\ 3 & \text { FCSZ }\end{array}$

R014 3 Saturated zone b parameter

3 not used $31.000 \mathrm{E}-03$

R014 3 water table drop rate (m/yr)

R014 3 Well pump intake depth ( $m$ below water table)

R014 3 Model: Nondispersion (ND) or Mass-Balance (MB)

not used $3 \quad 1.000 \mathrm{E}+01^{3}$

3 not used 3 ND

not used $32.500 \mathrm{E}+02$

3 not used 31

3 not used 3 4. $40 \odot \mathrm{E}+\Theta \Theta^{3}$

not used $31.500 E^{3}+00^{3}$

not used 3 1.500E

not used $4.000 \mathrm{E}-01$

not used $32.000 \mathrm{E}-01$

not used 3 2.000E- 01

3 not used $35.300 \mathrm{E}+00$

not used 3 1.000E+01

R015 3 Unsat. zone 1, soil-specific b parameter

R015 3 Unsat. zone 1, hydraulic conductivity (m/yr)

R016 3 Distribution coefficients for Cs -137

R016 3 Contaminated zone $\left(\mathrm{cm}^{* *} 3 / \mathrm{g}\right)$

R016 3 Unsaturated zone $1\left(\mathrm{~cm}^{* *} 3 / \mathrm{g}\right)$

R016 3 Saturated zone $\left(\mathrm{cm}^{* *} 3 / \mathrm{g}\right)$

R016 3 Leach rate (/yr)

R016 3 Solubility constant

R016 3 Distribution coefficients for Eu-152

R016 3 Contaminated zone $\left(\mathrm{cm}^{* *} 3 / \mathrm{g}\right)$

R016 3 Unsaturated zone $1\left(\mathrm{~cm}^{* *} 3 / \mathrm{g}\right)$

R016 3 Saturated zone $\left(\mathrm{cm}^{* *} 3 / \mathrm{g}\right)$

R016 3 Leach rate (/yr)

R016 3 Solubility constant

tribution coefficier

R016 3 Contaminated zone $\left(\mathrm{cm}^{* *} 3 / \mathrm{g}\right)$

R016 3 Unsaturated zone $1(\mathrm{~cm} * * 3 / \mathrm{g})$

R016 3 Saturated zone $\left(\mathrm{cm}^{* *} 3 / \mathrm{g}\right)$

R016 3 Leach rate (/yr)

R016 3 Solubility constant

R016 3 Distribution coefficients for Pu-239

R016 3 Contaminated zone $\left(\mathrm{cm}^{* *} 3 / \mathrm{g}\right)$

R016 3 Unsaturated zone $1(\mathrm{~cm} * * 3 / \mathrm{g})$

R016 3 Saturated zone $\left(\mathrm{cm}^{* *} 3 / \mathrm{g}\right)$

R016 3 Leach rate (/yr)

R016 3 Solubility constant

$4.600 \mathrm{E}+03 \quad 3 \quad 4.600 \mathrm{E}+03$

not used $34.600 \mathrm{C}^{3} \mathrm{~B}_{3}$

not used $3.600 \mathrm{E}+03$

not used $4.600 \mathrm{E}+03$

$\begin{array}{lll}0.000 \mathrm{E}+\odot \odot & 3 & 0.000 \mathrm{E}+\odot \odot \\ 0.000 \mathrm{E}+0 \odot & 3 & 0.000 \mathrm{E}+\odot \odot\end{array}$

$0.000 \mathrm{E}+00$ 3 $0.000 \mathrm{E}+\odot \odot^{3}$

$3-1.000 \mathrm{E}+00{ }^{3}-1.000 \mathrm{E}+00$

not used $3-1.000 \mathrm{E}+00$

3 not used $3-1.000 \mathrm{E}+00$

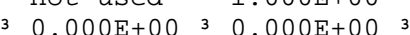

$\odot .00 \odot E+\odot \odot$ उ $\odot . \odot \odot \odot E+\odot \odot$

$32.000 \mathrm{E}+03 \quad 3 \quad 2.000 \mathrm{E}+03$

not used 3 2. $000 \mathrm{E}+03$

3 not used 3 2. $000 \mathrm{E}+03$

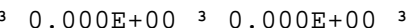

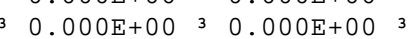

$2.000 E+03 \quad 3 \quad 2.000 \mathrm{E}+03$

3 not used $32.000 \mathrm{E}+03$

3 not used 3 2.000E+03

$3 \quad \odot .000 \mathrm{E}+0 \odot$ 3 $\odot .000 \mathrm{E}+0 \odot$

$\begin{array}{llll}3 & 0.000 E+\odot \odot ~ & 3 & 0.000 E+0 \odot \quad 3\end{array}$
HCSZ

3 HGWT

3 BSZ

3 VWT

DWIBWT

MODEL

UW

DENSUZ(1)

TPUZ (1)

EPUZ (1)

FCUZ (1)

3 BUZ(1)

$3 \operatorname{HCUZ}(1)$

DCNUCC $(2)$

DCNUCU $(2,1)$

DCNUCS( 2)

$\begin{array}{ll}5.507 \mathrm{E}-05 & 3 \text { ALEACH( } 2) \\ \text { not used } & 3 \operatorname{SOLUBK}(2)\end{array}$

8.249E+02 $\quad 3 \operatorname{DCNUCC}(3)$

$\operatorname{DCNUCU}(3,1)$

DCNUCS( 3 )

$\operatorname{ALEACH}(3)$

SOLUBK( 3)

3 DCNUCC ( 8)

$\operatorname{DCNUCU}(8,1)$

DCNUCS( 8)

ALEACH ( 8 )

SOLUBK( 8)

not used

$\operatorname{DCNUCC}(10)$

- -

1. 267E-04

DCNUCU $(10,1)$

not used

ALEACH $(10)$ 

1RESRAD, Version 6.3

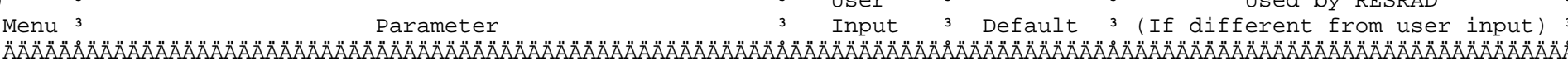

Used by RESRAD

3 Parameter

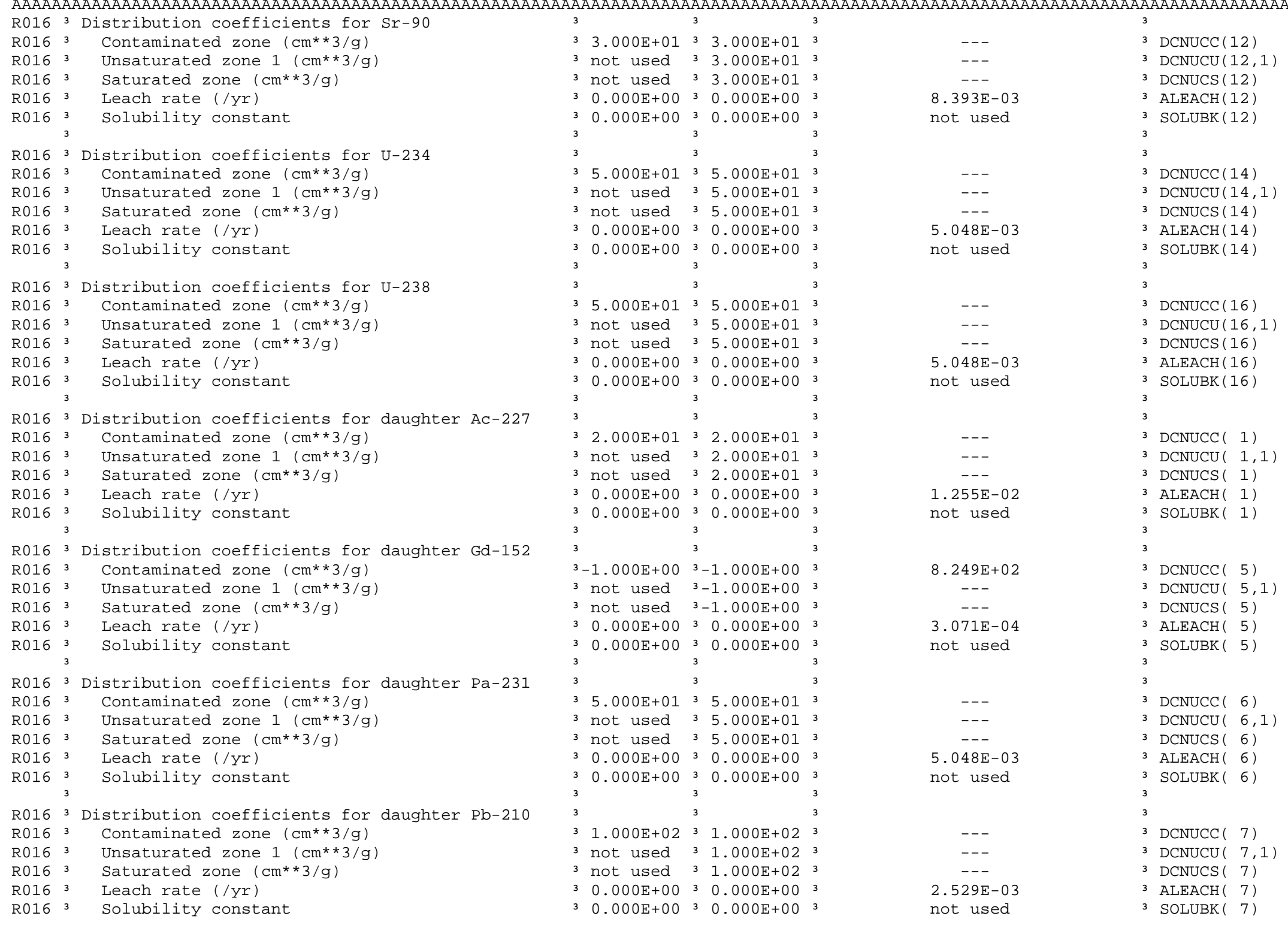



1RESRAD, Version 6.3

Menu 3 Parameter 3 Input 3 Default 3 (If different from user input) 3 Name

Used by RESRAD

3 Parameter

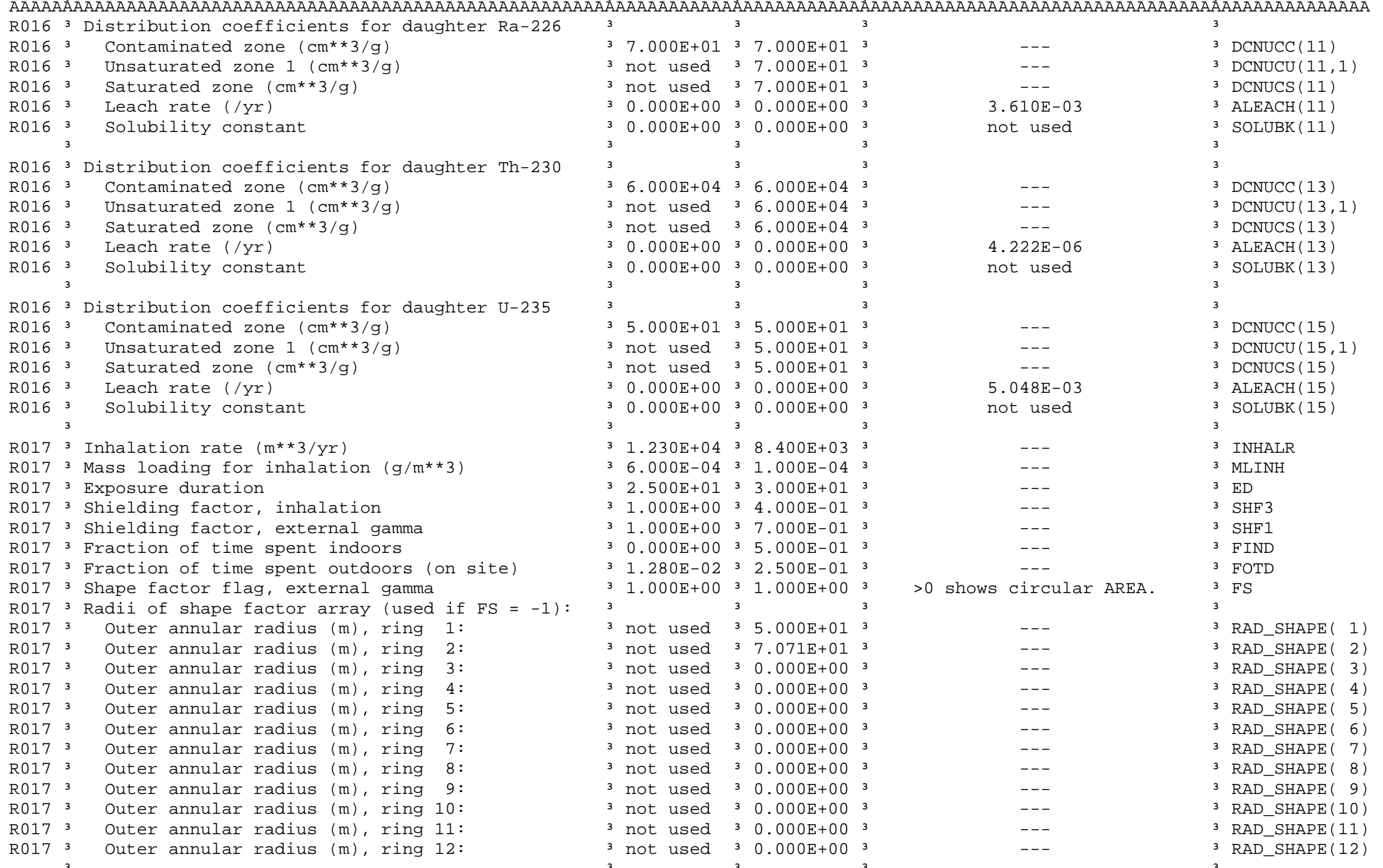



1RESRAD, Version 6.3
$\mathrm{T} \ll$ Limit $=180$ days
05/07/2006 17:31 Page 9

$0 \quad 3$

Site-Specific Parameter Summary (continued)

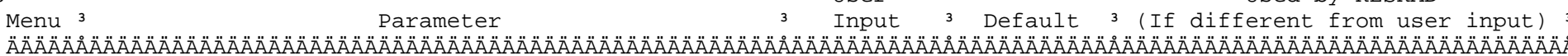

3 Default

Used by RESRAD

3 Parameter R017 3 Fractions of annular areas within AREA:

$\begin{array}{llll}\mathrm{R} 017 & 3 & \text { Ring } & 1 \\ \mathrm{R} 017 & 3 & \text { Ring } & 2 \\ \mathrm{R} 017 & 3 & \text { Ring } & 3 \\ \mathrm{R} 017 & 3 & \text { Ring } & 4 \\ \mathrm{R} 017 & 3 & \text { Ring } & 5 \\ \mathrm{R} 017 & 3 & \text { Ring } & 6 \\ \mathrm{R} 017 & 3 & \text { Ring } & 7 \\ \mathrm{R} 017 & 3 & \text { Ring } & 8 \\ \mathrm{R} 017 & 3 & \text { Ring } & 9 \\ \mathrm{R} 017 & 3 & \text { Ring } & 10 \\ \mathrm{R} 017 & 3 & \text { Ring } & 11 \\ \mathrm{R} 017 & 3 & \text { Ring } & 12\end{array}$

not used $3 \quad 1.000 \mathrm{E}+00$

3 not used $32.732 \mathrm{E}-01$

3 not used $30.000 \mathrm{E}+00$

3 not used $30.000 \mathrm{E}+\odot \odot$

3 not used $3 \odot, \odot \odot \odot E+\odot \odot$

3 not used 3 O.

3 not used $30.000 \mathrm{E}+0 \odot^{3}$

3 not used $30.000 \mathrm{E}+00^{3}$

not used $30.000 \mathrm{E}+0 \odot$

3 not used $30.000 \mathrm{E}+\odot \odot$

3 not used $30.000 \mathrm{E}+00$

not used $30.000 \mathrm{E}+0 \odot$

not used 3 1.600E+02

3 not used $31.400 \mathrm{E}+01$

not used $3 \quad 9.200 E+01$

not used $36.300 \mathrm{E}+01$

not used 3 5.400E+00

3 not used 3 9.000E-01

$\begin{array}{llll}3 & 2.020 \mathrm{E}+01 & 3 & 3.650 \mathrm{E}+01\end{array}$

3 not used $35.100 \mathrm{E}+02$

3 not used $31.000 E+00$

not used $31.000 E+00$

not used 31 .

not used $1.000 \mathrm{E}+0 \odot$

not used $1.000 \mathrm{E}+00$

not used 3 5.000E-01

3 not used $3-1$

not used $3-1$

not used $3_{-1}$

not used ${ }^{3} 6.800 E+01$

3

3 not used 3 5.500E +01

not used 3 5.000E+01

not used $31.600 \mathrm{E}+02$

3 not used 3 5.000E-01

3 not used 3 1.000E-04

3 1.500E-01 3 1.500E-01

3 not used $39.000 \mathrm{E}-01$

3 not used $31.000 E+00^{3}$

3 not used $31.000 \mathrm{E}+00^{3}$

not used $31.000 \mathrm{E}+00^{\circ}$

not used $31.000 \mathrm{E}+00$

3 not used 3 7.000E-01

3 not used 3 1.500E+ $\odot \odot$

3 not used $31.100 \mathrm{E}+00$

3 not used 3 1.700E-01

3 not used $32.500 \mathrm{E}-01$

not used 3 8.000E-02

3 not used $31.000 \mathrm{E}-013$

\begin{tabular}{|c|c|c|}
\hline-- & 3 & FRACA $(1$ \\
\hline-- & 3 & FRACA ( 2 \\
\hline-- & 3 & FRACA( \\
\hline-- & 3 & FRACA( \\
\hline-- & 3 & FRACA ( 5 \\
\hline-- & 3 & FRACA $(6$ \\
\hline-- & 3 & FRACA $(7$ \\
\hline-- & 3 & FRACA $(8$ \\
\hline$\cdots$ & 3 & FRACA $(9$ \\
\hline - - - & 3 & FRACA (10 \\
\hline-- & 3 & FRACA (11 \\
\hline--- & $\begin{array}{l}3 \\
3\end{array}$ & FRACA (12 \\
\hline-- & 3 & $\operatorname{DIET}(1)$ \\
\hline-- & 3 & $\operatorname{DIET}(2)$ \\
\hline-- & 3 & $\operatorname{DIET}(3)$ \\
\hline-- & 3 & DIET (4) \\
\hline-- & 3 & $\operatorname{DIET}(5)$ \\
\hline-- & 3 & $\operatorname{DIET}(6)$ \\
\hline-- & 3 & SOIL \\
\hline-- & 3 & DWI \\
\hline-- & 3 & FDW \\
\hline-- & 3 & FHHW \\
\hline-- & 3 & FLW \\
\hline-- & 3 & FIRW \\
\hline-- & 3 & FR9 \\
\hline$\cdots$ & 3 & FPLANT \\
\hline$\cdots$ & 3 & FMEAT \\
\hline$-\cdots$ & $\begin{array}{l}3 \\
3\end{array}$ & FMILK \\
\hline-- & 3 & LFI5 \\
\hline-- & 3 & LFI6 \\
\hline-- & 3 & LWI5 \\
\hline-- & 3 & LWI6 \\
\hline-- & 3 & LSI \\
\hline-- & 3 & MLFD \\
\hline-- & 3 & DM \\
\hline-- & 3 & DROOT \\
\hline$\ldots$ & 3 & FGWDW \\
\hline-- & 3 & FGWHH \\
\hline & 3 & FGWLW \\
\hline & 3 & FGWIR \\
\hline & 3 & \\
\hline & 3 & $\mathrm{YV}(1)$ \\
\hline & 3 & $Y V(2)$ \\
\hline & 3 & $Y V(3)$ \\
\hline & 3 & $\operatorname{TE}(1)$ \\
\hline & 3 & $\operatorname{TE}(2)$ \\
\hline & 3 & $\operatorname{TE}(3)$ \\
\hline & 3 & $\operatorname{TIV}(1)$ \\
\hline
\end{tabular}



1RESRAD, Version 6.3

Menu 3 Parameter 3 Input 3 Default 3 (If different from user input) 3 Name

Used by RESRAD

3 Parameter

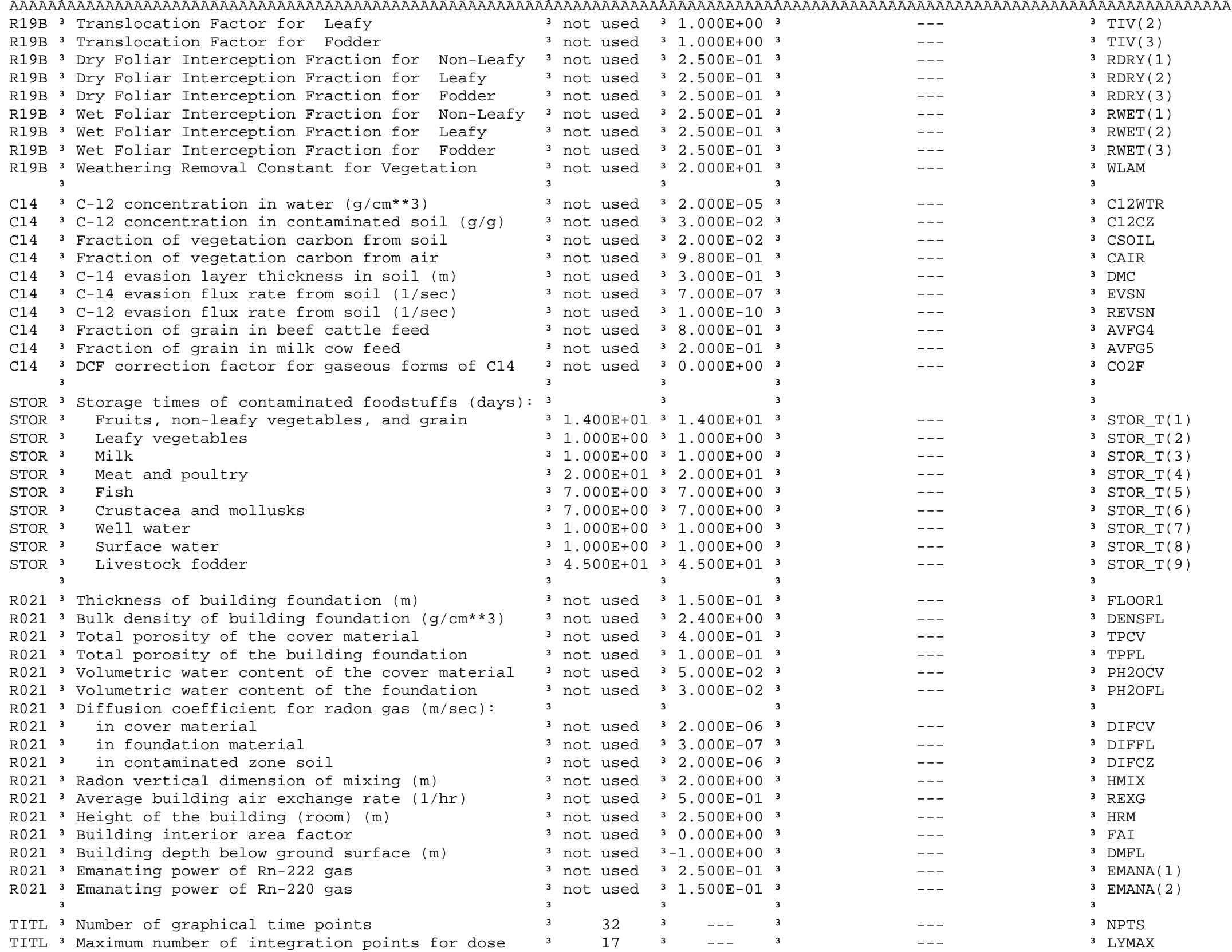


3 Default Used by RESRAD

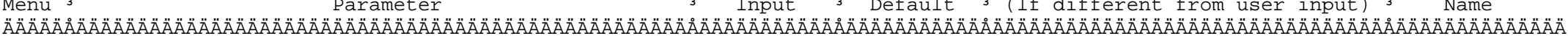
TITL 3 maximum number of integration points for risk 332573

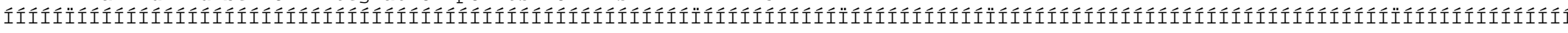

Summary of Pathway Selections

\begin{tabular}{|c|c|c|c|c|}
\hline \multirow{2}{*}{\multicolumn{4}{|c|}{ 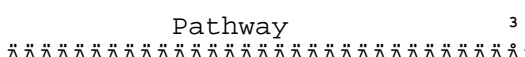 }} & \\
\hline & & & & \\
\hline 1 & - - external gamma & & 3 & active \\
\hline 2 & - - inhalation (w/o & radon) & & active \\
\hline 3 & -- plant ingestion & & 3 & suppressed \\
\hline 4 & - - meat ingestion & & 3 & suppressed \\
\hline 5 & -- milk ingestion & & 3 & suppressed \\
\hline 6 & - - aquatic foods & & 3 & suppressed \\
\hline 7 & -- drinking water & & 3 & suppressed \\
\hline 8 & - - soil ingestion & & 3 & active \\
\hline 9 & - - radon & & 3 & suppressed \\
\hline $\mathrm{Fi}$ & nd peak pathway do & es & 3 & suppressed \\
\hline
\end{tabular}


$\begin{array}{ll}\text { 1RESRAD, Version } 6.3 & \text { T« Limit }=180 \text { days } \\ \text { Summary : Mudpit Remote } & \text { Work Area }\end{array}$

Contaminated zone Dimensions

ÄÄÄÄÄÄÄÄÄÄÄÄÄÄÄÄÄÄÄÄÄÄÄÄÄÄÄÄÄ

$\begin{array}{ll}\text { Area: } \quad 100.00 & \text { square meters } \\ \text { Thickness: } & 0.15 \text { meters }\end{array}$

Cover Depth

0.00 meters

$\odot$

Total Dose TDOSE $(\mathrm{t}), \mathrm{mrem} / \mathrm{yr}$
Radiation Dose Limit $=2.500 \mathrm{E}+01 \mathrm{mrem} / \mathrm{yr}$

Total Mixture Sum $M(t)=$ Fraction of Basic Dose Limit Received at Time $(t)$

ÄÄÄÄÄÄÄÄÄÄÄÄÄÄÄÄÄÄÄÄÄÄÄÄÄÄÄÄÄÄÄÄÄÄÄÄÄÄÄÄÄÄÄÄÄÄÄÄÄÄÄÄÄÄÄÄÄÄÄÄÄÄÄÄÄÄÄÄÄ

$\mathrm{t}$ (years): $\quad \begin{array}{lllllllll} & 0.000 \mathrm{E}+00 & 1.000 \mathrm{E}+00 & 3.000 \mathrm{E}+00 & 1.000 \mathrm{E}+01 & 3.000 \mathrm{E}+01 & 1.000 \mathrm{E}+02 & 3.000 \mathrm{E}+02 & 1.000 \mathrm{E}+03\end{array}$

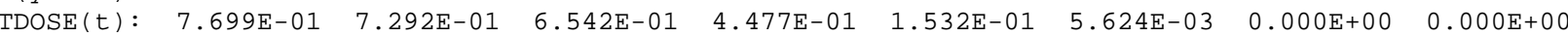

$1.701 \mathrm{E}-02$ (129E-03 $2.250 \mathrm{E}-04$ $0.000 \mathrm{E}+00-0$

OMaximum TDOSE(t): $7.699 \mathrm{E}-01 \mathrm{mrem} / \mathrm{yr}$ at $\mathrm{t}=0.000 \mathrm{E}+0 \odot$ years
/07/2006 $17: 31$ Page 12
File: Mudpit_Remote.RAD

Initial Soil Concentrations, pCi/g

$\begin{array}{ll}\text { CS }-137 & 7.800 \mathrm{E}-01 \\ \mathrm{EU}-152 & 1.234 \mathrm{E}+01 \\ \mathrm{Pu}-238 & 6.000 \mathrm{E}-02 \\ \mathrm{Pu}-239 & 2.280 \mathrm{E}+0 \odot \\ \mathrm{Sr}-90 & 6.000 \mathrm{E}-01 \\ \mathrm{U}-234 & 9.100 \mathrm{E}-01 \\ \mathrm{U}-238 & 8.600 \mathrm{E}-01\end{array}$



1RESRAD, Version 6.3
T« Limit $=180$ days
05/07/2006 17:31 Page 13
Summary : Mudpit Remote Work Area
File: Mudpit Remote.RA

Total Dose Contributions $\operatorname{TDOSE}(i, p, t)$ for Individual Radionuclides ( $i)$ and Pathways $(p)$ As mrem/yr and Fraction of Total Dose At $t=0.000 \mathrm{E}+00$ years

Ground Inhalation water Independent Pathways (Inhalation excludes radon) Radon Plant Meat Nuclide mrem/yr fract. ÄÄÄÄÄÄÄ ÄÄÄÄÄÄÄÄÄ ÄÄÄÄÄÄ Cs-137 2.386E-02 0.0310 Eu-152 7.382E-01 0.9589 $\begin{array}{lll}\mathrm{PU}-238 & 1.047 \mathrm{E}-07 & 0.000 \odot \\ \mathrm{Pu}-239 & 6.898 \mathrm{E}-06 & 0.0000\end{array}$ $\begin{array}{lll}\mathrm{PU}-239 & 6.898 \mathrm{E}-\odot 6 & \odot . \odot \odot \odot \odot ~ \\ \mathrm{Sr}-9 \odot & 1.390 \mathrm{E}-\odot 4 & 0.00 \odot 2\end{array}$ $\mathrm{U}-234 \quad 3.910 \mathrm{E}-06$ - 9.0000 $\mathrm{U}-238 \quad 1.201 \mathrm{E}-03 \quad 0.0016$ mrem/yr fract Ä̈̈ÄÄÄÄÄÄÄÄÄ

Milk $\mathrm{mrem} / \mathrm{yr}$ fract. mrem/yr fract. mrem/yr fract. mrem/yr fract. AAAAAAA AAAAAA AAAAAAAAA AAAAAA AAAAAAAAAA AAAAAA AAAAAAAAA AAAAAA $\begin{array}{llllllll}1.250 \mathrm{E}-07 & 0.0000 & 0.000 \mathrm{E}+00 & 0.0000 & 0.000 \mathrm{E}+00 & 0.0000 & 0.000 \mathrm{E}+00 & 0.0000\end{array}$ .351E-05 0.0000 $.191 \mathrm{E}-040.0002$ $4.972 \mathrm{E}-03 \quad 0.0065$ $3.928 \mathrm{E}-060.0000$ $.091 \mathrm{E}-040.0008$ $\odot . \odot \odot \odot \mathrm{E}+\odot \odot$ ० $\odot . \odot \odot \odot \odot$ $0.000 \mathrm{E}+00 \quad 0.0000$ $0.000 \mathrm{E}+00 \quad 0.0000$ $\odot .000 \mathrm{E}+00$ ००.0000 $.000 \mathrm{E}+00 \quad 0.0000$

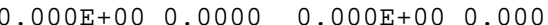
$0.000 \mathrm{E}+000.0000$ $0.0000+00$ (.) $\begin{array}{lllll}0.000 E+00 & 0.0000 & 0.000 \mathrm{E}+00 & 0.0000\end{array}$

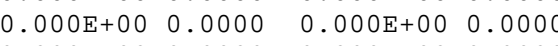
Íííííi ííííííí ííííí Total $.148 \mathrm{E}-040.000$ $\odot .000 \mathrm{E}+0 \odot \quad 0.000 \odot$ $\odot .000 \mathrm{E}+0 \odot \quad 0.000 \odot \quad 0.000 \mathrm{E}+0 \odot \quad 0.00 \odot 0$ $0.000 \mathrm{E}+00 \quad 0.0000 \quad 0.000 \mathrm{E}+00 \quad 0.0000$ $6.233 E-03$ 0.0081

$\odot .000 \mathrm{E}+00 \quad 0.0000$

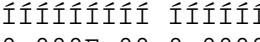

$\odot, \odot \odot \odot E+\odot \odot \odot, \odot \odot \odot \ominus$

$\odot .000 \mathrm{E}+0 \odot \quad \odot .0000$ ААААААААÄӒÄÄÄÄÄ $0.000 \mathrm{E}+00 \quad 0.0000 \quad 9.935 \mathrm{E}-07 \quad 0.0000$ $0.000 \mathrm{E}+00 \quad 0.0000 \quad 2.008 \mathrm{E}-06 \quad 0.0000$ $0.000 E+00$ 0.0000 $4.928 E-06 \quad 0.0000$ $\begin{array}{lllll}0.000 \mathrm{E}+00 & 0.0000 & 2.080 \mathrm{E}-04 & 0.0003\end{array}$ $\begin{array}{llll}0.000 \mathrm{E}+00 & 0.0000 & 2.325 \mathrm{E}-06 & 0.0000\end{array}$

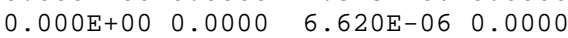
$\odot . \odot \odot \odot E+\odot \odot \quad \odot . \odot \odot \odot \odot \quad 5.940 \mathrm{E}-06 \quad \odot .0 \odot \odot \odot$ $\odot$

Total Dose Contributions TDOSE $(i, p, t)$ for Individual Radionuclides ( $i)$ and Pathways ( $p$ )

As $\mathrm{mrem} / \mathrm{yr}$ and Fraction of Total Dose At $t=0.000 \mathrm{E}+\odot \odot$ years

As mrem/yr and Fraction of Total Dose At $t$
Water Dependent Pathways Fish Radon Plant Meat
ÄÄÄÄÄÄÄÄÄÄÄÄÄÄÄÄ

Milk

All Pathways* Nuclide mrem/yr fract. ÄÄÄÄÄÄÄ ÄÄÄÄÄÄÄÄÄ ÄÄÄÄÄÄ CS-137 $0.000 \mathrm{E}+00 \quad 0.0000$ PU-238 $0.000 \mathrm{E}+00 \quad 0.0000$ Pu-239 $0.000 \mathrm{E}+00 \quad 0.0000$ $\mathrm{Sr}-90 \quad 0.000 \mathrm{E}+00 \quad 0.0000$ $\mathrm{U}-234 \quad 0.000 \mathrm{E}+0 \odot \quad 0.00 \odot \odot$ Аล̈ÄÄÄÄÄÄÄÄÄÄÄÄÄ ÄÄÄÄÄÄÄÄÄÄÄÄÄÄÄÄ АÄÄÄÄÄÄÄÄÄÄÄÄÄÄÄÄ ÄÄÄÄÄÄÄÄÄÄÄÄÄÄÄÄ

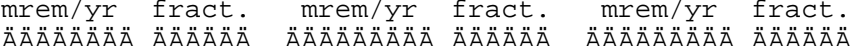
$0.000 \mathrm{E}+00 \quad 0.0000$ $0.000 \mathrm{E}+0 \odot \quad 0.0000$ $\odot .000 \mathrm{E}+0 \odot \quad \odot ., 0 \odot 0$ (1) $\odot .000 \mathrm{E}+\odot \odot$ $0.000 \odot$

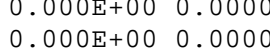
$\odot . \odot \odot \odot E+\odot \odot \quad \odot . \odot \odot \odot \odot$ $0.000 \mathrm{E}+00 \quad 0.0000$ $\odot .000 \mathrm{E}+0 \odot$ $0.000 \odot$ mrem/yr fract mrem/yr fract. ÄÄÄÄÄÄÄÄÄÄÄÄÄÄÄÄ (1) (1) $0.000 E+000.000$ O. $\begin{array}{lllll}0.000 \mathrm{E}+00 & 0.0000 & 7.382 \mathrm{E}-01 & 0.9589\end{array}$ $\begin{array}{lllll}0.000 \odot & 0.00 \odot E+\odot \odot & 0.000 \odot & 0.00 \odot \mathrm{E}+\odot \odot & 0.00 \odot 0\end{array}$

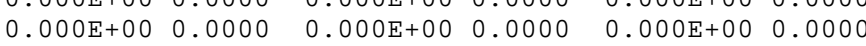
$0.000 \mathrm{c}+000.000$ $\begin{array}{lllll}0.000 E+00 & 0.0000 & 0.000 E+00 & 0.0000\end{array}$ $0.000 \mathrm{E}+00 \quad 0.0000$ $0.000 \mathrm{E}+000.0000$ $\odot .000 \mathrm{E}+00$ 0. 0.000 $1.241 \mathrm{E}-\mathrm{Q}$ $\begin{array}{lllll}-238 & 0.000 \mathrm{E}+00 & 0.0000 & 0.000 \mathrm{E}+00 & 0.0000\end{array}$

IIIIII IIIIIIIIIII ÍÍÍÍI

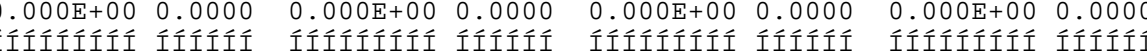

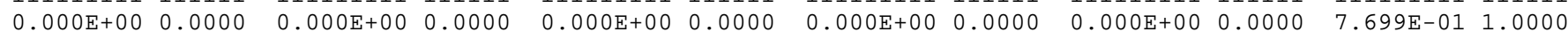

6.197E-04 0.0008 ÍÍÍÍÍÍI

*Sum of all water independent and dependent pathways. 

1RESRAD, Version 6.3
T« Limit $=180$ days
05/07/2006 17:31 Page 14
Summary : Mudpit Remote Work Area
File: Mudpit Remote.RA

Total Dose Contributions $\operatorname{TDOSE}(i, p, t)$ for Individual Radionuclides ( $i)$ and Pathways $(p)$ As mrem/yr and Fraction of Total Dose At $t=1.000 \mathrm{E}+00$ years

Inhalation ater Independent Pathways (Inhalation excludes radon)

Ground Radon

Plant

Milk

Soil

Radio - ÄÄÄÄÄÄÄÄÄÄÄÄÄÄÄÄ Nuclide $\mathrm{mrem} / \mathrm{yr}$ fract АAÄÄÄÄÄÄÄÄÄÄÄÄ Аล̈ÄÄÄÄÄÄÄÄÄÄÄÄÄÄ Meat

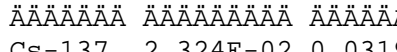

Eu-152 6.982E-01 0.9575

Ӓ̈̈̈̈̈̈̈̈̈̈̈̈̈̈ Ӓ̈̈̈̈̈̈̈̈̈

mrem/yr fract.  mrem/yr fract. АAลАAลA ÄÄÄÄÄÄÄÄĂ mrem/yr fract AAAÄÄÄÄÄÄÄÄÄÄÄÄ

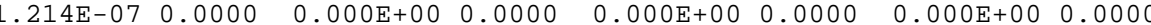
$1.273 \mathrm{E}-050.0000$ $1.174 \mathrm{E}-040.0002$ $\mathrm{Pu}-238 \quad 1.038 \mathrm{E}-07 \quad 0.0000$ $\mathrm{Pu}-239 \quad 6.885 \mathrm{E}-06 \quad 0.0000$ $\mathrm{Sr}-90 \quad 1.342 \mathrm{E}-04 \quad 0.0002$ $\mathrm{U}-234 \quad 3.888 \mathrm{E}-06 \quad 0.0000$ $\mathrm{U}-238 \quad 1.191 \mathrm{E}-03 \quad 0.0016$ 1.174E$3.778 \mathrm{E}-06 \quad 0.0000$ $.020 E-\odot 4 \quad 0.0008$ $\triangle . \odot \odot \odot \mathrm{E}+\odot \odot$ ० $\triangle . \odot \odot \odot \odot$ $\odot .000 \mathrm{E}+00 \quad 0.000 \odot$ $\odot .000 \mathrm{E}+0 \odot \quad 0.0000 \quad 0.000 \mathrm{E}+0 \odot \quad \odot .0000$ $0.000 \mathrm{E}+00 \quad 0.0000 \quad 0.000 \mathrm{E}+0 \odot \quad 0.000 \odot$ $\odot .000 \mathrm{E}+00 \quad 0.0000$ $\odot .00 \odot \mathrm{E}+\odot \odot \odot . \odot \odot \odot \odot$ $0.000 \mathrm{E}+00$ 0. 0000 . .0०E+๑๑ 0.0000 $0.000 E+00$ (.000 $\odot .000 \mathrm{E}+00 \quad 0.0000$ $\odot .000 E+00 \quad 0.0000$ $\begin{array}{lll}5.087 \mathrm{E}-04 & 0.0007\end{array}$ $.0000 \quad 0.000 \mathrm{E}+00 \quad 0.0000 \quad 0.000 \mathrm{E}+000.0000$ Íííííí ííííííí ííííí $0^{\text {Total }}$

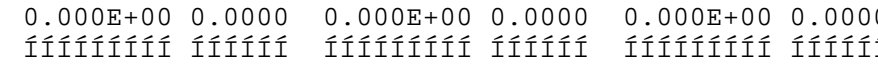

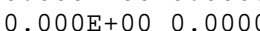

$0.000 \mathrm{E}+00 \quad 0.0000$ mrem/yr fract. $9.642 \mathrm{E}-07 \quad 0.0000$ $1.893 \mathrm{E}-06 \quad 0.0000$ $4.856 \mathrm{E}-06 \quad 0.0000$ $2.066 \mathrm{E}-04$ - 0.0003 $2.236 \mathrm{E}-06 \quad 0.0000$ $6.543 \mathrm{E}-06 \quad 0.0000$

IÍíííííi ííííi $5.871 \mathrm{E}-06 \quad 0.0000$ $\odot$

Total Dose Contributions TDOSE( $i, p, t)$ for Individual Radionuclides ( $i$ ) and Pathways ( $p$ ) As $\mathrm{mrem} / \mathrm{yr}$ and Fraction of Total Dose At $t=1.000 \mathrm{E}+00$ years

$\odot$ Radio- Water Nuclide m ӒӒ̈̈̈̈̈̈̈̈̈̈ ӒӒ̈̈̈̈̈̈̈̈̈̈̈̈̈̈ Cs-137 $0.000 \mathrm{E}+00 \quad 0.0000$ Eu-152 $0.000 \mathrm{E}+000.0000$ $\mathrm{Pu}-238 \quad 0.000 \mathrm{E}+00 \quad 0.0000$ Pu-239 $0.000 \mathrm{E}+00 \quad 0.0000$ $\mathrm{Sr}-90 \quad 0.000 \mathrm{E}+00 \quad 0.0000$ $\begin{array}{lll}\mathrm{U}-234 & 0.000 \mathrm{E}+00 & 0.0000 \\ \mathrm{U}-238 & 0.00 \odot \mathrm{E}+0 \odot & 0.000 \odot\end{array}$

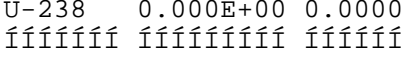
Total

$\odot .000 \mathrm{E}+0 \odot \odot .0000$ Radon Water Dependent Pathways Fish Plant Meat Milk ÄÄÄÄÄÄÄÄÄÄÄÄÄÄÄ ÄÄÄÄÄÄÄÄÄÄÄÄÄÄÄÄ ÄÄÄÄÄÄÄÄÄÄÄÄÄÄÄĂ mrem/yr fract. mrem/yr fract. mrem/yr fract. AAAAAAAAA AAAAAA AAAAAAAAA AAAAAA AAAAAAAAA AAAAAA $\begin{array}{llllll}0.00 \odot \mathrm{E}+00 & 0.000 \odot & 0.000 \mathrm{E}+00 & 0.0000 & 2.324 \mathrm{E}-02 & 0.0319\end{array}$ 作 0.00E

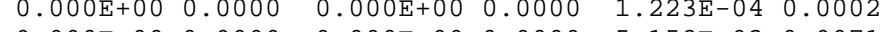
$\begin{array}{llllll}0.000 \mathrm{E}+0 \odot & 0.000 \odot & 0.000 \mathrm{E}+0 \odot & 0.000 \odot & 5.152 \mathrm{E}-03 & 0.0071\end{array}$ $\begin{array}{llllll}0.000 \mathrm{E}+0 \odot & 0.00 \odot \odot & 0.00 \odot \mathrm{E}+\odot \odot & 0.000 \odot & 1.402 \mathrm{E}-04 & 0.00 \odot 2\end{array}$

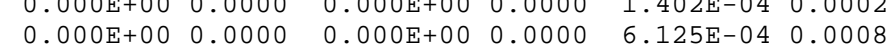
$\begin{array}{llllll}0.000 \mathrm{E}+00 & 0.0000 & 0.000 \mathrm{E}+00 & 0.0000 & 1.706 \mathrm{E}-03 & 0.0023\end{array}$ Íííííííi ííííí íííííííi ííííí íííííííi ííííí

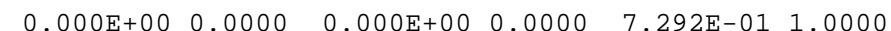

*Sum of all water independent and dependent pathways. 

1RESRAD, Version 6.3
T« Limit $=180$ days
05/07/2006 17:31 Page 15
Summary : Mudpit Remote Work Area
File: Mudpit Remote. RAD

Total Dose Contributions TDOSE $(i, p, t)$ for Individual Radionuclides ( $i)$ and Pathways $(p)$

As mrem/yr and Fraction of Total Dose At $t=3.000 \mathrm{E}+00$ years

$\odot$ Gadio- Ground Inhalation water Independent Pathways (Inhalation excludes radon) AÄAAAÄÄÄÄÄÄÄÄÄ Radon Plant Meat

Milk AลAAÄÄÄÄÄÄÄÄÄÄÄ АAАAАAАÄӒÄÄÄÄÄ ÄÄÄÄÄ Nuclide mrem/yr fract. $\begin{array}{lll}\text { ÄÄÄÄÄÄÄ ÄÄÄÄÄÄÄÄÄ ÄÄÄÄÄ̈ } \\ \text { CS-137 } & 2.205 \mathrm{E}-02 & 0.0337\end{array}$ Eu-152 6.245E-01 0.9546 $\mathrm{Pu}-238 \quad 1.022 \mathrm{E}-07 \quad 0.0000$

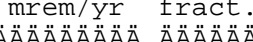
AAAAAAAAAAAAAAAA

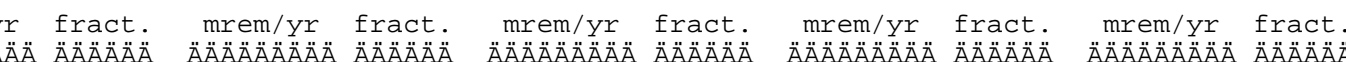
$1.131 \mathrm{E}-050.0000$ $1.139 \mathrm{E}-040.0002$ $4.870 \mathrm{E}-03 \quad 0.0074$ $3.494 \mathrm{E}-06 \quad 0.0000$ $\mathrm{Pu}-239 \quad 6.859 \mathrm{E}-06 \quad 0.0000$ $\mathrm{Sr}-90 \quad 1.252 \mathrm{E}-04 \quad 0.0002$ $\begin{array}{lll}\mathrm{U}-234 & 3.844 \mathrm{E}-06 & 0.0000 \\ \mathrm{U}-238 & 1.173 \mathrm{E}-03 & 0.0018\end{array}$

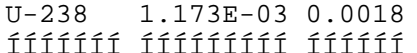
Total $0.000 \mathrm{E}+0 \odot \quad 0.000 \odot$ (1) $0.000 \mathrm{E}+00 \odot .0000$

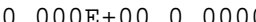
$\odot, \Theta \odot \odot E+\odot \odot \quad \odot, \odot \odot \odot \ominus$ $0.000 \mathrm{E}+00 \quad 0.0000$ (1) $0.000 \mathrm{E}+000.0000$ $0.000 \mathrm{E}+000.0000$ $0.000 \mathrm{E}+00 \quad 0.0000$

$\odot .000 \mathrm{E}+0 \odot \odot .0000$ $\odot .000 \mathrm{E}+00 \quad 0.0000$ $\begin{array}{llllll}0.000 E+00 & 0.0000 & 0.000 E+00 & 0.0000 & 0.000 E+00 & 0.0000\end{array}$

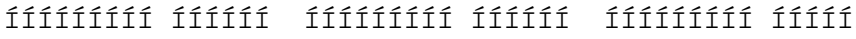
$\odot$ IIIIIII IIII IIIIIIII IIIII $0.000 \mathrm{E}+000.0000$

$\odot .000 \mathrm{E}+00$ 0. 0000

$\odot .000 \mathrm{E}+0 \odot$ ๑. 0000 A. $0.000 \mathrm{E}+0 \odot \quad 0.0000$ $\odot .000 E+0 \odot \quad 0.0000$ $0.000 \mathrm{E}+00 \quad 0.0000$ $0.000 E+00 \quad 0.0000$ $\odot .000 \mathrm{E}+0 \odot \quad 0.0000$ $0.000 \mathrm{E}+00 \quad 0.0000$ íilíifíi ííííi $0.000 E+00 \quad 0.0000$

Total Dose Contributions TDOSE $(i, p, t)$ for Individual Radionuclides ( $i)$ and Pathways ( $p$ )

As $\mathrm{mrem} / \mathrm{yr}$ and Fraction of Total Dose At $t=3.000 \mathrm{E}+00$ years

$\odot$ Fish Radon Water Dependent Pathways

\section{Radio- AAAAÄÄÄÄÄÄÄÄÄÄA}

Ä̈ÄÄÄ ÄÄÄÄÄÄÄÄÄÄÄÄÄÄÄ ÄÄÄÄÄÄÄÄÄÄÄÄÄÄÄÄ mrem/yr fract. mrem/yr fract. Meat

Milk ÄÄÄÄÄÄÄÄÄÄÄÄÄÄÄÄ ÄÄÄÄÄÄÄÄÄÄÄÄÄÄÄÄ
mrem/yr fract mrem/yr fract. AAAAAAA ÄÄÄÄÄÄÄÄÄ ÄÄÄÄÄÄ

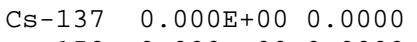
Eu-152 $0.000 \mathrm{E}+000.0000$

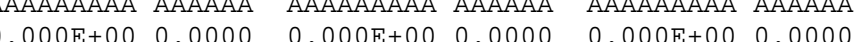
$0.000 \mathrm{C}+00$ (0.000 $0.000 \mathrm{E}+00 \quad 0.0000$ $\odot .000 \mathrm{E}+0 \odot \quad 0.000 \odot \quad \odot .000 \mathrm{E}+0 \odot \quad 0.0000$ $0.000 \mathrm{E}+00 \quad 0.0000$

$\odot, .00 \mathrm{E}+\odot \odot$

, $000 \mathrm{E}+00$ (0) mrem/yr fract. ÄÄÄÄÄÄÄÄÄ ÄÄÄÄÄ $\odot .000 \mathrm{E}+0 \odot$ $\odot .000 \odot$ $0.000 \mathrm{E}+00 \quad 0.0000$ $\odot .000 \mathrm{E}+000.0000$

Pu-238 $0.000 \mathrm{E}+00 \quad 0.0000$

All Pathways* ÄÄÄÄÄÄÄÄÄÄÄÄÄÄÄÄ mrem/yr fract.

$\mathrm{Pu}-239 \quad 0.000 \mathrm{E}+00 \quad 0.000 \odot$

$\begin{array}{lllll}\mathrm{Sr}-90 & 0.000 \mathrm{E}+00 & 0.0000 & 0.000 \mathrm{E}+00 & 0.0000\end{array}$

\begin{tabular}{lll}
$U-234$ & $0.000 \mathrm{E}+0 \odot \quad 0.0000$ \\
\hline
\end{tabular}

$0.000 E+00 \quad 0.0000$

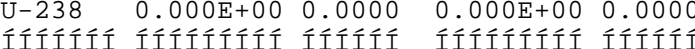

$.000 E+00 \quad 0.0000$ $0.000 \mathrm{E}+00 \quad 0.0000$

$0.000 \mathrm{E}+00 \quad 0.0000$

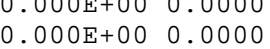

$\odot .000 \mathrm{E}+00 \quad \odot .0000$ $0.000 \mathrm{E}+000.0000$ $0.000 \mathrm{E}+00 \quad 0.0000$ 0.000 $0.000 \mathrm{C}+00000$

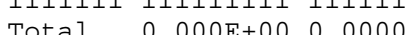

(1)



$0.000 \mathrm{E}+00 \quad 0.0000$

0 * Sum of all water independent and dependent pathways.

$\odot . \odot \odot \odot E+\odot \odot \odot . \odot \odot \odot \odot$ $\begin{array}{cc}0.000 E+0 \odot & 0.000 \odot \\ 0.000 E+0 \odot & 0.00 \odot \odot\end{array}$ $0.000 \mathrm{E}+000.0000$ $0.000 \mathrm{E}+000.0000$

IIIIIIII IIIIII
Soil АAАAАAАAАAАÄÄÄÄ A

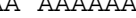
$9.082 \mathrm{E}-07 \quad 0.0000$ 1.682E-06 0.0000 (.714E-06 0.0000 $2.037 \mathrm{E}-04 \quad 0.0003$ $2.069 \mathrm{E}-06 \quad 0.0000$ $5.733 \mathrm{E}-060.0000$ Íííííííí íííííi $2.252 \mathrm{E}-04 \quad 0.0003$ 

1RESRAD, Version 6.3
T« Limit $=180$ days
05/07/2006 17:31 Page 16
Summary : Mudpit Remote Work Area
File: Mudpit Remote.RA

Total Dose Contributions $\operatorname{TDOSE}(i, p, t)$ for Individual Radionuclides ( $i)$ and Pathways $(p)$ As mrem/yr and Fraction of Total Dose At $t=1.000 \mathrm{E}+01$ years

Ground Inhalation Water Independent Pathways (Inhalation excludes radon) Radon Plant

Milk Nuclide mrem/yr fract. ÄÄÄÄÄÄÄ ÄÄÄÄÄÄÄÄÄ ÄÄÄÄÄÄ CS-137 1.833E- 02 - 0.0409 $\begin{array}{lll}\mathrm{Eu}-152 & 4.223 \mathrm{E}-01 & 0.9431 \\ \mathrm{Pu}-238 & 9.652 \mathrm{E}-08 & 0.0000\end{array}$ $\mathrm{Pu}-2396.762 \mathrm{E}-06 \quad 0.0000$ $\mathrm{Sr}-90 \quad 9.804 \mathrm{E}-05 \quad 0.0002$ $\mathrm{U}-234 \quad 3.704 \mathrm{E}-06 \quad 0.0000$ $\mathrm{U}-238 \quad 1.109 \mathrm{E}-03 \quad 0.0025$ Íííííí ííííííí ííííí Total Meat mrem/yr fract. mrem/yr fract. AӒ̈̈̈ÄÄÄÄÄÄÄÄÄÄÄÄ АÄAAAAÄÄÄÄÄÄÄ ÄÄÄÄÄÄÄÄÄ̈̈ $\begin{array}{llllllll}9.256 \mathrm{E}-08 & 0.0000 & 0.000 \mathrm{E}+0 \odot & 0.000 \odot & 0.000 \mathrm{E}+0 \odot & 0.000 \odot & 0.000 \mathrm{E}+00 & 0.0000\end{array}$ 7.471E-06 0.0000 $1.026 \mathrm{E}-04 \quad 0.0002$ $4.632 \mathrm{E}-03 \quad 0.0103$ $2.656 \mathrm{E}-06 \quad 0.0000$ . 405E-04 0.0012 $\triangle .00 \odot \mathrm{E}+\odot \odot$ ० $\triangle . \odot \odot \odot \odot$ $\odot .000 \mathrm{E}+\odot \odot \quad 0.000 \odot$ $\odot . \odot \odot \odot E+\odot \odot \odot . \odot \odot \odot \odot \quad \odot .0 \odot \odot E+\odot \odot \quad \odot ., \odot \odot$ $0.000 E+00$ Q 0000 $0.00 \odot \odot \quad \odot . \odot \odot \odot E$ $0.000 \mathrm{C}+00$ 0.0000 $0.000 E+000.0000$ $\begin{array}{llll}.567 E-04 & 0.0010 & 0.000 \mathrm{E}+0 \odot & 0.000 \odot\end{array}$ $0.000 \mathrm{E}+00 \quad 0.0000$ 0.0000 0.000E+00 0.0000

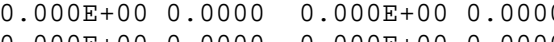
$\odot .000 \mathrm{E}+\odot \odot \quad 0.000 \odot \quad 0.0 \odot \odot \mathrm{E}+0 \odot \quad 0.00 \odot \bullet$ $0.000 \mathrm{E}+00 \quad 0.0000 \quad 0.000 \mathrm{E}+00 \quad 0.0000$ $5.742 \mathrm{E}-03 \quad 0.0128$

0

IIIIIIIÍi Íííít Mrem/yr fract. ÄÄÄÄÄÄÄÄÄÄÄÄÄÄÄÄ

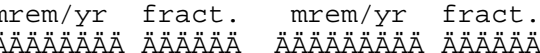
$0.000 \mathrm{E}+00 \quad 0.0000 \quad 1.110 \mathrm{E}-06 \quad 0.0000$ $0.000 \mathrm{E}+000.0000 \quad 4.244 \mathrm{E}-06 \quad 0.0000$ $0.000 \mathrm{E}+000.0000 \quad 1.938 \mathrm{E}-04 \quad 0.0004$ $0.000 \mathrm{E}+00 \quad 0.0000 \quad 1.572 \mathrm{E}-06 \quad 0.0000$ $0.000 \mathrm{E}+0 \odot \quad 0.0000 \quad 5.874 \mathrm{E}-06 \quad 0.0000$

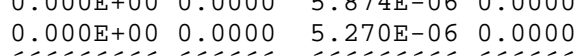
$\odot$

Total Dose Contributions TDOSE( $i, p, t)$ for Individual Radionuclides (i) and Pathways ( $p$ ) As $\mathrm{mrem} / \mathrm{yr}$ and Fraction of Total Dose At $\mathrm{t}=1.000 \mathrm{E}+01$ years As mrem/yr and Fraction of Total Dose At $t$
water Dependent Pathways Fish Radon Plant

Meat Milk Nuclide mrem/yr fract. ÄÄÄÄÄÄÄ ÄÄÄÄÄÄÄÄÄ ÄÄÄÄÄÄ Cs-137 $0.000 \mathrm{E}+00 \quad 0.0000$

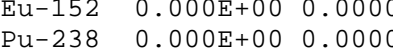

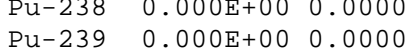
$\mathrm{Sr}-90 \quad 0.000 \mathrm{E}+00 \quad 0.0000$ $\mathrm{U}-234 \quad 0.000 \mathrm{E}+0 \odot \quad 0.000 \odot$ $\mathrm{U}-238 \quad 0.000 \mathrm{E}+0 \odot \quad 0.0000$ АÄÄÄÄÄÄÄÄÄÄÄÄÄÄÄ mrem/yr fract. ÄÄÄÄÄÄÄA ÄÄÄÄÄA $\odot .000 \mathrm{E}+0 \odot \quad 0.000 \odot$ $\odot .000 \mathrm{E}+000.0000$ $0.000 \mathrm{E}+000.0000$ $0.000 \mathrm{E}+00 \quad 0.0000$ $0.000 \mathrm{E}+00 \quad 0.0000$ $0.000 \mathrm{E}+0 \odot \quad 0.0000$ $\odot .000 \mathrm{E}+000.0000$ AAAÄÄÄÄÄÄÄÄÄÄÄÀ mrem/yr fract. ÄÄÄÄÄÄÄÄÄ ÄÄÄÄÄÄ $0.000 \mathrm{E}+00 \quad 0.0000$ $0.000 \mathrm{E}+000.0000$ $\begin{array}{ll}\odot .000 \mathrm{E}+0 \odot & 0.0000 \\ 0.000 \mathrm{E}+00 & 0.0000\end{array}$ $\begin{array}{lll}\odot .000 \mathrm{E}+\odot \odot & 0.0000 \\ 0.000 \mathrm{E}+0 \odot & 0.0000\end{array}$ $\begin{array}{ll}0.000 \mathrm{E}+0 \odot & 0.000 \odot \\ 0.000 \mathrm{E}+0 \odot & 0.000 \odot\end{array}$ $\begin{array}{ll}\odot .000 \mathrm{E}+\odot \odot & 0.0000 \\ 0.000 \mathrm{E}+0 \odot & 0.0000\end{array}$ Ííííííí ííííi

$\begin{array}{lllllllllllll}\text { Total } & 0.000 \mathrm{E}+00 & 0.0000 & 0.000 \mathrm{E}+00 & 0.0000 & 0.000 \mathrm{E}+00 & 0.0000\end{array}$ $\odot *$ Sum of all water independent and dependent pathways.

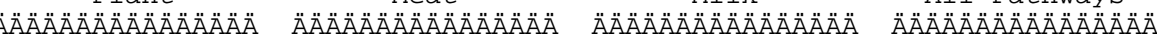
$\mathrm{mrem} / \mathrm{yr}$ fract. mrem/yr fract. mrem/yr fract. AAAAAAAAÄÄ ÄÄÄÄÄÄ ÄÄÄÄÄÄÄÄÄ ÄÄÄÄÄÄ $0.000 \mathrm{E}+0 \odot \quad 0.0000 \quad 0.000 \mathrm{E}+00 \quad 0.0000$ $\begin{array}{llll}0.000 \mathrm{E}+0 \odot & 0.000 \odot \quad 0.000 \mathrm{E}+\odot \odot \quad 0.000 \odot\end{array}$ $0.000 \mathrm{E}+00 \quad 0.0000 \quad 0.000 \mathrm{E}+00 \quad 0.0000$ $0.000 \mathrm{E}+00 \quad 0.0000 \quad 0.000 \mathrm{E}+0 \odot \quad 0.0000$ $0.000 \mathrm{E}+00 \quad 0.0000 \quad 0.000 \mathrm{E}+00 \quad 0.0000$ $\odot .000 \mathrm{E}+0 \odot \quad 0.000 \odot \quad 0.000 \mathrm{E}+\odot \odot \quad 0.0000$ $0.000 \mathrm{E}+00 \quad 0.0000 \quad 0.000 \mathrm{E}+000.0000$ Íííííííi ííííí íííííííi ííííi $\bullet .000 E+00 \quad 0.0000 \quad 0.000 E+00 \quad 0.0000$ \begin{tabular}{llll}
\hline & $000 \mathrm{~A}+\odot \odot$ & $0.000 \odot \quad 1.833 \mathrm{E}-02$ & 0.0409
\end{tabular} $0.000 \mathrm{E}+0 \odot \quad 0.000 \odot \quad 4.223 \mathrm{E}-01 \quad 0.9431$ $0.000 \mathrm{E}+00 \quad 0.0000 \quad 1.069 \mathrm{E}-04 \quad 0.0002$ $\odot .000 \mathrm{E}+0 \odot \quad 0.000 \odot \quad 4.833 \mathrm{E}-03 \quad 0.0108$ $0.000 \mathrm{E}+000.0000 \quad 1.023 \mathrm{E}-04 \quad 0.0002$ $\begin{array}{lllll}0.000 E+00 & 0.0000 & 5.501 \mathrm{E}-04 & 0.0012\end{array}$ $\begin{array}{llll}0.000 \mathrm{E}+00 & 0.0000 & 1.571 \mathrm{E}-03 & 0.0035\end{array}$ Ííííííí ííííi ííííííi ííííi $0.000 \mathrm{E}+00 \quad 0.0000 \quad 4.477 \mathrm{E}-01 \quad 1.0000$ 

1RESRAD, Version 6.3
T« Limit $=180$ days
05/07/2006 17:31 Page 17
Summary : Mudpit Remote work Area
File: Mudpit Remote.RA

Total Dose Contributions $\operatorname{TDOSE}(i, p, t)$ for Individual Radionuclides ( $i)$ and Pathways $(p)$ As mrem/yr and Fraction of Total Dose At $t=3.000 \mathrm{E}+01$ years

$\odot$

Ground Inhalation Radon Water Independent Pathways (Inhalation excludes radon)

萡 Plant Meat Nuclide mrem/yr fract ÄÄÄÄÄÄÄ ÄÄÄÄÄÄÄÄÄ ÄÄÄÄÄÄ $\begin{array}{lll}\mathrm{CS}-137 & 1.069 \mathrm{E}-02 & 0.0698 \\ \mathrm{EU}-152 & 1.365 \mathrm{E}-01 & 0.8912\end{array}$ $\mathrm{Pu}-238 \quad 8.193 \mathrm{E}-08 \quad 0.0000$ $\mathrm{Pu}-2396.452 \mathrm{E}-06 \quad 0.0000$ $\mathrm{Sr}-90 \quad 4.832 \mathrm{E}-05 \quad 0.0003$ $\mathrm{U}-234 \quad 3.393 \mathrm{E}-06$ - 0.0000 $\mathrm{U}-238 \quad 9.366 \mathrm{E}-04 \quad 0.0061$ Íííííí ííííííí ííííí Total

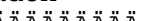

Milk Soil mrem/yr fract. mrem/yr fract. mrem/yr fract. mrem/yr fract.

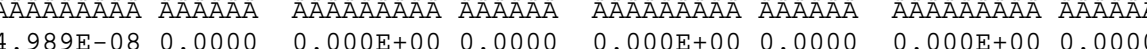

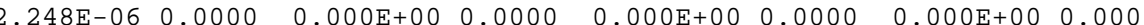
$3.956 \mathrm{E}-03 \quad 0.0258$ $1.195 \mathrm{E}-060.0000$ $.187 \mathrm{E}-04 \quad 0.0027$ $0.000 \mathrm{E}+00$ - 9.0000 $0.000+00$ (0) $0.0006+00$ (0.000 $0.000 \mathrm{E}+000.0000$ $0.000 \mathrm{C}+00$ (0.000 $0.000 \mathrm{E}+000.0000$ $\begin{array}{llllll}0.000 E+0 \odot & 0.000 \odot & 0.000 E+0 \odot & 0.0000 & 0.000 \mathrm{E}+0 \odot & 0.0000\end{array}$ $\begin{array}{llllll}0.000 \mathrm{E}+00 & 0.0000 & 0.000 \mathrm{E}+00 & 0.0000 & 0.000 \mathrm{E}+00 & 0.0000\end{array}$

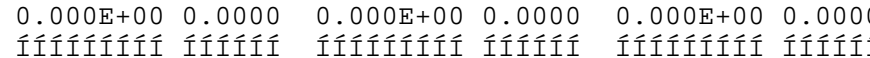
$0.000 \mathrm{E}+000.0000$ ÄÄÄÄÄÄÄÄÄÄÄÄÄÄÄÄ mrem/yr fract ААААAАAАÄÄÄÄÄÄÄ $0.000 \mathrm{E}+00 \quad 0.0000 \quad 3.964 \mathrm{E}-07 \quad 0.0000$ $0.000 \mathrm{E}+00 \quad 0.0000 \quad 3.342 \mathrm{E}-07 \quad 0.0000$ $0.000 \mathrm{E}+00 \quad 0.0000 \quad 3.096 \mathrm{E}-06 \quad 0.0000$ $0.000 E+00 \quad 0.0000 \quad 1.655 E-04 \quad 0.0011$ $0.000 \mathrm{E}+0 \odot \quad 0.0000 \quad 7.074 \mathrm{E}-07 \quad 0.0000$ $0.000 \mathrm{E}+0 \odot \quad 0.0000 \quad 4.550 \mathrm{E}-06 \quad 0.0000$ $\odot$

Total Dose Contributions TDOSE ( $i, p, t)$ for Individual Radionuclides ( $i)$ and Pathways ( $p$ )

As $\mathrm{mrem} / \mathrm{yr}$ and Fraction of Total Dose At $\mathrm{t}=3.000 \mathrm{E}+01$ years

water

Fish

Radon Plant

Meat

Milk

All Pathways*

Radio - ÄÄÄÄÄÄÄÄÄÄÄÄÄÄÄÄ Nuclide mrem/yr fract. ÄÄÄÄÄÄÄ ÄÄÄÄÄÄÄÄÄ ÄÄÄÄÄÄ ÄÄÄÄÄÄÄÄÄÄÄÄÄÄÄÄ ÄÄÄÄÄÄÄÄÄÄÄÄÄÄÄÄ mrem/yr fract. mrem/yr fract. ӒÄÄÄÄÄÄÄÄÄÄÄÄÄÄÄ ÄÄÄÄÄÄÄÄÄÄÄÄÄÄÄÄA AAAAAAAAA ÄÄÄÄÄ ÄÄÄÄÄÄÄÄ ÄÄÄÄÄ $0.000 \mathrm{E}+00 \quad 0.0000$ $0.000 \mathrm{O}+00$ - 0 . mrem/yr fract. mrem/yr fract. ÄÄÄÄÄÄÄÄÄÄÄÄÄÄÄÄ mrem/yr fract.

ÄÄÄÄÄÄÄÄÄÄÄÄÄÄÄÄÄ CS-137 $0.000 \mathrm{E}+\odot \odot \quad 0.0000$ $\mathrm{Pu}-238 \quad 0.000 \mathrm{E}+0 \odot \quad 0.000 \odot$ $\mathrm{Pu}-2390.000 \mathrm{E}+0 \odot \quad 0.000 \odot$ $0.000 \mathrm{E}+0 \odot \quad 0.0000 \quad 0.000 \mathrm{E}+0 \odot \quad 0.0000$ $0.000 \mathrm{E}+00$ ०. 0000 $0.000+00$ (0.000 $0.000 E+00$ 0.0000 $\odot .000 \mathrm{E}+\odot \odot$ $0.000 \odot$ AAAAAAAAA AAAAAA AAAAAAAAA AAAAAAA $0.000 \mathrm{E}+00 \quad 0.0000 \quad 0.000 \mathrm{E}+00 \quad 0.0000$ $\odot .0 \odot 0 \mathrm{E}+\odot \odot \quad \odot .000 \odot \quad 0.00 \odot \mathrm{E}+\odot \odot \quad \odot .00 \odot \odot$

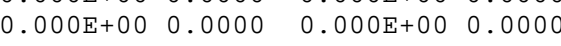
$\odot .000 E+00 \quad 0.0000 \quad 0.000 E+00 \quad 0.0000$

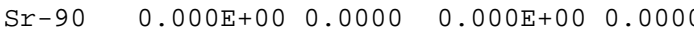
$\begin{array}{lllllll}-234 & 0.000 \mathrm{E}+00 & 0.0000 & 0.000 \mathrm{E}+00 & 0.0000 & 0.000 \mathrm{E}+00 & 0.0000\end{array}$

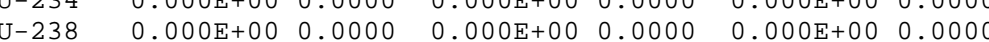

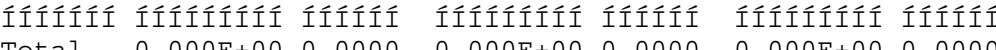

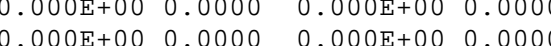
$0.000 \mathrm{E}+00 \quad 0.0000 \quad 0.000 \mathrm{E}+00 \quad 0.0000$ íííííííi ííííi íííííííi íííít Total $0.000 \mathrm{E}+00$ 0.0000

$\odot .000 \mathrm{E}+0 \odot \quad \odot .0000$ AÄAAAAAAA AÄÄÄÄ ÄÄÄÄÄÄÄÄ ÄÄÄÄÄ $0.000 \mathrm{E}+00 \quad 0.0000 \quad 1.069 \mathrm{E}-02 \quad 0.0698$ $\odot .000 \mathrm{E}+0 \odot \quad 0.000 \odot \quad 1.365 \mathrm{E}-01 \quad 0.8912$ $\odot .000 \mathrm{E}+0 \odot \quad 0.0000 \quad 7.800 \mathrm{E}-05 \quad 0.0005$ $0.000 \mathrm{E}+00 \quad 0.0000 \quad 4.128 \mathrm{E}-03 \quad 0.0269$ $0.000 \mathrm{E}+000.0000 \quad 5.022 \mathrm{E}-05 \quad 0.0003$ $0.000 \mathrm{E}+00 \quad 0.0000 \quad 4.267 \mathrm{E}-04 \quad 0.0028$ $0.000 \mathrm{E}+000.0000 \quad 1.294 \mathrm{E}-03 \quad 0.0084$ IIIIIIIII IIIIII IIIIIIIII Í́ííí $0.000 \mathrm{E}+00 \quad 0.0000 \quad 1.532 \mathrm{E}-01 \quad 1.0000$ $\odot *$ Sum of all water independent and dependent pathways. 

1RESRAD, Version 6.3
T« Limit $=180$ days
05/07/2006 17:31 Page 18
Summary : Mudpit Remote Work Area
File: Mudpit Remote. RAD

Total Dose Contributions $\operatorname{TDOSE}(i, p, t)$ for Individual Radionuclides ( $i)$ and Pathways $(p)$

As mrem/yr and Fraction of Total Dose At $t=1.000 \mathrm{E}+02$ years

Ground

Inhalation Water Independent Pathways (Inhalation excludes radon)

Plant

Milk

Soil АAลÄÄÄÄÄÄÄÄÄÄÄÄ̈ АAАÄÄÄÄÄÄÄÄÄÄÄÄ Meat

Nuclide mrem/yr fract.

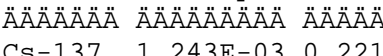

Eu-152 2.025E-03 0.3600

$\mathrm{Pu}-238 \quad 4.413 \mathrm{E}-08 \quad 0.0000$

mrem/yr fract

- mrem/yr fract. mrem/yr fract. mrem/yr fract. mrem/yr fract.

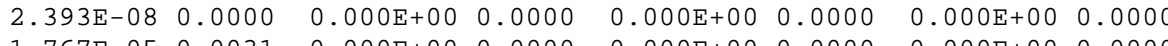

$1.621 \mathrm{E}-03 \quad 0.2882$

$\odot .000 \mathrm{E}+000.0000$

0.000

$\begin{array}{ll}4.563 \mathrm{E}-\odot 6 & \odot .00 \odot 8 \\ 3.197 \mathrm{E}-\odot 6 & 0.0006\end{array}$

$198 \mathrm{E}-08 \quad 0.0000$

$\odot .000 \mathrm{E}+000.0000$

$\begin{array}{lll}\mathrm{Sr}-9 \odot & 3.197 \mathrm{E}-06 & 0.0 \odot \odot 6 \\ \mathrm{U}-234 & 2.519 \mathrm{E}-06 & 0.0004 \\ \mathrm{U}-238 & 4.115 \mathrm{E}-04 & 0.0732\end{array}$

$\mathrm{U}-238 \quad 4.115 \mathrm{E}-04 \quad 0.0732$

$\begin{array}{llll}.221 \mathrm{E}-04 & 0.0217 & 0.000 \mathrm{E}+00 & 0.0000\end{array}$

$0.000 \mathrm{E}+000.0000$

$0.000 \mathrm{E}+00$ - 0.0000

0.0००E+0० 0.0000

$0.000 \mathrm{E}+00 \quad 0.0000$

$0.000 \mathrm{E}+00 \quad 0.0000$

$.000 \mathrm{E}+000.0000$

0

ÍÍIííííí ÍÍÍÍI

IIIIIIIIÍí ÍÍÍíi

Tota

IIIIIII IIIII IIIIIIIII IIIII

$0.000 \mathrm{E}+00 \quad 0.0000$

$\odot .000 \mathrm{E}+0 \odot \quad \odot .0000$

AAAAAAAAAAAAAAAA ÄÄÄÄÄÄÄÄ Ä ̈̈̈̈̈̈̈̈

$\odot .000 \mathrm{E}+00 \quad 0.0000$

$0.000 \mathrm{E}+000.0000$

$0.000 \mathrm{E}+000.0000$

$0.000 \mathrm{E}+00 \quad 0.0000$

$0.000 \mathrm{E}+00 \quad 0.0000$

$\odot .000 \mathrm{E}+00 \quad 0.0000$

$0.000 \mathrm{E}+000.0000$

(ifilifi lifít

$0.00 \mathrm{C}+0 \odot \quad 0,0000$

Total Dose Contributions TDOSE $(i, p, t)$ for Individual Radionuclides ( $i)$ and Pathways $(p)$

As $\mathrm{mrem} / \mathrm{yr}$ and Fraction of Total Dose At $t=1.000 \mathrm{E}+02$ years

$\begin{array}{lll} & \text { Water Dependent Pathways } \\ \text { Radon } & \text { Plant }\end{array}$

Water

Plant

Meat

Milk

Nuclide mrem/yr fract.

ÄÄÄÄÄÄÄ ÄÄÄÄÄÄÄÄÄ ÄÄÄÄÄÄ

CS-137 $0.000 \mathrm{E}+00 \quad 0.0000$

$\mathrm{Pu}-238 \quad 0.000 \mathrm{E}+0 \odot \quad 0.0000$

Pu-239 $0.000 \mathrm{E}+00 \quad 0.0000$

$\mathrm{Sr}-90 \quad 0.000 \mathrm{E}+00 \quad 0.0000$

$\mathrm{U}-234 \quad 0.000 \mathrm{E}+00 \quad 0.000 \odot$

АÄÄÄÄÄÄÄÄÄÄÄÄÄÄĂ АÄÄÄÄÄÄÄÄÄÄÄÄÄÄÄ ÄÄÄÄÄÄÄÄÄÄÄÄÄÄÄÄ ÄÄÄÄÄÄÄÄÄÄÄÄÄÄÄĂ

AAA mrem/yr fract. A $\begin{array}{lllll}0.000 \mathrm{E}+00 & 0.0000 & 0.000 \mathrm{E}+00 & 0.0000\end{array}$ $\odot .000 \mathrm{E}+00 \quad 0.0000$ $0.000 \mathrm{E}+0 \odot \quad 0.0000$

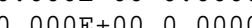
$0.000 \mathrm{E}+0 \odot \quad 0.0000$ $0.000 \mathrm{E}+0 \odot 0.0000$ $0.00 E+000$ $0.000 \mathrm{E}+0 \odot \quad 0.0000$ $\odot .000 \mathrm{E}+0 \odot \quad 0.000 \odot$ $0.000 \mathrm{E}+00$ 0.0000 $0.000 \mathrm{E}+00 \quad 0.0000$ $0.000 \mathrm{E}+00 \quad 0.0000$ 0.0000 $0.000 \mathrm{E}+000.0000$ $0.000 \mathrm{E}+00 \quad 0.0000$

$0.000 \mathrm{E}+00 \quad 0.0000$ $0.000 \mathrm{E}+00 \quad 0.0000$ $\odot .000 E+00$ \% 0.0000 $\odot .000 \mathrm{E}+00 \quad 0.0000$ $\odot .000 \mathrm{E}+0 \odot \quad 0.0000$ $0.000 \mathrm{E}+00 \quad 0.0000$ ííííííí íííít

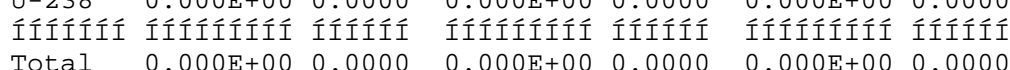

$0.000 \mathrm{E}+000.0000 \quad 0.000 \mathrm{E}+00 \quad 0.0000$

All Pathways* ÄÄÄÄÄÄÄÄÄÄÄÄÄÄÄÄ mrem/yr fract. 0. $000 \mathrm{E}+00$ 0. 0000 1.243E-03 0.2210 $0.000 \mathrm{E}+00 \quad 0.0000 \quad 2.025 \mathrm{E}-03 \quad 0.3600$ $0.000 \mathrm{C}+00$ 0.0000 $1.845 \mathrm{E}-050.0033$ $0.000 \mathrm{~T}+00$ 0.0000 $1.693 \mathrm{E}-03$ O.3011 $0.000 \mathrm{E}+0 \odot \quad 0.0000 \quad 3.279 \mathrm{E}-06 \quad 0.0006$ $0.000 \mathrm{E}+000.0000 \quad 1.259 \mathrm{E}-04 \quad 0.0224$ $0.000 \mathrm{E}+00 \quad 0.0000 \quad 5.156 \mathrm{E}-04 \quad 0.0917$ íííííííi ííííí íííííííi ííííí $0.000 \mathrm{E}+00 \quad 0.0000 \quad 5.624 \mathrm{E}-03 \quad 1.0000$ 

1RESRAD, Version 6.3
T« Limit $=180$ days
05/07/2006 17:31 Page 19
Summary : Mudpit Remote Work Area
File: Mudpit Remote. RAD

Total Dose Contributions $\operatorname{TDOSE}(i, p, t)$ for Individual Radionuclides ( $i)$ and Pathways $(p)$ As mrem/yr and Fraction of Total Dose At $t=3.000 \mathrm{E}+02$ years

Ground Inhalation Water Independent Pathways (Inhalation excludes radon)

Plant

Milk

Soi 1

Nuclide mrem/yr fract ÄÄÄÄÄÄÄ ÄÄÄÄÄÄÄÄÄ ÄÄÄÄÄA

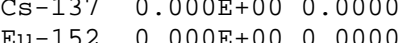
Pu-238 $0.000 \mathrm{E}+000.0000$ $\mathrm{Pu}-2390.000 \mathrm{E}+00 \quad 0.0000$ $\mathrm{Sr}-90 \quad 0.000 \mathrm{E}+00 \quad 0.0000$ $\mathrm{U}-234 \quad 0.000 \mathrm{E}+00$ - 9.0000 $\mathrm{U}-238 \quad 0.000 \mathrm{E}+00 \quad 0.0000$

íííííi ííííííí ííííí Total

ÄÄÄÄÄÄÄÄÄÄÄÄÄÄÄÄÄ
АAАÄÄÄÄÄÄÄÄÄÄÄÄ Meat

\section{mrem/yr fract} mrem/yr fract. mrem/yr fract. mrem/yr fract. ÄÄÄÄÄÄÄÄÄÄÄÄÄÄÄÄ АААÄÄÄÄÄÄÄÄÄÄÄÄÄ

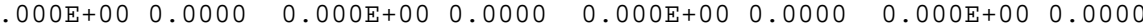
$0.000 \mathrm{E}+000.0000$ $.000 \mathrm{E}+0 \odot \quad 0.0000$ $0.000 \mathrm{E}+00 \quad 0.0000$ $0.000 \mathrm{E}+00 \quad 0.0000$ $.000 \mathrm{E}+00 \quad 0.0000$ $\triangle . \odot \odot \odot \mathrm{E}+\odot \odot$ ० $\triangle . \odot \odot \odot \odot$ $0.000 \mathrm{E}+00 \quad 0.0000$ $\odot . \odot \odot \odot E+\odot \odot \quad \odot . \odot \odot \odot \ominus$ 0.000 $0.0000 \quad 0.000 \mathrm{E}+000.0000$

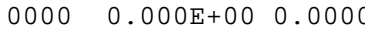

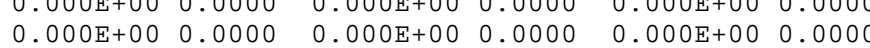
$0.000 \mathrm{E}+00 \quad 0.0000$ ííííííí ííííi $0.000 \mathrm{E}+000.0000$ $0.000 \mathrm{E}+00 \quad 0.0000$ $0.000 \mathrm{E}+000.0000$ $\odot \odot \odot E+\odot \odot \quad 0.0 \odot \odot \odot$ IIIIIíííi ííííi IIIIIIÍíí ííííi Ä̈ÄÄÄÄÄÄÄ ÄÄÄÄÄA $\odot .000 \mathrm{E}+0 \odot \quad 0.0000$ $.000 \mathrm{E}+000.0000$ $0.000 \mathrm{E}+0 \odot \quad 0.000 \odot$ $\odot .000 \mathrm{E}+00 \quad 0.0000$ $0.000 \mathrm{E}+00 \quad 0.0000$ $\odot .000 \mathrm{E}+00 \quad 0.0000$ $0.000 \mathrm{E}+00 \quad 0.0000$ IIIIIIÍí Ííííi

Total Dose Contributions TDOSE $(i, p, t)$ for Individual Radionuclides ( $i)$ and Pathways ( $p$ ) As $\mathrm{mrem} / \mathrm{yr}$ and Fraction of Total Dose At $t=3.000 \mathrm{E}+02$ years As $\mathrm{mrem} / \mathrm{yr}$ and Fraction of Total Dose At $t$
Water Dependent Pathways Fish Radon Plant

Meat Milk Nuclide mrem/yr fract. ÄÄÄÄÄÄÄ ÄÄÄÄÄÄÄÄÄ ÄÄÄÄÄÄ Cs-137 $0.000 \mathrm{E}+00 \quad 0.0000$

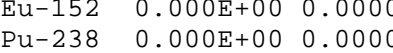
$\begin{array}{lll}\text { Pu-238 } & \odot . \odot \odot \odot E+\odot \odot ~ & 0 . \odot \odot \odot \odot ~ \\ \text { Pu-239 } & 0.00 \odot E+\odot \odot ~ & 0.00 \odot \odot\end{array}$ $\mathrm{Sr}-90 \quad 0.000 \mathrm{E}+00 \quad 0.0000$ $\mathrm{U}-234 \quad 0.000 \mathrm{E}+0 \odot \quad 0.000 \odot$ $\mathrm{U}-238 \quad 0.000 \mathrm{E}+0 \odot \mathrm{0} 0.0000$ АÄÄÄÄÄÄÄÄÄÄÄÄÄÄĂ mrem/yr fract. ÄÄÄÄÄÄÄ ÄÄÄÄÄA $0.000 \mathrm{E}+00$ - 0.0000 $0.000 \mathrm{E}+\odot \odot$ ๑. 0.0000 $0.00 \mathrm{E}+00$ 0. $0.000 \mathrm{E}+0 \odot \quad 0.0000$ $0.000 \mathrm{E}+00 \quad 0.0000$ $\odot .000 \mathrm{E}+\odot \odot$ $0.000 \odot$ Aล̈ÄÄÄÄÄÄÄÄÄÄÄÄÄÄ mrem/yr fract. ÄÄÄÄÄÄÄÄÄ ÄÄÄÄÄÄ $0.000 \mathrm{E}+00 \quad 0.0000$ $\odot .000 \mathrm{E}+0 \odot \quad 0.0000$ $\begin{array}{ll}\odot .000 \mathrm{E}+0 \odot & 0.0000 \\ 0.000 \mathrm{E}+00 & 0.0000\end{array}$

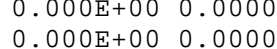
$\begin{array}{ll}0.000 E+0 \odot & 0.000 \odot \\ 0.000 E+0 \odot & 0.000 \odot\end{array}$ $\begin{array}{ll}0.000 E+00 & 0.000 \odot \\ 0.000 E+00 & 0.0000\end{array}$

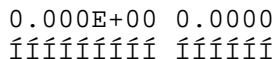

$\begin{array}{lllllllllllll}\text { Total } & 0.000 \mathrm{E}+00 & 0.0000 & 0.000 \mathrm{E}+00 & 0.0000 & 0.000 \mathrm{E}+00 & 0.0000\end{array}$ $\odot *$ Sum of all water independent and dependent pathways. $0.000 \mathrm{E}+000.0000 \quad 0.000 \mathrm{E}+000.0000$

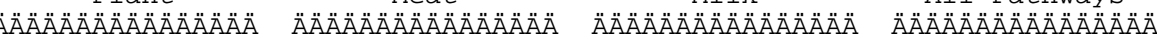
$\mathrm{mrem} / \mathrm{yr}$ fract. mrem/yr fract. mrem/yr fract. AAAAAÄÄÄÄ ÄÄÄÄÄÄ ÄÄÄÄÄÄÄÄÄ ÄÄÄÄÄÄ $0.000 \mathrm{E}+0 \odot \quad 0.000 \odot \quad 0.000 \mathrm{E}+0 \odot \quad 0.000 \odot$ $\begin{array}{ccc}0.000 \mathrm{E}+0 \odot & 0.000 \odot \quad 0.000 \mathrm{E}+00 & 0.000 \odot\end{array}$ $0.000 \mathrm{E}+00 \quad 0.0000 \quad 0.000 \mathrm{E}+00 \quad 0.0000$ $0.000 \mathrm{E}+00 \quad 0.0000 \quad 0.000 \mathrm{E}+0 \odot \quad 0.0000$ $0.000 \mathrm{E}+00 \quad 0.0000 \quad 0.000 \mathrm{E}+00 \quad 0.0000$ $\odot .000 \mathrm{E}+0 \odot \quad 0.0000 \quad 0.000 \mathrm{E}+0 \odot \quad 0.0000$ Íííííííi ííííí íííííííi ííííi $\bullet .000 E+00 \quad 0.0000 \quad 0.000 E+00 \quad 0.0000$ $\begin{array}{llll}0.000 \mathrm{~A}+0 \odot & 0.000 \odot & 0.000 \mathrm{E}+0 \odot & 0.0000\end{array}$ $0.000 \mathrm{E}+00 \quad 0.0000 \quad 0.000 \mathrm{E}+0 \odot \quad 0.0000$ $\begin{array}{lllll}0.000 E+00 & 0.0000 & 0.000 E+00 & 0.0000\end{array}$ $\odot .000 E+0 \odot \quad 0.000 \odot \quad \odot .000 E+0 \odot \quad \odot .000 \odot$ $0.000 \mathrm{E}+0 \odot \quad \odot .000 \odot \quad \odot .000 \mathrm{E}+0 \odot \quad 0.000 \odot$ $0.000 \mathrm{E}+00 \quad 0.0000 \quad 0.000 \mathrm{E}+00 \quad 0.0000$ $0.000 \mathrm{E}+00 \quad 0.0000 \quad 0.000 \mathrm{E}+00 \quad 0.0000$ Íííííííi ííííi íííííííi ííííi $0.000 E+00 \quad 0.0000 \quad 0.000 E+00 \quad 0.0000$ 

1RESRAD, Version 6.3
T« Limit $=180$ days
05/07/2006 17:31 Page 20
Summary : Mudpit Remote Work Area
File: Mudpit Remote. RA

Total Dose Contributions $\operatorname{TDOSE}(i, p, t)$ for Individual Radionuclides ( $i)$ and Pathways $(p)$

As mrem/yr and Fraction of Total Dose At $t=1.000 \mathrm{E}+03$ years

Ground Inhalation Water Independent Pathways (Inhalation excludes radon)

Plant

Milk

Soi 1

Nuclide mrem/yr fract. ÄÄÄÄÄÄÄ ÄÄÄÄÄÄÄÄÄ ÄÄÄÄÄA $\mathrm{Eu}-152 \quad 0.000 \mathrm{E}+00 \quad 0.0000$ $\mathrm{Pu}-238 \quad 0.000 \mathrm{E}+00 \quad 0.000 \odot$ $\mathrm{Pu}-239 \quad 0.000 \mathrm{E}+00 \quad 0.0000$ $\mathrm{Sr}-90 \quad 0.000 \mathrm{E}+00 \quad 0.0000$ $\mathrm{U}-234 \quad \odot .000 \mathrm{E}+0 \odot \odot .0000$ $\mathrm{U}-238 \quad 0.000 \mathrm{E}+00 \quad 0.0000$

íííííi ííííííí ííííí Total ÄÄÄÄÄÄÄÄÄÄÄÄÄÄÄÄ AAÄÄÄÄÄÄÄÄÄÄÄÄÄ Meat

mrem/yr fract. mrem/yr fract. mrem/yr fract. mrem/yr fract. ÄÄÄÄÄÄÄÄÄÄÄÄÄÄÄÄÄ AAAÄÄÄÄÄÄÄÄÄÄÄÄÄ

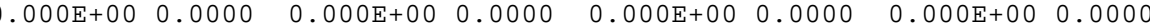
$0.000 \mathrm{E}+000.0000$ $.000 \mathrm{E}+0 \odot \quad 0.0000$ $0.000 \mathrm{E}+00 \quad 0.0000$ $0.000 \mathrm{E}+00 \quad 0.0000$ $.000 \mathrm{E}+00 \quad 0.0000$ $\triangle . \odot \odot \odot \mathrm{E}+\odot \odot$ ० $\triangle . \odot \odot \odot \odot$ $0.000 \mathrm{E}+00 \quad 0.0000$ $0.000 E+00$ 0.0000 $0.000 \mathrm{E}+0 \odot \quad 0.0000$

.

$0.000 \mathrm{E}+0 \odot \quad 0.000 \odot$ $0.000 \mathrm{E}+000.0000$ 0.000000 . $0.000 \mathrm{E}+00 \quad 0.0000$ ๑. $000 \mathrm{E}+0 \odot$ ०..0000 ĀÁA ÂÄÄ ÄÄÄÄÄA $0.000 \mathrm{E}+00 \quad 0.0000$ $\odot .000 \mathrm{E}+00 \quad 0.0000$ $\odot .000 \mathrm{E}+0 \odot \quad 0.0000$ $\odot .000 E+00 \quad 0.0000$ $0.000 \mathrm{E}+00 \quad 0.0000$ OE+०० 0.0000 $0.000 \mathrm{E}+00 \quad 0.0000$ $0.000 \mathrm{E}+0 \odot \quad 0.0000$

$0.000 \mathrm{E}+000.0000$

$\odot .000 \mathrm{E}+0 \odot \quad 0.00 \odot 0$

Total Dose Contributions TDOSE $(i, p, t)$ for Individual Radionuclides ( $i)$ and Pathways ( $p$ )

As $\mathrm{mrem} / \mathrm{yr}$ and Fraction of Total Dose At $t=1.000 \mathrm{E}+03$ years

As mrem/yr and Fraction of Total Dose At $t$
Water Dependent Pathways Fish Radon Plant

Meat

Milk

All Pathways* Nuclide mrem/yr fract. mrem/yr fract. mrem/yr fract. mrem/yr fract. mrem/yr fract. $\mathrm{mrem} / \mathrm{yr}$ fract. $\mathrm{mrem} / \mathrm{yr}$ fract.

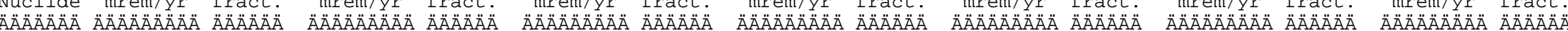

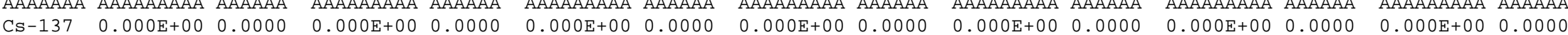
$\begin{array}{lllllllllll}\mathrm{Eu}-152 & 0.000 \mathrm{E}+00 & 0.0000 & 0.000 \mathrm{E}+00 & 0.0000 & 0.000 \mathrm{E}+00 & 0.0000 & 0.000 \mathrm{E}+00 & 0.0000 & 0.000 \mathrm{E}+00 & 0.0000\end{array}$ Pu-238 $0.000 E+000.0000$ 0.000E+00 0.0000 0.000E+00 0.0000 0.000E+00 0.0000 0.000E+00 0.0000 Pu-238 0.000 -

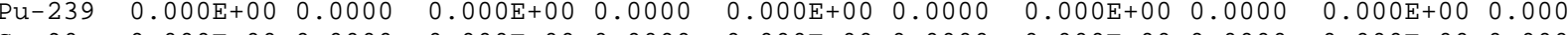

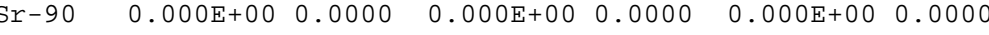
$\begin{array}{lllllll}\mathrm{U}-234 & 0.000 \mathrm{E}+0 \odot & 0.0000 & 0.000 \mathrm{E}+0 \odot & 0.0000 & 0.000 \mathrm{E}+00 & 0.00000\end{array}$

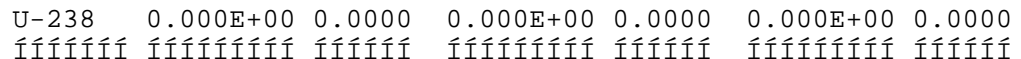
ÍIIIIII IIIIIIIIII IIIIIII $\quad$ IIIIIIIIIII IIIIIII $\quad$ IIIIIIIIII IIIIII $\begin{array}{llll}0.000 \mathrm{E}+00 & 0.0000 & 0.000 \mathrm{E}+00 & 0.0000 \\ 0.000 \mathrm{E}+0 \odot & 0.0000 & \odot .000 \mathrm{E}+0 \odot & 0.000 \odot\end{array}$ $\begin{array}{llll}0.000 \mathrm{E}+00 & 0.0000 & 0.000 \mathrm{E}+00 & 0.0000 \\ 0.000 \mathrm{E}+00 & 0.0000 & 0.000 \mathrm{E}+00 & 0.0000\end{array}$

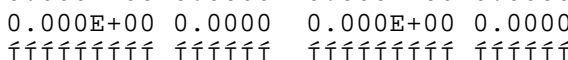
$0.000 \mathrm{E}+00 \quad 0.0000 \quad 0.000 \mathrm{E}+00 \quad 0.0000$ $0.000 \mathrm{C}+\odot \odot$ О. (.).

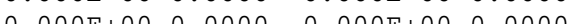

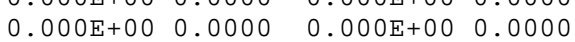
$0.000 \mathrm{E}+00 \quad 0.0000 \quad 0.000 \mathrm{E}+00 \quad 0.0000$

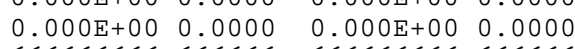
Ííííííí ííííi ííííííí ííííi $\odot *$ Sum of all water independent and dependent pathways. 
Dose/Source Ratios Summed Over All Pathways

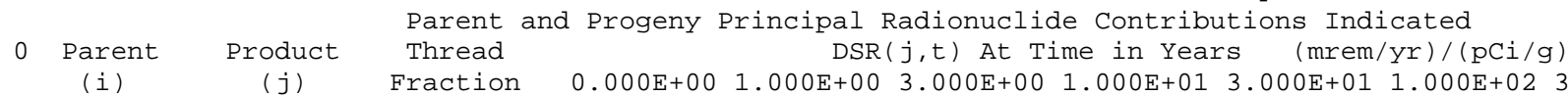

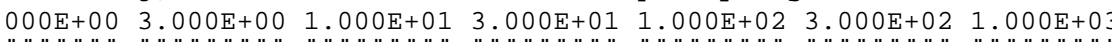

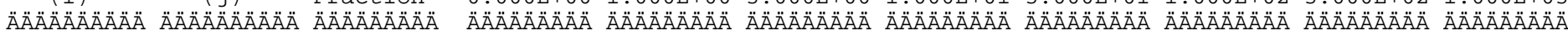

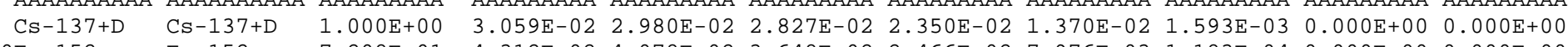

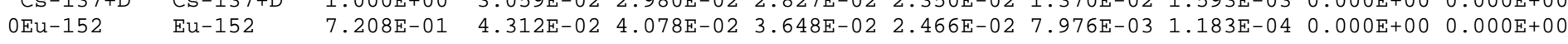

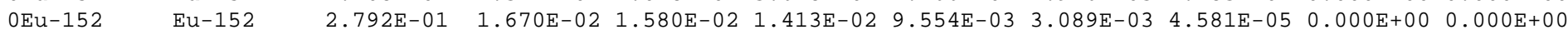
$\begin{array}{lllllllllll}\text { Eu-152 Gd-152 } & 2.792 \mathrm{E}-01 & 1.090 \mathrm{E}-18 & 3.177 \mathrm{E}-18 & 6.952 \mathrm{E}-18 & 1.671 \mathrm{E}-17 & 2.690 \mathrm{E}-17 & 1.364 \mathrm{E}-17 & 0.000 \mathrm{E}+00 & 0.000 \mathrm{E}+0 \odot\end{array}$ Eu-152 EU-152 OPU -238 OPu -238 $\mathrm{Pu}-238$ $\mathrm{Pu}-238$
$\mathrm{Pu}-238$ $\mathrm{Pu}-238$ $\mathrm{Pu}-238$ Pिu-239 Pu-239

Pu-239 Pu-239 OSr-90+D ๑U -234

$\mathrm{U}-234$

$\mathrm{U}-234$

$\mathrm{U}-234$

$\mathrm{U}-234$

๑U -238

०U-238+D

$\mathrm{U}-238+\mathrm{D}$

$\mathrm{U}-238+\mathrm{D}$ äDSR (j) Pu -238 $\mathrm{Pu}-238$ $\mathrm{U}-234$ Th-230

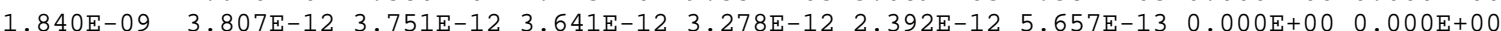

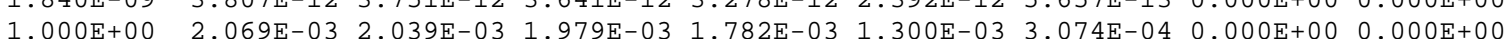

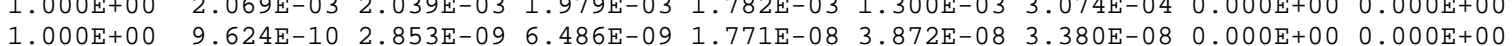

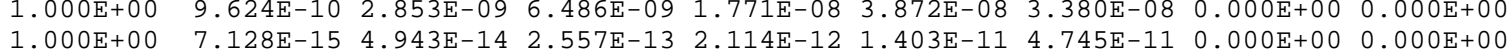
Ra-226+D $\quad 1.000 \mathrm{E}+00 \quad 4.366 \mathrm{E}-17 \quad 6.506 \mathrm{E}-16 \quad 7.475 \mathrm{E}-15 \quad 1.874 \mathrm{E}-13 \quad 3.860 \mathrm{E}-12 \quad 5.848 \mathrm{E}-11 \quad 0.000 \mathrm{E}+00 \quad 0.000 \mathrm{E}+00$

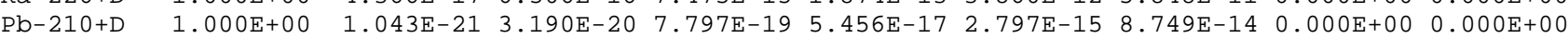
äDSR $(j)$ $\mathrm{Pu}-239$ Pu- 239 U $-235+1$ Ac $-227+$ D äDSR $(j)$ $\mathrm{Sr}-90+\mathrm{D}$ $\mathrm{U}-234$ Th-230

$\mathrm{Ra}-226+\mathrm{D}$ $\mathrm{Pb}-210+\mathrm{D}$ äDSR $(j)$ $\mathrm{J}-238$ $\mathrm{J}-238+\mathrm{D}$ $\mathrm{U}-234$

$1.000 \mathrm{E}+00$

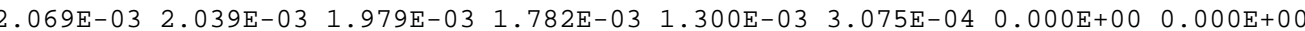

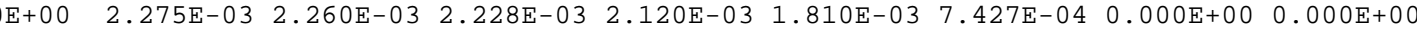

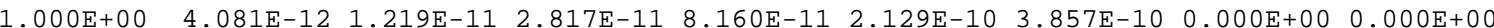

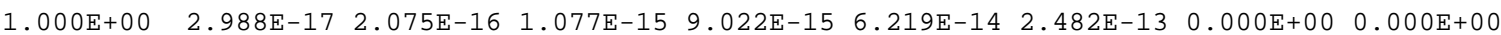

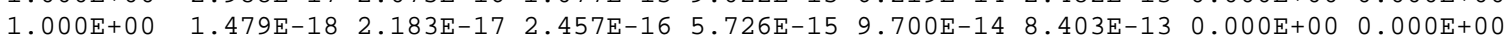
$2.275 \mathrm{E}-03 \quad 2.260 \mathrm{E}-03 \quad 2.228 \mathrm{E}-03 \quad 2.120 \mathrm{E}-03$ 1.810E-03 $7.427 \mathrm{E}-04 \quad 0.000 \mathrm{E}+00 \quad 0.000 \mathrm{E}+00$

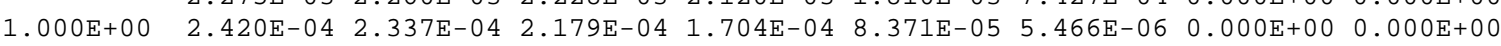

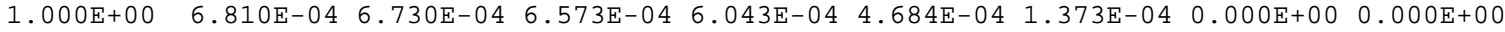

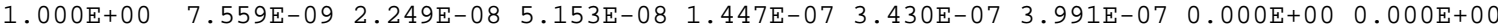
$\begin{array}{lllllllll}1.000 \mathrm{E}+0 \odot & 6.169 \mathrm{E}-11 & 4.294 \mathrm{E}-10 & 2.240 \mathrm{E}-09 & 1.911 \mathrm{E}-08 & 1.391 \mathrm{E}-07 & 6.964 \mathrm{E}-07 & 0.000 \mathrm{E}+00 & 0.000 \mathrm{E}+\odot \odot\end{array}$

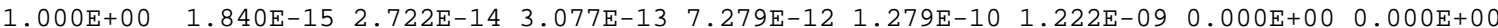

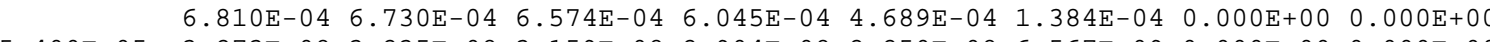

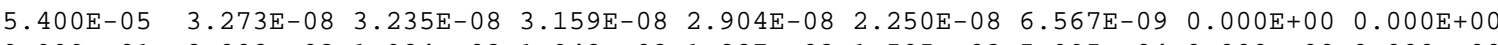

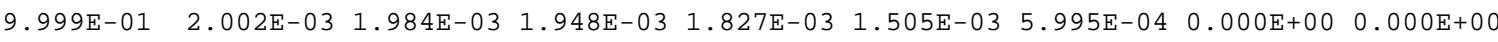

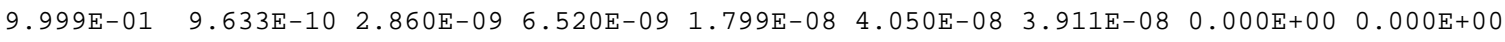
$\begin{array}{lllllllllll}\text { Th-230 } & 9.999 \mathrm{E}-01 & 7.133 \mathrm{E}-15 & 4.950 \mathrm{E}-14 & 2.566 \mathrm{E}-13 & 2.136 \mathrm{E}-12 & 1.445 \mathrm{E}-11 & 5.208 \mathrm{E}-11 & 0.000 \mathrm{E}+00 & 0.000 \mathrm{E}+00\end{array}$ $\begin{array}{lllllllll} & & & \end{array}$ $\mathrm{U}-238+\mathrm{D} \quad \mathrm{Pb}-210+\mathrm{D} \quad 9.999 \mathrm{E}-01$ 1.369E-17 $6.513 \mathrm{E}-16$ 7.495E-15 $1.889 \mathrm{E}-13$ 3.947E-12 $6.277 \mathrm{E}-11$ $11.0 \odot \odot \mathrm{E}+\odot \odot$ $\odot . \odot \odot \odot \mathrm{E}+\odot \odot$

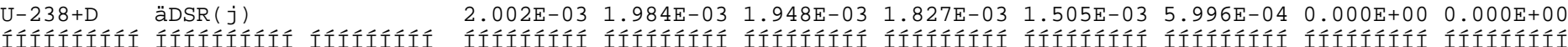
The DSR includes contributions from associated (half-life ó 180 days) daughters. 
Single Radionuclide Soil Guidelines $G(i, t)$ in $\mathrm{pCi} / \mathrm{g}$ Basic Radiation Dose Limit $=2.500 \mathrm{E}+01 \mathrm{mrem} / \mathrm{yr}$

\begin{tabular}{|c|c|c|c|c|c|c|c|c|}
\hline Nuclide & & & & & & & & \\
\hline $\begin{array}{c}(i) \\
\text { ÄÄÄÄÄÄÄ }\end{array}$ & $\mathrm{t}=\frac{0.00 \odot E+\odot \odot}{\mathrm{A} A ̈ A ̈ A ̈ A ̈ A ̈ A ̈ A ̈ A ̈}$ & $\begin{array}{l}1 . \odot \odot \odot E+\odot \odot \\
\text { ÄÄÄÄÄÄÄÄÄA }\end{array}$ & 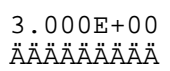 & $\begin{array}{l}\text { 1. } 000 E+01 \\
\text { ÄÄÄÄÄÄÄÄÄ }\end{array}$ & 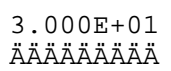 & $\begin{array}{l}1.000 E+\odot 2 \\
\text { ÄÄÄÄÄÄÄÄÄ }\end{array}$ & $\begin{array}{l}3.000 E+\odot 2 \\
\ddot{A ̈ A ̈ A ̈ A ̈ A ̈ A ̈ A ̈ A ̈ A ̈ ~}\end{array}$ & $\begin{array}{l}1.000 E+\odot 3 \\
\text { ÄÄÄÄÄÄÄÄÄ }\end{array}$ \\
\hline Cs -137 & $8.172 \mathrm{E}+02$ & $8.390 \mathrm{E}+02$ & $8.842 \mathrm{E}+02$ & $1.064 \mathrm{E}+03$ & 1.824 & $1.569 \mathrm{E}+04$ & $* 8.704 \mathrm{E}+13$ & $\star 8.704 \mathrm{E}+13$ \\
\hline Eu-152 & $4.179 \mathrm{E}+02$ & $E+\odot 2$ & 4.9 & & & & *1. & $5 E+14$ \\
\hline Pu- & +04 & $1.2(2)$ & & & & & & +13 \\
\hline Pu-239 & 1. $099 \mathrm{E}+04$ & $\mathrm{E}+04$ & $E+\odot 4$ & $E+04$ & 1. & $3.366 \mathrm{E}+04$ & $* 6.214 \mathrm{E}+10$ & ${ }^{*} 6.214 \mathrm{E}+10$ \\
\hline $\mathrm{Sr}-90$ & $1.033 E+05$ & 1. $070 E+05$ & 1.1 & 1.46 & $2 . \subseteq$ & $E+06$ & *1. & *1.365E+14 \\
\hline$U-234$ & & & & & & & & $=+09$ \\
\hline$u-2$ & 4 & 1.2 & & & & & *3 & $* 3$. \\
\hline Íííííí & Íííííííí & Íííííííí & Íííííííí & Íííííííí & Íííííííí & Íííííííí & Ííííí́ííí & Íííííííí \\
\hline
\end{tabular}

Summed Dose/Source Ratios DSR(i,t) in (mrem/yr)/(pCi/g)

and Single Radionuclide Soil Guidelines $\mathrm{G}(i, \mathrm{t})$ in $\mathrm{pCi} / \mathrm{g}$

at $\operatorname{tmin}=$ time of minimum single radionuclide soil guideline

and at $t \max =$ time of maximum total dose $=0.000 \mathrm{E}+00$ years

\begin{tabular}{|c|c|c|c|c|c|c|}
\hline $\begin{array}{l}\text { ONuclide } \\
\text { (i) }\end{array}$ & $\begin{array}{l}\text { Initial } \\
(\mathrm{pci} / \mathrm{g})\end{array}$ & $\begin{array}{c}\text { tmin } \\
\text { (years) }\end{array}$ & $\operatorname{DSR}(i, \operatorname{tmin})$ & $\begin{array}{c}G(i, \text { tmin }) \\
(\mathrm{pCi} / \mathrm{g})\end{array}$ & $\operatorname{DSR}(i, \operatorname{tmax})$ & $\begin{array}{c}\mathrm{G}(\mathrm{i}, \mathrm{tmax}) \\
(\mathrm{pCi} \mathrm{i} / \mathrm{g})\end{array}$ \\
\hline ÄÄÄÄÄÄ & овововово & $\triangle A \cap A ̈ A ̈ A ̈ A ̈ A \cap A ̈ A ̈ A ̈ A ̈$ & ÄÄÄÄ & $\triangle A A ̈ A ̈ A ̈ A ̈ A ̈ A ̈$ & ÄÄÄÄÄÄÄÄ & $\triangle A A A A A ̈ A A A ̈ A ̈$ \\
\hline Cs -137 & $7.800 \mathrm{E}-01$ & $\odot . \odot \odot \odot E+\odot \odot$ & 3. 059E- 02 & $8.172 \mathrm{E}+02$ & 3. 059E-02 & $8.172 \mathrm{E}+02$ \\
\hline Eu-152 & 1.2 & 0.0 & & 4.1 & $E-02$ & +02 \\
\hline Pu-238 & $6.6 .0-5)$ & 0.0 & 03 & 1. & $-\odot 3$ & $+\odot 4$ \\
\hline Pu-239 & $2.280 E+\odot \odot$ & $\odot .00 \odot E+\odot \odot$ & $2.275 \mathrm{E}-03$ & 1. $099 \mathrm{E}+04$ & $2.275 \mathrm{E}-03$ & 1. $099 \mathrm{E}+04$ \\
\hline $\mathrm{Sr}-90$ & -01 & 0.0 & $\odot 4$ & 1.0 & $E-04$ & +05 \\
\hline & & & $\odot 4$ & & -04 & 3.6 \\
\hline$U-2$ & $8.600 \mathrm{E}-01$ & 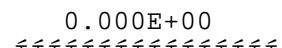 & $E-03$ & $1.249 \mathrm{E}+04$ & 2. $0 \odot 2 \mathrm{E}-03$ & $1.249 \mathrm{E}+04$ \\
\hline Íííííl & IIIIIIÍííí & Íííííííí & Ííííííí́ & Ííííííí & Íííííííí & Ííííííí \\
\hline
\end{tabular}


onuclide Parent THF(i) (j) (i)

ÄÄÄÄÄÄÄ ÄÄÄÄÄÄÄ ÄÄÄÄÄÄÄÄÄ Cs-137 Cs-137 1.000E+๑○ ๑Eu-152 Eu-152 7.208E-01 Eu-152 Eu-152 2.792E-01 $\operatorname{Eu}-152$ äDOSE $(j)$

๑Gd-152 Eu-152 2.792E-01

OGU 152 EU-152 2.792E-01

$\mathrm{Pu}-238$ Pu-238 $1.000 \mathrm{E}+00$

$\mathrm{Pu}-238$ äDOSE $(j)$

๑U-234 PU-238 $1.000 \mathrm{E}+\odot \odot$

$\mathrm{U}-234 \quad \mathrm{U}-234 \quad 1.000 \mathrm{E}+00$

U-234 U-238 9.999E-01

$\mathrm{U}-234$ äDOSE $(j)$

○Th-230 Pu-238 1.000E+००

Th-230 U-234 1.000E +00

Th-230 U-238 9.999E-01

Th-230 äDOSE $(j)$

ORa-226 Pu-238 $1.000 \mathrm{E}+00$

Ra-226 U-234 1.000E+०९

$\mathrm{Ra}-226$ U-238 9.999E-01

Ra-226 äDOSE $(j)$

PPb-210 Pu-238 1. $000 \mathrm{E}+\odot \odot$

$\mathrm{Pb}-210 \mathrm{U}-234 \quad 1.000 \mathrm{E}+00$

$\mathrm{Pb}-210 \quad \mathrm{U}-238 \quad 9.999 \mathrm{E}-01$

$\mathrm{Pb}-210$ äDOSE $(j)$

○िu-239 Pu-239 1. $000 \mathrm{E}+\odot \odot$

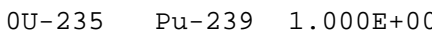

๑Pa-231 Pu-239 1.000E+๑O

OAC-227 Pu-239 1.000E +00

OSr-90 Sr-90 $1.000 \mathrm{E}+00$

OU-238 U-238 $5.400 \mathrm{E}-05$

$\mathrm{U}-238 \quad \mathrm{U}-238 \quad 9.999 \mathrm{E}-01$

$U-238$ äDOSE $(j)$

Íííííííi

Individual Nuclide Dose Summed Over All Pathways

Parent Nuclide and Branch Fraction Indicated

$\operatorname{DOSE}(j, t), \quad m r e m / y r$

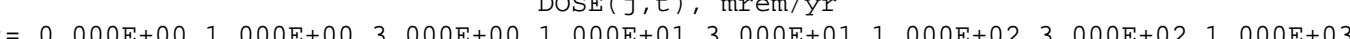

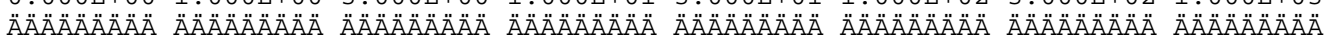

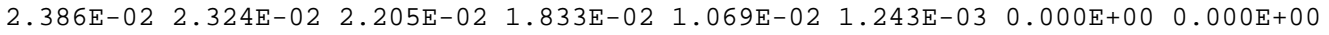

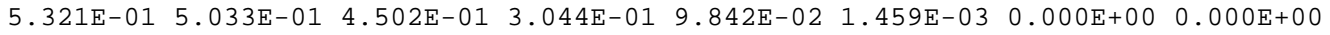
2.061E-01 1.949E-01 1.744E-01 $1.179 \mathrm{E}-01$ 3.812E-02 $5.653 \mathrm{E}-04 \quad 0.000 \mathrm{E}+00 \quad 0.000 \mathrm{E}+00$

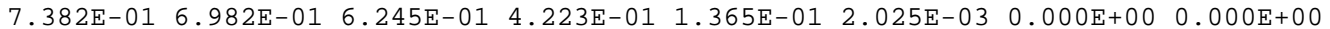

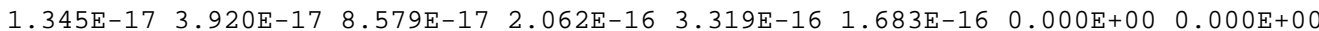
$2.284 \mathrm{E}-13 \quad 2.251 \mathrm{E}-13 \quad 2.185 \mathrm{E}-13 \quad 1.967 \mathrm{E}-13 \quad 1.435 \mathrm{E}-13 \quad 3.394 \mathrm{E}-14 \quad 0.000 \mathrm{E}+00 \quad 0.000 \mathrm{E}+00$

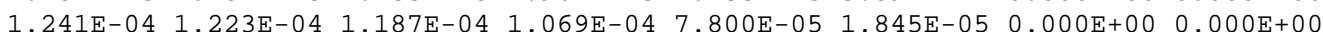
1.241E- 04 1.223E- 04 1.187E- 04 1.069E- $04 \quad 7.800 \mathrm{E}-05$ 1.845E- $05 \quad 0.000 \mathrm{E}+00 \quad 0.000 \mathrm{E}+00$ 5.774E-11 1.712E-10 3.892E-10 $1.063 \mathrm{E}-09$ 2.323E- 09 2.028E- $09 \quad 0.000 \mathrm{E}+00 \quad 0.000 \mathrm{E}+00$

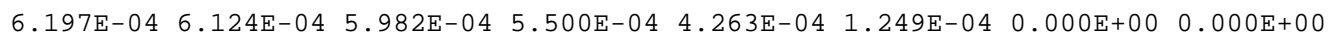

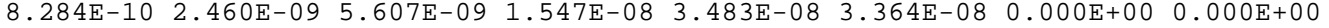

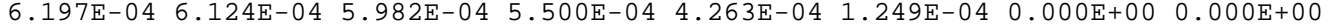
4.277E-16 2.966E-15 1.534E-14 1.269E-13 8.417E-13 2.847E-12 $0.000 \mathrm{E}+00 \quad 0.000 \mathrm{E}+00$ $6.879 \mathrm{E}-092.047 \mathrm{E}-08$ 4.690E-08 $1.317 \mathrm{E}-07$ 3.121E-07 3.632E-07 0.000E+00 0.000E+00

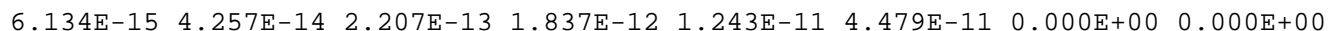

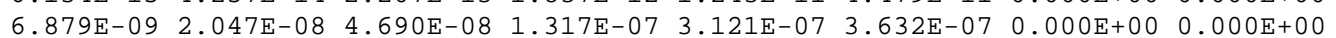
$2.620 \mathrm{E}-18 \quad 3.903 \mathrm{E}-17 \quad 4.485 \mathrm{E}-16 \quad 1.125 \mathrm{E}-14 \quad 2.316 \mathrm{E}-13 \quad 3.509 \mathrm{E}-12 \quad 0.000 \mathrm{E}+00 \quad 0.000 \mathrm{E}+0 \bullet$

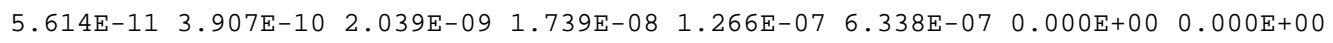
3.757E-17 5.602E-16 6.446E-15 1.624E-13 $3.395 \mathrm{E}-12 \quad 5.399 \mathrm{E}-11 \quad 0.000 \mathrm{E}+00 \quad 0.000 \mathrm{E}+00$ 5.614E-11 3.907E-10 2.039E- 09 1.739E-08 1.266E-07 6.338E-07 $0.000 \mathrm{E}+00$ ๑. $1000 \mathrm{E}+00$ 6.260E-23 1.914E-21 4.678E-20 3.273E-18 1.678E-16 5.249E-15 $0.0000 \mathrm{E}+00 \quad 0.000 \mathrm{E}+00$

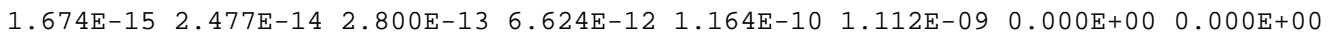

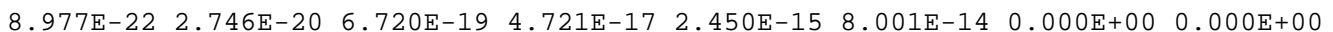

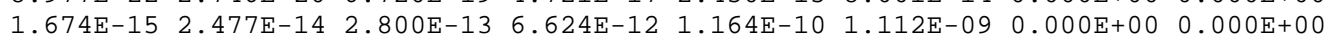

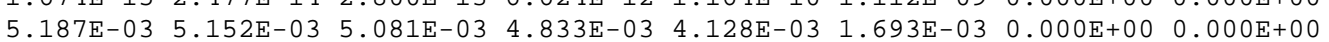

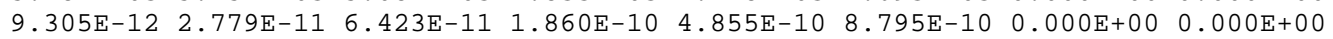
6.813E-17 4.731E-16 2.456E-15 2.057E-14 $1.418 \mathrm{E}-13 \quad 5.660 \mathrm{E}-13 \quad 0.000 \mathrm{E}+00 \quad 0.000 \mathrm{E}+\odot \odot$ $3.372 \mathrm{E}-18 \quad 4.978 \mathrm{E}-17 \quad 5.603 \mathrm{E}-16 \quad 1.306 \mathrm{E}-14 \quad 2.211 \mathrm{E}-13 \quad 1.916 \mathrm{E}-12 \quad 0.000 \mathrm{E}+00 \quad 0.000 \mathrm{E}+00$

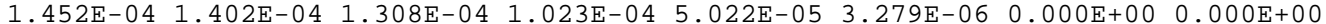
$2.815 \mathrm{E}-08 \quad 2.782 \mathrm{E}-08 \quad 2.717 \mathrm{E}-08 \quad 2.498 \mathrm{E}-08 \quad 1.935 \mathrm{E}-08 \quad 5.648 \mathrm{E}-09 \quad 0.000 \mathrm{E}+000.0 .000 \mathrm{E}+00$ $1.721 \mathrm{E}-03$ 1.706E-03 $1.675 \mathrm{E}-03$ 1.571E-03 $1.294 \mathrm{E}-035.156 \mathrm{E}-04 \mathrm{O}$. $000 \mathrm{E}+00 \mathrm{O} .00 \mathrm{E}+00$

$1.721 \mathrm{E}-03$ 1.706E-03 $1.675 \mathrm{E}-03$ 1.571E-03 $1.294 \mathrm{E}-03$ 5.156E-04 $0.000 \mathrm{E}+00-0.000 \mathrm{E}+00$

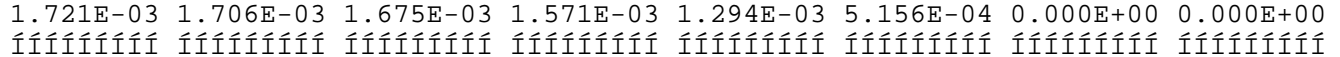
$\operatorname{THF}(i)$ is the thread fraction of the parent nuclide. 
onuclide Parent THF(i) (j) (i)

ÄÄÄÄÄÄÄ ÄÄÄÄÄÄÄ ÄÄÄÄÄÄÄÄÄ Cs-137 Cs-137 1.000E+O० ๑Eu-152 Eu-152 7.208E-01 Eu-152 Eu-152 2.792E-01 Eu-152 äS $(j)$ :

OGd-152 Eu-152 2.792E-01

$\mathrm{Pu}-238$ Pu-238 $1.000 \mathrm{E}+00$

$\mathrm{Pu}-238$ äS $(j)$ :

๑U-234 PU-238 $1.000 \mathrm{E}+\odot \odot$

$\mathrm{U}-234 \quad \mathrm{U}-234 \quad 1.000 \mathrm{E}+00$

U-234 U-238 9.999E-01

$\mathrm{U}-234$ äS $(j)$ :

๑Th-230 Pu-238 1.000E+००

Th-230 U-234 1.000E +00

Th-230 U-238 9.999E-01

Th-230 äs $(j)$

AS $(j)$ :

PU-226 1.000E+00

$\mathrm{Ra}-226 \mathrm{U}-234 \quad 1.000 \mathrm{E}+0 \odot$

Ra-226 U-238 9.999E-01

$\mathrm{Ra}-226$ äS $(j)$ :

๑Pb-210 Pu-238 1.000E $+0 \odot$

$\mathrm{Pb}-210 \quad \mathrm{U}-234 \quad 1.000 \mathrm{E}+00$

$\mathrm{Pb}-210 \quad \mathrm{U}-238 \quad 9.999 \mathrm{E}-01$

Pिu-239 $\mathrm{Pu}(\mathrm{j})$ :

(. $1.000 \mathrm{E}+00$

OU-235 PU-239 1.000E+००

OPa-231 $\mathrm{Pu}-239$ 1.000E +00

$\odot A C-227 \quad \mathrm{Pu}-239 \quad 1.000 \mathrm{E}+0 \bigcirc$

$\odot \mathrm{Sr}-90 \quad \mathrm{Sr}-90 \quad 1.000 \mathrm{E}+00$

OU-238 U-238 $5.400 \mathrm{E}-05$

$\mathrm{U}-238 \quad \mathrm{U}-238 \quad 9.999 \mathrm{E}-01$

$U-238$ äs $(j)$ :

Íííííííi

THF( $i$ ) is the thread fract

ORESCALC. EXE execution time =
Individual Nuclide Soil Concentration

Parent Nuclide and Branch Fraction Indicated

$S(j, t), p C i / g$

$=0.000 \mathrm{E}+001.000 \mathrm{E}+003.000 \mathrm{E}+0001.000 \mathrm{E}+013.000 \mathrm{E}+011.000 \mathrm{E}+023.000 \mathrm{E}+021.000 \mathrm{E}+03$ ÄÄÄÄÄÄÄÄ ÄÄÄÄÄÄÄÄÄ ÄÄÄÄÄÄÄÄÄ ÄÄÄÄÄÄÄÄÄ ÄÄÄÄÄÄÄÄÄ ÄÄÄÄÄÄÄÄÄ ÄÄÄÄÄÄÄÄÄ ÄÄÄÄÄÄÄÄÄ 7.800E-01 7.621E-01 7.276E-01 6.187E-01 3.894E-01 7.696E-02 7.492E-04 6.821E-11 $8.895 \mathrm{E}+00 \quad 8.441 \mathrm{E}+00 \quad 7.603 \mathrm{E}+00 \quad 5.272 \mathrm{E}+\odot \odot \quad 1.852 \mathrm{E}+0 \odot \quad 4.759 \mathrm{E}-02 \quad 1.362 \mathrm{E}-06 \quad 1.710 \mathrm{E}-22$ $3.445 \mathrm{E}+\odot \odot \quad 3.270 \mathrm{E}+\odot \odot \quad 2.945 \mathrm{E}+\odot \odot \quad 2.042 \mathrm{E}+\odot \odot \quad 7.174 \mathrm{E}-\odot 1 \quad 1.843 \mathrm{E}-\odot 2 \quad 5.277 \mathrm{E}-\odot 7 \quad 6.622 \mathrm{E}-23$

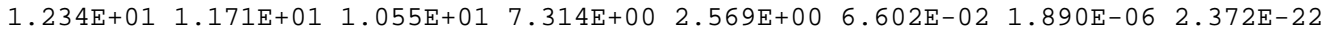
$0.000 \mathrm{E}+00 \quad 2.154 \mathrm{E}-14 \quad 6.136 \mathrm{E}-14 \quad 1.719 \mathrm{E}-13 \quad 3.328 \mathrm{E}-13 \quad 4.101 \mathrm{E}-13 \quad 3.878 \mathrm{E}-13 \quad 3.128 \mathrm{E}-13$ 1. $104 \mathrm{E}-10$ 1. $095 \mathrm{E}-10 \quad 1.078 \mathrm{E}-10$ 1. $019 \mathrm{E}-10 \quad 8.677 \mathrm{E}-11 \quad 4.947 \mathrm{E}-11$ 9. $935 \mathrm{E}-12 \quad 3.606 \mathrm{E}-14$ 6. $\odot \odot \odot \mathrm{E}-02 \quad 5.952 \mathrm{E}-02 \quad 5.857 \mathrm{E}-02 \quad 5.537 \mathrm{E}-02 \quad 4.716 \mathrm{E}-02 \quad 2.689 \mathrm{E}-02 \quad 5.400 \mathrm{E}-03 \quad 1.960 \mathrm{E}-05$ 6. $000 \mathrm{E}-02 \quad 5.952 \mathrm{E}-02$ 5.857E-02 5.537E-02 4 716E-02 2.689E-02 5.400E-03 1.960E-05

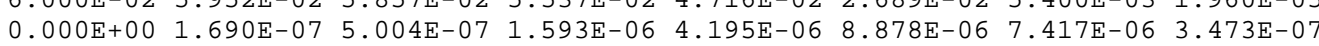
9.100E-01 9.054E-01 8.963E-01 8.652E-01 7.820E-01 5.491E-01 2.000E-01 5.826E-03 $0.000 \mathrm{E}+00$ 2.426E-06 7.204E-06 2.318E-05 6.286E-05 1.471E-04 1.608E-04 1.563E-05 9.100E-01 9.054E-01 8.963E-01 8.652E-01 7.821E-01 5.493E-01 2.001E-01 5.842E-03 $0.000 \mathrm{E}+00 \quad 7.623 \mathrm{E}-13 \quad 6.801 \mathrm{E}-12 \quad 7.330 \mathrm{E}-11 \quad 6.052 \mathrm{E}-10 \quad 5.018 \mathrm{E}-09 \quad 2.111 \mathrm{E}-08$ 3.680E-08

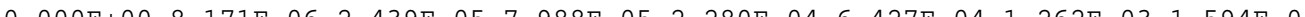

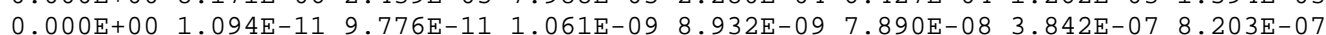

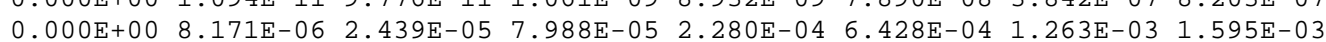
$\odot .000 \mathrm{E}+00$ 1.101E-16 $2.947 \mathrm{E}-15$ 1. $1.059 \mathrm{E}-13$ 2.627E-12 $7.264 \mathrm{E}-11$ 8.907E-10 $3.584 \mathrm{E}-09$

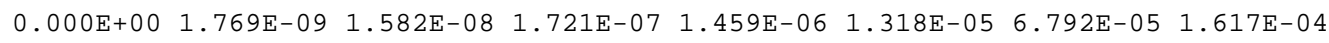
$0.000 \mathrm{E}+00$ 1.579E-15 4.233E-14 1.530E-12 3.849E-11 1.117E-09 $1.543 \mathrm{E}-08$ 7.730E-08 $0.000 \mathrm{E}+00$ 1.769E-09 $1.582 \mathrm{E}-08$ 1.721E-07 $1.459 \mathrm{E}-06$ 1.318E-05 6.793E-05 1.617E-04 $0.000 \mathrm{E}+00 \quad 8.504 \mathrm{E}-19 \quad 6.751 \mathrm{E}-17 \quad 7.771 \mathrm{E}-15 \quad 5.185 \mathrm{E}-13 \quad 3.453 \mathrm{E}-11 \quad 6.793 \mathrm{E}-10 \quad 3.270 \mathrm{E}-09$ $0.000 \mathrm{E}+00$ 1.819E-11 $4.808 \mathrm{E}-10$ 1.655E-08 3.659E-07 $\quad 7.352 \mathrm{E}-06 \quad 5.514 \mathrm{E}-05$ 1.484E- 04 $\odot .000 \mathrm{E}+00 \quad 1.220 \mathrm{E}-17 \quad 9.693 \mathrm{E}-16 \quad 1.120 \mathrm{E}-13 \quad 7.568 \mathrm{E}-12 \quad 5.262 \mathrm{E}-10$ 1. $161 \mathrm{E}-08 \quad 7.020 \mathrm{E}-08$

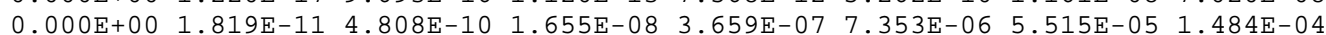

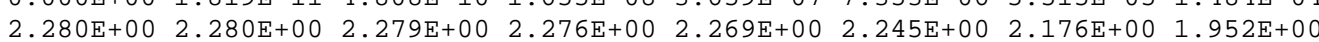

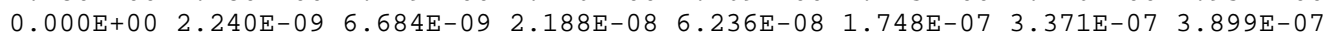
$0.000 \mathrm{E}+00 \quad 2.367 \mathrm{E}-14 \quad 2.116 \mathrm{E}-13 \quad 2.296 \mathrm{E}-12 \quad 1.930 \mathrm{E}-11 \quad 1.698 \mathrm{E}-10 \quad 8.156 \mathrm{E}-10 \quad 1.617 \mathrm{E}-09$

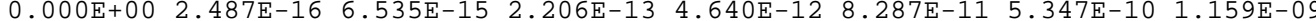
6. $000 \mathrm{E}-01 \quad 5.810 \mathrm{E}-01 \quad 5.448 \mathrm{E}-01 \quad 4.348 \mathrm{E}-01 \quad 2.284 \mathrm{E}-01 \quad 2.398 \mathrm{E}-02 \quad 3.831 \mathrm{E}-05 \quad 6.243 \mathrm{E}-15$ $4.644 \mathrm{E}-05 \quad 4.621 \mathrm{E}-05 \quad 4.574 \mathrm{E}-05 \quad 4.415 \mathrm{E}-05 \quad 3.991 \mathrm{E}-05 \quad 2.803 \mathrm{E}-05$ 1. $021 \mathrm{E}-05$ 2. $2825 \mathrm{E}-07$ 8. $600 \mathrm{E}-01 \quad 8.556 \mathrm{E}-01 \quad 8.470 \mathrm{E}-01 \quad 8.176 \mathrm{E}-01 \quad 7.391 \mathrm{E}-01 \quad 5.191 \mathrm{E}-01$ 1.891E-01 $5.521 \mathrm{E}-03$

8.600E-01 8.557E-01 8.471E-01 8.177E-01 7.391E-01 5.191E-01 1.891E-01 5.522E-03 íííííííí íííííííí íííííííí íííííííí íííííííí íííííííí íííííííí íííííííí of the parent nuclide.

1.50 seconds 


\section{Appendix $\mathrm{H}$}

Nevada Division of Environmental Protection Comments

(2 Pages) 


\section{NEVADA ENVIRONMENTAL RESTORATION PROJECT}

DOCUMENT REVIEW SHEET

\begin{tabular}{|l|l|}
\hline 1. Document Title/Number: & $\begin{array}{l}\text { Draft Draft Closure Report for Corrective Action Units 530, 531, 532, } \\
533,534, \text { 2. Document Date: } 06 / 13 / 2006 \\
\text { Nevada }\end{array}$ \\
\hline 3. Revision Number: $0 \quad$ 4. Nevada Test Site Mud Pits, Nevada Test Site, & \\
\hline 5. Responsible NNSA/NV ERP Project Manager: Kevin Cabble & 6. Date Comments Due: 06/09/2006 \\
\hline 7. Review Criteria: Full & \\
\hline 8. Reviewer/Organization/Phone No: John Wong, NDEP, 486-2850 & 9. Reviewer's Signature: \\
\hline
\end{tabular}

\begin{tabular}{|l|l|l|l|}
\hline $\begin{array}{l}\text { 10. Comment } \\
\text { Number/Location }\end{array}$ & 11. Type* & 12. Comment & $\begin{array}{l}\text { 13. Comment Response } \\
\text { 1.) Section 2.1.1.1, } \\
\text { Page 23 }\end{array}$ \\
\hline & $\begin{array}{l}\text { Explain how radiological field screening levels and field } \\
\text { screening results were established. }\end{array}$ & $\begin{array}{l}\text { The first three sentences in the second paragraph } \\
\text { in Section 2.1.1.1 was modified to include the } \\
\text { explanation and now reads: "Prior to sampling } \\
\text { activities, FSLs were established by collecting 10 } \\
\text { soil samples from outside of the CAS area that are } \\
\text { representative of the local area. These samples } \\
\text { were homogenized in a single collection pan and } \\
\text { given 10 one-minute counts. The alpha and } \\
\text { beta/gamma results of each one-minute count } \\
\text { were recorded and processed by using the Chi- } \\
\text { Square test. The FSL is the sum of the mean of } \\
\text { the 10 counts plus two standard deviations. The } \\
\text { FSL served two purposes. It is the criteria by } \\
\text { which samples were submitted for analysis of } \\
\text { radionuclides and to meet sample shipping } \\
\text { requirements. Field screening results were } \\
\text { obtained for all samples within a CAS by surveying } \\
\text { each soil sample within the collection pan using a } \\
\text { handheld alpha and beta/gamma survey } \\
\text { instrument (e.g., NE Electra). If any of these } \\
\text { FSRs..." }\end{array}$ \\
\hline
\end{tabular}

\section{Uncontrolled When Printed}




\section{NEVADA ENVIRONMENTAL RESTORATION PROJECT}

DOCUMENT REVIEW SHEET

\begin{tabular}{|l|l|l|l|}
\hline $\begin{array}{l}\text { 10. Comment } \\
\text { Number/Location }\end{array}$ & 11. Type & 12. Comment & 13. Comment Response \\
\hline $\begin{array}{l}\text { 2.) Section 2.1.2, } \\
\text { Page 27 }\end{array}$ & & $\begin{array}{l}\text { 14. } \\
\text { Visual habitat surveys were completed to confirm the } \\
\text { absence of habitats for endangered species. How were } \\
\text { these surveys documented? If possible, as an addendum } \\
\text { or an appendix, include copies of the documented survey } \\
\text { results. }\end{array}$ & $\begin{array}{l}\text { The habitat surveys were documented using a } \\
\text { standarized form that was created specifically for } \\
\text { this task. The text at the end of Section 2.1.2 has } \\
\text { been modified to address this documentation. Due } \\
\text { to the number of surveys completed, an addendum } \\
\text { or appendix is not appropriate for this report. For } \\
\text { NDEP's convenience, a compact disc with } \\
\text { scanned survey forms is being provided } \\
\text { separately. }\end{array}$ \\
\hline $\begin{array}{l}\text { 3.) Section 3.3, } \\
\text { Page 35 }\end{array}$ & $\begin{array}{l}\text { Discuss waste streams in terms of volumes disposed, and } \\
\text { ensure that all waste volumes disposed of are accounted } \\
\text { for in Appendix E. Provide more legible copies of all } \\
\text { applicable NTS Landfill Load Verification forms. }\end{array}$ & $\begin{array}{l}\text { Each waste stream discussed in Section 3.3 now } \\
\text { includes the approximate volume disposed, where } \\
\text { appropriate. All waste streams identified in } \\
\text { Section 3.3 are now accounted for in Appendix E. } \\
\text { A more legible copy of the NTS Landfill Load } \\
\text { Verification form for the sanitary debris disposed in } \\
\text { the Area 23 landfill was obtained, scanned, and } \\
\text { replaced in Appendix E. }\end{array}$ \\
\hline
\end{tabular}

\section{Uncontrolled When Printed}




\section{Library Distribution List}

\section{$\underline{\text { Copies }}$}

U.S. Department of Energy

1 (Uncontrolled)

National Nuclear Security Administration

Nevada Site Office

Technical Library

P.O. Box 98518, M/S 505

Las Vegas, NV 89193-8518

U.S. Department of Energy

1 (Uncontrolled, electronic copy)

Office of Scientific and Technical Information

P.O. Box 62

Oak Ridge, TN 37831-0062

Southern Nevada Public Reading Facility

2 (Uncontrolled, electronic copies)

c/o Nuclear Testing Archive

P.O. Box 98521, M/S 400

Las Vegas, NV 89193-8521

Manager, Northern Nevada FFACO

1 (Uncontrolled, electronic copy)

Public Reading Facility

c/o Nevada State Library \& Archives

100 N. Stewart Street

Carson City, NV 89701-4285 